UNIVERSIDADE DE SÃO PAULO

FACULDADE DE FILOSOFIA, LETRAS E CIÊNCIAS HUMANAS

DEPARTAMENTO DE CIÊNCIA POLÍTICA

PROGRAMA DE PÓS-GRADUAÇÃO EM CIÊNCIA POLÍTICA

Maria Isabel Meunier Ferraz

\title{
O Estado incremental: ação e interação do Executivo na política migratória brasileira
}

(Versão Corrigida)

Tese apresentada ao Programa de PósGraduação em Ciência Política do Departamento de Ciência Política da Faculdade de Filosofia, Letras e Ciências Humanas da Universidade de São Paulo para obtenção do título de Doutora em Ciência Política.

Orientadora: Prof. Dra. Janina Onuki

\section{São Paulo}


A meu pai, meu sertão de dentro.

$\mathrm{E}$ a todos aqueles que aprendem a ler

pra ensinar seus camaradas. 


\section{Agradecimentos}

Tenho a impressão que toda jornada doutoral é um processo de auto-explicação. A escolha do objeto, da metodologia ou do arcabouço teórico correspondem a tentativas de explicar escolhas de vida e trajetória profissional. Muito mais do que um item formal de reconhecimento pelo auxílio ao desenvolvimento deste trabalho, estes agradecimentos refletem uma sincera e viva gratidão àqueles que contribuíram para esse processo de descoberta e amadurecimento mais amplo. São agradecimentos que se querem abraços.

A minha mãe e minha irmã, primeiramente. Qualquer esforço que eu tenha empreendido após a perda de meu pai é indissociável de seus esforços em manter-nos serenas. A minha mãe, novamente, que será sempre meu primeiro e maior exemplo de docência engajada.

À professora Janina Onuki, pela compreensão e tranquilidade com que conduziu a orientação, além do senso de responsabilidade tão admirável. À professora Deisy Ventura e ao professor Pedro Feliú, meus supervisores no programa de aperfeiçoamento de ensino, docentes de extremo talento que tanto me inspiraram e seguirão me inspirando.

Aos professores e servidores do DCP, que com sua competência e excelência conformam um departamento ao mesmo tempo instigante e acolhedor. Às colegas e aos colegas do DCP que contribuíram neste mesmo sentido, dos quais citarei especialmente Radamés, pelo afeto.

A André, por me fazer crescer e crescer junto comigo.

Às mulheres que habitam minha vida, minhas amigas tão queridas, que tanto me ensinam e me empoderam.

A João Guilherme, Cyntia Sampaio e Camila Baraldi, que me colocaram na roda da política pública de migrações.

Aos colegas gestores da Prefeitura de São Paulo, pela compreensão que demonstraram no decorrer do processo de escritura da tese.

A todos os entrevistados, que cederam seu tempo e experiência com gentileza e simpatia, por vezes em momentos difíceis. 
A mainha, Bia, Leli, Diana e Filipe, pelas transcrições. A mainha e André, por ajudas de última hora.

Ao CNPq, que financiou boa parte da pesquisa, e à CAPES, que financiou as viagens de campo. Principalmente: aos políticos e gestores que acreditam na educação pública como instrumento de justiça social. 
No man is an island,

Entire of itself,

Every man is a piece of the continent,

A part of the main.

John Donne

\section{SÃO PAULO}

Adoro esta cidade

São Paulo do meu coração

Aqui nenhuma tradição

Nenhum preconceito

Antigo ou moderno

Só contam este apetite furioso esta confiança absoluta este otimismo esta audácia este trabalho este labor esta especulação que fazem construir dez casas por hora de todos os estilos ridículos grotescos belos grandes pequenos norte sul egípcio ianque cubista

Sem outra preocupação que a de seguir as estatísticas prever o futuro o conforto a utilidade a mais-valia e atrair uma grande imigração

Todos os países

Todos os povos

Gosto disso

As duas três velhas casas portuguesas que sobram são faianças azuis

Blaise Cendrars, 1924 (Tradução de Teresa Thieriot). 


\section{RESUMO}

Esta tese busca analisar os padrões de mudança e continuidade na política migratória brasileira, de maneira a observar o papel neles exercido pela dinâmica políticoburocrática interorganizacional. Nesse intuito, empreende uma análise do funcionamento do Executivo em uma abordagem institucionalista centrando-se no processo político subjacente aos resultados em política migratória. O trabalho testa a hipótese de que o desenho institucional caracterizado por fragmentação e sobreposição de competências que caracteriza a política migratória é estruturante de processos organizacionais correspondentes a um duplo mecanismo: de um lado, organizações, por meio de seus dirigentes políticos e burocratas, realizam mudanças incrementais setoriais na política, em decorrência do aumento de suas capacidades técnico-administrativas e político-relacionais. De outro, em função dos objetivos de manter seu espaço de poder e lógica de ação organizacional, tais organizações tenderão a opor obstáculos a reformas mais amplas. Paralelamente, a tese enfrenta duas outras questões de pesquisa: (i) como as arenas internacional e doméstica se influenciam mutuamente no processo político migratório; e (ii) como os diferentes atores governamentais que tomam parte na formulação e implementação da política migratória brasileira coordenam suas atividades em um arranjo institucional complexo. De maneira a testar empiricamente suas hipóteses, realiza um process-tracing da política migratória brasileira entre 2003 e abril de 2016.

Palavras-chave: Instituições; Política Migratória; Internacionalização; Burocratas; Organizações; Coordenação intragovernamental. 


\begin{abstract}
The present thesis seeks to analyze the patterns of change on Brazilian migration policy, in order to observe the role played by the interorganizational political-bureaucratic dynamics. To this end, it undertakes an analysis of how the Executive branch works, in an institutionalist approach focusing on the political process underlying the results in migration policy. The thesis tests the hypothesis that the institutional design of migration policy, characterized by fragmentation and overlapping of competences, structures organizational processes by a double mechanism: on the one hand, organizations, through their political leaders and bureaucrats, make incremental policy changes, as a result of the increase of its technical-administrative and political-relational capacities. On the other hand, according to the objectives of maintaining their space of power and their logic of organizational action, such organizations will tend to oppose wider reforms. At the same time, the thesis also addresses two other research questions: (i) how the international and domestic arenas influence each other in the migration policy process; and (ii) how different governmental actors that take part in the formulation and implementation of the Brazilian migration policy coordinate their activities in a complex institutional arrangement. In order to empirically test its hypotheses, it carries out a process-tracing of the Brazilian migration policy between 2003 and 2016.
\end{abstract}

Keywords: Institutions; Migration Policy; Internationalization; Bureaucrats; Organizations; Intragovernmental Coordination. 


\section{LISTA DE SIGLAS E ABREVIATURAS}

ABIN - Agência Brasileira de Inteligência

ACNUR - Alto Comissariado das Nações Unidas para os Refugiados

AGU - Advocacia Geral da União

CDTM - Convenção Internacional sobre a Proteção dos Direitos de Todos os

Trabalhadores Migrantes e dos Membros das suas Famílias

CGIg - Coordenação Geral de Imigração

CGMI - Comissão Global sobre Migrações Internacionais

CIE - Carteira de Identidade de Estrangeiro

CPLP - Comunidade dos Países de Língua Portuguesa

CNBB - Conferência Nacional dos Bispos do Brasil

CNPD - Comissão Nacional para População e Desenvolvimento

CNIg - Conselho Nacional de Imigração

CONARE - Comitê Nacional para os Refugiados

DEEST - Departamento de Estrangeiros

DICRE - Divisão Central de Registro de Estrangeiros

DIM - Divisão de Imigração

DNU - Divisão das Nações Unidas

DPF - Departamento de Polícia Federal

DPU - Defensoria Pública da União

DTS - Departamento de Direitos Humanos e Temas Sociais

DUDH - Declaração Universal de Direitos Humanos

EUA - Estados Unidos da América

ETP - Enfrentamento ao Tráfico de Pessoas

FSM - Fórum Social Mundial

GMG - Global Migration Group

ICMPD - International Centre for Migration Policy Development

IMDH - Instituto Migrações e Direitos Humanos

MDS - Ministério do Desenvolvimento Social e Combate à Fome

MJ - Ministério da Justiça

MPF - Ministério Público Federal

MPT - Ministério Público do Trabalho

MPS - Ministério da Previdência Social

MRE - Ministério das Relações Exteriores

MTE - Ministério do Trabalho e Emprego

NAFTA - Tratado Norte-Americano de Livre Comércio 
OEA - Organização de Estados Americanos

OHCHR - Escritório do Alto Comissariado das Nações Unidas para os Direitos Humanos

OIM - Organização Internacional para as Migrações

OIT - Organização Internacional do Trabalho

OMS - Organização Mundial de Saúde

ONU - Organização das Nações Unidas

PAM - Programa Alimentar Mundial

PL - Projeto de lei

PLS - Projeto de lei do Senado

PNUD - Programa das Nações Unidas para o Desenvolvimento

RN - Resolução Normativa (CNIg)

RR - Resolução Recomendada (CNIg)

SDH-PR - Secretaria de Direitos Humanos da Presidência da República

SEPPIR-PR - Secretaria de Políticas de Promoção da Igualdade Racial

SGEB - Subsecretaria das Comunidades de Brasileiros no Exterior

SNJ - Secretaria Nacional de Justiça

SPM-PR - Secretaria de Políticas para as Mulheres da Presidência da República

UE - União Europeia

UNCTAD - Conferência das Nações Unidas sobre Comércio e Desenvolvimento

UNDESA - Departamento de Assuntos Econômicos e Sociais das Nações Unidas

UNESCO - Organização das Nações Unidas para a Educação, a Ciência e a Cultura

UNFPA - Fundo de População das Nações Unidas

UNICEF - Fundo das Nações Unidas para a Infância

UNITAR- Instituto das Nações Unidas para Formação Profissional e Investigações

UNODC - Escritório das Nações Unidas sobre Drogas e Crime 


\section{LISTA DE FIGURAS E TABELAS}

Tabela 1.1: Status de tratados multilaterais dos regimes de direitos humanos, refúgio e apatridria, trabalhadores migrantes e tráfico de pessoas em janeiro de 2017. .55

Quadro 2.1: Modos de mudança segundo possibilidades de veto e nível de discricionariedade na implementação. .96

Quadro 2.2: Mecanismos causais relativos à dinâmica mudança/continuidade verificada na política migratória brasileira no período de 2003-2016. 125

Figura 3.1: Entradas de imigrantes no Brasil entre 1887-1972, por nacionalidades....161

Tabela 3.2: Refugiados reassentados durante o mandato da OIR

(1947-1951) por países de destino

Quadro 4.1: Mecanismos causais relativos ao padrão mudança/continuidade verificado na política migratória brasileira no período de 2003-2016 e manifestações empíricas observáveis. .225

Quadro 4.2: Alocações orçamentárias para política migratória no MTE 248

Quadro 4.3: Resoluções Normativas e Resoluções Recomendadas do CNIg (20032015) .252

Quadro 4.4: Alocações orçamentárias para política migratória no MJ (2003-2009)...258

Quadro 4.5: Alocações orçamentárias para política migratória no MJ (2010-2015)...270

Figura 4.6: Organograma da SGEB nos termos do Decreto $n^{\circ} 7.304 / 2010 \ldots \ldots \ldots \ldots \ldots . . .278$

Quadro 4.7: Normas do Mercosul afetas à temática migratória..................................295

Quadro 4.8: Normas afetas à temática migratória na CPLP......................................304

Figura 5.1: Entradas terrestres e aéreas de haitianos vs. emissão de vistos humanitários (2015). 345

Figura 5.2: Número de autorizações concedidas a haitianos pelo Conselho Nacional de Imigração com fundamento na RN 27, entre 2011 e 2015. .345

Quadro 5.3: Órgãos competentes e fundamentos normativos da concessão dos diferentes tipos de permanência...... .358

Quadro 5.4: Matriz interorganizacional da implementação da política migratória relativa à situação documental. 361 


\section{SUMÁRIO}

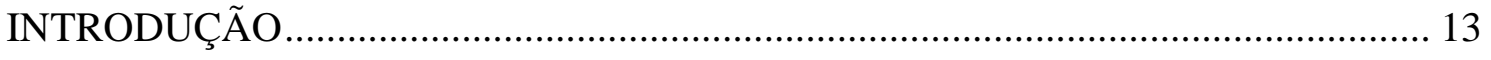

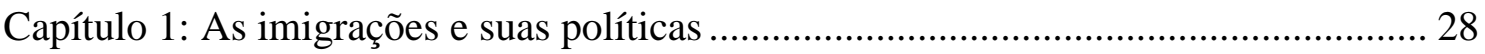

1.1. Introdução....................................................................................................................................... 28

1.2. Das migrações internacionais às políticas migratórias nacionais ................................. 28

1.3. Política migratória como política pública: o papel dos burocratas .............................. 38

1.4. Há um regime internacional das migrações? .................................................................... 46

1.5. Xadrez institucional da política migratória brasileira.................................................... 59

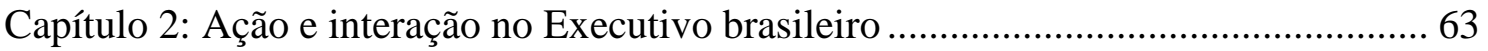

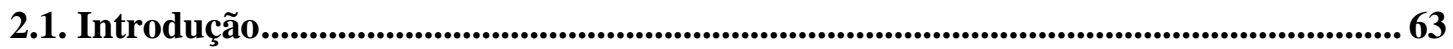

2.2. O Executivo em ação: como funciona o Poder Executivo brasileiro e onde a

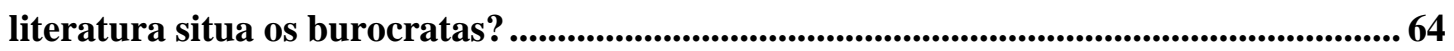

2.3. A ação dos burocratas: decisão e mudança institucional .......................................... 77

2.4. A decisão em arranjos institucionais complexos: coordenação intragovernamental e interação sócio-estatal .................................................................................................................... 93

2.5. Itamaraty: uma organização burocrática clássica e seus desafios contemporâneos

2.6. Definição das hipóteses com base na literatura pertinente.......................................... 115

Capítulo 3: Trajetórias institucionais da política migratória brasileira e do Ministério das Relações Exteriores na República: acomodações mútuas ......................................... 120

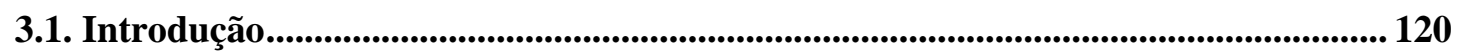

3.2. Definindo conceitos: Brasil, nacionalidade, cidadania (1889-1919)........................... 125

3.3. Das fronteiras externas às fronteiras internas: regulando a cidadania..................... 151

3.4. Securitização das fronteiras, trincheiras de direitos e permeabilidade econômica 185

3.5. Lei 6.815, de 1980: Estatuto do Estrangeiro .......................................................... 206

3.6. Considerações finais............................................................................................................ 211

Capítulo 4: Incrementalismo e burocracias: ação e reação na política migratória

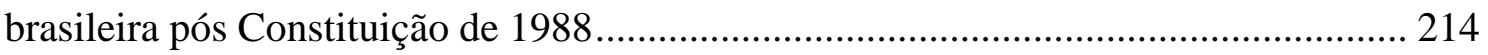

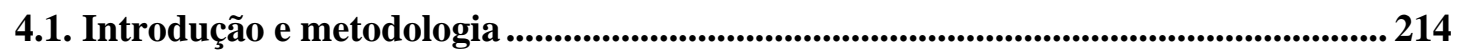

4.2. Contexto e formação de agendas: a questão se desenha ............................................. 219

4.3. Construção de capacidades estatais................................................................................. 229

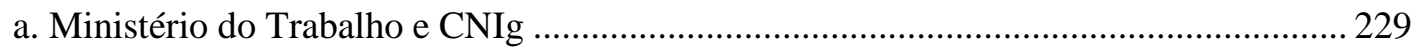

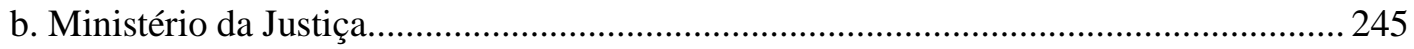

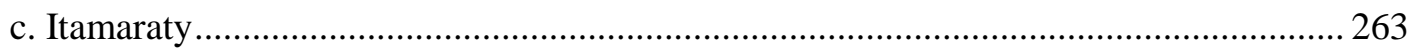

4.4. Multilateralismo e integração regional: moldando e disputando o internacional.. 275

4.5. Projetos de Lei ....................................................................................................................... 296

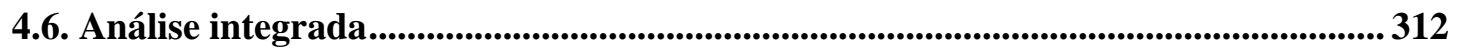

Capítulo 5: O Executivo em interação: arranjos de coordenação na política migratória brasileira 


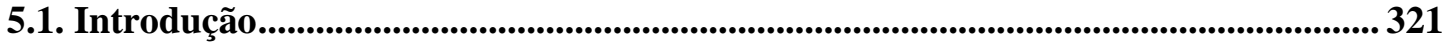

5.2. A política e os burocratas: o alarme da crise - Haitianos no Brasil........................... 322

5.3. A política e os burocratas: implementando uma plataforma de governo - Programa

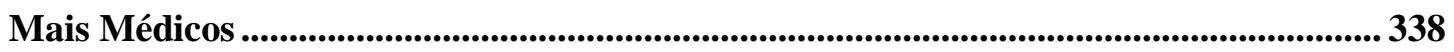

5.4. Os burocratas e a política: arranjos de coordenação horizontal ................................ 345

5.5. Análise integrada........................................................................................................................ 355

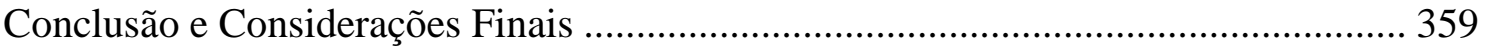

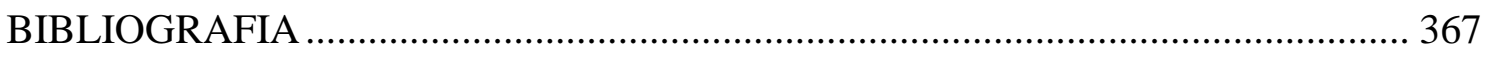

ANEXO 1 - Lista de entrevistados no trabalho de campo .......................................... 394 


\section{INTRODUÇÃO}

No início do século XXI, as migrações internacionais passaram a ocupar o epicentro da agenda política e social global. Segundo estimativas da ONU, havia, em 2015, um total de 244 milhões de migrantes internacionais no mundo (ONU, 2016). O número corresponde a cerca $3,3 \%$ da população mundial, percentual que não sofreu alterações significativas desde 1995. Não obstante esta constância percentual, os valores absolutos revelam um aumento de 91 milhões de migrantes entre 1990 e 2015, o que equivale a um crescimento de $60 \%$. Nesse contexto, a mobilidade se mostrou marcada por características acentuadamente conflituosas - tanto do ponto de vista dos conflitos nos territórios deixados, quanto da securitização das fronteiras de transposição almejada.

Por conseguinte, uma das peculiaridades do fenômeno migratório contemporâneo é sua elevada politização, seja no debate político doméstico, seja no internacional (CASTLES; MILLER, 2003). Outros elementos igualmente o particularizam: o maior número de países envolvidos nos fluxos migratórios (CASTLES; MILLER, 2003); a inserção dos indivíduos em redes de comunicação e relações de produção de ordem global (FARIA, 2015); o elemento transnacional das redes de migrantes (SCHILLER et al., 1992); a diversificação dos fluxos, compreendendo refúgios, deslocamentos ambientais, migrações temporárias e de longas duração. Percebe-se, ainda, a diversificação do papel exercido por cada país no contexto das migrações internacionais, com muitos deles se descobrindo, simultaneamente, pontos de origem, trânsito e destino de fluxos migratórios.

Dentre estes países se encontra o Brasil. Seu saldo migratório negativo ${ }^{1}$ ostentado entre as décadas de 1980 e 1990 iniciou movimento de reversão e aproximouse de zero entre 2000 e 2010 (CAMPOS, 2011), tendência que se reforçou nos anos seguintes. Dados da Polícia Federal apontam que o número de registros anuais de imigrantes aumentou $160 \%$ entre 2006 e 2015, quando atingiu 117.745 novos registros ${ }^{2}$. Entre os anos 2010 e 2015, os trabalhadores imigrantes aumentaram em $131 \%$ a presença no mercado de trabalho formal, passando de $54.333 \mathrm{em} 2010$ para $125.535 \mathrm{em}$ 31 de dezembro de 2015 (CAVALCANTI et al., 2016). As solicitações de refúgio

\footnotetext{
${ }^{1}$ Maior saída de nacionais do que entrada de estrangeiros.

2 Dados da Polícia Federal, disponibilizados via Lei de Acesso à Informação.
} 
cresceram 2.868\% entre 2010 e 2015: passaram de 966, em 2010; para 28.670, em 2015 (CONARE, 2016).

Esta conjuntura foi aprofundada e ressaltada pelo fluxo de haitianos que, entre 2010 e 2015, trouxe cerca de 80 mil migrantes ao território brasileiro, segundo estimativas da Secretaria Nacional de Justiça (SNJ, 2016). A ampla cobertura midiática sobre a questão e o envolvimento de uma pluralidade de atores governamentais dos diversos níveis federativos, além de organizações da sociedade civil, acentuaram a politização das migrações no debate público. Nesse contexto, evidenciou-se uma questão mais ampla: a de uma legislação nacional obsoleta embasando uma política migratória casuística.

O conceito de migrações internacionais abrange processos sociais plurais, com características e implicações políticas distintas, mas que convergem no ponto de referirem-se a indivíduos que, ao cruzarem fronteiras nacionais no intuito de estabelecerem residência, ainda que temporariamente, experimentam o acúmulo ou a modificação de suas cidadanias. Dentro deste amplo fenômeno, o direito internacional acolheu uma distinção básica: aquela entre o migrante voluntário, frequentemente referido como migrante laboral, e o refugiado, indivíduo que se desloca de seu país de nacionalidade em razão de fundados temores de perseguição por motivos de raça, religião, nacionalidade, grupo social ou opiniões políticas; ou por violações graves e generalizadas de direitos humanos - conceito adotado pela Lei $n^{\circ} 9.474 / 1997$, a Lei de Refúgio. Outra categoria mobilizada no cenário internacional é a de migrante irregular, a qual diz respeito ao indivíduo que entra ou permanece no território de um país sem atender às condições legais previstas.

A política migratória utiliza as capacidades institucionais do Estado para, de diferentes formas, intervir nos fluxos de entrada e saída de pessoas em seu território, bem como na integração dos que nele adentram à sua comunidade nacional. Aceitar refugiados mais ou menos amplamente; estabelecer regras de entrada ou de saída restritivas; recrudescer a securitização das fronteiras; restringir o acesso à nacionalidade ou aos direitos políticos; implementar programas de integração e de combate ao racismo e à xenofobia constituem atos eminentemente políticos: consagram determinados interesses em detrimento de outros. Essa acomodação de interesses pode ocorrer dentro da própria estrutura do Estado ou ainda entre diferentes Estados, visto que parte das 
dimensões políticas envolvidas refere-se a dissensos sobre o significado das fronteiras (REIS, 2004).

Em influente trabalho para a teoria das migrações internacionais, Aristides Zolberg (1999) afirma que as políticas de migração seriam historicamente moldadas, de um lado, pelas dinâmicas do capitalismo global e do sistema internacional, e de outro, pela conjuntura da dinâmica populacional. Não obstante, prossegue Zolberg, seriam as instituições políticas e os atores políticos domésticos que mediariam estas forças e as traduziriam em políticas migratórias. Em consequência, em uma abordagem política das migrações internacionais traz-se o Estado para seu estudo, examinando duplamente como as migrações influenciam o Estado e como o Estado influencia as migrações.

$\mathrm{Na}$ esteira de autores como Zolberg, assume-se que entender a política migratória demanda investigações sobre a agência estatal e seus mecanismos (HOLLIFIELD; WONG, 2015), os quais, segundo Martin Schain (2008), possuem um caráter dinâmico:

State agency is dynamics and changing, and knowing how it changes is part of understanding the politics of immigration. We need to understand not simply variations in state policy over time and across space but also the process through which policies change (SCHAIN, 2008, p.5).

O Estado, porém, não é uma entidade una e coesa. Ao contrário, compreende relações de poder entre diferentes atores, por vezes no interior do próprio Executivo. Tais relações de poder são verificadas nos âmbitos intraorganizacional e interorganizacional, implicando em mobilização de recursos institucionais variados para consecução de interesses determinados, os quais podem dizer respeito a mudanças ou perpetuação de uma certa instituição.

Internamente, da admissão do imigrante no território à sua eventual naturalização, as políticas de migração dos países variam em inúmeros aspectos. Esta variação entre resultados políticos é proveniente de um processo institucionalmente enquadrado no qual, potencialmente, tomam parte diversos atores, dadas as consequências transversais suscitadas pela questão em diferentes áreas de políticas. No caso do Brasil, a própria distribuição de competências legalmente estabelecida reflete esta transversalidade: são protagonistas na implementação e formulação da política migratória o Ministério da Justiça (MJ), o Ministério do Trabalho (MTE) e o Ministério das Relações Exteriores (MRE), além da Polícia Federal - atrelada ao MJ, porém com autonomia resguardada. Ademais, o Conselho Nacional de Imigração (CNIg) e o 
Comitê Nacional de Refugiados (CONARE) participam da tomada de decisão concernente, respectivamente, à política para população imigrante e àquela para refugiados, confirmando uma tendência do arcabouço institucional do Executivo brasileiro a prever órgãos colegiados para lidar com temáticas transversais.

Nesse contexto, a primeira questão de pesquisa que norteia a presente tese é a de quais consequências a fragmentação de competências engendra para a política migratória no Brasil. Ressalte-se que, do fato de examinarem-se as variações na política migratória de um país específico, a ênfase recairá sobre mudanças observadas longitudinalmente nesta política pública. Em decorrência de características do objeto de estudo, sobre o qual existe uma peculiar dificuldade de reunir dados, serão analisadas as mudanças institucionais qualitativamente observadas, e não indicadores de resultados da implementação política. Nesse quadro, encara-se a mudança institucional como um processo no qual distintos atores tomam parte e interagem, potencialmente alterando a balança de poder entre eles observada.

Além das interações intraestatais, o Estado tenderá a se relacionar com outros Estados no processo político migratório. A dimensão internacional das migrações se fundamenta no próprio ato de transpassar fronteiras por indivíduos que carregam vínculos de nacionalidade distintos daquele da comunidade de destino. Essa ação, no sistema internacional westfaliano, tem potencial de repercutir na relação entre Estados, provocando seus aparatos consulares e diplomáticos. No século $\mathrm{XX}$, as relações internacionais sobre o tema atingem arenas multilaterais, e assumem novas feições em instâncias regionais. Contudo, não foi criada organização multilateral com mandato específico e abrangente sobre as migrações até o presente, o que, somado à escassez de normas vinculantes, suscita questionamentos sobre se há um regime internacional de migrações.

Nesse contexto, quais as características da zona cinza entre o doméstico e o internacional (ZOLBERG, 1981; TEITELBAUM, 1984; WEINER, 1985) na qual se situa a política migratória? Em um quadro de análise de políticas públicas, a pergunta pode ser reformulada nos seguintes termos: como as arenas internacional e doméstica se influenciam mutuamente no processo político migratório? Trata-se da segunda questão de pesquisa desta tese. Tal como a primeira questão, esta tenciona contribuir para a análise da política pública, nela inserindo o elemento internacional como potencial 
variável explicativa. Diferentemente da primeira, porém, exige a mobilização de conceitos e abordagens das relações internacionais.

Por último, observa-se que a formulação e implementação da política migratória brasileira se dá em um contexto de arranjo institucional complexo, isto é, compreendendo diferentes relações estabelecidas em uma teia ampla de atores não apenas do Executivo, mas também da sociedade civil, setor privado e sindical, organizações internacionais, membros do Legislativo e do Judiciário. Dessa observação emerge a terceira questão de pesquisa: como os diferentes atores governamentais que tomam parte na formulação e implementação da política migratória brasileira coordenam suas atividades em um arranjo institucional complexo?

De maneira a enfrentar as mencionadas questões de pesquisa, esta tese se debruça sobre a política migratória brasileira no período de janeiro de 2003 a maio de 2016. O intervalo temporal foi delimitado de maneira a possibilitar um maior acesso à pesquisa empírica, particularmente a entrevistas com atores diretamente envolvidos nos processos políticos. Ademais, por corresponder aos mandatos presidenciais de Luís Inácio Lula da Silva (2003-2010) e Dilma Rousseff (2010-2016), ambos do Partido dos Trabalhadores (PT), o período permite controlar para a variável partidária da Presidência da República. Por este motivo, o marco temporal final é a entrada em exercício do presidente interino Michel Temer (PMDB), em 12 de maio de 2016.

Por política migratória, entende-se aqui a política referente à entrada e estada de migrantes voluntários ${ }^{3}$. Não abarca, portanto, a política para refugiados e a política de combate ao tráfico de pessoas. Esse recorte tem fundamentos empíricos, tendo em vista as distintas instituições domésticas e internacionais relacionadas a cada um dos campos; e principalmente analíticos, mirando alcançar um adequado rigor metodológico. Sem embargo, reconhece-se nesta tese a conexão e interdependência entre as três políticas, todas elas influenciadas pela norma geral que estatui o regime jurídico do imigrante. Ademais, como observa Mitchell (1989), a classificação como migrante laboral ou refugiado não configura uma categoria natural mas sim política, constituindo objeto de

\footnotetext{
3 A nomenclatura "migrantes voluntários" está sujeita a críticas, sob argumento de que se refere a indívuos que, muitas vezes, migram por razões de subsistência e não por opção. Concordamos com a justificativa, porém consideramos que o termo é menos restritivo do que aquele, também presente na literatura, de "migrações laborais". Como a intenção é diferenciar do instituto do refúgio, definido pela saída do território de origem em razão de perseguição ou violação de direitos humanos, e do tráfico de pessoas, consideramos que o adjetivo voluntário é adequado, embora com as ressalvas mencionadas.
} 
debates e processos políticos, o que deve ser levado em conta nas pesquisas sobre o tema.

Durante o período analisado nesta tese, a política migratória brasileira esteve ancorada em diplomas promulgados ainda pelo presidente João Figueiredo: a Lei $\mathrm{n}^{\circ}$ 6.815, de 1980 (Estatuto do Estrangeiro) e, regulamentando-a, o Decreto $\mathrm{n}^{\circ}$ 86.715, de 1981. Tais normas refletem os valores de segurança e proteção do trabalhador nacional caros ao regime militar, harmonizando-se ainda com dispositivos da Consolidação das Leis Trabalhistas (CLT), vigente desde $1943^{4}$. Entre suas promulgações e o presente, além dos novos desenhos do fenômeno migratório mencionados, mudanças significativas ocorreram no contexto doméstico do país, incluindo a transição democrática e a adoção da Constituição de 1988, bem como nas suas relações internacionais, sugerindo uma nova configuração de demandas sobre o tema. Em resposta a esta conjuntura fática e normativa, a política migratória experimentou o contraste de não ter sido reformada, mas ter passado por mudanças incrementais adstritas aos limites impostos pela obsoleta legislação.

Um elemento central dessas mudanças incrementais é o fato de serem conduzidas majoritariamente pelo poder Executivo e de terem em burocratas de médio escalão importantes protagonistas. Nesse contexto, o objetivo geral desta tese consiste em entender as mudanças e continuidades na política migratória brasileira a partir da dinâmica político-burocrática interorganizacional verificada no poder Executivo.

Subjaz a este objetivo geral o intuito específico de contribuir para o avanço na compreensão das relações verificadas entre diferentes atores no interior do Executivo no processo de formulação e implementação de políticas públicas. O trabalho busca, assim, somar ao conjunto de estudos que, partindo da constatação de que "The great bulk of government, however, is composed of bureaucratic agencies-unexciting as this may sound-and they are designed and adopted by public officials who make decisions under prevailing rules of the game" (MOE, 2005, p.218), focam nas agências burocráticas a fim de entender como funciona o poder Executivo. Em contextos democráticos, entende-se que os burocratas operarão em constante coordenação de valores com outros atores, sejam eles estatais ou sociais, envolvidos no processo político. Nesse quadro, de acordo com Lotta,

\footnotetext{
${ }^{4}$ Do seu artigo 352 ao 358 , a CLT disciplina a obrigatoriedade para as empresas de guardar uma proporção de $2 / 3$ de trabalhadores brasileiros.
} 
(..) as burocracias passam a ser vistas como sistemas abertos que respondem a pressões ambientais e externas que, por sua vez, precisam competir com outras formas de pressões internas e externas, bem como com os valores e procedimentos da própria burocracia (2003, p.29).

Três burocracias dividem o protagonismo na política migratória brasileira: a do Ministério da Justiça, do Ministério do Trabalho e do Ministério das Relações Exteriores. Uma análise endógena do funcionamento do Executivo brasileiro em temática migratória deve examinar em profundidade a atuação dessas três organizações e sua interação. No entanto, o foco é dirigido para o Itamaraty no estudo da trajetória histórica da política migratória brasileira, por motivo de constituir uma forte linha de continuidade no Estado administrativo, e na análise da mediação entre os ambientes doméstico e internacional.

Com efeito, o segundo objetivo específico do trabalho é mapear mecanismos de influência mútua entre os ambientes doméstico e internacional. Busca-se identificar como elementos do sistema internacional afetam a formulação e implementação da política pública, e como este processo político pode influenciar a política externa. Nesse ponto, procura-se observar a interação do Itamaraty com outros atores estatais e nãoestatais, o que conduz ao terceiro objetivo específico desta tese: analisar a coordenação intragovernamental em um contexto de arranjos institucionais complexos.

Percebe-se a existência de uma lacuna nas pesquisas acerca da coordenação intragovernamental na produção de políticas públicas no Brasil, acentuada no caso da participação do Itamaraty (FARIA et al., 2012), o que parece advir do frequente diagnóstico de insulamento burocrático da instituição (LIMA, 1994, 2000; PINHEIRO, 2004; FARIA, 2012). Perseguir os objetivos geral e específicos desta tese significa, pois, inserir o Ministério das Relações Exteriores dentro do contexto do Executivo brasileiro, observando suas particularidades em interação com outras burocracias que "não raro têm interesses e métodos diversos daqueles da diplomacia do país" (FARIA et al., 2012, p.173).

É o enfoque institucional que possibilitará o acento no papel que os burocratas e as estruturas organizacionais exercem sobre resultados políticos. Como coloca Sikkink (1993), o instrumental teórico fornecido pelas abordagens institucionalistas permite examinar o Estado em seu funcionamento concreto, com as estruturas, instituições e procedimentos envolvidos nas políticas resultantes. Ressalte-se que as perspectivas institucionalistas mais recentes raramente concentram nas instituições todo o poder de 
influência na política: procuram, alternativamente, inseri-las em uma cadeia causal complexa em que operam junto a outros fatores de causação.

Constata-se ainda em estudos institucionalistas mais recentes a opção por realizar intercâmbios entre as diferentes tradições da abordagem, visando a lançar luz sobre as dificuldades de cada uma delas (HALL; TAYLOR, 2003; HALL, 2010). Como exemplificam Hall e Taylor sobre análises históricas que empreendem tal caminho,

(...) à maneira dos teóricos da escola da escolha racional, elas mostram como os atores históricos selecionam novas instituições com um objetivo instrumental, mas o fazem a partir de uma lista de alternativas historicamente determinadas por mecanismos que o institucionalismo sociológico descreve (2003, p.222).

Nesses termos, a pesquisa compartilha com o institucionalismo da escolha racional a visão de atores que interagem estrategicamente de maneira estruturada por instituições, as quais influenciam as alternativas possíveis na agenda e reduzem a incerteza quanto à atuação dos demais atores (HALL e TAYLOR, 2003). Entretanto, determinados indícios relativos à política migratória desencorajam a adoção de uma perspectiva puramente de escolha racional: trata-se de política pública que, em razão das diferentes dimensões sobre as quais engendra consequências, dificilmente pode ter suas decisões pensadas em termos de ótimo de Pareto ou outra solução matemática. Ademais, no caso brasileiro, a perspectiva principal-agente sobre a representação política (DOWNS, [1957] 1999) não se verifica - os políticos não teriam incentivos para promover os direitos dos imigrantes, posto que seu apoio não se transmudaria diretamente em votos em razão de não se conferirem a esta parcela da população direitos políticos. Por último, uma abordagem puramente racional não se adequa a uma perspectiva do processo político como uma dinâmica interativa entre a formulação e a implementação. Isso porque, como coloca Labra, "Mesmo se fosse possível formular uma política 'racional', esta não sobrevive aos problemas da implementação. A segmentação das burocracias implica visões muito seletivas e parciais das políticas formuladas" (1999, p.161).

Estudos de implementação dirigem o foco para os burocratas, por vezes mediante a adoção de abordagens organizacionais. Essas tendem a observar padrões comportamentais e a investigar a dimensão cognitiva do impacto das instituições (HALL; TAYLOR, 2003), vinculando-se a tradições sociológicas. O quadro institucionalista organizacional oferece norte importante para este trabalho, o qual pode 
ser resumido na definição de instituições como "formal or informal rules, conventions or practices, together with the organizational manifestations these patterns of group behavior sometimes take on" (PARSONS, 2007, p.70). Entretanto, esta tese não se reveste do caráter interpretativista frequentemente observado em investigações que aderem à abordagem. Ao contrário, objetiva o mapeamento de regularidades empíricas e nexos causais. Além disso, os estudos organizacionais se centram em dinâmicas intraorganizacionais ou mesmo interorganizacionais afetas a um processo político, porém tendem a não enquadrá-las no contexto mais amplo do funcionamento do Estado. Esta tese, por seu turno, volta-se ao estudo do processo político intermediando instituições e uma política pública, remetendo-se, em suas explicações, ao Estado e às relações de poder que o perpassam.

O institucionalismo histórico, com sua ênfase na dinâmica de relações de poder que atravessam o Estado, permite incorporá-la ao estudo das burocracias. Ademais, toda abordagem institucionalista tem, no limite, um fundamento histórico, visto que parte da afirmação de que instituições, uma vez estabelecidas, tendem a perdurar - seja em decorrência de um equilíbrio em termos de Nash, seja por convenções sociais ou como resultado da trajetória. No institucionalismo, as ações se verificam em relação a regras e práticas que as precedem, que servem como nortes ou limites a partir dos quais se pensa a inovação. Entretanto, a ênfase na dependência da trajetória observada nos trabalhos institucionalistas históricos dificulta o enquadramento de mudanças incrementais, particularmente da agência a empreendê-las. Desta maneira, este estudo não se remete a mecanismos afetos à trajetória temporal como fundamento explicativo de sua hipótese.

$\mathrm{Na}$ presente tese, a abordagem institucionalista se intersecta com a análise de políticas públicas ${ }^{5}$. Atenta-se especialmente a duas diretrizes teóricas dessa última: a primeira é resumida na célebre frase de Lowi, segundo a qual "policies determine politics” (1972, p.299). Entende-se que as características da área de questões (issue area) migratória engendram particularidades quanto à influência dos diversos atores em seu desenho. Nesse sentido, para compreender os resultados políticos, importa examinar as características daquela política, os jogadores que nela tomam parte e as regras do

\footnotetext{
${ }^{5}$ Para Wanderley Guilherme dos Santos (1979), “em realidade, a análise de políticas públicas não consiste em nada mais do que um rótulo novo para o vetusto exercício de investigação e formulação de teorias sociais. Melhor dizendo, a análise contemporânea de políticas públicas trata, precisamente, da temática clássica das teorias sociais - a distribuição do poder, o papel do conflito, os processos de decisão, a repartição de custos e benefícios sociais por exemplo, somente com a diferença de atentar, com maior cuidado, para a necessidade de demonstrar, ao contrário de apenas presumir ou imputar, a plausibilidade de suas hipóteses" (1979, p. 13-14).
} 
jogo. Visando a este objetivo, uma revisão da literatura em política migratória e, mais amplamente, em teoria das migrações internacionais será realizada.

Uma das características da área de questões migratória é sua permeabilidade a fatores internacionais, motivo pelo qual o estudo recorrerá a modelos teóricos das relações internacionais. Para tanto, empregará conceitos da literatura de análise de política externa e de regimes internacionais. A análise de política externa (APE) foi abordagem adotada em virtude das possibilidades que oferece de criar pontes com a análise de políticas públicas, fundamentadas em seu foco na agência, segundo o qual "all that occurs between nations and across nations is grounded in human decision makers acting singly or in groups" (HUDSON, 2005, p.1). Quanto à teoria dos regimes internacionais, é mobilizada porque, uma vez pressuposto que a gestão das migrações internacionais implica em interações entre Estados, importa perquirir quais instituições, se existem, regem internacionalmente esta relação.

Outra orientação teórica da análise de políticas públicas particularmente central para esta tese é a que considera a política pública como um processo, observando como interativas e simultâneas as fases que, no modelo do ciclo de políticas, são compartimentadas. Notadamente, a interface entre a formulação e a implementação corresponde à zona de atuação dos burocratas de médio escalão, e dela provêm os resultados políticos aqui analisados.

A hipótese geral deste trabalho é a de que, na política migratória brasileira, o desenho institucional caracterizado por fragmentação e sobreposição de competências conduz a que organizações realizem mudanças incrementais setoriais na política, por meio do aumento de suas capacidades técnico-administrativas e político-relacionais. Entretanto, em razão de mecanismos relativos aos objetivos de manter seu espaço de poder e lógica de ação organizacional, tais organizações tenderão a opor obstáculos a reformas mais amplas.

Assume-se que tais organizações possuem o autointeresse da autonomia organizacional, do qual deriva o duplo mecanismo de aumento das capacidades estatais e de salvaguarda do espaço de poder e da lógica de ação. Entende-se, ainda, que as organizações são formadas por dirigentes políticos e burocratas públicos, agentes que empreendem os mecanismos teorizados. Dentre esses burocratas, destaca-se o papel exercido por aqueles de médio escalão. 
Argumenta-se, pois, que dirigentes políticos e burocratas de médio escalão buscam influenciar os resultados políticos de acordo com suas agendas, as quais derivam das estruturas organizacionais em que estão inseridos. Nesse processo, lançam mão de determinadas estratégias, algumas das quais relacionadas à internacionalização da política. Nesse ponto, a tese testa a hipótese específica de que o elemento internacional é mobilizado pelos atores em três distintas maneiras: 1. Recurso ao regime internacional e a boas práticas internacionais como argumento legitimador; 2 . Recurso a organizações internacionais para obtenção de financiamento e expertise; 3. Disputas por protagonismo em espaços internacionais.

No entanto, a despeito de defender-se que os resultados políticos em migração refletem dinâmicas organizacionais de salvaguarda da autonomia institucional setorialmente observadas, entende-se que as organizações interagem no processo das políticas públicas. Nesse contexto, o trabalho examina, por último, a hipótese descritiva de que, no arranjo institucional complexo da política migratória brasileira, a coordenação intragovernamental abarca elementos de arranjos hierárquicos, de mercado e de redes, em que burocratas operam por meio de relações e trocas não previstas no desenho institucional formal e interagem, ainda, com atores não-governamentais.

Explicações sobre política migratória com foco na influência de elementos do sistema internacional, assim como aquelas enfatizando determinadas variáveis independentes políticas e econômicas domésticas, podem adotar uma perspectiva blackbox da formulação de políticas (IKENBERRY, 1988). Nelas, busca-se explicar os “efeitos-das-causas" (GOERTZ; MAHONEY, 2006), estimando-se os efeitos médios das variáveis independentes sobre os resultados e, por conseguinte, devotando menor atenção a como os fatores explicativos propostos moldam as políticas.

$\mathrm{Na}$ busca do "como", a presente pesquisa realiza um estudo de caso da política migratória brasileira, direcionando a ênfase para os mecanismos do processo político. Em um estudo de caso, observam-se os fatores que ligam causas a efeitos, e em quais condições o fazem (GEORGE; BENNETT, 2005), em exame aprofundado de uma única unidade no decorrer do tempo. Considera-se que a causalidade deve ser investigada não apenas a partir de efeitos causais, mas também de mecanismos causais:

(...) causal arguments depend not only on measuring causal effect. They also presuppose the identification of a causal mechanism. (...) $X$ must be connected with $Y$ in a plausible fashion; otherwise, it is unclear whether a pattern of covariation is truly causal in nature. The identification of causal 
mechanisms happens when one puts together general knowledge of the world with empirical knowledge of how X and Y interrelate (GERRING, 2004, p.348)

Um mecanismo causal corresponde a um sistema de partes interligadas e em interação que transmitem força causal entre X e Y (BEACH; PEDERSEN, no prelo). O process-tracing constitui instrumento metodológico adotado para desvelar tais mecanismos, examinando como uma condição $X$ contribui para produção de um resultado $\mathrm{Y}$ em um caso específico. Desta forma, o process-tracing se apresenta como opção metodológica para responder à questão de pesquisa aqui colocada.

Não obstante haver uma considerável variação na maneira com que os governos nacionais tentam intervir no fenômeno das migrações internacionais (MASSEY, 1999a), os estudos de caso sobre o tema se focam principalmente em países desenvolvidos caracterizados por regimes democráticos liberais consolidados, restando pendentes análises sobre democracias mais recentes, também destinos de migrações internacionais. Particularmente, percebe-se uma carência de pesquisas sobre como os países em desenvolvimento lidam com a questão (HUJO e PIPER, 2010), embora cerca de $42 \%$ do volume global de migrantes vivam nesses países (ONU, 2015). Muito embora os países desenvolvidos continuem recebendo os maiores afluxos populacionais, entre 1990 e 2015 a população migrante procedente de países do Sul global vivendo em outros países do Sul aumentou de 57 milhões para 90 milhões, o que corresponde a um aumento de 57\% (ONU, 2015). Em 2015, dentre os maiores corredores migratórios mundiais, apenas um possuía um país do Norte como destino (México - Estados Unidos), todos os demais abarcando fluxos sul-sul. Entre os migrantes internacionais residentes no Sul global, $87 \%$ provêm de outras regiões em desenvolvimento (ONU, 2015), um dado que sugere configurações peculiares de relações internacionais sobre o tema.

No entanto, a literatura sobre o impacto das relações internacionais na política migratória possui, em grande parte, foco nos Estados Unidos e nos países europeus, Estados que ocupam uma posição particular no sistema internacional por suas capacidades militares, econômicas e políticas. Mas como fatores internacionais afetam a ação de países periféricos em relação à política migratória? Como tais países, os quais frequentemente acumulam os caracteres de territórios de origem e de destino de migrantes, mobilizam a temática migratória nas arenas internacionais?

O estudo do caso brasileiro se direciona a fornecer elementos para suprir tais carências. Se, em comparação às demais disciplinas sociais, a ciência política despertou 
mais tarde para o estudo da migração (HOLLIFIELD; WONG, 2015), no caso brasileiro essa lacuna é ainda mais aparente. Uma das razões possíveis para isso seria o baixo percentual de imigrantes na sociedade brasileira - estima-se que apenas cerca de $1 \%$ da população brasileira seja composta de imigrantes ${ }^{6}$. No entanto, entre 2006 e 2015 o número de registros de imigrantes aumentou consistentemente. Ademais, trata-se de uma população com organizações ativas ${ }^{7}$ na reivindicação de suas agendas políticas, as quais compreendem tanto ações governamentais específicas para os imigrantes, quanto a consideração das particularidades deste público em políticas mais gerais, por exemplo, saúde e educação. Desta forma, como colocam Neide Patarra e Rosana Baeninger,

(...) a importância do fenômeno migratório reside hoje muito mais em suas especificidades, em suas diferentes intensidades e especialidades e em seus impactos diferenciados (particularmente em nível local) do que no volume de imigrantes envolvidos nos deslocamentos populacionais (2006, p.3).

De outro lado, esta tese se justifica também pela abordagem proposta. O estudo dos atores burocráticos no Brasil, particularmente sobre seu papel nos processos decisórios de políticas públicas, debruçou-se em muito sobre burocratas da área econômica, especialmente examinando a criação e evolução do Estado nacionaldesenvolvimentista (DRAIBE, 1985; GEDDES, 1994; EVANS, 1995; NUNES, 2010). Tal literatura buscou destrinchar as especificidades que assumem as relações entre burocracia e política no Brasil, o que se insere em um debate mais amplo sobre as relações entre Estado e sociedade. Entretanto, haveria especificidades da atuação burocrática em políticas relacionadas a direitos humanos? Em outras palavras, qual o papel das burocracias na produção das políticas de direitos humanos no Brasil?

Nesses termos, a tese se estrutura em cinco capítulos. O capítulo 1 se propõe a deslindar seu objeto: a política migratória, realçando as peculiaridades a ela inerentes em conformidade com a visão de que "policies determine politics" (LOWI, 1972, p.299). A ênfase é conferida aos elementos que são mobilizados pela literatura para explicar e classificar políticas de imigração determinadas, bem como às peculiaridades da abordagem da política migratória como política pública, destacando neste último ponto o papel exercido pelos burocratas. Além disso, o capítulo explora a interface entre

\footnotetext{
${ }^{6}$ Dados da Polícia Federal extraídos em 26 de novembro de 2016 e obtidos via Lei de Acesso à Informação apontam para 1.224.463 registros ativos de estrangeiros no Brasil naquela data. Entretanto, como se verá mais a frente, uma série de dificuldades gravita em torno de dados quantitativos que dizem respeito a imigrantes.

${ }^{7}$ Mapeamento realizado pela Prefeitura de São Paulo em 2016 aponta para a existência de 93 coletivos atuando em temática migratória na cidade, compreendendo associações de imigrantes ou organizações voltadas para a defesa de direitos de imigrantes (PREFEITURA DE SÃO PAULO, 2016).
} 
o nível doméstico e o internacional inerente à política e indaga sobre se há um regime internacional de migrações, de maneira a investigar possíveis constrições internacionais às instituições domésticas. Fornece, ainda, um mapeamento geral do intrincado xadrez institucional da política migratória brasileira, com suas regulamentações e agências competentes para formulação e implementação.

Delineado o objeto de estudo, o capítulo 2 procede à discussão do instrumental analítico adotado para responder à questão de pesquisa. Em uma abordagem institucionalista, o capítulo explora maneiras de analisar-se o Estado em ação e em interação: busca examinar o funcionamento interno do poder Executivo brasileiro e nele situar os burocratas, mapeando seu papel no processo de políticas públicas e nas mudanças institucionais, bem como localizando as interações por eles protagonizadas em um contexto de arranjos institucionais complexos. Em específico, explicita a inserção analítica da organização burocrática do Itamaraty dentro do contexto do Executivo brasileiro. Reunidas as ferramentas teóricas às peculiaridades do objeto de pesquisa, derivam-se as hipóteses a serem empiricamente testadas nos capítulos 4 e 5 .

O capítulo 3 examina a evolução histórica da política migratória no Brasil a partir da proclamação da República até a promulgação da legislação em vigor, Lei $\mathrm{n}^{\circ}$ 6.815/1980, de modo a mapear os diferentes arranjos institucionais assumidos por esta política e avaliar, particularmente, o papel neles exercido pelo Ministério das Relações Exteriores. Tal análise objetiva: (i) fornecer inferências descritivas sobre como as relações internacionais do Brasil, particularmente por meio da ação do Itamaraty, podem influenciar a política migratória do país; (ii) identificar padrões de relacionamento entre Estado e sociedade civil na temática, bem como movimentos de centralização e descentralização; (iii) contextualizar historicamente a partilha de competências em política migratória e a atuação dos diversos Ministérios na temática.

Os capítulos 4 e 5 esmiúçam o funcionamento interno do Executivo como arena de tomada de decisão em política migratória, testando empiricamente as hipóteses arroladas no capítulo 2. No capítulo 4, parte-se da análise da construção de capacidades estatais pelas três organizações envolvidas; examina-se a atuação brasileira em arenas internacionais; e, por último, analisa-se o processo de tentativa de reforma da Lei $\mathrm{n}^{\mathrm{o}}$ 6.815/1980. Já no capítulo 5 a ênfase é na coordenação intragovernamental, a qual será analisada sob dois prismas: a coordenação conduzida pela Casa Civil nos casos da vinda 
de haitianos para o Brasil e do programa Mais Médicos do governo federal, e a coordenação horizontal empreendida pelos próprios burocratas.

Percebe-se uma ênfase desta tese, particularmente verificada nos capítulos 3 e 4, em textos normativos. De fato, a abordagem institucionalista proposta favorece este direcionamento, o que é acentuado pelo fato da política migratória ser inerentemente um fenômeno jurídico: são estes textos que estabelecem as condições de outorga de direitos, e quais deles, aos estrangeiros.

Por último, duas observações merecem ser realizadas. A primeira delas é que, embora não adote metodologia quantitativa, este trabalho se remete em diversas oportunidades a dados estatísticos referentes a fluxos migratórios. Não obstante, é importante ressaltar a complexidade inerente aos dados relacionados a migrações, devido a: (i) dificuldades na mensuração da imigração irregular, realidade na qual se enquadram, segundo estimativas do PNUD de 2009, cerca de 50 milhões de pessoas no mundo (PNUD, 2009, p.23); (ii) variação das definições entre os países: algumas estatísticas se baseiam nas afirmações dos imigrantes de sua intenção de permanecer no país, outras realizam contagem dos passageiros que entraram pelas fronteiras, outras levam em conta documentos de identidade emitidos, dentre outros parâmetros; (iii) dificuldade de contabilização do retorno dos migrantes a seus países de origem; (iv) por vezes a nacionalidade é caracterizada pelo ponto de embarque e não pela naturalidade, além de determinados grupos apresentarem identidade nacional diferente daquela de seu país de origem. Para enfrentar estes problemas, demógrafos empregam determinadas técnicas de estimação demográficas baseadas no saldo entre a população observada e a esperada (CARVALHO e CAMPOS, 2006) ou na agregação de dados de distintos órgãos da Administração Pública (CAVALCANTI et al., 2016).

Em segundo lugar, ressalte-se que esta tese não analisa empiricamente a atuação da Polícia Federal na política migratória brasileira. De um lado, isso se justifica pelo fato do órgão não possuir atribuições de formulação política no tema. Contudo, trata-se de órgão com amplas atribuições de implementação, possuindo assento como membro observador no CNIg e exercendo advocacy sobre a temática em múltiplas arenas. Não se conseguiu, porém, realizar entrevista com os responsáveis pela Divisão de Cadastro e Registro de Estrangeiros do Departamento de Polícia Federal. Ademais, a instituição possui uma estrutura organizacional demasiadamente distinta das demais, motivo pelo qual se optou por não inseri-la na análise empírica. 


\section{Capítulo 1: As imigrações e suas políticas}

"É a reciprocidade, que na frase de Niboyet, "tem uma cabeça internacional, mas dois pés nacionais»" (VIANA FILHO, 1938, p. 118).

\subsection{Introdução}

O tópico 1.1. busca explicitar a interface entre doméstico e internacional encontrada na literatura sobre migrações, partindo das teorias das migrações internacionais, mostrando como o elemento político passa a ser nelas inserido, sublinhando quais fatores são elencados pela literatura para explicar políticas de imigração determinadas e como essas políticas costumam ser classificadas. O item ressalva, ainda, o elemento externo da política migratória, inserindo-a no contexto do sistema internacional e da política externa dos países.

Já o tópico 1.2. foca a política migratória sob o prisma de tratar-se de política pública, ressaltando as peculiaridades do seu processo político e o papel que nele assumem os burocratas. O item seguinte, por sua vez, indaga sobre se há um regime internacional de migrações: se as políticas migratórias se situam na interface entre o doméstico e o internacional, importa investigar as constrições internacionais às instituições domésticas. Por último, o ponto 1.4 mapeia o intrincado xadrez institucional da política migratória brasileira, com suas regulamentações e agências competentes para formulação e implementação.

\subsection{Das migrações internacionais às políticas migratórias nacionais}

A literatura sobre migrações internacionais costuma situar seu objeto na interface entre o doméstico e o internacional, mobilizando conceitos e instrumentais teóricos característicos de ambos os níveis. Ao se relacionarem com definições de limites territoriais e jurisdicionais, as migrações estão intrincadas com o próprio conceito de soberania estatal, em decorrência de que incitam debates sobre segurança nacional; desenvolvimento econômico e mercado de trabalho; identidade nacional. Por outro lado, ao se referirem ao transpassar de fronteiras, compreendem inerentemente negociações, regras e acordos internacionais; com interveniência de organizações 
internacionais e da sociedade civil internacional; e instam debates delicados tais como universalismo dos direitos humanos, interculturalismo e remessas financeiras.

A teoria das migrações internacionais mostra-se sensível a essa diversidade de aspectos, enfatizando um ou vários deles no intuito de explicar, precipuamente, por que ocorrem os deslocamentos populacionais. Dentre estudos das mais variadas disciplinas, pode-se fazer um recorte amplo entre abordagens que adotam uma visão top-down, focando em forças do mercado ou nas políticas migratórias; e aquelas com uma postura bottom-up, com ênfase nos indivíduos imigrantes, suas famílias e suas redes (BRETTEL; HOLLIFIELD, 2015). Essa divisão se intersecta com outra, qual seja, aquela entre estudos que propõem explicações sistêmicas, fundamentando-se seja em processos macroestruturais de reestruturação produtiva (e.g. PATARRA, 2011), nos sistemas estáveis de migração internacional (e.g. ZLOTNIK; KRITZ, 1992), ou na teoria transnacional ${ }^{8}$ (e.g. SCHILLER et al., 1992); e modelos de atração-repulsão (push-and-pull), prevendo que determinados países atrairiam migrantes por possuírem certas condições sociais, econômicas ou políticas satisfatórias, enquanto outros repeliriam seus cidadãos por apresentarem-nas avessas.

Os modelos push-and-pull correspondem a uma importante parcela dos estudos sobre migrações internacionais, boa parte dos quais se fundamentam em argumentos econômicos, por vezes em uma perspectiva que analisa as diferenças entre a oferta e a demanda de mão-de-obra dos países; outras vezes baseados no cálculo individual de custos e benefícios que impeliria o indivíduo ao deslocamento (e.g. BORJAS, 1990; FREEMAN, 1998; BOMMES; GEDDES, 2000). Porém não apenas na economia se buscaram identificar fatores que desencadeassem fluxos migratórios ou que explicassem sua continuidade no tempo e espaço. Fatores de atração de ordem política são levantados, por exemplo, por Hollifield (apud HOLLIFIELD; WONG, 2015), ao medir a influência de mudanças da política migratória, aumentando ou restringindo direitos dos imigrantes, sobre o fluxo imigratório. Estudos de fatores push-and-pull associados à sociologia e antropologia podem, ainda, enfatizar fatores sociais de atração, como redes migratórias formadas entre os indivíduos que já migraram e os potenciais imigrantes ou a existência de rotas agenciadas por atores privados - designados como coiotes.

\footnotetext{
${ }^{8}$ Referindo-se aos padrões migratórios que compreendem a formação de redes, a execução de atividades e o desenvolvimento de padrões de vida que englobam tanto as sociedades de origem quanto as receptoras.
} 
Perceba-se, porém, que em um contexto no qual a oferta de imigrantes é maior que a demanda, tal como se verifica em diversos países, os modelos push-pull se tornam problemáticos por sua dificuldade em avaliar efeitos das forças de tração recíprocas exercidas pelos fatores de atração de determinados países em contraponto aos fatores de repulsão de outros países. Em outras palavras, como esses fatores se influenciam reciprocamente e podem ser contrapesados?

Ademais, autores como Massey (1999a) e Zolberg (1999) ressalvam que as explicações baseadas em modelos de atração e repulsão tenderiam a descuidar do caráter político do fenômeno migratório. Para os autores, as regulações impostas pelas políticas migratórias, o processo político de sua construção, suas variações históricas e espaciais e os interesses fundamentando-as costumariam não ser levados em conta nesses estudos sobre migrações internacionais. Em resposta, Zolberg (2006) define a migração internacional como um processo político, caracterizado por regulamentar tanto o trânsito de pessoas através de fronteiras soberanas, quanto as modificações de diversos status de pertencimento oriundas deste fato:

[A migração internacional é] an inherently political process, and the relevant policies encompass not only the regulation of outward and inward movement across state borders - including of persons who are not, or declare that they are not, migrants - but also rules governing the acquisition, maintenance, loss, or voluntary relinquishment of "membership" in all its aspects political, social, economic, and cultural (2006, p.11).

Nesse mesmo sentido, Abdelmalek Sayad complementa que pensar a imigração significaria pensar o Estado, e exigiria, portanto, a mobilização de categorias políticas. (SAYAD, 1998, p.6). Dentre tais categorias, sobressái a de soberania. O Estado enquanto forma de organização do poder típica do sistema westfaliano tem no território e na soberania interna e externa seus traços distintivos, os quais lhe conferem a prerrogativa de decidir sobre o transpassar de suas fronteiras por indivíduos. A cidadania nacional é o pressuposto normativo sobre o qual se fundamentam e se constroem as práticas soberanas nas fronteiras ${ }^{9}$ : o Estado delimita a comunidade política no seu interior com base na nacionalidade, e desta maneira estabelece jurídica e conceitualmente as fronteiras entre o cidadão e o estrangeiro (VENTURA, 2013). Nesse sentido, Brubaker (1992) defende a investigação da concepção não apenas de Estado, mas também de nação, de maneira a desvendar os fundamentos da política migratória.

\footnotetext{
${ }^{9}$ Ventura (2013), no âmbito da teoria política, empreende uma minuciosa explanação da construção dos elos entre fronteiras, Estados e direitos nacionais.
} 
A relação entre migrações e soberania suscita, também, análises sobre suas contradições: autores como Freeman (1998) e Arango (2007) salientam a assimetria, verificada nas democracias liberais, entre a abertura de fronteiras para a livre circulação de bens, capitais e informações; e seu fechamento para a mobilidade humana. Ademais, as práticas de exceção observadas nos limites fronteiriços, isentas do controle democrático e de garantias constitucionais como presunção de inocência e devido processo legal, assumem dimensões distintas em se tratando de indivíduos ou mercadorias: aqueles que ultrapassam fronteiras, na formulação de Salter (2006), estão sujeitos à lei, mas não são sujeitos na lei ("subject to the law, but not subject in the law", p.10).

Dado o caráter internacional das migrações e as dimensões interna e externa da soberania, trazer o Estado para o estudo das migrações implica em analisar o Estado em interação, contextualizando-o em suas relações internacionais, e o Estado em ação, analisando suas políticas públicas. Zolberg (1981), Teitelbaum (1984) e Weiner (1985) foram pioneiros em relacionar migrações com relações internacionais, inserindo o tópico no contexto de uma disciplina predominantemente voltada para questões de alta política. A expectativa de inter-relação entre política migratória, relações internacionais e política externa se arrima em indícios diversos: a política internacional tem potencial para afetar a migração internacional; as migrações são objeto de interação entre Estados, por meio de acordos bilaterais ou multilaterais; as iniciativas de integração regional compreendem discussões e possível implantação de zonas de livre circulação de pessoas; a gestão das áreas de fronteiras implica em negociações interestatais; as migrações envolvem remessas financeiras que movimentam somas importantes ${ }^{10}$ globalmente; dentre outros fatores.

A abordagem da teoria das relações internacionais sobre as migrações fornece diversificados instrumentos para compreender as políticas aplicadas aos movimentos de pessoas. Observe-se que a visão realista clássica da disciplina, descrita por Morgenthau (2003, [1948]) como política de poder entre entidades soberanas, dificulta que o nível de análise seja direcionado ao indivíduo. Não obstante, a partir da lógica realista da soberania, o pressuposto do dilema de segurança é assumido em muitos estudos que

\footnotetext{
${ }^{10}$ Segundo dados do Banco Mundial, o total de remessas para países em desenvolvimento, em 2011, foi de US\$ 372 bilhões (apud FARIA, 2015, p.58)
} 
observam a política migratória como uma questão de segurança nacional (e.g. WEINER, 1985), atraindo o tema para o âmbito da high politics.

Abordagens transnacionais como a de Rosenau (1990), ao argumentarem estar em andamento um processo de individualização no sistema internacional ante a transferência de parte da autoridade dos Estados para outros atores, permitem direcionar o foco para os indivíduos que ultrapassam fronteiras - inclusive relativizando, em um juízo normativo, o sentido das fronteiras. Já em uma perspectiva liberal, instituições internacionais e a interdependência complexa são a chave para explicar o comportamento dos Estados no sistema internacional (KEOHANE; NYE, 2001), conceitos aptos a instrumentalizarem a análise da influência das relações internacionais nas políticas migratórias. Unindo elementos dos dois quadros teóricos, Yasemin Soysal (1999) sugere que, desde o pós-guerra, se verificaria a emergência de um regime de direitos humanos que ultrapassa a cidadania fundamentada na lógica do Estado-nação, caracterizado por direitos universalistas e pós-nacionais, os quais se estenderiam, portanto, aos imigrantes ${ }^{11}$.

Por sua vez, a análise de política externa se diferencia enquanto subcampo das Relações Internacionais por buscar no plano doméstico, particularmente nos processos decisórios que nele se desenrolam, explicações para o comportamento dos Estados no plano internacional. A incoporação causal da dimensão doméstica se faz desvelando a caixa preta do Estado e afirmando o poder do agente nas escolhas daquele (PINHEIRO; MILANI, 2012), sem atribuir aprioristicamente as decisões de política externa a um único indivíduo ou instituição (HUDSON, 2005). Nesse sentido, Milner (1997) aponta que, para identificar e mensurar o peso dos arranjos institucionais domésticos na ação internacional do país, seria necessária uma análise minuciosa das competências, limites e funcionamento dos atores do Executivo e Legislativo em processos de tomada de decisão relacionados a questões internacionais. Dessa perspectiva, a análise da influência mútua entre migrações internacionais e política externa passaria pelo exame dos atores envolvidos na formulação e execução da última, dos quais os mais relevantes seriam os Ministérios das Relações Exteriores.

\footnotetext{
${ }^{11}$ Em sua perspectiva institucional sociológica, Soysal (1994) argumenta que as políticas de imigração de países da Europa e da América do Norte foram adotadas não por imperativos de funcionalidade, mas em aderência a determinados aspectos do regime internacional de direitos humanos que revestiram de legitimidade tais opções políticas, em detrimento de outras, para as autoridades nacionais.
} 
De um lado, seus membros constituem atores naturais de gestão da política migratória: o corpo consular é opção lógica para as atribuições de conferir vistos e de prestar serviços documentais a seus emigrantes, dada sua capilaridade mundial; e ao corpo diplomático cabe a negociação de regras bilaterais e multilaterais sobre movimento de pessoas, bem como dialogar com organizações internacionais e participar dos foros multilaterais sobre o tema. Além disso, o órgão responsável pelas relações exteriores pode prestar uma assistência mais ampla a seus nacionais no exterior, tendo potencial para intensificar as ligações dos migrantes com seus países de origem.

Ressalta da interação diplomática sobre o tema a relevância do princípio da reciprocidade: o paralelismo entre o tratamento dado a estrangeiros em um país e aquele recebido por seus nacionais do exterior. Princípio histórico do direito público, a reciprocidade é utilizada como argumento legitimador de retorsões também em temática migratória. No entanto, sua aplicação nessa seara levanta dificuldades relacionadas à heterogeneidade entre os países, particularmente entre aqueles majoritariamente de imigração e os de emigração.

Em um mundo onde a questão migratória suscita decisões importantes de chefes de Estado, o posicionamento de um país sobre o tema pode afetar sua projeção externa. Nesses termos, suas regras de admissão de migrantes e refugiados; a política para áreas de fronteiras; a existência de comunidades nacionais no exterior e de comunidades de origem estrangeira no território do país; dentre outros fatores, podem ser instrumentalizados como fatores de poder. Nesse sentido, Teitelbaum (1984) defende as influências mútuas entre migrações e política exterior, focando-se nos Estados Unidos para mostrar o quão suas regras em relação aos refugiados refletem escolhas de política externa no período da Guerra Fria ${ }^{12}$. Já Domínguez (1990) examina a relação entre controle imigratório e política externa norte-america para a América Latina, identificando inclusive o propósito de influenciar os regimes de governo dos países de origem dos migrantes.

Relatório de uma comissão formada a pedido do presidente norte-americano Harry Truman para analisar a política de imigração do país apontava, em 1953, o papel da política migratória no desenho da imagem internacional dos Estados Unidos, afirmando que "the immigration law is an image in which other nations see us. It tells

\footnotetext{
12 Outros autores também salientam a instrumentalização do instituto dos refugiados pelos norteamericanos, como Mitchell (1989) e Reis (2006).
} 
them how we really feel about them and their problems, and not how we say we do" (apud MORRIS, 1985, p.40). Morris (1985) defende que seria a ligação entre política externa e política migratória que teria impulsionado o poder Executivo norte-americano a assumir um papel de liderança na formulação da segunda, em detrimento do Legislativo. Isso compreendeu, dentre outras medidas, a admissão de milhares de europeus no pós-guerra; e de húngaros, cubanos e chineses durante a Guerra Fria.

Décadas depois, relatórios de diagnóstico ou de boas práticas publicados por organizações internacionais seguem afirmando a importância das políticas migratórias dos países para suas respectivas relações internacionais. Comunicado da Comissão Europeia de 03/12/2002 ao Conselho e ao Parlamento Europeu, intitulado "Integrar as questões ligadas à migração nas relações da União Europeia com países terceiros", ressalta a contribuição que as políticas e instrumentos externos da UE, especialmente a política de desenvolvimento, poderiam dar em resposta a fatores que estariam na origem dos fluxos migratórios, em razão de quê solicita uma integração da matéria de imigração às relações da União com os países terceiros.

Um dos marcos da construção europeia, o acordo Schengen (incorporado ao arcabouço institucional da UE em 1997 pelo Tratado de Amsterdã) consubstanciou a política de livre circulação de pessoas entre os países signatários, somando-a à desterritorialização dos mercados e permeabilização das fronteiras físicas. Seguiu-se a ele o Programa de Tampere (1999) que, entre questões mais amplas de justiça, propunha a criação de uma política comum em matéria de imigração e um sistema único para concessão de refúgio. O Programa de Haia, de 2004, atualizou-o e consolidou o Espaço Comum de Liberdade, Segurança e Justiça - infundindo a livre circulação na ideia de europeização. Esse processo de construção conviveu com processos domésticos de reformulação das leis de imigração, majoritariamente no sentido de uma maior restrição (FERRERO, 2008).

A política teve efeitos paradoxais: embora tornasse permeável as fronteiras dos países membros, levou ao recrudescimento do controle das fronteiras externas da União, corroborando uma lógica de securitização. Nesses termos, para Guiraudon (2011), a chamada "crise migratória de 2011", com a chegada de migrantes tunisianos à Itália, constituiria uma decorrência de desfuncionalidades do aparato institucional do espaço Schengen: a gestão regional das políticas de imigração, refúgio e fronteiras não foi revestida de um caráter supranacional, mas permaneceu objeto de uma cooperação 
intergovernamental casuística que evitou enfrentar a fundo os desafios e possíveis efeitos da política migratória.

Mas não é a União Europeia exemplo único das relações entre integração regional e políticas migratórias. Thiollet (2011) argumenta que os fluxos de migrantes e refugiados dirigidos para países ricos em petróleo teriam constituído o fator propulsor da integração árabe, na ausência de instituições efetivas e de processos de integração econômica. Nesse sentido, a autora conclui que a política migratória deveria ser analisada como uma forma indireta de política externa, que se utiliza de regras de seleção de migrantes e política de refúgio como instrumentos de diplomacia.

Já o processo de integração do NAFTA foi promovido, na década de 1990, com argumentos de que estimularia o crescimento econômico e a criação de empregos no México e, assim, reduziria a imigração irregular de seus nacionais para os Estados Unidos. Tais expectativas não se efetivaram: entre 1990 e 2000, o referido fluxo mais que dobrou. Analisando o assunto, Papademetriou (2004) defende que a iniciativa regional não teria afetado diretamente o aumento da imigração irregular, condicionado por outros fatores sociais e econômicos, mas que teria falhado em institucionalizar regulamentações que interviessem sobre o fenômeno.

No caso do Brasil, elementos de política externa e relações internacionais condicionariam as políticas migratórias? Patarra (2012) e Reis (2011) associam mudanças de orientação da política migratória brasileira a objetivos externos do país de inserção e liderança internacional. Esta tese busca enfrentar empiricamente esta questão, norteada por conceitos e questionamentos que serão levantados no capítulo 2.

Internamente, da admissão do imigrante à sua eventual naturalização, as políticas de migração dos países variam em inúmeros aspectos: regras de entrada e saída mais ou menos restritivas, com possíveis critérios de seletividade étnicos, sócioeconômicos, profissionais, políticos e de nacionalidade; outorga ou restrição de direitos políticos, sociais e culturais; existência ou não de sistema de detenção de imigrantes irregulares; promoção de medidas de integração do imigrante à sociedade e de combate à xenofobia e ao preconceito; incentivos à reunião familiar e às remessas financeiras; existência de medidas de fomento à imigração de trabalhadores de determinados segmentos profissionais; implantação de programas de retorno voluntário. Como explicar esta variação? 
Diversos autores empreenderam análises de modo a apontar quais fatores teriam maior poder explicativo sobre os resultados políticos em migração. Em um primeiro momento, essa literatura tendeu a voltar sua atenção para fatores econômicos: assim, para Shughart e colaboradores (1986), as políticas migratórias se modificariam de acordo com os ciclos econômicos do próprio país, de modo que seu indicador deportação, nos Estados Unidos, estaria negativamente relacionado com o valor do produto nacional bruto. Contrapondo-se a esta conclusão, Timmer e Williamson (1998), ao testarem modelo de mudança de políticas migratórias com indicadores agregados e dados de séries temporais para cinco países entre 1860 e 1929, encontraram que mudanças na política não tinham relação forte com circunstâncias macroeconômicas: a maior influência seria exercida por alterações nas características dos fluxos migratórios que tivessem potencial de alterar o salário relativo da população em geral ${ }^{13}$.

Gary Freeman (1998) afirma que, dada sua condição de política pública, a política migratória dependeria fortemente da ação de interesses organizados. Para prever a posição que tomarão esses grupos de interesse, tais como organizações sindicais, empresariais ou de agricultores, deve-se mapear a distribuição de custos e benefícios associados a distintos modelos políticos. Freeman sugere que, quando os benefícios de uma política são concentrados e os custos são difusos, como frequentemente se dá com a política migratória, uma política clientelista tenderá a ser verificada, na qual o Estado será capturado por interesses organizados - o que explicaria a adoção de políticas de admissão de imigrantes em períodos de recessão econômica ${ }^{14}$.

Embora o trabalho de Freeman seja clássico e traga achados relevantes, é importante ressaltar que as hipóteses alternativas são inúmeras em um fenômeno multidimensional. No intuito de enfrentar esse desafio, Milner e Tingley (2011) propõem um modelo de análise de política migratória no qual as variáveis independentes compreendem tanto fatores utilitários econômicos quanto culturais e ideológicos, e as variáveis dependentes correspondem à desagregação da política migratória em seis dimensões: (i) vistos para trabalhadores não-qualificados; (ii) vistos para trabalhadores qualificados; (iii) concessão de benefícios sociais para os imigrantes;

\footnotetext{
${ }^{13}$ Definido pelos autores como a razão entre a renda per capita e a da mão-de-obra não-qualificada.

14 Críticas foram apresentadas à hipótese de Freeman sob argumento de que desconsidera diversas variáveis institucionais relevantes (HOLLIFIELD; WONG, 2015). Para além deste fato, Freeman (1998) (i) não explica o mecanismo causal através do qual o clientelismo afetaria os resultados políticos; (ii) apresenta o clientelismo como uma resultante direta dos efeitos distributivos de uma dada política pública, sem levar em conta trajetórias institucionais do Estado em questão.
} 
(iv) restrições e penalidades para empresários que contratem imigrantes irregulares; (v) políticas de segurança de fronteiras; e (vi) votos na última etapa da aprovação de projeto de $\mathrm{lei}^{15}$. Concluem que as variáveis independentes teriam diferentes poderes explicativos em cada uma dessas dimensões.

Pesquisas mais recentes vêm enfatizando a opinião pública como variável explicativa de políticas migratórias, particularmente as de caráter restritivo. Kleemans e Klugman (2009) defendem que cidadãos de Estados com maiores desigualdades sociais estariam mais inclinados a defender que o mercado de trabalho priorize nacionais em detrimento dos não-nacionais. Já em países mais igualitários, a tendência observada na opinião pública a aceitar o controle migratório conviveria com a valorização da garantia de igualdade de tratamento no mercado de trabalho.

Dos dados de opinião pública sobre imigração publicado pela OIM (2011), depreende-se um recorte entre países com tradição histórica de imigração e os demais: o Canadá destaca-se com altos índices de apoio à vinda de imigrantes para o país, secundado por Austrália, e pelos Estados Unidos algumas posições atrás. Em contrapartida, em países europeus, à exceção da Bulgária, a maioria da população expressa percepções negativas sobre a presença de imigrantes (OIM, 2011).

Martin Schain (2008) investiga quais fatores levam a diferenças nas políticas migratórias dos Estados Unidos, França e Inglaterra - países com níveis de imigração semelhantes, além de conjunturas sócio-econômicas, demográficas e de empregabilidade comparáveis, porém distintos objetivos desenhados para suas respectivas políticas migratórias. Em uma perspectiva institucional top-down focada nos tomadores de decisão, o autor não desmerece a importância de fatores como a opinião pública e grupos de interesse, mas sugere que sua influência é mobilizada dentro do processo decisório e das instituições que o fundamentam. É o sistema político de cada caso e características institucionais específicas de suas políticas migratórias que determinam as diferenças dos resultados políticos, em uma dinâmica de pathdependence que não mudaria com facilidade. Nesses termos, atribui-se ao jogo político (politics) o papel de engendrar diferentes políticas de migração (policies).

Por outro lado, as diversas áreas políticas se caracterizam por processos políticos com especificidades (HILL, 2013). No campo das migrações, este processo se

\footnotetext{
${ }^{15}$ No processo legislativo norte-americano, trata-se de etapa referida como final passage vote.
} 
desenvolve com permeabilidade entre o doméstico e o externo não apenas em razão da natureza de seu objeto, mas também em decorrência das características do próprio processo político contemporâneo:

But there is a need not to forget the complexity of modern governance. This means that the institutions of government may be international, that groups may be organized outside and across individual states, that issues about inequalities of power need to be analyzed globally, and that choices are made by actors who are increasingly conscious that they are playing on an international stage (HILL, 2013, p.111).

\subsection{Política migratória como política pública: o papel dos burocratas}

Pensar a política migratória sob o prisma da análise de políticas públicas significa debruçar-se sobre questionamentos como aqueles colocados por Laswell (apud SOUZA, 2006): quem ganha o que, por que e que diferença faz. Nesse sentido, dirige-se o foco analítico para (i) a definição, pelo Estado, de quem nele entra, quem permanece e quais direitos lhe são concedidos, bem como quem dele se torna cidadão; (ii) quais variáveis influenciam essa definição; (iii) quais as consequências políticas e qual impacto social dessa definição.

No âmbito do quem ganha o que, a política migratória compreende decisões nas seguintes dimensões e suas diversas facetas:

(i) Gestão de fluxos de pessoas - quem entra na sociedade?: expedição de vistos e decisões sobre implementação de procedimentos especiais de demanda de visto para determinados grupos de pessoas; concessão de refúgio e desenho de sua interface com a migração voluntária; intercâmbio de informações e estatísticas sobre fluxos migratórios; implantação de medidas de atração de mãode-obra ou de estudantes direcionados a setores determinados do mercado de trabalho; negociação e execução de acordos migratórios bilaterais ou regionais;

(ii) Integração social dos migrantes - o que significa ser membro da sociedade?: amparo legal para a reunião familiar; regulação do acesso ao trabalho; regulação do acesso a serviços públicos e direitos sociais; políticas de acolhida e assistência primária; programas de combate ao racismo e xenofobia; inserção do princípio do interculturalismo em políticas de educação e cultura ou mesmo na constituição; regulação do acesso à nacionalidade; 
(iii) Controle da imigração irregular - o que significa não ser considerado membro da sociedade?: securitização do controle de fronteiras; política de deportação; condições para readmissão de migrantes que estiveram em situação irregular; condições para regularização de imigrantes irregulares; regulação do acesso a serviços públicos e direitos sociais para os migrantes irregulares; intercâmbio de informações e estudos sobre os fluxos migratórios; combate ao tráfico de pessoas e assistência às vítimas.

Nesse contexto, a política pública migratória possui algumas peculiaridades, para além da interface doméstico/internacional já abordada no tópico anterior. Primeiramente, nota-se seu caráter distributivo, de acordo com a tipologia proposta por Lowi (1972): os custos são difusos e os benefícios concentrados, o que tenderia a conduzir a práticas clientelísticas. Isso se coaduna às conclusões de Freeman (1998) supramencionadas. Se as atividades políticas se armam e se orientam segundo as políticas públicas (LOWI, 1972), as políticas migratórias seriam caracterizadas por uma arena relativamente pacífica, dadas as demandas não-rivais, o que corresponderia a uma baixa politização. Por politização, entende-se a cisão dos consensos relativos a uma determinada política, em decorrência do aumento da saliência da questão ou do número de atores interessados, gerando um embate entre diferentes atores político-sociais a fim de estabelecer seu conteúdo ${ }^{16}$.

Nesse contexto, Terri Givens e Adam Luedtke (apud SCHAIN 2008) trazem evidências comparativas de que, quando a questão migratória se concentra em um grupo restrito de tomadores de decisão e em poucos grupos de advocacy mobilizados, a política tenderá a ser mais aberta do que a opinião pública indicaria. Ou seja, a baixa politização, aliada a fatores institucionais, engendraria resultados políticos de maior abertura e, portanto, mais distantes do modelo de controle de acesso.

No entanto, a imigração é uma pauta muitas vezes altamente politizada, e políticas de controle de acesso predominam em países de destino de imigrantes (CASADO, 2008). Uma possível explicação está no fato que como sociedades receptoras respondem a entrada de novos membros constitui uma questão vinculada não apenas às suas apreciações políticas, mas também às suas próprias concepções de nação e identidade. Desta forma, a nacionalidade e a condição de não-pertencimento pleno à

\footnotetext{
${ }^{16}$ Essa definição agrega elementos de Lima em sua conceituação da politização da política externa (2009) e de Schain (2008).
} 
comunidade política poderiam conduzir a que as demandas de um determinado grupo sejam percebidas como rivais. No debate público sobre política migratória, segurança nacional; direitos humanos; competição no mercado de trabalho; elementos identitários e étnico-raciais; religião; dentre outros, são conceitos mobilizados embaraçada e conflituosamente. Em consequência, as políticas migratórias vêm sendo trazidas à tona, particularmente nos casos dos países da Europa e Estados Unidos, no debate eleitoral. Estudos em ciência política têm lançado mão de experimentos e surveys para estudar percepções anti-imigrantes, apresentando como possíveis variáveis explicativas ideologia partidária, patriotismo, mídia e preferências em outras áreas políticas (HOLLIFIELD; WONG, 2015).

Outra característica da política migratória é sua transversalidade. As migrações suscitam questões relacionadas ao desenvolvimento econômico, segurança, trabalho, comércio, assistência social, saúde, educação, cultura. Desta forma, instam a atuação do Estado em diferentes setores, o que implica no acionamento de diferentes burocracias, o que conduz à necessidade de coordenação. Nesse sentido, relatório da Comissão Mundial sobre Migrações Internacionais (2005) diagnosticou o desafio da coerência na governança nacional das migrações internacionais, advindo tanto da dificuldade dos Estados de definirem objetivos claros para suas políticas migratórias, quanto dos frequentes arranjos institucionais em que a fragmentação de competências está aliada à ausência de coordenação. O relatório apresenta, então, as seguintes recomendações:

O estabelecimento de uma abordagem coerente da questão das migrações internacionais é uma primeira etapa na direção de uma melhor governança nacional. A etapa seguinte consiste em coordenar a sua implementação. Há pelo menos três problemas de coordenação que deveriam ser resolvidos por muitos Estados. O primeiro é a coordenação dentro do governo, abordagem que costuma designar-se por 'governo unido' ou 'governo integral'. Quando a governança das migrações está dividida entre vários ministérios, devem estabelecer-se e manter-se mecanismos de coordenação.

Em segundo lugar, é necessária uma coordenação não só entre os diversos ministérios que têm o pelouro das migrações, mas também entre esses ministérios e os outros. (...)

A nível nacional, os governos devem consultar as outras partes interessadas. A formulação de políticas incumbe exclusivamente aos governos, mas a Comissão concluiu que esse processo terá mais probabilidades de êxito se se basear numa consulta alargada, nomeadamente junto do setor privado e dos diversos elementos da sociedade civil (COMISSÃO MUNDIAL SOBRE AS MIGRAÇÕES INTERNACIONAIS, 2005, p. 66 - grifo nosso). 
Destaca-se ainda a importância que assume na política migratória a obtenção de conhecimento e dados, os quais se tornam particularmente difíceis na temática em virtude dos fatores mencionados na introdução. Examinando o caso do Reino Unido, por exemplo, Geddes (2005) argumenta que avanços no conhecimento teriam significado melhorias na eficácia de medidas de controle de fluxos. Adicione-se que o caráter internacional da temática transnacionaliza a problemática dos dados, exigindo permanentes colaborações e parcerias interestatais e com organizações internacionais.

Ainda no quadro da análise de políticas públicas, frise-se a questão da eficácia das políticas migratórias. A avaliação da eficácia de uma política pública corresponde ao cotejar dos objetivos e instrumentos de um programa conforme explicitados em sua formulação a seus resultados (ARRETCHE, 2001). No caso da política migratória, a literatura costuma identificar lacunas entre a política formulada e seus efeitos (FREEMAN, 1998; SCHAIN, 2008; CORNELIUS; TSUDA, 2004). Cornelius e Tsuda (2004) identificam duas origens para esses gaps: consequências inesperadas da política e disjunções na implementação.

Desta forma, em meio a outras causas, o gap entre formulação e implementação pode ser remetido a dissonâncias entre política e administração. Nesse sentido, Virginie Guiraudon (2006) aponta que a política migratória na França teria características de uma política camuflada, cuja formulação ocorreria mais administrativa e judicialmente do que por atores políticos, o que, de acordo com a autora, teria um importante papel em garantir a igualdade de direitos para não-nacionais a despeito de contextos políticos adversos, nos quais a restrição desses direitos é mobilizada em plataformas eleitorais. Assim como Guiraudon, outros autores sustentam que as dinâmicas migratórias, bem como as políticas adotadas frente àquelas, não podem ser entendidas sem uma análise dos atores que as influenciam, dentre os quais os burocratas.

Morris (1985) realiza uma análise institucional da política migratória norteamericana a partir do exame da evolução, das características e do desempenho da burocracia da área. O protagonismo da agência burocrática, argumenta o autor, ganha espaço em um contexto de compromisso político ambíguo sobre a questão, caracterizado pelo dissenso histórico entre os interesses do Legislativo e do Executivo. Também sobre o caso norte-americano, Meyers (2000) aponta que as políticas concernentes ao trabalhador migrante seriam geralmente determinadas por grupos de interesse atuando junto a burocratas em cenário fora do alcance do público, enquanto 
aquelas para refugiados seriam desenhadas em negociações entre o Executivo e movimentos sociais.

Examinando o caso espanhol entre os anos de 2000 a 2004, Rut Casado (2008) ressalva o papel central dos burocratas de assessoramento superior na elaboração das políticas públicas migratórias, atuando em redes não-institucionalizadas das quais participam atores políticos e atores encarregados da implementação. A autora se debruça, ainda, sobre o caso do Reino Unido, salientando os conflitos entre os diferentes departamentos com competências sobre o tema - o que teria incentivado a criação de programas para melhorarem a eficácia da política focados na coordenação entre os atores e na inovação tecnológica.

De fato, com seu caráter de temática transversal, a política de imigração compreende diversas agências burocráticas em interação e em relação com diversos atores políticos, estatais e não-estatais. Nas palavras de Massey,

Immigration policy is the outcome of a political process through which competing interests interact within bureaucratic, legislative, judicial, and public arenas to construct and implement policies that encourage, discourage, or otherwise regulate the flow of immigrants (1999a, p.307).

É por meio dos burocratas, inclusive, que as diferentes dimensões da política migratória se intersectam: são os burocratas de nível-de-rua responsáveis pelo controle que têm um primeiro acesso direto aos usuários, inclusive encaminhando-os para os serviços de integração; enquanto burocratas de serviços de saúde, educação e assistência social, dentre outras áreas, podem orientar os imigrantes a procederem à sua regularização documental. Burocratas de nível-de-rua possuem, desta forma, o potencial de costurar as diferentes dimensões da política migratória em sua implementação.

Adicionalmente, os burocratas de nível-de-rua têm a oportunidade de definir termos da política migratória na implementação. Particularmente no caso dos burocratas encarregados da execução de atividades de controle e acesso, a ampla discricionariedade que lhes é conferida a fim de que exerçam práticas soberanas de exceção peculiarizam seu papel na política. Ellerman (2006) sublinha como esses atores enfrentam o desafio de realizar trade-offs entre valores e interesses sociais antagônicos, o que, conclui, levaria a políticas de maior controle do que as previstas na legislação.

Alexis Spire (2008) é um dos autores que se debruçam sobre a influência de agentes burocráticos na política imigratória: estudando o caso francês entre 1945 e 1980, o autor aponta que eles atuariam segundo um "mito estruturante" de "princípio de 
defesa dos interesses de Estado" (2008, p. 76). O autor observa o papel preponderante exercido pelas circulares administrativas na produção da política, salientando o exercício de discricionariedade pelos agentes burocráticos ao aplicá-las, inclusive instrumentalizando disposições que lhes fossem convenientes e ignorando outras seletivamente.

No caso dos países-membros da União Europeia, Jordan, Strath e Triandafyllidou (2003) salientam que a implementação por parte dos burocratas de nível-de-rua deve lidar com a complexidade adicional de aplicar dois ordenamentos normativos distintos. Para os autores, o aumento da convergência normativa e da cooperação entre os países membros da União Europeia é debilitado pelas diferenças na eficiência da implementação verificadas entre os países.

Channac (2006) opina que burocratas, no âmbito da política pública de imigração, estariam sujeitos a processos de difusão estimulados por instituições internacionais e regionais e pela cooperação intergovernamental; em consequência do que teriam potencial para integrar a seus países as experiências políticas de migração levadas a cabo em outros locais. Por sua vez, Schain (2008) aponta que atores domésticos da política migratória, burocráticos e políticos, fariam uso instrumental da diversidade de normas e instituições europeias e internacionais a fim de alterar as relações de força domésticas.

O uso instrumental do internacional na arena doméstica, dada a transversalidade da política migratória, pode permear as dinâmicas interburocráticas. Para Weiner,

As international migration has become more salient among policymakers, and as policymakers have become more aware of the international-relations aspects of decisions involving migrants, new bureaucratic agencies become involved in the decision-making process. (...) Any examination of the internationalization of migration issues must entail a close study of the changing intra-bureaucratic relationships within both sending and receiving countries (1985, p.453).

Essa interação entre burocracias não constitui um processo sem conflitos ou barganhas. Ao contrário, envolvem interesses divergentes e mudanças em arranjos de poder. De acordo com Rossana Reis,

A pluralidade de opiniões e a complexidade do processo de elaboração das políticas de imigração e nacionalidade refletem-se na forma final das legislações sobre essas questões. De fato, tais políticas não são fruto da ação de uma entidade abstrata, o "Estado", mas da luta e da acomodação de interesses divergentes na sociedade e dentro do próprio Estado, sobretudo em democracias liberais (REIS, 2004, p.160). 
Mas quais fatores afetariam a atuação das burocracias em política migratória? Algumas hipóteses são levantadas pela literatura: Ardittis e Laczo (2008) sustentam que, com a intensificação dos fluxos de pessoas, ocorreria um direcionamento de recursos financeiros e humanos para a gestão da migração. Com mais recursos a ela dirigidos, haveria mais interesse das burocracias em influenciá-las. Já Guiraudon (2000) sugere que atores políticos e burocráticos acessariam instâncias e instrumentos internacionais nos assuntos migratórios quando esses se mostrassem mais adequados a seus interesses.

Por último, uma das características frequentemente associadas à política migratória é sua classificação, usualmente dicotômica, entre controle ou abertura. Tom Wong descreve a era atual de migrações como "an unrelenting age of immigration control" (apud HOLLIFIELD; WONG, 2015, p.237). Casado aponta que "los países receptores de inmigración en su conjunto han aceptado que una parte invariable de sus políticas públicas, es decir, de sus respuestas ante los movimentos migratórios de personas, sea el control" (CASADO, 2008, p.25). Pesquisas voltadas para identificar os fatores determinantes das políticas migratórias utilizam como variáveis dependentes gradações do controle (e.g. SHUGHART et al., 1986). Mas o que se entende por política de controle?

Para Cornelius e Tsuda (2004), a eficácia da política de controle seria medida pela diferença entre o número de entradas de imigrantes previsto pela política e o número efetivamente verificado. No entanto, complementam os autores, os governos por vezes não possuem políticas claras, o que dificultaria esta avaliação. Adicione-se que não só a falta de clareza das políticas de controle engendra dificuldades na aferição de sua eficácia, mas também o fato de que elas englobam medidas nas três dimensões das políticas migratórias supramencionadas: compreendem o controle do trânsito de indivíduos nas fronteiras, assim como o controle durante a estadia do imigrante, relativo aos procedimentos para renovações dos vistos, quantidade de registros e de informações retidas; práticas relacionadas à deportação; e mesmo medidas de política externa relacionadas a intervir, externamente, nos fluxos.

Políticas de controle migratório, quando mais restritivas, conferem ênfase ao policiamento e ao controle criminal, de onde o termo "crimigração" (ABRAHAM, 2015, p.286), que vem sendo utilizado pela literatura. A ênfase no controle e na criminalização do imigrante irregular pode ofuscar, porém, outro aspecto importante das 
políticas migratórias: o acesso ou a exclusão de direitos, para aqueles que se encontram regularizados ou não. Isso engloba direitos civis, sociais e políticos, cuja amplitude em que são conferidos a não-nacionais varia acentuadamente entre os países.

Em oposição ao conceito de controle, alguns autores identificam o de gestão das migrações. Do ponto de vista da Organização Internacional de Migrações (OIM), a gestão de migrações refere-se a abordar o deslocamento populacional em suas diferentes facetas, englobando suas causas, o processo de viagem e entrada, permanência ou retorno, integração ou reintegração, nacionalização, etc. (OIM, 2004). Massey (1999b) apresenta a gestão migratória como uma iniciativa de maximizar os benefícios e minimizar os custos da imigração para a sociedade. Para Patarra, "Em matéria de políticas de migração, a globalização fará cada vez mais necessária a transição do ‘controle migratório para a 'gestão migratória', em um sentido amplo” (2006, p.15).

A classificação da gestão migratória como um modelo de política em oposição ao controle, porém, é problemática como categoria analítica. Ao abranger um excesso de aspectos da política, torna difícil avaliá-la: encaixar uma política migratória como de controle ou de gestão, sem atentar para suas diferentes dimensões, tem pouco poder explicativo. Por exemplo, na Europa após 2000 observa-se uma abertura para a entrada selecionada de imigrantes qualificados simultânea ao fechamento para a reunificação familiar (SCHAIN, 2008).

Particularmente, nota-se que as políticas migratórias variam, por um lado, em um continuum que vai da inclusão à exclusão de direitos em relação aos nacionais e, por outro, em um continuum variando de menor a maior controle na admissão e permanência. Tendo em vista o exposto, propõe-se, na esteira de Milner e Tingley (2011), que estudos explicativos da política migratória levem em conta diferentes aspectos da mesma: restrições à entrada; acesso ao mercado de trabalho; reunião familiar; acesso à residência permanente; acesso a direitos sociais em comparação aos nacionais; direito ao voto; políticas de combate à discriminação e xenofobia; concessão de nacionalidade. Cada uma dessas dimensões políticas levanta questionamentos e politizações distintas: cada uma terá um peso diferenciado na mobilização dos debates sobre as migrações, e suscitará diferentes divisões de grupos de interesse.

Por último, as políticas migratórias podem se caracterizar pelo caráter reativo, respondendo a estímulos pontuais ou inesperados, com objetivos de curto ou médio prazo; ou políticas proativas, de mais largo prazo. Ambas podem ocorrer 
simultaneamente e complementarem-se de maneira dinâmica: a política migratória, como as demais políticas públicas, não é um dado imutável ou estanque. Nesse sentido, conclui Schain:

State agency is dynamics and changing, and knowing how it changes is part of understanding the politics of immigration. We need to understand not simply variations in state policy over time and across space but also the process through which policies change (SCHAIN, 2008, p.5).

\subsection{Há um regime internacional das migrações?}

Como mencionado nos tópicos anteriores, as conexões entre migrações e relações internacionais são amplas e compreendem acordos bilaterais, multilaterais e regionais, além de organizações internacionais, com potencial para afetar as instituições domésticas regulando o tema. À vista disso, a literatura sobre regimes internacionais (e.g. KRASNER, 1983; HAGGARD e SIMMONS, 1987; KEOHANE; NYE, 2001) pode se mostrar um instrumento interessante para estudar a matéria. No quadro deste marco teórico, um questionamento primário pode ser levantado: há um regime internacional das migrações? Quais seriam suas características?

A teoria dos regimes internacionais constitui um dos mais importantes exemplos de neoinstitucionalismo nas relações internacionais. Nela, a refutação da anarquia como elemento central das relações internacionais se dá por meio de instituições que promovem a cooperação: os regimes internacionais, "sets of implicit or explicit principles, norms, rules, and decision-making procedures around which actors' expectations converge in a given area of international relations" (KRASNER, 1983, p.2). A definição de Krasner salienta o elemento da convergência das expectativas dos atores, o que, segundo DiMaggio e Powell (1991a), leva à estabilização da ordem internacional. Desta forma, os regimes conduzem a comportamentos cooperativos, ao mesmo tempo em que deles resultam, e assim regulam a interação dos Estados em uma determinada área de questões. Na concepção de Keohane e Nye (2001), os regimes compreendem uma variedade de instituições, normas e procedimentos, em arranjos desenhados pelos governos a fim de afetar a interdependência internacional, regulamentando o comportamento dos atores e intervindo em seus efeitos.

A interdependência, por sua vez, caracteriza-se pela presença de múltiplos canais conectando as sociedades, incluindo não apenas os arranjos oficiais interestatais, 
mas também aqueles, formais e informais, entre as burocracias governamentais, elites não-governamentais e organizações transnacionais. Regimes internacionais são os fatores intermediários entre a estrutura de poder de um sistema internacional e a barganha política e econômica que nele tem lugar (KEOHANE; NYE, 2001).

Os regimes emergem quando os custos de comunicação, monitoramento e enforcement das decisões são mais baixos do que os benefícios derivados - ainda que os países percam liberdade de ação ao submeterem-se a eles. Ao se formarem, no entanto, as instituições assumem autonomia em relação aos atores que a criaram, e passam a modelar suas preferências e relações de poder (DIMAGGIO; POWELL, 1991a).

Ao analisar a origem dos regimes de direitos humanos, Moravcsik (2000) sublinha seu contraste em relação às instituições internacionais voltadas para políticas de comércio, monetária, ambiental ou de segurança: enquanto essas últimas são desenhadas primordialmente para regular externalidades políticas oriundas de interações internacionais, os direitos humanos são regulamentados a fim de viabilizar a responsabilização dos governos por suas atividades no interior de seus próprios territórios. De acordo com o autor, "The distinctiveness of such regimes lies instead in their empowerment of individual citizens to bring suit to challenge the domestic activities of their own government" (MORAVCSIK, 2000, p.217).

Nesses termos, arranjos institucionais de direitos humanos constituiriam um desafio tanto para o ideal de soberania westfaliano quanto para aquele de legitimidade democrática, visto que a instituição internacional à qual se adere opõe restrições à soberania doméstica, podendo fazê-lo de maneira contramajoritária. Deste modo, a questão de pesquisa enunciada por Moravcsik (2000) é: por que Estados adeririam a regimes de direitos humanos?

Segundo o autor, os atores assim o fariam quando os benefícios de reduzir a incerteza política futura superam os "custos de soberania" (2000, p.220) da adesão ao regime - deste modo, buscam proteger um determinado objeto de intempéries políticas vindouras atrelando-o a uma normativa internacional. Focando no caso da Convenção Europeia para Proteção de Direitos Humanos e Liberdades Fundamentais (1950), Moravcsik identifica que suas origens se encontram não em atitudes coercitivas de uma política de poder, nem em processos de socialização normativa, mas sim em esforços políticos empreendidos por democracias à época recentes, ou recentemente 
reestabelecidas, a fim de protegerem seu status quo político doméstico de opositores não-democráticos.

No que concerne às migrações internacionais, a dimensão dos custos de soberania é particularmente acentuada, visto que "a autonomia do Estado no campo das migrações é uma das principais características do direito internacional tradicional" (REIS, 2004, p.150). De fato, instituições internacionais regulamentando as migrações explicitamente contrapõem a soberania dos Estados à liberdade dos indivíduos. Não obstante, esta característica é identificada no regime de direitos humanos em geral, conforme abordado por Moravcsik (2000). Ademais, a proteção internacional ao imigrante e refugiado tem fundamento justamente em direitos que lhes seriam intrínsecos, a despeito de sua não-pertinência a determinada comunidade política: é no regime internacional de direitos humanos, portanto, que ela se assenta. Vai neste sentido observação da diplomata Maria Rita Faria, para quem:

(...) o regime internacional de direitos humanos lato sensu (que inclui convenções internacionais sobre direitos humanos, o regime para refugiados, padrões trabalhistas internacionais e o direito criminal transnacional - como o tráfico de migrantes) oferece arcabouço sólido o suficiente para a ação da comunidade internacional na proteção dos migrantes (FARIA, 2015, p.179).

Não é, pois, o elemento soberania estatal que particulariza o regime internacional de migrações, assumindo-se que ele exista. Como visto, a adesão a todo regime internacional implica em cessão de soberania e, no caso do regime de direitos humanos, a prerrogativa estatal é relativizada em relação a indivíduos que se encontram em seu próprio território. Essa dualidade é partilhada pelo regime internacional de migrações, porém com uma peculiaridade central: uma interação que contrapõe um Estado a um indivíduo migrante contrapõe diretamente duas soberanias, uma delas em tutela de um seus nacionais fora de suas fronteiras.

Nesse contexto, pode-se afirmar que as normas internacionais regulamentando a relação entre Estados e imigrantes compreendem: (i) normas do regime internacional de direitos humanos lato sensu; (ii) normas específicas de direito internacional de caráter consular; (iii) normas internacionais direcionadas ao imigrante; (iv) normas do regime internacional de refugiados e de tráfico internacional de pessoas.

Assim, a Declaração Universal de Direitos Humanos (1948) consagra o direito de abandonar o país em que se encontra e o de retornar ao país de origem (artigo 13.2); o direito à procura de asilo em caso de perseguição (art. 14) e o direito a ter uma 
nacionalidade, não a perder e poder modificá-la (art.15). Embora tenha sido assinada em tempos de eclosão da questão dos refugiados, não se refere expressamente ao direito de migrar. Por seu turno, o Pacto Internacional sobre Direitos Civis e Políticos (1966, promulgado no ordenamento brasileiro pelo Decreto $n^{\circ}$ 592/1992), instrumento que buscou positivar os princípios da Declaração, dita em seu art. 13 que:

\begin{abstract}
um estrangeiro que se ache legalmente no território de um Estado Parte do presente Pacto só poderá dele ser expulso em decorrência de decisão adotada em conformidade com a lei e, a menos que razões imperativas de segurança nacional a isso se oponham, terá a possibilidade de expor as razões que militem contra sua expulsão e de ter seu caso reexaminado pelas autoridades competentes, ou por uma ou várias pessoas especialmente designadas pelas referidas autoridades, e de fazer-se representar com esse objetivo.
\end{abstract}

Ressalte-se que tanto a Declaração de Direitos Humanos quanto o Pacto sobre Direitos Civis e Políticos garantem a igualdade de direitos a todos os indivíduos (art. $2^{\circ}$ e arts. $2^{\circ}$ e 14 , respectivamente), o que estende a totalidade dos direitos neles previstos aos migrantes ${ }^{17}$. Especificamente, o Pacto elenca a não-discriminação por motivo de origem nacional como uma de suas diretrizes. Também o faz a Convenção Internacional sobre toda forma de Discriminação Racial (1968, promulgada pelo Decreto ${ }^{\circ}$ 65.810, de 1969), ao dispor, em seu artigo $5^{\circ}$, que seus signatários se comprometem "a proibir e a eliminar a discriminação racial em todas suas formas e a garantir o direito de cada um à igualdade perante a lei sem distinção de raça, de cor ou de origem nacional ou étnica".

No âmbito da Organização de Estados Americanos (OEA), a Convenção Americana de Direitos Humanos (1969, promulgada pelo Decreto $\mathrm{n}^{\mathbf{o}} 678$ de 1992) aborda a situação jurídica do migrante em seu artigo 22, ao tratar do direito à circulação e à residência. Em que pese seus nove itens não assegurarem o direito à migração, garantem o direito de asilo, ressaltam o princípio de não-devolução de refugiados, proíbem a expulsão coletiva de estrangeiros e estabelecem que a expulsão individual só pode se dar em virtude de decisão legalmente fundamentada. Ademais, a Convenção consagra, em seu artigo 24, a igualdade de todas as pessoas perante a lei.

Quanto aos regimes conexos, a Convenção de Genebra de 1951, complementada

\footnotetext{
17 Desta forma garantem os seguintes direitos, embora não únicos, aos migrantes: direito à vida (Declaração Universal dos Direitos Humanos, art. $3^{\circ}$; Pacto Internacional sobre Direitos Civis e Políticos, art. $6^{\circ}$ ); direito à liberdade e à segurança pessoal (DUDH, art. $3^{\circ}$; PIDCP, art. $9^{\circ}$ ); direito à igualdade perante a lei (DUDH, art. $2^{\circ}$; PIDCP, arts. $2^{\circ}$ e 14 ;); direito à liberdade de pensamento, consciência e religião (DUDH, art.18; PIDCP, art.18); direito à liberdade de expressão (DUDH, art.19; PIDCP, art.19); proibição de trabalho escravo ou forçado (DUDH, art. $4^{\circ}$; PIDCP, art. $8^{\circ}$ ); proibição de discriminação racial sistemática (PIDCP, arts. 20, 26 e 27; Convenção Internacional sobre a Eliminação de Todas as Formas de Discriminação Racial, art. $2^{\circ}$ ).
} 
por Protocolo de 1967, atribui aos Estados signatários a responsabilidade de analisar os pedidos de refúgio e de conceder aos refugiados o direito a saúde, educação e condições de emprego em paridade aos nacionais. A Convenção consagra ainda o princípio da não-devolução, ou non-réfoulement, o qual proíbe a expulsão de refugiado para países ou territórios nos quais sua vida ou liberdade se encontrem ameaçadas.

As referidas normas guardavam, entretanto, uma reserva geográfica, circunscrevendo-se aos acontecimentos ocorridos na Europa. A Declaração de Cartagena, assinada em 1984 por representantes de governos e juristas latinoamericanos, teve um importante papel no cenário internacional ao recomendar aos países que incorporassem a seus ordenamentos jurídicos o conceito ampliado de refugiado, eliminando a reserva geográfica ${ }^{18}$. Apesar de não possuir caráter vinculante, a Declaração é um marco para o regime de refugiados, sendo mobilizada como fundamento normativo não apenas pelos países signatários, mas pela ONU e o ACNUR.

Com a Convenção Relativa aos Apátridas (1954) e a Convenção de Prevenção de Formação de Apátridas (1961), indivíduos que não são considerados cidadãos nacionais por nenhum país passam a ter seus direitos garantidos pelo Estado no qual residem. De acordo com Reis, “(...) as convenções relativas aos refugiados e apátridas representam um ponto de inflexão no direito internacional, pois pela primeira vez é reconhecida a existência do indivíduo no cenário internacional” (2004, p.151).

Por último, o tráfico de pessoas é regulamentado dentro do quadro da Convenção das Nações Unidas contra o Crime Organizado, aprovada em 2000 pela Assembleia Geral, particularmente por seus protocolos adicionais: Protocolo Relativo à Prevenção, Repressão e Punição do Tráfico de Pessoas, em especial Mulheres e Crianças; e o Protocolo Relativo ao Combate ao Tráfico de Migrantes por Via Terrestre, Marítima e Aérea.

\footnotetext{
18 Recomendação III da Declaração de Cartagena: "Reiterar que, face à experiência adquirida pela afluência em massa de refugiados na América Central, se toma necessário encarar a extensão do conceito de refugiado tendo em conta, no que é pertinente, e de acordo com as características da situação existente na região, o previsto na Convenção da OEA (artigo $1^{\circ}, \S 2^{\circ}$ ) e a doutrina utilizada nos relatórios da Comissão Interamericana dos Direitos Humanos. Deste modo, a definição ou o conceito de refugiado recomendável para sua utilização na região é o que, além de conter os elementos da Convenção de 1951 e do Protocolo de 1967, considere também como refugiados as pessoas que tenham fugido dos seus países porque a sua vida, segurança ou liberdade tenham sido ameaçadas pela violência generalizada, a agressão estrangeira, os conflitos internos, a violação maciça dos direitos humanos ou outras circunstâncias que tenham perturbado gravemente a ordem pública".
} 
No que atine ao direito consular, tem na Convenção de Viena sobre Relações Consulares, assinada em 1963 e incorporada ao ordenamento brasileiro pelo Decreto $\mathrm{n}^{\circ}$ 61.078/1967, sua normativa central. Ao precisar elementos da função consular de proteção dos interesses do Estado que envia e de seus nacionais (art. $5^{\circ}$ ), a Convenção prevê o exercício de ajuda e assistência aos seus nacionais; da proteção dos interesses dos menores e incapazes; e da representação de seus nacionais perante tribunais e outras autoridades. Deste modo, confere um rol de direitos mínimos aos migrantes que recorram a postos consulares de seus países de origem.

Para além das Convenções gerais da OIT que, por se aplicarem a todos os trabalhadores, se estendem também aos migrantes, a organização publicou normas direcionadas especificamente a esses últimos. Dentre elas destaca-se, por sua amplitude, a Convenção $\mathrm{n}^{\circ}$ 97, em sua versão revista de 1949 incorporada ao ordenamento brasileiro por meio do Decreto $\mathrm{n}^{\mathrm{o}} 58.819 / 1966$, a qual vincula os Estados signatários ao comprometimento de, entre outras ações, manter um serviço apropriado de informação e auxílio gratuito para os migrantes sobre a política e legislação nacionais referentes à imigração e sobre condições de trabalho e movimentos de trabalhadores migrantes (arts. $1^{\mathrm{o}}$ e $2^{\mathrm{o}}$ ); e garantir a igualdade de oportunidades e de tratamento dos trabalhadores migrantes, em condição regular, relativamente aos nacionais, inclusive em questões de saúde, condições de trabalho e moradia, previdência social e acesso à justiça (art. $6^{\circ}$ ).

Já a Convenção no 143 da OIT (1975) avançou no sentido de estabelecer que os Estados-membros são obrigados a respeitar os direitos humanos de todos trabalhadores migrantes, inclusive os irregulares, apresentando regulamentação para as imigrações efetuadas em condições abusivas. Também estendeu o escopo da igualdade de oportunidades e tratamento para outros direitos, como o de aderir a sindicato. Embora tenha sido assinada pelo Brasil em 1989, não foi internalizada pelo país.

A Convenção Internacional sobre a Proteção dos Direitos de Todos os Trabalhadores Migrantes e dos Membros das suas Famílias (CDTM) foi adotada em 1990 na Assembleia Geral das Nações Unidas e se encontra em vigor desde 2003. Em março de 2017, 50 Estados haviam ratificado a Convenção, nenhum dos quais detentores dos maiores afluxos de imigrantes do mundo ${ }^{19}$. Relatório da ONU sobre Migrações Internacionais de 2015 observou que o total dos Estados signatários (à época eram 48, aos quais se juntaram Madagascar e Venezuela no ano seguinte) abrigava

\footnotetext{
${ }^{19}$ Dados disponíveis em: https://treaties.un.org. Acesso em: 08 jan. 2017.
} 
cerca de $7 \%$ do montante global de migrantes internacionais. O Brasil é um dos países que não ratificaram o instrumento, tendo-o encaminhado para apreciação do Congresso Nacional em $2010^{20}$. Desta forma, distingue-se da grande maioria dos países da América do Sul, visto que apenas Suriname acompanha-o em não aderir à Convenção.

A CDTM tem sua origem em mais de 10 anos de negociações no âmbito das Nações Unidas, das quais resultou texto que busca, fundamentalmente, conciliar os direitos humanos dos migrantes com a prerrogativa estatal de definir quem tem acesso a seu território (BOHNING, 1991, apud FARIA, 2015). Nesse contexto, a Convenção elenca uma série de direitos, em sua maioria já reconhecidos pelo regime internacional de direitos humanos, adaptados a particularidades dos trabalhadores migrantes; e reserva uma seção para direitos cuja prevalência independe do status migratório do indivíduo. A Convenção cria, ainda, mecanismos de monitoramento e de transparência para sua aplicação, além de um sistema de solução de controvérsias - instituição que, quando e se implementada, terá potencial de reforçar a eficácia da norma e de consolidar o tratamento internacional das interações entre Estados.

A Tabela 1.1 esquematiza dados sobre o status de ratificação, em janeiro de 2017, de normas centrais dos regimes internacionais de direitos humanos, refúgio e apatridia, trabalhadores migrantes e tráfico de pessoas, sublinhando as informações concernentes ao Brasil.

\footnotetext{
${ }^{20}$ Esse tema será abordado mais atentamente no capítulo 4 desta tese.
} 
Tabela 1.1: Status de tratados multilaterais dos regimes de direitos humanos, refúgio e apatridia, trabalhadores migrantes e tráfico de pessoas em janeiro de 2017

\begin{tabular}{|c|c|c|c|c|c|}
\hline & \multirow{2}{*}{$\begin{array}{l}\text { Ano de } \\
\text { entrada } \\
\text { em vigor }\end{array}$} & \multicolumn{2}{|c|}{ Estados partes } & \multicolumn{2}{|c|}{ Brasil } \\
\hline & & $\mathrm{N}^{\circ}$ & $\%$ & Assinou & Ratificou \\
\hline $\begin{array}{l}\text { Direitos Humanos } \\
\text { Pacto Internacional sobre Direitos Civis e } \\
\text { Políticos de } 1966\end{array}$ & 1976 & 169 & 87 & Sim & $\begin{array}{l}\text { Decreto } n^{\circ} \\
592 / 1992\end{array}$ \\
\hline $\begin{array}{l}\text { Convenção Internacional contra todas as } \\
\text { formas de discriminação racial de } 1966\end{array}$ & 1969 & 178 & 92 & Sim & $\begin{array}{l}\text { Decreto } \mathrm{n}^{\circ} \\
65.810 / 1969\end{array}$ \\
\hline Convenção Americana de Direitos Humanos & 1969 & 22 & 64 & Sim & $\begin{array}{l}\text { Decreto } n^{\circ} \\
678 / 1992\end{array}$ \\
\hline $\begin{array}{l}\text { Refugiados e Apatridia } \\
\text { Convenção sobre o Estatuto dos Refugiados } \\
\text { de } 1951\end{array}$ & 1954 & 145 & 74 & Sim & $\begin{array}{l}\text { Decreto } \mathrm{n}^{\circ} \\
50.215 / 1961\end{array}$ \\
\hline $\begin{array}{l}\text { Protocolo de } 1967 \text { sobre o Estatuto dos } \\
\text { Refugiados }\end{array}$ & 1967 & 146 & 75 & Sim & $\begin{array}{l}\text { Decreto } \mathrm{n}^{\circ} \\
70.946 / 1972\end{array}$ \\
\hline $\begin{array}{l}\text { Convenção sobre o Estatuto dos Apátridas de } \\
1954 .\end{array}$ & 1960 & 89 & 46 & Sim & $\begin{array}{l}\text { Decreto } \mathrm{n}^{\mathrm{o}} \\
4.246 / 2002 \text {. }\end{array}$ \\
\hline $\begin{array}{l}\text { Trabalhadores Migrantes } \\
\text { Convenção nº } 97 \text { da OIT de } 1949 \text { sobre } \\
\text { Trabalhadores Migrantes }\end{array}$ & 1952 & 49 & 26 & Sim & $\begin{array}{l}\text { Decreto } \mathrm{n}^{\circ} \\
58.822 / 1966\end{array}$ \\
\hline $\begin{array}{l}\text { Convenção nº } 143 \text { da OIT de } 1975 \text { sobre as } \\
\text { Imigrações Efetuadas em Condições Abusivas } \\
\text { e Sobre a Promoção da Igualdade de } \\
\text { Oportunidades e de Tratamento dos } \\
\text { Trabalhadores Migrantes }\end{array}$ & 1978 & 23 & 12 & Sim & Não \\
\hline $\begin{array}{l}\text { Convenção Internacional de } 1990 \text { sobre a } \\
\text { Proteção dos Direitos de Todos os } \\
\text { Trabalhadores Migrantes e Membros de Suas } \\
\text { Famílias }\end{array}$ & 2003 & 50 & 25 & Não & Não \\
\hline $\begin{array}{l}\text { Tráfico de pessoas } \\
\text { Protocolo Adicional de } 2000 \text { à Convenção da } \\
\text { ONU contra o Crime Organizado } \\
\text { Transnacional Relativo à Prevenção, } \\
\text { Repressão e Punição do Tráfico de Pessoas, } \\
\text { em Especial Mulheres e Crianças }\end{array}$ & 2003 & 167 & 86 & Sim & $\begin{array}{l}\text { Decreto } \mathrm{n}^{\circ} \\
5.017 / 2004\end{array}$ \\
\hline $\begin{array}{l}\text { Protocolo Adicional de } 2000 \text { à Convenção da } \\
\text { ONU Contra o Crime Organizado } \\
\text { Transnacional Relativo ao Combate ao } \\
\text { Tráfico de Migrantes por Via Terrestre, } \\
\text { Marítima e Aérea }\end{array}$ & 2004 & 140 & 72 & Sim & $\begin{array}{l}\text { Decreto } \mathrm{n}^{\circ} \\
5.016 / 2004\end{array}$ \\
\hline
\end{tabular}

Fonte: Tabela adaptada a partir de ONU (2015, p.20), com dados da Câmara dos Deputados (2017), da ONU (2017) e OEA (2017). 
No cenário internacional, as migrações constituem objeto de um elevado número de foros. Dentro do sistema ONU, a OIT aborda o tema sob a ótica dos trabalhadores; o Alto Comissariado das Nações Unidas para Refugiados (ACNUR) foca nos refugiados; o Escritório das Nações Unidas sobre Drogas e Crime (UNODC) trata do tráfico de imigrantes; o Programa Alimentar Mundial (PAM) tem ampla atuação nos campos de refugiados; a Organização Mundial de Saúde (OMS) debruça-se sobre o tema na saúde. Por seu turno, o escritório do Alto Comissário das Nações Unidas para os Direitos Humanos tangencia as migrações internacionais, mas tem capacidade de atuação reduzida em relação ao tema, não possuindo pessoal específico ou recursos operacionais a ele dedicados (FARIA, 2015).

Nenhum desses organismos, entretanto, possui mandato específico para as migrações internacionais e abrangente no sentido de englobar o fenômeno em suas diversas facetas. Nesse vácuo, observa-se uma tendência à criação superposta de instâncias informais e sem caráter vinculante para discutir o tema. Na origem dessa tendência, aponta-se a Conferência da ONU sobre População e Desenvolvimento, ocorrida no Cairo em 1994 (FARIA, 2015; PATARRA, 2011). Tal Conferência, além de ter marcado a adoção do paradigma das migrações e desenvolvimento, o qual caracterizaria as discussões das próximas décadas, deu início à estratégia de fortalecimento da cooperação internacional em migrações por meio de espaços regionais de discussão, informais e não-vinculantes. De acordo com Maria Rita Faria (2015), os países em desenvolvimento presentes na Conferência haviam sugerido convocação de conferência global sobre migrações, a que se opuseram os países desenvolvidos de destino. Os processos consultivos regionais teriam, então, sido apresentados como solução intermediária. Dentre os processos consultivos regionais criados, destaca-se a Conferência Sul-Americana de Migrações (OIM, 2012).

Em 1999, a Comissão das Nações Unidas sobre Direitos Humanos criou a figura do Relator Especial sobre os Direitos Humanos dos Migrantes, com atribuição de coletar informações sobre violações aos direitos humanos desses indivíduos, examinar medidas e formular recomendações para superar os obstáculos à sua proteção efetiva. 
Desde então, o mandato do Relator Especial, que cobre todos os países independente de aderirem à CDTM, vem sendo renovado a cada três anos ${ }^{21}$.

Em 2002, o Secretário-Geral das Nações Unidas, Kofi Annan, elencou as migrações internacionais como uma das prioridades da comunidade internacional no Relatório Strenghtening of the United Nations: an agenda for further change, o qual determinou a criação de um Grupo de Trabalho sobre a temática. No ano seguinte, Kofi Annan conduziu a formação de Comissão Global sobre Migrações Internacionais (CGMI), organismo independente formado por corpo técnico de distintos países com o mandato específico de fornecer um enquadramento para a formulação de uma resposta coerente, completa e global à questão das migrações internacionais - o que se materializou no relatório "As migrações num mundo interligado: Novas linhas de acção" (CGMI, 2005). A diplomata brasileira Maria Rita Faria (2015) narra que, nas reuniões com as delegações da Comissão, notava-se uma diferença entre os discursos dos países em desenvolvimento, baseados na proteção dos direitos humanos dos migrantes e na natureza multidimensional do tema migratório, e aqueles dos países desenvolvidos, focados em considerações econômicas sobre a relação entre migrações e desenvolvimento e em medidas restritivas dos fluxos migratórios.

Uma das recomendações assinaladas no relatório da CGMI foi a promoção de mecanismos de coordenação entre os órgãos já existentes relacionados ao tema, o que veio a ser concretizado com a criação do Global Migration Group (GMG) ${ }^{22}$. Trata-se de grupo interinstitucional que reúne representantes de diversos organismos internacionais do sistema ONU a fim de fomentar a coerência e coordenação na aplicação e formulação de normas migratórias.

Em 2004, a Assembleia Geral das Nações Unidas adotou a resolução A/58/208, convocando para 2006 o primeiro Diálogo de Alto Nível sobre Migrações e Desenvolvimento. No Diálogo, afirmou-se a relação intrínseca entre migrações, desenvolvimento e direitos humanos e reiterou-se a importância da implementação das

\footnotetext{
${ }^{21}$ Relatórios disponíveis em: http://www.ohchr.org/EN/Issues/Migration/SRMigrants/Pages/AnnualReports.aspx. Acesso em: 08 jan. 2017.

${ }_{22}$ Compõe-se de: OIT, a Conferência das Nações Unidas sobre Comércio e Desenvolvimento (UNCTAD), a OIM, o Departamento de Assuntos Econômicos e Sociais das Nações Unidas (UNDESA), o PNUD, a UNESCO, o Fundo de População das Nações Unidas (UNFPA), o Escritório do Alto Comissariado das Nações Unidas para os Direitos Humanos (OHCHR), o ACNUR, a UNICEF, o Instituto das Nações Unidas para Formação Profissional e Investigações (UNITAR), o Escritório das Nações Unidas contra a Droga e o Crime (UNODC), ONU Mulheres, Banco Mundial, OMS e as Comissões Regionais das Nações Unidas.
} 
convenções internacionais sobre direitos humanos - inclusive a CDTM (FARIA, $2015)^{23}$. Dele resultou a criação do Fórum Global sobre Migrações, formalmente desvinculado da ONU e de natureza consultiva, funcionando com base em mesas redondas temáticas de que participam agentes governamentais, acadêmicos e representantes da sociedade civil. A OIM atua como secretariado do fórum.

A OIM constitui a única instância internacional dedicada exclusivamente às migrações, porém suas atribuições são operativas e não normativas, não estando inserida no sistema ONU. Isso significa que ela atua junto a parceiros governamentais, intergovernamentais e não-governamentais a fim de promover a gestão das migrações e a cooperação na temática, operando em quatro áreas: migração e desenvolvimento; facilitação da migração; regulação da migração; manejo das migrações forçadas (OIM, 2016). Na prática, a organização presta serviços aos países que a contratam, tais como capacitação institucional; pesquisa; operações de deslocamentos dos grupos de migrantes; serviços de apoio aos postos consulares. No âmbito internacional, é responsável pelo secretariado do Fórum Global sobre Migrações e de alguns processos consultivos regionais.

Nesse quadro, Maria Rita Faria pontua que, “ante a inexistência de princípios multilaterais para o tratamento das migrações, a OIM norteia suas atividades de acordo com os preceitos das políticas migratórias nacionais dos países que a contratam" (FARIA, 2015, p.187). Acrescenta que, dado o fato da OIM depender de financiamento direto dos Estados para a execução de projetos específicos, sua independência na condução dos mesmos seria limitada (FARIA, 2015). De fato, diante da carência de instituições multilaterais específicas sobre as migrações, a atuação da OIM se baseia sobretudo em princípios gerais de proteção dos direitos humanos e em diretrizes de boas práticas afirmadas pela própria organização.

Por último, ressalte-se que as origens da OIM podem ser remetidas a 1951, quando foi criado o Comitê Intergovernamental Provisório para o Movimento de Migrantes da Europa. É em 1989, porém, que ela se estabelece no atual formato. Em 2017, a organização possui 166 Estados Partes, entre os quais o Brasil.

No contexto das Américas, em que pese não haver referência às migrações na Carta da Organização de Estados Americanos (OEA), elas são abordadas pela

\footnotetext{
${ }^{23}$ O II Diálogo de Alto Nível sobre Migrações ocorreu em 2013, e em muito repetiu a agenda do anterior.
} 
organização em algumas frentes, tal como a Comissão Especial sobre Assuntos de Migração. No Sistema Interamericano de Direitos Humanos, a temática recebeu destaque em casos julgados pela Corte Interamericana de Direitos Humanos que constituíram referência para proteção dos direitos humanos dos migrantes ${ }^{24}$.

Paralelamente, a sociedade civil organizada, além de exercer advocacy nos organismos internacionais e governos, passou a se organizar no Fórum Social Mundial das Migrações (FSMM), um dos processos temáticos derivados do Fórum Social Mundial $(\mathrm{FSM})^{25}$. O primeiro FSMM se deu em 2005, na cidade de Porto Alegre, Brasil, e foi promovido por entidades e movimentos como Serviço Pastoral dos Migrantes e Grito dos Excluídos. Desde então, o Fórum se reuniu com frequência bianual $^{26}$, do que resultaram declarações e publicações apontando, sobretudo, para os valores dos direitos humanos e cidadania universal.

Em suma, percebe-se que as instituições internacionais voltadas às migrações são fragmentadas e caracterizadas pela informalidade, com poucos elementos de caráter normativo e ausência de instância com mandato para proteção dos imigrantes. Tal fragmentação dificulta tanto a governança das migrações em um nível global, quanto a formulação de políticas que levem em conta sua transversalidade. Em decorrência, Maria Rita Faria avalia que:

\begin{abstract}
$\mathrm{Na}$ ausência de arcabouço multilateral integral sobre migrações, os Estados têm criado instituições temporárias e $a d$ hoc para tratar dos vários aspectos relacionados ao tema. Ademais, os países tradicionais de destino têm mais liberdade para fazer valer, no plano internacional, suas políticas nacionais migratórias, bem como para exercer a prática de forum shopping, seja escolhendo entre as instituições internacionais que mais se adequam a seus interesses, seja pela exclusão de parceiros ou de aspectos alegadamente mais controversos inerentes ao debate sobre migrações (FARIA, 2015, p.176).
\end{abstract}

Nos termos da autora, portanto, o regime internacional das migrações, na prática, seria definido pela política migratória dos países desenvolvidos. Ainda segundo Faria (2015), tal realidade seria verificada desde a convocação unilateral, pelos Estados Unidos, da Conferência de Evian $(1938)^{27}$ para tratar da temática dos refugiados - a

\footnotetext{
${ }^{24}$ Entre esses casos, destacam-se Nadege Dorzema e outros vs. República Dominicana; bem como Vélez Loor vs. Panamá. Salienta-se, ainda, Opinião Consultiva nº 18 , de 2003, sobre a Condição Jurídica e Direitos dos Migrantes Indocumentados nas Américas.

${ }^{25}$ O FSM ocorreu, pela primeira vez, em Porto Alegre no ano de 2001, por iniciativa dos movimentos sociais, organizações não-governamentais, sociedade civil, pastorais sociais e ativistas políticos.

${ }^{26}$ Em 2006 e 2008, ocorreu na Espanha; 2010, Equador; 2012, Filipinas; 2014, África do Sul; 2016, Brasil.

${ }^{27}$ Tratada no capítulo 3 desta tese.
} 
despeito de iniciativas paralelas que vinham sendo empreendidas pela Liga das Nações. Diante dessas características, pode-se sequer afirmar a existência de um regime internacional de migrações?

Uma primeira observação sobre este questionamento é a de que o regime internacional das migrações está intrinsecamente ligado ao regime internacional dos direitos humanos. Isso se observa de uma perspectiva histórica, visto que a construção do regime internacional dos direitos humanos se deu justamente de maneira a enfrentar a devastação do pós-guerra, e nesse ponto as negociações internacionais relacionadas aos deslocados pelo conflito foram centrais; de uma perspectiva jurídica, dado que as normas que compõem o regime internacional de direitos humanos preconizam a igualdade independentemente de nacionalidade, logo se aplicam aos imigrantes; e de uma perspectiva política, tendo em vista observar-se nas instâncias multilaterais a mobilização da temática migratória vinculada à da proteção dos direitos humanos.

No entanto, é na falha do regime de direitos humanos em se impor ante restrições fundamentadas na nacionalidade que normas e instituições voltadas especificamente para os imigrantes emergem. Essas normas e instituições são, como exposto acima, fragmentadas e pouco formalizadas. Não obstante, de acordo com a definição de regimes como instituições, normas e procedimentos que regulamentam o comportamento dos atores de maneira a afetar a interdependência internacional, pode-se afirmar que há, sim, um regime internacional de migrações. Os arranjos institucionais, oficiais ou informais, que conectam os Estados em matéria migratória, formados pelas normas e instituições supramencionadas, por uma ampla gama de acordos bilaterais e multilaterais focados em aspectos operacionais, por organizações transnacionais e por burocracias governamentais em interação, correspondem, efetivamente, a fatores intermediários entre a estrutura de poder do sistema internacional e a barganha política que nele tem lugar (KEOHANE; NYE, 2001).

Desta forma, em que pesem a inexistência de uma instância multilateral com mandato específico e abrangente sobre as migrações e a escassez de normas vinculantes, a criação de fóruns e diálogos; a atuação setorial de agências ONU; os diagnósticos e recomendações do Relator Especial em Migrações e da Comissão Global sobre Migrações Internacionais; a atuação da OIM em 188 países, dentre outros elementos, contribuem para a criação e consolidação de conceitos e boas práticas aptos a serem mobilizados pelos Estados e a enquadrarem suas interações. 


\subsection{Xadrez institucional da política migratória brasileira}

Para além das normas internacionais incorporadas pelo Brasil, a política migratória do país é enquadrada por: (i) Constituição, leis e decretos federais; (ii) portarias e resoluções normativas; (iii) acordos regionais e bilaterais.

No período analisado por esta tese (2002-2016), a política migratória brasileira orbitava em torno da Lei ${ }^{\circ}$ 6.815/1980, o Estatuto do Estrangeiro, e do instrumento que a regulamentava, Decreto $\mathrm{n}^{\circ} 86.715 / 1981^{28}$. No entanto, o quadro normativo que regia a política migratória brasileira ultrapassava estes diplomas e até mesmo os confrontava. A Constituição brasileira de 1988 fundamenta os direitos dos migrantes no caput de seu artigo $5^{\circ}$, definindo que "todos são iguais perante a lei, sem distinção de qualquer natureza, garantindo-se aos brasileiros e aos estrangeiros residentes no País a inviolabilidade do direito à vida, à liberdade, à igualdade, à segurança e à propriedade 29 ". Esse princípio da igualdade era, também, garantido pela Lei 6.815/1980 (art.95). Havia, porém, um descompasso principiológico entre ambos os diplomas: a garantia dos direitos humanos, tão cara ao texto constitucional, não encontrava guarida no Estatuto do Estrangeiro, o qual erigia como valores primordiais a segurança nacional e a abstrata noção de interesse nacional.

Dentre as leis federais conexas à política migratória, destaca-se a Lei do Refúgio (Lei $n^{\circ}$ 9.474/1997) e a Lei de Combate ao Tráfico de Pessoas (Lei $n^{\circ}$ 13.344/2016), ambas amplamente ancoradas nos direitos humanos e nos respectivos regimes internacionais. Também se observam as várias leis de anistia, as quais regularizaram aqueles que se encontravam em situação migratória irregular à época de suas promulgações (desde o Estatuto do Estrangeiro, leis 6.964/1981, 7.685/1988, 9.675/98, 11.961/2009). Pode-se citar, ainda, o ainda vigente dispositivo da Consolidação das Leis do Trabalho (Decreto-Lei $n^{\circ} 5.457 / 1943$ ) que estabelece cotas de 2/3 de trabalhadores brasileiros para empresas atuantes no Brasil (art. 354).

As Resoluções Normativas (RN) do Conselho Nacional de Imigração (CNIg) possuem caráter vinculante e são instrumentos dos quais o órgão lança mão para efetivar suas competências de formular a política de imigração e de dirimir dúvidas e

\footnotetext{
${ }^{28}$ Em 25 de maio de 2017, foi sancionada a Lei n ${ }^{\circ}$ 13.445, a nova Lei de Migração.

29 No entanto, o próprio texto constitucional institui algumas diferenças de tratamento, notadamente quanto aos direitos políticos, visto que os estrangeiros não possuem direito ao voto e à elegibilidade. Este ponto constitui uma pauta central nas reivindicações da sociedade civil.
} 
solucionar casos omissos concernentes aos imigrantes. Dentre essas normas, pode-se destacar, pela amplitude de sua aplicação, a $\mathrm{RN} \mathrm{n}^{\circ}$ 27/1998, a qual disciplina a avaliação de situações especiais e casos omissos pelo CNIg. Já as Portarias do Ministério da Justiça regulamentam os procedimentos de sua competência, podendo-se destacar, pelo impacto gerado na política migratória, a Portaria $n^{\circ} 04 / 2015$, que dispõe sobre os procedimentos de permanência definitiva e registro de estrangeiro.

Por último, saliente-se que o Acordo sobre Residência para Nacionais dos Estados Partes do Mercado Comum do Sul (Mercosul), Bolívia e Chile, promulgado pelo Decreto ${ }^{\circ} 6.975 / 2009$, apresenta uma regulamentação específica para os nacionais desses Estados, além de Peru, Equador e Colômbia, os quais aderiram posteriormente ao instrumento comunitário.

Nos termos da Lei $\mathrm{n}^{\mathrm{o}} 10.683 / 2010$, que dispõe sobre a organização da Presidência da República e Ministérios, o Ministério da Justiça (MJ) reúne competência sobre nacionalidade, imigração e estrangeiros. Dentro de sua estrutura, a Secretaria Nacional de Justiça (SNJ), órgão específico singular, possui atribuições de formulação e implementação relativas às seguintes políticas, dentre outras: “a) política nacional de migrações, especialmente no que se refere à nacionalidade, à naturalização, ao regime jurídico e à migração, inclusive por meio da representação do Ministério no Conselho Nacional de Imigração; b) política nacional sobre refugiados; c) política nacional de enfrentamento ao tráfico de pessoas" (Decreto 8.668/2016, art. 9, V).

Para exercer sua competência sobre a política nacional de migrações, a SNJ conta com o Departamento de Migrações ${ }^{30}$. Antes da promulgação do Decreto $n^{\circ} 8.668$, em 11 de fevereiro de 2016, o Departamento de Migrações era denominado

\footnotetext{
${ }^{30}$ Art. 11. Ao Departamento de Migrações compete: I - estruturar, implementar e monitorar a política nacional de migração e de refúgio; II - promover, em parceria com os demais órgãos da administração pública federal e com redes de atores da sociedade civil, a disseminação e a consolidação de garantias e direitos dos migrantes e refugiados, nas áreas de sua competência; III - atuar para a ampliação e a maior eficácia das políticas e dos serviços públicos destinados à prevenção da violação de garantias e à promoção dos direitos dos migrantes; IV - apoiar o desenvolvimento de planos, diagnósticos, políticas e ações voltadas à inclusão social de migrantes junto aos órgãos federais, estaduais, distritais e municipais e entidades da sociedade civil; $\mathrm{V}$ - negociar acordos e conduzir estudos e iniciativas para o aperfeiçoamento do regime jurídico dos migrantes; VI - promover a articulação dos órgãos dos Poderes Executivo e Judiciário e do Ministério Público no que se refere à migração; VII - instruir processos e deliberar sobre temas de nacionalidade e apatridia, naturalização, prorrogação do prazo de estada de migrante no País, transformação de vistos e residências e concessão de permanência; VIII - instruir processos de reconhecimento, cassação e perda da condição de refugiado e de asilado político, autorizar a saída e o reingresso no País e expedir o respectivo documento de viagem; IX - fornecer apoio administrativo ao Comitê Nacional para os Refugiados; e X - receber, processar e encaminhar assuntos relacionados ao tráfico de migrantes.
} 
Departamento de Estrangeiros (DEEST). Como esta última denominação abarca a maior parte do intervalo temporal examinado na tese, será o termo majoritariamente utilizado.

Vinculado ao Departamento de Migrações se encontra o Comitê Nacional para os Refugiados (CONARE), órgão colegiado ${ }^{31}$ cuja principal atribuição consiste em declarar o status de refugiado em primeira instância. É regulado pela Lei no 9.474/1997, a qual lhe atribui a competência de implementar a política de refúgio, nos termos do regime internacional correspondente ${ }^{32}$ : nesse desiderato, seus membros se reúnem com periodicidade mensal para analisar, individualmente, a existência de fundado temor de perseguição que dará guarida para a declaração reconhecendo sua condição de refugiado e conferindo-lhe proteção internacional.

O Departamento de Polícia Federal (DPF) é órgão de atendimento na ponta dos serviços prestados ao imigrante, particularmente aqueles atinentes ao seu registro e fornecimento da Carteira de Identidade de Estrangeiro (CIE). O exercício de suas funções se dá por meio dos seus mais de 100 pontos de atendimento em território brasileiro e da Divisão Central de Registro de Estrangeiros (DICRE), órgão central que reúne o recebimento dos processos remetidos pelas unidades descentralizadas.

A Lei $\mathrm{n}^{\circ} 10.683 / 2003$ atribui ao Ministério do Trabalho $\left(\mathrm{MTE}^{33}\right)$ a competência sobre política de imigração (art. 27, XIX). Exerce-a através de dois órgãos: a Coordenação-Geral de Imigração (CGIg) e o Conselho Nacional de Imigração (CNIg). A CGIg é o órgão responsável por operacionalizar e decidir sobre os pedidos de autorização para trabalho de estrangeiros no Brasil, bem como opinar sobre demandas de prorrogação de estada e transformação de visto relativos a trabalho. Avalia, ainda, solicitações de alteração de função exercida por trabalhadores estrangeiros no Brasil, alteração de empresa contratante (desde que no mesmo grupo ou conglomerado

\footnotetext{
${ }^{31}$ Seus membros são: o MJ, que o preside, o MRE, MTE, Ministério da Saúde, Ministério da Educação, Departamento de Polícia Federal, organização não-governamental que se dedique a atividade de assistência e proteção do refugiado no país, e Alto Comissariado das Nações Unidas para o Refugiado (ACNUR) - este último com direito a voz, sem voto.

${ }^{32}$ De acordo com o art. 12 da Lei 9.474/97, compete ao CONARE: I - analisar o pedido e declarar o reconhecimento, em primeira instância, da condição de refugiado; II - decidir a cessação, em primeira instância, ex officio ou mediante requerimento das autoridades competentes, da condição de refugiado; III- determinar a perda, em primeira instância, da condição de refugiado; IV - orientar e coordenar as ações necessárias à eficácia de proteção, assistência e apoio jurídico aos refugiados; V - aprovar instruções normativas esclarecedoras à execução desta lei.

${ }^{33}$ Opta-se pela utilização da sigla MTE no decorrer de todo o trabalho porque a denominação Ministério do Trabalho e Emprego predominou largamente no período analisado. No entanto, o órgão agrega a Previdência Social em 02 de outubro de 2015, passando a se chamar Ministério do Trabalho e Previdência Social.
} 
econômico) e acúmulo de funções ou cargos exercidos. Ademais, supervisiona atividades relacionadas à contratação ou transferência de brasileiros para trabalho no exterior, além de prestar apoio técnico e administrativo ao CNIg.

O CNIg constitui um órgão colegiado ${ }^{34}$, vinculado ao gabinete do Ministro do Trabalho e com a presidência destinada ao MTE. Criado pela Lei $n^{\circ} 6.815 / 1980$, tem seu funcionamento e organização definidos pelos Decretos no 840/1993 e 3.574/2000. Suas competências se referem a formular a política, coordenar e orientar as atividades de imigração; efetuar o levantamento periódico das necessidades de mão-de-obra estrangeira qualificada e elaborar os respectivos planos de imigração; promover ou fornecer estudos de programas relativos à imigração; estabelecer normas de seleção de imigrantes, visando a proporcionar mão-de-obra especializada a setores da economia nacional; e opinar sobre a alteração da legislação relativa à imigração, quando proposta por órgão do poder Executivo.

No que concerne à questão migratória, o Itamaraty detém a competência de promover e gerir as negociações diplomáticas com outros Estados sobre o tema, sendo ainda o órgão que, ao manter os serviços consulares, lida diretamente com os estrangeiros interessados em vir ao Brasil, bem como com os brasileiros vivendo no exterior. Assim, compete ao MRE a emissão de documento que permitirá o acesso do estrangeiro ao país, podendo conceder visto de trânsito, turista, temporário, permanente, de cortesia, oficial e diplomático. É de sua responsabilidade, ainda, negociar acordos de isenção e facilitação de vistos, bilateral ou multilateralmente. Por último, cabe ao Itamaraty representar o Brasil em instâncias multilaterais sobre migrações.

\footnotetext{
${ }^{34}$ São seus membros: I - Setor Governo: Ministério do Trabalho e Emprego; Ministério da Justiça Ministério das Relações Exteriores; Ministério da Agricultura, Pecuária e Abastecimento; Ministério da Saúde; Ministério do Desenvolvimento, Indústria e Comércio Exterior; Ministério da Ciência, Tecnologia e Inovação; Ministério da Educação; Ministério do Turismo. II - Setor Trabalhadores: Central dos Trabalhadores e Trabalhadoras Do Brasil; Central Única dos Trabalhadores; Força Sindical; União Geral dos Trabalhadores; Nova Central Sindical de Trabalhadores. III - Setor Empregadores: Confederação Nacional da Indústria; Confederação Nacional do Comércio de Bens, Serviços e Turismo; Confederação da Agricultura e Pecuária Do Brasil; Confederação Nacional do Transporte; Confederação Nacional das Instituições Financeiras. IV - Setor Comunidade Científica e Tecnológica: Sociedade Brasileira para o Progresso da Ciência.V - Observadores: Comissão Nacional para População e Desenvolvimento; Instituto Migrações e Direitos Humanos; Organização Internacional do Trabalho; Organização Internacional para as Migrações; Secretaria de Políticas para as Mulheres da Presidência da República; Secretaria de Políticas de Previdência Social; Secretaria de Direitos Humanos da Presidência da República; Secretaria de Políticas de Promoção da Igualdade Racial; Defensoria Pública da União; Advocacia Geral da União; Departamento de Polícia Federal; Agência Brasileira de Inteligência; Ministério Público Federal; Ministério Público do Trabalho.
} 


\title{
Capítulo 2: Ação e interação no Executivo brasileiro
}

\author{
"There is nothing more difficult to carry out, nor more \\ doubtful of success, nor more dangerous to handle, than to \\ initiate a new order of things. For the reformer has enemies \\ in all those who profit by the old order, and only lukewarm \\ defenders in all those who would profit by the new" \\ (Maquiavel, O príncipe - apud GEDDES, 1993, p.43). \\ "The nightmare of the modern state is the hugeness of \\ bureaucracy, and the problem is how to get coherence and \\ design in it" (Henry Kissinger, apud ART, 1973, p.467)
}

\subsection{Introdução}

O presente capítulo busca inserir os burocratas dentro do Executivo brasileiro, em uma abordagem institucionalista, mapeando seu papel no processo de políticas públicas e nas mudanças institucionais, bem como localizando as interações por eles protagonizadas em um contexto de arranjos institucionais complexos. Ao amparar-se no conceito de arranjo institucional, o capítulo objetiva debruçar-se sobre como regras, organizações e processos que definem desenhos de políticas influenciam os atores burocráticos que nelas tomam parte e, desta forma, afetam resultados políticos (LOTTA et al., 2016).

Na primeira seção, busca-se situar o burocrata no cenário dos estudos sobre o Executivo brasileiro, oferecendo uma revisão da literatura sobre o funcionamento interno deste poder no país. Embora não exaustiva, esta revisão visa a fornecer um panorama geral de possíveis variáveis explicativas para o objeto de análise. Em seguida, debruça-se sobre a literatura relativa ao elemento político da ação burocrática, dentro de um quadro de análise de política pública, em especial de estudos sobre implementação. Nesse ponto, foca-se em quais fatores são levantados pela literatura para explicar as decisões dos burocratas, e como sua agência pode intervir na mudança institucional.

O próximo tópico, por sua vez, enfatiza como os burocratas agregam suas preferências, particularmente voltando-se para a coordenação intragovernamental. Em seguida, busca-se inserir a organização burocrática do Itamaraty dentro do contexto do Executivo brasileiro. Ao final, tendo em vista a literatura exposta, derivam-se as hipóteses a serem empiricamente testadas nos capítulos 4 e 5 . 


\subsection{O Executivo em ação: como funciona o Poder Executivo brasileiro e onde a literatura situa os burocratas?}

Os estudos políticos que têm por objeto o funcionamento interno do Poder Executivo no Brasil podem ser divididos em dois macrogrupos: o primeiro deles prioriza a lógica do governo, conferindo ênfase à Presidência e às condições de governabilidade; já o segundo antefere a lógica política da administração pública, com foco nos burocratas que a compõem ou nas políticas públicas que nela são construídas.

A primeira abordagem tende a concentrar-se nos políticos, analisando o funcionamento do Executivo a partir da Presidência de maneira a avaliar sua capacidade de governo, seja debruçando-se sobre a formação do governo, seja enfatizando como ele é operacionalizado (BATISTA, 2016; INÁCIO, 2006) ${ }^{35}$. Adota-se o pressuposto da racionalidade, identificando-o com o objetivo dos atores de influenciar políticas com vistas ao resultado eleitoral ansiado (DOWNS, [1957] 1999). Uma das perspectivas comumente adotadas pela literatura é aquela que aplica o modelo de principal-agent à relação entre a presidência e unidades administrativas (e.g., MARTIN; VANBERG, 2004), investigando os mecanismos institucionais através dos quais os principais podem exercer controle ou influência sobre as atividades de seus agentes ${ }^{36}$. No caso de governos de coalizão, o modelo principal-agente é traduzido no questionamento sobre como, em coalizões formadas por partidos de distintas preferências, assegura-se que os ministros optem por orientar-se em função não de suas preferências individuais, mas sim daquelas de seus parceiros de coalizão.

Outra importante referência para esta literatura é a análise dos pontos de veto em processos decisórios: inspirada em Tsebelis (1995), examina atores, individuais ou coletivos, a quem se confere poder de veto sobre determinada questão, relacionando tal mecanismo institucional a resultados políticos. Um dos pontos sustentados por Tsebelis (1995) é o de que, quanto mais concentrado o processo decisório, menos pontos de veto existirão e, consequentemente, mais fácil será para o Executivo implementar as políticas de sua preferência.

\footnotetext{
${ }^{35}$ Não é objetivo deste capítulo realizar um inventário detalhado dos estudos de cada um dos grupos. Para revisões da literatura do que é aqui identificado como primeiro grupo, ver Batista (2016) e Palermo (2000).

${ }^{36}$ Os modelos principal-agente se fundamentam no pressuposto de que o principal possui limitações de tempo e conhecimento, motivo pelo qual terá ganhos se contratar um agente com expertise para exercer determinado trabalho. O agente, por sua vez, ganhará uma recompensa monetária. Não obstante os mútuos ganhos, a cooperação não é evidente, posto que os agentes terão interesses próprios, por vezes divergentes daqueles do principal. Isto geraria dilemas de confiança entre ambos os polos (MOE, 2005).
} 
Dado o foco na governabilidade, os estudos da primeira abordagem se dividem entre análises da relação entre a Presidência e o Legislativo, focando na dinâmica da formação de gabinetes de coalizão e nos recursos legislativos do Presidente; e pesquisas relativas ao poder de ingerência dos Presidentes sobre os Ministérios e outras agências. Estas últimas, em muito inspiradas no influente trabalho de Terry Moe (1985), frequentemente abordam as dinâmicas de centralização, referindo-se ao deslocamento de funções para o gabinete presidencial, e/ou de politização, significando os esforços presidenciais de intervir nas burocracias do Executivo de maneira a torná-las responsivas a suas preferências.

Moe (1985) propõe que as duas estratégias seriam complementares, enquanto Rudalevige e Lewis (2005) sugerem-nas substitutivas. Para Moe (1985), maior centralização é esperada quanto mais numerosas e mais complexas as questões a serem tratadas, bem como quanto mais fragmentada a burocracia. Rudalevige e Lewis (2005) detalham e aprofundam esses argumentos, prevendo maior centralização quando, dentre outros fatores, (i) o projeto envolver vários setores do governo, caso em que as informações fornecidas pelas diferentes burocracias não seriam confiáveis; (ii) questão requerer urgência, mostrando-se inviável aguardar resposta da burocracia; (iii) questão constituir um tema novo. Já nos casos de aumento de complexidade política, uma maior delegação seria esperada, por exigir-se maior expertise.

Em suma, nesta primeira abordagem do Poder Executivo, analisam-se as estratégias presidenciais de coordenação política e de implantação da agenda governamental (INÁCIO, 2006). Já o segundo grupo de estudos aborda o Executivo em ação no processo de políticas públicas. Ao fazê-lo, ultrapassa o exame dos fatores institucionais relacionados ao presidencialismo de coalizão e incorpora outras características do ambiente decisório do poder Executivo brasileiro, tais como federalismo e descentralização de políticas; instâncias de participação social; parcerias com o setor privado e organizações da sociedade civil. Nesses termos, insere os burocratas no entendimento das dinâmicas de interação intraestatal e sócio-estatal, canalizadas pelas políticas públicas. Incorporam-se, neste intuito, modelos teóricos da análise de políticas públicas, especialmente sobre implementação, e da literatura sobre capacidades estatais.

A análise de políticas públicas é definida, na clássica afirmação de Laswell, como a resposta às seguintes perguntas "quem ganha o que, por que e que diferença faz" 
(apud SOUZA, 2006, p.24). De modo amplo, a política pública é vista como um processo em que se observa o Estado em ação, seja atuando diretamente ou através de delegação. Falar em política pública como um processo implica considerar a interatividade e simultaneidade das fases que são discriminadas no modelo do ciclo de políticas públicas, quais sejam, definição de agenda, formulação, implementação e avaliação (HILL, 2013). Não obstante, algumas particularidades dessas fases, em seu desenho didático, são importantes para compreensão da dinâmica do Poder Executivo ${ }^{37}$.

Assim, a definição de agenda constitui a parte mais política de todo o ciclo, ao envolver a inclusão de problemas em uma lista de prioridades; a seleção de determinadas questões, em paralelo à exclusão de outras, para serem enfrentadas pelo governo; bem como a apresentação e discussão de alternativas. Para John Kingdon (1995), atores políticos seriam protagonistas nessa fase, sendo que os burocratas assumiriam destaque ao desenvolver e operacionalizar soluções para os problemas elencados.

Já a formulação política pode envolver desde decisões de alta cúpula com forte aspecto político, até decisões procedimentais com predominante caráter técnico, englobando, portanto, o trabalho tanto de políticos como de burocratas. Por vezes, a formulação contempla interações intraestatais ou sócio-estatais, tais como em comitês e conselhos participativos. A literatura sobre a formulação discute, ainda, as dimensões da tomada de decisão, se baseadas unicamente em racionalidade, concebida de maneira absoluta ou limitada, ou se incorporam outras variáveis à análise, tal como sugere Lindblom (1959).

Dentre as críticas que aponta ao modelo racional, Lindblom (1959) afirma que ele não estaria adaptado à limitada capacidade humana de processamento de informação, nem à eventual falta de informação ou a seus custos. Ressalta que a formulação política corresponderia a uma sucessão de tentativas e erros, na qual o administrador público "tateia" (muddle through) para encontrar alternativas - o que, salienta o autor, corresponderia a um método de tomada de decisão, e não à ausência dele. Nesses termos, confere-se um papel de destaque aos burocratas na formulação política. Vinte anos depois, esta conclusão é acentuada por Lindblom (1979) ao aprofundar sua análise e propor um modelo incremental de políticas públicas,

\footnotetext{
${ }^{37}$ Não se vai explorar a etapa da avaliação de políticas, por escapar aos fins do presente trabalho.
} 
argumentando que as decisões políticas não partem do zero, mas sim de mudanças marginais sobre políticas já existentes.

Quanto à implementação, trata-se da arena de atuação burocrática por excelência, envolvendo agentes de esfera governamental semelhante ou distinta àquela da formulação política, além de outros atores públicos ou privados, voltados para a realização de objetivos políticos. Pressman e Wildavsky ([1973], 1984), em trabalho clássico sobre a implementação, definiram-na como a "interaction between the setting of goals and actions geared to achieve them" (p.xxiii).

Um dos debates que perpassaram a evolução da análise de políticas públicas foi aquele que questionou se, na prática, formulação e implementação seriam duas atividades separadas. Teorias tradicionais do ciclo de políticas públicas eram de opinião de que haveria não apenas uma distinção entre formulação e implementação, como também uma precessão em importância, sendo que esta deveria seguir os preceitos daquela. Uma segunda geração de estudos contestou esta separação dentro de um questionamento mais amplo da distinção entre administração e política, e atribuiu um papel mais amplo à ação dos burocratas ${ }^{38}$. Nesses termos, realizaram críticas como: (i) as políticas formuladas frequentemente são ambíguas ou possuem lacunas, exigindo a discricionariedade do burocrata para torná-las exequíveis; (ii) há uma diversidade de contextos de implementação para uma mesma formulação política; (iii) a interação com os usuários e com a rede mais ampla de políticas públicas pode levar a redefinições da política; dentre outras (SABATIER; MAZMANIAN, 1980; ARRETCHE, 2001; HILL, 2013; LOTTA, 2015). A partir deste ponto de vista, os estágios da formulação e da implementação de um construto institucional são vistos como permeáveis; e a mudança conduzida por burocratas com poder discricionário assume um papel de destaque.

Assim como os estudos da primeira abordagem, algumas análises voltadas para os outcomes de agências burocráticas também se inspiraram em modelos de delegação principal-agente (GEDDES, 1994), particularmente explorando os dilemas entre delegação e eficiência burocrática e entre discricionariedade e legitimidade democrática. Essa abordagem, especialmente verificada na literatura norte-americana e em sua

\footnotetext{
${ }^{38}$ Um dos grandes debates da literatura de análise de políticas públicas é a abordagem da implementação em uma perspectiva top-down e bottom-up. Consideramos que, de um lado, revisões literárias mais sintéticas deste debate tendem a abordar indistintamente argumentos prescritivos (especialmente vinculados ao conceito de eficiência) e descritivos, o que, a nosso ver, prejudica seu poder explicativo; por outro lado, julgamos que um exame contrapondo, em detalhe, ambas as perspectivas foge ao escopo do presente trabalho, motivo pelo qual nos furtamos a realizá-lo na presente ocasião.
} 
análise da delegação de poder entre os congressistas e burocratas (e.g. WOOD, 1988), tem maiores dificuldades para explicar o sistema brasileiro, no qual esta relação não se verifica (SOUZA, 2015; LOUREIRO et al., 2010).

A despeito de suas diferenças, tanto os estudos da lógica de governo como os das políticas públicas confluem em dois princípios: assentam seus fundamentos em uma perspectiva institucionalista, realizando considerações sobre o impacto dos desenhos institucionais em resultados políticos; e orbitam em torno do diagnóstico de presidencialismo de coalizão.

Quanto ao primeiro ponto, o argumento de que instituições possuiriam um efeito causal sobre resultados políticos é central para a teoria democrática contemporânea e sua hegemônica visão formalista da representação, cujo foco é centrado nos arranjos institucionais que a precedem e possibilitam. Nesse contexto, sobressai o influente trabalho de Lijphart (1991) que confronta o desempenho de democracias majoritárias, com maior concentração de poder no Executivo, ao das democracias consociativas, nas quais o poder de decisão está mais fragmentado - indicando que a redução dos atores políticos que podem constituir pontos de veto não geraria, necessariamente, melhores resultados nas políticas governamentais.

Debruçando-se sobre os fatores institucionais que afetam a qualidade das democracias, autores somaram ao conceito de representação aquele de responsividade, entendido como a capacidade do processo democrático de induzir o governo a formar e implementar as políticas desejadas pelos cidadãos (POWELL, 2004), em mecanismo encadeado por liames causais entre as preferências políticas dos cidadãos e as políticas públicas. Przeworski, Stokes e Manin (1999) salientam que entre esses dois polos encontram-se atores não-eleitos: os burocratas, os quais estariam sujeitos ao controle democrático por meio de mecanismos horizontais de accountability. Do ponto de vista do controle político, os presidentes instrumentalizariam variáveis institucionais de maneira a intervir nas agências burocráticas, tornando-as mais responsivas às suas preferências (MOE, 1989; GEDDES, 1994).

Por outro lado, é a partir do paradigma institucionalista, particularmente em sua vertente histórica, que as análises de políticas públicas passam a conferir maior ênfase ao Estado: reforçar o papel das instituições e seus desenhos nos resultados políticos implicou em voltar-se para o Estado e seu funcionamento. Nesse sentido, Theda Skocpol (1979) representou marco importante ao incorporar novas perspectivas ao 
estudo do processo político intermediando as instituições e políticas públicas. Nessa esteira, numerosos pesquisadores examinam a influência de arranjos institucionais sobre políticas públicas, seja averiguando a relação entre arranjos mais ou menos participativos e governabilidade, seja observando seus resultados concretos nas políticas - destacando-se a ênfase na sua estabilidade (LOUREIRO et al., 2014) e eficiência (GEDDES, 1994). Tais pesquisas também se voltam, no limite, para os mecanismos e efeitos dos sistemas de checks and balances, ao analisarem distintos atores, seus diferentes objetivos e respectivos poderes de veto.

No que concerne ao presidencialismo de coalizão, trata-se de diagnóstico amplamente acatado na literatura política de acordo com o qual, em contextos de tensão entre um sistema partidário fragmentado e uma concentração de poder normativo no Executivo, os presidentes, cujo partido jamais consegue obter isoladamente a maioria das cadeiras do Congresso, atuariam segundo uma lógica de sistemas parlamentares, formando alianças com vários outros partidos e distribuindo, aos membros de sua coalizão, o controle de agências governamentais (ABRANCHES, 1988; FIGUEIREDO, LIMONGI; 2001). Em decorrência, formar e manter governos de coalizão implica em gerenciar complexos contextos de barganha (INÁCIO, 2006), advindos da tensão entre o interesse coletivo na acomodação mútua e os incentivos individuais para perseguirem-se objetivos políticos particulares (MARTIN; VANBERG, apud BATISTA, 2016).

Esta conjuntura é afetada por variáveis atinentes à burocracia, bem como as afeta. Como colocam Maria Rita Loureiro e Fernando Abrucio, "a relação entre política e burocracia é fundamental na definição do processo de governo, sobretudo no presidencialismo" (1999, p.69), dados os dilemas de delegação e os mecanismos de distribuição de cargos supramencionados. Por outro lado, essa dinâmica traz influências institucionais para a arena de formulação e implementação de políticas públicas: como explicam Abers e Keck (2013), uma das resultantes da tensão entre a força centrífuga dos partidos e a força centrípeta da Presidência seria a fragmentação produzida dentro do poder Executivo. De acordo com as autoras,

This set of practices renders the system governable but complicates its administration, insofar as granting substantial autonomy to each government agency means that they work according to diverse and sometimes contradictory logics (ABERS; KECK, 2013, p.36). 
No Brasil, a literatura sobre Executivo com foco na governabilidade tem como importante referencial o trabalho de Amorim Neto (2006), no qual se defende que a estratégia adotada pelo presidente sobre a composição do governo estaria relacionada à sua escolha entre uma agenda legislativa com forte contribuição do Congresso ou com mais medidas unilaterais do Executivo. Nessa perspectiva, observa-se o caso brasileiro como de acentuada verticalização do processo de tomada de decisão, insculpida em mecanismos institucionais previstos na Constituição de 1988.

No contexto do presidencialismo de coalizão, Magna Inácio (2006) argumenta que, para responder ao desafio de coordenar de coalizões complexas, o presidente faria uso de diferentes recursos institucionais, dentre os quais a criação e expansão de estruturas especializadas dentro da Presidência. Essa estratégia visaria à ampliação dos recursos informacionais disponíveis, de maneira a fazer frente aos dilemas da delegação. No quadro da força centrípeta da presidência, Camila Lameirão (2011) analisa a evolução histórica do papel da Casa Civil até tornar-se a principal esfera de coordenação política e administrativa do Executivo. A autora observa, a partir dos mandatos de Fernando Henrique Cardoso e Luiz Inácio Lula da Silva, a consolidação da Casa Civil como um espaço que concentra o controle das atividades ministeriais, visando a assegurar a consecução dos interesses e preferências da Presidência no âmbito do Executivo.

A coordenação do gabinete presidencial pode, também, ser conduzida por um ministério chave para a gestão. Foi o caso do Ministério da Fazenda no primeiro governo Fernando Henrique Cardoso, conforme argumentam Maria Rita Loureiro e Fernando Abrucio (1999). Loureiro e Abrucio ressaltam a estratégia do Presidente de nomear, para os ministérios concedidos a partidos de sua base de coalizão no Congresso, pessoas de sua confiança como secretário executivo ou outro cargo de importância. Esses indivíduos, a quem os autores denominam "homens do presidente" (1999, p.82), contribuiriam para que as decisões tomadas nos Ministérios se coadunassem às diretrizes do núcleo governamental.

Mariana Batista (2013), por sua vez, ressalta que o presidencialismo de coalizão implica em barganhas políticas dentro do Executivo, visto que os Ministros membros da coalizão, em troca do apoio de seu partido no Legislativo, buscariam exercer influência no governo. Por isso, conclui a autora, "o ministro não pode ser visto como um funcionário regular do presidente" (2013, p.15), mas sim como um ator político com 
preferências próprias e membro de um partido com agenda política própria. Os achados da autora apontam para a influência dos Ministros e seus partidos no processo decisório do Executivo, porém com atuação contingencial da Presidência no controle das decisões por meio da delegação de decisões para parceiros ideologicamente mais próximos.

Quanto à estratégia presidencial de politização da burocracia no Executivo brasileiro, Praça, Freitas e Hoepers (2012) examinam a rotatividade dos funcionários de confiança no governo federal, concluindo que mudanças partidárias na direção dos Ministérios não necessariamente se refletiriam na composição dos cargos de confiança. Já Maria Celina D’Araujo (2014) testa a hipótese de que, na organização do poder Executivo, particularmente na nomeação dos cargos de dirigentes públicos de livre provimento, os presidentes da República (1995-2012) teriam se pautado em critérios de profissionalização, educação e experiência, mas sem negligenciar a dimensão políticopartidária e associativa. A autora ressalta, pois, que entre os dirigentes públicos haveria qualificação e profisssionalização, "desmentindo a mítica de que esse seja espaço para clientelismo deslavado" (D’ARAUJO, 2014, p.226).

$\mathrm{Na}$ interseção entre as abordagens da governabilidade e a burocrática, Barbara Geddes (1994) foca nas possíveis estratégias de nomeação de servidores utilizadas por Presidentes de governos latino-americanos: estratégias clientelistas de nomeações diretas ou delegadas a partidos da coalizão ou de grupos de interesse, estratégias fundamentadas em critérios técnicos, ou estratégias mistas. De acordo com a autora, ao decidir entre essas diferentes estratégias, o político enfrenta um dilema fundamentado nos seus interesses básicos de maximizar seu poder e conquistar influência política a longo prazo. A fim de persegui-los, o presidente deve, simultaneamente, governar com eficiência e construir uma conjuntura governamental de fortes lealdades políticas. Em termos de estratégias de nomeação, tais objetivos se conflitariam. Uma das estratégias para gerenciar este conflito teria sido a adotada no Brasil por Vargas e Kubitschek: construir ilhas de excelência burocrática em meio a um ambiente clientelista.

No entendimento de Geddes, o insulamento corresponderia à capacidade de uma burocracia manter-se adstrita a seus objetivos e tarefas, com coerência organizacional, a despeito de interações com outros atores:

Rather, an insulated agency is like a cell surrounded by its semipermeable membrane. Information and resources flow through the membrane from the environment into the agency and vice versa, but the agency, like the cell, is able to maintain its organizational integrity and stick to its own goals. It can 
enter into coalitions and cooperative relationships, but it is able to limit the capacity of outside actors to define its tasks or to 'capture' it (GEDDES, 1994, p.50 - grifo nosso).

Já o conceito de clientelismo, de acordo com José Murilo de Carvalho, “indica um tipo de relação entre atores políticos que envolve concessão de benefícios públicos, na forma de empregos, benefícios fiscais, isenções, em troca de apoio político, sobretudo na forma de voto" (1997, p.02). Clientelismo e insulamento são dois conceitos que estão na base da segunda vertente de estudos do Executivo brasileiro aqui trabalhada. Isso porque uma das preocupações desses autores é explicar as relações entre Estado e sociedade por intermédio da atuação do burocrata nas políticas públicas.

Em livro de 1976, Maria do Carmo Campello de Souza parte do sistema partidário para analisar as relações entre Estado, burocracia e demandas sociais no Brasil entre 1930 e 1964. A autora inova ao buscar no Estado brasileiro respostas para o que identifica como problemas centrais do seu sistema partidário, quais sejam, a fragilidade institucional e as práticas clientelísticas. Ao entender o Estado como organização de governo, compreendendo mecanismos de tomada de decisões e sua implementação, e ao enfatizar as relações estabelecidas entre esta organização e os partidos no policy making, Souza ([1976]1983) desvela atores antes invisibilizados: os burocratas. Nas palavras da autora, "O estudo da centralização - e sobretudo dos mecanismos concretos acionados nessa direção - tem para nós o sentido de visualizar a progressiva 'ocupação' do espaço organizacional e decisório por agências burocráticoestatais" ([1976], 1983, p.84 - grifo no original).

A autora explica como a Constituição de 1946 trouxe inovações institucionais cruciais como pluralismo partidário, eleições diretas e formalização de mecanismos de separação dos poderes do Estado; acoplando-as à estrutura anterior, caracterizada por relações corporativistas, sistema de interventorias e uma burocracia estatal com forte capacidade decisória. Daí decorreria uma dinâmica histórica do Estado brasileiro: a presença dominante de burocratas nas arenas decisórias em políticas públicas, inclusive constituindo canal de maior importância para introduzir os interesses da sociedade no Estado, aliada à incapacidade dos partidos políticos assumirem atribuições de governo. Embora a análise de autora date de 1976, pode-se observar a perpetuação deste cenário após a Constituição de 1988 e as subsequentes transformações experimentadas pelo aparato estatal brasileiro. 
Em estudo sobre o papel do Estado brasileiro no seu processo de industrialização entre 1930-1960, Sônia Draibe (1985) localiza a burocracia no centro dos conflitos que tomam lugar nos órgãos de decisão econômica, identificando em seu conhecimento técnico especializado um importante recurso político mobilizado nas articulações interburocráticas e nas alianças com grupos de interesse. Por sua vez, Luciano Martins (1985) argumenta que o afastamento entre os núcleos de decisão e o locus formal do poder teria criado condições para colocar à disposição das burocracias da área econômica os recursos políticos e financeiros que lhe permitiram atuar com resultados. Tais burocracias teriam uma autonomia relativa, em virtude de se colocarem como arenas de articulação de interesses intraburocráticos e de setores privados, legitimandose em nome da eficiência econômica e promoção da empresa brasileira. Nas palavras do autor,

(...) não é tanto a delegação de atribuições pelo poder político que confere graus distintos de importância a cada uma dessas agências, mas os recursos de poder que conseguem reunir e maximizar através de suas próprias ações e a partir das faculdades conferidas pela natureza de suas respectivas inserções no aparelho de Estado (1985, p.85).

A ideia de autonomia das burocracias é destrinchada por Evans $(1993 ; 1995) \mathrm{em}$ seu conceito de autonomia imersa (embedded autonomy): corpos burocráticos caracterizados por sua profissionalização e conhecimento técnico que atuam imersos na sociedade, ou seja, em conexão com grupos sociais organizados. Segundo Evans (1995), o Estado brasileiro pós Constituição de 1998 expõe uma natureza dual, caracterizada tanto por "bolsões de eficiência" quanto por instituições porosas de caráter mais clientelista, a qual se conformou historicamente a partir de movimentos pendulares de centralização e descentralização do aparelho estatal.

Para o autor, autonomia burocrática é fundamental para Estados desenvolvimentistas, porém deve estar combinada a interações sócio-estatais - por isso falar-se em uma autonomia "inserida". Se o caso do Brasil se distancia do tipo ideal de Estado desenvolvimentista devido a práticas clientelísticas, determinados "bolsões de eficiência" incrustados no aparelho estatal, com burocracias profissionalizadas, teriam possibilitado que objetivos econômicos desenvolvimentistas fossem atingidos ${ }^{39}$. Essa modernização de determinadas burocracias teria ocorrido de maneira pontual e

\footnotetext{
${ }^{39}$ Nesse mesmo sentido, Sikkink (1993) conclui que a existência de instituições especializadas fortes e relativamente insuladas do jogo político, como o Dasp e empresas estatais, haveria tido um papel significativo no sucesso das políticas desenvolvimentistas.
} 
particularizada, e não por meio de uma ampla reforma, motivo pelo qual a autonomia inserida seria um atributo parcial do Estado brasileiro. Como consequência,

O incrementalismo, ou reforma por acréscimo, provavelmente resulta em expansão descoordenada e dificulta muito mais a execução da seletividade estratégica. (...) Tentar modernizar por meio de acréscimo gradativo também reduz a coerência organizacional do aparelho de Estado como um todo. $\mathrm{Na}$ medida em que novas unidades são acrescentadas, surge uma estrutura maior e ainda mais barroca. O aparelho resultante tem sido caracterizado como "segmentado", "dividido" ou "fragmentado". É uma estrutura que não somente dificulta a coordenação política, como estimula o recurso a soluções personalistas (EVANS, 1993, p.13).

Nessa mesma linha, Edson Nunes (2010, [1997]) aponta o insulamento burocrático como uma das "quatro gramáticas políticas" que estruturariam as relações entre o Estado e a sociedade brasileira, juntamente ao clientelismo, corporativismo e universalismo de procedimentos. Estes padrões institucionalizados de relações teriam convivido desde o governo de Getúlio Vargas, cuja estratégia incipiente de criação de burocracias insuladas, reforçada e aprimorada no governo Juscelino Kubitschek, teria o objetivo de elaborar e implementar políticas desenvolvimentistas sem os limites do clientelismo. No entanto, como já esboçado por Evans (1993) e Sikkink (1993), a lógica do insulamento burocrático não substituiu a clientelista, mas sim somou-se a ela, sendo usualmente implantada em espaços delimitados, sem desmontar instituições prévias.

Nunes caracteriza as burocracias insuladas como "ilhas de racionalidade e de especialização técnica" (2010, p.54), às quais se atribuiria a execução de objetivos específicos, e que seriam protegidas dos interesses do público em geral ou de atores políticos e sociais. O fortalecimento dessas burocracias estatais não ocorreria, porém, em desconexão dos atores políticos. Para manterem-se insuladas, defende Nunes, essas agências necessitariam o apoio de atores políticos relevantes:

\footnotetext{
Ao contrário da retórica de seus patrocinadores, o insulamento burocrático não é de forma nenhuma um processo técnico e apolítico: agências e grupos competem entre si pela alocação de valores alternativos; coalizões políticas são firmadas com grupos e atores fora da arena administrativa, com o objetivo de garantir a exequibilidade dos projetos; partidos políticos são bajulados para proteger projetos no Congresso (NUNES, 2010, p.35).
}

Já Ben Schneider (1991) encontra uma explicação concorrente para o fato do Estado brasileiro ter conseguido influenciar positivamente a industrialização do país, a despeito de sua baixa institucionalização. Se, de um lado, o autor constata a existência de organizações estatais mal estruturadas e fragmentadas; de outro, a alta mobilidade dos burocratas entre organizações permitiria aos funcionários formular e coordenar 
políticas apesar da fragmentação institucional. O personalismo das relações, portanto, é que geraria uma coordenação eficiente.

Gilda Gouvêa (1994), em trabalho em que analisa o espaço de poder da burocracia governamental da área das finanças públicas, testa a hipótese de que esses burocratas foram capazes de criar um sistema de autoproteção isolado de influências político partidárias ao identificarem-se com o ethos do interesse público. Para a autora, portanto, a autonomia desta burocracia teria sido autodelineada, fundamentada no que define como corporativismo dos burocratas - o qual, por sua vez, estaria ancorado no ethos do interesse público.

Focando-se nas disputas interburocráticas, Vera Coelho (2001) analisa o processo de reformas previdenciárias de Brasil, Uruguai e Argentina de maneira a avaliar o papel da conjuntura econômica, das condições do sistema previdenciário e das relações de poder no interior do Executivo no curso das reformas, destacando a importância das últimas para a promoção ou contenção da privatização da previdência social. A autora explica que

(...) as burocracias previdenciária e econômica, os políticos que ocupam postos de mando nas agências do Executivo e o Presidente defendem projetos diferentes e lutam entre si para fazer prevalecer o que cada um reconhece como o projeto não só mais adequado econômica e politicamente, como também que lhe reservará o maior quinhão de poder político na gestão do novo sistema previdenciário (2001, p.94 - grifo nosso).

Essas preferências dos atores estariam ligadas às suas posições institucionais. Para Coelho, seus achados sugerem que "viabilizar um processo de mudança das políticas públicas significa alterar não só a balança de poder entre os atores sociais, mas também entre os atores estatais" (2001, p.108).

Embora não se debruce sobre a construção ou eficiência do Estado desenvolvimentista, o trabalho de Coelho (2001) segue a tradição de seus predecessores de focar-se nas burocracias econômicas. Mais recentemente, acompanhando a complexificação dos estudos sobre o processo das políticas públicas e à importância neles assumida da fase implementação (ARRETCHE, 2001), uma nova onda de estudos burocráticos pode ser identificada no contexto brasileiro, marcada pela análise da influência na definição e redefinição de política por burocratas implementadores, sejam eles burocratas de nível de rua ou de médio escalão.

O estudo sobre a atuação dos burocratas de nível de rua ganha destaque com o trabalho de Gabriela Lotta (2015) sobre agentes comunitários de saúde. A autora 
ressalta como a discricionariedade e a autonomia desses burocratas permitem que eles, por meio da interação com atores comunitários e outros profissionais, tornem a implementação um processo dinâmico que interfere no conteúdo das políticas públicas.

Em volume organizado por Pedro Costa Cavalcante e Gabriela Lotta (2015), diversos autores se voltam para o estudo dos burocratas de médio escalão, os quais correspondem ao elo, no Poder Executivo, entre o alto escalão e os executores - isto é, entre a formulação e a implementação política. Trata-se dos atores encarregados de operacionalizar a política conforme delineada pelo alto escalão e conferir-lhe exequibilidade. Correspondem à parcela intermediária de burocratas que se encontra entre a cúpula do Executivo (secretários e ministros) e os servidores sem cargos de direção e assessoramento superiores - DAS ${ }^{40}$. Como explicam Freire e colaboradores,

\begin{abstract}
Esse corpo burocrático é composto por um conjunto de profissionais responsáveis pela intermediação entre técnica e política. Se, por um lado, assessoram o alto escalão no processo de tomada de decisões, por outro, são responsáveis diretamente pela articulação dos processos de trabalho internos às organizações governamentais. (...) Nesse sentido, o ocupante do médio escalão, em organizações públicas ou privadas, atua como um catalisador ou enabler, um agente responsável por ações transformadoras no interior de agências públicas e privadas, conectado a diferentes extratos organizacionais (2015, p.91-92).
\end{abstract}

Dentre as conclusões atingidas pelos autores sobre os burocratas de médio escalão no governo federal brasileiro, podem-se destacar as seguintes: (i) quanto aos fatores determinantes da nomeação do burocrata, os estudos apontam a prevalência da competência técnica e da experiência profissional em detrimento das dimensões política e de relações pessoais, não obstante variações entre distintos órgãos do governo; (ii) estudos de caso mostram o acentuado envolvimento pessoal dos burocratas com a política ou programa, o qual por vezes implica em uma atuação naquela área setorial para além do campo profissional, como descrito no conceito de burocrata ativista de Abers (2015); (iii) o exercício da autonomia por parte dos burocratas de médio escalão pode ser instrumentalizado a fim de institucionalizar um programa político e preservá-lo de interferências políticas (LOTTA; CAVALCANTE, 2015).

Nesses termos, pode-se observar que a segunda abordagem sobre o Executivo brasileiro avançou recentemente no sentido de adotar uma perspectiva relacional sobre os burocratas, observados em suas múltiplas relações com distintos atores estatais e não estatais e na dinâmica de poder assim engendrada. Eduardo Marques (2013) sintetiza a

\footnotetext{
${ }^{40}$ Aproximadamente $96 \%$ dos servidores federais não possuem cargos de DAS (PIRES et al., 2015).
} 
visão de políticas públicas delineada nesta perspectiva ao afirmar que "public policies are based on the connections between several actors, within institutional environments and crossing organizational boundaries" (2013, p.8).

Em suma, pode-se concluir, do primeiro grupo de estudos aqui elencado, que "a agenda do Executivo é o resultado de uma barganha" (FIGUEIREDO; LIMONGI, 2008, p. 23). Esta barganha é apresentada como uma consequência do presidencialismo de coalizão, observando-se a macrodinâmica institucional. Por sua vez, o segundo grupo de estudos também apresenta o Executivo como um campo de barganhas, mas se remete a outros fatores institucionais para explicá-las. Nessa perspectiva, tensões arraigadas no Estado brasileiro são evidenciadas: clientelismo versus ilhas de eficiência; centralização versus delegação. Dado o objetivo de entender o funcionamento das políticas públicas, as interações de atores diversos no seu desenho e redesenho são examinadas, com ênfase nos burocratas governamentais, nos ambientes institucionais e organizacionais em que se situam, em seus interesses e nos recursos em disputa. Nesse quadro, as disputas interburocráticas e as relações de poder dentro do Executivo são evidenciadas, inclusive em seu potencial de induzir mudanças políticas.

\subsection{A ação dos burocratas: decisão e mudança institucional}

$\mathrm{Na}$ abordagem tradicional do ciclo de políticas públicas, procede-se a uma precisa distinção entre a formulação, realizada pelo núcleo decisório das políticas, e sua implementação, empreendida pelo núcleo administrativo e operacional. Essa perspectiva se coaduna ao tipo ideal weberiano de funcionamento do Estado, no qual burocratas dotados de competência técnica e qualificação específica, segundo o princípio da autoridade hierárquica, responderiam aos políticos, os quais, por sua vez, responderiam à sociedade. Nesta visão, burocratas, imbuídos de uma missão racionalizadora que lhes seria própria ${ }^{41}$, administrariam a coisa pública segundo critérios de eficiência e com fundamento em um conjunto de leis e regras (GOUVÊA, 1994).

Sabatier e Mazmanian (1980) estão entre os primeiros autores a pontuarem a necessidade da análise de políticas públicas de ultrapassar a teoria baseada em estágios.

\footnotetext{
${ }^{41}$ Loureiro, Abrucio e Pacheco (2010) sugerem que a abordagem weberiana de burocracia transcende a sua análise enquanto mecanismo de racionalização da administração pública, abarcando também a ideia de que se trata de um grupo de poder, cuja relação com os políticos seria, muitas vezes, marcada por tensões e conflitos.
} 
Isso porque não se identifica nas políticas públicas uma sequência de etapas sucessivas claramente distintas, mas sim fases que se sobrepõem e interagem. Desse ponto de vista, observa-se a implementação como um processo contínuo que envolve não apenas atividades de execução, mas novas tomadas de decisão e reformulações sobre a política. Uma vez que a burocracia constitui ferramenta indispensável para a implementação de políticas, esta abordagem de análise das políticas públicas traz à tona renovações no debate sobre o papel dos burocratas.

Superados os limites estanques entre a formulação e a implementação, percebese que esta última envolve múltiplas tomadas de decisão e negociações contínuas relativas a alocação de recursos; incertezas oriundas da formulação, tais como as concernentes a objetivos vagos ou contraditórios; controle e/ou interferência dos políticos envolvidos na formulação; interações intraestatais e sócio-estatais; mudanças conjunturais; busca de apoio político ou social; arranjos institucionais ineficientes e problemas de gestão. A discricionariedade torna-se, então, um conceito central para pensar-se a implementação, referindo-se à margem que os burocratas possuem para tomada de decisão, desde que dentro da moldura das regras aplicáveis ${ }^{42}$.

O caráter político da agência burocrática é, nesse contexto, trazido à cena (e.g. ABERBACH; PUTNAM; ROCKMAN, 1981), verificado tanto pelas consequências políticas de suas decisões, quanto pela interveniência de fatores políticos no seu processo decisório. Como sumarizam Maria Rita Loureiro e colaboradores (2010), autores contemporâneos diagnosticam

(...) a burocratização da política e a politização da burocracia, fazendo com que ambos adotem estratégias híbridas de atuação - os políticos fundamentando tecnicamente suas decisões e os burocratas reforçando seu papel nas decisões políticas, seja mediando interesses de clientelas específicas, seja norteando-se pelos sinais emitidos pelo político (2010, p.74).

Nesse momento, importa especificar de quais burocratas trata este trabalho, visto que a tomada de decisão terá características diversificadas de acordo com o escalão em que se situam. Diante do objeto da construção da política migratória em nível federal, vai-se aqui cuidar dos burocratas de médio escalão, tal como definidos pela literatura mencionada no tópico anterior (CAVALCANTE; LOTTA, 2015): integrantes do governo sujeitos ao controle dos políticos, dirigindo equipes ou organizações, fazendo a

\footnotetext{
${ }^{42}$ Lipsky (1980) trouxe a discricionariedade ao cerne da implementação em seu trabalho sobre os burocratas de nível de rua. O autor marcou os estudos em políticas públicas ao identificar similaridades estruturais entre professores, assistentes sociais e policiais; apontando como o exercício da discrição era um elemento essencial nas suas atividades.
} 
ponte entre o alto escalão e os implementadores da política de maneira a torná-la operacional $^{43}$.

No quadro abordado de politização dos burocratas, como esses últimos definem suas preferências políticas e tomam decisões? Em uma abordagem de escolha racional utilitarista, assume-se que o burocrata atuaria a partir de cálculos de maximização de seus interesses, os quais poderiam se materializar em prestígio pessoal, progressões na carreira ou destinação de recursos (e.g. TULLOCK, 1965). Haveria, em decorrência, uma dinâmica de incentivos e controle entre burocratas e políticos.

Aplicando os modelos utilitaristas de burocracia à análise das capacidades do Estado brasileiro na implantação dos moldes desenvolvimentistas, Ben Schneider (1991) parte do pressuposto de que burocratas estão primeiramente interessados nas suas carreiras ${ }^{44}$. Para o autor, quanto menos os setores privados influenciarem as carreiras dos burocratas, mais esses últimos tenderão a perseguir preferências estatistas, e maior será o potencial para a autonomia burocrática.

Visando a apresentar uma abordagem do Estado com foco nos indivíduos que o compõem, e particularmente nos incentivos que afetam suas decisões, Barbara Geddes (1994) avança modelos de comportamento de políticos e burocratas como atores racionais. Segundo a autora, "since state decisions are made by these human beings, the

\footnotetext{
${ }^{43}$ Uma outra opção conceitual seria referir-se, como Daniel de Bonis e Regina Silva Pacheco, aos dirigentes públicos, "pessoas que ocupam cargos no alto escalão governamental, com responsabilidade significativa pelas políticas públicas e pelo desempenho das organizações públicas, respondendo diretamente aos ministros ou secretários de Estado" (2010, p.330). O conceito coincide em muito com o de burocrata de médio escalão, porém dele se aparta ao frisar as diferenças dos dirigentes tanto em relação aos políticos como aos burocratas, derivadas do fato de que possuiriam um ethos da direção pública, qual seja, o da geração do máximo valor público com eficiência na alocação de recursos. Para os autores, isso os singularizaria em relação ao ethos burocrático em sua concepção weberiana, qual seja, o de cumprimento da regra e respeito à hierarquia. Como a presente pesquisa não avança em termos de análises do ethos dos atores envolvidos, preferimos adotar o conceito de burocratas de médio escalão.

Bonis e Pacheco (2010) colacionam, ainda, outros elementos que diferenciariam dirigentes públicos e burocratas. Um deles é a distinção entre competências gerenciais dos dirigentes e operacionais para burocratas - contemplada, também, no conceito de burocrata de médio escalão. Não julgamos, porém, que isso os destituiria de sua condição de burocratas, visto que esses servidores, ainda que com competências gerenciais, exercem-nas tendo em vista operacionalizar uma política pública, na condição de braço executor do Estado. Por último, outra característica levantada pelos autores como definidora do dirigente público seria o maior nível de discricionariedade de suas ações. A dificuldade de mensurar graus de discricionariedade se impõe a esta variável: a ação discricionária de burocratas de nível de rua, amplamente documentada pela literatura, atingiria menos graus em uma escala de discricionariedade do que a ação de dirigentes públicos na gestão de pessoas? Nesse quadro, a distinção crucial parece estar não na discricionariedade, mas no maior acesso a recursos proporcionado pela mais alta posição hierárquica.

${ }^{44}$ A perspectiva de carreira adotada por Schneider (1991) leva em conta de onde o burocrata veio e para onde almeja ir, analisando cinco dimensões: (i) qual a base de recrutamento social da elite burocrática?; (ii) o quão estreito é o funil educacional?; (iii) as carreiras são vinculadas ao Estado e a uma única agência?; (iv) como os servidores progridem? (v) para onde vão os servidores quando deixam o Estado?
} 
content of their decisions - including decisions that contribute to reforming the state itself - will reflect their interests" (GEDDES, 1994, p.8 - grifo no original). A autora desvela, então, quais seriam esses interesses: no caso dos líderes políticos, orbitariam em torno da permanência no mandato. No caso dos burocratas, as instituições políticas moldariam seus interesses via incentivos tais como recompensas de carreira. A finalidade desses mecanismos seria aproximar os objetivos individuais dos burocratas dos objetivos estatais - quais sejam, o aumento de suas capacidades.

Dentre esses mecanismos, se encontrariam pressões por eficiência, as quais se apresentariam de maneiras diferentes em distintos campos organizacionais. Percebe-se que, embora desenvolva uma explicação de escolha racional, Geddes (1994) recorre tangencialmente a argumentos organizacionais. A autora o faz, por exemplo, ao descrever os processos de insulamento burocrático:

over time, an agency ideology and sense of mission tend to develop among personnel, as do informal boundaries between themselves and the environment that insulate them from pressures the agency deems inappropriate (GEDDES, 1994, p.51- grifo nosso).

Elementos organizacionais foram incorporados a explicações políticas em estreita ligação com a tradição sociológica, particularmente representada por Marx Weber e suas construções sobre dominação política (DIMAGGIO; POWELL, 1991a). Constroem-se modelos explicativos que apontam características de organizações como instrumentos aos quais recorrem os indivíduos para superarem os limites de sua racionalidade (DIMAGGIO; POWELL, 1991b). Nesse quadro, examina-se como as estruturas das organizações refletem os mitos de seus ambientes (MEYER; ROWAN, 1991); as interações de seus participantes (ZUCKER, 1991); ou ainda suas rotinas organizacionais (DIMAGGIO, 1991).

Com fulcro nas teorias organizacionais, Allison (1969) propõe seu modelo II $^{45}$ de tomada de decisão em política externa, colocando as preferências e ações dos burocratas como produtos $\left(\right.$ outputs $^{46}$ ) das organizações, as quais seguiriam padrões regulares de comportamento. Allison (1969) sugere que, a despeito da utilidade da abordagem racionalista, seus pressupostos de atores perfeitamente informados e

\footnotetext{
${ }^{45}$ Em seu influente trabalho, Allison (1969) propõe três modelos decisórios: o racional, o organizacional e o burocrático.

${ }^{46}$ Allison usa a expressão output organizacional em contraste ao outcome do modelo burocrático. A escolha de output, termo que traduzimos como produto, é feita no sentido de naturalizar o resultado como uma função direta de determinados fatores. Trata-se pois de uma resultante estática de uma combinação de fatores. Já o outcome burocrático seria o resultado advindo de barganhas entre diferentes atores construído, portanto, em dinâmica de interação.
} 
maximizadores de utilidade não se aplicariam a todos os casos, devido ao fato dos governos constituírem “(...) a conglomerate of semi-feudal, loosely allied organizations, each with a substantial life of its own” (1969, p.698).

No modelo organizacional de Allison (1969), as alternativas políticas são definidas por organizações que processam informações, e o fazem por meio de rotinas previamente estabelecidas - um conjunto de procedimentos operacionais e programas. Cada organização detém competência sobre um determinado conjunto de problemas, no qual é especializada e atua com relativa autonomia. Isso incentivaria, segundo Allison, o paroquialismo organizacional. O conceito se refere a uma propensão à definição estável de prioridades, percepções e questões no interior das organizações, em virtude, dentre outros fatores, da seletividade de informações disponíveis e dos modos de recrutamento e ascensão profissional. O paroquialismo estaria relacionado, ademais, a procedimentos operacionais padrões: organizações realizam suas funções mais complexas por meio de tarefas mais simples, como orçamentos, relatórios, desenvolvimento de fluxos e sistemas operacionais. Esses elementos fariam com que a busca por alternativas políticas seja largamente determinada pelas rotinas organizacionais existentes.

Em contraponto aos modelos racional e organizacional, Allison (1969) avançou modelo de política burocrática, visando a explicar as decisões em política externa como resultados (outcomes) de jogos de barganha sucessivos e sobrepostos entre atores governamentais. O foco analítico está nos atores governamentais, nas suas diferentes visões dos problemas e em como as soluções encontradas são, na realidade, resultados de barganhas e compromissos. O modelo prevê, destarte, a análise das percepções e motivações dos atores, de suas posições no xadrez governamental, de seus poderes e das manobras por eles realizadas para que o outcome emirja. Esse último corresponderia, pois, a uma resultante de interesses pessoais, organizacionais, governamentais e de interesse nacional; colocados em jogo por diversos atores em múltiplas partidas.

Um dos primeiros a apresentar críticas ao modelo burocrático de Allison ${ }^{47}$ foi Robert Art (1973), destacando sua deficiência em apontar o mecanismo através do qual as burocracias influenciariam a política externa, particularmente em sua relação com os líderes políticos. Para Art (1973), os líderes políticos, negligenciados no modelo de Allison, é que determinariam a extensão do campo de ação dos burocratas: o output

\footnotetext{
${ }^{47}$ Foram inúmeras as críticas recebidas pelo autor, o que é compreensível dada sua enorme influência para a ciência política e relações internacionais.
} 
organizacional ganharia espaço na ausência de comprometimento ativo de líderes governamentais sobre o tema. Em contraste, os presidentes e líderes governamentais avocariam o tratamento de questões políticas que julgassem importantes, e cuidariam para que não houvesse, nesses casos, desvios na implementação.

Percebe-se que as variáveis propostas por Allison (1969) compreendem distintos níveis de análise, dificultando sua operacionalização em asserções explicativas. Além disso, embora o modelo pareça exigir estudos qualitativos para aplicá-lo, o autor não avança em mecanismos causais a serem verificados, nem propõe hipóteses referentes ao desenrolar do jogo de barganhas. Por último, a despeito de seu aforismo "where you stand depends on where you sit" (1969, p.711), Allison negligencia o elemento institucional em sua análise. Como coloca Lima (2002), o modelo não considera os problemas de ação coletiva, nem leva em conta as diferenças de poder e recursos entre os atores. De modo geral, o modelo burocrático de Allison carece de uma visão mais ampla do Estado, com seus múltiplos atores internos em interface com atores externos.

Em revisão do modelo burocrático de análise de política externa, Drezner (2000) sugere reforçar o exame dos mecanismos que conduzem à translação de preferências em resultados políticos. Para tanto, opta por uma abordagem neoinstitucionalista ideacional, argumentando que o posicionamento das instituições no arranjo de política externa influencia sua capacidade de sobreviver e prosperar, em contexto no qual a cultura organizacional seria um mecanismo importante utilizado pelos burocratas para propagar ideias e, consequentemente, determinar resultados políticos.

Sobre a cultura organizacional, Drezner afirma tratar-se de "method through which desired ends and means are communicated from managers to operators and outsiders" (DREZNER, 2000, p.736-737), acrescentado ser composta por determinadas ideias fundadoras e atuar no fornecimento de informações e na construção dos objetivos e possibilidades de atuação do grupo. Como consequência, a cultura organizacional mune o burocrata de instrumentos para atuar discricionariamente em situações de incerteza. Desses pressupostos, o autor avança algumas hipóteses sobre relações interburocráticas, dentre as quais a de que diferenças entre culturas organizacionais contribuem para que as burocracias atuem como competidoras, tentando limitar a influência de outras instituições.

Em modelo de análise de política externa desenvolvido a partir de casos norteamericanos, Halperin e Clapp (2006) colocam que organizações usualmente possuem 
uma missão a cumprir, em decorrência do que possuem capacidades para exercê-las e buscam influência a fim de efetivá-las. Os autores introduzem, ainda, o conceito de “essência organizacional” (2006, p.27), isto é, a visão sustentada pelo grupo dominante da organização sobre quais missões e capacidades ela deveria possuir - a que se relacionam convicções sobre quem deveria ser seu membro, ou seja, qual expertise, experiência e conhecimento deveria possuir. Estas quatro dimensões (missão, capacidades, influência e essência organizacional) afetariam o comportamento dos burocratas nelas inseridos, os quais atuariam visando aos seguintes interesses:

- Manutenção ou ampliação da autonomia: burocratas de uma organização acreditariam estar na melhor posição para determinar quais capacidades ela deve possuir e como elas serão operacionalizadas para cumprir com a missão organizacional, e confeririam alta prioridade ao controle de seus próprios recursos. Algumas consequências decorreriam do interesse na autonomia: (i) organizações buscariam o controle operacional total sobre os recursos requeridos para executar uma decisão, relutando em participar de operações compartilhadas; e (ii) em negociações entre organizações, cada uma prefere um acordo que lhe conceda autonomia para perseguir seus próprios interesses, mesmo que tal decisão possa levar, aos olhos de observadores externos, a políticas ineficientes ou descoordenadas;

- Reforço da moral organizacional: a moral organizacional estaria relacionada à motivação de seu pessoal e percepção de legitimidade de sua atuação, o que geraria interesses específicos relativos ao aumento da influência da organização e à conservação de sua essência, tais como: (i) que a organização avance ou, ao menos, não seja alvo de restrições de orçamento e recursos; (ii) que seus postos mais altos sejam detidos por profissionais de carreira.

Paroquialismo organizacional, cultura organizacional, missão da organização, rotinas de trabalho, essência organizacional. São numerosos e, por vezes, sobrepostos e obscuros os conceitos relacionados aos elementos organizacionais aptos a intervir na formação de preferências dos burocratas. Percebe-se que eles se relacionam a um processo histórico de formação de um campo de atuação política; ao conjunto de informações reunidas que conferem sentido ao campo e moldam a produção de novas informações; ou ainda ao modo de recrutamento de novos membros para a organização. 
Compreendem a ideia de uma influência do ambiente organizacional sobre a atuação dos seus membros por meio de práticas e estruturas, materiais e simbólicas, que suprem os limites de racionalidade dos atores ou, ainda, o fazem tomar decisões sub-ótimas (MEYER; ROWAN, 1991; DIMAGGIO; POWELL, 1991b).

Em uma abordagem institucionalista, tal como a proposta por Drezner (2000), esses elementos organizacionais são analisados em sua capacidade de enquadrar as decisões políticas, as quais são vistas como uma resultante distinta da macro-agregação de preferências individuais (IMMERGUT, 1998). March e Olsen (1984) ressaltam que, embora tenha origens nas teorias organizacionais, o neoinstitucionalismo se situaria em oposição às mesmas ao assumir o conflito como endêmico às organizações. Isso significa observar a burocracia, ao mesmo tempo, como uma arena na qual atuam forças sociais em disputa e como um ator político (MARCH; OLSEN, 1984).

Assim, embora as organizações tenham como objetivo de sua institucionalização a superação de dilemas de ação coletiva, não deixam de constituir arenas de relações de poder, nas quais recursos estão em disputa. Gilda Gouvêa (1994) afirma que os conflitos intra e interburocráticos fortaleceriam os laços internos de uma agência ou órgão, o que contribuiria para que consolidassem seus interesses. Daí surgiria o que a autora define como "corporativismo voltado para a autodefesa" (GOUVÊA, 1994, p.69).

Gouvêa (1994) assenta sua tese sobre autonomia da burocracia governamental da área econômica no Brasil em dois conceitos: espaço de poder e lógica de ação burocrática. $\mathrm{O}$ espaço de poder, entende a autora, corresponderia tanto ao conjunto de recursos (políticos e, às vezes, financeiros) aos quais os burocratas teriam acesso, quanto aos resultados de suas práticas, compreendendo

\footnotetext{
(...) sua qualificação técnica, do conhecimento dos regulamentos, das informações que detêm, como gostaria Weber, mas não só. Eles vêm principalmente das ligações que consegue estabelecer com o poder central, com outros segmentos burocráticos, com a sociedade, e com o Legislativo (GOUVÊA, 1994, p.59).
}

Já a lógica de ação das burocracias não é precisamente definida por Gouvêa. A autora afirma tentar identificá-la historicamente: a visão da burocracia seria a de atender ao "interesse público", mas a construção do interesse público se transforma nas várias conjunturas históricas, visto ser ela resultante da dinâmica de relações de poder que atravessam o Estado. 
Incorporar a dimensão do poder no estudo das burocracias e instituições é uma preocupação de Moe (1989; 2005). Para o autor (2005), as instituições políticas não podem ser vistas apenas como estruturas de cooperação voluntária para resolver problemas de ação coletiva, uma vez que correspondem a processos políticos que envolvem conflitos de poder. Moe aponta que, a despeito de autores da escolha racional levantarem o elemento poder em suas discussões, os fundamentos de sua teoria se encontram no questionamento sobre como indivíduos racionais cooperarão frente a problemas de ação coletiva, e suas explicações orbitam em torno de benefícios mútuos, compromissos, equilíbrio e outros conceitos advindos da lógica da escolha voluntária. No entanto, segundo o autor,

Both power and cooperation are essential, therefore, to any effort to understand public agencies. Bureaucracies are institutions that are imposed by winners on losers. But they are also cooperative and mutually beneficial for the subset of actors who agree to their creation. Each property, in fact, is fundamental to the other (MOE, 2005, p.220).

Moe (1989) sugere que cada agência burocrática é um reflexo de sua própria política: os atores burocráticos teriam interesses institucionais e de carreira, que podem ou não ser coerentes com suas missões formais; e possuiriam recursos, ou seja, expertise e autoridade delegada, que podem ser empregados visando a seus interesses individuais. $\mathrm{Na}$ consecução de suas atividades, os burocratas enfrentam, tal como outros atores políticos, a incerteza política, podendo adotar duas estratégias para enfrentá-la: ou alimentar relações mutuamente benéficas com políticos e grupos que forneçam o apoio político necessário para a agência; ou insular-se burocraticamente, por meio de ações como profissionalização, formalização dos procedimentos decisórios e valorização dos precedentes na tomada de decisão. Em sua análise sobre agências envolvidas com políticas de regulação social, Moe (1989) não identifica barganhas específicas sobre o conteúdo das políticas: os conflitos com consequências para as políticas teriam sido sobre arranjos institucionais, compreendendo poderes e procedimentos.

Nos termos colocados por Moe (1989), Geddes (1994) e Gouvêa (1994), portanto, burocratas controlam recursos, sejam eles técnicos, políticos, financeiros e administrativos, e por eles competem. A operacionalização desses recursos na formulação e implementação de políticas públicas pelos burocratas corresponde à capacidade estatal, definida como a capacidade de ação do Estado (EVANS, 1993) ou a eficácia do aparato estatal em instrumentalizar seus objetivos oficiais (SIKKINK, 1993). 
O conceito de capacidades estatais suscitou diferentes abordagens, especialmente a partir da década de 1980 com os trabalhos de Skocpol (1985), Evans, Rueschemeyer e Skocpol (1985), dentre outros ${ }^{48}$. Diversos atributos são mobilizados por esta literatura para caracterizá-lo, compreendendo dimensões políticas, institucionais, administrativas e técnicas. Um interessante modelo analítico é aquele proposto por Gomide e Pires (2014) para seu exame comparativo em diferentes arranjos institucionais. Para os autores, as capacidades estatais dependeriam de dois componentes: o técnico-administrativo, derivado de modelo weberiano de burocracia, contemplaria as competências dos agentes estatais de levarem a efeito suas políticas; e o político-relacional, concernente aos mecanismos destinados a produzir apoio e conferir legitimidade à política.

Cada um desses componentes seria constituído por diversos elementos. No caso das capacidades técnico-administrativas, envolvem burocracias competentes e profissionalizadas, dotadas de recursos organizacionais, financeiros e tecnológicos. Já as capacidades político-relacionais compreendem mecanismos e procedimentos (i) de inclusão de atores do setor privado e da sociedade civil; (ii) de articulação entre os entes federativos; (iii) de negociação com o poder Legislativo; (iv) de processar os conflitos de interesse (GOMIDE; PIRES, 2014).

A construção de capacidades estatais, assim como as disputas interburocráticas por recursos e as variações de distribuição de poder decorrentes, relacionam-se com mudanças institucionais. No desenrolar destas mudanças, distintos atores tomam parte. Especificamente sobre as mudanças na agenda, John Kingdon (1995) coloca que ocorreria a partir da convergência de três fluxos: o dos problemas, o das alternativas e o da política - o que formaria uma janela de oportunidades. O fluxo da política (politics) compreende as negociações, barganhas e consensos sobre o tema, e tem nos atores políticos seus protagonistas. Envolve reflexões sobre governabilidade, especialmente

\footnotetext{
${ }^{48}$ Bersch e colaboradores (2013) assinalam as dificuldades de mensurar-se, com finalidades explicativas, a capacidade estatal. Isso abrange várias dimensões: a ampla variedade de definições oriundas de diferentes áreas das ciências sociais; a dificuldades de disponibilidade de dados; dificuldade de discriminar indicadores e de selecioná-los. De maneira a enfrentar estas questões, os autores propõem um modelo no qual distinguem a capacidade estatal da autonomia burocrática. A capacidade estatal seria formada pelos indicadores: (i) força da carreira, isto é, percentual de servidores de carreira; (ii) especialização da carreira $\mathrm{A}$, isto é, longevidade média na carreira; (iii) especialização da carreira $\mathrm{B}$, isto é, percentual de servidores requeridos por outras agências; (iv) especialização da carreira C, isto é, salário médio dos servidores dentro da carreira. Já autonomia: (i) proporção de indicações de DAS de baixo nível pelo partido; (ii) proporção de indicações de DAS de alto nível pelo partido; (iii) proporção de servidores que são membros do partido.
} 
em contextos de presidencialismo por coalizão. Já no fluxo dos problemas, assumem destaque os políticos, empresas, candidatos, partidos, organizações da sociedade civil, dentre outros "atores visíveis", que investem recursos nas políticas, atuando para que um "estado de coisas" seja reconhecido como problema. Mas é no fluxo das alternativas políticas que burocratas atuariam com destaque, desenvolvendo e operacionalizando as soluções para os problemas elencados, no que agiriam junto a outros "atores invisíveis" como comunidades epistêmicas e lobbies. Tais atores formariam uma comunidade política (policy community), conjunto de atores estatais e não-estatais com padrões de interação que têm interesse e influência sobre uma determinada área política.

Assim, Baumgartner e Jones (2009) apontam que a análise da mudança política não pode se restringir aos objetos tradicionais da política partidária. Ao analisarem temáticas como regulamentação de segurança de automóveis, pesticidas e fumo, os autores ressaltam que o conflito político também eclode em áreas políticas de menor destaque, enfatizando a atuação de burocratas no policymaking e na mudança.

Abordagens institucionalistas, ao definirem instituições com ênfase nas suas características de auto-reprodução (institucionalismo organizacional), em mecanismos de coordenação que sustentam equilíbrios específicos (escolha racional), ou em padrões que persistem por mecanismos de path dependence (institucionalismo histórico), acabam definindo seu foco na estabilidade. De fato, os mesmos dilemas de ação coletiva que instam a criação de instituições dificultam suas mudanças (PRESSMAN; WILDAVSKY [1973]; 1984). Por outro lado, Ellen Immergut (1996) argumenta que os mesmos fatores institucionais podem explicar tanto a estabilidade quanto a mudança, o que se deve, segundo a autora, a diferenças nos contextos. Assim, quais mecanismos podem explicar que fatores institucionais conduzam à estabilidade ou à mudança?

Os primeiros estudos que passam a abordar a mudança institucional enfatizam os momentos cruciais de quebra de estabilidade que levam a reconfigurações institucionais radicais. No caso das abordagens históricas, tais momentos foram conceituados como "conjunturas críticas", períodos nos quais as limitações usuais à ação são reforçadas ou aliviadas (CAPOCCIA; KELEMEN, 2007), e abrem caminho para bifurcações na trajetória. Essas limitações advêm dos contextos políticos, tecnológicos e institucionais que, por meio de mecanismos de dependência da trajetória, colocam custos altos para alterações de cursos de ação. Há, portanto, uma separação radical entre os períodos de 
estabilidade institucional e de mudança, a qual é concebida como uma resposta a choques exógenos ao sistema (JEPPERSON, 1991).

Em sua teoria do equilíbrio pontuado, Baumgartner e Jones (2009) preveem que longos períodos de estabilidade, nos quais se perceberiam alterações incrementais, seriam pontuados por mudanças políticas de larga escala, oriundas do feedback positivo, por parte de atores políticos, sobre uma mudança na imagem da política. Assim, embora admitam o incrementalismo, os autores o conceituam como estabilidade e não desvelam seus mecanismos, dirigindo o foco de sua teoria para mudanças amplas.

Essas visões dualistas de separação entre estabilidade e mudança (HALL, 2010) foram pouco a pouco contestadas por trabalhos que concebiam as mudanças como contínuas, endógenas e tendentes a produzir resultados incrementais. Tal perspectiva já fora abordada pela teoria organizacional: Allison (1969), no seu modelo organizacional, prevê que o comportamento da organização em um momento determinado do tempo será apenas marginalmente diferente do comportamento em momento anterior, de maneira que a melhor explicação para o comportamento de uma organização em $t$ é $t-$ 1. Assim, nos termos propostos por Allison (1969), enquanto o modelo de escolha racional abarcaria mudanças radicais nas alternativas políticas, o modelo organizacional seria necessariamente incremental.

Da mesma forma, a dinâmica política definida por Lindblom (1979) como incrementalismo é caracterizada por engendrar refinamentos e pequenas alterações de decisões passadas, ao invés de explorar novas alternativas políticas. Como não há desvios significativos de decisões anteriores, o risco de fracasso das decisões é menor. Em contraste, o incrementalismo não assegura que haverá uma maximização da utilidade, como previsto no modelo do ator racional.

Tal processo se desenvolve de maneira endógena, o que, em um quadro institucionalista, significa assumir as instituições como causa. Mahoney e Thelen (2010), ao buscarem construir um modelo que possa abrigar tanto fontes exógenas quanto endógenas para a mudança, defendem como primeiro passo que se definam as propriedades básicas das instituições em termos aptos a abarcar a mudança endógena. Nese sentido, concebem instituições como "distributional instruments laden with power implication" (MAHONEY; THELEN, 2010, p.8 - grifo dos autores). Tal definição implica em pensar instituições como arenas que abarcam tensões, uma vez que levanta questões sobre recursos e sua distribuição, e em perceber a estabilidade 
como fundamentada na contínua mobilização de recursos. Para construir seu modelo, os autores se debruçam sobre trabalhos com uma abordagem institucional focada na distribuição de poder, presente sobretudo no institucionalismo histórico ${ }^{49}$, mas também no organizacional ${ }^{50}$ e de escolha racional.

Deste modo, verifica-se que Mahoney e Thelen (2010) agregam elementos das diferentes vertentes institucionalistas na elaboração de seu modelo explicativo. Alinham-se, deste modo, à proposta de Hall (2010), para quem a dificuldade das teorias institucionalistas para analisar a mudança pode ser enfrentada via agregação conceitual de diferentes abordagens. Particularmente, se o institucionalismo se destaca como perspectiva teórica ao apontar a tendência de instituições perdurarem para além das condições que propiciaram seu surgimento, a dimensão histórica é um de seus fundamentos iniciais (SIKKINK, 1993; POWELL, 1991; JEPPERSON, 1991). Assim, Hall (2010) enfatiza os pontos de interface entre o institucionalismo racional e histórico, e incentiva estudiosos a absorverem conclusões de análises organizacionais.

No modelo avançado por Mahoney e Thelen (2010), determinados modos de mudança incremental estão ligados a características do contexto institucional e das instituições, em relação intermediada por estratégias de mudança e agentes de mudança. Os resultados institucionais podem refletir os objetivos de um grupo específico, o conflito entre grupos distintos ou o compromisso, muitas vezes ambíguo, entre atores. De qualquer modo, são moldados por duas características institucionais: o número de pontos de veto e a discricionariedade dos atores.

Ao explorar as influências dos pontos de veto, o modelo se inspira em Tsebelis (1995). Em seu trabalho, Tsebelis elege como variável dependente o potencial de mudança de políticas de diferentes contextos institucionais, associando previsões de mudanças de políticas a mudanças de identidades e de posições de veto players, sendo que quanto mais numerosos os pontos de veto, menos significativo seria o impacto marginal de mudanças de um deles. Por outro lado, ao abordar a discricionariedade dos atores na execução, Mahoney e Thelen (2010) abarcam em seu modelo a dinâmica entre as normas formuladas e sua implementação.

\footnotetext{
${ }^{49}$ Hall e Taylor (2003) apontam como uma característica que distinguiria o institucionalismo histórico das demais vertentes sua ênfase nas "assimetrias de poder associadas ao funcionamento e ao desenvolvimento das instituições" (p.196).

${ }^{50}$ Em uma perspectiva neoinstitucionalista organizacional, examinam-se organizações justamente com foco nos processos de influência mútua entre elas (DI MAGGIO, 1991), os quais envolverão a aquisição e manutenção de poder por parte das organizações (DIMAGGIO; POWELL, 1991).
} 
Nesta perspectiva distributiva das instituições, parte-se do pressuposto, compartilhado com as teorias da escolha racional, de que atores institucionais se mobilizam se a mudança lhes trouxer benefícios. No entanto, admite-se que as ambiguidades e incertezas inerentes a instituições e, principalmente, à transformação das mesmas dificultam a avaliação sobre quais atores auferem benefícios e quais serão prejudicados. Além disso, em arranjos institucionais complexos, os atores tendem a estar simultaneamente inseridos em múltiplas instituições, o que, por vezes, os torna vencedores em determinadas arenas e perdedores em outras (MAHONEY; THELEN, 2010).

Mahoney e Thelen (2010) propõem, então, um esquema de análise que classifica os modos de mudanças em quatro tipos: (i) substituição, isto é, a remoção de regras existentes e introdução de novas; (ii) disposição em camadas, ou seja, a introdução de novas regras acima ou ao lado de regras já existentes; (iii) mudança à deriva, relativa ao impacto de mudanças do ambiente nas regras existentes combinada à inação dos atores; (iv) conversão, concernente a regras que permanecem formalmente, mas são interpretadas de novas maneiras.

Quando agentes de mudança se deparam com instituições nas quais há pouco espaço para discricionariedade na execução, a conversão e a mudança à deriva são menos prováveis. Nesses casos, tenderá a haver mudança via substituição ou disposição em camadas, mecanismos que não se ancoram em ambiguidades e lacunas da formulação. A disposição em camadas normalmente ocorre quando agentes de mudança não têm capacidade de transformar de fato as regras originais em virtude de obstáculos colocados por veto players, contornando a situação via criação de novas instituições. $\mathrm{O}$ quadro 2.1 abaixo relaciona os tipos de mudanças prováveis segundo as características do contexto político e da instituição visada.

Quadro 2.1: Modos de mudança segundo possibilidades de veto e nível de discricionariedade na implementação

\begin{tabular}{|l|l|l|}
\hline & $\begin{array}{l}\text { Menor discricionariedade } \\
\text { na execução }\end{array}$ & $\begin{array}{l}\text { Maior discricionariedade } \\
\text { na execução }\end{array}$ \\
\hline Pontos de veto mais numerosos & Disposição em camadas & Mudança à deriva \\
\hline Pontos de veto menos numerosos & Substituição & Conversão \\
\hline
\end{tabular}

Fonte: MAHONEY; THELEN, 2010, p.19

Com ênfase na agência, o modelo de Mahoney e Thelen (2010) liga as condições do contexto político e da execução aos modos de mudança institucional por meio da 
variável dos tipos de agentes de mudança, definida segundo seu interesse em preservar a instituição e sua obediência às regras da instituição, e que por sua vez seria influenciada também pela amplitude dos pontos de veto e da discricionariedade. Consideramos que, neste ponto, o modelo dos autores padece de um problema de endogeneidade entre os elos do mecanismo proposto: se os pontos de veto e a amplitude da discricionariedade determinam tanto o tipo do agente de mudança quanto o modo de mudança, o papel do tipo de agente como variável interveniente entre os fatores determinantes e a mudança não resta claro.

Por sua vez, no campo da análise de política externa, Hermann (1990) identifica quatro tipos de agentes de mudanças: (i) líderes proativos; (ii) advocacy burocrática; (iii) reestruturação doméstica, referindo-se a alterações na composição ou na percepção das elites; (iv) choque externo, correspondendo a eventos internacionais dramáticos. De acordo com a hipótese defendida pelo autor, o processo de tomada de decisão realiza a mediação entre os fatores domésticos e externos e os resultados políticos obtidos, definidos pela magnitude da mudança na política ${ }^{51}$. Portanto, o processo decisório, por si, poderia obstruir ou facilitar a mudança.

Sobre a advocacy burocrática como um dos agentes aptos a produzir mudanças na política externa, Hermann (1990) coloca que burocratas do médio escalão de governo tendem a estar em uma melhor posição que seus superiores para receber e apreender sinais de que uma determinada política não está funcionando. $\mathrm{O}$ autor pontua que:

Bureaucratic advocacy as an agent of change may seem a contradiction in view of what has been described as the resistance of bureaucratic organizations to major redirection of policy. The suggestion is not that an entire government becomes seized with the need for change, but rather that a group within the government become and advocate of redirection. This group may be located in one agency or scattered among different organizations but with some means for regular interaction (1990, p.11).

A resistência das organizações burocráticas à mudança é associada por Powell (1991) a quatro caminhos de reprodução institucional: (i) o exercício de poder; (ii) interdependência complexa; (iii) assunções pressupostas; (iv) processos dependentes da trajetória. No caso do exercício do poder, o autor ressalta que práticas e estruturas frequentemente continuam graças ao esforço ativo daqueles que delas se beneficiam. Já

\footnotetext{
${ }^{51}$ As mudanças poderiam constituir-se em amplitudes crescentes: (i) ajustes, se dão no nível do esforço empreendido ou no escopo dos recipientes; (ii) mudanças de programa, nas quais se transforma o que é feito ou como é feito, mas os objetivos continuam os mesmos; (iii) mudanças de objetivo; (iv) mudanças de orientação internacional, envolvem o redirecionamento total da orientação internacional do ator.
} 
na interdependência, a continuidade não vem de uma atitude proativa, mas do enraizamento de certa prática ou estrutura em uma rede de práticas e estruturas, de tal modo que mudar um aspecto ressoaria em diversos outros elementos. Adicionalmente, determinadas práticas e estruturas são reproduzidas porque são pressupostas pelos atores como naturais ou legítimas, não sendo questionadas ou comparadas a outras alternativas.

Por último, Powell (1991) aponta que procedimentos e formas organizacionais podem perdurar em razão de padrões de desenvolvimento path-dependent nos quais as escolhas iniciais condicionam as opções futuras. $\mathrm{O}$ conceito de path-dependence se refere ao efeito de decisões iniciais sobre a escolha de um, dentre vários, equilíbrios - o qual por vezes será sub-ótimo ${ }^{52}$. Modelos que focam na dependência da trajetória preveem que mecanismos de feedback positivos sobre escolhas institucionais iniciais atuam sobre as organizações, tornando-as pouco flexíveis. Isso porque as retribuições por continuar na trajetória aumentariam quanto mais se avança na trajetória (increasing returns), de maneira que os custos de saída da trajetória poderiam levar à persistência de padrões institucionais menos eficientes (PIERSON, 2000).

De fato, mudanças trazem custos, alguns dos quais a serem arcados pelos burocratas. Empreender reformas amplas pode engendrar transformações sobre a divisão de responsabilidades; os mecanismos de decisão e coordenação; os fluxos de trabalho; a estrutura organizacional; a distribuição dos recursos; a estrutura de incentivos aos atores burocráticos e de seu controle (COSTA; BRONZO, 2003). Os burocratas se veem, portanto, diante de um cálculo estratégico sobre custos e benefícios potenciais de iniciativas de reforma (REZENDE, 2002).

Particularmente sobre reformas da administração pública no Brasil, Rezende (2002) diagnostica a sobreposição de falhas sequenciais, isto é, uma trajetória acumulada de reformas que enfrentam a resistência de setores-alvo, não atingem os resultados propostos e levam à persistência de problemas de performance. Essas falhas sequenciais tendem a gerar políticas que absorvem características de distintos processos, em decorrência da não-conclusão dos ciclos de reforma.

Rezende (2002) arrola diversas explicações fornecidas pela literatura para as falhas sequenciais: (i) o elemento democrático faria com que as reformas não possam

\footnotetext{
${ }^{52}$ Diferente de teorias probabilísticas, a abordagem path-dependent busca explicar fenômenos nos quais a ocorrência de uma ação torna mais provável ocorrências posteriores (CROUCH; FARELL, 2004).
} 
ser implementadas de maneira top-down, devendo envolver a construção de coalizões políticas com diversos setores burocráticos; (ii) a incerteza gerada pelas reformas desencadearia problemas de cooperação entre os atores estratégicos; (iii) a multiplicidade de objetivos contraditórios e os conflitos de poder entre atores burocráticos e políticos dificultariam a coordenação entre os interesses.

De todo o exposto, pode-se concluir que a mudança institucional em ambientes complexos tende a ser desafiadora, em decorrência da distribuição do poder ocorrer: (i) entre organizações múltiplas e heterogêneas; (ii) frequentemente com competências ambiguamente compartilhadas, o que pode produzir competição pela autoridade política, ou ainda lacunas sobre a mesma. A esse fenômeno, Abers e Keck (2013) nomeiam embaraçamento (entanglement), e pontuam engendrar, de um lado, uma força inercial que constituiria um obstáculo para a ação, com certos atores resistindo ativamente à emergência de novos locais de decision-making; e de outro, caminhos para iniciativas criativas ${ }^{53}$.

Para as autoras, o entanglement possibilitaria mais oportunidades para abordagens criativas e inovação institucional do que ambientes institucionais mais uniformes e hierárquicos: a diversidade de regras e instituições acabaria permitindo aos atores burocráticos a interpretação e a discricionariedade. Nesse contexto, burocratas implementadores de diferentes escalões operariam processos relacionais de institutionbuilding.

\subsection{A decisão em arranjos institucionais complexos: coordenação intragovernamental e interação sócio-estatal}

Em um quadro de análise de processos de políticas públicas, adotar uma perspectiva institucionalista significa, muitas vezes, debruçar-se sobre sistemas interorganizacionais, englobando relações entre organizações verticalmente hierarquizadas e horizontalmente coordenadas, públicas ou privadas (SCOTT; MEYER, 1991). Tais opções teóricas levam à necessidade de enfrentar o problema da coordenação das atividades de unidades independentes que operam em diferentes arenas de políticas públicas.

\footnotetext{
53 Abers e Keck (2013) esmiúçam, no caso da política de gestão de recursos hídricos no Brasil, como ativistas institucionais, governamentais ou não, transitariam nas complexas configurações de organizações e regras e mobilizariam diversos entendimentos a fim de produzir mudanças.
} 
O estudo das instituições nasce da questão da agregação de preferências e de como este processo molda os interesses ao somá-los. Se as preferências de atores individuais podem gerar resultados sub-ótimos para a coletividade, instituições são criadas para estruturar a interação entre esses atores de maneira a otimizar a agregação das preferências, fornecendo informações, incentivos e controles. As políticas públicas derivam desse processo, o qual perpassa conflitos sobre a distribuição de poder:

Public policy is not assumed to be an efficient outcome of the aggregation of individual preferences, technological progress and market forces, a free-forall of ideas, or even of the 'vested' interests. Political decisions emerge from highly complex combinations of factors that include both systematic features of political regimes and 'accidents of the struggle for power' (IMMERGUT, 1998, p. 26).

No tópico anterior, abordaram-se como os burocratas decidem e empreendem mudanças institucionais, e como as organizações em que se inserem influenciam este processo. Mas as organizações também interagem e exercem influência mutuamente (DI MAGGIO, 1991), em processo que envolve a aquisição e manutenção de poder (DIMAGGIO; POWELL, 1991). Nesse contexto, a pluralização dos atores e a diversificação dos processos de políticas públicas complexificam a agregação de preferências na formação do output político: para além do nível intraorganizacional, a questão passa a englobar a coordenação intragovernamental e as arenas de interface sócio-estatal.

Ressalte-se que as relações entre burocracias e outros atores no processo de políticas públicas são institucionalmente estruturadas. Deste modo, a coordenação da atuação desses diversos agentes em áreas políticas determinadas é enquadrada pelos arranjos institucionais correspondentes, isto é, pelo "conjunto de regras, mecanismos e processos que definem a forma particular como se coordenam atores e interesses na implementação de uma política pública específica" (GOMIDE; PIRES, 2014, p.19-20).

Como explicam Gomide e Pires (2014), os arranjos definem quem participará de um determinado processo político, quais serão o objeto e os objetivos deste último, como se desenrolarão as relações. Determinados arranjos institucionais se caracterizam por sua complexidade: apresentam interconexões entre áreas e atores plurais, governamentais e não-governamentais, com diversos padrões de interação e, consequentemente, regras decisórias e mecanismos de coordenação mais complexos. 
Arranjos complexos podem constituir arenas intersetoriais, caracterizadas por envolverem múltiplas áreas de políticas públicas e não pretenderem "substituir as estruturas setoriais existentes, embora pressuponha $[m]$ a introdução de novos pontos de vista, novas linhas de trabalho e de objetivos em relação aos já existentes nos diversos setores" (Serra, 2005, apud COSTA; BRONZO, 2012, p.62). De acordo com Gabriela Lotta e colaboradores (2016), a lógica intersetorial se refere ao ajuste entre atores que articulam suas competências setoriais, programas ou temas de políticas públicas com foco em um território, público-alvo ou problema complexo. Nesse sentido, implica em uma constante articulação institucional, engendrando tanto a criação de visões e objetivos compartilhados, quanto conflitos e necessidade de coordenação entre visões e objetivos distintos.

Costa e Bronzo (2012) salientam a importância de recursos de conhecimento e capacidade relacional nos arranjos institucionais de maneira a superar a lógica da setorialidade, a qual "se expressa não só na cultura organizacional, estruturada em secretarias e programas especializados, como também nos mecanismos de destinação dos recursos e nos sistemas de informação" (2012, p.64). Assim, os autores sugerem que as dificuldades de intersetorialidade seriam mais fortes em setores mais consolidados, "com estruturas, padrões e cursos de ação mais solidificados pelo tempo e pelas práticas disciplinares e institucionais" (2012, p.70), enquanto setores ainda em processo de consolidação estariam em busca de espaço e tenderiam a perceber as arenas intersetoriais como estratégicas.

Ressalte-se que o conceito de arranjo institucional foi primeiramente desenvolvido na economia, tendo sido pensado por Davis e North (1971) como o conjunto de regras que governa a forma pela qual os agentes econômicos podem cooperar ou competir (apud FIANI, 2014). Cooperação e competição estão, pois, no cerne do conceito de arranjos, e tornam possível sua classificação em três variantes: mercado; hierarquia e redes. No caso dos arranjos de mercado, são desenvolvidos em ambientes de competitividade nos quais os agentes possuem total autonomia, posto que as relações tendem a encerrar-se a cada transação; os custos e benefícios dos atores constituem os elementos centrais das relações; não se pressupõe ou incentiva a formação de objetivos compartilhados; não há um centro estratégico de concertação; entende-se que a coordenação resultará das barganhas entre atores com ativos próprios, 
direitos decisórios próprios e que fruirão de recompensas individuais com a transação (PETERS, 1998; FIANI, 2014).

$\mathrm{Na}$ hierarquia, as estruturas são verticalmente integradas e os agentes possuem baixa autonomia, por estarem sujeitos a um controle centralizado; a mudança no ambiente da transação é coordenada por agentes com maior autoridade hierárquica, de maneira que os atores subordinados operam com reduzida flexibilidade; os incentivos para os atores se referem a mecanismos concernentes às relações de autoridade e ao controle; a coordenação é empreendida pela agência central, em uma perspectiva top down, na qual os custos de transação da cooperação são minimizados a partir do recurso à autoridade para diminuir os graus de conflito e competição.

Os arranjos em rede compreendem diversos meios de interação intragovernamentais e com atores estatais e sociais voltados para uma determinada área política; caracterizam-se por relações interdependentes e, boa parte das vezes, voluntárias; a coordenação provém da barganha entre agentes com padrões de interação repetidos e, muitas vezes, rotinizados; há potencial para formação de visões e objetivos compartilhados sobre o tema. Dentre as várias definições propostas para as redes, podese destacar a abordagem minimalista de Börzel, para quem o conceito se referiria a

\footnotetext{
[...] um conjunto de relações relativamente estáveis, que são interdependentes e não hierárquicas, ligando entre si uma variedade de atores que compartilham interesses comuns acerca de uma política pública e que intercambiam recursos na busca da consecução desses interesses compartilhados, reconhecendo que a cooperação é a melhor maneira de se atingir os objetivos comuns (1997, apud FARIA, 2003, p.26).
}

Peters (1998) ressalta que haveria uma evolução contemporânea de arranjos hierárquicos para padrões complexos, nos quais se incorporam princípios do mercado e das redes. Esses arranjos se caracterizam pela percepção da autonomia do Estado como semi-permeável a influências externas na elaboração e implementação de políticas públicas (EVANS, 1993; GEDDES, 1994), e das capacidades estatais como dependentes não apenas de uma estrutura interna estanque, mas de processos de interação e negociação dos resultados políticos com atores múltiplos. Essa interação compreende, pois, tanto a "cadeia de relações entre formuladores e implementadores, e entre implementadores situados em diferentes posições na máquina governamental" (ARRETCHE, 2001, p. 49); quanto as relações com outros atores estatais e não-estatais. Nesse contexto, Pimenta de Faria (2003) salienta como, entre as décadas de 1980 e 1990, os estudos sobre a interação entre os atores estatais e privados no processo de 
produção das políticas públicas passaram por reformulações significativas no intuito de dar conta da diversificação e complexificação desses processos.

No caso do Brasil, a análise das interações sócio-estatais imprescinde de sua contextualização em transformações recentes do Estado brasileiro impulsionadas pela Constituição Federal de 1988 e pela reorganização da estrutura administrativa dos anos 1990, conduzida em grande parte pela reforma Bresser. Tal conjuntura fomentou a emergência de novos arranjos institucionais marcados pela presença de parcerias entre Estado e atores privados e da sociedade civil (FARAH, 2001), bem como por mecanismos democráticos participativos, "formas diferenciadas de incorporação de cidadãos e associações da sociedade civil na deliberação sobre políticas" (AVRITZER, 2008 , p. 45$)^{54}$.

A coordenação entre organizações autônomas é, desde Allison (1969), vista como um desafio: o modelo organizacional do autor previa que projetos que requisessem a participação coordenada de diferentes organizações tenderiam a não ter sucesso; e que líderes governamentais por ventura encarregados de coordenar poderiam esperar informações incompletas e distorcidas de cada organização. De fato, em contextos nos quais a complexidade das relações ultrapassa os limites do controle hierárquico, a coordenação das atividades das organizações adquire maior importância e apresenta desafios particulares. Nesse sentido se posiciona Alexander (1993), em trabalho no qual define coordenação como uma atividade deliberada voltada para a convergência de decisões e ações de subunidades ou organizações membro, dentro de uma organização ou sistema interorganizacional.

Alexander (1993) aponta que a coordenação interorganizacional constitui objeto de estudos da teoria organizacional, de um lado, e da literatura de implementação e políticas públicas, de outro. Dado o objeto desta tese, a ênfase é conferida ao segundo grupo de estudos, pensando-se a coordenação com foco não na gestão de unidades administrativas, mas sim no processo de políticas públicas. Nesse quadro, Guy Peters (1998) define-a como a concertação para que, em arranjos institucionais complexos,

\footnotetext{
${ }^{54}$ Podem-se identificar dois pontos relevados pela literatura de participação com efeitos sobre os arranjos institucionais: primeiramente, o fato de que se observam distintas modalidades de participação de associações da sociedade civil, destacando-se um forte grupo de associações religiosas com tradição de organização social e um grupo de associações acentuadamente ligadas ao Estado (AVRITZER, 2012) diferenças essas com potenciais consequências para as políticas públicas. Por outro lado, Hoyler (2014) salienta como arenas participativas compostas não por movimentos sociais, mas por entidades patronais, são menos estudadas pela literatura brasileira de participação, a qual procede a uma compartimentalização desse objeto no quadro das análises dos grupos de interesse.
} 
organizações públicas e privadas de diferentes níveis hierárquicos e federativos atuem na formulação e implementação de políticas públicas de maneira a reforçar sua coerência, evitando sobreposições, contradições ou lacunas na entrega dos serviços à população $^{55}$.

No intuito de precisar conceitualmente a coordenação, autores empreendem sua pormenorização e sua diferenciação em relação a outros conceitos ${ }^{56}$. Um dos detalhamentos comumente realizados pelos autores é aquele que discrimina a coordenação enquanto processo e resultado (REGENS, 1989; ALEXANDER, 1993; BOUCKAERT et al., 2010) - sendo que a coordenação como processo se referiria às interações entre agências que conduzem, ou não, à coordenação como estado efetivo. Dessa forma, abordar a coordenação como um processo significa enfatizar as estratégias, mecanismos e instrumentos empregados a fim de concertar a atuação de diferentes organizações dentro do governo. Significa, ainda, salientar seu caráter nãolinear: organizações se engajam em um curso inicial de ação coletiva, o qual poderá continuar, expandir-se ou, ainda, ser revisto por seus participantes.

A abordagem da coordenação como um processo pode ser observada na tipologia proposta por Alexander (1993), segundo a qual diferentes estruturas de coordenação poderiam coexistir, englobando desde mecanismos informais, passando por grupos interorganizacionais (nível mais baixo de coordenação formal, com baixa autonomia de ações e curta permanência, sem orçamento próprio e formado por profissionais que mantêm suas afiliações originais) e organizações líderes (quando uma organização assume a responsabilidade de coordenar as atividades de uma rede interorganizacional), dentre outros mecanismos. Já o modelo proposto por Les Metcalfe

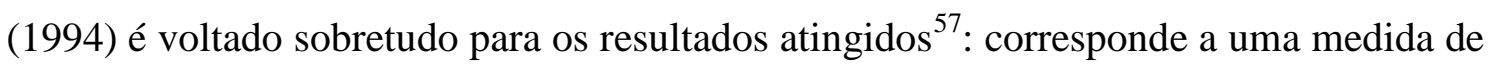
comparação das capacidades de coordenação domésticas dos Estados na construção do posicionamento regionalmente sustentado escalonada em nove níveis que evoluem, de maneira crescente, da tomada de decisão autônoma por um Ministério (nível 1, a

\footnotetext{
${ }^{55}$ Bouckaert et al. (2010, p.16) também apresentam definição neste sentido.

${ }^{56}$ Termos usualmente mobilizados pela literatura em contraponto ao de coordenação são o de cooperação (BOUCKAERT et al., 2010), relativo a mecanismos menos estruturados; e o de colaboração (BARDACH, 1996; THOMSON, PERRY, 2006), vista como uma coordenação mais profunda, que envolveria normas compartilhadas.

${ }^{57}$ Ressalte-se que os níveis de coordenação propostos pelo autor correspondem, de fato, a modos de tomada de decisão em grupo, não se referindo a instituições nem levando em conta a influência dos diferentes desenhos institucionais sobre a decisão. Ademais, a escala delineada tem dificuldade de adaptar-se a uma abordagem de política pública como um processo contínuo.
} 
ausência de coordenação) à estratégia governamental (nível 9, máximo nível de coordenação).

Observa-se que, dentre as várias tipologias apresentadas pelos autores sobre os mecanismos de coordenação, a maior parte delas se remete à divisão entre arranjos institucionais hierárquicos, de mercado ou em rede (REGENS, 1989; ALEXANDER, 1993; BOUCKAERT et al., 2010). Assim, mecanismos hierárquicos se referem à orquestração top-down por uma autoridade centralizada, com base em regras, rotinas e controle; em arranjos de mercado a competição entre os participantes com interesses individuais gera espontaneamente resultados cooperativos; e nas estratégias de redes a cooperação espontânea entre as partes estaria fundamentada em valores e objetivos compartilhados.

Essas estratégias de coordenação enfrentam, por seu turno, diversas dificuldades. Para Peters (1998), os problemas de coordenação, os quais teriam existido desde que as estruturas governamentais se arranjaram em organizações diferenciadas, teriam se acentuado com o crescimento dos governos modernos e a sofisticação de seu aparato administrativo - isso porque, como colocam Bouckaert e colaboradores (2010), não há trade-off fácil entre especialização e coordenação. Por conseguinte, nas palavras de Les Metcalfe, "co-ordination is always precarious because the organizational division of labour, reinforced by professional specialization, political demands and bureaucratic self-interest, engenders centrifugal tendencies” (1993, p.278).

Peters (1998) considera que tais dificuldades adviriam de informação assimétrica entre as organizações e de percepções de que seus programas seriam contraditórios e/ou redundantes. Jennings Jr. e Krane (1994) também reforçam a importância de barreiras organizacionais à cooperação, junto a outras de ordens legal, técnica e política. As barreiras de ordem organizacional estariam relacionadas a diferentes (i) missões; (ii) orientações profissionais; (iii) estruturas e processos das organizações. As barreiras legais e técnicas poderiam derivar de condições ou limitações colocadas pelos dispositivos legais aplicados a cada organização, ou de incongruências entre eles, ou ainda de diferenças nas capacidades técnicas das organizações, particularmente nos sistemas de informação.

Já as barreiras políticas à coordenação poderiam advir do ambiente político externo ou da própria política burocrática. Quanto à política burocrática, Jennings e 
Krane se remetem ao conceito de turf protection $^{58}$ : cada agência se esforça para manter seu domínio de atuação e excluir deste espaço os demais. Essa proteção do território de atuação da organização é apontada por Bardach (1996), após survey com agentes públicos de serviços sociais nos Estados Unidos, como uma das principais dificuldades à colaboração. Segundo Bardach, a turf protection teria várias origens, dentre as quais o autointeresse dos burocratas sobre suas carreiras e o senso de identidade e legitimidade da agência. Ainda para o autor, as barreiras impostas pela proteção de território à colaboração aparecem nas falhas dos indivíduos em comunicarem-se e desenvolverem confiança, e na relutância das organizações em contribuírem com recursos demandados.

Por último, as barreiras políticas externas, ainda na concepção de Jennings Jr. e Krane (1994), se refeririam às pressões dos atores políticos tradicionais, partidários, do Executivo ou Legislativo, de acordo com suas agendas políticas.

Em estudo sobre as implicações da implementação política para a gestão de redes interorganizacionais, O’Toole (1995) foca na incerteza como um obstáculo essencial enfrentado para a cooperação interorganizacional. Esta resultaria da falta de conhecimento sobre as reais preferências dos outros atores, do elevado número de estratégias possíveis para atingi-las, bem como do comportamento estratégico relacionado à interdependência: enquanto alguns atores podem buscar a segmentação entre jogos distintos, outros podem perceber maiores vantagens na imbricação entre eles. Por esse motivo, "There may be virtually no end to the 'moves' available in interorganizational negotiations, and models simply cannot capture the full array of options" (O’TOOLE, 1995, p.46). Nesse sentido, o autor conclui que abordagens analíticas de escolha racional não seriam capazes de fornecer um arcabouço para entendimento de casos de implementação interorganizacional.

Ressalte-se que a ênfase dos modelos supracitados em barreiras organizacionais os leva a descuidarem dos possíveis obstáculos colocados pelos próprios processos

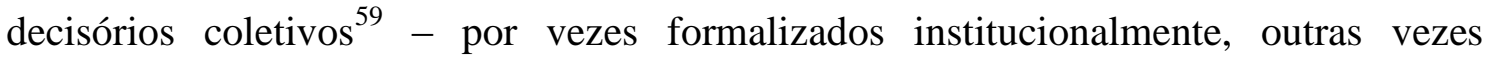
consolidados em usos e costumes. De maneira a explorar esta dimensão, remetemo-nos ao estudo de Hermann e colaboradores (2001) sobre o efeito de conflitos de grupo em

\footnotetext{
${ }^{58}$ Faria et al. traduzem o termo como "proteção do território" (2012, p.190).

${ }^{59}$ Embora orbite em torno do processo decisório coletivo, o modelo de Les Metcalfe (1994) não se propõe a analisá-lo como um fator de fomento ou limitação à coordenação, mas sim como o próprio resultado da coordenação.
} 
decisões de política externa, em que definem seu objeto como o processo decisório coletivo e interativo cujo output será uma solução que do grupo deriva.

O argumento dos autores é que há três diferentes modelos sobre como os grupos podem lidar com o conflito interno: (i) concorrência, no qual há uma tendência a evitar conflito no grupo; (ii) unanimidade, no qual há uma tendência a resolver o conflito no grupo; (iii) e pluralidade, em que há uma tendência a aceitar conflitos no grupo. Tais modelos afetariam os outputs do grupo, classificados em: (i) impasse, quando os membros do grupo não resolvem suas diferenças; (ii) solução dominante, quando o grupo escolhe a única solução vista, por todos os membros, como plausível; (iii) solução do subconjunto, é aquela que é satisfatória para uma parcela do grupo, porém não reflete as preferências de todos os membros; (iv) solução integrativa, uma alternativa que, durante o curso das discussões, torna-se a preferida por todos os membros, o que envolveu mudança das escolhas iniciais de alguns dos membros.

Particularmente, a ideia do modelo da concorrência é a da ênfase na supressão do desacordo de maneira a preservar o bem-estar da unidade decisória. Para os autores, nos casos em que os grupos são formados por indivíduos provenientes de distintas organizações lidando com a mesma questão política, haveria uma identidade grupal primária vinculando esses membros à coletividade que se somaria a suas vinculações organizacionais originárias. De maneira a preservar o bem-estar do grupo, os membros tenderiam a evitar desacordos, arriscando desta forma a reduzir o exame crítico das ideias apresentadas. Nesse caso, o grupo tenderá a adotar soluções dominantes, propostas no início da deliberação e prontamente endossadas - por vezes, soluções menos complexas e qualificadas que as derivadas de debates mais aprofundados. Para tanto, contribuiria a existência de líderes ou normas que desencorajassem o desacordo.

\subsection{Itamaraty: uma organização burocrática clássica e seus desafios contemporâneos}

Desde que a Análise de Política Externa redirecionou o foco dos estudos sobre o tema para o processo decisório e, consequentemente, para os atores que nele figuram, as organizações e instituições foram gradativamente ocupando um importante papel como variável explicativa dos trabalhos. Em volume especial do periódico International Studies Review de 2001, diversos autores se propuseram a classificar as unidades decisórias de maneira a explicar o comportamento dos governos na arena de política 
externa, mesclando para tanto argumentos institucionais e organizacionais. Dentre eles, Margaret Hermann (2001) sumariza o pressuposto de que, embora se reconheça serem vários os fatores, domésticos e internacionais, aptos a influenciar decisões em política externa, assume-se que esses são necessariamente canalizados pelo aparato governamental competente para tomar decisões em política externa e implementá-las.

No caso do Brasil, Karina Mariano e Marcelo Mariano (2008) apontam a tendência das análises de política exterior a focarem nas características institucionais da diplomacia, dadas as peculiaridades da inserção de seu corpo burocrático na estrutura estatal. De fato, Amorim Neto (2011) identifica os fatores burocráticos, junto aos sistêmicos, como os que mais peso têm na definição dos rumos da política externa brasileira. Nesse contexto, a literatura sobre a política externa brasileira tende a partir do diagnóstico de insulamento burocrático do Itamaraty, seja para afirmá-lo ou para identificar padrões de flexibilização (e.g. LIMA, 1994, 2000; PINHEIRO, 2003; CASON e POWER, 2009; FARIA, 2012).

Alexandre Barros (1986) é o primeiro a mencionar o insulamento do processo de formulação e implementação da política externa brasileira, associando-o ao sprit de corps da organização. $\mathrm{O}$ autor busca vincular fatores organizacionais da instituição e sua inserção no poder Executivo aos rumos gerais da política externa brasileira, ressaltando que “(...) à exceção das Forças Armadas, nenhum outro departamento ou Ministério do governo brasileiro dispõe de um símbolo histórico tão poderoso para auxiliá-los a agir coerentemente e a enfrentar, atualmente, as incertezas da competição burocrática" (BARROS, 1986, p.29).

Para além de identificá-lo, Barros não avança nas origens e consequências políticas do insulamento burocrático, até pela incipiência do conceito na literatura: os estudos de burocracias insuladas começam a despontar na ciência política com a onda de trabalhos que trouxeram o Estado de volta à baila nos anos 1980. Sua introdução ao contexto brasileiro, por sua vez, data dos anos 1990, com os trabalhos de Geddes (1994), Sikkink (1993), Evans (1993) e Nunes ([1997], 2010), dentre outros.

Barros (1986) inaugurou, contudo, uma importante linha de pesquisa que se debruçou sobre peculiaridades organizacionais do Itamaraty. Tais estudos destacaram suas características de possuir um forte espírito de corpo e um ethos aristocrático compartilhado, alimentados por recursos simbólicos que orbitam em torno da imagem do Barão do Rio Branco e dela lançam mão para promover vínculos entre os indivíduos 
recrutados, a organização e, argumenta Moura (2006), entre eles e a formação nacional. Esta cultura organizacional aristocrática encontraria uma arena favorável para sua disseminação em burocratas com origem social comum, proveniente de elites (CHEIBUB, 1985; BELÉM LOPES, 2013), e submetidos a processos de socialização intensos ao ingressarem na carreira diplomática. Nesse sentido, destaca-se a importância da criação do Instituto Rio Branco, em 1945, para o fortalecimento institucional do Itamaraty, apontado como um centro de formação de expertise e socialização de valores, fomentando a constituição de quadros coesos e homogêneos (CHEIBUB, 1985; BARROS, 1986; FIGUEIRA, 2010; FARIA et al., 2015). Como explica o diplomata Paulo Roberto de Almeida,

\footnotetext{
O slogan preferido do Itamaraty é o de, pretensamente, saber renovar-se na continuidade, o que de fato é assegurado pela importância dos arquivos e pelo peso da memória nos rituais de trabalho, bem como pela estrutura hierárquica e disciplinada, que mantém o poder nas mãos dos 'barões' da Casa (2008, p.29).
}

Para além de uma metáfora descritiva, o conceito de insulamento burocrático é utilizado pela literatura como recurso analítico de inserção do Ministério das Relações Exteriores no contexto do Estado brasileiro. Embora não faça uso do conceito de insulamento burocrático, Zairo Cheibub (1985; 1989) examina a autonomia do Itamaraty em duas perspectivas: vinculando a história institucional da diplomacia à da construção do Estado brasileiro (1985); e analisando a influência de fatores diversos sobre o padrão de carreira dos diplomatas (1989), concluindo que ela se encontraria em um processo crescente de autonomização face a influências externas. Ressalve-se, porém, que a conclusão de Cheibub se refere a uma autonomia da carreira, ou seja, à consolidação de bases meritocráticas na carreira burocrática, e não à autonomia das decisões políticas tomadas no seio da instituição.

Cheibub (1985) sustenta que o diferencial no desenvolvimento histórico da organização do Ministério das Relações Exteriores, em relação aos demais ministérios, teria sido sua transição pioneira do momento patrimonialista, caracterizado pela não discriminação entre a Administração Pública e a esfera privada dos seus membros, para o período definido pelo autor como carismático, no qual se destaca a figura do Barão do Rio Branco e sua condução personalista e centralizadora da política externa. Este momento carismático teria fragilizado os processos administrativos do órgão, mas fortaleceu-o enquanto instituição, "tanto porque consegue manter sua homogeneidade 
face a outros grupos de elite, como por ser bem-sucedido ao forjar símbolos em seu passado que o ajudam a atuar coerentemente no futuro" (CHEIBUB, 1985, p.123).

Assim, é após a gestão Rio Branco que o Itamaraty entra na sua fase burocráticaracional, processo que se intensificou após 1930, como de resto ocorreu de maneira mais ampla na administração pública federal. A reforma administrativa empreendida por Vargas, a qual objetivou consagrar os princípios da tecnicidade e da racionalização de procedimentos, teve no Itamaraty sua inspiração e gerou impacto na organização do Ministério $^{60}$, a qual experimentou, nesse período, a fusão entre o quadro de oficiais da Secretaria de Estado, do Serviço Consular e do Serviço Diplomático (reformas Mello Franco, 1931, e Oswaldo Aranha, 1939), e, alguns anos depois, a criação do Instituto Rio Branco (1945). Segundo Cheibub (1985), findo o período no qual se assentaram as bases do Itamaraty moderno, isto é, após 1945, não se observaram grandes inovações no órgão, constatando-se, porém, seu fortalecimento, com aquisição de autonomia e expansão do papel dos burocratas, especialmente depois de 1964.

Em trabalho de 1994, Maria Regina Soares de Lima analisa a característica do "alto grau de insulamento dessa burocracia em relação aos influxos provenientes do seu ambiente político e social" como consequência tanto do processo de institucionalização do serviço diplomático, quanto de sua " missão organizacional precípua que não gera vínculos específicos ou clientelas particulares na sociedade e na política doméstica" (1994, p.75). Esta característica seria ao mesmo tempo um recurso, tornando o MRE menos permeável a ingerências políticas indesejadas, e uma fragilidade, pois a falta de enraizamento social da política externa conduziria a uma maior concentração das decisões no chefe do Executivo.

Em seus diversos trabalhos, Lima vincula o conceito de insulamento ao papel preponderante do MRE na formulação e implementação da política externa; à autonomia decisória da organização em relação a influências sociais e políticas; à percepção de que a política externa estaria desvinculada e acima da política doméstica; e à ideia de estabilidade da política externa (1994; 2005a; 2005b). De fato, a estabilidade é apontada, historicamente, como uma das características centrais da política exterior brasileira, e suas causas são usualmente remetidas à centralização e

\footnotetext{
${ }^{60}$ Nesse contexto, destaca-se o papel de Maurício Nabuco, primeiro oficial da Secretaria de Estado durante a gestão de Otávio Mangabeira (1926-1930), em promover reformas administrativas no Itamaraty - tendo sido posteriormente convocado por Vargas para conduzir a reforma burocrática do Estado brasileiro (BRESSER-PEREIRA, 1998).
} 
autonomia do seu processo de formulação e a características organizacionais do Itamaraty (CHEIBUB, 1989; LIMA, 2000).

Pimenta de Faria (2008), por sua vez, explica o insulamento como uma resultante de distintos fatores de ordem institucional, qual seja, o distanciamento do Legislativo do tema e atributos centralizadores do Executivo brasileiro; econômica, com o isolamento internacional do país derivado do modelo de desenvolvimento por substituição das importações; e organizacionais, relativos ao Itamaraty.

Ressalte-se que o conceito de insulamento do Itamaraty cumpre, ademais, uma função normativa. Maria Regina Soares de Lima aponta que a difundida crença na especificidade da política externa no contexto das demais políticas "legitimou entre seus praticantes a necessidade, para o sucesso da política externa, da autonomia com relação às respectivas sociedades nacionais para a coerência e estabilidade da mesma no longo prazo" (2013, p.144). O insulamento é associado ao alto grau de profissionalismo, especialização e estabilidade do corpo diplomático, características que lhes confeririam legitimidade por serem associadas à ideia de eficiência (BARROS, 1986; PINHEIRO, 2003; MARIANO; MARIANO, 2008; FARIA et al., 2015).

No entanto, este mesmo insulamento que contribui para sua eficiência significa, também, o distanciamento de outros atores estatais e da política doméstica. Ao final do século XX, essas características passam a se mostrar enrijecidas em um contexto internacional e doméstico de demandas por legitimidade democrática. Nesse sentido, Lima (2000) argumenta que a liberalização política e a interdependência econômica teriam modificado a natureza da política externa ao inseri-la no conflito distributivo interno, tornando-a suscetível a pressões democratizantes. Quando a ação externa engendra consequências assimétricas para diferentes segmentos sociais, o órgão responsável pela sua condução passaria a ter que negociar interesses setoriais, levando à “politização da política externa" (LIMA, 2000, p.289). Por conseguinte, acrescenta a autora, o insulamento "tende a ser disfuncional na medida em que a agenda externa se modifique com a introdução de novos temas e novos atores e a própria internalização dos acordos internacionais politizem a política externa" (LIMA, 2005a, p.7-8).

Acrescente-se que o Estado brasileiro, que vivenciara uma transição democrática na década de 1980, dedicou-se na década seguinte a adaptar seu aparato administrativo e suas políticas públicas às pressões democratizantes, tornando-se permeável a novos interesses de atores sociais - movimento que foi sentido, ademais, no Itamaraty. Essa 
pluralização dos atores envolvidos teve seu correspondente no âmbito internacional, com o fortalecimento de novos tipos de "esferas de autoridade" (PUNTIGLIANO, 2008, p.28).

Nesse sentido, diversos autores se propõem a analisar o declínio da centralidade do Ministério das Relações Exteriores na formulação da política externa brasileira, embora concordem que a condução dessa política permaneceu concentrada nas instituições do Estado e, particularmente, no Itamaraty (CASON; POWER, 2009; HIRST, 2012; MILANI; PINHEIRO, 2013). Faria e colaboradores (2015) apontam que esse processo teria como característica mais marcante a pluralização dos atores interessados na inserção internacional do Brasil, embora reconheçam tratar-se de movimento que já se iniciara na década de $1960^{61}$. De fato, Barros (1986) salientava, já na década de 1980, a existência deste movimento de pluralização e o ambiente de competição que engendrava entre os atores governamentais.

O processo de pluralização de atores da PEB engendra consequências políticas em duas direções: de um lado, leva à incorporação de agendas domésticas na política externa, com participação de diversos atores, estatais ou não, na formulação das ações brasileiras a serem empreendidas no âmbito internacional e na sua implementação; de outro, influi sobre a internacionalização das políticas públicas, por meio de cooperação e adoção de marcos normativos ou boas práticas internacionais nas várias áreas setoriais. Nesse contexto, alguns estudos focam em aspectos específicos da pluralização de atores na formulação e condução da PEB: (i) relação entre o Executivo e o Legislativo; (ii) abertura para interesses de setores privados e da sociedade civil; (iii) relação com outros atores do Executivo.

Em contraponto ao influente trabalho de Lima e Santos (2001) que constatou um padrão histórico de abdicação pelo Congresso Nacional das matérias de política externa, Diniz e Ribeiro (2008) defendem que há um espectro de participação política na formulação de política exterior mais amplo do que aquele usualmente apontado pela literatura. Analisando mensagens presidenciais relacionadas a acordos internacionais dirigidas ao Congresso (1988-2006), os autores contestam a visão da indiferença do Legislativo sobre temas de política externa, identificando mecanismos institucionais de

\footnotetext{
${ }^{61}$ Também sobre a pluralização de atores, ver PINHEIRO; MILANI, 2012; CASON; POWER, 2009. Esses últimos frisam que este processo estaria vinculado à presidencialização da diplomacia (DANESE, 2009; AMORIM NETO, 2011)
} 
que lançam mão deputados federais para facilitar a aprovação de atos negociados pelo Executivo. Já Oliveira e Onuki (2007), estudando a temática do comércio exterior, mostram que o Poder Legislativo assume relevância como interlocutor de interesses organizados, que o acionariam quando a política comercial promovida pelo Executivo se afastasse de seus interesses.

Realizando um balanço das atividades do Itamaraty entre 1995 a 1998, Sebastião do Rego Barros, embaixador e secretário-geral das Relações Exteriores no período mencionado, identificou a "necessidade de uma crescente aproximação da instituição com a sociedade" (1998, p.18) como orientação geral do período, em consonância com as diretrizes que estariam sendo propostas pelo governo Fernando Henrique Cardoso para a máquina estatal brasileira e com o aumento de interesse da sociedade brasileira sobre os temas de política externa. Essa busca da legitimidade via representatividade e responsividade democrática (PINHEIRO, 2014) teria implicado na criação de canais de diálogo com atores políticos e sociedade civil, incluindo grupos de interesse, sociedade civil organizada e setores não-organizados, dentro da estrutura do órgão e das arenas regionais em que o Brasil toma parte.

Trata-se do que Faria denomina "resposta adaptativa do Executivo brasileiro" (2008, p.87), compreendendo, dentre outras iniciativas, a criação da Assessoria de Relações Federativas em 1997; de escritórios regionais em estados da federação; de fóruns e grupos interministeriais; de estruturas de diálogo relacionadas ao Mercosul, OMC, ALCA e brasileiros no exterior. Figueira (2009) ressalta que as subsecretarias possuem diferentes dinâmicas de relacionamento com outros atores governamentais e grupos da sociedade civil, elencando como exemplos de maior abertura a SubsecretariaGeral de Assuntos Econômicos e Tecnológicos, a Subsecretaria-Geral das Comunidades Brasileiras no Exterior e a Subsecretaria-Geral de Cooperação e Promoção Comercial setores com maior relevância da atividade consular.

Sobre a relação entre o Itamaraty e outras agências do Executivo, volume editado por Pinheiro e Milani (2012) reúne várias análises. Dentre as contribuições, Pinheiro e Beshara (2012) partem da reflexão de que a educação seria parte constitutiva da agenda da política externa brasileira e estudam as interações entre os atores do Executivo sobre o tema. Para os autores, o movimento de ampliação da agência em política externa estaria acompanhado de um anseio de protagonismo do MRE no gerenciamento deste processo - o que denominam de "horizontalização controlada" 
(2012, p.154). No caso da política de direitos humanos, Milani afirma que:

(...) as demandas de atores não governamentais domésticos (Comissão de Justiça e Paz, Caritas etc.) e a política burocrática instaurada entre o Itamaraty, a Presidência da República, o Ministério da Justiça, as diferentes secretarias especiais (sobretudo a Secretaria Especial de Direitos Humanos) e o Congresso ampliam as zonas de conflitualidade, enriquecem o próprio processo de redemocratização do Estado, além de engendrar novos arranjos institucionais mais abertos ao debate contraditório, a exemplo do Comitê Brasileiro de Política Externa e Direitos Humanos (MILANI, 2012, p.61).

Nesse sentido, Milani e Pinheiro (2013) concluem que a pluralização de caminhos de inserção de temáticas na agenda de política externa levaria a que a politização da área fosse realizada, em grande parte, via alargamento da participação ministerial. Isso, segundo os autores, “(...) enseja disputas inter e, principalmente, intraburocráticas, na medida em que as questões de política externa não cabem mais em uma rígida categorização por temas (issue areas), assumindo cada vez mais uma natureza transversal" (2013, p.32).

Analisando o aumento da interatividade ministerial na definição do posicionamento internacional do país, Ariane Figueira (2010) aponta como evidências o aumento de comissões interministeriais institucionalizadas para tratar de temáticas transversais das quais o Itamaraty toma parte (comparando os períodos de 1968-1987 a 1988-2007); o aumento no número de funcionários do MRE emprestados para outros Ministérios; e a constituição de Assessorias de Relações Internacionais em outras pastas ministeriais.

Outros autores concordam que o MRE teria, nos últimos anos, ampliado seus esforços de coordenação intragovernamental (FARIA, 2012; BELÉM LOPES, 2013). Analisando os processos de coordenação para a implementação das diretrizes do Fórum IBAS no Brasil; Pimenta de Faria e colaboradores (2012) constatam uma significativa capilaridade intragovernamental das ações do fórum, com acentuada importância da fase da implementação na definição da política, devido à complexidade técnica dos assuntos envolvidos e da diversidade de interesses das burocracias governamentais. Concluem os autores:

A necessidade de uma coordenação intragovernamental eficiente entre essas agências tem levado o Ministério das Relações Exteriores a reposicionar-se no ciclo de policymaking da PEB - passando da condição de operador preferencial e praticamente onipresente, pela via diplomática, para uma função mais propriamente supervisora e articuladora das dinâmicas de cooperação internacional do Brasil (FARIA et al., p.212-213). 
A quebra do monopólio do Itamaraty na inserção internacional do Brasil e sua interação com outras burocracias na implementação da política externa e na internacionalização de políticas setoriais são definidas por alguns autores como horizontalização (e.g. FRANÇA; BADIN, 2010; PINHEIRO; BESHARA, 2012) ou politização da PEB (e.g. LIMA, 2000; MILANI, 2012), sendo observadas como uma flexibilização do insulamento. Farias e Ramanzini Júnior (2013) criticam essa tese, apontando fragilidades em sua base empírica e conceitual. Os autores julgam que indicadores usualmente utilizados pela literatura para aferir a horizontalização, tal como a existência de áreas internacionais no organograma de outros órgãos, teriam limitações para atestar a efetiva influência no processo decisório. Para os autores, o mapeamento do processo de tomada de decisão seria necessário para averiguar a influência no resultado político final - o posicionamento do país no âmbito internacional.

Quanto ao elemento conceitual, os autores contestam o parâmetro pressuposto de comparação da tese da horizontalização, qual seja, o insulamento burocrático do órgão. Para tanto, trazem exemplos de intensa interação do Itamaraty com outros Ministérios em distintos períodos históricos. Nesse ponto, embora concordemos com a crítica dos autores de imprecisão teórica da tese da horizontalização ${ }^{62}$, consideramos que seus argumentos padecem da mesma fragilidade. Explique-se: se a horizontalização é relacionada, na literatura, ao insulamento burocrático, isso não significa tratar-se de sua antítese. Dito de outro modo, o insulamento burocrático não é definido pela literatura em política externa brasileira como agência livre de interações burocráticas. De fato, o insulamento como recurso analítico é poucas vezes definido com precisão, o que seguramente representa uma deficiência dos trabalhos. No entanto, quando conceitualmente definido, o é em termos da literatura mais ampla sobre o tema, ou seja, como autonomia decisória da organização em relação a influências sociais e políticas (LIMA, 1994).

Insulamento burocrático não é uma característica exclusiva do MRE: como já mencionado neste capítulo, Nunes (2010) aponta-o como uma das gramáticas políticas

\footnotetext{
${ }^{62}$ Assim como concordamos com a crítica realizada à fragilidade das evidências empíricas elencadas por parte de seus adeptos. De fato, o mapeamento de organogramas, por si só, dificilmente terá consistência o suficiente para dar respaldo a inferências causais sobre influência política. Argumentamos que a tese da horizontalização ou pluralização de atores na política externa como um fenômeno recente terá conclusões mais precisas se testar, separadamente, as dimensões da internacionalização das políticas públicas e da maior internalização da política doméstica na política externa.
} 
que estruturariam o Estado brasileiro. $\mathrm{O}$ autor caracteriza as burocracias insuladas como "ilhas de racionalidade e de especialização técnica" (2010, p.54), às quais se atribuiria a execução de objetivos específicos, e que seriam protegidas dos interesses do público em geral ou de atores políticos e sociais. Ressalte-se que o fortalecimento dessas burocracias não seria sem causas nem efeitos políticos.

Sem embargo, Edson Nunes não faz, em seu trabalho, menção ao Itamaraty como órgão especialmente caracterizado pelo insulamento burocrático. Ao classificar os ministérios em políticos e tecnocrático-militares de acordo com a origem dos ministros, antes e depois de 1964, Nunes aponta o Itamaraty como relativamente político no primeiro momento, e no segundo como relativamente tecnocrático-militar. Este movimento não se distanciou da tendência geral observada no período, fundamentada na busca pela racionalidade tecnoburocrática iniciada em Vargas, aprofundada em Kubitschek e, posteriormente, nos governos militares. Como exemplos paradigmáticos do insulamento, o autor se refere sobretudo a agências voltadas à política econômica, como a Petrobrás e o Banco Nacional de Desenvolvimento Econômico (BNDES).

Por outro lado, analisando as nomeações ministeriais entre os governos Sarney e o primeiro governo Fernando Henrique Cardoso (1985-1997), Loureiro e Abrucio (1999), ao distribuírem em um continuum o conjunto dos ministérios existentes em função de seu grau de abertura à nomeação política, colocam os ministérios militares como "mais fechados", seguidos do Itamaraty. Desta forma, se assumimos a nomeação dos ministros como um indicador de insulamento burocrático, poderíamos afirmar que o Itamaraty possui tal característica ${ }^{63}$. Já Bersch et al. (2013), partindo de indicadores de autonomia burocrática e capacidade estatal, analisam dados de 2011 e concluem que o Itamaraty constituiria uma das ilhas de excelência do Executivo, todavia junto a outras 27 agências com índices de alta capacidade e alta autonomia - sugerindo, pois, não se tratar de características que singularizem o Ministério das Relações Exteriores.

Quanto ao conceito de insulamento, Pinheiro e Milani, embora concordem que as características institucionais do Itamaraty teriam contribuído historicamente para

\footnotetext{
${ }^{63}$ Já Amorim Neto (2011) se baseia na politização da escolha dos chanceleres, na estabilidade da elite de embaixadores e no número de viagens internacionais do chefe de Estado para afirmar que haveria perda progressiva da autonomia decisória do órgão pós redemocratização. $O$ autor pressupõe que a nomeação de uma maioria de Ministros oriundos da carreira diplomática estaria associada à perda de autonomia do MRE, pois simplificaria o controle do aparato diplomático pelo chefe do Executivo, isolando o órgão das barganhas do presidencialismo de coalizão. Repare-se, porém, que o argumento contrário pode ser igualmente sustentado: a nomeação de uma maioria de ministros oriundos da carreira diplomática isolaria o órgão de barganhas políticas, logo o tornaria mais insulado burocraticamente.
} 
preservá-lo de injunções políticas, ressalvam que tal fato não seria sinônimo de um total insulamento. Explicam os autores:

(...) se em seus primórdios, como instituição de um Estado independente, os interesses públicos em muito se confundiram com os interesses privados em função do patrimonialismo que caracterizava a política nacional de um modo geral (Cheibub, 1985), passado esse período, interesses setoriais sempre tiveram acesso à arena de formulação das políticas públicas, inclusive a política externa. A diferença estaria fundamentalmente na ausência de canais regulares de transmissão das demandas dos interesses sociais para as agências do Estado, assim como, et pour cause, na possibilidade de essas agências absorverem seletivamente as demandas da sociedade (PINHEIRO; MILANI, 2012, p.18 - grifo nosso).

De fato, Lima (2000) discorre sobre a participação, na década de 1950, de setores industriais no Executivo e no GATT, por intermédio dos agentes diplomáticos, na consolidação do regime de proteção industrial. O insulamento burocrático se erigia, pois, em relação às demandas sociais e políticas que divergiam daquelas sustentadas pelos grupos de pressão reconhecidos como legítimos - cujos interesses eram, em consequência, identificados com o interesse nacional. Adicionalmente, e como observado por Farias e Ramanzini Jr. (2013), o MRE não detém, no decorrer de sua história, o monopólio decisório de muitas das áreas nas quais atua, dentre as quais, a questão migratória.

Nos termos expostos, observam-se as dificuldades de operar o conceito de insulamento burocrático como categoria analítica explicativa, dadas as imprecisões conceituais verificadas na literatura; o excesso de pressupostos contestáveis; e a fragilidade das evidências empíricas elencadas por parte dos autores - de fato, o mapeamento de organogramas, por si só, dificilmente terá consistência o suficiente para dar respaldo a inferências causais sobre influência política. Por sua vez, argumentamos que a tese da horizontalização ou pluralização de atores na política externa como um fenômeno recente terá conclusões mais precisas se se desvencilhar do conceito de insulamento e testar, separadamente, as dimensões da internacionalização das políticas públicas e da maior inserção da política doméstica na formação da política externa.

Por último, é interessante mencionar a crítica de Gilda Gouvêa (1994) relativa à dificuldade dos estudos que mobilizam o conceito de insulamento em enfrentarem suas origens ou consequências políticas:

O que esta análise não avança, e por isso sua utilidade é parcial, é a questão dos recursos políticos necessários para isolar uma agência ou um conjunto de burocratas e principalmente a quem interessa ou quem promove este 
isolamento ou a criação das 'ilhas de racionalidade' técnica. E isto acontece, pois há uma preocupação formalista por trás do conceito de insulamento, que pode ser útil (como outros conceitos com o mesmo tratamento) apenas na esfera descritiva (1994, p.66).

Em contrapartida, a literatura de insulamento burocrático traz entendimentos descritivos consolidados importantes, dentre os quais o de que o Itamaraty possui características organizacionais peculiares que o aproximam do modelo administração pública racional-legal, com mecanismos hierárquicos orientados por relações de autoridade e obediência a regras e formalidades. A estrutura hierárquica se reflete no processo decisório intraburocrático, no qual os Chefes de Divisões respondem hierarquicamente ao Chefe de Departamento, e esses, por sua vez, ao Subsecretário Geral. Os Subsecretários Gerais estão submetidos ao Secretário Geral, que compõe, junto ao Ministro e respectivo gabinete, o núcleo decisório em política externa brasileira. Figueira (2010) salienta que, quanto mais uma questão for sensível ou envolver maiores recursos financeiros, mais seu processo decisório será concentrado na cúpula. Nos casos considerados de menor relevância, os níveis hierárquicos mais baixos terão maior autonomia.

Em um contexto mais geral, a Análise de Política Externa salienta as especificidades das burocracias responsáveis pela temática: usufruem de um determinado grau de autonomia em relação a atores importantes para política doméstica, o que as preserva relativamente de intempéries políticas; ao mesmo tempo, raramente possuem o total monopólio sobre o tema da política externa, devendo cooperar de modo a implementar suas políticas (DREZNER, 2000); tendem a focar-se mais nos meios que nos fins, em razão do difícil monitoramento e avaliação de suas políticas, o que pode gerar uma excessiva ênfase em procedimentos. Em função disso, Moses e Knutsen (2001) consideram que os arranjos institucionais de política externa dos vários países seriam antiquados e ineficientes, especialmente com o gradativo aprofundamento da interdependência entre questões internacionais e domésticas, sugerindo arranjos comandados por instituições mais enxutas, com funções de coordenação das atividades externas exercidas pelos diversos Ministérios.

Ariane Figueira (2009) levanta a hipótese de que haveria um processo de incipiente mudança no padrão decisório em política externa, com um aumento da porosidade institucional do MRE correspondendo à transição do modelo de administração pública racional-legal para o gerencial. Esta hipótese se aproxima das 
teses e achados dos autores que tratam da perda de centralidade decisória do Itamaraty. Assumindo-se este processo, quais suas consequências e origens políticas? Mudanças na estrutura organizacional engendrariam uma maior aproximação do cidadão? E de outros atores estatais? No intuito de responder a esses, dentre outros, questionamentos, modelos analíticos se fazem necessários. Esta preocupação é compartilhada por Carlos Milani no trecho abaixo:

E, analiticamente falando, como construir modelos de análise, indo além do que propõe o modelo de política burocrática de Allison (1971), que nos permitam dar conta das demandas de participação social no campo da política externa, da ruptura com o padrão do insulamento burocrático do Ministério das Relações Exteriores e das tensões causadas pela assimetria de informação entre os atores? (MILANI, 2012, p.65).

Uma opção teórica que vem sendo adotada pela literatura é a de analisar a política externa como política pública, tendo em vista o objeto das características e efeitos do processo de politização desta política. Definida política externa como "the sum of official external relations conducted by an independent actor (usually a state) in international relations" (HILL, 2003, p.03), concebê-la como política pública implica em ressaltar seu aspecto de politics: constitui-se como uma arena de negociações, barganhas, conflitos e coordenação (MILANI; PINHEIRO, 2013). Implica, ainda, em observar com mais cuidado as diversas fases do seu ciclo e atores que nelas tomam parte, percebendo a política externa como "o Estado e o governo em ação no plano internacional” (PINHEIRO; MILANI, 2012, p.332).

Conceber a política externa como política pública possibilita, ainda, análises sobre mudanças em suas agendas ou nas políticas implementadas, seja em decorrência de condições sistêmicas, seja em razão de fatores domésticos, dentre os quais os burocráticos. A mudança é um desafio teórico para abordagens tradicionais da política externa brasileira (MILANI, 2012) - como, de resto, o é para a ciência política em geral. A fim de enfrentá-lo no campo da Análise de Política Externa, Hermann (1990) defende a hipótese de que o processo de tomada de decisão media entre as fontes de mudança e os resultados políticos obtidos, abordagem que direciona o foco de análise para o desenrolar da mudança conduzido por atores burocráticos e políticos.

No quadro de pensar sobre as fases do processo de política externa, o diplomata Sebastião do Rego Barros (1998) descreve da seguinte maneira as funções do Itamaraty: (1) Antes da execução da política externa: (i) formulação de diretrizes gerais; (ii) coordenação com os demais órgãos do Governo e entidades civis; (2) Na execução: (i) 
representação do Governo no exterior por meio de atividades de representação, negociação e informação; (ii) prestação de serviços específicos, no quadro dos quais “identificam-se interesses particulares que vão ao encontro dos objetivos nacionais e contribuem para que sejam alcançados" (BARROS, 1998, p. 24), tais como a assistência aos brasileiros no exterior, a promoção comercial e a difusão cultural.

A formulação de Barros (1998) nos possibilita atentar para uma dimensão da PEB frequentemente negligenciada: a atividade consular. O estatuto consular se refere à função protetora do Estado no exterior (FELDMAN, 2009a), compreendendo atos notariais, assistência e defesa de direitos. Enquanto à diplomacia cabem funções de representação da soberania e do Estado, a atividade consular se refere à atenção a interesses privados dos nacionais que se encontram no exterior. Essa atuação não se dá de maneira aleijada da política. Como coloca Barros, "É importante notar o sentido político deste apoio: a atuação do consulado traduz o interesse do Estado por seus nacionais afastados e sua determinação de protegê-los. Representa, por isto, um fator de preservação da cidadania (...)” (BARROS, 1998, p.25).

Sobre o que nomeia como a "consularização da política externa brasileira”, Luiz Feldman (2009a) coloca que a atuação do Estado na proteção de interesses e, mais especificamente, na promoção de direitos de seus nacionais no estrangeiro “(...) elucida como o nexo entre governo e sociedade civil refeito desde a fundação da Nova República repercute no interior da agenda diplomática, re-escalonando suas prioridades" (2009a, p.12). O autor analisa que a dimensão consular teria adquirido maior centralidade na condução da PEB em razão de dois fatores: o crescimento das comunidades brasileiras no exterior e a repercussão pública do tema. Não obstante se verifique esse movimento de mudança, o estatuto consular não ultrapassou a condição de componente secundário nas relações interestatais. Feldman menciona, ainda, os dilemas de implementação levantados por essa questão, referentes à oposição entre os direitos dos brasileiros e a soberania do ordenamento jurídico dos países ${ }^{64}$.

A literatura de implementação se mostra uma abordagem possível da atuação consular, com potencial aplicação para o objeto das migrações internacionais. Nesse quadro, Alpes e Spires (2013) analisam as práticas de cônsules e funcionários dos

\footnotetext{
${ }^{64}$ Isto estaria sumarizado na disposição do Manual de Serviço Consular e Jurídico na sua versão 2.0, tomo I, capítulo $3^{\circ}$, seção $1^{\mathrm{a}}$, item 3.1.1., sobre Assistência e Proteção a Brasileiros: “A autoridade Consular zelará para que os brasileiros dentro de sua jurisdição possam gozar, plena e eficazmente, dos preceitos apropriados contidos na Constituição Federal de 1988” (FELDMAN, 2009a, p.12).
} 
postos consulares, defendendo a importância do poder discricionário dos cônsules com três razões: (i) os burocratas de nível de rua dos consulados são responsáveis por lidar com direitos fundamentais de indivíduos que consideram como não-cidadãos, sendo que os demandantes de vistos possuem pouca margem para influenciar ou desafiar seus poderes discricionários; (ii) a atuação dos burocratas nos consulados é caracterizada pela possibilidade de uma ampla interpretação das leis e regulamentações, em razão tanto das lacunas e contradições normativas verificadas na área, quanto de sua distância de mecanismos de controle administrativo; (iii) a discricionariedade dos burocratas consulares tem o diferencial de ser legitimada pela defesa do interesse nacional, sustentada na distinção entre migrantes desejáveis e aqueles considerados ameaçadores aos interesses nacionais do país.

Em conclusão, observa-se que uma abordagem de análise de políticas públicas se mostra uma opção apta a inserir as relações internacionais do Brasil, em geral, e o Itamaraty, em particular, no contexto do Executivo brasileiro, permitindo, com seu instrumental teórico, tanto analisar o fenômeno de internacionalização das políticas públicas, quanto atentar para as atividades de coordenação intragovernamental envolvendo o MRE e a dinâmica observada na organização entre a formulação e a implementação política.

\subsection{Definição das hipóteses com base na literatura pertinente}

A política migratória brasileira, conforme esboçado no capítulo 1, possui algumas peculiaridades no interregno temporal analisado nesta tese: (i) acentuada fragmentação de competências, tanto para sua formulação, quanto para a implementação; (ii) regulamentação geral por uma normativa antiga e com problemas de adaptação à realidade fática; (iii) atores sociais participam de sua formulação e implementação; (iv) a implementação é multinível, central e local; (v) constitui política intersetorial e interconectada com políticas diversas, tanto mais gerais, como educação e saúde, quanto especificamente relacionadas a seu objeto, tais como refúgio e tráfico de pessoas.

Nesse quadro, quais consequências o desenho institucional da política migratória pode engendrar sobre seus resultados políticos? Quais propriedades deste desenho podem fomentar ou obstar a mudança? 
O objetivo deste trabalho, conforme exposto na introdução, é analisar os padrões de mudança e continuidade na política migratória brasileira, de maneira a observar o papel neles exercido pela dinâmica político-burocrática interorganizacional. Busca-se costurar, para o caso da política migratória, explicações do funcionamento do Executivo que englobem o processo das políticas públicas, levando em conta o fato de tratar-se de um poder responsável não apenas pela formulação, mas também pela implementação de políticas, e que atua não como um bloco monolítico, mas por meio de agências em constante interação entre si e com atores não-estatais. Logo, os estudos de caso realizados nos capítulos 4 e 5 possuem o objetivo de fornecer explicações compreensivas do caso individual, em uma moldura institucional.

A hipótese geral deste trabalho é a de que, na política migratória brasileira, o desenho institucional com fragmentação e sobreposição de competências conduz a que organizações, por meio de seus dirigentes políticos e burocratas, realizem mudanças incrementais setoriais na política, em decorrência do aumento de suas capacidades técnico-administrativas e político-relacionais. Entretanto, em razão de estratégias voltadas para manter seu espaço de poder e lógica de ação organizacional, tais organizações tenderão a opor obstáculos a reformas mais amplas. Esse duplo mecanismo corresponde a duas faces de um mesmo objetivo: a manutenção ou ampliação da autonomia da organização.

As capacidades técnico-administrativas contemplam as competências dos agentes estatais de levarem a efeito suas políticas e envolvem burocracias competentes e profissionalizadas, dotadas de recursos organizacionais, financeiros e tecnológicos. Já as capacidades político-relacionais destinam-se a produzir apoio e conferir legitimidade à política e compreendem mecanismos e procedimentos (i) de inclusão de atores do setor privado e da sociedade civil; (ii) de articulação entre os entes federativos; (iii) de negociação com o poder Legislativo (GOMIDE; PIRES, 2014). É a operacionalização desses recursos e mecanismos que possibilita à organização concretizar seus objetivos e agir enquanto braço do Estado.

Ao esquema conceitual de Gomide e Pires (2014) adiciona-se, aqui, um outro elemento: mecanismos de interface com instituições internacionais. Por outro lado, exclui-se a capacidade de processar os conflitos de interesse, uma vez que se trata de fator previsto na outra face do mecanismo, na qual se preveem justamente dificuldades 
de processar conflitos de interesse e coordenar uma posição comum em contextos de desenho institucional fragmentado.

Com efeito, na outra face do mecanismo, a conservação ou ampliação do espaço de poder compreende: (i) recursos financeiros; (ii) recursos técnico-administrativos, incluindo recursos humanos capacitados, materiais, infraestrutura; (iii) recursos políticos, englobando as competências e atribuições sob seu escopo, recursos de conhecimento e capacidade relacional.

O conceito de lógica de ação organizacional aqui proposto se inspira nos de cultura (DREZNER, 2000), missão (JENNINGS JR.; KRANE, 1994) ou paroquialismo organizacional (ALLISON, 1969) presentes na literatura organizacional, porém enfatiza seus aspectos empiricamente observáveis ao alicerçá-lo no conceito de competências institucionais. Desta forma, a lógica de ação organizacional se refere a práticas e modos de atuação empreendidos pelos membros de uma organização com vistas a perfazer suas competências institucionalmente estabelecidas, envolvendo tanto seus objetivos, prioridades e projetos; quanto suas estruturas e processos de trabalho, incluídos os sistemas informacionais.

Definida a abordagem teórica como institucional, e partindo da hipótese de que a explicação causal será sobre o mecanismo que liga as causas aos resultados, cabe explicitar o mecanismo teorizado em termos de quais entidades se engajariam em quais atividades para que os resultados ocorram ${ }^{65}$. Nesses termos, o desenho teorizado está expresso no quadro 2.2 .

Quadro 2.2: Mecanismos causais relativos à dinâmica mudança/continuidade verificada na política migratória brasileira no período de 2003-2016

\begin{tabular}{|c|c|c|}
\hline \multicolumn{3}{|c|}{ Mecanismo causal } \\
\hline \multirow{2}{*}{$\begin{array}{l}\text { Causa: } \\
\text { Desenho institucional com } \\
\text { sobreposição e } \\
\text { fragmentação de } \\
\text { competências }\end{array}$} & $\begin{array}{l}\text { Parte 1: } \\
\text { Organizações, por meio de seus dirigentes políticos } \\
\text { e burocratas, empreendem estratégias para aumentar } \\
\text { suas capacidades estatais técnico-administrativas e } \\
\text { político-relacionais }\end{array}$ & $\begin{array}{c}\text { Resultado 1: } \\
\text { Mudanças } \\
\text { incrementais } \\
\text { setoriais na política }\end{array}$ \\
\hline & $\begin{array}{l}\text { Parte 2: } \\
\text { Organizações, por meio de seus dirigentes políticos } \\
\text { e burocratas, tentam manter ou ampliar seu espaço } \\
\text { de poder e sua lógica de ação organizacional }\end{array}$ & $\begin{array}{c}\text { Resultado 2: } \\
\text { Dificuldades de } \\
\text { reformas da política }\end{array}$ \\
\hline
\end{tabular}

Fonte: Elaboração da autora.

\footnotetext{
${ }^{65} \mathrm{O}$ desenho metodológico deste trabalho muito se inspira em Beach e Pedersen (no prelo).
} 
Subjaz ao mecanismo causal explicitado o pressuposto, de caráter racional, de que atores institucionais se mobilizam se a mudança lhes trouxer benefícios. $\mathrm{O}$ autointeresse assumido, de caráter organizacional, é a manutenção ou ampliação da autonomia da organização (HALPERIN; CLAPP, 2006).

A hipótese arrolada se coaduna, ainda, à literatura sobre o Estado brasileiro que salienta sua frequente opção de acrescentar novas instituições a estruturas anteriores, por meio de reformas particulares, ao invés de empreender reformas mais amplas em uma determinada área política (SOUZA, 1983; EVANS, 1993; GEDDES, 1994; REZENDE, 2000; SCHMITTER, 1971). Desvelar o mecanismo da mudança nesse Estado incremental é o objetivo do estudo de caso do capítulo 4. Um dos elementos desse mecanismo que receberá atenção específica é a internacionalização.

A internacionalização das políticas públicas vem sendo associada a mudanças mais amplas da política externa brasileira, mas detalhamentos analíticos deste processo ainda são poucos. A hipótese aqui levantada é a de internacionalização como estratégia de ampliação da capacidade estatal das burocracias, tanto capacidades técnicoadministrativas, por meio de recursos organizacionais, financeiros e de expertise, quanto capacidades político-relacionais, e nesse sentido a hipótese adiciona ao esquema de Gomide e Pires (2014) mecanismos de interface com instituições internacionais. Por interface com instituições internacionais, entende-se não apenas relações com organizações internacionais e regionais, mas também processos de adesão a regimes internacionais. Dessa forma, tal abordagem se associa à literatura segundo a qual, para atores domésticos, os atores e instituições internacionais são meios e recursos no processo político doméstico (MORAVCSIK, 2000).

Por último, na estrutura do Executivo brasileiro, os principais órgãos que formulam e implementam a política migratória se encontram no mesmo nível hierárquico, portanto executam suas funções de maneira autônoma, submetidos apenas à Presidência da República. Trata-se, ademais, de Ministérios tradicionais, com burocracias e processos cristalizados. Nesses termos, emerge o difícil tradeoff entre especialização e coordenação: caso se atinja uma coordenação, pode-se implantar uma decisão que é Pareto superior às implementadas por cada gabinete. No entanto, mecanismos de coordenação têm potencial para alterar ou manter a distribuição de poder entre os agentes, de modo que o processo de coordenação enfrenta diversos 
obstáculos. Nesse contexto, esta tese deriva de Peters (1998) e trabalha, em seu capítulo 5, a hipótese descritiva de que se verifica, no arranjo institucional complexo na política migratória brasileira, elementos de coordenação de arranjos hierárquicos, de mercado e de redes, em que burocratas operam por meio de relações e trocas não previstas no desenho institucional formal e interagem, ainda, com atores não-governamentais.

De maneira a responder a esse conjunto de questões e hipóteses de pesquisa, e nos termos da revisão de literatura empreendida neste capítulo, este trabalho adota uma abordagem institucional, com foco nas distribuições e redistribuições de poder (MOE, 1989, 2005; DIMAGGIO; POWELL, 1991; MAHONEY; THELEN, 2010), de caráter histórico por assumir a importância das trajetórias históricas nos arranjos de poder, racional por entender que há cálculos de custo-benefício na dinâmica institucional de continuidade e mudança, mas principalmente organizacional por considerar que as preferências dos atores estariam ligadas às suas posições institucionais, ou seja, às organizações a que pertencem. Adere, pois, à proposta de Hall (2010) de examinar-se a mudança via agregação conceitual de diferentes abordagens institucionais.

Ressalte-se, por último, que a revisão da literatura exposta respalda, ainda, a opção deste trabalho de estudar a política migratória mantendo a vista aquelas de emigração, refugiados e tráfico de pessoas. Em uma perspectiva de distribuição do poder em arranjos institucionais complexos, a alocação de recursos em determinadas instituições pode afetar os resultados de conflitos relacionados à distribuição de recursos referentes a outras instituições. Nesse sentido, atores em desvantagem em uma instituição podem conseguir um status mais vantajoso em outra instituição para fomentar a mudança (MAHONEY; THELEN, 2010, p.9): os jogos ocorrem simultaneamente em múltiplos níveis. 


\title{
Capítulo 3: Trajetórias institucionais da política migratória brasileira e do Ministério das Relações Exteriores na República: acomodações mútuas
}

\author{
"Policy in Brazil changes by accretion rather than \\ by substitution" (SCHMITTER, 1971, p.256)
}

\subsection{Introdução}

Este capítulo examina a evolução histórica da política migratória no Brasil a partir da proclamação da República até a promulgação da Lei nº 6.815/1980, de modo a mapear os diferentes arranjos institucionais assumidos por esta política e avaliar, particularmente, o papel neles exercido pelo Ministério das Relações Exteriores. Tal análise objetiva fornecer inferências descritivas sobre como as relações internacionais do Brasil, particularmente por meio da ação do Itamaraty, podem influenciar a política migratória do país. O mapeamento dos arranjos institucionais visa a, outrossim, identificar distintos padrões de atuação do Estado e da sociedade civil na temática. Busca-se, desta maneira, contextualizar a atuação dos diversos Ministérios em política migratória, a ser examinada nos próximos capítulos em uma abordagem causal; bem como revisar e robustecer, à luz da narrativa historiográfica, as hipóteses desenvolvidas no capítulo 2 com base na literatura.

Propor-se a construir narrativas de fundo (background narratives) que possam ser codificadas em categorias teóricas relevantes (LUSTICK, 1996) não exime o pesquisador de explicitar suas escolhas metodológicas a fim de respaldar a realização de inferências descritivas. Essas são entendidas por King, Keohane e Verba como "process of understanding an unobserved phenomenon on the basis of a set of observations" (1994, p.55), e se fundamentam, de acordo com os autores, em uma organização direcionada dos detalhes históricos de maneira a fracionar o mundo em componentes sistemáticos e não-sistemáticos (1994, p.75). Embora o objetivo da descrição não seja o de identificar relações causais, a realização de inferências descritivas, ao contrário de simples interpretações, requer atenção ao método científico - e um critério importante para observar esta aderência é a ausência de viés de seleção ${ }^{66}$.

\footnotetext{
${ }^{66} \mathrm{Na}$ definição de Collier, viés de seleção ocorre quando "the nonrandom selection of cases results in inferences, based on the resulting sample, that are not statistically representative of the population" (1995, p. 462).
} 
A abordagem histórica na ciência política caracteriza-se pela fundamentação, dentre outras fontes, em narrativas historiográficas anteriores, o que pode conduzir a viés de seleção na escolha, ainda que inconsciente, de narrativas que se mostrem consistentes com o argumento do pesquisador (LUSTICK, 1999). De maneira a evitar o viés a que a pesquisa de abordagem histórica está sujeita (como qualquer outra metodologia científica, questão particularmente agravada no caso de métodos qualitativos dada sua tendência a selecionar casos com base na variável dependente), este capítulo adota as seguintes técnicas combinadas:

(i) Toma por fio condutor de sua análise uma exploração direcionada de fontes primárias, no caso concreto facilitada por se tratar de análise institucional e abrangendo discussões de alta política a que corresponde uma relevante memória documental, com o objetivo de organizar informações nas categorias conceituais do marco teórico adotado ${ }^{67}$;

(ii) Busca explicitar padrões encontrados na narrativa historiográfica, bem como apontar, quando houver, inconsistências entre narrativas -sublinhando destarte o debate historiográfico como resultado de trabalhos conduzidos por pesquisadores comprometidos com determinadas teorias, e não evidências primárias;

(iii) Empreende uma vasta revisão bibliográfica ${ }^{68}$, inclusive englobando metodologias distintas, valendo-se da assunção de que um amplo quadro de narrativas tenderia a refletir uma distribuição normal de comprometimentos teóricos implícitos (LUSTICK, 1999).

Nesse sentido, o capítulo utiliza duas categorias de fontes primárias. Primeiramente, pauta-se na normativa federal ${ }^{69}$ e internacional sobre política migratória no período estudado. Em seguida, vale-se da análise dos Relatórios Anuais da Secretaria de Negócios Estrangeiros, posteriormente Ministério das Relações Exteriores. Tais relatórios foram produzidos entre 1830 e 1960 como meio de prestação de contas das atividades do Ministério, dirigindo-se, no Império, ao Poder Legislativo; e na

\footnotetext{
${ }^{67}$ Essa técnica é estimulada por Skocpol (1984).

${ }^{68}$ Como a questão migratória suscita o interesse de disciplinas diversas, a revisão bibliográfica mencionada contemplou trabalhos da Antropologia, Geografia, Ciência Política e, principalmente, História e História das Relações Internacionais.

${ }^{69}$ Disponíveis no acervo digital da Câmara dos Deputados (disponível em: http://www.planalto.gov.br/. Acesso em: 07 out 2014) e no Sistema de Informações do Arquivo Nacional (disponível em: http://www.an.gov.br/. Acesso em: 06 out 2014). Suplementarmente, foi consultada a coletânea de IOTTI, 2001a.
} 
República, ao Chefe do Executivo ${ }^{70}$. Esses documentos, ao autodescreverem as atividades do órgão, adquirem valor probatório sobre sua atuação na implementação da política migratória e em sua formulação, evidenciando inclusive articulações com outros atores; além de serem representativos da visão oficial da instituição quanto ao tema.

O recorte temporal do capítulo, entre 1889 e 1980, foi estabelecido com os objetivos de manter constante a forma de governo e de partir de um momento em que as características institucionais dos diferentes Ministérios envolvidos já possuíam um desenho consolidado, ainda que incipiente. Seguiu, ainda, razões atinentes ao fluxo migratório, intensificado sobremaneira nas últimas décadas do século XIX, o que criou uma conjuntura completamente distinta dos anos precedentes ${ }^{71}$. Além disso, buscou posicionar-se após o fim da escravidão, por considerar que a análise da transição para a mão-de-obra livre e das negociações diplomáticas envolvidas, embora firmemente trançadas à questão migratória, foge aos objetivos do presente trabalho ${ }^{72}$.

Em balanço dos estudos historiográficos realizados sobre a imigração no Brasil, Boris Fausto (1991) sublinha que a questão tendeu a ser encarada como uma "história de final feliz" (1991, p.13), frisando-se a ascensão social dos imigrantes, corroborada pelo paradigma de mestiçagem que permeou boa parte do pensamento social brasileiro no século XX. Um abordagem política da migração permite observar-se os conflitos e barganhas subjacentes aos afluxos populacionais, inclusive os associando a elementos do Estado brasileiro em formação.

Pontue-se que, ao realizar uma abordagem da política migratória brasileira que retrocede ao início da República, este trabalho engloba não apenas os imigrantes e refugiados como definidos na atualidade, mas também os afluxos de estrangeiros para

\footnotetext{
${ }^{70}$ Os relatórios foram disponibilizados para consulta por meio do projeto Latin-American Microfilm Project, levado a cabo pelo Center for Research Libraries. Disponível em: http://wwwapps.crl.edu/brazil/ministerial/rela\%C3\%A7oes exteriores. Acesso em: 01 mar 2016.

${ }^{71}$ José Fernando Carneiro (1950), em seu trabalho sobre a história da imigração para o Brasil, aponta os anos de 1886 e 1887 como marco de entrada para a fase em que o imigrante se tornou elemento substitutivo, e não mais supletivo, da mão-de-obra escrava. Para corroborar a afirmação, o autor traz dados (1950, p.82) que denotam a magnitude do aumento de entradas entre 1886 (33.486 imigrantes), 1887 (55.963) e 1888 (133.253).

${ }^{72}$ Calógeras (1998) salienta que os esforços da diplomacia brasileira para chegar a um acordo com a GrãBretanha, diante da pressão desta última pelo fim da escravidão, foram acompanhados de apresentação de projetos e de relatos de experiências de imigração. Já Soares (1984) narra a importância do Ministro José Maria Paranhos nas negociações relacionadas ao fim da escravidão em paralelo a sua atuação na atração de imigração italiana. Sobre o posicionamento do Parlamento ante o MRE quanto às negociações referentes à transição de mão-de-obra, Manzur (1999) traça histórico.
} 
colonização de novas áreas do território brasileiro em consolidação ${ }^{73}$, os quais por vezes se diferenciavam da imigração voluntária clássica por contarem com subsídios ou incentivos de terceiros. Por outro lado, o mapeamento das instituições referentes à política migratória englobará atos normativos regulando entradas e saídas, naturalizações, concessões de terras, critérios para reconhecimento de nacionalidade, reigstro e controle da permanência, inserção do estrangeiro no mercado de trabalho, exercício do direito de associação, dentre outros.

O estudo histórico da política migratória brasileira revela um importante aspecto desta área setorial de atuação governamental: as suas incipientes instituições e os jogos de interesses a elas subjacentes respondem por papel importante no state-building brasileiro, e estão simultaneamente atreladas ao nation-building do país. Em período de construção do Estado administrativo no Brasil, as competências para formulação e implementação da política migratória oscilaram entre diversos órgãos, e diferentes agentes do Executivo, Legislativo e da iniciativa privada tomaram parte neste desenrolar histórico, perseguindo fins, por vezes, cingidos por limitações de recursos administrativos, burocráticos e de orçamento; e que se relacionavam com distintos ou sucessivos projetos nacionais.

Tais projetos nacionais, definidos por objetivos alternativamente prioritários de ocupar o território, intervir na composição étnica da população, garantir o fornecimento de mão-de-obra para determinados setores econômicos e ampliar o mercado consumidor, não se desvencilharam da projeção internacional do país. Ao contrário, estiveram relacionados diretamente com o reconhecimento do Brasil como ator internacional. Se a inserção internacional do Brasil processava-se, até os fins do século XIX, através das potências europeias (VISENTINI, 2013), os diálogos e negociações concernentes a fluxos migratórios exerceram um papel importante nessa projeção, como se observa nas próximas seções. E se a política migratória atende a interesses tanto dos países de origem dos indivíduos quanto daqueles de destino, seus meandros são construídos por vias diplomáticas, fazendo de embaixadores, cônsules, adidos, chefes de delegação e de missão, atores potenciais de sua formulação e execução.

\footnotetext{
73 Sobre a relação entre os conceitos de "colonização" e de "imigração", os quais se entrelaçam no Brasil do século XIX, discurso do Senador Escragnolle de Taunay no Senado (1886) oferece uma interessante explicação, ao afirmar que a legislação estaria finalmente se orientando em favor do primeiro. Para Taunay (1886), "colonização" remete às relações coloniais estabelecidas pelas metrópoles europeias, e ao vínculo desigual nelas estabelecido; bem como às relações de trabalho servis observadas em glebas. Já imigração possibilitaria o desenvolvimento de novos vínculos, políticos e sociais, com o país de acolhida.
} 
Em estudo sobre o Itamaraty, Danese (1999) opina que o Estado brasileiro precederia o processo de construção nacional e nele teria grande protagonismo, tendo atuado precipuamente por meio de sua burocracia, em cujo quadro assumiria particular destaque o corpo diplomático. Isso porque, ao tratar-se de “importante 'sorvedouro' de nossa elite letrada oitocentista" (BELÉM LOPES, 2013, p.183), o Itamaraty era composto de membros da reduzida elite intelectual e política de uma nação que se construía, e em cuja construção buscava intervir. Isso se acentuaria, segundo Belém Lopes (2013), com a independência em 1822 e a autonomia identificada como interesse nacional primeiro, trazendo às elites o desafio da integração nacional.

Adicionalmente, a ocupação do território era uma questão de segurança nacional. Se a política externa dos fins do século XIX e início do XX envolveu intensas negociações sobre territórios, não deixou de pensar na nação que nele se acomodaria como consequência, inclusive, da definição clássica de Estado como território, povo e soberania.

Este capítulo se debruça, portanto, sobre este duplo aspecto da política migratória: de um lado, como afetou o Estado brasileiro ao envolver a construção de diferentes arranjos institucionais que compreendiam atores públicos e privados sediados dos dois lados do Atlântico; de outro, como engendrou regras e instrumentos que objetivavam balizar a construção nacional.

Os projetos social, nacional e político insculpidos nas sucessivas políticas migratórias brasileiras necessitavam da intervenção do Estado para ser levado a cabo, por meio da ação diuturna das diversas burocracias. Agentes de imigração, inspetores de polícia e de saúde dos portos, agentes recrutadores na Europa, cônsules e diplomatas, burocratas das diversas agências de imigração que se sucederam: trata-se de atores cujas atividades se relacionam com um corpus jurídico-administrativo que não apenas regula suas relações com demais agentes sociais, mas também reveste suas ações da legitimidade estatal (RAMOS, 2003). Em um quadro mais amplo, José Murilo de Carvalho (1982) aponta que os burocratas, os quais compunham boa parte da elite política brasileira, constituiriam importante fator explicativo sobre o state-building do país. Desta forma, focar no papel desses atores fornece um acurado panorama das disputas de poder sobre a temática migratória que tinham lugar no aparato estatal. 


\subsection{Definindo conceitos: Brasil, nacionalidade, cidadania (1889-1919)}

A arena institucional em que se desenrola a política migratória da República tem seus contornos gerais determinados nos anos que antecederam seu advento. De fato, se a história dos fluxos populacionais para Brasil remontam ao seu ingresso na história ocidental, as origens da regulação estatal sobre o tema provêm da vinda de D. João VI ao país ${ }^{74}$ - como, de resto, as raízes da estrutura administrativa do Estado brasileiro. Entre 1808 a 1889, o governo central e alguns governos de províncias ${ }^{75}$ articularam iniciativas incipientes de fomento à vinda de migrantes para colonização e povoamento do território, inclusive com financiamento do transporte para chegada ao Brasil, concessão régia de pequenas propriedades agrárias para formação de núcleos de povoamento $^{76}$, contratação de soldados e tropas estrangeiras sob promessa de distribuição de terras; e envio de agentes brasileiros para recrutar colonos no exterior.

A execução destas iniciativas oscilou historicamente de acordo com a prevalência de interesses distintos sobre o tema, a que corresponderam movimentos nos quais o protagonismo da política migratória esteve mais concentrado no governo central, inclusive por meio do exercício do poder de regulação; ou, alternativamente, esteve descentralizado entre governos provinciais e atores não-governamentais. Assim, por exemplo, a política baseada em núcleos de colonização subsidiados pelo Estado não era apoiada pelos grandes proprietários de terra, interessados em obter mão-de-obra para suas lavouras e não concorrência da produção de pequenas propriedades (PETRONE, 1982), motivo pelo qual passam a enviar agentes recrutadores à Europa de modo a estimular a contratação por parceria, na qual o imigrante comprometia-se a trabalhar

\footnotetext{
${ }^{74}$ A historiografia costuma apontar como marco a Carta Régia de 28 de janeiro de 1808 , abrindo os portos brasileiros ao comércio direto com navios estrangeiros e garantindo o direito aos súditos da Coroa Portuguesa e, igualmente, aos nacionais de outros Estados a exportarem produtos aos portos de seu interesse (SEYFERTH, 2008; IOTTI, 2010) - ressalte-se que este diploma representou "a primeira lei feita no Brasil para o Brasil" (VIANA FILHO, 1938, p.13). Outro marco histórico importante seria decreto imperial de 02 de dezembro de 1820 que determina a exigência de apresentação de passaporte ou documento equivalente no desembarque, para nacionais e estrangeiros, indicando procedência e destino. Desde então, afirma Biaggi (2014), a questão documental passou a ser instrumentalizada com objetivos políticos pelo Império, por meio do recrudescimento ou flexibilização do controle na emissão de passaporte de entrada no país - exercido por agentes da Secretaria Geral das Relações Exteriores.

${ }^{75} \mathrm{Com}$ a Lei $\mathrm{n}^{\circ} 16$, de 12 de agosto de 1834 , a qual reorganizava a estrutura político-administrativa do Estado brasileiro, conferiu-se maior autonomia às províncias. Particularmente, seu art. 11 , item $5^{\circ}$, ditava competir às assembleias legislativas provinciais, cumulativamente com o governo central, a promoção do estabelecimento de colônias.

${ }^{76}$ E.g: Carta Régia de 02 de maio de 1818 (IOTTI, 2010); decreto de 12 de julho de 1819 (Disponível em: http://www.brown.edu/Facilities/John_Carter_Brown_Library/exhibitions/CB/1819 docs/L10 p01.html Acesso em: 23 jul. 2015); Decisão no 80, de 31 de março de 1824 (BRASIL, Coleção de Decisões de 1824).
} 
para o fazendeiro até ressarci-lo por custos de transporte, alimentação e outros com que tivesse arcado.

A iniciativa privada também se fazia representar por companhias de navegação e por companhias de colonização privadas, as quais acumulavam funções de acolhida aos imigrantes, intermediação de sua contratação e de seu transporte, e contavam com subsídios públicos para suas atividades (CHRYSOSTOMO; VIDAL, 2014). Já no final do século XIX, hospedarias se consolidaram como atores responsáveis pela acolhida, normalmente também associando a iniciativa pública à privada. De um lado, o Estado não possuía uma estrutura administrativa com capilaridade que assegurasse a oferta do serviço em todo território. De outro, a imigração se mostrava um negócio lucrativo para companhias e indivíduos ligados à execução de serviços de recrutamento e transporte e à introdução do imigrante em território brasileiro ${ }^{77}$.

No alvorecer da República, embora não se tratasse do principal órgão responsável pela gestão da imigração (este seria o Ministério da Agricultura, Comércio e Obras Públicas, por meio de sua Inspetoria Geral de Terras e Colonização ${ }^{78}$; com participação do Ministério da Justiça, responsável pelas naturalizações e a quem estavam atreladas a Secretaria de Polícia da Corte e a das Províncias, às quais cabiam o serviço de controle dos estrangeiros ${ }^{79}$ ), a Secretaria de Estado dos Negócios Estrangeiros atuava através de suas legações e consulados na Europa, validando contratos de transporte e de trabalho e concedendo vistos, bem como estimulando a imigração por meio da busca de indivíduos que satisfizessem o perfil visado pela política em vigor $^{80}$. Tais competências haviam sido relevantes na construção organizacional da Secretaria ${ }^{81}$, em um esforço de adaptar seu arcabouço institucional a

\footnotetext{
${ }^{77}$ Sobre os agentes que fizeram da migração italiana para o Brasil sua atividade econômica em finais do século XIX, a tese de Paulo César Gonçalves (2008) traça um detalhista panorama.

${ }^{78}$ Fundada pelo decreto $\mathrm{n}^{\mathrm{o}} 6.129$, de 23 de fevereiro de 1876 e com competências definidas no decreto $\mathrm{n}^{\mathrm{o}}$ 603, de 26 de julho de 1890, quais sejam: a coordenação e fiscalização dos serviços atinentes à imigração e colonização (inclusive o registro e matrícula dos migrantes, realizado em suas delegacias; a organização de dados estatísticos sobre o tema; a manutenção de hospedarias e a produção de núcleos de colonização), e a promoção da imigração.

${ }^{79}$ Nos termos do regulamento $\mathrm{n}^{\circ} 120$, de 31 de janeiro de 1842 . Disponível em: http://www.planalto.gov.br/ccivil 03/Regulamentos/R120.htm. Acesso em: 16 mai 2016.

${ }^{80}$ O regimento consular de 1847 , promulgado através do decreto $\mathrm{n}^{\circ} 520$, de 11 de junho, estabeleceu ser dever dos cônsules "esmerar-se em indagar se no seu Distrito há pobres robustos, trabalhadores e diligentes no serviço de que se encarregam, e que estejam prontos a imigrar" (art.227).

81 Assim, ainda no Império, pleiteando pela reforma da organização, o secretário José Maria da Silva Paranhos, em seu relatório de 1859, asseverava: "O progresso natural de nossas relações comerciais, a posição política em que desde 1850 ficamos colocados no rio da Prata, os novos interesses e circunstâncias que resultaram da facilidade das comunicações, e do impulso dado à imigração estrangeira, patentearam de todo o vício radical daquela organização" (apud SOARES, 1984, p. 68).
} 
seus amplos objetivos. Estes, segundo Amado Cervo, compreendiam a questão migratória:

O pensamento diplomático brasileiro evidenciou três grandes objetivos externos durante o período monárquico, resultantes da leitura que se fazia do interesse nacional: o reconhecimento da soberania e a aceitação da autonomia decisória pelos outros governos, a conformação do comércio exterior e do fluxo de imigrantes às estruturas da sociedade e da economia, enfim, a convivência pacífica com os vizinhos mediante o traçado dos limites do território (2013, p.43).

Assim, já se iniciara no Império e se consolidou na República a prática de criar e suprimir consulados segundo interesses migratórios, normalmente vinculados a objetivos agroexportadores, porém não necessariamente ${ }^{82}$. Além disso, o tratamento conferido aos imigrantes no Brasil e suas repercussões internacionais geraram uma nova atribuição para o MRE: a atuação internacional em prol da imagem do país. Já em 1859, por exemplo, a Prússia promulgara o decreto de Heydt, proibindo a propaganda voltada à imigração para o Brasil devido aos maus-tratos sofridos por seus nacionais nas colônias - só tendo sido revogado em 1896 (LEVY, 1974).

No final do século XIX, a hegemonia da influência britânica no Brasil é quebrada com a gradual entrada de novos concorrentes no mercado brasileiro: americanos, alemães e franceses (MOURA, 2012, p.33). Essa ampliação abriu espaço para a pluralização de acordos comerciais, muitas vezes negociados por diplomatas em concomitância com acordos migratórios. É o caso, por exemplo, de Itália e Alemanha, e posteriormente, Japão.

Em uma estrutura administrativa incipiente, porém, as competências para gestão das migrações não eram temática pacífica, gerando discussões no Congresso e no próprio Executivo ${ }^{83}$. Em relatório dirigido ao Vice-Presidente do Brasil, Floriano Peixoto, o então Ministro das Relações Exteriores Innocencio Serzedello Corrêa

\footnotetext{
${ }^{82}$ Em 1895, por exemplo, o MRE requereu a supressão do Consulado em Tanger, Marrocos, sob alegação de que, depois de adquirirem a qualidade de cidadãos brasileiros em período de curta residência no país, marroquinos voltavam à terra natal e faziam uso da naturalização brasileira para colocar-se sob a proteção da autoridade consular brasileira (REL.EXT., 1896, p.66).

${ }^{83}$ Ainda no Império, em sessão do Senado para discussão de orçamento do Ministério da Agricultura, em 1886, a imigração e a colonização foram objeto central, tendo o discurso do senador Escragnolle de Taunay levantado a questão do imigrante como sendo crucial para o desenvolvimento da nação e salientado a importância do Senado tomar o protagonismo na confecção das leis para reger o tema, leis que, de fato, configurassem uma política de imigração, em contraponto a expedientes "corriqueiros" (TAUNAY, 1886, p.15). Os discursos da referida sessão mostram críticas à condução da política migratória pelo Ministério da Agricultura, suscitando sugestões de criar uma pasta específica para o tema ou de transferi-lo para a alçada do Ministério das Relações Exteriores.
} 
expressava sua concordância com a opinião que houvera sido expressa pelo VicePresidente em mensagem dirigida ao Congresso Nacional, qual fosse, "a conveniência de não ficar a cargo deste Ministério o serviço de imigração e colonização" (REL.EXT., 1892, p.24).

A República brasileira nasceu em um ambiente de instabilidade política, advinda da acomodação do Estado às novas regras do jogo político e aos novos atores que se consolidavam como hegemônicos: os proprietários de lavouras cafeeiras de Minas Gerais e, principalmente, São Paulo. Nesse contexto, tanto a política migratória quanto a política exterior foram afetadas pelos interesses do café, em particular; e da agroexportação, em geral. Sobre a estrutura do Secretaria das Relações Exteriores ${ }^{84}$, Amado Cervo coloca que:

\begin{abstract}
A República prosseguiu, ao estilo do Império, com pequenas reformas, porém sucessivas, visando adaptar sempre o Ministério às novas necessidades, que eram sobretudo a manutenção e a ampliação dos mercados para a economia agroexportadora (1992, p.6).
\end{abstract}

Em direção oposta à historiografia tradicional, que privilegia as questões de fronteira no estudo da política exterior do início da República (particularmente com ênfase na gestão de Rio Branco), Bueno (1995) ressalta que coexistiam junto a tais questões interesses relacionados à agroexportação e à imigração. Para o autor, a República representava uma acomodação do Estado às transformações sociais que fizeram com que fazendeiros de café emergissem como elite, e a diplomacia de agroexportação deste fato derivada teria englobado acordos de caráter migratório.

Assim, apreende-se da análise dos relatórios do MRE entre o fim do século XIX e início do XX que legações e consulados foram criados e extintos em função das necessidades de mercado para produção cafeeira. Essas modificações na estrutura da organização passavam por discussões no Poder Legislativo: por exemplo, Bueno (1995, p.311) retoma discussão em 1890 na Câmara e no Senado, por ocasião da apreciação do orçamento do Ministério das Relações Exteriores, sobre a supressão do consulado brasileiro em Trieste. Segundo o autor, enquanto alguns congressistas argumentavam que o consulado era deficitário, outros apontavam sua instrumentalidade para persecução dos interesses de comércio do café e da imigração de austríacos e poloneses.

\footnotetext{
${ }^{84}$ Com a República, a antiga Secretaria dos Negócios Estrangeiros passou a ser denominada Secretaria de Estado das Relações Exteriores, cuja organização foi determinada pelos decretos $n^{\circ} 291$, de 29 de março de 1890 , e n ${ }^{\circ} 1.120$ de 5 de dezembro de 1890 .
} 
Manzur (1999), por sua vez, se remete a congressos agrícolas promovidos pelo Parlamento a fim de consultar os fazendeiros sobre possibilidades de fluxos migratórios.

No que concerne à relação entre a lavoura de café e a política migratória, está vinculada à necessidade de arregimentação de mão-de-obra livre após a abolição do trabalho escravo, relacionando-se, outrossim, à expansão urbana e, progressivamente, ao desenvolvimento industrial que dos lucros do café decorreram. O braço trabalhador livre era, também, o mercado consumidor interno que se formava, como salienta Paula Beiguelman (1987). Do outro lado do Atlântico, operavam os push factors europeus: seus excedentes populacionais, consequência das revoluções agrícola e industrial e da expansão capitalista e consequente concorrência entre países por mercados (VAINER, 2000; SAKURAI, 2000), se dirigiram às Américas na busca de uma inserção no mercado de trabalho. Por último, a imigração como estratégia de implantação do trabalho livre perpetrado por europeus era considerada pela elite brasileira um “instrumento de civilização" (SEYFERTH, 2000, p.45): a naturalização assegurada pelo jus soli se coadunava com um ideal de nação formada por uma miscigenação seletiva, conduzida por brancos europeus. Esta estratégia estaria, segundo Feldman (2009), inserida em um ideal maior de europeização do Brasil, para o qual o MRE atuaria como articulador.

Assim, entre 1889 e 1919, o Brasil registrou a entrada de 2.636 .187 imigrantes (LEVY, 1973), sendo que a primeira década da República foi a que apresentou maior afluxo em toda a história do país (total de 1.198.327 estrangeiros). Tomando-se em conta a população de São Paulo, estado com maior presença de imigrantes ${ }^{85}$, sua proporção em relação à população total foi de $21 \%$ em 1900 (SALES e BAENINGER, 2000 , p. $34^{86}$ ). Em consequência, no período de 1881 a 1915 o Brasil ocupou o posto de terceiro país com maior afluxo de imigrantes, a frente de outros importantes Estados

\footnotetext{
${ }^{85}$ Em 1900, o Sudeste e o Sul do Brasil concentravam 97\% da população imigrante do Brasil, proporção que manteve-se em 94\% até a década de 1980 (SALES e BAENINGER, 2000).

86 "Os imigrantes, que chegavam em grupos numerosos, eram depois de desembarcados em Santos, imediatamente fechados e trancados nos vagões da companhia de estrada de ferro. O trem que os conduzia para São Paulo (e do qual tinham a oportunidade de admirar as belezas da Serra do Mar, como afirma um depoimento apologético da imigração subvencionada), depositava-os diretamente no pátio da Hospedaria dos Imigrantes, que pensadamente se localizava à margem dos trilhos da S.P.R., hoje Estrada de ferro Santos-Jundiaí. Durante sua estadia na capital, os imigrantes alojados na hospedaria não podiam afastar-se dela, e aí permaneciam como numa verdadeira prisão. Uma vez determinado o destino do imigrante, a fazenda para a qual fora destinado (assunto em que ele não era consultado) era novamente embarcado na própria estação da Hospedaria; e mais uma vez, sob estreita vigilância, transportado para a estação mais próxima daquela fazenda, onde já o aguardava o fazendeiro ou seu preposto para receber e tomar posse do novo trabalhador" (PRADO JÚNIOR, apud VAINER, 2000, p.18).
} 
imigrantistas como o Canadá e a Austrália (TAFT, 1955). Embora exercesse este papel no quadro das migrações internacional, o Brasil distava em muito dos números que afluíam para os Estados Unidos ${ }^{87}$ : este último recebeu, no período total, aproximadamente 21 milhões de imigrantes, enquanto o primeiro, cerca de 3 milhões. $\mathrm{O}$ destino preferencial dos europeus era, portanto, o norte da América, motivo pelo qual a política migratória do Brasil, interessado em atrair imigrantes, passava pelo desenvolvimento e institucionalização de instrumentos de incentivo, de modo a constituir pull factors eficazes.

Nesses termos, a República trouxe consigo uma naturalização geral, quase compulsória: o decreto 58-A, de 14 de dezembro de 1889, concedeu nacionalidade brasileira a todos os estrangeiros presentes no país quando da proclamação, bem como a todos aqueles que chegassem ao país no prazo de dois anos, devendo se manifestar em contrário os que não a desejassem em seis meses contados da publicação do decreto. Tal decreto foi complementado em 1890 por normas que revogaram a exigência de passaporte para entrada e permanência no território nacional em tempos de paz (Decreto $\mathrm{n}^{\mathrm{o}} 212$, de 22 de fevereiro de 1890); e que possibilitaram o alistamento eleitoral de estrangeiros alfabetizados, ainda que desconhessem a língua portuguesa (decisão $\mathrm{n}^{\circ} 38$, de 14 de março de 1890 e Decreto ${ }^{\circ}$ 227-E, de 22 de março de 1890).

Esta normativa definiu a prevalência, no Brasil, do princípio do jus soli sobre o jus sanguinis para definição de nacionalidade, como de praxe em outros países americanos de imigração, de modo a estimular a permanência de estrangeiros que a eles afluíam. Contrapunham-se aos países europeus que, interessados em manter vínculos com seus emigrantes e seus filhos, adotavam o jus sanguinis. Esta diferença gerou frequentes questionamentos diplomáticos, através dos quais os representantes do Ministério das Relações Exteriores definiram contornos da nacionalidade - e, por conseguinte, da nação - brasileira.

Em Relatório de 1893, o MRE observou ter recebido reclamações sobre a aplicação do decreto aos cidadãos da: França, Portugal, Itália, Espanha, Grã-Bretanha e Áustria-Hungria. O governo português afirmou que o decreto "restringe a liberdade individual, é contrário aos princípios geralmente adotados do direito internacional e prejudica os interesses dos estrangeiros residentes no Brasil” (REL.EXT., 1893, Anexo 1, p.4), e que, caso o Brasil não revisse a norma, a reconheceria como nula, em defesa

\footnotetext{
${ }^{87} \mathrm{O}$ segundo país com maior número de entradas de imigrantes era a Argentina.
} 
dos interesses de seus cidadãos. Os demais países citados ratificaram o memorando português, com justificativas semelhantes.

Esse período correspondia à gestão de Francesco Crispi no Ministério das Relações Exteriores da Itália (1887-1891), a qual foi marcada pela formulação e implementação pioneira de uma política migratória caracterizada por duas diretrizes: tutelar os italianos no exterior e mantê-los vinculados à pátria (CERVO, 1992, p.12). Para tanto, mostrava-se importante desenvolver iniciativas que atrelassem o italiano deslocado ao país de origem, como a comemoração de datas comemorativas e o incentivo à criação de escolas, hospitais, jornais, associações beneficentes italianas nos países receptores. Destas funções foram incumbidas as representações diplomáticas italianas no Brasil, às quais também se atribuía a responsabilidade de trabalhar para obstar as naturalizações.

A atenção de Crispi voltara-se para os fluxos emigratórios diante de seu vertiginoso aumento nas últimas décadas do século XIX, em uma Itália recém-unificada e com elevados excedentes populacionais. Constatando que não poderia diminuí-los, decidiu regulamentá-los, a fim de não apenas proteger os emigrados, mas fazer da emigração um instrumento de política exterior. A emigração tutelada favorecia, ainda, os cofres públicos, tanto por meio da cobrança de passagem, quanto como estratégia de comércio internacional visando ao aumento das exportações e às remessas de lucros dos emigrantes $^{88}$. Iotti (2001) traz trecho de discurso de Crispi ao apresentar e justificar o anteprojeto da lei de emigração à Câmara dos Deputados, em 15 de dezembro de 1887:

\footnotetext{
“[...] [o governo] não deve nunca perdê-los de vista a sua nova pátria, quer para tutelá-los eficazmente em caso de necessidade, e para manter firmes os vínculos que os ligam à antiga [pátria], como para encaminhar em vantagem desta os frutos do seu trabalho. As colônias devem ser como braços que o país estende longe de si sobre terras estranhas para trazê-las à órbita de suas relações de trabalho e troca; deve ser como um alargamento dos confins de sua ação e da sua potência econômica" (CRISPI, apud IOTTI, 2001, p.51).
}

Do lado do Brasil, há uma preocupação especial com as negociações com a Itália voltadas a "(...) fornecimento de imigrantes, tanto para acionar a economia cafeeira em expansão no oeste paulista quanto para o povoamento de outras áreas férteis e de baixa

\footnotetext{
88 “[...] a emigração, enquanto exportação de grande quantidade de mão-de-obra, contribuiu de modo decisivo para equilibrar a balança de pagamentos no período em questão. No decênio 1901-10, as entradas de remessas dos emigrantes na Itália sob a forma de vales internacionais e depósitos nas caixas econômicas postais, no Banco de Nápoles, no Banco da Sićlía e em outros institutos de crédito superaram os 300 milhões de liras em cada ano e chegaram a 500 milhões em 1907 e 1908" (CANDELORO, apud IOTTI, 2001, p.58).
} 
densidade demográfica; o mercado para seus produtos agrícolas, mormente o café" (CERVO, 1992, p. 40). Percebe-se nos relatórios do Ministério das Relações Exteriores frequentes prestações de contas, entre 1889 e 1918, sobre as relações mantidas com a Itália, focando-se nos dois eixos supracitados. De fato, entre 1877 e 1903 entraram no Brasil, segundo dados recolhidos por Levy $(1974)^{89}, 1.654 .830$ imigrantes, dos quais $60 \%$ italianos.

Ainda em 1890, o Decreto $\mathrm{n}^{\mathrm{o}} 528^{90}$, de 28 de junho, traçou o novo desenho institucional da política migratória da República. Regulamentou o serviço de introdução e localização de imigrantes a partir de incentivos como: financiamento da viagem pelo Governo Federal a indivíduos que preenchessem determinados requisitos ${ }^{91}$; subvenção às companhias de transporte marítimo; regulamentação dos direitos dos imigrantes em referência ao trabalho e à aquisição de lotes; incentivos aos proprietários rurais que recebessem família imigrantes. O decreto reconhece, em suma, uma política imigratória ativa fundamentada em subsídios públicos como instrumento de desenvolvimento nacional, como se verifica no excerto do preâmbulo:

\begin{abstract}
Considerando que da adopção de medidas adequadas e tendentes a demonstrar o empenho e as intenções do Governo, relativamente á immigração, depende o desenvolvimento da corrente immigratoria e a segura aplicação dos subsídios destinados áquelle serviço, ao qual se acha intimamente ligado o progresso da nação (Decreto nº 528/1890, preâmbulo).
\end{abstract}

O mesmo diploma estabelecia, em seu artigo $1^{\circ}$, ser livre a entrada de indivíduos válidos e aptos para o trabalho, desde que não processados criminalmente em seus países, excetuados os asiáticos e africanos, os quais só podiam ser admitidos mediante autorização do Congresso Nacional ${ }^{92}$. A República explicita seu objetivo branqueador, e

\footnotetext{
${ }^{89}$ O texto de Maria Stella Levy sobre o papel da migração internacional na evolução da população brasileira (1974) é uma referência na literatura sobre migrações no Brasil, com compilação de dados históricos utilizados amplamente pelos estudos que o sucederam.

${ }^{90}$ Disponível em: http://www2.camara.leg.br/legin/fed/decret/1824-1899/decreto-528-28-junho-1890506935-publicacaooriginal-1-pe.html. Acesso em: 02 set 2015.

91 Sendo eles: "1 ${ }^{\circ}$ As familias de agricultores, limitados aos respectivos chefes, ou aos seus ascendentes os individuos maiores de 50 annos; $2^{\circ}$ Os varões solteiros maiores de 18 annos e menores de 50 , uma vez que sejam trabalhadores agricolas; $3^{\circ}$ Os operarios de artes mecanicas ou industriaes, artezãos e os individuos que se destinarem ao serviço domestico, cujas idades se acharem comprehendidas entre os limites do paragrapho precedente. Os individuos enfermos ou com defeitos physicos, sómente terão passagem gratuita, si pertencerem a alguma familia que tenha pelo menos duas pessoas válidas" (Decreto $\mathrm{n}^{\circ} 528 / 1890$, art. $\left.5^{\circ}\right)$.

${ }^{92}$ Uma tal disposição equivalia a restringir a entrada aos imigrantes europeus, visto que os demais países americanos não eram, à época, emissores de imigrantes. Tal elemento está explícito no artigo 20 do mesmo diploma, estabelecendo que "todo proprietario territorial, que desejar collocar immigrantes europeus em sua propriedade, tem direito aos favores constantes deste decreto, desde que sejam preenchidas as condições aqui estipuladas".
} 
o Estado se arvora a gerenciar a formação nacional, segundo critérios eugenistas ${ }^{93}$. Ressalte-se que, de acordo com o artigo $2^{\circ}$, cabia aos agentes diplomáticos e consulares obstar "pelos meios a seu alcance a vinda dos immigrantes daquelles continentes", e à polícia dos portos da República impedir seu desembarque (art. $3^{\circ}$ ). Tratava-se, pois, de agentes implementadores da política migratória à época, inclusive em seu caráter repressivo. Aos agentes consulares cabia ainda a expedição de documento de identificação dos imigrantes que vinham sob contratos, remetendo-o para arquivamento na Inspetoria Geral das Terras e Colonização.

A Inspetoria estava subordinada ao Ministério da Agricultura, Comércio e Obras Públicas. De fato, o Decreto n 528 é de autoria de Francisco Glicério de Sousa Leite, então Ministro da Agricultura. Glicério, que houvera participado na linha de frente dos movimentos abolicionista e republicanista, assinala na sua exposição de motivos o desenvolvimento da imigração como "uma das mais palpitantes necessidades, a que convem attender, para fomentar a expansão das forças productoras da Republica”, para o quê se mostrava necessario reformular o serviço de introdução e localização dos imigrantes. Glicério foi responsável, também, pela redação do Decreto nº 603, de 26 de julho de 1890, reorganizando a Inspetoria Geral das Terras e Colonização ${ }^{94}$.

No entanto, alguns meses depois da publicação do Decreto $\mathrm{n}^{\circ} 528$, os altos gastos com imigração e colonização por ele engendrados levaram o Governo a publicar, em 20 de dezembro, o Decreto $n^{\circ} 1.187$, determinando que os contratos para introdução de migrantes e fundação de núcleos agrícolas só poderiam ser realizados com autorização expressa do Congresso Nacional. Formado predominantemente por membros da elite agroexportadora, é esperado que o Congresso tentasse exercer um papel protagonista no vultuoso modelo de política migratória que havia sido implantado.

A Constituição de 1891, primeira da República, conferia amplo reconhecimento de cidadania brasileira a estrangeiros, segundo estabelecido em seu artigo 69, sendo considerados cidadãos brasileiros: (i) os estrangeiros que, se achando no Brasil aos 15

\footnotetext{
${ }^{93}$ Em 1895, em resposta à contestação da França sobre a proibição de entrada dos sírios, o Ministro das Relações Exteriores explicara que o decreto 528 se aplicaria apenas ao serviço de imigração, ou seja, a imigração tutelada, não se estendendo ao ingresso daqueles que vêm para o Brasil por conta própria.

${ }^{94}$ Cabiam-lhe as competências de gerenciamento de questões de terra, inclusive aquelas atinentes às terras devolutas, e todos os serviços referentes à colonização e à imigração de competência do governo federal, dentre os quais: a fundação de núcleos coloniais; a organização de estatística concernente à imigração e aos núcleos; o registro de imigrantes, com seus dados pessoais; a intermediação dos contratos de transporte e de trabalho; a manutenção de hospedarias.
} 
de novembro de 1889, não declarassem, dentro de seis meses da entrada em vigor da Constituição, o ânimo de conservar a nacionalidade de origem; (ii) os estrangeiros que possuíssem bens imóveis no Brasil e fossem casados com brasileiros ou tivessem filhos brasileiros contanto que residissem no Brasil, salvo se manifestassem a intenção de não mudar de nacionalidade; (iii) os estrangeiros por outro modo naturalizados. Tratou-se, pois, de um segundo momento de naturalização quase compulsória. A Carta atribuía, ainda, ao Congresso a competência de "animar a imigração" (art. 35).

Ao corroborar a adoção do jus soli em seu texto constitucional, o Brasil suscitava novas manifestações em contrário dos países europeus. Um deles foi a França, que recorreu ao MRE (REL.EXT., 1895, p.45) para interceder a favor de cidadãos que julgava franceses por serem filhos de franceses. Em relatório de 1895, o Ministro Carlos Augusto de Carvalho apresenta sua resposta ao protesto francês, no qual discorre sobre "o conflito permanente entre a nacionalidade que deriva do jus sanguinis e do jus soli" (REL.EXT., 1895, p.45) e remete-se a teóricos do direito internacional, reconhecendo que "a influência da nacionalidade, quando contrariada, determina conflitos de legislação que constituem árduas questões práticas de direito", em razão de quê "são frequentes os atritos entre as autoridades judiciárias e os agentes consulares" (REL.EXT., 1895, p.47). Após arrazoar seus argumentos, conclui o governo brasileiro nada poder fazer em resposta ao pedido francês, posto contrariar o art. 69 da Constituição, consagrando destarte o jus soli como princípio definidor da nacionalidade brasileira.

Paralelamente, a Lei $\mathrm{n}^{\circ} 23$, de 30 de outubro de 1891, reorganizara a Administração Federal, suprimindo o Ministério da Agricultura e criando o Ministério da Indústria, Viação e Obras Públicas, sem contudo conferir a este último qualquer competência em temática migratória, nem prever alocação para a Inspetoria Geral das Terras e Colonização. Ademais, reformulou a Secretaria das Relações Exteriores, que passava a ser denominada Ministério das Relações Exteriores e a deter as seguintes competências (art. $7^{\circ}$ ): “ a) o expediente e despacho dos negocios e serviços incumbidos ao actual Ministerio do Exterior; b) a colonização; c) o serviço dos nucleios coloniaes. Paragrapho unico. Crear-se-ha na secretaria deste Ministerio uma secção que terá a seu cargo o serviço indicado no artigo antecedente, lettras b e c".

Esse dispositivo inovou na organização das competências em temática imigratória, visto que não as conferia a qualquer outro órgão além do MRE. Não 
obstante, a lei orçamentária referente ao exercício de 1893, que colocou em prática a reorganização administrativa, passou a prover o Ministério da Indústria com verbas referentes os serviços de colonização (Lei 126-b, de 1892, art. $6^{\circ}$, item $3^{95}$ ), sem contudo ampliar o orçamento do MRE para englobar as atividades como previstas na Lei $\mathrm{n}^{\circ}$ 23/1891. A despeito da concentração de competências migratórias neste órgão não se ter efetivado, a promulgação da Lei $n^{\circ} 23$ denota a importância que o Ministério possuía, à época, como ator na política migratória. Uma das razões para tanto parece ser seu papel central em uma questão para a qual as atenções do Executivo e do Legislativo se voltaram no período: a celebração de tratados de amizade, com cláusulas migratórias, com o Japão e a China.

Dois anos após o Decreto $n^{\circ} 528$ supracitado, a Lei $n^{\circ}$ 97, de 15 de outubro de $1892^{96}$, passou a permitir livre entrada de imigrantes de nacionalidade japonesa e chinesa aptos ao trabalho (exceto indigentes, mendigos, piratas ou sujeitos a ação criminal em seus países). A lei autorizou o governo a promover a execução do tratado celebrado com a China em 05 de setembro de 1880 (em Relatório de 1893, a Secretaria das Relações Exteriores sublinha que o tratado citado na lei houvera sido substituído por outro, de 03 de outubro de $1881^{97}$, e apenas este último seria válido); a celebrar tratado de comércio, paz e amizade com o Japão; e a estabelecer agentes diplomáticos e consulares nesses países, especialmente encarregados de fiscalizar a imigração para o Brasil.

Ressalte-se que a lei ${ }^{\circ} 97$ foi promulgada após negociações do MRE: (i) com a China, lastreadas em tratado de amizade que permitiu a instalação de serviço de fiscalização a ser conduzido pelos cônsules; (ii) com o Japão, que se mostrara aberto a receber uma missão especialmente destinada a negociar um tratado de amizade, porém havia colocado termos dos quais discordara o MRE, sob argumento de não estar sendo tratado em igualdade de condições com outros países (REL.EXT., 1893, p.37). Tal dissídio estava relacionado ao princípio territorial da jurisdição, que o Japão queria

\footnotetext{
95 Disponível em: http://www2.camara.leg.br/legin/fed/lei/1824-1899/lei-126-b-21-novembro-1892541382-publicacaooriginal-44950-pl.html. Acesso em: 25 abr 2016.

${ }^{96}$ Disponível em: http://www2.camara.leg.br/legin/fed/lei/1824-1899/lei-97-5-outubro-1892-541345publicacaooriginal-44841-pl.html. Acesso em: 25 abr 2016.

97 Redação do tratado de 03 de outubro de 1881, art.1 ${ }^{\circ}$ : "Haverá paz perpétua e amizade constante entre o Império do Brasil e o Império da China, bem como entre os seus respectivos súditos. Estes poderão ir livremente de um para o outro Estado das duas Altas Partes contratantes e aí residir. Em cada um dos dois países obterão plena e inteira proteção para suas pessoas, famílias e bens, e gozarão de todos os direitos, vantagens e franquezas concedidos aos súditos da nação mais favorecida” (REL.EXT., 1893, p.34).
} 
afirmar em relação ao Brasil porém não havia, ainda, conveniado com as potências europeias.

De modo a possibilitar a execução da lei $\mathrm{n}^{\circ}$ 97, uma missão especial foi enviada à China, em 1893. Floriano Peixoto encarregara, como chefe extraordinário da missão ${ }^{98}$, o Almirante Costa Azevedo, o qual se manifestou, em troca de correspondências com o presidente, contrário à imigração proveniente daquele país, e a favor daquela de origem japonesa (BUENO, 1992; CARNEIRO, 2003). Não foi a única opinião contrária: o dispêndio financeiro oriundo das frequentes alocações orçamentárias suplementares para o MRE que se fizeram necessárias para manutenção da missão (apud Relatórios de 1894 e 1895) tornou o tema da imigração de chineses e japoneses, bem como da instalação de legações e consulados nesses países, controverso em sede do Executivo e do Legislativo.

A situação foi agravada quando, segundo relato do MRE (REL.EXT., 1894, p.28), a Companhia Metropolitana do Rio de Janeiro contratou, autonomamente, 475 trabalhadores chineses e embarcou-os ao Brasil, contra o quê protestou a legação chinesa em Paris, pedindo o reenvio daqueles indivíduos à China. O MRE explicou sua recusa ao pedido chinês sob pretexto de que o contrato de imigrantes havia se dado legalmente e com aviso das autoridades chinesas, e que a repatriação de indivíduos já estabelecidos seria ato impraticável. A isso se seguiu a ordem de proibição, por parte do governo da China, de que navios de quaisquer nacionalidades transportassem emigrantes chineses ao Brasil. Embora o então Ministro das Relações Exteriores, Alexandro Cassiano do Nascimento, não tenha julgado que tal incidente comprometesse a negociação de um acordo migratório com a China (REL.EXT. 1894, p.33), ele somouse a uma série de circunstâncias que malograram a missão especial do Brasil neste país, dentre as quais o falecimento de um de seus chefes e o retorno do outro ao Brasil para assumir como Senador, além da eclosão de guerra entre a China e o Japão.

Nesse contexto, a missão à China foi cancelada, e o presidente brasileiro Prudente de Morais passou a expressar preferência pela opção japonesa, segundo narra o Ministro das Relações Exteriores Carlos Augusto de Carvalho (REL.EXT., 1895, p.43). Bueno (1995) colaciona mensagem de Prudente de Morais, de 03 de maio de 1895, na qual explicara ao Congresso Nacional o redirecionamento dos esforços de

\footnotetext{
${ }^{98}$ Em conjunto com o ministro José Gurgel do Amaral Valente, o qual se dirigia à Pequim para quedar-se em missão ordinária.
} 
negociação de tratados de imigração dos chineses para os japoneses. O autor menciona, ainda, ter o Congresso Nacional questionado detalhadamente o Executivo sobre o término da missão na China, denotando a atenção conferida pela Casa Legislativa à questão migratória e, particularmente, a como o MRE estaria conduzindo a persecução dos interesses nacionais sobre o tema.

A preferência pelo Japão foi consolidada, então, no seio do MRE que, após os dissídios de 1892, passou a insistir junto ao governo japonês a fim de que se realizassem negociações sobre a temática migratória (REL.EXT., 1895, p. 44). Essa nova fase das relações Brasil-Japão viria a coincidir com a vigência da Lei de Proteção aos Emigrantes, de 1896, a qual convalidava as características da política emigratória verificada no período Meiji (1868-1912): uma política de intervenção na pressão populacional que combinava o controle dos movimentos dos indivíduos para o exterior com esforços de manutenção de fortes vínculos com seus nacionais (LEÃO NETO, 1989; SAKURAI, 2000).

O Tratado de Amizade, Comércio e Navegação entre as duas nações foi assinado em 05 de novembro de 1895 (REL.EXT., 1896, p.67), em Paris, pelos plenipotenciários das duas nações envolvidas - posto que não contavam com legações nos territórios do parceiro. Embora não se refira expressamente à migração, o tratado cria as condições jurídicas para fomentá-la, tendo o Ministro Carlos de Carvalho se apoiado no fato de que o governo japonês, interessado em escoar seu excedente populacional, não criaria dificuldades para a saída de seus nacionais (REL.EXT., 1896, Anexo 1, p.187). O tratado foi incorporado à legislação brasileira após controversos debates nas duas Casas Legislativas (BUENO, 1995, p. 316-317) ${ }^{99}$, pela Lei n ${ }^{\circ}$ 419, de 27 de novembro de 1896 e mandado executar pelo Decreto n ${ }^{\circ} 2.489$, de 31 de março de 1897. Na mesma época, o Brasil instalou consulados gerais em Yokohama e Kobe (REL.EXT., 1897, p. 34). Não obstante, decidiu-se na Casa Legislativa não implementar a Legação e suprimir alguns Consulados brasileiros no Japão, contra o quê protestou o diplomata Ribeiro Lisboa,

\footnotetext{
${ }^{99}$ Clodoaldo Bueno (1995) narra algumas das intervenções que ocorreram no Congresso Nacional, dentre as quais, por exemplo, a do senador Quintino Bocaiúva (Rio de Janeiro) defendendo o tratado por entender que a corrente migratória incentivaria o aprofundamento das relações comerciais entre os dois países; e a do senador Coelho Rodrigues (Piauí), que se opunha a qualquer imigração subsidiada por entender que "não temos o direito de cobrar impostos do brasileiro, pobre ou rico, para mandar buscar proletário estrangeiro à custa deste país, os quais enquanto não estão estabelecidos tornam-se pensionistas do tesouro, sustentados à custa da Nação, do pobre e do rico, e depois de estabelecidos são concorrentes invencíveis com que os brasileiros têm de lutar pela vida e em condições de inferioridade, porque aqueles estão armados à custa deles mesmos" (apud BUENO, 1995, p.319).
} 
representante do Brasil no país, que argumentava estar ali em crescimento o interesse sobre emigração ao Brasil (REL.EXT., 1899, p.25.

Conquanto o cenário jurídico diplomático houvesse sido montado, iniciativas concretas de trazer imigrantes japoneses ao Brasil não vingaram à época. $\mathrm{O}$ mesmo Ministro Ribeiro Lisboa (REL.EXT., 1898, p.27) fornecia como possível explicação para o insucesso o que ouvira de um dos agentes da Companhia Japonesa de Emigração, e que houvera sido divulgado na mídia local: a emigração japonesa ao Brasil não seria vantajosa dado o alto preço das passagens comparado, por um lado, com o custo do transporte ao Brasil do emigrante europeu, e por outro, com o do emigrante japonês destinado ao México, Peru e Repúblicas da América Central.

Em 1900, a temática do envio de legação e da manutenção de consulados no Japão seguia controversa, como mostram os debates ocorridos quando da apreciação do orçamento do Ministério das Relações Exteriores no Congresso reforçados pelo pedido do Ministro Japonês no Brasil de que uma legação fosse providenciada (BUENO, 1995). A apreciação dos orçamentos dos Ministérios se consolidava, aliás, como arena principal de controle do legislativo sobre a política migratória, exercendo desta forma influência direta sobre seus rumos.

O início do fluxo de japoneses não diminuiu o interesse em braços europeus. Em 1895, o MRE iniciou negociações com a Alemanha com vistas à elaboração de convenção consular com mútuo alargamento de competências de maneira a remover os obstáculos à imigração alemã, obstada, segundo Relatório do MRE, pelo fato de que "aos alemães repugna a condição de assalariados, preferem a autonomia da pequena propriedade rural” (REL.EXT., 1895, p.48).

Quanto à Itália, o fluxo populacional mais significativo no início do século XX, foi alvo de intensa propaganda do Estado brasileiro, enaltecendo as qualidades do país visando a não apenas atrair imigrantes, mas também recompor a imagem do Brasil, combalida após relatos de más condições de trabalho e não cumprimento das promessas realizadas pelos agentes de imigração. No entanto, as negociações entre os dois países sobre migrações foram atreladas às concernentes a um acordo comercial, ambas atribuladas e constantemente postergadas, o que gerou a necessidade de que acordos e tomadas de decisão fossem realizados, principalmente, em casos específicos. Sobre o assunto, analisou Cervo: 
Em suma, a conclusão de atos bilaterais, entre 1861 e 1918, tendo em vista conduzir a contento as matérias de interesse de ambos os povos esteve abaixo das efetivas necessidades. Além do tardio Acordo Comercial de 1900, um tanto precário, como se verá mais a frente, a grande lacuna dizia respeito aos assuntos da imigração italiana, que ficaram abandonados aos improvisos de parte a parte, em detrimento de um milhão de pessoas, cuja proteção não foi acordada em momento algum (1992, p.50)

Nesse sentido, em nota enviada pelo Enviado Extraordinário e Ministro Plenipotenciário italiano, Conde Antonelli, ao Ministro das Relações Exteriores brasileiro, no quadro de negociações sobre um acordo comercial entre 1899 e 1900, o primeiro explicava:

\begin{abstract}
A Itália vê com prazer que numerosa população italiana vem ao Brasil para contribuir no desenvolvimento econômico desta grande e vasta República e será certamente o objeto de todos os cuidados do Governo do Rei, se for ajudado pelo da República, evitar este doloroso contrassenso de uma livre entrada de população Italiana e de uma clausura para seus produtos em um país em que os nossos vínculos de amizade se prendem a outros de ordem superior aos de uma troca das nossas recíprocas tarifas comerciais (REL. EXT., 1900, Anexo 1, p.212).
\end{abstract}

Vários foram os dissídios observados entre as duas nações, as quais, não obstante coincidissem nos interesses, de um lado, de escoar seus excedentes populacionais e, de outro, de receber fluxos migratórios; tinham objetivos conflitantes referentes aos indivíduos que se deslocavam: à Itália interessava tutelá-los proximamente e manter, ao máximo, seus vínculos com o Estado de origem; ao Brasil interessava que se integrassem à sociedade de modo a se tornarem cidadãos brasileiros.

Nesse sentido, por exemplo, ainda no ano de 1896, a representação italiana no Rio de Janeiro requerera autorização para que os consulados italianos realizassem o registro civil dos súditos residentes no Brasil. Em resposta, o governo brasileiro comunicou que os consulados eram livres para fazê-lo, mas que tais registros não seriam válidos no Brasil, em virtude do princípio da territorialidade dos atos (REL.EXT., 1896, Anexo 1, p.170). Sobre o tema, cabe novamente a análise de Cervo:

Nesse momento, pairavam sobre as atitudes e as decisões as questões de fundo, que no caso das relações entre o Brasil e a Itália resumiam-se em dois contenciosos: o jurídico, acerca dos direitos de cidadania e consequente forma de encaminhar a proteção dos interesses dos italianos, e o de soberania, relativo ao exercício do poder sobre estrangeiros residentes no Brasil, naturalizados ou não. O choque tinha sua síntese na questão das reclamações italianas e dos pedidos de indenização (1992, p.35). 
Soberania, cidadania e nacionalidade não são conceitos dados ou autoexplicativos: ao contrário, foram construídos paulatina e dialeticamente em relação ao ordenamento jurídico nacional e às relações internacionais do país ${ }^{100}$. Particularmente sobre o conceito de soberania, Feldman (2009) descreve o papel do Itamaraty na sua construção no século XIX e início do XX, por meio da presença, na reflexão em política externa e no discurso diplomático, da antítese entre o particular (soberania estatal) e o universal (ordenamento jurídico internacional) e do debate sobre quem deveria predominar sobre o outro. As imigrações constituíram o caso empírico que instou a reflexão transversal sobre os três conceitos, exigindo definições sobre quem determinaria direitos, quais direitos seriam atribuídos e a quem se lhes confeririam.

Por conseguinte, a negociação de tratados e acordos que se referiam à temática migratória regulamentavam, bilateralmente, questões mais amplas de direito internacional, como por exemplo, competência jurisdicional para dissídios entre nacionais de diferentes Estados ou concernentes a seus bens, questões atinentes a arrecadação de heranças e a alistamento militar. Como exemplos, podem se citar as negociações dos tratados de amizade com a China (1891) e com o Japão (1895) (REL.EXT., 1894, 1895); os protestos das legações francesa e italiana contra a disposição sobre naturalização da Constituição de 1891 e as respectivas respostas do MRE (REL.EXT., 1895); o debate quanto às consequências da naturalização para o alistamento militar no país de nascimento suscitado por Portugal, que gerou uma orientação do MRE para seus consulados afirmando que as naturalizações não anulavam as obrigações antes delas contraídas (REL.EXT., 1898, Anexo 1, p. 97); e a troca de notas ocorrida entre o Ministério das Relações Exteriores brasileiro e a legação italiana no ano de 1895 , em que esta última requeria ao primeiro solução para noventa casos, relativos a quase trezentos e cinquenta reclamações de particulares (REL.EXT., 1896, p.104-162), englobando questões de arrecadação de heranças, indenizações, conflitos com a Inspetoria de Terras e Colonização, dentre outros.

\footnotetext{
${ }^{100}$ Sobre o direito internacional privado, Viana Filho expunha, em 1938, que entre as diferentes correntes que buscavam explicar seu desenvolvimento, uma colocava que, "acompanhando a própria evolução das relações internacionais, alargou o seu campo de ação, cuidando especialmente da condição jurídica dos estrangeiros, que passou a preocupar de tal modo alguns internacionalistas, como Pillet e Niboyet, na França, Zittelman, na Alemanha, e Rodrigo Otávio, no Brasil, que muitos viram nesse aspecto do direito internacional privado seu objetivo único. No Brasil esta opinião foi sustentada por Gomes de Castro, que chegou mesmo a definir o direito internacional privado como o conjunto de regras e princípios que definem e regulam a situação jurídica do estrangeiro" (1938, p.2).
} 
A definição de quem seria considerado nacional brasileiro era construída a partir de questionamentos suscitados pelos cônsules e discutidos em pareceres do MRE. Em relatório correspondente aos anos de 1918 e 1919, por exemplo, o órgão dá parecer sobre questionamento que vinha sendo levantado por diferentes cônsules, sobre a possibilidade de conceder nacionalidade a esposa de brasileiro: “(...) a estrangeira que, pelo casamento com brasileiro, perde a nacionalidade de origem, deve ser considerada, enquanto existir o vínculo matrimonial, seguindo a nacionalidade do marido, isto é, temporariamente brasileira" (REL.EXT.,1921, p.27).

No início da República, a política exterior brasileira buscou seu objetivo de inserção internacional a partir da participação intensa em fóruns multilaterais (e.g., LIMA, 2005; CERVO, 2005). No que atine à questão migratória, ressalte-se sua participação entre 1889 e 1890 na Conferência dos Estados Independentes da América em Washington, a qual aprovou a seguinte resolução sobre direitos dos estrangeiros:

" 1 o- Os estrangeiros gozam de todos os direitos civis de que gozam os nacionais; e podem fazer uso delles tanto na materia como na fórma, ou processo e nos recursos que tenham logar absolutamente nos mesmos termos que os ditos nacionais.

$2^{\circ}$ - A Nação não tem nem reconhece a favor dos estrangeiros outras obrigações ou responsabilidades além das estabelecidas em igual caso a favor dos nacionaes pela Constituição e as leis." Votaram afirmativamente: Nicarágua, Peru, Guatemala, Colômbia, Argentina, Costa Rica, Paraguai, Brasil, Honduras, México, Bolívia, Venezuela, Chile, Salvador e Equador. Os Estados Unidos votaram negativamente (REL. EXT., 1891, p.25).

As Conferências Internacionais Americanas ${ }^{101}$ representaram importante instância multilateral do período, como se apreende dos relatórios do Ministério das Relações Exteriores. Formadas por países que consolidavam suas fronteiras e sua atuação internacional, as Conferências destrincharam diversas questões jurídicas no intuito de embasar a cooperação interamericana. Esta primeira iniciativa institucionalizada dos objetivos de integração do continente ${ }^{102}$ teve influência da doutrina Monroe e dos objetivos de política externa estadounidense (RICUPERO, 2013; DULCI, 2008), porém também representava a aproximação das novas instituições

101 I Conferência Internacional Americana (1889-1890, Washington); II Conferência Internacional Americana (1901, Cidade do México); III Conferência Internacional Americana (1906, Rio de Janeiro); IV Conferência Internacional Americana (Buenos Aires, 1910); V Conferência Internacional Americana (1923, Santiago do Chile); VI Conferência Internacional Americana (1928, Havana); VII Conferência Internacional Americana (1933, Montevidéu); VIII Conferência Internacional Americana (1938, Lima); IX Conferência Internacional Americana (1948, Bogotá - quando houve a formação da Organização de Estados Americanos).

${ }^{102}$ E que está nas raízes do sistema interamericano consolidado na Organização de Estados Americanos, criada na sua última Conferência Internacional (1948). 
republicanas da região (BUENO, 1995). Dentre os debates que as perpassaram, encontra-se o regime jurídico a ser aplicado ao imigrante.

Assim, o programa da $2^{\text {a }}$ Conferência continha a elaboração de projeto de declaração dos direitos de estrangeiros (DULCI, 2008), tendo aprovado uma "Convenção sobre o direito dos estrangeiros sobre reclamações por perdas e danos pecuniários"; e tendo modificado o aprovado no art. $1^{\circ}$ da Conferência anterior, acrescentando-lhe "salvo o disposto pela Constituição de cada país" (VIANA FILHO, 1938, p.80). Fortaleceu-se, assim, o princípio da soberania no incipiente direito internacional privado americano.

Já na $3^{\text {a }}$ Conferência Americana, realizada no Rio de Janeiro em 1906, assinouse, dentre outros atos, a Convenção sobre Naturalização (13 de agosto de 1906) ${ }^{103}$, fixando a condição dos cidadãos naturalizados que renovam sua residência no país de origem (REL.EXT., 1913, p.47). Rio Branco (o qual, antes de Ministro das Relações Exteriores, havia trabalhado junto aos serviços brasileiros de imigração em Paris), ao abrir a Conferência, apontou que a importância do Velho Mundo para o Brasil se traduziria no fornecimento de imigrantes e capitais (apud BUENO, 1995). Na ocasião, decidiu-se que nos códigos a serem elaborados pela Comissão de Jurisconsultos ali criada fossem incluídas as matérias referentes aos direitos e obrigações dos estrangeiros. Assim, nos anos seguintes, representantes dos países americanos discutiram propostas referentes a uma regulação regional do tema (VIANA FILHO, 1938).

Para a $4^{\circ}$ Conferência, a delegação argentina apresentou a proposta de discussão do seguinte princípio de política pan-americana: "os estrangeiros não gozarão de mais direitos civis, nem outros recursos ou privilégios, além dos assegurados pela Constituição e pelas leis de cada país aos seus respectivos nacionais" (REL.EXT., 1914, p.86). Embora não tenha sido aprovada, a Conferência tratou em profundidade de outro assunto que tocaria a temática migratória: o intercâmbio de estudantes e professores universitários no continente, cuja resolução foi internalizada no ordenamento brasileiro pelo Decreto $\mathrm{n}^{\mathrm{o}}$ 12.989/1918 ${ }^{104}$.

Ressalte-se que as primeiras décadas da República consolidaram arranjos institucionais mistos, descentralizados entre governo brasileiro e entes federativos, bem

\footnotetext{
${ }^{103}$ A Convenção foi submetida ao Congresso Nacional e sancionada pelo Decreto $n^{\circ} 2.115$, de 08 de outubro de 1909, e promulgada pelo Decreto ${ }^{\circ}$ 9.193, de 06 de dezembro de 1911.

${ }_{104}$ Disponível em: http://www.camara.gov.br/legin/fed/decret/1910-1919/decreto-12989-24-abril-1918776255-publicacaooriginal-140133-pe.html. Acesso em 03 mai 2016.
} 
como entre atores públicos e privados. A Constituição de 1891 adotou o regime federativo e, em seu artigo 64, transferira para os estados o domínio das terras devolutas, nas quais alguns núcleos de colonização estavam situados. Por sua vez, a Lei 126-B, de 21 de novembro de $1892^{105}$, ao dispor sobre as condições para o financiamento federal à iniciativa privada para o serviço de estabelecimento de colônias, ditava que os estados deveriam requerer o número de imigrantes desejados e financiar um vigésimo de sua passagem, cabendo à União quitar o restante.

Assim, o governo de São Paulo foi assumindo protagonismo na contratação direta de imigrantes, como por exemplo estabelecido na Lei estadual $n^{\circ} 194$, de 28 de agosto de $1893^{106}$, autorizando "o Governo a contractar, mediante concorrencia publica, a introducção de 50.000 immigrantes em familias, exclusivamente destinados aos serviços da lavoura”. Leão Neto aponta que, "nos quinze primeiros anos da República, uma comparação entre o dispêndio realizado pela União e pelo Estado de São Paulo com a subvenção da imigração revela por vezes cifras surpreendentemente próximas e, em alguns anos, valores mais elevados do lado paulista" (1989, p.14).

Paralelamente, a lei orçamentária para o exercício de 1897 (Lei n ${ }^{\circ}$ 429, de 10 de dezembro de 1896) suprimiu os gastos de manutenção da Inspetoria Geral de Terras e Colonização, diluindo suas competências, inclusive a gestão de hospedarias, no quadro Ministério da Indústria. A descentralização da gestão pelos estados foi, então, reforçada, junto ao fomento a parcerias com companhias privadas de gerenciamento das funções de acolhimento do imigrante e seu direcionamento ao mercado de trabalho.

Estes arranjos que continham parcerias e diálogos constantes entre o setor público e companhias privadas geravam, por vezes, conflitos entre os dois polos. Quando os atores privados de tais conflitos eram de origem estrangeira, o MRE era chamado a intermediar o conflito junto à respectiva legação: foi o que ocorreu, por exemplo, com o caso General Franzini e Ministério da Agricultura (1872-1894) relativo a contrato para introdução de imigrantes (REL.EXT., 1895).

Ressalte-se que este movimento de descentralização fez parte de um contexto geral de estruturação do federalismo dos primeiros anos da República, caracterizado por uma baixa institucionalização dos mecanismos de governo. Como maturação do arranjo

\footnotetext{
${ }^{105}$ Disponível em: http://www.planalto.gov.br/ccivil_03/leis/1851-1900/L126-B.htm. Acesso em: 03 set 2015.

${ }^{106}$ Disponível em: http://www.al.sp.gov.br/repositorio/legislacao/lei/1893/lei-194-28.08.1893.html. Acesso em: 25 abr 2016.
} 
institucional e influenciado pelo primeira crise de superprodução do café em 1901, o presidente Campos Sales (1898-1902) buscou empreender uma "obra administrativa" com tendências centrípetas (LESSA, 1988). Analisando o processo que resultou na intervenção federal nos preços do café, Elisa Pereira Reis (apud RAMOS, 2003) mostra que a expansão da capacidade infra-estrutural do Estado durante a Primeira República permitiu a recentralização do poder Público no período.

Os efeitos da crise do café se estenderiam nos anos seguintes. Com a redução dos postos de trabalho, a baixa dos salários e a hesitação do governo brasileiro em adotar medidas de proteção ao trabalhador, o ministro italiano dos Negócios Estrangeiros, Giulio Prinetti convocou o ministro brasileiro, Olinto de Magalhães, a Roma, para apresentar como exigências ao Brasil o pagamento dos salários atrasados e uma lei salarial que garantisse direitos aos trabalhadores - caso contrário, proibiria a emigração para o país (CERVO, 1992, p.69). Como Magalhães exigisse, em contrapartida, a denúncia do Acordo de Comércio, as negociações truncaram, e Prinetti não viu suas demandas atendidas até o ano seguinte, quando o Comissariado Geral de Imigração na Itália baixou em 1902 o Decreto Prinetti, proibindo, de fato, a emigração subsidiada para o Brasil. O ato não foi sem consequências: se a média anual de entrada de italianos é de 58.000 entre 1887 e 1903, entre 1904 e 1914 reduz-se a 19.000 (LEVY, 1974).

A retomada de confiança na lavoura de café, consubstanciada no Convênio de Taubaté de 1906, ressaltou a urgência de reativar a imigração. O Japão também reforçou, à época, seu interesse no envio de emigrantes para o Brasil: data de 1905 mensagem da legação japonesa ao MRE que afirmava "Dêem-nos os Senhores terras e nós lhes daremos colonos" (apud LEÃO NETO, 1998, p. 24). As negociações que se seguiram contaram com forte participação da Companhia Imperial de Emigração japonesa, do governo do Estado de São Paulo e do Ministério de Agricultura, com subsidío sobretudo do governo estadual. Não havia, entre os brasileiros, consenso, com as opiniões contrárias fortemente ancoradas na apreciação do imigrante japonês como indesejável, tal como verificado na mensagem de Luiz Guimarães, em 1906, então Encarregado de Negócios do Brasil em Tóquio, aos Ministros das Relações Exteriores, Rio Branco, e da Indústria, Viação e Obras, Miguel Calmon: 
impor os seus. Além disso é um colono que incomoda os Governos com queixas de todos os dias, podendo dar origem a reclamações e atritos desagradáveis, porque o Japão de hoje é um país ao qual é preciso dar-se contas desde que ele as reclame (apud LEÃO VAZ, 1989, p. 25).

Percebe-se no seu discurso a indesejabilidade do imigrante japonês apresentada com base em argumentos políticos de ordem interna, relacionados a diferenças culturais e dificuldades de assimilação, e de ordem externa, concernente a potenciais atritos diplomáticos oriundos de reivindicações dos imigrantes.

Não obstante tais divergências, diante das proibições de emigração para o Brasil que eram impostas sucessivamente por países europeus e com a diminuição do fluxo dessa região agravada com a eclosão da I Guerra, o Governo paulista reforçou seu interesse na mão-de-obra japonesa, e a lei orçamentária referente ao exercício de 1907 (Lei 1.617, de 1906) autorizou o presidente a subvencionar a companhia de navegação que estabelecesse carreira regular entre o Brasil e o Japão, com o intuito de desenvolver as relações comerciais entre os dois países e o transporte de imigrantes.

De fato, em 1910, foi a vez da Espanha proibir a emigração gratuita para o Brasil, por decreto de 20 de agosto de 1910, após entendimento do Conselho Superior de Emigração segundo o qual seriam lastimáveis as condições de vida dos emigrantes espanhóis, expostos a graves doenças, inadimplência contratual e exploração laboral por parte dos empregadores (REL.EXT., 1912, Anexo 1, p.3). À época, os espanhóis representavam o segundo fluxo mais importante para o país, com $22 \%$ das entradas entre 1904 e 1914, atrás apenas dos portugueses (LEVY, 1974). Em resposta à proibição, o MRE determinou que seu encarregado em Madri, Sylvino Gurgel do Amaral, atuasse em prol da revogação do decreto, em que obteve sucesso em 05 de janeiro de 1911 - embora a Espanha se reservasse o direito a informar a seus emigrantes sobre as condições de insalubridade no trabalho na Estrada de Ferro Madeira-Mamoré (REL.EXT., 1912, Anexo 1, p.16).

Ressalte-se que, em sua negociação, Gurgel do Amaral optou por ressaltar o grande número de espanhóis que afluíam para o Brasil, inclusive após a publicação do decreto, o que constituiria, segundo o diplomata, “demonstração segura, essa, de não serem, como parecem ao Decreto, tão desastrosas as condições da vida para quem quer trabalhar no país" (REL.EXT., 1912, Anexo 1, p.6), bem como colacionou depoimentos de jornais e cônsules espanhois no Brasil, que consideravam a medida do governo central uma generalização exagerada. Ainda, sugere que a medida espanhola teria sido 
tomada no interesse de evitar o êxodo do país, e não em decorrência de fatores relacionados ao Brasil (REL.EXT., 1912, Anexo 1, p.14). Infere-se, ainda, de memorando do governo espanhol, que o governo brasileiro havia se comprometido a fiscalizar mais intensamente o serviço de imigração, evitar abusos e violências, reorganizar a assistência médica e o serviço de instrução primária, facilitar as reclamações judiciais, dentre outras medidas (REL.EXT., 1912, Anexo 1, p.15).

A Itália, por sua vez, voltou atrás em negociações com a União e o estado de São Paulo, em 1912, sobre uma linha exclusiva de companhias de navegação entre Gênova ou Nápoles e Santos. A despeito de seus interesses comerciais, o governo italiano interrompeu o contrato, que já se encontrava em execução, por entender que aumentaria a emigração para o Brasil. Tal medida desencadeou uma intensa campanha diplomática brasileira em prol da imagem do país, porém não logrou que a Itália voltasse atrás nesta decisão específica (REL.EXT., 1913, p.12-13).

Em 1907, o Decreto nº 6.455 instituiu o Serviço de Povoamento do Território Nacional e o regulamentou, recentralizando a temática migratória na União, por meio do Ministério da Indústria, Viação e Obras Públicas ${ }^{107}$; porém a ser executado em colaboração com os governos estaduais, empresas de viação férrea e fluvial, companhias e associações e particulares. O decreto criou, ainda, seção da Diretoria para atuação nos portos, primeiro contato e registro no desembarque do imigrante: a Intendência de Imigração. A política traçada foi a que consagrou mais amplamente incentivos para a vinda de imigrantes, englobando: o subsídio do transporte ao Brasil; a acolhida nos primeiros dias em hospedarias; o auxílio financeiro para instalação nos núcleos coloniais. Foi, ainda, pioneira em disposições relacionadas à responsabilidade do Estado pelo bem estar dos migrantes. O decreto n n $^{\circ} .081$ de 1911, que o substituiu, segue a mesma linha de concessão de direitos e liberdade de entrada.

O decreto definia, em seu artigo 95, serem considerados imigrantes espontâneos aqueles que "vierem dos portos estrangeiros com passagem de $2^{\mathrm{a}}$ ou $3^{\mathrm{a}}$ classe, por conta própria”. Como não se tratava do fluxo majoritário, a norma colocava que

Art. 97. Emquanto se não tornar sufficientemente abundante e crescente a entrada de immigrantes expontaneos no paiz, a União fornecerá, gratuitamente - sem que os beneficiados tenham de indemnizar o Governo ou quem quer que seja - aos estrangeiros que exerçam a profissão de agricultores

\footnotetext{
${ }^{107}$ Com a restruturação ministerial engendrada pelo decreto $\mathrm{n}^{\circ} 1.606$ de 1906 e regulamentada pelo decreto $\mathrm{n}^{\circ} 7.727$ de 1909, este Ministério foi incorporado à Secretaria dos Negócios da Agricultura, Indústria e Comércio, na qual foi alocada a Diretoria Geral do Serviço de Povoamento.
} 
e cheguem acompanhados de suas familias, ou a chamado das mesmas, uma vez que estejam nos casos de ser acolhidos como immigrantes nos termos do art. $2^{\circ}$, e venham estabelecer-se como proprietarios territoriaes.

Tem-se então um período de não apenas fomento à imigração, mas também de recrudescimento do aparato institucional doméstico destinado a gerenciá-la. Paralelamente, foi institucionalizado o serviço de propaganda e expansão econômica do Brasil no estrangeiro (Decreto 6.668/1907), a ser exercido, em países europeus, por delegados especiais que responderiam ao Ministro da Indústria, Viação e Obras Públicas. Detinham, dentre outras, as competências de "empregar os melhores meios de vulgarização de notícias sobre coisas pátrias por jornais, boletins e opúsculos, ou como entender proveitoso, promovendo a divulgação de dados oficiais e de informações sobre as vantagens naturais que os diversos Estados da União oferecem ao trabalho e ao capital" (art.2 $\left.2^{\circ}, \mathrm{I}\right)$ e "prestar todos os esclarecimentos aos que desejarem conhecer o Brasil ou quiserem nele fixar residência, auxiliando-os pelos meios estabelecidos nas leis ou regulamentos em vigor" $\left(\operatorname{art} .3^{\circ}, \mathrm{I}\right)$.

À medida que a acumulação cafeeira gerava investimentos industriais e urbanos, os fluxos migratórios foram também se dirigindo às cidades (RICUPERO, 2013). Ressalte-se que, em um país ainda carente de legislação trabalhista e em uma cidade como São Paulo, onde a maior parte da força de trabalho era estrangeira (BEIGUELMAN, 1987), o movimento operário surgiu impulsionado por italianos, espanhóis e portugueses, muitos deles expulsos de seus países por razões políticas (CERVO, 1992, p.62). Nesse contexto, o Brasil promulgou o decreto $\mathrm{n}^{\circ} 1.641$, de 07 de janeiro de $1907^{108}$, sobre a expulsão de estrangeiros do território nacional. A chamada "Lei Adolfo Gordo" visava à repressão do movimento operário nacional por meio da intimidação ao trabalhador imigrante, ao enunciar em seu artigo $1^{\circ}$ a possibilidade de expulsão de estrangeiro que, por qualquer motivo, comprometesse a segurança ou a tranquilidade públicas. Entre 1907 e 1921, 556 estrangeiros foram expulsos (CERVO, 1992, p.62). Nesse intervalo, greves operárias eclodiram nos centros urbanos, fazendo com que as medidas concernentes à expulsão fossem recrudescidas pelo Decreto $\mathrm{n}^{\mathrm{o}}$ 2.741 , de $1913^{109}$.

\footnotetext{
108 Disponível em: http://www2.camara.leg.br/legin/fed/decret/1900-1909/decreto-1641-7-janeiro-1907582166-publicacaooriginal-104906-pl.html. Acesso em: 27 ago 2015.

${ }_{109}$ Disponível em: http://www2.camara.leg.br/legin/fed/decret/1910-1919/decreto-2741-8-janeiro-1913575766-publicacaooriginal-99068-pl.html. Acesso em: 05 jun 2016.
} 
Essa conjuntura levava a uma redefinição, pelas elites, do papel que cabia ao imigrante na sociedade brasileira. De um lado, o projeto de branqueamento da nação não vinha surtindo os efeitos esperados. De outro, os imigrantes vinham se destacando no cenário político de contestação operária, incomodando os dirigentes econômicos e políticos, à época coincidentes. Ademais, com a crise econômica engendrada posteriormente pela I Guerra Mundial, acompanhada de alta inflação e seguida da queda do preço do café, os imigrantes passaram a ser vistos com desconfiança pela classe operária dos grandes centros urbanos, vistos como concorrentes na disputa por empregos (LESSER, 1994, p.29). Nesse contexto, conforme análise de Cláudia Leal sobre o anarquismo e sua repressão no Brasil no início do século XX, "o Estado, representado pelo poder executivo, estava, apesar de algumas reclamações do movimento operário, do judiciário e das embaixadas, totalmente à vontade para exercer seu projeto de controle e disciplina da população classificada como indesejável" (apud BONFÁ, 2009, p.187). Sobre a atuação das embaixadas, destaca-se a italiana, a qual exerceu recorrentemente pressão referente a direitos trabalhistas e pedidos de explicação sobre a expulsão de seus cidadãos.

No que concerne à ressignificação do papel do imigrante, conduziu paulatinamente a um novo ideário: o da assimilação. Pensa-se o imigrante ideal como aquele que se assimila à cultura urbana brasileira, que se desvincula de seus laços de origem e de adapta à identidade do nacional para a ele se incorporar. O conceito de assimilação incluía em seu bojo uma "concepção homogeneizante de nação" (SEYFERTH, 2000, p.46), e acaba vinculando a questão migratória a posturas normativas sobre a composição étnica nacional.

Os fluxos migratórios também cambiaram: na Europa, o início da guerra fortalecia temporariamente as economias locais, bem como exigia o alistamento de homens (LESSER, 1994). Durante a I Guerra, o MRE relata haver intercedido junto às potências beligerantes para obter o repatriamento de brasileiros natos, filhos de pais europeus, que se encontravam na Europa no início do combate. Explica o MRE que tinham consciência destes pedidos irem contra o princípio do jus sanguinis adotado no continente europeu e, portanto, de carecerem de fundamentos jurídicos, porém justifica sua iniciativa por dever de humanidade (REL.EXT., 1915, p.100). Nesta mesma ocasião, o MRE relata a iniciativa do Governo Federal, aplicada pelas autoridades policiais federais e estaduais, de aumentar o rigor na concessão de passaportes a 
brasileiros naturalizados, ou filhos de pais estrangeiros (REL.EXT., 1915, p.100), de modo a que a concessão da nacionalidade brasileira não fosse utilizada como instrumento para burlar a convocação militar. As instruções eram as de não fornecer passaporte brasileiro a naturais de países beligerantes, e coube, à época, ao Ministério das Relações Exteriores articular o cumprimento da decisão federal nos estados (Circular n.46, 22 set. 1914).

Ainda na I Guerra, a atuação do MRE em questões de nacionalidade foi importante inclusive para fazer prevalecer os direitos e deveres de neutralidade do Brasil $^{110}$. Nesses termos, relata o Ministro em 1915:

Este Ministério tem tido conhecimento de que cidadãos brasileiros, filhos de estrangeiros, receberam aqui intimações consulares, a respeito de prestação do serviço militar nos países de seus pais.

Em virtude do art. 69 da Constituição Federal, são cidadãos brasileiros os indivíduos nascidos no Brasil, ainda que de pai estrangeiro, não residindo este ao serviço de sua nação. Os indivíduos que incidem nesta última condição estão subordinados, como Brasileiros, exclusivamente às leis do país e às obrigações impostas aos seus nacionais, não podendo sofrer no Brasil ação alguma de autoridades estrangeiras. (...)

Nestes termos, em 23 de janeiro de 1915, o Ministério passou Nota às Legações dos seguintes países empenhados no atual conflito europeu: Alemanha, Austria-Hungria, Bélgica, França, Grã-Bretanha, Japão, Rússia”. (REL.EXT., 1915, p.99).

A Primeira Guerra constituiu, ademais, um período crítico de definição do conceito de nacionalidade. Nela, os governos europeus intensificaram o processo dual de identificação dos seus nacionais e diferenciação desses em relação aos estrangeiros. Isso se realizou através de medidas de controle à entrada e circulação de pessoas, tais como passaportes e vistos de entrada, bem como de restrições aos direitos dos estrangeiros (FARIA, 2015). Também os Estados Unidos, principal destino de imigrantes à época, fortaleceu as barreiras de entrada em suas fronteiras.

Finda a guerra, os fluxos europeus para o Brasil, que haviam se reduzido a uma média anual de 27.000 entre 1915 e 1918, retomaram seu crescimento. As nacionalidades majoritárias, contudo, se modificaram substancialmente: o conjunto de nacionais russos, poloneses, romenos e judeus passa a assumir o segundo posto em

\footnotetext{
${ }^{110}$ Dentre as regras gerais de neutralidade, consubstanciadas no Decreto n ${ }^{\circ}$ 11.037/1914, estão: Art. $2^{\circ}$ Não é permittido aos belligerantes promover no Brasil o alistamento do nacionaes seus, de cidadãos brasileiros, ou de naturaes de outros paizes para servirem nas suas forças de terra e mar.
} 
número de entradas (LEVY, 1974), delineando os primeiros traços de questão que marcaria a sociedade internacional na década de 1920 - os refugiados.

Por sua vez, o paradigma da política migratória nacional se modificara: a ocupação do território não mais constituia seu objetivo, o qual passou a centrar-se no fornecimento de mão-de-obra e de mercado consumidor; e a atração de indivíduos a fim de participarem da construção nacional foi substituída pelo ideal da assimilação dos recém-chegados a uma nação homogênea e prévia.

Com essas mudanças, o decreto $\mathrm{n}^{\circ} 3.550$, de 16 de outubro de 1918, reformulou a Diretoria do Serviço de Povoamento e denominou-a Departamento Nacional do Trabalho, o qual se tornaria embrião do futuro Ministério do Trabalho, criado por Vargas em $1930^{111}$. A ele foram atribuídos os objetivos de $\left(\operatorname{art} .2^{\circ}\right)$ :

a) preparar e dar execução regulamentar às medidas referentes ao trabalho em geral;

b) dirigir e proteger as correntes emigratórias que procurarem o país e amparar as que se formarem dentro do mesmo;

c) superintender a colonização nacional e estrangeira;

d) executar todas as medidas atinentes ao serviço das terras devolutas do Acre, a que se referem os decretos números 10.105 e 10.320 , de 5 de março e 7 de julho de 1915, exercendo, para isso, as attribuições que deveriam ser conferidas à Diretoria de Terras Públicas, conforme o disposto no primeiro dos aludidos decretos;

e) regulamentar e inspecionar o Patronato Agrícola.

Em 1918, reforma do Ministério das Relações Exteriores dividiu-o em duas diretorias gerais, uma delas reunindo Negócios Diplomáticos, Consulares e Econômicos, e instituiu Conselho Administrativo que tinha entre suas competências dar parecer sobre assuntos relativos à colonização e à imigração (Decreto 12.997, 24 de abril de $1918^{112}$, art. 36). A reorganização se dá em momento de transformação nas relações internacionais sobre o tema. Se a primeira Conferência Internacional de Assistência Pública aos Estrangeiros, reunida em Paris em 1912 e para a qual o Brasil não enviou delegado (REL.EXT., 1914, p.225), não obteve sucesso em aprovar seus projetos de Estatuto Internacional das Sociedades de Beneficência que tinham por fim socorrer os Estrangeiros e de Convenção Internacional para Assistência aos Estrangeiros (REL.EXT., 1914, p.225), os deslocados da I Guerra Mundial despertaram as atenções da sociedade internacional sobre o tema, e ativaram a necessidade de encontrar-se

\footnotetext{
${ }^{111}$ Decreto n $^{\circ} 19.433 / 1930$.

112 Disponível em: http://www2.camara.leg.br/legin/fed/decret/1910-1919/decreto-12997-24-abril-1918572359-publicacaooriginal-95491-pe.html. Acesso em: 02 mai 2016.
} 
soluções conjuntas. Um novo cenário, internacional e doméstico, se desenhava para a política migratória brasileira.

\subsection{Das fronteiras externas às fronteiras internas: regulando a cidadania}

A I Guerra gerou uma redução drástica nos fluxos europeus para o Brasil, como se verifica na figura 3.1. Paralelamente, a tendência dos imigrantes destes países a se dirigirem aos grandes centros urbanos, aliada ao aumento da desconfiança em relação a suas atividades políticas, especialmente após a greve geral de 1917 e as que lhe seguiram (BEIGUELMAN, 1987), contribuíram para que, no início da década de 1920, os japoneses passassem a ser vistos pelo governo brasileiro como etnia preferencial para trabalho agrícola. O Japão, por sua vez, se mostrava mais ativo na persecução de interesses relacionados à emigração, dirigindo suas atenções progressivamente para o Brasil, especialmente após as medidas restritivas do governo norte-americano que viriam a culminar, em 1924, na proibição da imigração japonesa por meio do Quota Immigration Act (TAFT; ROBBINS, 1955, p.32). Neste mesmo ano, o governo paulista interrompeu o subsídio para vinda de imigrantes japoneses, o qual passou a ser fornecido inteiramente pelo governo nipônico. Essa conjuntura gerou aumento nos fluxos: se entre 1885 e 1923, 20,9\% dos emigrados japoneses se dirigiram aos Estados Unidos e apenas 6,4\% ao Brasil, entre 1924 e 1934 estes números são, respectivamente, $2,6 \%$ e $63 \%$ (LEÃO NETO, 1989). 
Figura 3.1: Entradas de imigrantes no Brasil entre 1887-1972, por nacionalidades

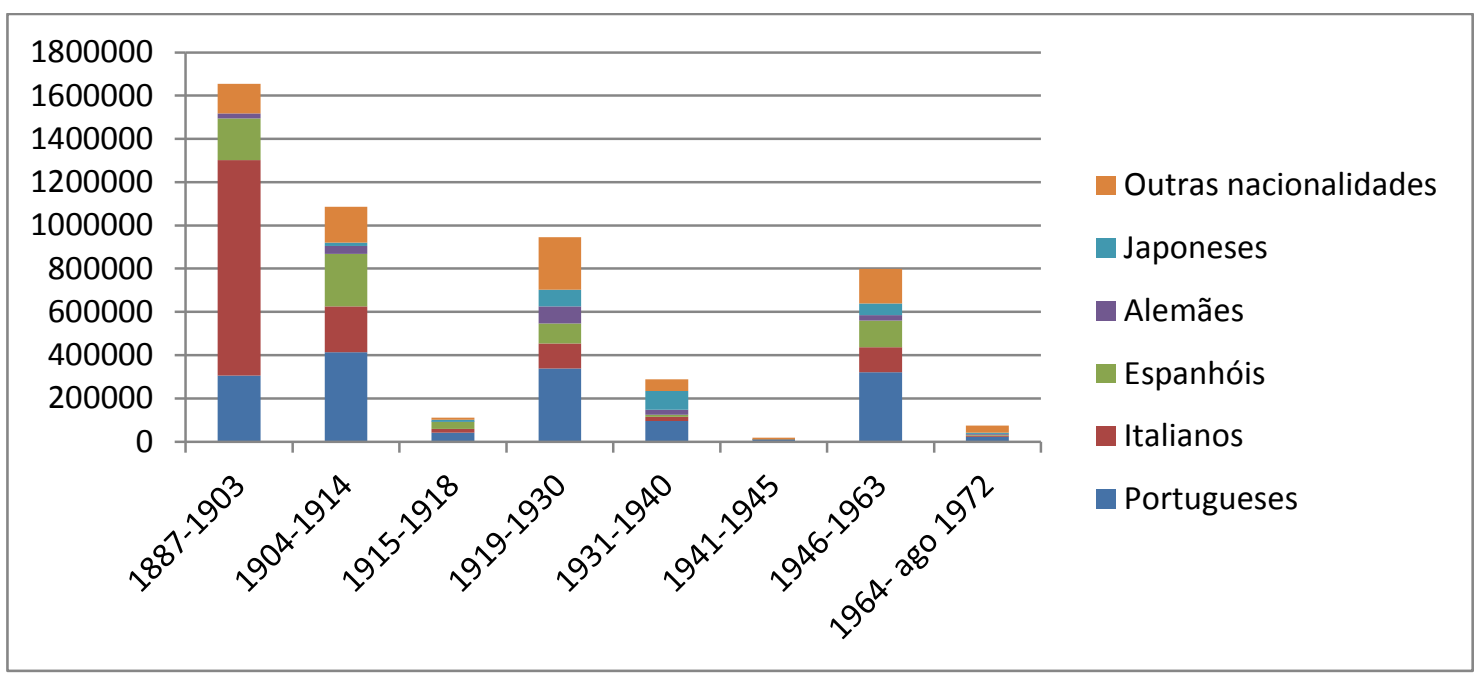

Fonte: Elaboração própria, com dados de Levy (1974)

Sakurai (2000) descreve a planejada atuação do governo japonês na tutela dos imigrantes que se dirigiam ao Brasil. Segundo a autora, o Ministério das Relações Exteriores do Japão, assim como seu Ministério do Interior, intervinham até no gerenciamento das colônias japonesas em território brasileiro, por meio de companhias privadas ou mistas de colonização. Ainda de acordo com a autora, esta tutela dos emigrantes se juntava a outras estratégias de atuação externa na persecução de interesse econômicos mais amplos, tais como o investimento na compra de terras e na introdução de benfeitorias, no intuito de produzir e exportar para o Japão (2000, p.86).

O interesse na vinda de imigrantes estava, pois, no início da década de 1920, atrelado aos interesses agrários. Nesse sentido, a reforma do Ministério das Relações Exteriores de 1920 (Decreto $\mathrm{n}^{\mathrm{o}}$ 14.056), concebida de modo a favorecer $\mathrm{o}$ desenvolvimento dos serviços consulares em consequência do aumento progressivo das relações comerciais com os países estrangeiros (REL.EXT., 1919-1920), buscava fornecer o embasamento institucional para a celebração de dois tipos de tratados: os comerciais e os de trabalho, estes últimos sendo discutidos pelo MRE em parceria com o Ministério da Agricultura.

Sem embargo, em meio a contexto internacional e doméstico cambiante, o Decreto $\mathrm{n}^{\mathrm{o}} 4.247$, de 06 de janeiro de 1921, foi a primeira normativa a dispor sobre a entrada de estrangeiros com medidas tendentes a seu controle e limitação ${ }^{113}$. Passou-se a exigir dos estrangeiros entrantes (definidos como "passageiros de segunda e terceira

\footnotetext{
${ }^{113}$ Corroborado, posteriormente, pelo Decreto $\mathrm{n}^{\circ} 16.761$, de 31/12/1924, o qual destrincha os procedimentos de concessão de visto e fiscalização.
} 
classe") comprovação de condições financeiras para subsistir no país e atestados de bons-antecedentes; e das empresas de navegação, autorização federal para trazer imigrantes. Exames de saúde eram realizados no desembarque dos passageiros, proibindo-se entradas segundo restrições de ordem física e sanitária. As expulsões passaram a ser tratadas no mesmo diploma das admissões, e eram permitidas em amplas hipóteses, tais como ter provocado atos de violência para, por meio de fatos criminosos, impor qualquer seita religiosa ou política; ou ser considerado nocivo à ordem pública ou à segurança nacional $\left(\operatorname{art} .2^{\circ}\right)$.

O que teria levado a uma tal mudança de paradigma, uma vez que ainda havia interesse na vinda de imigrantes para o país? Quatro fatores parecem se complementar nesta explicação: (i) o receio de que a imigração se dirigisse para as cidades e, de um lado, reforçasse os movimentos operários, ou, de outro, ocupasse postos de trabalho anseados pelos nacionais; (ii) ponderações sobre a origem étnica dos imigrantes e sua pretensa dificuldade de assimilação à nação brasileira; (iii) indefinições quanto à questão dos refugiados, que se desenhava no cenário internacional; (iv) a conjuntura internacional que consolidava o conceito de soberania a partir da adoção de requisitos documentais para entrada nos territórios.

Assim, na contramão do interesse nos trabalhadores japoneses, via-se com desconfiança a imigração judaica, sob pretexto de sua inadequação ao trabalho agrícola e sua tendência a dirigir-se a centros urbanos. O fluxo de judeus para o Brasil se tornara crescente após a I Guerra, em decorrência, inclusive, de cláusulas restritivas a sua entrada adotadas pela legislação imigratória dos Estados Unidos, Canadá, Argentina e África do Sul (LESSER, 1994). Assim, Carneiro (2003) traz ofício de 1921 assinado pelo então Diretor do Serviço de Povoamento, Dulphe Pinheiro Machado, e dirigido ao Diretor dos Negócios Comerciais e Consulares do MRE, no qual reage a consulta acerca da introdução de agricultores russos de origem israelita no Brasil. Para Dulphe Machado, a entrada de judeus "não viria contribuir para o incremento da atividade agrícola" (apud CARNEIRO, 2003, p.7), e levaria, ao contrário, ao impulso ao urbanismo - e, no limite, ao desequilíbrio entre urbano e rural no Brasil. Tais argumentos eram entrelaçados a outros de fundameno anti-semita, referindo ao judeu como "elemento, sabidamente, parasytário e inassimilável, causa de constantes e sangrentos conflictos, motivados por odios de raça e religião" (apud CARNEIRO, 2003, p.8). 
Neste mesmo ano, porém, a Jewish Colonization Association (ICA) iniciava sua atuação no Brasil, empenhando-se em conseguir a autorização do governo brasileiro para entrada de um grupo de sessenta tchecoslovacos, frisando que se direcionariam a fazendas de café (CARNEIRO, 2003). Em 1923, a Associação nomeou o rabino Isaiah Raffalovich como chefe das operações no Brasil, a partir do quê suas relações com o MRE se tornaram intensas, e renderam frutos em prol da concessão de vistos para judeus nos consolados. Jeffrey Lesser (1994, p.63) aponta que, em 1926, “os cônsules em Riga, Danzig, Paris, Varsóvia e Galatz receberam ordens do Ministro das Relações Exteriores para que fossem concedidos vistos aos possuidores de passaportes russos patrocinados pela ICA, a despeito de uma ordem especial para que fossem negados vistos para os russos" (LESSER, 1994, p.63).

Sem embargo, as ideias de assimilação problematizavam os desta nacionalidade. De fato, mesmo entre aqueles que apoiavam a entrada de fluxos migratórios estava presente a ideia de que se deveria evitar a formação de núcleos concentrados, os chamados "quistos étnicos", para que o almejado "caldeamento" pudesse ocorrer (GERALDO, 2009a; SEYFERTH， 2000; CARNEIRO， 2003). Fortalecia-se paulatinamente o nativismo de caráter eugênico, o qual atingiria seu ápice de aceitação social e inserção governamental no Estado Novo ${ }^{114}$ (CARNEIRO, 2003).

O nativismo tinha como principais alvos os japoneses e judeus. Não obstante, episódios relativos a outras nacionalidades também ocorreram, tendo sido rejeitadas, sob argumento de que obstariam o caldeamento da população brasileira, algumas propostas do governo da Índia de envio de emigrantes lavradores nas décadas de 1920 e 1930; bem como, em 1921, a proposta de um grupo de negros norte-americanos, o Brazilian-American Colonization Syndicate, que pretendia imigrar para o Brasil e fundar uma colônia no estado do Mato Grosso ${ }^{115}$.

\footnotetext{
${ }^{114}$ Acadêmicos, jornalistas e políticos tiveram um importante papel na difusão de ideias anti-semitas no Brasil. Destaca-se a atuação de Oliveira Vianna, advogado, historiador e professor na Faculdade Nacional de Direito (na qual se formaram vários dos diplomatas à época), autor de Raça e Assimilação, no qual expõe sua opinião sobre a indesejabilidade dos japoneses por ser "como o enxofre, inassimilável" (1959, p.155). Entretanto, o movimento eugenista brasileiro em muito transcendia a figura de Vianna, materializando-se em Congressos nacionais que reuníam políticos, acadêmicos, médicos, dentre outros membros da elite brasileira, conforme expõe Lesser (1994).

${ }^{115}$ Sobre o debate público suscitado pela proposta, ver Gomes (2003). Um dos textos a que se remete ao autor justificava: "É possível atingirmos a um caldeamento completo. É de esperar-se que não tenhamos sempre o bloco irredutível da carne preta, como os Estados Unidos. Por que dificultar e retardar a hora dessa homogeneização, injetando contingente endurecido do corpo cuja dissolução se vai operando?" (Veiga de Miranda, apud GOMES, 2003, p. 319).
} 
Em contrapartida, não se colocavam obstáculos aos europeus com fluxos tradicionais para o Brasil. No que concerne à Itália, se no início do século a diplomacia italiana tentara, sem sucesso, obter compromisso do governo brasileiro relativo à promulgação de tratados de trabalho protetivos, retomou o objetivo na década de 1920 (CERVO, 1992). Após negociações entre o MRE e o Comissariado-Geral da Imigração da Itália, o embaixador brasileiro em Roma, Souza Dantas, firmou com o Comissáriogeral italiano a Convenção de trabalho de 08 de outubro de $1921^{116}$. Entre outras previsões, o contrato dispunha sobre as indenizações e benefícios estabelecidos pela lei trabalhista, bem como sobre os contratos de trabalho e sua fiscalização, garantindo a igualdade de direitos entre trabalhadores das duas nacionalidades em ambos os territórios.

No ano seguinte, durante uma das únicas visitas de chefes de Estado ao país na República Velha, foi a vez do presidente de Portugal, Antônio José de Almeida, assinar junto ao governo brasileiro uma Convenção de Emigração e Trabalho, em 26 de setembro de 1922 (REL.EXT., 1923). Este acordo garantia aos emigrantes igualdade, em relação aos nacionais, de "direitos estabelecidos pela legislação relativa ao trabalho, á protecção aos trabalhadores, á providencia social, á assistencia, á instrucção geral e profissional e á liberdade de reunião, de associação e de organisação professional ${ }^{117,}$ $\left(\operatorname{art.} 1^{\circ}\right)$. Na mesma ocasião, os Ministros das Relações Exteriores de ambos os países firmaram ainda um Tratado Regulando a Isenção do Serviço Militar e a Dupla Nacionalidade ${ }^{118}$. Ainda em 1922, o Brasil assinou tratado sobre o mesmo tema com a Grã-Bretanha ${ }^{119}$.

Ressalte-se que os primeiros passos empreendidos pelo governo brasileiro de progressivamente limitar a entrada e os direitos dos estrangeiros encontrava, na Constituição de 1891 (ainda vigente), um obstáculo. O artigo 72 da Carta assegurava igualdade de direitos a nacionais e estrangeiros, ressaltando a inviolabilidade dos direitos concernentes à liberdade, à segurança individual e à propriedade. Esta disposição fundamentou posicionamentos do Judiciário contrários a medidas de

\footnotetext{
${ }^{116}$ Disponível em: http://dai-mre.serpro.gov.br/atos-internacionais/bilaterais/1921/b_50/. Acesso em: 17 mai 2016

${ }^{117}$ Disponível em: http://dai-mre.serpro.gov.br/atos-internacionais/bilaterais/1922/b_44/. Acesso em: 17 mai 2016.

${ }^{118}$ Disponível em: http://dai-mre.serpro.gov.br/atos-internacionais/bilaterais/1922/tratado-entre-brasil-eportugal-regulando-a-isencao-do-servico-militar-e-a-dupla-nacionalidade/. Acesso em: 17 mai 2016 ${ }^{119}$ Disponível em: http://dai-mre.serpro.gov.br/atos-internacionais/bilaterais/1922/b 42/. Acesso em 17 mai 2016
} 
expulsão decretadas pelo Executivo, e gerou inflamados debates doutrinários (VIANA FILHO, 1938). De modo a por fim às contestações judiciais, a emenda constitucional de 03 de setembro de 1926 incluiu no dispositivo o parágrafo 33, segundo o qual "É permitido ao Poder Executivo expulsar do território nacional os súditos estrangeiros perigosos á ordem publica ou nocivos aos interesses da Republica".

No plano internacional, os conflitos e as crises econômicas e políticas que marcaram o entreguerras levaram ao remodelamento dos deslocamentos populacionais: embora tenha havido uma redução nas migrações voluntárias, os deslocamentos forçados se avolumaram a se colocaram como questão para a sociedade internacional ${ }^{120}$. Ao contrário dos movimentos de migração que os precederam, os refugiados, apátridas e minorias étnicas da I Guerra não queriam mudar-se, nem eram particularmente bemvindos em outros locais (TAFT; ROBBINS, 1955). Nesse contexto, constituiram um desafio para as arenas multilaterais que se consolidavam: a Liga das Nações e a Organização Internacional do Trabalho.

Em 1921, a Organização Internacional do Trabalho criou a Comissão Internacional de Emigração. Embora não tenha nas migrações internacionais seu objeto central (o qual se refere, em resumo, à promoção do trabalho decente), a OIT contempla a questão em sua agenda desde sua fundação, no Tratado de Versalhes em 1919. Tratase, pois, da mais antiga organização internacional a lidar com a temática migratória, além da mais institucionalizada. À época, a criação da Comissão Internacional conferiu destaque à temática dentro da organização, produzindo relatórios técnicos, planos e programas de ação, e promovendo sessões anuais e conferências para tratamento multilateral do tema.

$\mathrm{Na}$ V Assembleia da Liga das Nações, realizada em setembro de 1924, a Comissão sobre Questões Sociais e Humanitárias, tratou, dentre outras questões, dos refugiados armênios. No mesmo ano, a VI Conferência Internacional do Trabalho discutia de forma central a igualdade de tratamento dos trabalhadores estrangeiros, princípio que obteve o apoio da delegação brasileira, porém teve sua decisão adiada por proposta da delegação britânica (REL.EXT., 1924-1925). Mas foi a Conferência Internacional de Emigração e Imigração de Roma que fez de 1924 um ano marcante

\footnotetext{
120 Hannah Arendt, em seu Origem do Totalitarismo, ressaltou como os apátridas e as minorias constituíram um ponto de inflexão no ideário dos direitos humanos. Estes, antes vistos como inerentes ao ser humano, passaram a ser relativizados em prol da soberania estatal, e a serem conferidos aos indivíduos através do vínculo da nacionalidade (2004, p.301).
} 
para as regulamentações internacionais das migrações. A convite do governo italiano, cinquenta e sete países se fizeram presentes, além da Liga das Nações e da Organização Internacional do Trabalho, para discutir o estabelecimento de princípios e critérios para a imigração e a emigração (REL.EXT., 1924-1925).

A delegação brasileira composta por membros do MRE, Departamento de Saúde Pública e consultores jurídicos, participou ativamente das sessões, as quais orbitaram em torno de questões de transporte e saúde; assistência aos migrantes antes da partida e por ocasião do desembarque; medidas de cooperação entre os países de emigração e imigração no sentido de adaptar os deslocamentos às necessidades de mão-de-obra; além de princípios gerais para embasar regulações posteriores. Foram adotadas resoluções no sentido da uniformização das disposições sanitárias referentes aos migrantes, aos navios de transporte e às hospedarias; da proibição da propaganda a favor da emigração; e recomendou-se que os países de migração facilitassem a admissão de estrangeiros em sociedades de assistência mútua, assistência judiciária e associações privadas de assistência.

Debateram-se estratégias de permuta de informações, entre Estados de emigração ou imigração, sobre a situação do mercado de trabalho, condições de salário e outras informações trabalhistas, de modo a adequar os fluxos migratórios às necessidades dos países receptores, "manifestando o desejo de ver abolida a exigência dos passaportes e demonstrando a necessidade de uma carta de identidade uniforme, independente de qualquer taxa ou contribuição" (REL.EXT., 1924-1925, p.53). Entretanto, apontou-se a necessidade de restringir-se o recrutamento coletivo de imigrantes, bem como se aconselhou a punição severa aos que facilitassem a migração irregular.

Um ponto que suscitou várias divergências na Conferência foi a discussão do significado do termo imigrante. A proposta trazida pela delegação italiana afirmava que os países de imigração confeririam, ao imigrante que manifeste intenção de se estabelecer de maneira durável no seu território, vantagens e privilégios especiais. Esta redação foi combatida pelos delegados de Argentina, Brasil e França, destinos principais dos fluxos italianos, tendo sido ao final adotado que "consideram-se emigrantes e imigrantes todas as pessoas que deixarem sua pátria em busca de trabalho, ou que vão dedicar-se ao pequeno comércio, ou que vão reunir-se a parentes que já emigraram em busca de trabalho" (REL.EXT., 1924-1925, p.54). 
Uma proposta da Itália de criar um Estatuto do Imigrante como norma de direito internacional não chegou a ser aprovada ${ }^{121}$. Sobre as resoluções adotadas, declarou o Ministério das Relações Exteriores do Brasil:

Do conjunto de medidas votadas na Conferência, verifica-se que ela teve, sobretudo, em vista, zelar pelos interesses do emigrante, sem tratar com a mesma solicitude dos interesses dos países de imigração que não podem conceder aos imigrantes uma situação privilegiada, que os torne, de qualquer modo, mais protegidos do que o trabalhador nacional. Além disso, as condições dos países que empregam a mão de obra estrangeira, diferem grandemente entre si, não sendo possível aplicar as mesmas medidas e regras aos que recebem trabalhadores agrícolas adventícios, que voltam ao país de origem logo que recolhem o produto da colheita do ano e aos que os acolhem de uma maneira permanente e definitiva (REL.EXT., 1924-1925, p.56).

O Congresso de Roma marcou o início de um processo internacional de esboço de um regime internacional de migrações, o qual se estendeu durante as décadas seguintes, em um período que se caracterizava pela tensão entre nacionalismos. Tratouse, de fato, de um período em que a imigração foi discutida amplamente no cenário internacional. Entre 12 e 18 de maio de 1926, a segunda Conferência Internacional sobre o regime de passaportes ${ }^{122}$, organizada pela Sociedade de Nações, estipulou recomendações sobre o formato dos passaportes, sobre os procedimentos de entrega e validade dos passaportes e dos vistos, bem como sobre o trânsito de imigrantes. Conforme percepção do Ministério das Relações Exteriores, "Pelas discussões havidas, tornou-se evidente a tendência para a supressão de todos os vistos, bem como para a conclusão de acordos parciais o sentido da supressão dos passaportes" (REL.EXT., 1926, p.34) ${ }^{123}$. O Brasil enviara à Conferência Hildebrando Acciolly, representante que, segundo alega em relatório enviado ao Ministério das Relações Exteriores, não estava suficientemente provido de informações sobre o regime de passaportes no Brasil, e "Na falta de instruções do Governo, ele se inspirava nos princípios liberais da Constituição Federal" (Hildebrando Acciolly, REL.EXT., 1926, Anexo A, p.43).

\footnotetext{
${ }^{121}$ Embora alguns de seus princípios terem sido votados, ainda que com numerosas abstenções: liberdade de emigrar e imigrar com reserva de restrições estabelecidas por motivos de ordem pública, econômica (notadamente de estudo de mercado de trabalho) ou de saúde pública; liberdades de emigrar e imigrar deveriam ser estendidas aos diferentes membros da família; os imigrantes e suas famílias deveriam gozar dos direitos civis nas mesmas condições que os nacionais, sob reserva de reciprocidade; dentre outros.

${ }^{122}$ A primeira houvera sido realizada em 1920, buscando solucionar obstáculos à circulação de pessoas que se instalaram como decorrência da I Guerra.

${ }^{123}$ A despeito da percepção do MRE, o relatório do seu delegado sobre a Conferência demonstra que, se países como a Polônia e a Tcheco-Eslováquia defendiam a abolição de passaportes, outros rejeitaram ardentemente a proposta, especialmente a Grã-Bretanha, seguindo-lhe a Itália, Romênia, Suíça e Turquia (Hildebrando Acciolly, REL.EXT., 1926)
} 
É interessante constatar que, no ano seguinte à Conferência, o Relatório Anual de atividades do MRE de 1927 retoma o assunto do regime de passaportes, frisando as dificuldades enfrentadas pelos cônsules em implementá-lo:

Um dos efeitos da guerra de 1914-1918 foi a revivescência em todos os países de medidas restritivas da liberdade, antes quase absoluta, de entrada e saída nos respectivos territórios. As precauções exigidas pela situação internacional fizeram restabelecer-se por toda parte, inclusive no Brasil, o regime do passaporte para poder alguém viajar. Passado o conflito, as medidas de defesa contra a propaganda revolucionárias e as agitações anárquicas mantiveram esse regime. Na sua aplicação entra em muito a cooperação do Ministério das Relações Exteriores, uma vez que aos Consulados nacionais compete conceder passaportes aos nossos patrícios do estrangeiro e visar os dos alienígenas que procuram o Brasil. Entretanto, por falta de unidade nas disposições legais que, entre nós, regem o assunto, não pequenos têm sido os embaraços à ação daqueles nossos agentes no exterior. (REL.EXT., 1927, p.220).

O texto segue reclamando uma maior uniformidade na atuação das autoridades federais na fiscalização da entrada de imigrantes, em harmonia com aquela já realizada nos consulados. Aponta que, em decorrência das esparsas e incompletas regulamentações do MRE e do Ministério da Agricultura, Indústria e Comércio, os agentes consulares atuavam sob uma série de dúvidas quanto aos requisitos que deveriam exigir dos que pretendiam se dirigir ao Brasil. Desta forma, o MRE afirma haver submetido aos Ministérios da Justiça e Negócios Interiores e da Agricultura, Indústria e Comércio um projeto de regulamentação do assunto, que viria a ser debatido pelos três órgãos (REL.EXT., 1927).

Em 1928, publicou-se então o decreto $\mathrm{n}^{\circ}$ 18.408, regulando a concessão de passaportes e vistos pelos consulados brasileiros, destrinchado posteriormente por instruções do MRE. Segundo o órgão, as regulamentações estavam voltadas para o objetivo de "conciliar, com o nosso interesse em receber estrangeiros, o da defesa que nos acautele contra as imigrações indesejáveis, de que não raro temos sido vítimas" (REL.EXT., 1929, p.XXVIII). O trecho resume a visão de política migratória do período: a atração de mão-de-obra segundo condicionantes de desejabilidade. De fato, o Decreto $\mathrm{n}^{\circ}$ 18.408/1928 institucionalizou a categoria "indesejável”, explicitando desde seu preâmbulo o objetivo de "conciliar os interesses dos immigrantes e viajantes com a defesa, do Brasil contra, os indesejaveis de toda especie".

Como consequência deste decreto, instalou-se no MRE o serviço de passaportes, sobre cuja criação afirmou o Ministério: "Esse serviço tem sido de grande utilidade, não 
só porque, ao lado de facilidades para os viajantes, tem permitido uma defesa mais eficaz contra os indesejáveis de toda espécie" (REL.EXT., 1929, p. 83). Em seu relatório de 1929, o MRE expõe o desperdício que seria manter sua grande e dispendiosa estrutura internacional para exercer meramente atividades burocráticas e de representação, motivo pelo qual a organização buscava atuar em áreas que vinham crescendo em importância para o país: comércio exterior, crédito externo e imigração. A política migratória era, portanto, vista como um setor de atuação estratégico para o Itamaraty.

No âmbito regional, a IV Conferência Panamericana (Havana, 1928) aprovou, dentre outras, a Convenção sobre condição dos estrangeiros, incorporada ao ordenamento brasileiro pelo Decreto ${ }^{\circ} 18.956 / 1929^{124}$. A norma definia que:

\begin{abstract}
Art. 5': Los Estados deben reconocer a los extranjeros domiciliados o transeuntes en su territorio todas las garantías individuales que reconocen a favor de sus propios nacionales y el goce de los derechos civiles esenciales, sin perjuicio, en cuanto concierne a los extranjeros, de las prescripciones legales relativas a la extención y modalidades del ejercicio de dichos derechos y garantias (grifo nosso).
\end{abstract}

Adotou-se, assim, um dúbio formato, no qual se reconhece a igualdade entre imigrantes e nacionais, porém resguarda-se a soberania dos países para limitar os direitos dos estrangeiros em seu território. Isso é corroborado pelo art. $6^{\circ}$, que facultava aos Estados, por motivo de ordem ou segurança pública, expulsar estrangeiros. Um dos motivos para tal provisão é elencado no artigo seguinte: "el extranjero no debe inmiscuirse en las actividades políticas privativas de los ciudadanos del país en que se encuentre; si lo hiciere, quedará sujeto a las sanciones previstas en la legislación local" $\left(\operatorname{art} .7^{\circ}\right)$.

Percebe-se que o regime regional que se desenhava no período adotava uma perspectiva de não obstar os fluxos migratórios, conquanto legitimasse a soberania dos Estados de oferecer aos estrangeiros direitos diferenciados, regulando sua cidadania. Sendo a Conferência Pan-Americana formada pelos maiores receptores de imigrantes do período, as normas nela adotadas sobre a temática afetavam consideravelmente o regime internacional de migrações à época, imprimindo-lhe os interesses dos países de imigração.

\footnotetext{
${ }^{124}$ Disponível em: http://www2.camara.leg.br/legin/fed/decret/1920-1929/decreto-18956-22-outubro1929-549004-publicacaooriginal-64267-pe.html. Acesso em: 15 abr 2016.
} 
Em 1929, uma Conferência sobre o Tratamento de Estrangeiros foi convocada pela Sociedade de Nações, visando a convir sobre um conjunto de garantias mínimas a serem concedidas pelos Estados aos estrangeiros neles domiciliados, compreendendo direitos civis, econômicos, judiciais e encargos fiscais. Tratou-se de uma iniciativa estimulada pelos países de emigração, os quais buscavam tutelar seus nacionais. Entretanto, não se conseguiu atingir um acordo (REL.EXT., 1929).

Em 1929, o Japão cria o Ministério da Colonização. Nesse mesmo ano, funda-se a Sociedade Colonizadora do Brasil Limitada, tendo como objetivo "a compra, venda, locação e hipoteca de imóveis, introdução de imigrantes, construção de vias de comunicação com estradas de rodagem, estradas de ferro, exploração das terras de sua propriedade, tudo referente à colonização" (SAKURAI, 2000, p. 105). Escolas japonesas eram criadas e sustentadas pelo consulado, por meio de um órgão chamado Liga dos Amigos da Escola Japonesa, em um total de 176 (SAKURAI, 2000); a Sociedade de Beneficência Japonesa, também ligada ao cônsul de São Paulo, encarregava-se da questão da saúde. $\mathrm{O}$ aparato institucional japonês voltado para a tutela de seus nacionais em território brasileiro era largo e cumpria, inclusive, o papel de provedor de políticas públicas.

Nesse período, o primeiro-ministro italiano Benito Mussolini oscilava entre a visão dos italianos no exterior como instrumento de difusão ideológica e de expansão capitalista; e a restrição da emigração de modo a combater o esvaziamento populacional. A posse de Bernardo Attolico como embaixador no Rio de Janeiro, em 1927, fomentou a vinculação da política ideológica do regime fascista à área de imigração. O Ministério das Relações Exteriores italiano arrogou-se o papel de tutelar os bens de seus nacionais residentes no Brasil (CERVO, 1992 p.126); e, junto ao Ministério da Propaganda e Cultura Popular, vinha exercendo práticas ante a imprensa brasileira para melhorar a imagem do regime de Mussolini. Não obstante, como a reação da comunidade italiana do Brasil não fora muito favorável à propaganda (CERVO, 1992), prevaleceu a política de restrição da emigração, estimulada ainda pela crise de 1929 e a continuidade de más condições de trabalho no país.

Marco na história brasileira devido ao rearranjo de forças políticas que perduravam desde a proclamação da República, a revolução de 1930, sob liderança de Getúlio Vargas, representou uma modificação radical do Estado brasileiro. A economia estava em declínio, sob efeito da quebra da bolsa de Nova York, do esgotamento do 
modelo monocultor, e de tensões políticas e sociais. O jogo de forças políticas, que vinha se complexificando, tensionou-se e passou a evidenciar uma multiplicidade de interesses distintos, por vezes antagônicos. As antigas oligarquias agrárias se mantiveram no jogo, porém a elas somaram-se a burocracia militar e o empresariado industrial e comercial emergentes (MANZUR, 1999). No poder, com uma coalizão de apoio interno fragmentada, Vargas precisou conduzir uma tentativa perene de conciliação de interesses, o que "significou a desagregação das políticas estatais em muitas direções diferentes" (NUNES, 1997, p.75), e levou ao que ficou conhecido como "Estado de compromisso" (idem, ibidem). Esse Estado, além de apto a gerenciar interesses antagônicos, devia estar organizado de maneira a fundamentar o objetivo central do governo varguista: o desenvolvimento nacional.

Para tanto, empreenderam-se uma série de ações de state-building que levaram ao redesenho do Estado brasileiro, com acentuada centralização da autoridade estatal no Poder Executivo federal. O efetivo rompimento com a dinâmica política provinciana da República Velha demandava ações de fortalecimento do governo central; assim como a implementação de uma estratégia de desenvolvimento conduzida pelo Estado - a qual, conforme aponta Barbara Geddes (1994), implicaria em mudanças na distribuição de recursos, e exigiria uma burocracia fortalecida institucionalmente para enfrentar interesses contrários e efetivar as decisões tomadas. Objetivou-se, assim, adequar a administração pública e seu funcionalismo ${ }^{125}$ a fundamentos racionais-legais e critérios de eficiência, investindo-lhe de autonomia, a fim de empreender uma rápida industrialização por meio de investimentos estatais direcionados. Não obstante, conforme aponta Maria do Carmo Campello de Souza, a expansão e centralização burocrática do período não se desvincula da dinâmica corporativista da época, e se deram "sob o signo da absorção ou cooptação dos agrupamentos de interesse, quer regionais, quer funcionais" (SOUZA, 1983, p.103).

Esse contexto doméstico se desenrolava sob influência da turbulenta conjuntura internacional que caracterizou o período entre a crise de 1929 e a Segunda Guerra Mundial, marcada por depressão econômica; desemprego; crescimento de movimentos

\footnotetext{
${ }^{125}$ Nesse sentido, a reforma do funcionalismo contou com medidas de profissionalização gradativas que culminara, em 1937, com a criação do Departamento Administrativo de Serviço Público (DASP), agência administrativa encarregada do funcionalismo público. Respondendo diretamente ao Presidente da República e investido de amplos poderes, o DASP implementou importantes reformas no governo Vargas, dentre as quais a adoção da regra da obrigatoriedade de concurso para ingresso nas carreiras públicas e supervisão do processo de gestão do pessoal segundo critérios meritocráticos (GEDDES, 1994; ABRUCIO et al., 2010; NUNES, 2010).
} 
sociais socialistas e fascistas; e divisão do mundo em blocos antagônicos, com competição entre as potências para ampliar sua área de atuação estratégica (MOURA, Gerson, 2012; CERVO, 2005). Neste cenário, autores apontam que o Brasil buscou redefinir sua inserção na ordem capitalista internacional (GAMBINI, 1977) a partir da adoção de um conceito norteador para a política exterior que viria a perdurar na sua história: o de desenvolvimento. O nacional-desenvolvimentismo que começou então a ser desenhado compreendeu a busca do desenvolvimento interno pela via da política externa (MANZUR,2014). Como analisa Amado Cervo:

\footnotetext{
O esquema de relações internacionais que teve origem nos anos trinta passou a funcionar adaptando-se às circunstâncias em termos conceituais e operativos pelas décadas a seguir. Produziu efeitos sobre a formação nacional durante sessenta anos, em três etapas: a montagem do parque industrial nacional, seu equipamento em matéria de fatores básicos e de sustentabilidade, enfim, a capacitação tecnológica alcançada pelas grandes empresas de matriz nacional (CERVO, 2005, p.16).
}

Mas não apenas o objetivo do desenvolvimento definiu a política externa nos governos Vargas: também a marcou o procedimento por ele adotado para negociações, jogando com os atores internacionais que visavam a ampliar sua presença no Brasil (GAMBINI, 1977; MOURA, Gerson, 2012), ao mesmo tempo em que tentava conciliar os interesses de distintos atores domésticos.

Nesta reconfiguração de forças sociais e políticas, modificou-se também o interesse nacional em temática migratória. Com efeito, é a própria percepção de interesse nacional que cambia: antes percebido como uma resultante dos interesses da oligarquia agrária, agora se complexifica, compondo o objetivo mais amplo de desenvolvimento a partir de diferentes visões. Nesse contexto, o governo Vargas trouxe a questão migratória ao epicentro da agenda política, transformando-a em problema político a ser debatido por vários grupos sociais - excetuando-se os próprios imigrantes.

Isso porque a temática foi instrumentalizada como fundamento do discurso nacionalista que marcou a década de 1930, baseado no slogan "promover o homem brasileiro e defender o desenvolvimento econômico e a paz social do país" (CARNEIRO, 2003, p.06). Como aponta Gilda Gouvêa, simultaneamente à reforma do Estado, "tentava-se introduzir a língua da Nação" (1994, p.80), de modo a contrapor-se ao discurso particularista dos coronéis da República Velha. Por conseguinte, de acordo com a análise de Lesser, 
O nacionalismo viria transformar antigas ideias sobre o "branqueamento" do Brasil em políticas federais voltadas para o "abrasileiramento". Isso acabaria por conduzir a um movimento anti-estrangeiros plenamente desenvolvido entre muitos funcionários federais e estaduais (1994, p.98).

A política migratória nesses termos construída imprimiu em suas instituições argumentos que combinavam considerações sobre desemprego com aquelas de ordem racial e política. Para Getúlio Vargas, "Os imigrantes devem constituir (...) uma força para o progresso (...) (mas) devemos nos resguardar contra a infiltração de elementos que possam ser transformados em dissidentes ideológicos ou raciais" (apud LESSER, 1994, p.32).

Note-se que a depressão iniciada em 1929 foi acompanhada de uma redução radical nos deslocamentos migratórios mundiais, e os governos de alguns países, como o dos Estados Unidos, passaram a estimular e assistir o retorno voluntário (TAFT; ROBBINS, 1955). Nesse contexto, entre 1929 e 1930 verificou-se uma redução acentuada da entrada de imigrantes no Brasil, correspondente a 30\% (LESSER, 1994, p.86). Não obstante esta diminuição, o governo brasileiro adotou em suas instituições a lógica da limitação da entrada de estrangeiros, com o argumento de proteção do trabalhador nacional.

Assim, o Decreto $n^{\circ} 19.482$, de 12 de dezembro de 1930, conhecido como "Lei de Dois Terços", estabeleceu que as empresas deveriam apresentar, entre seus empregados, pelo menos dois terços de brasileiros natos. Restringiu a entrada de "passageiros de terceira classe" àqueles já domiciliados no país, aos solicitados pelo Ministério do Trabalho para serviços agrícolas, aos portadores de cartas de chamada (emitidos por parentes a famílias de agricultores com colocação certa), e a famílias de agricultores. Foi regulamentado pelo Decreto 20.291/1931, que definia o objetivo de "nacionalização do trabalho ${ }^{126 "}$. O então Ministro do Trabalho, Lindolfo Collor, alegou o objetivo de "Não permitir que, daqui em diante, os desocupados das indústrias e do comércio de outros países venham, dentro de nossas fronteiras, desalojar das suas ocupações os trabalhadores nacionais" (apud SAKURAI, 2000, p.96). Ressalte-se que a Consolidação das Leis do Trabalho, de 1943 e ainda vigente, mantém esta mesma exigência para as empresas dos $2 / 3$ dos postos de trabalho ocupados por brasileiros (art. $354)$.

\footnotetext{
${ }^{126}$ Foi seguido pelo decreto 20.303/1931, que nacionalizou a marinha mercante e reservou os serviços marítimos exclusivamente aos brasileiros natos.
} 
Após a criação do Ministério do Trabalho, Indústria e Comércio (Decreto $\mathrm{n}^{\circ}$ $19.667 / 1931^{127}$ ), foi-lhe transferida a competência para questões de povoamento e entrada de estrangeiros, serviços de imigração e colonização - atribuições estas que seguiriam atreladas ao Ministério do Trabalho até 1954. Se a constituição da classe operária brasileira foi marcada por trabalhadores estrangeiros e por sua contribuição para a formação de movimentos de classe (BEIGUELMAN, 1987; VAINER, 2000), o corporativismo que marcou o governo Vargas ressignificou as relações entre o governo brasileiro e os estrangeiros a partir do prisma do trabalho.

O corporativismo atuou como importante instrumento de controle e vinculação do trabalho ao Estado, consistindo em "mecanismo que serve ao propósito de absorver de forma antecipada o conflito político através da incorporação e da organização do trabalho" (NUNES, 2010, p.58) ${ }^{128}$, por meio de controle do movimento trabalhista e cooptação dos seus líderes pelo governo, proibição do direito de greve e legislação trabalhista protetiva. Observe-se que o corporativismo se relaciona com o conceito descrito por Santos (1979) como cidadania regulada, isto é, com a definição da extensão da cidadania via regulamentação de profissões e ocupações e via ampliação dos direitos a elas associados, que caracterizou o período entre 1930 e 1964. Nesses termos, "a regulamentação das profissões, a carteira profissional e o sindicato público definem, assim, os três parâmetros no interior dos quais passa a definir a cidadania" (SANTOS, 1979, p.76).

Nesse contexto, os direitos dos imigrantes eram, também, cingidos ao local que a lei lhes concedia ocupar dentro do processo produtivo - local este de exceção, isto é, ofertado em caráter suplementar, após priorização do trabalhador nacional. Desta forma, a cidadania do imigrante, sujeita a mais condicionalidades e restrições que a dos brasileiros com fundamento na nacionalidade, era duplamente regulada.

Esta nova visão sobre imigração repercutiu na atuação do Itamaraty, desenvolvendo-se em paralelo a modificações em sua estrutura organizacional. Em 1931, iniciaram-se as reformas do órgão que viriam a fundir as carreiras de diplomatas, cônsules, e de oficiais da Secretaria de Estado, sob pretexto de que os diferentes serviços estariam atuando de maneira descoordenada, e sem a adequada formação

127 Disponível em: http://www2.camara.leg.br/legin/fed/decret/1930-1939/decreto-19667-4-fevereiro1931-503116-publicacaooriginal-1-pe.html. Acesso em: 16 mai 2016.

${ }^{128}$ Nunes (2010), dentre vários autores, salienta a diferença entre o corporativismo à brasileira e o corporativismo societal de outros países. 
técnica (REL.EXT., 1931, p.11) ${ }^{129}$. O fortalecimento burocrático da instituição se inseria, ademais, dentro da tendência maior de reforma do funcionalismo pelo governo Vargas. Dentre outras mudanças estruturais, criaram-se escritórios de propaganda e expansão comercial, além de um serviço de informações. Em 1933, o Itamaraty conduziu a implementação de um tipo de passaporte unificado para todo o território nacional.

Ministro das Relações Exteriores entre 1930 e 1934, Afrânio de Mello Franco, adotou diversas medidas para recrudescer as fronteiras brasileiras em relação à influência da União Soviética, com a qual o Brasil rompera relações em 1918. Segundo relata Stanley Hilton (2013), sob comando de Mello Franco, o Itamaraty estabeleceu uma estreita troca de informações com a polícia do Distrito Federal sobre atividades subversivas, inclusive articulando uma cooperação anticomunista com a polícia argentina, e apoiou no governo brasileiro a adoção de restrições à imigração russa. Ressalte-se que os russos constituíam uma parcela importante do fluxo de refugiados da década de 1920, parte deles apátridas, visto que a União Soviética retirara a nacionalidade dos desertores do regime.

Não apenas a imigração daqueles vistos como indesejáveis politicamente preocupava o Itamaraty. Ao longo das décadas de 1930 e 1940, o corpo diplomático brasileiro enviou comentários periódicos sobre determinadas correntes migratórias ao Ministério, dentre as quais se destacaram a judaica e a japonesa. Quanto à primeira, aponta Lesser (1994) que:

\begin{abstract}
Aproximadamente vinte diplomatas brasileiros, a maioria nos níveis de embaixador ou cônsul-geral, argumentaram ativamente contra a concessão de vistos para judeus. Todos haviam progredido em suas carreiras de forma mais marcante após Vargas haver assumido o poder e diversos haviam sido promovidos a cargos de embaixador ou cônsul-geral no espaço de um ano após o estabelecimento do Estado Novo (LESSER, 1994, p.106).
\end{abstract}

Não obstante as limitações, entre 1933 e 1942, quase vinte e cinco mil judeus entraram legalmente no Brasil, em sua maioria alemães e poloneses fugindo do nazismo. Isso porque, a despeito do declínio da migração voluntária, a migração com razão política, de indivíduos fugindo das guerras ou dos Estados, se recrudescia e viria atingir seu ápice com a eclosão da II Guerra:

\footnotetext{
${ }^{129}$ A Reforma Mello Franco (1931) iniciou o processo de fusão das carreiras, que foi concluído em 1938 pela reforma Oswaldo Aranha.
} 
Just as the immigrant worker was the symbol of the great overseas movement of eastern and southern Europeans prior to World War I, so the 'homeless refugee' became the symbol of the international crisis which broke one after the other between 1937 and 1939 (TAFT; ROBBINS, 1955, p.35).

Marque-se, contudo, que não havia à época uma clara distinção conceitual entre migrantes laborais, apátridas e refugiados - o que só viria a ocorrer com o Estatuto de Refugiados, de 1951. Sem embargo, os deslocados involuntários já se apresentavam como problema para a sociedade internacional desde o fim da I Guerra, tendo sido abordado pela Liga das Nações em 1921, com a criação do cargo de Alto Comissário da Liga das Nações para Refugiados, com mandato legal para tratar do tema dos refugiados, a partir de uma abordagem laboral e em parceria com organizações voluntárias aptas a coordenar atividades de assistência (FARIA, Maria Rita, 2015). O então Alto Comissário, Fridjtof Nansen, teve êxito na negociação dos acordos que criaram o "passaporte Nansen”, documento de identificação, aceito internacionalmente, conferido pela Liga aos refugiados. Em 1930, o Alto Comissariado foi institucionalizado como estrutura permanente na Liga, intitulado Nansen International Office for Refugees.

Em 1932, o Nansen International Office for Refugees solicitou que o governo brasileiro acolhesse cerca de 20 mil refugiados assírios, argumentando, para tanto, tratar-se de "uma população cristã", de "raça ariana, sem qualquer característica semítica ou árabe" (CARNEIRO, 2003, p.8). O governo acedeu ao pedido, desde que em grupos de 500 indivíduos.

Em 1933, o Escritório Nansen promoveu a assinatura da Convenção sobre o Estatuto Internacional dos Refugiados, a qual obteve a ratificação de apenas nove países, mas logrou inserir no repertório do Direito Internacional o conceito de nonréfoulement, isto é, a proibição dos países signatários expulsarem os refugiados para territórios em que suas vidas são ameaçadas, sejam seus países de origem ou países terceiros (FARIA, 2015).

Ainda em 1933, Conferência da OIT discutiu o crescimento dos refugiados vindos da Alemanha, a pedido de países europeus temerosos da pressão que poderia ser exercida sobre seus mercados de trabalho (FARIA, 2015). Em consequência, a Liga das Nações nomeou James McDonald, um diplomata norte-americano, como Alto Comissário para Refugiados (Judeus e Outros) Vindos da Alemanha, a fim de negociar e conduzir a "colaboração interna" necessária para resolver o "problema econômico, 
financeiro e social" dos refugiados não-arianos perseguidos na Alemanha nacionalsocialista (MCDONALD, 1935, p.5). Dentre as negociações por ele empreendidas, o Alto Comissário concentrou esforços para que o Brasil aceitasse refugiados, objetivo frustrado após intensa campanha contrária dos nativistas. Jeffrey Lesser (1994) narra as longas negociações empreendidas entre McDonald, Vargas e funcionários de alto escalão do governo, sugerindo que "Vargas esperava desarmar a pressão internacional, ao dar impressão de que iria estudar exceções à política brasileira. McDonald ficou impressionado com o tratamento que recebeu" (LESSER, 1994, p.129). O autor coloca, ainda, que esta estratégia se inseriria no modus operandi do presidente na condução das relações internacionais do país: "Getúlio Vargas era adepto de promover falsas esperanças entre os observadores internacionais, uma estratégia que utilizaria para lidar com a questão dos refugiados até deixar o poder em 1945” (LESSER, 1994, p.130).

Ainda segundo Lesser, o período foi marcado pela visão, presente na opinião pública e na mídia, de que o Itamaraty estaria apoiando a vinda dos refugiados, em contraponto à oposição de outros setores do governo - capitaneados por Agamenon Magalhães, o Ministro do Trabalho, Indústria e Comércio, que se havia oposto publicamente aos planos de McDonald. De fato, além das discussões da sede com o Alto Comissário para Refugiados e com o Escritório Nansen, o MRE, por meio de determinados diplomatas lotados em países europeus, atuou em negociações descentralizadas quanto à vinda de grupos de refugiados para o Brasil. Entretanto, as incongruências não eram apenas interburocráticas, mas também intraburocráticas. Lesser (1994) cita o exemplo de pedido do embaixador Souza Dantas ${ }^{130}$, em 1934, após encontrar-se com James McDonald, de permissão de entrada de seiscentos imigrantes judeus alemães por mês, durante seis meses, para o Brasil. A requisição foi remetida ao Ministério do Trabalho, que não objetou e encaminhou para o Itamaraty, órgão que acabou por recusar o pedido. Nesse contexto, o historiador Benjamin Moser sustenta que "A ideologia racista que muitos diplomatas tinham absorvido na Escola Nacional de Direito do Rio de Janeiro fazia do MRE um bastião do antissemitismo" (2011, p.236).

Além de iniciativas de burocratas do Itamaraty, o apoio de governos estaduais para a vinda de refugiados também existia, inclusive com a contratação de acadêmicos judeus alemães para auxiliar na agricultura em São Paulo. No entanto, tais medidas não

\footnotetext{
${ }^{130}$ Souza Dantas, embaixador brasileiro em Paris entre 1922 e 1942, é o exemplo mais conhecido de diplomata que praticou auxílio humanitário ao emitir vistos para perseguidos do nazismo, muitas vezes de maneira irregular, em razão de que foi afastado do cargo (MOSER, 2011; KOIFMAN, ).
} 
foram suficientes para modificar a tendência ao fechamento de fronteiras das normas federais - tendência essa verificada mundialmente. Já em 1935, McDonald resignou de seu cargo, afirmando que, embora houvessem conseguido, com o auxílio de organizações filantrópicas, realocar aproximadamente $75 \%$ dos 80.000 refugiados no período, a situação na Alemanha degenerara de tal forma que o desenho institucional do Alto Comissariado (apartado do organograma da Liga das Nações); a baixa capacidade de absorção de refugiados pelos países europeus; a depressão econômica que tornou o desemprego a preocupação central das agendas políticas e o consequente fechamento de fronteiras de países antes incentivadores de fluxos imigratórios havia tornado o refúgio um problema internacional de difícil resolução (MCDONALD, 1935).

Com o decreto $\mathrm{n}^{\circ}$ 24.215, de 09 de maio de 1934, Getúlio Vargas consolidou sua política de restrição à entrada de estrangeiros, enumerando as condições que impediriam a entrada e seu procedimento de fiscalização. O decreto $\mathrm{n}^{\mathrm{o}} 24.258 / 1934^{131}$, que o regulamentou, dividia os imigrantes em duas categorias, agricultores e não-agricultores, sendo que para os segundos, a entrada só seria permitida em casos excepcionais. Quanto aos imigrantes agrícolas, poderiam entrar por chamado de governos estaduais, de empresas ou proprietários rurais que os contratassem, ou por "cartas de chamada" assinadas por agricultores já residentes no país. Para operacionalização desses mecanismos, o Ministério do Trabalho atuaria em parceria com os consulados brasileiros.

A trajetória da política migratória brasileira teve, na Constituição de 1934, o ápice de seu caráter restritivo. Aos rígidos procedimentos de fiscalização e às barreiras de entrada já desenhadas no decreto $\mathrm{n}^{\circ} 24.215$, adicionou-se um novo elemento de limitação por meio do art. $121, \S 6^{\circ}$, do texto constitucional ${ }^{132}$ : as cotas por nacionalidade, as quais previam que a corrente imigratória de cada país não poderia exceder, anualmente, o limite de dois por cento sobre o número total dos respectivos nacionais fixados no Brasil durante os cinquenta anos anteriores. Tal medida favorecia indiretamente nacionais de países europeus, especialmente Portugal ${ }^{133}$ e Itália, e

\footnotetext{
${ }^{131}$ Disponível em: http://www2.camara.leg.br/legin/fed/decret/1930-1939/decreto-24258-16-maio-1934557864-publicacaooriginal-78583-pe.html. Acesso em: 11 abr 2016.

${ }^{132}$ Posteriormente acolhida no artigo 151 da Constituição de 1937.

${ }^{133}$ De fato, Mendes (2013) mostra como, entre 1930 e 1940, a corrente de imigrantes portugueses foi mesmo incentivada, estando presente no discurso das autoridades do Brasil e Portugal a ideia de que ambos os povos se aproximavam etnicamente.
} 
rejeitava aqueles correspondente a fluxos recentes para o Brasil, como judeus e japoneses.

Nesses termos, a Constituição de 1934 não apenas se propunha a delinear uma ordem política, como também uma ordem nacional, estruturada sobre argumentos étnicos e culturais. Seu texto foi elaborado em Assembleia Constituinte que teve, na questão migratória, o epicentro de acalorados debates. Neles, percebe-se a inspiração em modelos teóricos produzidos por racialistas europeus, influenciados pela ideia de eugenia e almejando a homogeneidade racial (CARNEIRO, 2003) ${ }^{134}$. No seu discurso de abertura das sessões da Assembleia, Vargas defendeu a necessidade de povoar o território brasileiro e de prover braços para o cultivo da terra, porém ressalvou a impossibilidade de continuar-se uma política de livre entrada de imigrantes (GERALDO, 2009a).

Ressalte-se que os debates da assembleia se referiam à proposição de emendas elaboradas para modificar o texto de anteprojeto de Constituição elaborado pelo que ficou conhecida como a "Subcomissão do Itamaraty", por ser presidida pelo Ministro das Relações Exteriores, Afrânio de Mello Franco, e por suas reuniões terem lugar no Palácio do Itamaraty. O texto original já previa mudanças na temática migratória, modificando a competência concorrente entre União e estados, prevista na Constituição anterior, por acreditar que o tema pertencia ao âmbito da de defesa nacional; e colocando que a entrada individual de imigrantes seria controlada a partir de exames médicos e policiais, e que a coletiva seria selecionada ou impedida pelo Congresso. Entretanto, as cotas foram-lhe inseridas por deputados no transcorrer dos debates ${ }^{135}$, tendo sido aprovadas por 146 deputados a favor, contra 71 que se opuseram.

Sakurai (2000) reúne os discursos dos deputados constituintes sobre a questão das cotas, sublinhando os de Xavier de Oliveira, Artur Neiva e Miguel Couto, que se

\footnotetext{
${ }^{134}$ Acadêmicos, jornalistas e políticos tiveram um importante papel na difusão de ideias nativistas de caráter eugênico no Brasil. Destaca-se a atuação de Oliveira Vianna, advogado, historiador e professor na Faculdade Nacional de Direito (na qual se formaram vários dos diplomatas à época), autor de Raça $e$ Assimilação, no qual expõe sua opinião sobre a indesejabilidade do imigrante japonês por ser "como o enxofre, inassimilável" (1959, p.155). Entretanto, o movimento eugenista brasileiro em muito transcendia a figura de Vianna, materializando-se em congressos nacionais que reuniam políticos, acadêmicos, médicos, dentre outros membros da elite brasileira, conforme expõe Lesser (1994).

${ }^{135}$ A proposta original de Xavier de Oliveira era de proibição de entrada de africanos e cota de $2 \%$ para asiáticos, a qual reunia mais de 130 assinaturas. Segundo Geraldo (2009a), foi a pressão realizada pelo Itamaraty sobre esta proposta que levou à sua reformulação, estabelecendo cotas de $2 \%$ para todos os imigrantes.
} 
opunham à imigração japonesa sob argumentos da defesa da brasilidade ${ }^{136}$ e do temor quanto à posição ocupada, à epoca, pelo Japão no cenário internacional, reforçado com a invasão da Manchúria. Desta forma, unia-se a noção de formação nacional à de segurança nacional. Percebe-se, ainda, nos discursos dos deputados a demanda para que uma política de imigração brasileira, rígida, lograsse fazer frente às políticas de emigração delineadas pelos países de origem, de modo a fazer prevalecer os interesses do Brasil em detrimento dos estrangeiros (Xavier de Oliveira, 1934, apud SAKURAI, 2000, p.96).

O deputado Xavier de Oliveira pronunciou-se, ainda, contra "a política de imigração que vem seguindo certos órgãos do Governo Provisório, em especial o Itamaraty" (GERALDO, 2009a, p. 185), referindo-se à possibilidade de entrada no Brasil de 14 mil refugiados assírios, em resposta a demanda da Sociedade das Nações. Geraldo (2009a) narra que, em resposta à declaração, o Itamaraty afirmara que seu papel era de intermediário entre o governo brasileiro e a Sociedade das Nações e algumas potências europeias, porém que a responsabilidade do projeto era do Ministério do Trabalho - ao que Xavier retrucou que este último apenas cedera às pressões do MRE.

Leão Neto (1989) classifica o movimento contrário à imigração nipônica, deflagrado na Assembleia Constituinte e reforçado na imprensa brasileira, como a crise da imigração japonesa, a qual teria instado a atuação do Itamaraty. De fato, a tensão suscitou negociações diplomáticas entre os dois países, com forte pressão do governo japonês - de tal modo que, ao cabo da constituinte, o embaixador japonês no Brasil e o Ministro das Relações Exteriores no Japão pediram demissão dos seus cargos (SAKURAI, 2000, p.67). Nesse período, o governo japonês vinha implementando uma estratégia de importar algodão produzido pelos seus colonos no Brasil, na expectativa de exportar produtos têxteis para o país.

Como resultado da Assembleia, a Constituição de 1934 centralizou na União a competência para legislar sobre "naturalização, entrada e expulsão de estrangeiros, extradição; emigração e imigração, que deverá ser regulada e orientada, podendo ser

\footnotetext{
${ }^{136}$ Em trecho de discurso proferido na Assembleia, Xavier de Oliveira afirmara: "Senhores, sou brasileiro, autêntico, nacionalista e integral nativista convicto. Amo, acima de tudo, a minha Pátria. E se não tenho, repito, preconceitos de raça, tenho, entretanto, o preconceito da minha nacionalidade! Quero, assim, ver a nação brasileira eugenicamente sadia, educada e feliz, vivendo em paz e em harmonia com todos os países do globo!" (apud SAKURAI, 2000, p.64).
} 
proibida totalmente, ou em razão da procedência" (art. $5^{\circ}$, XIX, g). Esta disposição é complementada pelo artigo 121, segundo o qual:

$\S 6^{\circ}$ - A entrada de imigrantes no território nacional sofrerá as restrições necessárias à garantia da integração étnica e capacidade física e civil do imigrante, não podendo, porém, a corrente imigratória de cada país exceder, anualmente, o limite de dois por cento sobre o número total dos respectivos nacionais fixados no Brasil durante os últimos cinquenta anos. $\S 7^{\circ}$ - É vedada a concentração de imigrantes em qualquer ponto do território da União, devendo a lei regular a seleção, localização e assimilação do alienígena.

Ao instituir, aos moldes corporativistas, um sistema de eleição para a Câmara dos Deputados composto de algumas cadeiras eleitas por sufrágio universal e outras ocupadas por representantes eleitos por organizações profissionais (art.23), a Constituição frisava que, em nenhum dos mecanismos, os estrangeiros teriam direito a voto (art.23 c/c 108). Além disso, a fim de instrumentalizar seus objetivos nacionalistas, a Carta estabeleceu que a educação deveria ser proporcionada pelos Poderes Públicos a brasileiros e estrangeiros domiciliados no País, sendo que, nos estabelecimentos particulares, o ensino deveria ser ministrado em português (art.149, parágrafo único, $d$ ).

Sem embargo, a Constituição de 1934 repetia quase literalmente a fórmula da Carta de 1891 assegurando a igualdade, perante a lei, de brasileiro e estrangeiros (art.113), proibia a diferença salarial para o mesmo trabalho por motivo de nacionalidade (art.121, $\S 1^{\circ}, a$ ); e até dispunha que "em tempo de paz, salvas as exigências de passaporte quanto à entrada de estrangeiros, e as restrições da lei, qualquer pessoa pode entrar no território nacional, nele fixar residência ou dele sair" (art.113, 14).

Ressalte-se que, nos anos de vigência do sistema, as cotas anuais designadas aos portugueses, italianos, espanhóis e alemães não foram preenchidas. Ao contrário, todas as correntes caíram significativamente ${ }^{137}$, tanto em razão da conjuntura socioeconômica internacional, quanto em decorrência dos elementos restritivos que vinham sendo incorporados à legislação imigratória, como a exigência de cartas de chamada, a proibição da concessão de vistos a analfabetos, a canalização da imigração para o campo (MENDES, 2013; CERVO, 1992; SOUZA, 2010).

\footnotetext{
${ }^{137}$ À exceção da alemã no ano de 1937, às vésperas da II Guerra, que quase atingiu o máximo de 4.772 desembarques permitidos em lei (MENDES, 2013).
} 
Sobre a questão imigratória na Constituição de 1934, Vargas se pronunciou em mensagem apresentada ao Congresso Nacional em 03 de maio de 1935, analisando que, não obstante a relevância das resoluções adotadas no sentido da assimilação dos imigrantes e controle dos fluxos, a opção pelas cotas de entrada de estrangeiros não se coadunaria com a rigidez dos textos constitucionais (1935, p.126). Em decorrência, afirma que "o Governo organizou uma comissão, composta de membros governamentais e especialistas nos assuntos relativos à imigração e à eugenia, incumbindo-a de estudar a questão ${ }^{138}$,. Vargas salientava que o critério constitucional, além de exigir grande esforço estatístico e suscitar inúmeras dificuldades conceituais, estaria em desacordo com as demandas por mão-de-obra das fazendas e com as necessidades de povoamento do território. Afirmou ainda que:

Para compreender os inconvenientes de semelhante restrição, intransponível pelo fato de estar contida num dispositivo constitucional, basta observar que só de colonos japoneses as fazendas paulistas precisam de cerca de 40.000 para o ano corrente. Dentro do limite fixado, não é possível a entrada dos referidos colonos, como também não é possível suprir o déficit com elementos de outras nacionalidades, igualmente sujeitos à quota de $2 \%$ (1935, p. 127).

No entanto, se havia interesse na vinda de imigrantes, por que a adoção de normas que restringiam sua entrada? $\mathrm{Na}$ visão de Vargas, o objetivo da política migratória seria "armar o Estado de instrumentos e recursos que assegurem o desdobramento de uma política capaz de acelerar o processo de nacionalização dos contingentes migratórios" (idem, p.124). Justificou, ainda, a legislação imigratória já adotada por seu governo com o argumento da proteção do trabalhador nacional em um contexto em que já se notavam sintomas de desemprego nas cidades e centros industriais, asseverando que apenas os estrangeiros agricultores ou com outro destino rural seriam aceitos, sendo vedada a entrada de indesejáveis, tais como aqueles inaptos para o trabalho ou os "considerados nocivos à sociedade, à ordem e à segurança nacional" (p.124).

A mensagem de Vargas torna patente sua estratégia política de composição entre interesses fragmentados. Na opinião de Lesser, isto se direcionaria não a um objetivo de conciliação, mas sim de estimular "a tensão entre as forças políticas rivais como uma

\footnotetext{
${ }^{138}$ Da Comissão faziam parte: Dr. Roquette Pinto, antropólogo e diretor do Museu Nacional, Dr. Renato Kehl, eugenista; Conde Debanné, antigo cônsul do Brasil nos países do Oriente; Dr. Dulphe Pinheiro Machado, antigo Diretor do Departamento do Povoamento; Dr. Vaz de Mello, Diretor dos Serviços de Passaportes do Ministério das Relações Exteriores; Raul de Paulo, representante da Sociedade dos Amigos de Alberto Torres; Dr. Oliveira Vianna, consultor jurídico do governo.
} 
forma de aumentar e consolidar seu próprio poder" (1994, p.99). Interesses fragmentados estavam, também, presentes nas forças políticas que buscavam atuar sobre a política migratória: a elite agrária das regiões Sul e Sudeste demandavam mão-de-obra barata; determinados deputados e seus eleitorados urbanos pleiteavam uma legislação imigratória restritiva com fundamento em discurso xenófobo e na proteção do trabalhador nacional; militares, que vinham ganhando importância como grupo de interesse, avançavam argumentos securitários. Enquadrando os debates, a Constituição de 1937 mantinha, muitas vezes de maneira literal, as disposições de sua antecessora no que atine aos estrangeiros - marcadas por seu caráter restritivo, porém ambíguo o suficiente para permitir manobras na condução da política migratória.

Ressalte-se que este jogo político de Vargas tinha seu correspondente no plano internacional: nas palavras de Gambini, tratava-se da "neutralização das forças políticas no plano interno e a política de duplo compromisso no externo" (GAMBINI, 1977, p.77). Ambas as dimensões são acentuadas no Estado Novo, período caracterizado pela personalização do processo de tomada de decisões, estreitamento dos círculos decisórios e divisões políticas no interior do aparato estatal, o que, segundo Gerson Moura (2012), conferia a Vargas o poder do voto de Minerva. Sua política externa dúbia em relação aos países do Eixo e dos Aliados, cultivada de modo a atribuir-lhe determinado poder de barganha junto às potências, foi definida por Gerson Moura como política de "equilíbrio pragmático" (2012, p.51). Envolvia, de um lado, perseguir externamente objetivos internos do governo Vargas, sendo eles reequipar as forças armadas e atrair investimentos, particularmente de modo a obter uma grande siderúrgica. De outro, correspondia ao contrabalanço das preferências distintas presentes no debate doméstico, envolvendo diferentes grupos de interesse e órgãos estatais (MOURA, 2012).

A política de equilíbrio pragmático compreendeu, outrossim, a composição do governo com indivíduos favoráveis ao Eixo e aos americanos (CERVO, 1992, p.22), sendo exemplo deste último caso o Ministro das Relações Exteriores, Oswaldo Aranha. Aranha fora um dos líderes políticos da Revolução de 1930, e ocupou postos de ministro da Justiça, ministro da Fazenda e embaixador em Washington antes de ser nomeado ministro das Relações Exteriores, em 1938 - segundo Moura, como uma cartada de Vargas para agradar o governo norte-americano (2012, p.55).

À época, o Serviço de Passaportes do MRE vinha ampliando gradativamente suas atividades, sendo que em 1937 lhe fora atribuída a seu cargo a elaboração e 
transmissão de instruções sobre a entrada de estrangeiros em território nacional e a expulsão de indesejáveis (REL.EXT., 1937). O relatório do Ministério das Relações Exteriores daquele ano narra que:

Ainda em 1937, pela primeira vez no Brasil, cogitou-se proibir a imigração de certos elementos inassimiláveis. Tratando-se de medidas que contrariavam interesses importantes, elas provocavam, como seria de prever, numerosos protestos. Mas, de um modo geral, pode-se dizer que tais disposições foram cumpridas. A entrada de elementos inassimiláveis que, nos anos anteriores, havia crescido espantosamente, diminuiu (REL.EXT., 1937, p.109-110).

O relatório informava, ainda, sobre a proibição então vigente de conceder vistos a apátridas. Em paralelo a tal interdição, em 07 de junho de 1937, a circular secreta 1.127 do MRE, pessoalmente autorizada por Getúlio Vargas, proibiu a concessão de vistos para todas as pessoas de "origem semítica" (LESSER, 1994, p.22), o que levou a uma redução em $75 \%$ na imigração judaica no ano seguinte ${ }^{139}$. O então secretário-geral do MRE, Hildebrando Accioly, em ofício secreto para Oswaldo Aranha, afirma, sobre a circular secreta, tratar-se de resultado de entendimento entre o Ministério do Trabalho, MRE e da Presidência da República, motivo pelo qual a indesejabilidade dos judeus para o governo brasileiro seria indiscutível - além de ser justificada pela alteração na composição étnica brasileira que seria produzida caso entrassem indivíduos vistos como inassimiláveis e subversivos (apud CARNEIRO, 2003).

Quando tornou-se patente a proibição de entrada de judeus no Brasil, a questão começou a ser discutida pelos governos americano e inglês, os quais passaram a tentar enfrentá-la, com o apoio de seus diplomatas no Brasil, especialmente junto a Oswaldo Aranha. O Brasil constituía, à época, o terceiro país com maior afluxo de refugiados judeus ${ }^{140}$, sendo visto como estratégico pelos EUA em seus planos de reassentamento. Desta forma, os norte-americanos adotaram o expediente de inserir a questão dos refugiados como moeda de troca em um movimento mais amplo de aproximação entre as nações.

Como consequência, já em 1938 verificou-se uma flexibilização da proibição sumária de entrada de judeus, embora a legislação continuasse restritiva e vistos permanentes continuassem sendo negados. Publicou-se a circular secreta $n^{\circ} 1.249$ do

\footnotetext{
${ }^{139}$ Uma década depois, em 25 de setembro de 1947, Oswaldo Aranha foi eleito presidente da Assembleia Geral das Nações Unidas, atuando ativamente junto ao representante brasileiro na organização, João Carlos Muniz, ex-diretor do Conselho de Imigração e Colonização, rumo à criação do Estado de Israel (LESSER, 1994).

${ }^{140}$ Em 1939, os EUA foram destino de 53,6\% da migração judaica, ante 34,1\% da Palestina, 5,7\% do Brasil e 5,3\% da Argentina (LESSER, 1994).
} 
Itamaraty, sobre "A Entrada de Israelitas em Território Nacional”, a qual circunscrevia a entrada de judeus a casos específicos ${ }^{141}$, mas já atenuava a total restrição da circular 1.127. Em decorrência, no ano seguinte, mais de quatro mil judeus entraram regularmente no Brasil, maior número registrado desde 1929 - em 1938, haviam sido 500 (LESSER, 1994). Ademais, planos de deportação coletiva que vinham sendo anunciados pelo Ministro da Justiça Francisco Campos foram abandonados, tendo ele declarado a repórteres estrangeiros que "o propósito do regime Vargas era fazer todo o possível para provar ao mundo, e aos Estados Unidos em particular, que o estado corporativo do Brasil não está motivado por nenhum espírito nazista ou fascista e não irá tolerar tais ideologias que se manifestem em opressões raciais ou religiosas" (apud LESSER, 1994, p. 186).

O ano de 1938 foi marcado por numerosos diplomas legais concernentes aos imigrantes, em esforço normativo com ares de engenharia social. São eles: o DecretoLei $\mathrm{n}^{\circ}$ 406, de 04 de maio de 1938, dispondo sobre a entrada de estrangeiros e criando o Conselho de Imigração e Colonização (CIC); o Decreto-lei $\mathrm{n}^{\circ} 383$, vedando aos estrangeiros o exercício de atividade política no Brasil; o Decreto-lei ${ }^{\circ} 392$, regulando a expulsão de estrangeiros; o Decreto-Lei $\mathrm{n}^{\circ}$ 389, regulando as naturalizações; o Decreto-Lei $n^{\circ} 639$ e os Decretos $n^{\circ} 3.010$ e 3.016, modificando e regulamentando o Decreto-Lei $n^{\circ} 406$; e o Decreto-Lei $n^{\circ} 948$, conferindo ao Conselho de Imigração e Colonização a atribuição de órgão gestor das políticas de assimilação da população de origem estrangeira; e o Decreto-Lei $\mathrm{n}^{\circ}$ 1.023-A, criando o Departamento Nacional de Imigração, o qual assumiu as atribuições do Departamento Nacional de Povoamento, dentro do quadro do Ministério do Trabalho, Indústria e Comércio.

O Decreto-Lei $\mathrm{n}^{\mathbf{0}} 406$ reafirmou cotas de acordo com as nacionalidades, conferiu ao governo federal o direito de limitar ou suspender a entrada de indivíduos de determinadas raças ou origens, e impôs inúmeras outras restrições de entrada relativas a características físicas ou à conduta dos indivíduos ${ }^{142}$. Condicionou, ainda, publicações em língua estrangeira à autorização federal, e proibiu às escolas rurais lecionarem em

\footnotetext{
${ }^{141}$ Portadores de licença de retorno; turistas e representantes de comércio, por no máximo seis meses; cônjuges ou parentes consanguíneos, até o $2^{\circ}$ grau; cientistas e artistas de reconhecido valor internacional; técnicos requisitados oficialmente por governos estaduais; capitalistas ou industriais que desejam fundar empresas ou sociedade no Brasil, comprovando a transferência de um capital mínimo de 500 contos.

${ }^{142}$ Dentre os impedimentos à entrada dispostos no artigo $1^{\circ}$, encontram-se: "I - aleijados ou mutilados, inválidos, cégos, surdos-mudos; II - indigentes, vagabundos, ciganos e congêneres; III - que apresentem afecção nervosa ou mental de qualquer natureza, verificada na forma do regulamento, alcoolistas ou toxicômanos; (...) VIII - de conduta manifestamente nociva à ordem pública, à segurança nacional ou à estrutura das instituições", dentre outros.
} 
língua estrangeira. Sem embargo, o diploma previa a atração de trabalhadores agrícolas para o país, por meio de tratados bilaterais, e regulamentava toda a estrutura governamental de recepção e integração dos imigrantes, inclusive por meio de hospedarias e transporte para as fazendas e indústrias agrícolas. Criou, ainda, um novo órgão formulador de política migratória, o Conselho de Imigração e Colonização. A fiscalização passaria a ser exercida em conjunto pela polícia e pelo Departamento de Imigração (órgão também criado em 1938 no seio do Ministério do Trabalho).

Quanto à naturalização, se antes era considerada um direito daquele estrangeiro que cumprisse determinadas condições, com o Decreto-Lei no 389 passou a constituir ato discricionário de autoridade administrativa. Também a expulsão, com o Decreto-lei n 392 , deixou de exigir, para os crimes de natureza política, a condenação do indivíduo, bastando o simples indiciamento.

No que se refere à vedação do exercício de atividade política determinada pelo decreto-lei $n^{\circ} 383 / 1938^{143}$ e sua regulamentação, atribuiu ao Ministério da Justiça a competência de concessão do direito de funcionamento para associações de estrangeiros, bem como sua cassação. Esta providência, reforçada pela ampliação de competências do MJ concernentes à permanência de estrangeiros definida pelo DecretoLei $\mathrm{n}^{\mathrm{o}} 1.532 / 1939$, inaugurou a tendência, que viria a se verificar no Estado Novo, de canalização das atribuições relacionadas à imigração para este Ministério.

É interessante pontuar-se, ainda sobre o decreto-lei no 383/1938, que a redação do seu artigo $1^{\mathrm{o}}$, qual seja, "Os estrangeiros fixados no território nacional e os que nele se acham em caráter temporário não podem exercer qualquer atividade de natureza política nem imiscuir-se, direta ou indiretamente, nos negócios públicos do país", foi recepcionada pelas legislações que a sucederam, inclusive pelo artigo 107 da Lei $\mathrm{n}^{\circ}$ $6.815 / 1980$, segundo o qual "o estrangeiro admitido no território nacional não pode exercer atividade de natureza política, nem se imiscuir, direta ou indiretamente, nos negócios públicos do Brasil" ${ }^{\text {144. }}$.

A criação do Conselho de Imigração e Colonização (CIC) correspondeu ao propósito de centralização institucional a fim de tornar mais eficiente o controle e a gestão migratória: objetivou-se formar um órgão misto que aglutinasse os atores de

${ }^{143}$ Disponível em: http://www2.camara.leg.br/legin/fed/declei/1930-1939/decreto-lei-383-18-abril-1938350781-publicacaooriginal-1-pe.html. Acesso em: 13 set 2016.

${ }^{144}$ Os incisos de ambos os dispositivos, elencando as atividades especialmente vedadas, também se aproximam bastante. 
execução, antes com competências fragmentadas, e reunisse competências normativas. O órgão estava subordinado diretamente à Presidência da República, e seus membros foram nomeados por Vargas entre representantes de Ministérios e órgãos do governo ${ }^{145}$. Em sua primeira reunião, em 26 de setembro de 1938 no Palácio do Itamaraty, o presidente do Conselho, diplomata João Carlos Muniz, anteriormente chefe de gabinete de Oswaldo Aranha, descreveu o objetivo da política migratória brasileira como "atrair para o país e nele fixar trabalhadores estrangeiros que correspondam, em quantidade e qualidade, às necessidades econômicas e étnicas do Brasil", de uma maneira "dosada, controlada pelo Estado" (apud GERALDO, 2009b, p.175).

Ao CIC foram atribuídas, pois, responsabilidades relacionadas ao caráter racial da política imigratória brasileira, sob o paradigma da "assimilação dos alienígenas" (Decreto-lei $\mathrm{n}^{\mathrm{o}}$ 938) ${ }^{146}$. Cabia-lhe determinar as quotas de admissão de estrangeiros no território nacional e julgar o cumprimento da formação étnica dos núcleos de colonização e centros agrícolas; limitar ou suspender a entrada de indivíduos de determinadas raças ou origens; e conceder licença de imigração coletiva para estados, sociedades, empresas e particulares que pretendessem introduzir estrangeiros. A ideia de assimilação era defendida por meio da proibição de que colônias ou centros agrícolas fossem formados por indivíduos de apenas uma nacionalidade, sendo que cada núcleo deveria possuir um mínimo de $30 \%$ de brasileiros, e não mais que $25 \%$ de cada nacionalidade estrangeira.

À época, uma das iniciativas do CIC foi sugerir ao MRE celebrar tratados de imigração com Dinamarca, Finlândia, Noruega, Países Baixos, Portugal, Suécia, Suíça e Iugoslávia, cujo perfil corresponderia ao de imigrante desejável (GERALDO, 2013). Nesse sentido, relatório de atividades do primeiro ano do Conselho explicitava que:

(...) a política imigratória que mais convém é a que tem em vista evitar os elementos indesejáveis e os de difícil assimilação e promover a entrada de

\footnotetext{
${ }^{145} \mathrm{Na}$ formação original, o presidente do CIC era João Carlos Muniz (Itamaraty), seus vices eram dois militares, o Capitão Attila Monteiro Aché e o Major Aristóteles de Lima Câmara, e os demais membros eram Arthur Neiva (Diretor Geral do Expediente e da Contabilidade da Polícia Civil do Distrito Federal), Dulphe Pinheiro Machado (Diretor do Departamento Nacional de Imigração), José de Oliveira Marques (Diretor da Divisão de Terras e Colonização do Ministério da Agricultura) e Luiz Betim de Paes Leme (engenheiro) (GERALDO, 2009b).

${ }^{146}$ Entre 1940 e 1955, o CIC publicou a Revista de Imigração e Colonização, compilando conteúdos sobre a imigração de maneira a consolidar o discurso oficial sobre a política migratória brasileira. Debruçando-se sobre os exemplares da Revista, Elena Peres (1997) mostra como este discurso, revestido pela autoridade de autores médicos, diplomatas, jornalistas e bacharéis, legitimava a política restritiva do governo Vargas por meio de argumentos racistas e eugênicos, e que apontavam o estrangeiro como um perigo para a segurança nacional.
} 
boas correntes imigratórias em harmonia com a expansão econômica do país, mas, principalmente, como fator de formação da nacionalidade (apud GERALDO, 2009, p.176).

Essa seletividade racial na entrada de estrangeiros foi acompanhada de uma campanha de nacionalização daqueles que viviam no território, bem como de seus descendentes. A política de assimilação do governo foi normatizada por meio do Decreto $\mathrm{n}^{\circ} 1.545$, de 25 de agosto de $1939^{147}$, o qual conferiu a todos os órgãos federais, estaduais e municipais a responsabilidade de contribuir para a "adaptação, ao meio nacional, dos brasileiros descendentes de estrangeiros", a qual seria atingida por meio de "ensino e pelo uso da língua nacional, pelo cultivo da história do Brasil, pela incorporação em associações de caráter patriótico e por todos os meios que possam contribuir para a formação de uma consciência comum" (art. $1^{\circ}$ ). Dentre outras medidas, o decreto estabeleceu diretrizes para uma educação nacionalizada, proibiu o uso de línguas estrangeiras em repartições públicas e em cultos religiosos, e atribuiu competências sobre o tema ao Estado Maior do Exército, dentre as quais a de centralizar as informações sobre o assunto (art. $7^{\circ}$, parágrafo único).

Ainda em 1938, a Liga das Nações decidiu unir a estrutura do Escritório Nansen à do Alto Comissariado para Refugiados (Judeus e outros) Vindos da Alemanha, formando o Alto Comissariado da Liga das Nações para Proteção de Todos os Refugiados. A nova agência propunha-se a supervisionar a aplicação da Convenção de 1933; fornecer assistência legal e política a refugiados; e prover incentivo à emigração e ao reassentamento (TAFT; ROBBINS, 1955).

Neste mesmo ano, Franklin Roosevelt, presidente dos Estados Unidos (país que não fazia parte da Liga das Nações), convocou a Conferência de Evian para tratar da questão dos refugiados judeus, em um período em que 150.000 judeus alemães já haviam deixado a Alemanha. A Conferência contou com a participação de 32 países, contudo, não teve sucesso em apresentar soluções para o problema dos deslocados. Seu resultado mais concreto foi a criação do Comitê Intergovernamental para Refugiados, organização externa à Liga das Nações cujos planos de reassentamentos, embora não tenham sido materializados nos primeiros anos de sua existência, conseguiram maior êxito no pós-guerra (TAFT; ROBBINS, 1955). Convidado a ocupar a vice-presidência do Comitê, o Brasil inicialmente se negou a aceitá-la, alegando o pretexto de o posto

\footnotetext{
${ }^{147}$ Disponível em: http://www2.camara.leg.br/legin/fed/declei/1930-1939/decreto-lei-1545-25-agosto1939-411654-publicacaooriginal-1-pe.html. Acesso em: 14 abr 2016.
} 
haver sido ofertado primeiramente à Argentina (LESSER, 1994), e assentiu em seguida, nunca havendo, porém, comparecido efetivamente.

Diversos fatores contribuíram para o fracasso de Evian: o não reconhecimento de sua autoridade pelo governo da Alemanha; a indisposição dos potenciais países de acolhida para oferecer planos de reassentamento - apenas a República Dominicana apresentou proposta concreta de admissão de refugiados (FARIA, 2015), e mesmo os Estados Unidos possuíam cotas para entrada de migrantes judeus (MORRIS, 1985); e o antissemitismo. Jeffrey Lesser cita depoimento de funcionário de alto escalão do Itamaraty segundo o qual "todas as repúblicas sul-americanas deixaram claro em Evian que repudiavam a imigração judaica (...) (e jamais irão) receber esses elementos subversivos que trazem a desordem social" (1994, p. 195).

Maria Rita Faria (2015) realiza duas importantes reflexões sobre a Conferência de Evian. Primeiramente, sua convocação pelos EUA, a despeito de iniciativas paralelas da Liga das Nações, evidenciou aquilo que viria a marcar o tratamento das migrações internacionais nas décadas seguintes: a polarização entre uma abordagem multilateral do tema e uma focada nas legislações nacionais. Em segundo lugar, a Conferência deu pistas do propósito norte-americano de distinguir os conceitos de migrante e refugiado, atribuindo a cada um deles um arcabouço institucional, de modo a resguardar sua política migratória da influência de instâncias internacionais.

A eclosão da II Guerra Mundial exacerbou a problemática dos refugiados. Desde meados dos anos 1930, Estados Unidos e Grã-Bretanha vinham tentando persuadir o governo brasileiro a relativizar as restrições à imigração judaica e a receber fluxos de refugiados, defrontando-se com o dúbio método de condução de negociações de Vargas. Com a posse de Oswaldo Aranha como Ministro do Exterior, passou-se a aventar a perspectiva de que a questão dos judeus poderia ajudar o Brasil a solidificar sua aliança com os Estados Unidos (LESSER, 1994). Assim, em 23 de junho de 1939, atendendo a pedido do papa Pio XII para entrada no Brasil de três mil imigrantes católicos de origem semita, o CIC aquiesceu e disciplinou o pedido, porém adaptando-o à legislação de controle de entrada baixada por Vargas: poderiam vir somente famílias, respeitadas as quotas de nacionalidades e mediante transferência de uma alta soma em dinheiro (CERVO, 1992). Além disso, limitou-se a emissão dos vistos ao posto consular de Berlim e do Vaticano, e exigiram-se evidências da fé católica. Já em 1940, o acordo foi suspenso (LESSER, 1994). 
No decorrer da Guerra, o Decreto-Lei n 3.175, de 07 de abril de 1941, restringiu mais contundentemente a imigração, suspendendo a concessão de vistos temporários e permanentes - com algumas exceções, dentre as quais, aos nacionais de Estados americanos. Sublinhe-se a fórmula legal pela primeira vez adotada: definir a proibição da imigração como regra para, em caráter excepcional, conceder o direito. A normativa de 1941 trouxe ainda outra novidade: a ampliação das competências do Ministro da Justiça, a quem se atribuiu a execução da lei (art. $3^{\circ}$ ), cabendo-lhe autorizar a concessão de vistos ou declará-la impedida a determinados indivíduos ou "categorias de estrangeiros" (art. $3^{\circ}$, inciso I). Ressalte-se que o decreto-lei foi resultado de longos debates e disputas entre os Ministérios envolvidos na temática, além do CIC, e marcou o protagonismo do Ministério da Justiça, então liderado por Francisco Campos, em temática migratória (KOIFMAN, 2003). De fato, o próprio Francisco Campos redigira o decreto-lei, na perspectiva de que "a imigração livre, ou espontânea, não consulta o interesse do país (...) a entrada de estrangeiros deixou de ser assunto de interesse econômico para tornar-se, antes, uma questão de polícia" (Francisco Campos, apud KOIFMAN, 2003, p.2). A questão migratória vai, paulatinamente, sendo direcionada do enquadramento do trabalho para o da ordem pública.

Ao Ministério das Relações Exteriores, o Decreto-Lei $n^{\circ} 3.175$ frisou caber a disposição do cumprimento da lei por suas repartições no exterior (art. $8^{\circ}$ ), sendo que seu relacionamento com o Ministério da Justiça se daria segundo o procedimento exposto no parágrafo primeiro do art. $3^{\circ}$ :

$\S 1^{\circ}$ Para esse fim, a autoridade consular, depois de entrar em contato com o
interessado e concluir que ele reúne os requisitos físicos e morais exigidos
pela legislação em vigor, tem aptidão para os trabalhos a que se propõe e
condições de assimilação ao meio brasileiro, encaminhará o pedido ao
Ministério das Relações Exteriores com suas observações sobre o estrangeiro
e a declaração de que este apresentou os documentos exigidos pelo art. 30 do
decreto $\mathrm{n}^{\circ} 3.010$, de 20 de agosto de 1938 . O Ministério da Justiça e
Negócios Interiores, depois de examinar o pedido e ouvir, se julgar
conveniente, outros órgãos do Governo, concederá ou não a autorização para
o visto, a qual será comunicada à autoridade consular pelo Ministério das
Relações Exteriores.

Ainda em 1941, os decretos-leis 3.090 e 3.183 criaram o Serviço de Registro de Estrangeiros e a Delegacia de Estrangeiros no âmbito da Polícia Civil do Distrito Federal, com atribuições de fiscalização, registro, repressão, expulsão, e sindicância de processos de naturalização. Nesse contexto, Koifman (2003) ressalta a importância dos burocratas de médio escalão no delineamento desta política restritiva, destacando 
particularmente Ernani Reis, secretário do MJ que concentrou poder significativo sobre a entrada de estrangeiros no país, por meio de decisões e pareceres caracterizados por caráter restritivo e xenófobo.

Quando navios brasileiros foram atingidos pelas forças do Eixo, o governo emitiu sua primeira declaração de guerra, esta internamente travada: o Decreto-lei $n^{\circ}$ 4.166 de 11 de março de 1942, que autorizava o Estado a compensar os danos advindos dos atos de agressão por meio do confisco de propriedades dos cidadãos do Eixo; ordenando o sequestro de uma parte dos depósitos bancários ou obrigações de natureza patrimonial de que fossem titulares súditos alemães, japoneses e italianos, de modo a constituir o Fundo de Indenizações de Guerra, destinado a garantir a reparação dos danos (REL.EXT., 1948). Com a declaração de guerra ao Eixo pelo Brasil, em agosto de 1942, o objetivo da assimilação incorpora a integração cultural como estratégia de defesa da soberania nacional. Além das medidas da campanha de nacionalização institucionalizadas no Decreto $\mathrm{n}^{\circ} 1.545$, o governo não hesitou em materializar os inimigos externos em seus nacionais emigrados, vigiando-os e controlando-os com forte participação militar. O propósito da campanha de nacionalização passa, então, a transcender o rompimento da situação de enquistamento (SEYFERTH, 1999) e englobar a repressão militar com vistas a confrontar a propagação de propagandas ideológicas da Alemanha, Japão e Itália ${ }^{148}$.

Lesser (1994) questiona o porquê de, entre 1939 e 1942, alguns judeus terem tido o visto negado e outros dez mil o terem recebido, sem que se possam identificar condições determinantes para a variação - sejam elas referentes a características pessoais do demandante, sejam elas relativas a condicionantes externos, tais como a pressão diplomática dos Estados Unidos. $\mathrm{O}$ autor sugere a explicação de que as decisões sobre concessão de vistos seguiriam "uma lógica interna baseada nas imagens duplas sobre os judeus no Brasil” (LESSER, 1994, p.224).

Sem embargo, independentemente de perscrutações sobre o elemento ideacional das tomadas de decisões, observa-se que dois elementos institucionais sobressaem no

\footnotetext{
${ }^{148}$ Roberto Gambini (1977) sugere a existência de um tratamento diferenciado conferido pelo governo brasileiro aos italianos, possivelmente relacionado, segundo documentos colacionados pelo autor, a semelhanças culturais entre ambos os países, latinos e católicos, e a tratar-se de um antagonista visto como de menor importância pelos Estados Unidos. Paralelamente, Seyferth (1999) salienta a repressão sofrida pela comunidade teutônica no Sul do Brasil, fundamentada no medo da propaganda nazista; enquanto Fernando Morais, em seu livro "Corações Sujos: a história da Shindo Renmei" (2001), narra a repressão em uma colônia japonesa no estado de São Paulo.
} 
contexto analisado: a pulverização de competências entre diferentes órgãos de formulação, bem como a instabilidade dos diferentes arranjos; e a inconsistência por vezes identificada entre a formulação e a implementação da política migratória, ou entre seus vários agentes implementadores. Estes dois fatores explicam, conforme neste capítulo descrito, determinadas variações observadas nas concessões de vistos para judeus e outros grupos. No entanto, o questionamento sobre se tais elementos institucionais derivam de uma determinada dinâmica organizacional; de divergentes impulsos ideacionais; ou de estratégia racional de atender, ao mesmo tempo, às demandas internacionais e aos interesses domésticos antagônicos, exigiria um estudo de caso mais detalhado sobre o período em tela.

Em carta preparatória ao encontro de Vargas com Roosevelt, em 1943, Aranha expunha sua opinião sobre o cenário internacional e recomendações sobre as atitudes que o Brasil deveria tomar frente ao término da guerra avistado (ALMEIDA; ARAÚJO, 2013). Dentre essas últimas, encontrava-se a ampla liberdade de imigração e de transferência de capitais para o Brasil. Por sua vez, com o armistício italiano em 1943, a chancelaria italiana apressou-se em retomar relações amistosas com o Brasil, inclusive acenando com uma nova corrente emigratória (CERVO, 1992, p.172). Neste mesmo ano, o embaixador brasileiro em Portugal assinou acordo sobre a admissão no Brasil de imigrantes portugueses, concedendo-lhes um estatuto especial e dispensando a consulta prévia para concessão de vistos permanentes. Ainda em 1944, Holanda e da Suíça, demonstraram interesse em celebrar acordos de imigração com o Brasil (REL.EXT., 1945).

A seu turno, o Comitê Intergovernamental de Refugiados solicitou ao Brasil, em 1944, que acolhesse uma parcela de crianças judias refugiadas na França e ameaçadas de deportação pelas autoridades alemães. O Governo brasileiro consentiu em receber um grupo de 500 crianças $^{149}$ (REL. MRE, 1945), além de um grupo de crianças judias da Hungria (REL. MRE, 1945).

Essas iniciativas vinham em período de drástica retração nas entradas de estrangeiros no Brasil, observada durante a guerra e especialmente entre os anos de 1942 a 1945, quando se manteve em cerca de 02 mil imigrantes anuais. Entre 1930 e

\footnotetext{
${ }^{149}$ O Comitê, não obstante, respondeu que haviam aumentado as dificuldades para a retirada das crianças do território francês, e que voltaria a tratar do assunto.
} 
1940, a média anual de entrada fora de cerca de 29.000 imigrantes (LEVY, 1974), com considerável parcela japonesa.

Internamente, o governo concentrava esforços no rearranjo geográfico da força trabalhadora nacional, com a Marcha para o Oeste e a Batalha da Borracha (VAINER, 2000). Não obstante, o trabalhador nacional era, ainda, visto como menos apto e preparado, como se observa em relato de 1943:

Enfraquecido pelas endemias, o nosso caboclo não tem disposição para o trabalho e, desajustado, fracassa em qualquer iniciativa que toma. Impõe-se, portanto, a adoção sistemática de uma política imigratória e colonizadora, econômica e financeira, sanitária e educativa (Oliveira, apud VAINER, 2000, p.22).

Nesse contexto, o governo brasileiro passou a contemplar a ideia de reformar a legislação migratória, abrandando-a e detalhando os mecanismos de direcionamento dos fluxos dentro do território nacional. Sobre o tema, o relatório do MRE de 1945 discorria:

\begin{abstract}
A legislação terá ainda que evoluir num sentido mais amplo de modo que, consultados os interesses nacionais, possa encontrar-se o Brasil aparelhado para receber as grandes correntes de imigrantes que, como se prevê, demandarão o Hemisfério ocidental, acossados pelas condições de miséria no Continente europeu. Os órgãos competentes (Conselho de Imigração e Colonização, Departamento Nacional de Imigração e a recém-criada Comissão do Planejamento Econômico) considera a imigração em larga escala imprescindível ao progresso nacional e cuidam da elaboração de uma nova lei imigratória, mais de acordo com as necessidades atuais e o interesse do Brasil (REL.EXT., 1945, p. 87).
\end{abstract}

O proibitivo Decreto-Lei n ${ }^{\circ} 3.175 / 1941$ foi, então, revogado pelo Decreto-Lei ${ }^{\circ}$ 7.575/1945, alegando-se, em seu preâmbulo, haver cessado os motivos de ordens políticas que levaram o governo a restringir a entrada de estrangeiros, e por julgar-se conveniente facilitar a imigração de europeus ao Brasil. Corroborando esta lógica, o Decreto-Lei $n^{\circ} 7.967 / 1945$ flexibiliza a restrição da imigração, mas retoma o sistema de cotas, assumindo em seu art. $2^{\circ}$ que "atender-se-á, na admissão dos imigrantes, à necessidade de preservar e desenvolver, na composição étnica da população, as características mais convenientes da sua ascendência europeia, assim como a defesa do trabalhador nacional”. A norma institui o modelo de imigração dirigida (art.38), promovida pelo poder público, empresa ou particular que introduziriam, hospedariam e localizariam imigrantes. 
É interessante ressaltar que o referido decreto-lei não explicitou a quais órgãos federais seriam atribuídas as atividades nele instituídas, o que viria a ocorrer por normatizações posteriores. O final do período abordado neste item corresponde, contudo, a um direcionamento das atribuições em política migratória para o Ministério da Justiça. Com a transformação da Polícia Civil do Distrito Federal em Departamento Federal de Segurança Pública (DFSP), em $1944^{150}$, criou-se em seu âmbito a Divisão de Polícia Marítima, a qual incluía a Seção de Segurança de Fronteiras e a Delegacia de Estrangeiros, posteriormente Serviço de Registro de Estrangeiros (Decreto-Lei $\mathrm{n}^{\circ}$ $8.805 / 1946^{151}$ ). Não sem revezes em sua trajetória institucional (ARANTES, 2011), o DFSP foi o embrião do Departamento de Polícia Federal, e iniciou então um acúmulo gradativo de responsabilidades quanto à execução da política migratória.

Em suma, o Estado reformado em Vargas, além de caracterizado pela negociação constante, nos planos interno e externo, entre interesses distintos; foi marcado pelo ímpeto centralizador, em virtude do qual reestruturou o aparato do Executivo central. Nesse contexto, a política migratória do período foi marcada pela fragmentação de competências, constantemente rearranjadas baixo a responsabilidade de um ou outro órgão, de acordo com o objetivo político que se lhe visava a imprimir; e pelo fortalecimento de mecanismos institucionais atrelados ao governo central, antes repartidos com estados e atores não-governamentais. Por último, o Estado governado por Vargas sofreu reformas administrativas almejando ao modelo racional-legal, com fortalecimento da burocracia, inclusive na implementação da política migratória.

Já a nação brasileira, conforme vista pelas instituições políticas, ainda se queria europeia e homogênea, mas agora se reconhecia como uma formação sólida, à qual o estrangeiro deveria adaptar-se e assimilar-se. Por último, ao nacional se garantia a cidadania, enquanto do estrangeiro, lhe regulavam os direitos.

\subsection{Securitização das fronteiras, trincheiras de direitos e permeabilidade econômica}

A II Guerra e seu término intensificaram o fluxo de refugiados e, por conseguinte, diferentes iniciativas internacionais sobrevieram visando a gerenciar a

\footnotetext{
${ }^{150}$ Decreto-Lei no 6.378/44. Disponível em: http://www2.camara.leg.br/legin/fed/declei/19401949/decreto-lei-6378-28-marco-1944-389489-publicacaooriginal-1-pe.html. Acesso em: 17 mai 2016. ${ }_{151}$ Disponível em: http://www2.camara.leg.br/legin/fed/declei/1940-1949/decreto-lei-8805-24-janeiro1946-416509-publicacaooriginal-1-pe.html. Acesso em: 17 mai 2016.
} 
questão, materializando-se em sucessivas organizações. É de se sublinhar que este período pós-guerra foi marcado por um entusiasmo pelo multilateralismo, refletido em uma profusão de conferências internacionais e em múltiplas experiências institucionais $^{152}$. Dentre os êxitos mais relevantes, a Declaração Universal de Direitos Humanos, de 1948, delineia o direito de abandonar o país em que se encontra e o de retornar ao país de origem (artigo 13.2), o direito à procura de asilo em caso de perseguição (art. 14) e o direito a ter uma nacionalidade, não perdê-la e de poder modificá-la (art.15).

Nesse contexto, o aprimoramento do conceito de refugiado, e sua diferenciação daquele de migrante laboral, foi realizado junto à criação de novas instituições e reformas das já existentes - não sem envolver o debate entre projetos políticos distintos. Definiram-se, ainda, as três medidas políticas de manejo da questão dos refugiados que perduram até a atualidade: (i) repatriação, isto é, o apoio ao retorno voluntário e à reintegração do indivíduo ao país de origem; (ii) integração local, no âmbito legal, econômico e sociocultural; e (iii) reassentamento, com a transferência do refugiado do país de asilo a um terceiro Estado disposto a admiti-lo em caráter permanente ${ }^{153}$.

Ainda antes do término da Guerra, foi organizada, em 1943, a Administração das Nações Unidas para Auxílio e Reabilitação (UNRRA, United Nations Relief and Rehabilitation Administration), com a tarefa de fornecer às vítimas da guerra e do nazismo alimentação, abrigo e outros serviços de primeira necessidade. Incluída no organograma da ONU em 1945, a UNRRA foi dotada do papel de administração dos campos de refugiados do Eixo, auxiliando na reapatriação de cerca de sete milhões de pessoas até sua extinção, em 1947 (TAFT; ROBBINS, 1955, p. 239).

Não obstante, a repatriação não configurava medida suficiente para abarcar todos os deslocados pela II Guerra. Assim, em 1946, a Assembleia Geral das Nações Unidas aprovou a criação da Organização Internacional dos Refugiados (OIR), agência especializada e transitória destinada a implementar medidas de integração e reassentamento dos refugiados europeus, sendo que esta última acabou sendo a solução priorizada. Ressalte-se que o mandato da OIR excluía da definição de refugiado aqueles

\footnotetext{
152 Farias (2006) cita testemunho de um diplomata brasileiro afirmando que, em 1947, estariam programadas quarenta e três reuniões internacionais das quais o Brasil deveria participar, e que o aparelho estatal à época não estaria preparado para dar conta.

${ }^{153}$ Disponível em: http://www.acnur.org/que-hace/soluciones-duraderas/. Acesso em 16 abr 2016.
} 
deslocados de países não-europeus, bem como criminosos de guerra e pessoas de origem étnica germânica (TAFT; ROBBINS, 1955).

Os Estados Unidos exerceram um papel central na recepção dos refugiados, tendo já recebido cerca de 200.000 nacionais do Eixo durante o conflito bélico (TAFT; ROBBINS, 1955). Em sua tese sobre migrações internacionais e multilateralismo, a diplomata Maria Rita Faria (2015) opina que os EUA teriam visto a OIR como instrumento para avançar seus interesses no contexto de acirramento da Guerra Fria, e que, para assegurar sua influência, revestiram-na do status de agência especializada. Segundo a autora,

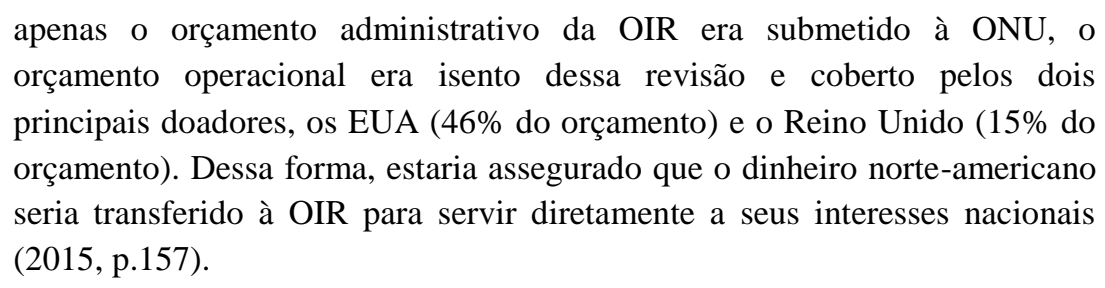
principais doadores, os EUA (46\% do orçamento) e o Reino Unido (15\% do orçamento). Dessa forma, estaria assegurado que o dinheiro norte-americano seria transferido à OIR para servir diretamente a seus interesses nacionais (2015, p.157).

Meses antes da criação da organização, o Brasil, por meio do Embaixador Muniz de Aragão, assinara o “Acordo de Londres", aceitando o recrutamento de 1.000 famílias (máximo de 5.000 pessoas), desde que as despesas de transporte marítimo fossem cobertas pelo Comitê Intergovernamental e o direito de seleção fosse exercido pelas autoridades brasileiras. O Brasil se comprometia, ainda, a reconhecer um representante do Comitê em seu território. Com a formação da OIR, o acordo de Londres foi reavaliado a fim de garantir sua execução, com o Brasil se comprometendo a receber mais 1.000 famílias, e acertos financeiros sendo colocados em pauta. Uma Comissão Mista Brasil-OIR, destinada a supervisionar as tarefas de colocação dos deslocados no Brasil, foi inserida no Departamento Nacional de Imigração. Já na Europa, uma Comissão de Seleção Brasileira escolheria os imigrantes, também vinculada ao Departamento Nacional de Imigração e submissa ao Conselho de Imigração e Colonização ${ }^{154}$. Este modus operandi caracterizou o recebimento de refugiados pelo

\footnotetext{
${ }^{154}$ A Comissão daria preferência para: técnicos e operários especializados; técnicos e trabalhadores agrícolas; chamada de parentes - sendo que a razão para os núcleos familiares desejados deveria ser dois membros ativos para três inativos, considerando-se ativos os maiores de 18 e menores de 50 anos. Foram interditadas as profissões: (i) regulamentadas; (ii) intelectuais, tais como professores, artistas, jornalistas; (iii) urbanas, tais como barbeiro, caixeiro, contador.
} 
Brasil durante o mandato da OIR (1947-1951), que contemplou 28.848 indivíduos (tabela 3.2) e rendeu-lhe a oitava posição entre os países com maior afluxo ${ }^{155}$.

De fato, a OIR atuava: (i) na arena internacional, encontrando e negociando bi e multilateralmente oportunidades de reassentamento, bem como realizando acordos para transporte dos migrantes; (ii) nos países de acolhida, agindo junto ao governo e a empresas de modo a inserir migrantes nos planos de recrutamento de mão-de-obra e, posteriormente, supervisioná-los; (iii) nos países de origem, preparando os emigrantes para a seleção realizada pelos países de acolhida segundo os critérios de elegibilidade desses últimos, oferecendo-lhes cursos de formação e línguas, além de orientação sobre o processo migratório para os países de destino. Perceba-se que isso significava tratar, em geral, os refugiados como trabalhadores migrantes, atendendo aos interesses do mercado de trabalho dos países de acolhida.

Centrada nos indivíduos deslocados em razão da II Guerra, a OIR teve um curto período de atuação, encerrando suas atividades em 1951. Para Taft e Robbins, "whatever may be the criticisms of certain aspects of IRO's experiment in multilateralism, the organization of this migration and resettlement must be set down as a major accomplishment of the postwar world" (1955, p.243). Milhares de refugiados foram reassentados, sendo a distribuição entre países exposta na tabela 3.2.

Tabela 3.2: Refugiados reassentados durante o mandato da OIR

(1947-1951) por países de destino

\begin{tabular}{cc}
\hline País de destino & Refugiados \\
\hline Estados Unidos & 328.851 \\
Austrália & 182.159 \\
Israel & 132.109 \\
Canadá & 123.479 \\
Reino Unido & 86.346 \\
França & 38.455 \\
Argentina & 32.712 \\
Brasil & 28.848 \\
Bélgica & 22.477 \\
Venezuela & 17.277 \\
\hline Fonte: TAFT;ROBBINS, $1955, \mathrm{p} .262$ & \\
\hline
\end{tabular}

Fonte: TAFT;ROBBINS, 1955, p.262

\footnotetext{
${ }^{155}$ Um exemplo de acordo entre Brasil e OIR pode ser encontrado em instrumento de fevereiro de 1951 para introdução de 5000 imigrantes, disponível em: http://dai-mre.serpro.gov.br/atosinternacionais/bilaterais/1951/b_6/. Acesso em: 16 mai 2016.
} 
No Brasil, a Constituição de 1946 ratificara a tendência a atenuar a legislação migratória, suprimindo as cotas de entrada e estabelecendo, em seu art. 162, que a “seleção, entrada, distribuição e fixação de imigrantes ficarão sujeitas, na forma da lei, às exigências do interesse nacional". No parágrafo único do mesmo dispositivo, enunciava que caberia "a um órgão federal orientar esses serviços e coordená-los com os de naturalização e de colonização, devendo nesta aproveitar nacionais". Não precisava, contudo, qual seria esse órgão, ratificando apenas a competência centralizada no âmbito federal.

Os fluxos migratórios retomam o crescimento e atingem, entre 1945 e 1963, uma média de 44.000 entradas anuais (LEVY, 1974). O volume não corresponde aos níveis do início da República, mas alcança os maiores índices desde 1930, com ampla participação de europeus, diminuição dos fluxos de japoneses e início de entrada de nacionalidades árabes e africanas.

Mas não apenas de refugiados intermediados por organizações internacionais consistiu a imigração para o período: perceba-se que, na década de 1950, a imigração espontânea passa, pela primeira vez na história, a ser responsável pela maioria do fluxo de pessoas para o Brasil (em 1950, foram 35.000 pessoas que correspondiam a essa classificação, em 1952, até agosto, eram 51.252), sendo incentivada nas repartições consulares (REL.EXT., 1952). Nesse contexto, a década de 1950 foi o período com maior número de acordos bilaterais sobre temática migratória.

Em 15 de dezembro de 1950, o Brasil firmou com os Países Baixos um Acordo de Imigração e Colonização ${ }^{156}$. Assinado, do lado brasileiro, pelos ministros das Relações Exteriores, Agricultura e do Trabalho, o acordo focava a agricultura e a cooperação técnica e científica, compreendendo inclusive o aporte de gado holandês para o Brasil, e assim se justificava:

a) de um lado, as possibilidades do território brasileiro, a valorização de suas regiões parcial ou totalmente inexploradas, o aproveitamento de seus recursos naturais, os planos de recuperação econômica formulados e outros aspectos do progresso nacional brasileiro; e,

b) de outro, a capacidade técnica geral e especializada, bem como a experiência dos neerlandeses na direção do trato das culturas tropicais, propõem-se a estimular viagens de professores, intelectuais, especialistas, individualmente ou em missões organizadas, para excursões e estágios planejados no Brasil e nos Países Baixos (art.4 $4^{\circ}$.

\footnotetext{
${ }^{156}$ Internalizado pelo Decreto Legislativo n. 55/1951. Disponível em: http://www2.camara.leg.br/legin/fed/decleg/1950-1959/decretolegislativo-55-13-novembro-1951-367193publicacaooriginal-1-pl.html Acesso em: 13 mai 2016
} 
Outra característica do Acordo é sua estrutura de financiamento: os Países Baixos se comprometiam a subsidiar o transporte do migrante, o governo brasileiro era responsável por sua acolhida, transporte e alimentação até seu destino final, inclusive financiando os pequenos proprietários em seu primeiro ano no país. Por último, o acordo previa uma Comissão Mista de Execução, composta por representantes de ambas as partes, de modo a levar a cabo sua implementação.

Após Declaração de Amizade e Cooperação ter sido assinada em 1949 destinando-se a retomar as relações harmoniosas entre Brasil e Itália e preceder um novo acordo de imigração entre os países (REL.EXT., 1948), seus Ministros das Relações Exteriores Raul Fernandes e Mario Augusto Martini firmaram, em 5 de julho de 1950, um Acordo de Migração ${ }^{157}$. O acordo regia três tipos de imigração de italianos para o Brasil: (i) migração espontânea baseada em carta de chamada familiar ou em oferta de trabalho; (ii) transferência de sociedades, de cooperativas ou de grupos de trabalho condicionada à aprovação dos seus programas pelas autoridades brasileiras e italianas competentes; (iii) migração dirigida, baseada em listas acordadas, para cada leva, pelos representantes de ambos os Governos. No caso da dirigida, contava, para sua execução, com a colaboração de Comissões Consultivas Mistas, as quais atuavam na seleção e recrutamento, de um lado, e na fiscalização das condições de acolhida e de trabalho, do outro. A imigração dirigida se fundamentava, ainda, em financiamento italiano do transporte, e brasileiro para manutenção, assistência e transporte interno do imigrante ${ }^{158}$.

Sobre o recrutamento de imigrantes na Itália, o Itamaraty (REL.EXT., 1951) instruía seus agentes a concederem vistos aos indivíduos que interessassem à economia do país, isto é, agricultores, sendo que o recrutamento de operários para a indústria ocorreria apenas sob demanda governamental. Entretanto, apesar dos esforços bilaterais, entre 1946 e 1960, o Brasil recebeu apenas 12\% do total de italianos que se dirigiu à América Latina (CERVO, 1992, p.196).

Em 1951, foram iniciadas as execuções de acordo com a Suíça para a vinda de quinhentas famílias (2.500 pessoas) refugiadas, de nacionalidade germânica. O acordo

\footnotetext{
${ }^{157}$ Internalizado pelo Decreto $\mathrm{n}^{\text {o }} 30.824$, de 7 de maio de 1952.

${ }^{158}$ Ressalte-se que, no mesmo 05 de julho de 1950, Brasil e Itália assinaram acordo administrativo para regulamentação da Companhia Brasileira de Colonização e Imigração Italiana ${ }^{158}$, a qual houvera sido criada pelos convênios que acompanharam a Declaração de Amizade de 1949 e atuaria enquanto não entrasse em vigência o Acordo de Migração.
} 
foi realizado junto à legação da Suíça no Brasil com intermediação de duas organizações de caridade suíças ("Ajuda Suíça à Europa" e "União Suíça de Caridade"), as quais se comprometiam a angariar recursos de bancos e exportadores suíços para prover às despesas de transporte e localização desses imigrantes em colônias no Estado de Goiás. Em contrapartida, requeriam que o Brasil facilitasse a exportação de mercadorias suíças em volume aproximado, à época, de trinta e um milhões de francos suíços $^{159}$.

Ressalte-se que esses acordos implicavam em concessão de tratamento especial aos nacionais dos respectivos países, o que gerava para o Itamaraty a necessidade de negociá-los não apenas externamente, como também internamente, junto ao Conselho de Imigração e Colonização - como se depreende das trocas de notas do Ministro Raul Fernandes com seu homólogo italiano ${ }^{160}$.

A despeito de acordos bilaterais terem se disseminado e obtido êxito em canalizar determinados grupos de indivíduos, relatório da ONU de 1951 sobre migração europeia frisava a importância do multilateralismo em temática migratória nos seguintes termos:

\begin{abstract}
However carefully bilateral agreements are drafted, numerous disturbing but unpredictable events will occur to upset their implementation. Political developments such as changes of governments, strikes or economic crises, natural causes such as epidemics, floods or crop failures, are bound to bring about changes in the rates of movement and disrupt carefully established and costly schedules. (...) In contrast to this, a pool of resources under the control of an international agency with world-wide responsibilities can be sufficiently flexible to divert ships, planes or trains from one assignment to another. Such an agency can combine many migration schemes in one operation or replace one by another without waiting for any faltering plan to retrieve its originally-scheduled momentum. By supplying indispensable machinery for the multilateral control of migration movements, such an agency can substantially lighten the burden, which in the case of bilateral agreements, lies upon the shoulders of the interested governments alone (apud TAFT; ROBBINS, 1955, p.197-198).
\end{abstract}

\footnotetext{
${ }^{159}$ Este fluxo era parte de projeto idealizado pelo suíço René Bertholet de implementação de colônias agrícolas de famílias europeias em território brasileiro. Viria a se tornar um dos diretores da Companhia Progresso Rural, criada em 1952 com os objetivos de gerir o Plano de Colonização Brasileiro. Bertholet foi responsável, em 1953, pela implantação do projeto de Cooperativa Agrícola Pindorama, no estado de Alagoas, para onde se dirigiram imigrantes nas décadas seguintes, especialmente técnicos agrícolas. Entre 1963 e 1968, uma série de convênios foi assinada com a Alemanha envolvendo a vinda de técnicos para a cooperativa de Pindorama.

${ }_{160}$ Disponível em: http://dai-mre.serpro.gov.br/atos-internacionais/bilaterais/1950/b_15/. Acesso em: 16 mai 2016.
} 
Sem embargo, o formato deste multilateralismo encontrava-se em disputa: haveria um regime internacional de migrações inserido na estrutura das Nações Unidas ou, consoante proposta norte-americana, criar-se-ia agência com mandato limitado e não-submetida às instâncias decisórias da ONU (FARIA, 2015)? Nesse contexto, verificaram-se intensas mudanças institucionais sobre o tema no período.

Em 1950, se havia criado o Alto Comissariado das Nações Unidas para Refugiados (ACNUR), solução de compromisso entre os dois modelos institucionais: existiria no seio da ONU, porém se trataria de agência de mandato restrito, com independência de qualquer instância das Nações Unidas para decidir sobre suas operações. No ano seguinte, foi adotada a Convenção sobre o Estatuto de Refugiados e Apátridas, por ocasião da Conferência de Plenipotenciários sobre o Estatuto de Refugiados e Apátridas, em Genebra ${ }^{161}$. A Convenção entrou em vigor em 1954, e balizou o regime internacional de refugiados a partir do princípio do non-réfoulement, a não-devolução, proibindo os Estados de expulsarem o refugiado para seu território de origem, ou qualquer outro em que "sua vida ou a sua liberdade seja ameaçada em virtude da sua raça, da sua religião, da sua nacionalidade, do grupo social a que pertence ou das suas opiniões políticas" (art.33). Contudo, a Convenção de 1951 restringia sua definição de refugiado às situações decorrentes "dos acontecimentos ocorridos antes de $1^{\circ}$ de janeiro" (art. $1^{\circ}$ ), e aos países signatários facultou-se adotar a reserva geográfica na interpretação da norma, aplicando-a apenas a europeus (MOREIRA, 2010).

Também em 1951, reuniu-se em Bruxelas a Conferência Mundial de Imigração, ainda visando a tratar dos deslocamentos suscitados pela Guerra. O Brasil, presente no encontro, "defendeu o ponto de vista de que o problema imigratório deve ser encarado como parte do problema do desenvolvimento global das áreas menos desenvolvidas, uma vez que o assunto vinha sendo encarado apenas sob o prisma dos interesses europeus" (REL.EXT., 1952, p.55). Este pronunciamento do Itamaraty constitui, simultaneamente, um aprimoramento dos protestos que vinham sendo feitos desde a década de 1920, por representantes brasileiros presentes em conferências internacionais, sobre a ênfase nelas conferidas aos interesses dos países de emigração; e um anúncio do que viria a constituir o posicionamento do Brasil nas arenas internacionais em temática migratória nas décadas seguintes, particularmente após a redemocratização.

${ }^{161}$ Assinado pelo Brasil a 15 de julho de 1952. 
Na ocasião da Conferência, foi criado o Comitê Intergovernamental para as Migrações Europeias (CIME), com o objetivo de substituir a ORI, orientando os problemas gerais dos deslocamentos inter-continentais e facilitando o transporte dos imigrantes (REL.EXT., 1953). A criação do CIME atendeu a interesses de tratar a temática migratória em instância externa às Nações Unidas, possibilitando a exclusão dos países soviéticos dos acordos - interesses esses principalmente dos Estados Unidos, responsável por cerca de um terço de seu orçamento, com recursos do Plano Marshall. O CIME se tornou o organismo relacionado a migrações preferencial do financiamento norte-americano (FARIA, 2015), elemento determinante em sua longa existência: o Comitê perdurou até 1989, quando foi reformulado e tornou-se a Organização Internacional de Migrações (OIM).

Ressalte-se que o CIME substituia a ORI mas não se atinha a refugiados, até porque esta categoria ainda se encontrava rudimentarmente definida. Sua diferenciação em relação ao mandato do ACNUR se dava porque, enquanto o Alto Comissariado se restringia a ações de auxílio a refugiados no quadro jurídico da Convenção de 1951, o Comitê atendia a refugiados ou migrantes voluntários em uma abordagem laboral dos deslocamentos. Assim, o CIME atuou, por exemplo, junto aos governos brasileiro e italiano na celebração de acordo que instituía curso de formação profissional, na indústria da construção, para cerca de 600 trabalhadores italianos que, após a conclusão do curso, seriam selecionados pelo Governo brasileiro como imigrantes ${ }^{162}$. O financiamento para todo o esquema migratório seria fornecido pelas três partes.

No mesmo ano de 1951, a OIT convocara uma conferência sobre migração em Nápoles, onde apresentou seu plano operacional para deslocamento de cerca de 1,7 milhões de imigrantes europeus em um período de 5 anos, por meio da institucionalização de uma agência centralizada, a Administração de Migrações, que gerenciaria desde a intermediação de acordos bilaterais entre países até um sistema de financiamento para o indivíduo se reassentar em outro país. Durante a Conferência de Nápoles, a OIT apresentou as migrações como uma questão que transcenderia o domínio da força de trabalho, sendo essencial para a paz e o desenvolvimento mundial. O plano não foi, todavia, aceito na conferência, com a oposição dos EUA, Reino Unido e Austrália.

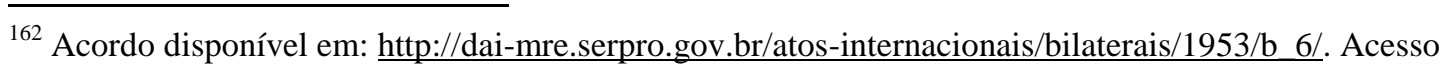
em: 16 mai 2016.
} 
A OIT tivera grande relevo na década precedente: manteve no pós-guerra seu Comitê Permanente de Migração (criado em 1940); organizou em 1950 uma conferência para facilitar a mobilidade internacional de mão-de-obra por meio da difusão de boas práticas de gestão de operações migratórias; submeteu para aprovação dos países a revisão da Convenção no 97 sobre Trabalhadores Migrantes (1949); organizou um programa com o objetivo de fornecer consultoria e assistência técnica para países com projetos de programas imigratórios ou emigratórios; e atuou em cooperação junto a outras agências onusianas para o estabelecimento de padrões para a seleção médica dos migrantes e para o planejamento dos reassentamentos. Não obstante, o CIME, com sua estrutura intergovernamental e por abarcar, simultaneamente, migrantes forçados e voluntários, passou a exercer o protagonismo no cenário internacional das migrações.

Em suma, observa-se que a atuação do governo brasileiro em parceira com o CIME e outras organizações internacionais delineou um modelo de imigração dirigida, com indivíduos selecionados, orientados e transportados por agentes dos países de origem, de destino e de organismos internacionais; e voltados para setores específicos do mercado de trabalho, particularmente a agricultura, atendendo desta forma a interesses econômicos e de colonização.

Nesse sentido, a Lei $\mathrm{n}^{\mathrm{o}} 2.163 / 1954^{163}$ criou o Instituto Nacional de Imigração e Colonização, autarquia sob a jurisdição do Ministério da Agricultura, encarregado de assistir e encaminhar as migrações internas entre regiões; orientar e promover a seleção, entrada, distribuição e fixação de imigrantes; e de traçar e executar o programa nacional de colonização, voltado para trabalhadores nacionais e estrangeiros (art. $3^{\circ}$ ). Foram extintos o Conselho de Imigração e Colonização, o Departamento Nacional de Imigração do Ministério do Trabalho, Indústria e Comércio e a Divisão de Terras e Colonização do Ministério da Agricultura (art. 14). Em detrimento do anterior arranjo descentralizado e intersetorial, a centralização institucional seguindo uma estratégia agrária de colonização passou a balizar a atração de imigrantes à época.

Ao Itamaraty, cabia a concessão de vistos permanentes, por meio do serviço consular, para casos de imigração espontânea -em 1952, correspondera a uma média de 6.400 por mês, sendo a grande maioria de portugueses, segundo dados do próprio

\footnotetext{
${ }^{163}$ Disponível em: http://www2.camara.leg.br/legin/fed/lei/1950-1959/lei-2163-5-janeiro-1954-361499publicacaooriginal-1-pl.html. Acesso em: 18 abr 2016.
} 
Ministério (REL.EXT., 1953). Atuava, ainda, junto ao Serviço de Seleção de Imigrantes na Europa criado pelo INIC (REL.EXT., 1955), bem como junto a entidades dos países de origem que tratavam da emigração de seus nacionais, tais como o Instituto Espanhol de Imigração, órgão criado pela Espanha em 1956 a fim de tutelar seus emigrantes, em período que correspondeu à segunda onda de migração espanhola para o Brasil (SOUZA, 2010).

De outro lado, o MRE intensificava sua atuação como interlocutor do Brasil nas instâncias internacionais, das quais o país participava ativamente e era eleito com significativa frequência para ocupar funções nos comitês consultivos ou executivos, dada sua importância no cenário de migrações mundial. No caso do ACNUR, o MRE descreve, em 1957, que lhe entregava contribuições financeiras e negociava, em parceria com o Instituto Nacional de Imigração e Colonização, o recebimento de contingentes de refugiados (REL.EXT., 1957). Já quanto ao CIME, o MRE atuava buscando conciliar os interesses do governo brasileiro com o manejo dos fluxos populacionais realizada pelo Comitê, inclusive no sentido de atrair fluxos, como se depreende do relatório de 1953:

Para 1952, a quota de imigrantes atribuída ao Brasil alcançou a cifra de 18.000 emigrantes, sobretudo italianos e holandeses. Já para 1953, a Delegação brasileira conseguiu elevar aqueles números para 23.000, devendo ser mais volumosas as correntes de italianos, holandeses, gregos e alemães (REL.EXT., 1952, p.156).

Ainda na década de 1950, depreende-se uma abordagem higienista da atuação tanto do MRE quanto do INIC na seleção de imigrantes. A legislação então vigente (Decreto-Lei 7.967/1945) interditava a entrada de indivíduo que não satisfizesse as exigências de saúde prefixadas (art. 11, III), e conferia especial ênfase à fiscalização sanitária tanto na concessão de vistos, quanto nas fronteiras. Esta preocupação parece estar relacionada com o objetivo de atrair indivíduos aptos a incorporarem-se ao mercado de trabalho. Em pesquisa sobre a seleção brasileira de imigrantes espanhóis entre 1950 e 1960, Ismara de Souza aponta instrução do Itamaraty para sua embaixada em Madrid, de 1954, explicando que "a atual orientação do INIC é no sentido de evitar a entrada de imigrantes que, de futuro, apelando para a feição humana da reintegração de família, venham a promover a admissão no país, de parentes enfermos e inúteis" (2010, p.119). 
Mas era o comunismo o grande fantasma cuja entrada no Brasil se buscava evitar. Se a concessão de vistos já era, há décadas, submetida a juízos políticos, o ambiente maniqueísta do pós-guerra gerou em muitos diplomatas e altos funcionários a necessidade de posicionar-se ao lado dos EUA ${ }^{164}$ - o que se refletiu na implementação da política imigratória. Segundo Cervo, a Comissão Permanente de Seleção na Itália (vinculada ao CIC até 1954, e em seguida ao INIC) rejeitava, na década de 1950, cerca de $20 \%$ dos candidatos por julgá-los com tendência comunista (1992, p.200). Ao explicar como se desenrolava a concessão de vistos aos imigrantes, o Itamaraty pontuava, em relatório de 1957, a atenção conferida ao comunismo:

Quanto aos inúmeros pedidos de visto permanente, esse trabalho absorveu cuidadosa atenção e esforço por parte dos funcionários da Divisão de Passaportes. Seguindo as normas de defesa dos interesses do Brasil, pela adoção de medidas de preocupação e máximo rigor contra a entrada de elementos indesejáveis, nocivos à ordem pública e a segurança das instituições, o Itamaraty esteve sempre vigilante e contou com a colaboração do Ministério da Justiça para apreciação dos pedidos formulados por imigrantes já radicados no país em favor de seus parentes, refugiados políticos ou residentes em países sob regime comunista. Nesse sentido, procedia-se a um exame prévio dos antecedentes penais e político-sociais, bem como da situação financeira do interessado. A respeito do assunto, expediu-se circular recomendando que, ao se conceder qualquer espécie de visto, principalmente visto em caráter temporário, houvesse o maior cuidado e o máximo rigor na apreciação da profissão declarada e ideologia política do candidato (REL.EXT., 1956, p.221).

O Relatório do MRE de 1958 vai no mesmo sentido, salientando o exame dos antecedentes político-sociais como "medida preliminar para a concessão do visto", "no sentido de salvaguardar a ordem pública e a segurança das instituições contra possíveis infiltrações de ideologias estranhas aos princípios democráticos do regime" (1958, p.229). O Itamaraty condicionou, ainda, os pedidos de visto temporários de viajantes oriundos de países comunistas à aprovação do Chefe da Divisão de Ordem Política e Social, bem como institucionalizou um procedimento de consulta no qual a Secretaria de Estado poderia solicitar às autoridades consulares informações sobre profissão, ideologia política e antecedentes dos candidatos ${ }^{165}$ (REL.EXT., 1958).

\footnotetext{
${ }^{164}$ Essa é a visão de Paulo Roberto de Almeida (2009), em análise sobre a atuação do Itamaraty durante o regime militar brasileiro.

${ }^{165}$ Um exemplo de como se manifestava, na prática, a desconfiança em relação ao comunismo pode ser encontrado na Circular 1.864, de 26 de fevereiro de 1958, do Departamente Consular e de Passaporte, na qual Itamaraty esclareceu que, dentre 1.800 cidadãos húngaros que haviam sido acolhidos pelo Brasil "não como imigrantes, mas como refugiados", "82\% já se encontravam inteira e permanentemente colocados" (REL.EXT., 1958, p.233). Com esses dados, o Itamaraty respondia a alegações de 11 refugiados que partiram do Brasil para a Inglaterra, pleiteando serem reassentados em razão de não haver
} 
Não apenas entre a sede do MRE e seus postos consulares se estabelecia, porém, o fluxo de informações sobre os demandantes de vistos, o qual se estendia aos demais órgãos governamentais envolvidos com a temática migratória, como descrito no Relatório de 1959:

(...) em conexão com o Departamento do Interior e da Justiça e o Instituto Nacional de Imigração e Colonização, a Divisão de Passaportes age como intermediária junto às nossas Missões diplomáticas e Repartições consulares para efeito de obtenção de informações sobre antecedentes penais e políticossociais de estrangeiros, a fim de instruir processos de legalização de sua permanência no país, efetuada por aqueles dois órgãos" (REL.EXT., 1959, p.179).

A Circular do MRE $\mathrm{n}^{\circ}$ 2.785, de 09 de outubro de 1957, determinava a concessão de visto permanente aos candidatos que, após consulta individual ao INIC, fossem considerados "de profíssão útil e de fácil colocação no mercado de trabalho brasileiro", após averiguação da situação financeira (REL.EXT., 1958, p.230). A seleção realizada nos postos consulares obedecia, portanto, a dois objetivos principais: canalização de imigrantes segundo demandas do mercado de trabalho brasileiro e detecção de indivíduos indesejáveis, politicamente ou por motivos de saúde. Assim o sintetizou o MRE em seu relatório de 1959:

Na concessão de visto permanente a Divisão de Passaportes coloca em primeiro plano dois aspectos: $1^{\circ}$ ) a nacionalidade e a proveniência dos interessados; $2^{\circ}$ ) a profissão. $\mathrm{O}$ primeiro prende-se naturalmente ao sentido político da vinda de estrangeiros, sendo levadas em consideração as condições do país de origem e os motivos que teriam ditado a decisão de emigrar; o segundo atenta para o fato da adaptação do emigrante ao mercado de trabalho brasileiro (REL.EXT., 1959, p.185).

Em 1959, a preferência se dirige para aqueles que possuem especialidade técnica no campo industrial, "obedecendo às diretrizes da política desenvolvimentista brasileira” (REL.EXT., 1960, p.198). O nacional-desenvolvimentismo, conforme executado no governo de Juscelino Kubitschek, buscava soluções para os problemas nacionais, identificados como o subdesenvolvimento e a pobreza, no contexto externo, via busca de capitais e tecnologia estrangeiros (MANZUR, 1999). A estratégia de

encontrado habitação ou emprego no Brasil - e levando o caso para o Alto Comissariado das Nações Unidas para Refugiados, o CIME, o Comitê Húngaro do Brasil, dentre outras entidades. O Itamaraty alegou que, tendo sido os húngaros acolhidos como refugiados, não haviam sido escolhidos na base de seu potencial para inserir-se no mercado de trabalho, mas sim por "dever humanitário de dar acolhida e agasalho aos que buscavam abrigo" (1958, p.233). E complementou: "ainda com força subversiva, poderia ser apontada a perniciosa influência de elementos entre eles infiltrados e cujo verdadeiro propósito seria o de desmoralizar a atuação humanitária dos países democráticos que acolheram as vítimas de regime de opressão" (1958, p.234). 
atração de mão-de-obra qualificada correspondia, portanto, a uma de suas materializações.

Nesse sentido, é de autoria de Juscelino mensagem direcionada ao Congresso, em 1957, afirmando ser necessário promover “(...) uma prospecção cuidadosa dos vários mercados potenciais de imigrantes com o objetivo de aprimorar cada vez mais no futuro, do ponto de vista moral, profissional e eugênico, os contingentes de imigrantes" (apud VAINER, 2000, p.24).

No quadro do desenvolvimentismo de Juscelino, destaca-se a criação da Sudene, Superintendência de Desenvolvimento do Nordeste (Lei n ${ }^{\circ} 3.692 / 1959$ ), com o objetivo de diminuir as desigualdades regionais do país por meio da intervenção no Nordeste, promovendo soluções de planejamento que coordenassem o desenvolvimento da região. Para tanto, firmaram-se acordos de cooperação técnica com países como a antiga Tchecoslováquia, Japão, Israel, França e Estados Unidos, os quais compreenderam acordos para vinda de profissionais desses países para atuar em grupos de trabalho sob liderança de Celso Furtado.

É interessante notar que, desde o fim da II Guerra até 1960, os Relatórios do MRE sublinham a intensidade das atividades da Divisão de Passaportes, por vezes assinalando sua superioridade em relação ao ano anterior. Dentre essas atividades, encontravam-se, para além da concessão de vistos, solicitações "quer de órgãos da administração pública brasileira, quer de organizações de caráter internacional (Hias Service, Comitê Romeno da Cruz Vermelha, Comissão Nacional Católica de Imigração, Comitê Húngaro da Cruz Vermelha), requerimentos e cartas de particulares e de firmas interessadas na vinda de técnicos estrangeiros" (REL.EXT., 1959, p.179).

De fato, em Relatório de 1958, o MRE já citara a intensificação da articulação de sua Divisão de Passaportes com várias sociedades de assistência, destacando a Comissão Nacional Católica de Imigração e a United Hias Service (1958, p.235), entidades confessionais. Após o movimento centralizador empreendido no governo Vargas, o Estado acenava para uma abertura ao diálogo com essas organizações, as quais iniciavam atuação assistencial voltada aos imigrantes e refugiados que desembarcavam no Brasil.

Ressalte-se que a interlocução com outros órgãos do governo e organizações internacionais e não-governamentais constituíram fundamento para a reforma do MRE 
desenhada pela portaria ministerial $\mathrm{n}^{\circ} 28$, de 16 de novembro de 1958, a qual reestruturou o Serviço de Assuntos Consulares e de Passaportes e criou uma Divisão de Imigração, cabendo-lhe atuar "junto ao CIME, ao INIC, e a todas as entidades benévolas ligadas aos problemas migratórios” (REL.EXT., 1959, p.190).

Em 1960, o Brasil assinou três acordos bilaterais de imigração: com a Espanha $^{166}$, com a Itália ${ }^{167}$ e com o Japão ${ }^{168}$. Nos casos espanhol e italiano, remetiam-se ao CIME como parte colaboradora e fianciadora. Compreendiam a migração espontânea e a dirigida, sendo que, na segunda, os programas de migração deveriam ser elaborados pelo INIC e seu respectivo contraparte, e, após seleção dos migrantes pelas autoridades locais e representante brasileiros, seriam executados com monitoramento de Comissões mistas. As assinaturas dos acordos foram, porém, extemporâneas, sobrevindo em período no qual os fluxos oriundos dos referidos países, retomados após a II Guerra, já minguavam.

Entre 1959 e 1960, deu-se o Ano Mundial do Refugiado, instituído pela Resolução n ${ }^{\circ} 1.285$ (XIII) da Assembleia Geral das Nações Unidas, com os objetivos de:

a) chamar a atenção de todos para o problema dos refugiados e instar os governos, as organizações benévolas e o público em geral a oferecer contribuições financeiras suplementares, visando a resolvê-lo,

b) suscitar, a título puramente humanitário e de acordo com o anseio livremente expresso pelos próprios refugiados, novas possibilidades de soluções permanentes, mediante o repatriamente voluntário, a reinstalação ou a integração (REL.EXT., 1959, p.191).

Tal fato engendrou no Brasil, "a exemplo do que ocorreu em cerca de 50 países, que aderiram ao movimento, de âmbito internacional, para erradicação do refugiado da superfície do planeta" (REL.EXT., 1959, p.192), a criação de um Comitê Nacional para o Ano Nacional do Refugiado ${ }^{169}$, tendo como presidente o Ministro das Relações Exteriores (Horácio Lafer) e formado por membros do MRE, do INIC e da sociedade

\footnotetext{
${ }^{166}$ Acordo promulgado pelo Decreto no 53.998/1964. Disponível em: http://dai-mre.serpro.gov.br/atosinternacionais/bilaterais/1960/b_52/. Acesso em: 16 mai 2016.

${ }^{167}$ Acordo promulgado pelo Decreto n ${ }^{\circ} 57.759 / 1966$. Disponível em: http://dai-mre.serpro.gov.br/atosinternacionais/bilaterais/1960/b_48/. Acesso em: 16 mai 2016.

${ }^{168}$ Acordo promulgado pelo Decreto n ${ }^{\circ} 52.920 / 1963$. Disponível em: http://dai-mre.serpro.gov.br/atosinternacionais/bilaterais/1960/b 43/. Acesso em: 16 mai 2016.

${ }^{169}$ O Relatório do Ministério das Relações Exteriores de 1960 narra as atividades que foram realizadas em razão do Ano do Refugiado, englobando concursos culturais, publicação de reportagens, contribuições financeiras ao ACNUR, dentre outras (REL.EXT., 1960, p.210).
} 
civil - dentre esses últimos, todos pertencentes a entidades confessionais ${ }^{170}$. Ainda em 1959, o Brasil prontificou-se a acolher 730 refugiados, "de origem europeia, procedentes do Extremo Oriente" (REL.EXT., 1959, p.167); e em 1960 concedeu visto a 150 famílias de origem romena, atendendo a solicitação do United Hias Service (REL.EXT., 1960).

Em 1960, o MRE assinou com o CIME um acordo de ação conjunta pelo qual o Comitê prestaria assistência e serviços técnicos à administração brasileira, "com o objetivo de aumentar o fluxo migratório de operários qualificados, homens do campo e suas famílias para a indústria e a agricultura" (REL.EXT., 1960, p.205) ${ }^{171}$. Troca de notas $^{172}$ entre o Ministro das Relações Exteriores, Horácio Lafer, e o Diretor Geral do CIME, Marcus Daly, conveniou os termos de novo acordo migratório entre o Brasil e a organização. Tal acordo assentia nas seguintes condições colocadas por Lafer:

1) O Governo brasileiro tem repetidamente declarado no Conselho do CIME que está vivamente interessado em tomar medidas adicionais em cooperação com os governos membros e a administração do CIME e, em conjunto, com outras iniciativas apropriadas nacionais e internacionais de desenvolvimento a fim de aumentar o fluxo imigratório de operários qualificados e suas famílias para a indústria e a agricultura brasileiras, evitando sempre qualquer competição prejudicial aos interêsses dos trabalhadores nacionais.

Reconhecendo que, para preparar e implementar planos com o fim de atingir êste objetivo o CIME necessita, da parte de seus governos membros, um apôio substancial e efetivo, o Govêrno brasileiro está pronto a assegurar, a partir de 1961, uma contribuição especial de US\$ 50.000,00 para suplementar o custo dos serviços que forem projetados de conformidade com as indicações a seguir.(...)

Fica estabelecido que o CIME, após prévia aprovação do seu Conselho, contribuirá:

a) até US\$ 10.000,00 em 1961, como participação nas despesas relativas à manutenção, calculadas numa base "per capita". Essa contribuição "per capita" começará quando os alojamentos no edifício reconstruído ficarem prontos e em uso.

b) até US\$ $15.000,00$, como participação no custo total do equipamento adequado da Hospedaria de São Paulo, tipo hotel (LAFER, 27 de outubro de 1960).

\footnotetext{
${ }^{170}$ Eram membros, além do presidente Horácio Lafer: Ilmar Penna Marinho (diplomata), Manuel Emílio Pereira Guilhon (diplomata), Walter Cechella (presidente do INIC), Guilherme Joffily (membro do INIC), Dom Helder Câmara (bispo e fundador da Comissão Nacional Católica de Imigração), Andrew Muravieff (representante do Conselho Mundial de Igrejas no Brasil), e Israel Jacobson (representante da United Hias no Brasil).

${ }^{171}$ As ações incluiriam cursos de formação profissional para trabalhadores estrangeiros; bem como a instalação de uma "hospedaria modelo" que fornecesse, a preços reduzidos, casa e comida na primeira fase de adaptação e integração do imigrante (REL.EXT., 1960); o recrutamento de trabalhadores; e o treinamento de funcionários brasileiros de imigração.

${ }_{172}$ Disponível em: http://dai-mre.serpro.gov.br/atos-internacionais/bilaterais/1960/b_41/. Acesso em: 16 mai 2016.
} 
O período correspondente à Política Externa Independente (1961-1964), caracterizado pelo anseio de buscar a inserção internacional do Brasil sem constrangimentos ideológicos, em pleno período de Guerra Fria (MANZUR, 2014), enfatizou o tema dos direitos humanos, particularmente dos direitos sociais (MILANI, 2012). Nesse sentido, a questão migratória começa a ser abordada em uma perspectiva de direitos. É o que se depreende do resumo de atividades da delegação brasileira na XVI sessão da Assembleia Geral das Nações Unidas, em 28 de dezembro de 1961, quando teve atuação destacada no exame do projeto de Pacto dos Direitos Civis e Políticos e no debate sobre os refugiados árabes em Israel. Na ocasião, visando a consolidar uma linguagem de direitos, "A delegação do Brasil defendeu a tese de que agrupamentos humanos criados pela imigração não podem ser qualificados como minorias e estabeleceu a distinção necessária entre minoria jurídica e sociológica" (REL.EXT., p.261).

Em conclusão, observe-se que se, nos anos 60, o Brasil passa a ser reconhecido como um interlocutor no cenário internacional em virtude, entre outros fatores, de sua presença internacional multifacetada (LIMA, 2005), isso se deve, embora não exclusivamente, a sua intensa atuação na temática de imigração e refúgio.

Com as pendências dos refugiados da II Guerra pouco a pouco se solucionando, o epicentro dos fluxos populacionais mundiais deixa de ser a Europa e passa a se centrar, na década de 1960, nos conflitos da África e Ásia, os quais eclodiam em meio à Guerra Fria e a movimentos de independência. Em decorrência, o Protocolo sobre o Estatuto dos Refugiados, em 1967, estendeu as provisões da Convenção de 1951 a todos os refugiados enquadrados na definição da carta, sem limite de datas ou de espaço geográfico.

Não obstante, o contexto doméstico no Brasil se modificava. A imigração foi paulatinamente desvinculada das estratégias agrárias do país, sendo que as migrações inter-regionais se tornam os deslocamentos populacionais predominantes em um momento de êxodo rural e intensa urbanização (VAINER, 2000). Assim, em 1962, por meio da Lei Delegada $n^{\circ} 11$, o Instituto Nacional de Imigração e Colonização foi extinto, e concentraram-se no MRE as competências atinentes à concessão de vistos. 
Ademais, em 1964, o golpe militar dava início a vinte anos de ditadura no Brasil $^{173}$. Exercendo o poder de forma autoritária, os militares buscaram legitimar simbolicamente seus governos por meio do patriotismo e do discurso anticomunista (ABRUCIO et al., 2010). As diretrizes que imprimiram à sua política compreenderam a continuidade do desenvolvimentismo, o recrudescimento da ideia de soberania nacional e a aproximação da mesma ao conceito de segurança nacional. Nesses termos, não se verificou no período um rompimento com os princípios que vinham sendo aplicados à política migratória, exceto o marcado recrudescimento da perseguição de ordem política. Assim, já em 1964, a Lei $\mathrm{n}^{\circ} 4.473^{174}$ dispôs sobre as atribuições das autoridades para fiscalizar a entrada de estrangeiros no território nacional, definindo-as como "autoridades de Polícia" (art. $1^{\circ}$ ). Data do mesmo ano o episódio da prisão de um grupo de chineses, vindos ao Brasil para a instalação de um escritório comercial, sob acusação de espionagem e subversão, o que gerou um imbróglio diplomático entre os países (ALMEIDA, 2008, p.78).

Sem embargo, é nos primeiros anos da ditadura militar que a Convenção 97 da OIT, em sua versão revista de 1949, foi incorporada ao ordenamento brasileiro por meio do Decreto $n^{\circ}$ 58.819/1966. A Convenção, vigente até a atualidade, vincula os Estadospartes ao comprometimento de, entre várias outras ações, manter um serviço apropriado de informação e auxílio gratuito para os migrantes sobre a política e legislação nacionais referentes à imigração e sobre condições de trabalho e movimentos de trabalhadores migrantes (arts. $1^{\mathrm{o}}$ e $2^{\mathrm{o}}$ ); estabelecer, quando considerar oportuno, disposições com o objetivo de facilitar a saída, a viagem e o recebimento dos trabalhadores migrantes (art. $4^{\circ}$ ); garantir a igualdade de oportunidades e de tratamento dos trabalhadores migrantes, em condição regular, relativamente aos nacionais (art. $6^{\circ}$ ).

Perceba-se que uma modalidade particular de entrada de estrangeiros recebeu fomento do regime militar: aquela destinada à cooperação técnica e científica, com envio de especialistas e técnicos em missões específicas, com assinaturas de protocolos, acordos e convênios com a Alemanha ${ }^{175}$, Espanha e Israel ${ }^{176}$. Além disso, em meados

\footnotetext{
${ }^{173}$ Para este período, não se encontram disponíveis os Relatórios do Ministério das Relações Exteriores. $\mathrm{Na}$ tentativa de suprir esta ausência, a pesquisa valeu-se da análise dos atos bilaterais assinados pelo Itamaraty e dos relatórios da Comissão Nacional da Verdade.

${ }^{174}$ Disponível em: http://www.planalto.gov.br/ccivil 03/leis/1950-1969/L4473.htm. Acesso em: 21 mai 2016.

175 Exemplos: Convênios Complementares ao Acordo Básico, de 30 de novembro de 1963,sobre Cooperação Técnica com o Governo alemão (de 12 de outubro de 1966, entre a Escola Veterinária Superior de Hannover e a Universidade do Rio Grande do Sul; de 21 de dezembro de 1967, para o
} 
dos anos 1970, a conjuntura econômica em declínio, as tendências à adoção de medidas protecionistas por parte dos países centrais e a emergência da pauta do subdesenvolvimento levaram o Brasil a buscar a cooperação com países periféricos como estratégia mais ampla de integração à economia internacional - inclusive por meio da celebração de acordos culturais bilaterais com países da América Latina canalizando a vinda de estudantes, em nível de graduação e pós-graduação, por períodos superiores a quatro anos (MARTINS, 1974).

As negociações com Portugal também se destacaram, havendo culminado na Convenção sobre Igualdade de Direitos entre Brasileiros e Portugueses, internalizada pelo Decreto Federal no 70.391/1972.

O período militar tampouco interrompeu a atividade do Brasil no Comitê Intergovernamental para as Migrações Europeias. Por meio de acordo de 17 de maio de 1968, o governo brasileiro regulamentou a concessão de privilégios e imunidades ao CIME e seus funcionários ${ }^{177}$. Assinou-se, ainda, o Protocolo de 1967 sobre a Convenção dos Refugiados, e o ACNUR continuava dialogando com o país, embora não se lhe tenha permitido instalar sua sede local, no Rio de Janeiro, antes de 1977.

As mudanças gerais da política migratória do período tenderam, contudo, à restrição. A fim de facilitar a expulsão do estrangeiro que "atente contra a segurança nacional, a ordem política ou social, a tranqüilidade e moralidade públicas e a economia popular, ou cujo procedimento o torne nocivo ou perigoso a conveniência ou aos interêsses nacionais" (art. $1^{\circ}$ ), o Decreto-Lei no 417 de $1969^{178}$ previu um procedimento sumário mediante interveniência do Presidente da República.

Em tempos de AI-5, o Decreto-lei no 941 de 1969, que redefiniu a situação jurídica do estrangeiro, e o Decreto $n^{\circ}$ 66.689/1970, que o regulamentou, centralizaram a competência para concessão de vistos no Ministério de Justiça e das Relações

\footnotetext{
Instituto de Medicina Tropical da Universidade de Recife e o Instituto "Desidério Finamor", em Guaíba, no Rio Grande do Sul; de 06 de dezembro de 1967, para a missão Geológica da SUDENE; envio de especialistas agrícolas à estação experimental do Ministério da Agricultura em Curitiba; planejamento hidráulico do Vale do Rio dos Sinos, no Rio Grande do Sul, de 25 de janeiro de 1967 (disponíveis em: http://dai-mre.serpro.gov.br/atos-internacionais/bilaterais/. Acesso em: 16 mai 2016).

${ }^{176}$ Disponível em: http://dai-mre.serpro.gov.br/atos-internacionais/bilaterais/1967/b_22/. Acesso em: 16 mai 2016.

${ }_{177}^{177}$ Disponível em: http://dai-mre.serpro.gov.br/atos-internacionais/bilaterais/1968/b_15/

${ }^{178}$ Disponível em: http://www.planalto.gov.br/ccivil_03/decreto-lei/1965-1988/Del0417.htm. Acesso em: 20 jun 2016.
} 
Exteriores ${ }^{179}$ e aumentaram a discricionariedade dos órgãos implementadores, dentre os quais, o Departamento de Polícia Federal, a quem cabia o controle da entrada, o registro e outras responsabilidades documentais, a expulsão e a naturalização - sendo-lhe conferido, para tanto, um orçamento específico. Conquanto estabelecesse que "Todo estrangeiro poderá entrar no Brasil, desde que satisfaça as condições estabelecidas neste Decreto-lei" (art.1 $\left.1^{\circ}\right)$ e não se destacasse em relação às normas que o precederam em termos de limitações à entrada ou restrições de direitos, o Decreto-lei $\mathrm{n}^{\circ} 941$ se particularizou por inaugurar um movimento de concentração de competências relacionadas ao imigrante na Polícia Federal ${ }^{180}$.

O Departamento Federal de Segurança Pública havia sido transformado em Departamento de Polícia Federal pelo Decreto-Lei no 200/1967 - no bojo do qual a Divisão de Polícia Marítima, Aérea e de Fronteiras (DPMAF) lidava com a admissão de estrangeiros no território. O decreto-lei no 200/1967 é considerado a segunda grande reforma administrativa brasileira do século $\mathrm{XX}$, e desenhou o Estado conforme concebido e instrumentalizado pelos militares: autoritário, tecnocrático, fortemente centralizador, embora conferindo maior flexibilidade à administração indireta (ABRUCIO et al, 2010).

Relatório da Comissão Nacional da $\operatorname{Verdade}^{181}$ (2014) aponta que, dentre as funções do Departamento de Ordem Política e Social (DOPS), órgão central da repressão política ao lado dos Destacamentos de Operações de Informações (DOIs), estavam fiscalizar a entrada, a permanência e a saída dos estrangeiros do território nacional - junto a competências relacionadas a investigação, prevenção e repressão dos delitos de caráter político.

O relatório da CNV discorre, ainda, sobre a atuação do Centro de Informações do Exterior (Ciex), órgão de informação que, por agir muitas vezes clandestinamente, não estava formalmente na estrutura do MRE, porém com ele realizava ações conjuntas,

\footnotetext{
${ }^{179}$ Embora estabelecesse que a competência para fixar as normas disciplinadoras da seleção de imigrantes caberia, além do MRE e Ministério da Justiça, ao Ministério do Trabalho, da Saúde e da Agricultura (art. $\left.22, \S 2^{\circ}\right)$.

${ }^{180}$ É importante ressalvar que, como coloca Arantes (2011), a Polícia Federal não teve protagonismo repressor no período militar, papel este exercido, principalmente, pelos Destacamentos de Operações de Informações (DOIs) e Departamentos de Ordem Política e Social (DOPS).

181 As pesquisas conduzidas pela Comissão Nacional da Verdade contaram, dentre seus grupos de trabalho, com o campo temático das "violações de direitos humanos de brasileiros no exterior ou de estrangeiros no Brasil” (CNV, 2014, p.51).
} 
principalmente junto à Divisão de Segurança e Informações (DSI) ${ }^{182}$, no intuito de coletar informações sobre brasileiros exilados e estrangeiros considerados subversivos $^{183}$. Para além desses dois órgãos, o relatório afirma enfaticamente a colaboração do Itamaraty com a política do regime, sublinhando que "todas as missões diplomáticas e repartições consulares brasileiras estiveram integradas, de alguma forma, à política repressiva da ditadura" (CNV, 2014, p.176).

As pesquisas da CNV salientam a importância conferida à época para operações multilaterais voltadas à repressão transnacional de indivíduos considerados subversivos, das quais a Operação Condor foi a mais estruturada. Como resultado desta operação, chilenos, paraguaios, uruguaios, bolivianos e argentinos foram perseguidos no Brasil particularmente os últimos ${ }^{184}$. Os argentinos foram, ainda, alvo de outra operação do serviço de repressão brasileiro: a Operação Gringo (CNV, 2014, p.258). Em decorrência, a nacionalidade argentina é aquela, entre os estrangeiros, com maior número de vítimas do regime militar brasileiro: onze mortos ou desaparecidos ${ }^{185}$, entre os 434 indivíduos vitimados pelo Estado brasileiro entre 1964 e 1985.

Por último, o relatório da $\mathrm{CNV}$ cita a ata da $69^{\mathrm{a}}$ Reunião dos Órgãos Responsáveis pela Produção de Informações Externas, na qual se discutira a "situação de estrangeiros no Brasil sob a proteção do Alto Comissariado das Nações Unidas para os Refugiados (ACNUR)”, observando-se que “os serviços responsáveis pela segurança interna têm manifestado preocupação quanto aos antecedentes de algumas pessoas relacionadas pelo ACNUR, cuja seleção e triagem não se processam de maneira muito rigorosa" (CNV, 2014, p.257). A ata demonstra que, embora se aderisse formalmente ao regime de refúgio, buscava-se manipular o conceito de refugiado segundo um entendimento específico de migrante desejável. Desta forma, “(...) quando argentinos, etíopes, uruguaios, etc. solicitavam proteção ao Brasil, era-lhes permitida tão-somente

\footnotetext{
${ }^{182}$ Com a criação do Serviço Nacional de Informações, em 1964, foi criada no organograma de todos os ministérios uma Divisão de Segurança e Informações, à qual incumbia zelar pela efetividade dos princípios do regime em todo o Executivo, especialmente via identificação de comunistas infiltrados (ALMEIDA, 2008).

${ }_{183}$ O relatório pontua que "os principais focos de atuação do Ciex foram os países do Cone Sul da América Latina, nomeadamente o Uruguai, a Argentina e o Chile, onde houve grande número de exilados. Na Europa, o Ciex teve bases em Paris, Lisboa e em capitais de países comunistas, como Moscou e Praga" (CNV, 2014, p.161).

${ }^{184}$ Conferiu-se, no Relatório da CNV, uma sessão específica aos mortos e desaparecidos argentinos (2014, p.256).

${ }^{185}$ Portanto, uma das conclusões do relatório é a de que "Diante dos documentos e testemunhos expostos, está claro que graves violações de direitos humanos foram praticadas contra cidadãos argentinos em território brasileiro, por ações de agentes brasileiros e argentinos, com o conhecimento de altas autoridades governamentais do Brasil e da Argentina" (2014, p.260).
} 
uma permanência temporária até que outros países os aceitassem via reassentamento" (ANDRADE, 1996, p.41).

No geral, o período militar foi marcado por fluxos significativamente menos intensos, porém mais variados em termos de nacionalidades. Sales e Baeninger (2000) ressalvam que, em virtude da rigidez do regime geral e de proibições específicas quanto a determinadas nacionalidades, acentuaram-se os fluxos clandestinos de imigrantes, especialmente coreanos, bolivianos, e, mais intensamente na década de 1980, angolanos.

Havia, ainda, os refugiados. $\mathrm{O}$ afastamento do setor governamental dos migrantes abriu caminho para a ação não-governamental. Nos anos 1970, a Igreja católica foi ator central no acolhimento, compreendendo especialmente nacionais de países latino-americanos, mas tendo incluído também vietnamitas, angolanos e iranianos. A Cáritas Arquidiocesana do Rio de Janeiro e a de São Paulo, assim como a Comissão de Justiça e Paz, foram as organizações com maior atuação. Sobre o assunto, narra Dom Eugênio de Araújo Sales, arcebispo emérito do Rio de Janeiro que liderou a atuação da Cáritas no tema:

\begin{abstract}
Foram quase 05 mil pessoas refugiadas que apoiamos naquele período que vai de 1976 até 1982, quando o governo brasileiro não reconhecia sequer a presença oficial do Alto Comissariado das Nações Unidas para Refugiados (Acnur) e ainda estávamos muito distante da condição que temos hoje, de ter uma lei de proteção aos refugiados $(2010$, p.62)
\end{abstract}

\title{
3.5. Lei 6.815, de 1980: Estatuto do Estrangeiro
}

Como decorrência da diminuição dos fluxos, se a população estrangeira representava, em 1920, 5,1\% do total da população nacional, em 1980 esse índice se reduzira a 0,77\% (SALES e BAENINGER, 2000, p. 39). A tendência, confirmada no decorrer da década, era a de começarem a se manifestar saldos migratórios negativos.

No final dos anos 1970, o governo militar, comandado por João Figueiredo, já iniciara uma flexibilização na repressão política e liberdade de expressão, bem como um movimento de melhoria de serviços públicos, na tentativa de angariar popularidade. A crise política do regime militar, acompanhada da crise econômica após um período de crescimento acelerado; da crise financeira do Estado; e da crise do nacionaldesenvolvimentismo levariam, em alguns anos, à transição para o regime democrático 
(GOUVÊA, 1994; BRESSER-PEREIRA, 1989). Apesar disso, externamente, a Guerra Fria ainda perdurava; assim como, internamente, a Operação Condor seguia levada a cabo.

Data deste período o Estatuto do Estrangeiro (Lei $n^{\circ}$ 6.815/1980 ${ }^{186}$ ). Seus artigos iniciais explicitam os princípios da política migratória então adotada:

Art. $1^{\circ}$ Em tempo de paz, qualquer estrangeiro poderá, satisfeitas as condições desta Lei, entrar e permanecer no Brasil e dele sair, resguardados os interesses nacionais.

Art. $2^{\circ} \mathrm{Na}$ aplicação desta Lei atender-se-á precipuamente à segurança nacional, à organização institucional, aos interesses políticos, sócioeconômicos e culturais do Brasil, bem assim à defesa do trabalhador nacional.

Art. $3^{\circ}$ A concessão do visto, a sua prorrogação ou transformação ficarão sempre condicionadas aos interesses nacionais.

Observa-se a premência do interesse nacional, conceito introduzido na legislação migratória apenas na ditadura militar, por ocasião do Decreto-lei nº 941 de 1969. Todavia, este último o empregara com bem menos frequência ${ }^{187}$, além de fazê-lo como diretriz de implementação e não como princípio geral. O mesmo ocorre com a segurança nacional: tratava-se, desde a década de 1920, de elemento limitador da entrada de indivíduos e motivador de sua expulsão, mas ainda não fora elencado como princípio da política. Passa a sê-lo na legislação de 1980, em consonância com a Lei de Segurança Nacional (Decreto-Lei $n^{\circ}$ 314/1967) e seu entendimento de segurança nacional como "a garantia da consecução dos objetivos nacionais contra antagonismos, tanto internos como externos" (art. $2^{\circ}$ ). Já a defesa do trabalhador nacional é princípio resgatado do período Vargas, ausente da regulamentação militar precedente. Ao adotar a fórmula acima citada, os legisladores explicitam a superioridade da soberania estatal frente aos direitos dos indivíduos.

A Lei 6.815/1980 é não apenas uma norma promulgada por um regime militar em decadência - é uma norma que repete, em muito, os dispositivos de sua antecessora, esta publicada em tempos de AI-5. A disciplina geral dos vistos é bastante semelhante, à exceção de algumas especificidades e da categoria de imigração dirigida não estar presente na lei de 1980.

\footnotetext{
${ }^{186}$ Regulamentada pelo decreto 86.715 , de 10 de dezembro de 1981 .

187 Assim, enquanto o Decreto ${ }^{0} 941$ impede a concessão de visto ao estrangeiro "nocivo à ordem pública" (art. $5^{\circ}, \mathrm{II}$ ), a Lei $\mathrm{n}^{\circ} 6.815$ o proíbe para aquele "nocivo à ordem pública e aos interesses nacionais" (art. $7^{\circ}$, II).
} 
A grande inovação do Estatuto do Estrangeiro em relação à sua norma predecessora é institucional: o Ministério do Trabalho retoma competências em política migratória, e cria-se o Conselho Nacional de Imigração (CNIg). O Decreto $\mathrm{n}^{\circ}$ 86.715/1981, que regulamentou o Estatuto, vinculou o CNIg ao Ministério do Trabalho e estabeleceu que este último o presidiria. O Conselho seria formado, ademais, por representantes de outros Ministérios ${ }^{188}$ e do Conselho Nacional de Desenvolvimento Científico e Tecnológico, com funções de orientar e coordenar as atividades de imigração; formular objetivos para a elaboração da política imigratória; estabelecer normas de seleção de imigrantes, visando proporcionar mão-de-obra especializada aos vários setores da economia nacional; dentre outros. A estrutura institucional do CNIg, bem como suas atribuições, denotam a retomada do elemento trabalho como eixo balizador da política migratória brasileira, como se depreende outrossim do artigo 16 da Lei $n^{\circ} 6.815$ :

Parágrafo único: A imigração objetivará, primordialmente, propiciar mão-de-
obra especializada aos vários setores da economia nacional, visando à
Política Nacional de Desenvolvimento em todos os aspectos e, em especial,
ao aumento da produtividade, à assimilação de tecnologia e à captação de
recursos para setores específicos.

No quadro da migração laboral, a lei direciona seu foco para a mão-de-obra especializada segundo as necessidades das empresas brasileiras. Restavam, aos que não se encaixassem nessas características, as opções de casar-se com brasileiro ou ter filho em território nacional. Ressalte-se, por último, que o Decreto $\mathrm{n}^{\circ} 86.715$ centraliza na Polícia Federal as competências referentes à fiscalização da entrada e ao registro do estrangeiro, abarcando, no caso desta última, todo o contato com a ponta na implementação da política.

Segundo observa Marcia Sprandel (2015), a apresentação do projeto de lei ao Congresso ocorre ato contínuo ao retorno de viagem do General Figueiredo a Paraguai e Argentina, onde visitara seus correspondentes General Alfredo Stroessner e General Jorge Videla - cúmplices na Operação Condor. Ainda de acordo com Sprandel, isso teria suscitado, em parlamentares opositores, a percepção de que o fundamento principal do projeto estaria em facilitar a expulsão de estrangeiros considerados inimigos do regime.

\footnotetext{
${ }^{188} \mathrm{Na}$ sua formação original, o Ministério da Justiça, Ministério das Relações Exteriores, Ministério da Agricultura, Ministério da Saúde, Ministério da Indústria e do Comércio.
} 
Assim, a mensagem $n^{\circ} 64$ do Executivo foi recebida pelo Congresso Nacional em 26/05/1980, tendo o Presidente Figueiredo requerido que fosse apreciada dentro de 45 dias, prerrogativa que lhe concedia o artigo 54 da Constituição de $1967^{189}$. Nos termos do dispositivo constitucional, se a matéria não fosse apreciada no prazo estabelecido, seria automaticamente aprovada - e assim o foi. A mensagem do Executivo, assinada pelos Ministros da Justiça, das Relações Exteriores e do Trabalho, bem como pelo Secretário-Geral do Conselho de Segurança Nacional, argumentava:

A proposta visa, outrossim, propiciar os instrumentos legais indispensáveis à
consecução da política migratória do Governo de Vossa Excelência,
orientada no sentido de reduzir o afluxo de estrangeiros aos estritamente úteis
e necessários ao nosso desenvolvimento, por não mais consultar aos
interesses nacionais da imigração indiscriminada para o Brasil.
O incluso anteprojeto de lei é, portanto fruto de cuidadoso e coordenado
estudo, por parte dos diversos Ministérios interessados na questão. Visa,
como se disse, adequar nossa legislação aos princípios fixados, em 1976, para
a política de imigração do Governo brasileiro e dar cumprimento as diretrizes
governamentais no sentido de só permitir a radicação no País, dos
estrangeiros que venham complementar a mão-de-obra nacional, nos níveis
de qualificação em que esta não puder atender à demanda resultante do atual
processo de desenvolvimento econômico (DCN, n53, p. 1129).

A proposta suscitou calorosos debates e franca oposição de diversos deputados e senadores, os quais contestaram o prazo de aprovação de 45 dias, alegando tratar-se de artifício visando à aprovação automática mediante a manipulação dos quóruns presentes às votações pela bancada majoritária ${ }^{190}$; e chegaram a apresentar 36 emendas, rejeitadas em sua quase totalidade (à exceção de duas) pelo relator Senador Bernardino Viana ${ }^{191}$. Durantes as cinco sessões em que o Projeto de Lei $n^{\circ} 09$ foi colocado na ordem do dia, presenciaram-se discussões acaloradas, porém em nenhuma das ocasiões obteve-se quórum para votação, sendo o projeto automaticamente aprovado por decurso de prazo em 06 de agosto de 1980. Colaciona-se abaixo dois trechos de pronunciamentos de congressistas que contemplam uma análise sobre os fundamentos da Lei:

\footnotetext{
${ }^{189}$ Agradeço ao funcionário da Secretaria de Gestão de Informação e Documentação do Senado Federal, Sr. José Evandro Camargo Godim, pelo auxílio prestado no mapeamento da tramitação da Lei no 6.815 .

${ }^{190}$ Disponível no Diário do Congresso Nacional, no 79, publicado em 06/08/1980, sessão de 05/08/1980, p.1703-1718. Disponível em: http://legis.senado.gov.br/diarios/BuscaDiario?datSessao=05/08/1980\&tipDiario=2. Acesso em: 22 set 2016.

${ }^{191}$ Parecer no96, de 1980. Disponível no Diário do Congresso Nacional, $\mathrm{n}^{\circ} 71$, publicado em 24/06/1980, sessão de 23/06/1980, p.1513-1516. Disponível em: http://legis.senado.gov.br/diarios/BuscaDiario?datSessao=23/06/1980\&tipDiario=2. Acesso em: 22 set 2016.
} 
O SR. JOSÉ CARLOS VASCONCELOS (PMDB - PE. Sem Revisão do orador.) - Sr. Presidente, Srs. Congressistas, entrará o Estatuto dos Estrangeiros, que hoje discutiremos e votaremos, revela mais uma vez o autoritarismo do Governo implantado no Brasil em decorrência do uso da força e contra os mais legítimos interesses do povo brasileiro. O Poder Executivo, Sr. Presidente, levou oito anos elaborando esse diploma legal, porém o remeteu ao Congresso Nacional para que sobre ele se pronunciasse no prazo de 45 dias. Usa - o Executivo - de expediente absurdo, imposto pela força, que não permite a apreciação de matéria tão importante em prazo mais dilatado. Mais ainda, obriga o seu partido a se retirar do Plenário, a fim de que não haja número para a votação da matéria e esta, afinal, seja aprovada por decurso de prazo.(...)

SR. EDISON KHAIR (PMDB - RJ Sem Revisão do orador). Sabemos muito bem que este projeto visa a três objetivos, dois deles já denunciados por vários Deputados e entidades, e o terceiro ainda não abordado. O primeiro é a perseguição aos membros do clero que se colocam contra a estrutura injusta e a ditadura ainda vigentes no Pais; o segundo é a perseguição aos exilados políticos de toda a América Latina, particularmente àqueles do Cone Sul; e o terceiro, ainda não abordado até hoje, é exatamente a colocação nas mãos do Governo - o que vale dizer nas mãos da polícia, de uma fonte de corrupção muito grande, Sr. Presidente, que vai permitir possam os agentes policiais a qualquer hora e a qualquer momento, achacar estrangeiros em nosso País ${ }^{192}$.

De fato, a análise das atas correspondentes ao trâmite de aprovação da Lei no Diário do Congresso Nacional ${ }^{193}$ mostra a profundidade dos debates ocorridos no Congresso, que contaram com exposição de experiências comparadas, cotejamento com normas internacionais, discussões mais amplas sobre a perspectiva adotada e mais restritas sobre determinados dispositivos. Em pesquisa que se fundamenta no banco de dados "Discursos e Notas Taquigráficas", da Câmara dos Deputados, Marcia Sprandel (2015, p.152) encontrou 140 discursos referindo-se ao Projeto de Lei $n^{\circ}$ 9/1980.

O debate se espraiou, ademais, para a esfera pública. Sprandel (2015) narra que, em 05 de agosto de 1980, o Movimento de Anistia e o Comitê Brasileiro de Solidariedade aos Povos da América Latina entregaram ao presidente da Câmara dos Deputados documento com mais de 17 mil assinaturas contra o Estatuto do Estrangeiro. Relata a autora que mesmo o Papa João Paulo II, em visita ao país, demonstrara preocupação com o texto.

192 Diário do Congresso Nacional, nº 79, publicado em 06/08/1980, sessão de 05/08/1980, p.1702. Disponível em: http://legis.senado.gov.br/diarios/BuscaDiario?datSessao=05/08/1980\&tipDiario=2. Acesso em: 22 set 2016.

${ }^{193}$ Para acessá-las, a presente pesquisa procedeu à análise da tramitação da mensagem no ${ }^{\circ}$ 64/1980 na base de dados do Senado Federal (disponível em: http://www25.senado.leg.br/web/atividade/materias/Imateria/9758 , acesso em: 22 set 2016); e mapeou, em cada ação, as referências a publicações no Diário do Congresso Nacional (disponível em: http://legis.senado.gov.br/diarios/, acesso em: 22 set 2016). 
A despeito das manifestações contrárias, a Lei foi aprovada - e manteve-se vigente por mais de trinta anos. Em paralelo a tal continuidade, mudanças incrementais se verificaram na política, dinâmica esta que será explorada no capítulo 4.

\subsection{Considerações finais}

A política migratória brasileira passou por sucessivas reformas e redesenhos institucionais que se situam na interface entre os processos de state-building e nationbuilding do país. Se cada um desses processos de mudança representou uma adequação a interesses domésticos historicamente situados e foram, também, afetados por distintas conjunturas e atores internacionais; não deixaram de ser influenciados e, por vezes, de coexistir com fortes traços dos arranjos institucionais precedentes. Os projetos de mudança que se verificaram no decorrer do século $\mathrm{XX}$, ao criarem novas instituições ou redistribuírem as competências entre organizações existentes, tenderam a não excluir os atores envolvidos do jogo político. Dessa forma, as reformas parciais levaram a uma pluralidade de organizações com responsabilidades sobrepostas.

Observa-se do exposto no capítulo a importância histórica da imigração como um fenômeno político, estruturante e estruturado pelo Estado brasileiro. No intuito de responder a demandas da política imigratória, estruturas importantes do Estado foram criadas ou aprimoradas, dentre as quais o departamento que deu origem ao Ministério do Trabalho. Em contrapartida, as tensões que caracterizam o Estado brasileiro estão presentes na história de sua política migratória: a tensão entre centralização ou descentralização federativa; entre um sistema partidário aliado a interesses fragmentados e um Executivo com amplos poderes legislativos; entre os diferentes padrões de interação Estado-sociedade.

Paralelamente, práticas institucionais em relação ao imigrante refletiram tanto a construção do conceito de nacionalidade, seara em que os burocratas do Itamaraty exerceram um importante papel, quanto à construção do ideal de cidadania nacional: o recrutamento de mão-de-obra não se desvencilhou, nem mesmo no auge do getulismo, do recrutamento de membros da nação - sob critérios raciais e culturais.

Em suma, não se entende a política migratória brasileira sem passar pelo Estado como arena em que se desenrolaram relações de poder, se construíram interesses e se 
competiu por recursos. Junto aos políticos, burocratas ${ }^{194}$ foram atores centrais na sua transformação, com relativa autonomia das classes econômicas dominantes. De fato, interesses de grupos econômicos não são suficientes para explicar mudanças na política migratória: embora tenham sido assimiladas, suas demandas foram continuamente contrabalançadas ao projeto de nação e a influências externas. Em contrapartida, objetivos mais amplos do Estado brasileiro se mostraram diretamente refletidos na política migratória, como se nota no sumário de suas fases:

1. Projeto de nação contrabalançado com interesses clientelísticos

1.1. Delimitação do campo político a partir do conceito de nacionalidade (1889-1920)

1.2. Restrição do campo político a partir da separação entre nacionalidade e cidadania (1920-1945)

2. Burocratização do Estado brasileiro e imigração vinculada a sucessivos projetos de governo.

2.1. Aprimoramento conceitual dos critérios de exclusão legitimados - racial, sanitário, político (1945-1970)

2.2. Do controle à exclusão (1970-1988).

Um dos atores a quem consistentemente se atribuíram competências em política migratória foi o Itamaraty, embora seu papel e protagonismo tenha oscilado no decorrer da história. Nas primeiras décadas da República, o MRE participou ativamente da tomada de decisão sobre migração, momento em que sobressai a construção do conceito de nacionalidade brasileira, realizada com participação dos agentes implementadores da política (os cônsules) e em constante interconexão com outros conceitos de direito internacional igualmente incipientes à época - destacando-se os dissídios provenientes do contraponto entre jus soli e jus sanguinis. A inserção internacional do Brasil processava-se através das grandes potências do sistema internacional e tinha na atração de mão-de-obra um de seus eixos direcionadores, em estreito vínculo com os interesses comerciais da economia agrária. Deste modo, o MRE constituía o elo que atrelava o projeto nacional, viabilizado pela política migratória, aos mecanismos de inserção internacional do país.

\footnotetext{
${ }^{194} \mathrm{E}$, de maneira mais ampla, funcionários estatais, visto que, em termos weberianos, a burocratização da máquina administrativa brasileira se dá apenas na era Vargas.
} 
A inserção internacional do Brasil, definida a partir de possibilidades sistêmicas e visões do interesse nacional oriundas de coalizões domésticas, seguiu afetando as linhas gerais da política migratória brasileira nos períodos posteriores: é o relacionamento com os Estados Unidos o fator internacional com maior influência sobre a mesma nas décadas de 1930 e 1940; seguido pela multilateralização nas décadas de 1950 e 1960.

Já a inserção internacional concebida após as mudanças fáticas e institucionais, internacionais e domésticas, verificadas posteriormente à Constituição Federal de 1988, é definida por Vigevani e Cepaluni (2007) como, em um primeiro momento, autonomia pela participação, marcada pela adesão aos regimes internacionais, seguida, no governo Lula da Silva (2003-2010), pela autonomia pela diversificação, com a adesão do país a princípios e normas internacionais sob juízo de que reduziriam as assimetrias nas relações exteriores. Em ambas as fases, os direitos humanos assumem um importante papel, inclusive com o Brasil assumindo o discurso de contestar a instrumentalização política de seu universalismo pelas diplomacias das economias avançadas ocidentais (MILANI, 2012). Nesse contexto, pode-se supor que os direitos humanos fornecerão a tônica da mobilização internacional da temática migratória pelo Brasil após a Constituição de 1988.

Em suma, percebe-se que, embora as políticas migratórias tenham se transformado associadas a objetivos políticos distintos, sua trajetória histórica costumou agregar órgãos a elementos do arranjo institucional previamente estabelecido. Por conseguinte, o arranjo institucional em vigência quando da promulgação da $C F / 88$ é composto de uma pluralidade de instituições. Nesses termos, harmonizando as hipóteses desenvolvidas no capítulo 2 aos achados do presente, notadamente o de que objetivos maiores do Estado brasileiro enquadraram sua política migratória, pode-se supor que no período abarcado no process-tracing ela será influenciada por elementos do Estado gerencial, e que sua projeção internacional estará vinculada à temática dos direitos humanos. 


\title{
Capítulo 4: Incrementalismo e burocracias: ação e reação na política migratória brasileira pós Constituição de 1988
}

"a organização é a mobilização do preconceito" Hall e Taylor (2003, p.218) ${ }^{195}$

\subsection{Introdução e metodologia}

Este capítulo empreende um process-tracing no intuito de mapear a relação de causalidade proposta na hipótese de trabalho por meio de "uncovering traces of a hypothesized causal mechanism within the confines of one or a few cases" (BENNETT; ELMAN, 2007, p.183). Em se tratando de um process-tracing, busca-se comparar a teorização de um mecanismo com uma rígida pesquisa empírica sobre os processos hipotetizados, reunindo pedaços de evidência em uma teia teoricamente estruturada. $\mathrm{O}$ intuito é o de desvelar "the causal arrow(s) linking cause and outcome into a series of interlocking and interacting parts" (BEACH; PEDERSEN, no prelo, p. 18).

Estudos de processos políticos são inerentemente sobre como ocorre determinado fenômeno, objetivando desta maneira explicar um resultado político (HILL, 2013). As causas são conectadas aos resultados através de mecanismos sobre os quais recai o foco analítico, conferindo-se relevo às agências e às práticas por elas empregadas. Como explicam Abers e Keck,

\begin{abstract}
Exploring such how questions require focusing on processes and not just on conditions. It also means looking at micro-processes, the actual practices in which people engage. A focus on the micro scale is not a negation of the importance of what Tilly (1984) called 'big structures' and 'large processes' but a recognition that even the most macro phenomena comprise multitudes of specific acts of debating, reworking and testing ideas, building organizations, engaging in conflicts and negotiations, connecting people, and building capacities (ABERS; KECK, 2013, p. 198).
\end{abstract}

A ênfase nos mecanismos vem sendo apontada pela literatura como o cerne do process-tracing (BENNET, 2008; COLLIER et al., 2010; MAHONEY; GOERTZ, 2012; BEACH; PEDERSEN, no prelo). Destrinchar o mecanismo ligando as causas ao outcome, dentro de uma moldura explicativa explícita, é o caminho proposto para que o estudo de caso ultrapasse a narrativa histórica, apta a embasar inferências descritivas, e possa fundamentar inferências causais.

195 Frase colocada pelos autores como resumo das ideias propostas pela geração anterior de institucionalistas. 
Beach e Pedersen optam por definir mecanismos como "theoretical systems linking $X$ to $Y$ " (no prelo, p.22), explicando tratar-se de uma cadeia em que entidades se engajam em atividades para transmitir forças causais que conduzem aos resultados. As entidades (atores, organizações ou estruturas) corresponderiam a cada uma das engrenagens, e as atividades seriam o que as fazem movimentar - conduzindo a força motriz para a próxima engrenagem e produzindo, ao final, o outcome.

Ressalte-se que, nesta perspectiva, realizam-se afirmações causais de caráter assimétrico, isto é, a afirmação sobre a causa $\mathrm{X}$ de $\mathrm{Y}$ não implica em qualquer afirmação sobre as causas de não-Y, ou sobre o que resulta de não-X. O fundamento de tais afirmações reside na teoria dos conjuntos, de acordo com a qual determinados parâmetros qualitativos definirão o pertencimento de um caso a um conjunto teórico conceitual (BEACH; PEDERSEN, no prelo).

Como operacionalizar esta abordagem metodológica? Uma definição operacional dos conceitos causais teorizados deve identificar os atributos de modo a possibilitar sua observação empírica. Definida a hipótese de trabalho, cabe questionar-se que tipo de evidência se espera ver em cada uma das partes do mecanismo.

Ressalve-se que a definição da hipótese não se desvencilha da escolha do caso: "case selection in explaining outcome process tracing is driven by a strong interest in accounting for a particular interesting and/or historically important outcome". (BEACH; PEDERSEN, no prelo, p.402). A isso se coadunam as recomendações de King, Keohane e Verba para casos com pequeno número de observações, nos quais "selection must be done in an intentional fashion, consistent with our research objectives and strategy" (2004, p.139).

O caso em análise, como justificado na introdução, é a política migratória brasileira entre 2003-2016. O lapso temporal foi determinado visando a manter constante o partido no governo, controlando desta forma para possíveis divergências de agendas partidárias, e a facilitar a coleta de fontes diretas via entrevistas e documentos governamentais. O intervalo entre 1988 e 2002 será investigado no que delineia o contexto da política posterior e no que apresenta de formação de agenda sobre o tema.

A hipótese de trabalho, retome-se, é a de que, na política migratória brasileira, dado o desenho institucional com fragmentação e sobreposição de competências, as organizações realizam mudanças incrementais setoriais na política por meio do aumento 
de suas capacidades técnico-administrativas e político relacionais. Entretanto, em razão de mecanismos relativos aos objetivos de manter seu espaço de poder e lógica de ação organizacional, tais organizações tenderão a opor obstáculos a reformas mais amplas.

O quadro 4.1 recupera o mecanismo desenhado no capítulo 2 e conecta suas fases, pensadas em termos de entidades e atividades, a possíveis manifestações empíricas observáveis.

Quadro 4.1: Mecanismos causais relativos ao padrão mudança/continuidade verificado na política migratória brasileira no período de 2003-2016 e manifestações empíricas observáveis

\begin{tabular}{|c|c|c|}
\hline \multirow{4}{*}{$\begin{array}{l}\text { Causa: } \\
\text { Desenho institucional } \\
\text { com sobreposição e } \\
\text { fragmentação de } \\
\text { competências }\end{array}$} & $\begin{array}{l}\text { Parte 1: } \\
\text { Organizações, por meio de seus dirigentes políticos e } \\
\text { burocratas, empreendem estratégias para aumentar suas } \\
\text { capacidades estatais técnico-administrativas e político- } \\
\text { relacionais. }\end{array}$ & $\begin{array}{c}\text { Resultado 1: } \\
\text { Mudanças } \\
\text { incrementais } \\
\text { setoriais na política }\end{array}$ \\
\hline & $\begin{array}{l}\text { Manifestações empíricas: } \\
\text { (i) Investimento em recursos organizacionais, } \\
\text { financeiros, administrativos e tecnológicos, inclusive } \\
\text { dados e informações; } \\
\text { (ii) Contratação de consultorias com expertise sobre a } \\
\text { matéria; } \\
\text { (iii) Iniciativas de participação social; } \\
\text { (iv) Promoção de seminários e oficinas; } \\
\text { (v) Advocacy junto aos membros do Legislativo; } \\
\text { (vi) Articulação com entidades subnacionais. } \\
\text { (vii) Relações e mecanismos de interface com } \\
\text { instituições internacionais. }\end{array}$ & $\begin{array}{c}\text { Manifestações } \\
\text { empíricas: } \\
\text { Outcomes de } \\
\text { inovação, } \\
\text { alterações e } \\
\text { melhorias no } \\
\text { âmbito da política, } \\
\text { seus objetivos ou } \\
\text { processos de } \\
\text { gestão. }\end{array}$ \\
\hline & $\begin{array}{l}\text { Parte 2: } \\
\text { Organizações, por meio de seus dirigentes políticos e } \\
\text { burocratas, tentam manter ou ampliar seu espaço de } \\
\text { poder e sua lógica de ação organizacional }\end{array}$ & $\begin{array}{c}\text { Resultado 2: } \\
\text { Dificuldades de } \\
\text { reformas da política }\end{array}$ \\
\hline & $\begin{array}{l}\text { Manifestações empíricas: } \\
\text { (i) Oposição a propostas de reforma que reduzam seu } \\
\text { espaço de poder; } \\
\text { (ii) Oposição a propostas de reforma que suscitem } \\
\text { modificações em sua lógica de ação organizacional; } \\
\text { (iii) Dificuldade de coordenação de uma proposta } \\
\text { comum. }\end{array}$ & $\begin{array}{c}\text { Manifestações } \\
\text { empíricas: } \\
\text { Morosidade e/ou } \\
\text { revezes nos } \\
\text { processos de } \\
\text { reforma legal. }\end{array}$ \\
\hline
\end{tabular}

Fonte: Elaboração da autora.

Além da hipótese geral causal, testa-se ainda no presente capítulo a hipótese específica descritiva de que o elemento internacional é mobilizado pelos atores burocráticos em três distintas maneiras: 1. Regime internacional como argumento legitimador; 2. Adoção de boas práticas no intuito de ampliação da capacidade estatal; 3. Disputas por espaços internacionais de influência.

Por se tratar de um process-tracing, atenção particular deve ser conferida ao contexto. Isso porque a influência de fatores contextuais não pode, no método, ser 
controlada por técnicas experimentais ou estatísticas (GEORGE; McKEOWN, 1985). Desta forma, a pesquisa deve compreender a investigação empírica dos próprios fatores, mediante prévio levantamento teórico de quais seriam. Essa etapa será efetivada no item 4.2 do presente capítulo.

Outra importante prática em process-tracing é a atenção explícita a explicações alternativas: o que mais pode ser verdade sobre o processo através do qual o resultado surgiu (BENNETT; ELMAN, 2007)? Tais explicações também devem ser derivadas da teoria e confrontadas com as evidências empíricas colecionadas.

Nesse contexto, este capítulo faz uso de uma ampla variedade de fontes empíricas, buscando viabilizar a triangularização das informações obtidas. As fontes documentais contaram com o mapeamento da normativa relacionada à política migratória, compreendendo não apenas leis, decretos e normas internacionais; mas principalmente portarias e resoluções de elaboração dos referidos Ministérios, com potencial para gerar mudanças incrementais na política. Outras fontes importantes foram os projetos de lei relacionados à temática, o registro de sua tramitação, suas exposições de motivos e respectivas relatorias das Comissões do Congresso ${ }^{196}$.

A análise da atuação dos Ministérios da Justiça, do Trabalho e das Relações Exteriores em muito se fundamentou nos Relatórios de Gestão por eles fornecidos ao Tribunal de Contas da União ${ }^{197}$, disponíveis para o intervalo entre 2008 e 2015 . Nesses documentos, as instituições elencam as atividades realizadas e seus resultados, de maneira a prestar contas dos recursos que lhes foram destinados ${ }^{198}$. Quando necessário, coletaram-se suplementarmente informações sobre o orçamento reservado a cada instituição no Projeto de Lei Orçamentária do Executivo de cada exercício, de 2003 a $2015^{199}$. Foram examinadas ainda as atas das reuniões do $\mathrm{CNIg}^{200}$ e as Resenhas de Política Exterior do Brasil ${ }^{201}$.

Como a hipótese testada se foca na atuação das burocracias e na interação entre elas, realizaram-se entrevistas em profundidade com burocratas de vários órgãos e níveis para identificar padrões de articulação intraburocráticos e interburocráticos, além

\footnotetext{
${ }^{196}$ Disponíveis em: http://www2.camara.leg.br/. Acesso em: 14 mar 2017.

${ }^{197}$ Disponíveis em: https://contas.tcu.gov.br/. Acesso em: 01 fev 2017.

${ }^{198}$ Ressalte-se que a Secretaria Nacional de Justiça (MJ) e a Subsecretaria-Geral das Comunidades de Brasileiros no Exterior (MRE) possuem relatórios próprios referentes a determinados exercícios.

${ }^{199}$ Disponíveis em: https://www12.senado.leg.br/orcamento/documentos/loa/. Acesso em: 01 fev 2017.

${ }^{200}$ Disponíveis em: http://acesso.mte.gov.br/cni/atas.htm. Acesso em: 14 mar 2017.

${ }^{201}$ Disponíveis em: http://www.itamaraty.gov.br/pt-BR/resenha-de-politica-exterior-do-brasil. Acesso em: 14 mar 2017.
} 
da interação com atores não-estatais, na dinâmica entre formulação e a implementação. Um total de 30 entrevistados pertencentes aos órgãos governamentais federais diretamente envolvidos na temática; além de 13 entrevistados da sociedade civil, consultores legislativos, órgãos municipais e organizações internacionais. $\mathrm{O}$ anexo 1 traz a relação dos entrevistados e a data e local das entrevistas realizadas.

$\mathrm{Na}$ seleção das fontes e avaliação de sua confiabilidade, levou-se em consideração: (i) se a fonte foi diretamente exposta a informações sobre o ocorrido; (ii) se a fonte teria motivos de fornecer um relato enviesado; (iii) se os relatos podem ser corroborados por fontes independentes. Buscou-se confrontar as entrevistas entre si e com as fontes primárias.

Ao escolher-se um caso para realizar um process-tracing explicativo do outcome, busca-se entender "cases that in and of themselves are historically important to understand the causes of" (BEACH; PEDERSEN, no prelo, p. 403). Os achados do process-tracing têm, deste modo, dificuldades para ser generalizados: de maneira a preservar a acuidade da inferência causal na pesquisa qualitativa, a conceitualização das causas e do outcome é feita em termos específicos, isto é, referem-se à política migratória brasileira entre 2003-2016, e não à política migratória em geral ou a políticas públicas. Não obstante, as categorias analíticas mobilizadas pelo trabalho são gerais, facilitando sua generalização para políticas que igualmente exijam a atuação intersetorial para sua formulação e implementação.

Este capítulo se inicia com uma análise dos fatores contextuais e dos primeiros momentos de formação de agenda de reforma da política migratória. Em seguida, partese para um exame da construção das capacidades estatais pelos órgãos governamentais, nos termos da hipótese de trabalho. Com foco na dimensão externa da política migratória, o item 4.3. analisa a inserção das migrações nos foros multilaterais e regionais. Já o item 4.4. mapeia o processo de tentativas de mudança legislativa do Estatuto do Estrangeiro. Por último, a análise integrada de indicadores sistematiza os resultados do estudo de caso de maneira a examinar, reformular ou elaborar a teoria inicial. 


\subsection{Contexto e formação de agendas: a questão se desenha}

Promulgada em 1980, a Lei $\mathrm{n}^{\circ} 6.815$ seguiu vigente por mais de três décadas. Nesse período, o Estado brasileiro se modificou amplamente, tendo passado por uma transição democrática e pela adoção de novo texto constitucional, além de haver experimentado posteriormente reformas no seu aparato estatal. Os fluxos migratórios se transformaram dinamicamente, inclusive com eventos demográficos circunstanciais que demandaram respostas políticas específicas. Áreas políticas de forte interdependência com a política migratória, o refúgio e o tráfico de pessoas, foram objeto de reformas amplas. O Estatuto do Estrangeiro e sua regulamentação, Decreto nº 86.715/1981, aos seus turnos, continuaram.

Dentre as poucas modificações que foram feitas na normativa mencionada, a maioria delas se refere ao CNIg. Assim, a Lei $n^{\circ} 6.964 / 1981$ realizou mudanças pontuais em seu corpo, notadamente ampliando os assentos governamentais na composição do Conselho ${ }^{202}$; e a Lei n ${ }^{\circ} 8.490 / 1992$, que tratava da estrutura mais ampla da Presidência e Ministérios, consolidou sua localização como órgão específico do Ministério do Trabalho e revogou as disposições anteriores sobre sua formação, reservando a temática para regulamentação do poder Executivo. Versam sobre o objeto, então, o Decreto nº 840/1993, que acrescentou à sua composição representantes dos trabalhadores, empregadores e da comunidade científica e tecnológica; e Decreto $\mathrm{n}^{\circ}$ 3.574/2000, que alterou o número de membros e acresceu o Ministério da Educação.

As mudanças relativas ao CNIg se referem, até meados dos anos 1990, ao seu processo de implementação e operacionalização. A partir do governo Fernando Henrique Cardoso, com a aprovação de seu regimento interno pela Portaria $n^{\circ} 634 / 1996$, o CNIg passou a atuar por meio de Resoluções Normativas (RN), tendo a RN nº 01, de 29 de abril de 1997, versado sobre concessão de visto para professor ou pesquisador de alto nível e para cientistas estrangeiros. Desde então, o órgão vai assumindo paulatinamente um papel mais amplo na política migratória brasileira, o que, no final dos anos 1990, se volta principalmente para casos de reunião familiar e vinda de mãode-obra qualificada.

\footnotetext{
202 Aos representantes iniciais do Ministério da Justiça, do Ministério das Relações Exteriores, do Ministério da Agricultura e do Ministério da Saúde; acresceu-se um do Ministério da Indústria e do Comércio e um do Conselho Nacional de Desenvolvimento Científico e Tecnológico (arts.128 e 129).
} 
Em que pese a continuidade do Estatuto, seu descompasso com os direitos humanos previstos na Constituição de 1988 e normas conexas, bem como em relação à própria realidade fática, são argumentos levantados pelas organizações de defesa dos direitos dos migrantes ${ }^{203}$, por diversos autores ${ }^{204}$ e pela totalidade dos entrevistados desta tese. A mudança da legislação constituía, portanto, pleito por esses atores defendido.

De acordo com o exposto no capítulo 1, a literatura aponta basicamente os seguintes fatores com potencial efeito de mudança sobre a política migratória: (i) sistema político e agendas partidárias; (ii) fatores econômicos; (iii) fatores demográficos; (iv) processos político-burocráticos; (v) opinião pública. As hipóteses causais deste trabalho se referem à influência exercida pelos processos políticoburocráticos, motivo pelo qual as demais condições serão controladas como contextuais no decorrer deste process-tracing. Neste tópico, fornece-se uma visão geral desses fatores contextuais e da conjuntura estatal na qual têm lugar os processos políticos em análise. Delineiam-se, ainda, os primeiros momentos de formação das agendas em política migratória e temas conexos no período.

Ao definir, em 1988, o "dilema institucional brasileiro", Abranches (1988, p.8) referia-se à necessidade de estruturar um aparato institucional apto a agregar e processar pressões relacionadas à complexificação da conjuntura econômica e social, às acentuadas desigualdades e, consequentemente, à ampliação e diversificação de interesses. O Estado a ser redesenhado pelo texto constitucional deveria, portanto, contemplar a capacidade de processar institucionalmente esta diversidade de interesses e valores.

Nesses termos, a CF/88 trouxe, não apenas com seu texto mas também em seu processo de elaboração, uma narrativa democratizante que se concretizou em arranjos institucionais com participação de diversos atores políticos, sociais e econômicos; assim como instrumentos de controle e mecanismos de transparência e accountability (FARAH, 2001; AVRITZER, 2008; ABERS; KECK, 2013). A Constituição aumentou, ainda, a autonomia dos estados e municípios, inclusive por meio de transferências fiscais compulsórias (ABRUCIO, 2005), de maneira a responder a demandas por descentralização e eficácia na implementação de políticas. Dentro de um contexto de

\footnotetext{
${ }^{203}$ ACNUR et al., 2007; OIM, 2009; MILESI, 2007; CONECTAS, 2012; "Política migratória do brasil é 'de outra época', afirma Relator da OEA", In: Folha de São Paulo, 15 fev 2015;

${ }^{204}$ REIS, 2011; GODOY, 2011; VENTURA; ILLES, 2012.
} 
fortalecimento do sistema burocrático, foram fornecidas garantias e amplos direitos aos servidores, corroborando ainda o concurso público como método de entrada na Administração.

Estas modificações tornaram o ambiente de formulação e implementação de políticas públicas no Brasil mais complexo (GOMIDE; PIRES, 2014), o que, junto à narrativa de liberalização econômica, inspirou uma reorganização administrativa do governo federal iniciada em 1995, durante o governo Fernando Henrique Cardoso, comandada por Luiz Carlos Bresser-Pereira, então ministro da Administração e Reforma do Estado (Mare). Buscava-se conferir um caráter gerencial à administração, com a gestão voltada para resultados e não mais para processos, apartando-se dessa maneira, segundo Bresser-Pereira (2007), do modelo weberiano de racionalidade formal da organização, sob influência das diretrizes do que ficou conhecida como Nova Gestão Pública $^{205}$. A reforma administrativa introduziu o princípio da eficiência como um dos norteadores da Administração Pública e visualizou na sociedade civil uma alternativa para concretizá-lo (BRESSER-PEREIRA, 2007), propagando novos espaços de interação sociedade-Estado.

Tais mudanças implicaram em uma revisão sobre o papel desempenhado pela burocracia nas políticas públicas brasileiras. De um lado, a gestão por resultados; o foco nos usuários quando da prestação dos serviços públicos; e o investimento na transparência e acessibilidade de informações conduziram a um maior controle do Estado - e, logo, de seus burocratas - pela sociedade. De outro, a diretriz de que o Estado apenas deveria executar diretamente tarefas que lhes fossem exclusivas, cabendo-lhe contratar com entidades não-governamentais a execução de boa parte de suas políticas, redimensionou o papel dos burocratas na formulação e implementação: ao caber-lhes o monitoramento e a definição dos termos dos serviços contratados, a burocracia passou a transitar mais fluidamente entre as várias fases do processo político.

A tendência à consolidação de arranjos abrangendo uma pluralidade de padrões de interação sócio-estatais aprofundou-se nas décadas seguintes, levando à aprovação do Marco Regulatório de Organizações da Sociedade Civil (Lei n ${ }^{\circ}$ 13.019/2014, com as

\footnotetext{
${ }^{205}$ Regina Pacheco (2010) esquematiza como características do modelo de New Public Management, constituído a partir de experiências de reformas administrativas empreendidas na década de 1990 e 2000 em países da Organização para Cooperação e Desenvolvimento Econômico (OCDE): orientação da administração pública para a eficiência e o desempenho; flexibilização de seus procedimentos e direcionamento ao usuário; governos mais abertos, transparentes e acessíveis; mecanismos de orçamento, controle e gestão voltados para os resultados.
} 
alterações da Lei $\mathrm{n}^{\circ}$ 13.204/2015), versando sobre as parcerias nas políticas públicas, e da Política Nacional de Participação Social (Decreto n ${ }^{\circ}$ 8.243/2014), articulando os mecanismos de diálogo e compartilhamento de decisões entre governo e sociedade civil.

Abrucio e colaboradores (2010) enumeram alguns movimentos que caracterizariam a gestão pública brasileira após a redemocratização, dos quais se podem destacar dois relacionados ao objeto desta tese: a ação de governos estaduais e, particularmente, municipais em trazerem inovações ao campo das políticas públicas; e marcantes inovações nas políticas públicas vinculadas à área social, inclusive relacionadas a formas de coordenação administrativa e ações intersetoriais.

No que tange aos temas conexos à política migratória, ressalta, desde a redemocratização, o comprometimento do governo brasileiro com a temática dos direitos humanos, com adesão sistemática da política externa ao seu regime multilateral (MILANI, 2012), fazendo do tema um vetor de inserção internacional do país ${ }^{206}$; em paralelo à realização, no plano interno, das Conferências Nacionais de Direitos Humanos (anualmente a partir de 1996); à criação da Secretaria de Estado dos Direitos Humanos no âmbito do Ministério da Justiça (1997); e à adoção do Programa Nacional de Direitos Humanos (PNDH-I), em 1996, seguido de suas segunda (2002) e terceira (2009) versões ${ }^{207}$. Tais iniciativas alçaram os direitos humanos ao status de política pública, traçando metas e objetivos a serem atingidos por meio de recursos especificamente alocados para o tema, em cuja formulação tomaram parte organizações internacionais e da sociedade civil.

O PNDH-I define os direitos humanos como "os direitos fundamentais de todas as pessoas, sejam elas mulheres, negros, homossexuais, índios, idosos, pessoas portadoras de deficiências, populações de fronteiras, estrangeiros e emigrantes, refugiados, portadores de HIV positivo, crianças e adolescentes, policiais, presos, despossuídos e os que têm acesso a riqueza" (BRASIL, 1996). Esta explicitação das categorias de migrantes na própria definição de direitos humanos não era por acaso: o Plano formulou metas de curto, médio e longo prazo especialmente voltadas para imigrantes, visando à construção de uma política migratória norteada pela proteção dos direitos humanos. As metas se encontram enumeradas abaixo:

\footnotetext{
${ }^{206}$ Para lidar com a questão, criou-se em 1995, no Itamaraty, o Departamento de Direitos Humanos e Questões Especiais.

${ }^{207}$ Respectivamente promulgados via: Decreto $\mathrm{n}^{\circ} 1.904$, de 13 de maio de 1996; Decreto $\mathrm{n}^{\circ} 4.229$, de 13 de maio de 2002; e Decreto n $^{\circ} 7.037$ de 21 de dezembro de 2009.
} 


\section{ESTRANGEIROS, REFUGIADOS E MIGRANTES BRASILEIROS \\ CURTO PRAZO}

164. Desenvolver programa e campanha visando à regularização da situação dos estrangeiros atualmente no país.

165. Adotar medidas para impedir e punir a violência e discriminação contra estrangeiros no Brasil e migrantes brasileiros no exterior.

166. Propor projeto de lei estabelecendo o estatuto dos refugiados.

MÉDIO PRAZO

167. Estabelecer política de proteção aos direitos humanos das comunidades estrangeiras no Brasil.

168. Estabelecer política de proteção aos direitos humanos das comunidades brasileiras no exterior.

LONGO PRAZO

169. Reformular a Lei dos Estrangeiros, através da apreciação pelo Congresso do projeto de lei $1.813 / 91$, que regula a situação jurídica do estrangeiro no Brasil (BRASIL, 1996 - grifo nosso).

Nota-se que o fluxo do problema das migrações começava a se desenhar, com o seu estado das coisas sendo reconhecido, politicamente, como problema. Em que pese a apreciação do projeto do projeto de lei 1.813/1991 não ter ocorrido ${ }^{208}$, as demais metas foram, em maior ou menor nível, contempladas: procedeu-se à regularização da situação de estrangeiros via anistia de 1998, a qual beneficiou 40.909 pessoas $^{209}$; políticas de proteção aos direitos das comunidades estrangeiras no Brasil e de comunidades brasileiras no exterior começaram a ser esboçadas pelo MRE; e o projeto de lei estabelecendo o Estatuto dos Refugiados foi formulado e aprovado pelo Congresso Nacional.

No que atine ao projeto de lei $\mathrm{n}^{\mathrm{o}} 1.936 / 96$, versando sobre o refúgio, foi rapidamente aprovado: apresentado ao Congresso Nacional em 15/05/1996, foi publicado como Lei $\mathrm{n}^{\text {o }} 9.474$ em 22/07/1997. De acordo com depoimento do Embaixador Paulo Tarrisse (07/03/2016), à época chefe da Divisão de Nações Unidas do MRE, o PL foi suscitado, de um lado, pela entrada de refugiados de Angola, majoritariamente, além de outros provenientes do Congo e do Zaire; e, de outro, pelo compromisso que houvera sido assumido pelo Estado brasileiro na Declaração de Cartagena.

Os países latino-americanos haviam assumido um determinado protagonismo na temática do refúgio quando, na década de 1980, buscaram uma definição de refugiado que contemplasse a dinâmica populacional regional motivada por perseguições políticas. Deste impulso decorreu a Declaração de Cartagena, instrumento não-

\footnotetext{
${ }^{208}$ O item 4.6 discorre sobre a tramitação do PL nº 1.813/1996.

${ }^{209}$ Dados sobre beneficiados da anistia de MILESI; ANDRADE, 2010, p.6. Duas outras anistias já haviam sido concedidas durante a vigência da Lei 6.815, por meio das leis 6.964/1981 e 7.685/1988, tendo atingido 27 mil e 36.900 pessoas, respectivamente.
} 
vinculante resultante de colóquio realizado em 1984 do qual participaram países da América Latina, com apoio do ACNUR. Na Declaração, os atores se comprometem a ampliar a definição de refúgio internacional da ONU eliminando a reserva geográfica prevista no Estatuto dos Refugiados de 1951 - o que foi feito pelo Brasil por meio do Decreto $\mathrm{n}^{\mathrm{o}} 98.602 / 89^{210}$.

Com a chegada dos refugiados angolanos no início dos anos 1990, o Brasil começou a aplicar de maneira individual a definição ampliada de refúgio, porém sem uma estrutura institucional que o amparasse. Paulo Tarrisse (Entrevista, 07/03/2016) narra que, nesse contexto, reuniu-se com a Secretária Nacional de Justiça, Sandra Vale, o diretor do DEEST, Luiz Paulo Barreto, e o representante regional do ACNUR, Guilherme Cunha, para debater alternativas de marco normativo, optando-se por nele acolher os avanços da Declaração de Cartagena, expandindo a proteção do refúgio a situações de grave e generalizada violação de direitos humanos. Ainda segundo o Embaixador, uma das questões institucionais discutidas pelo grupo era a alocação do CONARE e sua presidência:

\begin{abstract}
Eles queriam que o Itamaraty fosse presidente. Ocorre que os refugiados têm uma dimensão externa pra chegar ao Brasil, depois tudo é nacional, tudo é interno. É relação com a questão de acesso a saúde, mobilidade interna, Polícia Federal, Ministério do Trabalho. Estes são órgãos que o Ministério da Justiça tem interlocução. (...) A participação do Itamaraty era muito pequena porque refugiado é aquele que chega aqui. Nós defendemos diretamente a questão dos refugiados em Genebra como política de Estado: qual é a posição do governo brasileiro pra assuntos mais variados - não só relativos a Brasil -, relativos ao conceito de refugiados, relativos aos instrumentos, à doação, arrecadação de fundos, reassentamento... Mas pro dia a dia do refugiado é interno. E aí nossa decisão foi colocar o CONARE no Ministério da Justiça. Aí a Sandra Vale e eu discutimos quem devia ser presidente e quem devia ser vice-presidente. Com o mesmo argumento que eu estou usando pra ser o Ministério da Justiça, não compete ao MRE ser presidente de algo interno. Se fosse uma coisa pra falar sobre posições brasileiras no ACNUR em Genebra ou na ONU em NY é claro que nós tínhamos que ser presidentes. Nós somos formuladores de política externa junto com a presidenta. Mas se tratando da parte interna, que diz respeito a você conseguir ou não conseguir o seu cartão de acesso ao sistema interno de saúde, ou se você tem carteira de trabalho, CPF... não é no Itamaraty (Paulo Tarrise, Entrevista, 07/03/2016).
\end{abstract}

Remetido ao Congresso, o projeto do governo foi alvo de debates na Comissão de Direitos Humanos da Câmara dos Deputados, com participação e pressão de atores sociais, particularmente de entidades vinculadas à Igreja Católica, como a Cáritas, o

\footnotetext{
${ }^{210}$ O Decreto $n^{\circ} 98.602 / 89$ revogou, no ordenamento brasileiro, a reserva geográfica do refúgio, ao alterar a redação do Decreto $\mathrm{n}^{\circ} 50.215 / 1961$, o qual incorporara a Convenção relativa ao Estatuto dos Refugiados.
} 
Instituto Migrações e Direitos Humanos (IMDH) e o Centro Scalabriniano de Estudos Migratórios (CSEM), dirigido à época pela Irmã Rosita Milesi ${ }^{211}$.

Com a aprovação da Lei $n^{\circ}$ 9.474/1997, o Brasil avançou na consolidação dos princípios e diretrizes de Cartagena e tornou-se o primeiro país na América Latina a elaborar uma legislação nacional específica na área. A política de refúgio brasileira passou a ser caracterizada como uma das mais avançadas do mundo (ACNUR; CONARE, 2007) e influenciou as legislações de diversos países da região. De fato, embora a Declaração de Cartagena não tenha constituído um foro formal de coordenação, ela abriu caminho para a cooperação e concertação regional no tema do refúgio, no que se verifica um papel de assessoria técnica exercido pelo ACNUR.

Paralelamente, o ACNUR fortalecia sua atuação no país, particularmente via programas e ações de reassentamento. O número de refugiados reconhecidos pelo Brasil vai de 1.991, em 1998, a 2.884 em 2002 (ACNUR; CONARE, 2007); e no ano 2000 a temática começa a ganhar destaque na atuação externa brasileira ${ }^{212}$. Tal cenário abriu caminho para que, no Plano Nacional de Direitos Humanos de 2002, PNDH-II, o tema dos refugiados ganhasse acentuado destaque:

ESTRANGEIROS, REFUGIADOS E MIGRANTES

250. Apoiar, no âmbito do Ministério da Justiça, o funcionamento do Comitê Nacional para Refugiados - CONARE.

251. Implementar a Convenção da ONU relativa ao Estatuto dos Refugiados, de 1951, e o Protocolo Adicional de 1966.

252. Promover a capacitação das autoridades nacionais diretamente envolvidas na execução da política nacional para refugiados.

253. Promover e apoiar estudos e pesquisas relativos à proteção, promoção e difusão dos direitos dos refugiados, incluindo as soluções duráveis (reassentamento, integração local e repatriação), com especial atenção para a situação das mulheres e crianças refugiadas.

254. Apoiar projetos públicos e privados de educação e de capacitação profissional de refugiados, assim como campanhas de esclarecimento sobre a situação jurídica do refugiado no Brasil.

255. Desenvolver programa e campanha visando à regularização da situação dos estrangeiros atualmente no país, atendendo a critérios de reciprocidade de tratamento.

256. Adotar medidas para impedir e punir a violência e discriminação contra estrangeiros no Brasil e brasileiros no exterior.

257. Estabelecer políticas de promoção e proteção dos direitos das comunidades brasileiras no exterior e das comunidades estrangeiras no Brasil.

258. Propor a elaboração de uma nova lei de imigração e naturalização, regulando a situação jurídica dos estrangeiros no Brasil (BRASIL, 2002).

\footnotetext{
${ }^{211}$ Para uma cronologia do período de aprovação, no Congresso Nacional, da Lei de Refúgio, ver MILESI; ANDRADE, 2010.

${ }^{212} \mathrm{O}$ que se depreende da análise de conteúdo dos discursos da Resenha de Política Exterior Brasileira.
} 
A exemplo do PNDH-I, o seu sucessor coloca como uma das metas da política de direitos humanos brasileira a reforma da lei de imigração, além de outras medidas de política migratória. Não é durante a sua vigência, porém, que tal mudança será verificada.

Ressalte-se que as décadas subsequentes ao Estatuto do Estrangeiro presenciaram uma considerável variação no cenário econômico. A lei foi promulgada em período de grave déficit público, endividamento externo e aumento da inflação, com diminuição da renda per capita e crescimento da proporção de famílias vivendo abaixo da linha da pobreza (BRESSER-PEREIRA, 1989); cenário que se agravou no governo Sarney (1985-1990) e se consolidou no governo Collor (1990-1992). O controle inflacionário iniciado no fim do governo Itamar Franco (1992-1995), com o Plano Real, proporcionou um período de estabilidade econômica que perdurou durante o primeiro mandato de Fernando Henrique Cardoso (1995-2002), colaborando para a melhoria dos indicadores sociais e redução da desigualdade social. Este período foi abalado pela crise asiática de 1997 e crises externas subsequentes, que levaram a uma deterioração da conjuntura econômica e ao recurso ao endividamento externo. Em resposta, o governo Lula (2003-2010) promoveu ajustes macroeconômicos que permitiram ao país acumular sucessivos superávits na balança de pagamentos ao longo da década de 2000, o que resultou no período de maior crescimento econômico desde a redemocratização. A taxa de crescimento do PIB cai em 2009, recupera-se e volta a cair em 2012. Desta forma, percebe-se que uma explicação da política migratória unicamente baseada em indicadores macroeconômicos haveria previsto alguma reformano período entre 1980 e 2016 - o que não se verificou.

No que concerne ao contexto demográfico, o interregno em análise compreende acentuadas variações. Nos anos 1980, iniciou-se um movimento nítido de saída de brasileiros para residir no exterior, motivo pelo qual o país passou a sustentar saldo negativo de migração, estimado por Carvalho (1996) em aproximadamente 1,5 milhão de pessoas. Esta tendência é apontada por Sales e Baeninger (2000) como correlacionada à crise econômica supramencionada, a que a literatura acrescenta a influência de questões estruturais relacionadas à globalização, inclusive maior disponibilidade de informações sobre trabalho no exterior (FARIA, 2015), e políticas de atração de mão-de-obra de países como Paraguai e Japão (SALES e BAENINGER, 
2000) ${ }^{213}$. Em decorrência, segundo Patarra (1996), a emigração passou a figurar como uma questão social e demográfica importante, o que não ocorreu sem consequências políticas.

Assim, nos anos 1990, o balanço populacional continuou negativo para o país. O Ministério das Relações Exteriores divisou a questão, que vinha sendo suscitada por comunidades de brasileiros no exterior ${ }^{214}$. Assim, em artigo publicado em 1996, o Ministro das Relações Exteriores Embaixador Luiz Felipe Lampreia (1995-2001) elencou a proteção e assistência aos brasileiros no exterior como objeto de especial atenção do presidente da República, explicitando que:

Talvez o dado mais novo para a diplomacia brasileira nestes últimos tempos seja o da imigração brasileira ao exterior. Em países fronteiriços ou em países desenvolvidos, o contingente de brasileiros que vive temporariamente ou em bases mais definitivas no exterior aumentou geometricamente, alcançando hoje perto de 2 milhões de cidadãos. (...) A proteção ao nacional no exterior é tradicionalmente uma das atribuições básicas da diplomacia, ao lado da representação, da negociação e da informação. (...) O Itamaraty tem passado por uma grande renovação em sua área consular e hoje já concentra cerca de $25 \%$ do seu orçamento nas tarefas consulares e de assistência a brasileiros no exterior. (Resenha de Pol. Ext. Brasil, a. 23, n. 78, $1^{\circ}$ semestre 1996, p.146147)

Sebastião do Rego Barros, Secretário-Geral das Relações Exteriores no primeiro governo Cardoso, corrobora a afirmação de que a assistência aos brasileiros no exterior fora alçada a prioridade do Itamaraty em cumprimento à orientação do Presidente da República (1998, p. 24). O Itamaraty implementou, à época, o Programa de Apoio aos Brasileiros no Exterior, incluindo medidas internas e externas: criou-se, no organograma do Ministério, a Diretoria-Geral Consular, Jurídica e de Assistência a Brasileiros no Exterior, a qual respondia diretamente à Secretaria-Geral do Itamaraty.

No exterior, ampliou-se a rede consular; implementaram-se missões consulares itinerantes; iniciou-se a assistência a presos brasileiros no exterior e a prestação de assistência jurídica em situações determinadas; editaram-se Cartilhas Consulares e criaram-se os Conselhos de Cidadãos, "órgãos apolíticos de aconselhamento do Consulado, com vistas a uma melhor adaptação dos brasileiros à realidade de cada país" (BARROS, 1996, p.237). Segundo Barros, tais unidades (em um total de 29) correspondem a "uma iniciativa de enorme relevância, pois constitui, na linha de

\footnotetext{
${ }^{213}$ Sobre os "brasiguaios", ver SPRANDEL (2006). No que atine aos dekasseguis brasileiros no Japão, ver SASAKI (2006).

${ }^{214}$ Entre outras iniciativas, realizou-se em 1997 o I Simpósio Internacional sobre Emigração Brasileira, promovido pela Casa do Brasil em Lisboa, com participação do Grupo Atitude da Suíça, do Jornal "Brazilnews" do Canadá e de emigrantes brasileiros (MILESI; FANTAZINI, 2008).
} 
orientação do Presidente Fernando Henrique Cardoso, um precioso canal de comunicação, cooperação e interação entre o Governo e a sociedade civil no exterior" (1996, p.237).

Em 2002, a estimativa do Departamento de Assistência Consular do MRE foi de 1.964.498 brasileiros residindo no exterior; número que chega a mais de 3 milhões em 2007 - um crescimento de 55\%; diminuindo para cerca de 2,5 milhões em 2012 (MRE, 2012, p.20) $)^{215}$. Além dos fluxos tradicionais, observa-se deslocamentos importantes para a Guiana Francesa, outros países da América do Sul e Angola (PATARRA, 2008).

Na outra face do fenômeno migratório internacional, o Brasil passa a receber novos contingentes de imigrantes. Coreanos, chineses, bolivianos, paraguaios, chilenos, peruanos e diversas nacionalidades de africanos (PATARRA, 2008) entram no país, em direção principalmente às grandes metrópoles; além de, em menor medida, dirigentes de empresas e técnicos europeus, na esteira do movimento de abertura econômica (OLIVEIRA; O`NEILL, 2012). Baeninger e Soares (2009) salientam que o exame dos fluxos migratórios na América do Sul a partir da década de 1980 apontaria para uma modificação na situação do Brasil no contexto regional: as autoras caracterizam os deslocamentos na região como evasão decrescente de brasileiros para a Argentina; evasão para o Paraguai; evasão crescente para a Venezuela e recepção crescente quanto a nacionais de Bolívia, Chile, Peru, Uruguai e Colômbia. De acordo com relatório da OIM, a inserção do Brasil nas migrações latino-americanas a partir de 1980 teria observado o reforço dos afluxos de tipo fronteiriço; daqueles em direção às áreas metropolitanas, como no caso de bolivianos e peruanos; e das migrações intrarregionais com países não-limítrofes, como o Chile (OIM, 2009, p.30).

Nesse contexto, dados da Polícia Federal apontam que o número de registros anuais de imigrantes aumentou 160\% entre 2006 e 2015, quando atingiu 117.745 novos registros. Entre os anos 2010 e 2015, os trabalhadores imigrantes aumentaram em 131\% a presença no mercado de trabalho formal, passando de 54.333 em 2010 para 125.535 em 31 de dezembro de 2015 (OBMigra, 2016), boa parte dos quais de nacionalidade

\footnotetext{
${ }^{215}$ Sobre suas estimativas de brasileiros no exterior, o Itamaraty explica que "buscam levar em conta vários fatores, como: dados oficiais fornecidos por autoridades migratórias locais, censos oficiais, número de eleitores registrados na jurisdição; número de matriculados nos consulados; sondagens junto à comunidade; solicitações de passaportes e outros documentos por brasileiros; movimento geral da repartição e de consulados itinerantes; dados disponíveis sobre saída do país e retorno de brasileiros; percentuais de redução de remessas; publicações da Organização Internacional para Migrações (OIM); estudos da OCDE; trabalhos acadêmicos e artigos na imprensa" (BRASIL, 2012, p.21).
} 
haitiana. As solicitações de refúgio cresceram 2.868\% entre 2010 e 2015: passaram de 966, em 2010; para 28.670, em 2015 (CONARE, 2016). Desta forma, um modelo que preveja mudanças e continuidades em função unicamente dos fluxos migratórios terá dificuldades em explicar o caso brasileiro.

Por último, não há dados sobre a opinião pública em política migratória no Brasil no período em análise. Não obstante, pode-se afirmar que a questão não foi mobilizada nos debates eleitorais, à exceção da iniciativa de campanha do então candidato à presidência da República, Luiz Inácio Lula da Silva, de divulgar uma "Carta aos Brasileiros que vivem longe de casa" (2002), enumerando ações que seriam voltadas aos brasileiros que viviam no exterior - restringindo-se, pois, à emigração. Boa parte dos entrevistados desta tese salientou que a política migratória não corresponde a uma prioridade do governo, embora tenha dele recebido uma especial atenção em questões específicas. Resguardada de grandes disputas políticas, a política migratória se mostra um interessante objeto de análise da agência burocrática.

\subsection{Construção de capacidades estatais}

\section{a. Ministério do Trabalho e CNIg}

Opta-se, neste item, pela análise do Ministério do Trabalho junto ao CNIg. Conforme explicado no capítulo 1, o Conselho Nacional de Imigração é um órgão quadripartite de deliberação coletiva, com participação de atores do governo, patronato, centrais sindicais e sociedade civil. Não obstante, além de ser presidido pelo Ministério do Trabalho, está vinculado à sua estrutura organizacional. Ressalte-se que o CNIg não tem orçamento ou recursos humanos próprios, sendo a Coordenação Geral de Imigração (CGIg) responsável por atividades de apoio executivo ao Conselho ${ }^{216}$. Ademais, o regimento interno do Conselho, cuja elaboração é de sua competência, deve ser submetido à aprovação do Ministro do Trabalho (Decreto $n^{\circ} 840 / 1993$, art. 1º, IX), a quem se delega, outrossim, a competência de designação dos membros do CNIg (Decreto $\mathrm{n}^{\circ} 3.574 / 2000$, art. $2^{\circ}$ ).

\footnotetext{
${ }^{216}$ Convocação das reuniões; pagamento de diárias e passagens aos conselheiros que não residem em Brasília; preparação de publicações a serem distribuídas aos conselheiros; registro, degravação e elaboração de atas das reuniões do CNIg e de seus grupos de trabalho; e publicação de suas decisões em Diário Oficial da União.
} 
A análise dos marcos normativos que regulam o $\mathrm{CNIg}$, bem como das atas de suas reuniões, denota tratar-se de:

(i) arena de monitoramento periódico da implementação política, empreendido por meio de relatos dos próprios atores responsáveis pela sua execução, na qual o levantamento de determinadas questões vistas como problemáticas, conduzidas ao debate no plenário ou ao aprofundamento em grupos de trabalho específicos, pode suscitar a formulação política por meio da emissão de Resolução Normativa;

(ii) arena de formulação política, inclusive a partir de atividades de execução, visto que o art. $1^{\text {o }}$, VII, do Decreto n ${ }^{\circ}$ 840/1993, regulamentado pela $\mathrm{RN} \mathrm{n}^{\mathrm{o}} 27$, de 25 de novembro de 1998, atribui-lhe a competência de dispor sobre as situações especiais e os casos omissos, o que é feito a partir de análise de casos individuais e decisão administrativa concedendo ou rejeitando visto ou permanência;

(iii) um ator de advocacy, por meio da publicação de resoluções recomendadas emitindo a opinião do colegiado a órgão da Administração Pública.

Nesse contexto, percebe-se que, no início dos anos 2000, o CNIg buscou consolidar-se enquanto órgão de formulação da política migratória. Data deste período a RR $\mathrm{n}^{\mathrm{o}}$ 08, de 19 de dezembro de $2006^{217}$, recomendando ao CONARE o encaminhamento ao Conselho dos pedidos de refúgio que não sejam passíveis de concessão, mas que, a critério do CONARE, tenham fundamentos humanitários. Como se verifica na ata da reunião em que a resolução foi aprovada, ela adveio de Grupo de Trabalho sobre Trabalho Decente, Migrações e Direitos Humanos, criado em razão de manifestação do CONARE sobre um elevado número de pedidos que não cumpriam os requisitos da concessão de refúgio, mas nos quais se verificavam motivos humanitários para a permanência. Tal resolução demarca a adoção de estratégia pelo órgão no sentido de ampliar os limites de sua atuação. Caracteriza, ainda, seu posicionamento no sentido de pensar a política migratória em um enquadramento mais amplo que o da Lei $\mathrm{n}^{\mathrm{o}}$ 6.815/1980 - o que já havia sido sinalizado pela RR no 02/2000, sugerindo ao MRE concessão de visto temporário para tratamento de saúde.

\footnotetext{
${ }^{217}$ Disponível em: http://acesso.mte.gov.br/trab_estrang/resolucao-recomendada-n-08-de-19-12-2006.htm
} 
Esse caráter de formulação da política atinge inclusive a dimensão internacional, por meio de resoluções recomendadas: por exemplo, a $R R n^{\circ} 4$, de 22 de outubro de 2003, recomendava ao MJ, MTE, MRE e MEC o ingresso do Brasil na OIM; e a RR no 6, de 07 de junho de 2005, orientando o MJ e o MRE a concluírem e implementarem o Acordo de Regularização Migratória com a Bolívia.

O direcionamento do foco do Conselho para atividades de formulação se deu, segundo a Conselheira Marjolaine Canto ${ }^{218}$ (09/03/2016), inclusive em resposta à falta de condições operacionais de realizar a relatoria do elevado número de processosdestacando-se à época as decisões com base na RN 36/1999, a qual disciplinava a permanência por reunião familiar ${ }^{219}$. De acordo com a conselheira,

Quando eu assumi [em 1993], eu relatava 300, 400 processos [ao mês]. A coordenação de imigração devia ter uns 6.000 processos. Ninguém trabalhava naquilo, tinha uma corrupção enorme. Ninguém nem sabia, porque não tinha norma, então nós tínhamos muito problemas. Hoje não relata-se tanto, porque as normas foram sendo criadas e sanando os problema pontualmente, as lacunas (Marjolaine Canto, Entrevista, 09/03/2016).

Aldo Cândido ${ }^{220}$, Coordenador-Geral de Imigração do MTE, corrobora "Há uns 10 anos atrás, eu lembro, a reunião do Conselho era extremamente desgastante, analisando processo individual. Perdia um tempo enorme do Conselho relatando processo" (Entrevista, 03/03/2016). Nesse sentido, construiu-se paulatinamente entre os membros a visão de que "São essas grandes questões que o Conselho tem de se envolver. E não decidir caso a caso." (Luiz Alberto Matos ${ }^{221}$, Coordenador do CNIg, Entrevista, 03/03/2016).

Por outro lado, percebe-se, a partir de 2005, um movimento do Ministério do Trabalho e CNIg em direção à temática das comunidades brasileiras no exterior. Em depoimento em publicação do Ministério da Justiça, o presidente do CNIg (2007-2017), Paulo Sérgio de Almeida ${ }^{222}$, afirma:

A evolução do contexto migratório brasileiro refletiu-se em novas demandas, que desembocaram no CNIg. Demandas vinculadas às trabalhadoras e aos trabalhadores brasileiros emigrantes ao exterior. Embora o tema da emigração de brasileiras e brasileiros ao exterior não estivesse entre as atribuições do CNIg, na prática, as demandas que chegavam necessitavam ser

\footnotetext{
${ }^{218}$ Representante da Confederação Nacional do Comércio (CNC). Conselheira do CNIg desde 1993.

${ }^{219}$ Autoriza o MRE a conceder visto temporário ou permanente a título de reunião familiar, aos dependentes legais de cidadão brasileiro ou de estrangeiro residente temporário ou permanente no país, maior de 21 anos. Disponível em: http://acesso.mte.gov.br/trab_estrang/resolucao-normativa-n-36-de-2809-1999.htm.

${ }^{220}$ Auditor fiscal do trabalho.

${ }^{221}$ Auditor fiscal do trabalho.

${ }^{222}$ Auditor fiscal do trabalho.
} 


\begin{abstract}
respondidas. O CNIg iniciou, então, processo de revisão de suas atribuições - o qual, ainda hoje, está em marcha -, com vistas a englobar entre suas competências a formulação de políticas destinadas à emigração de trabalhadoras e trabalhadores brasileiros ao exterior. Desde 2005, representantes do CNIg vêm participando de encontros com as comunidades brasileiras no exterior. No ano de 2008, o CNIg realizou visitas a comunidades brasileiras nos EUA, na Espanha, no Paraguai e no Japão. Esses encontros contribuíram para que o CNIg conhecesse a realidade dos brasileiros no exterior e pudesse contribuir para a construção de políticas específicas (ALMEIDA, 2009, p.18 - grifo nosso).
\end{abstract}

De fato, no ano de 2008 observa-se uma intensificação da atuação do CNIg no exterior, com as visitas aos países citados e o lançamento de cartilha "Brasileiras e Brasileiros no Exterior - Informações úteis", distribuída nos postos de emissão de passaporte no Brasil e Consulados Brasileiros no Exterior. Para auxiliar em sua elaboração, conforme relata Marcia Sprandel $^{223}$ (Entrevista, 03/03/2016), o recémempossado Presidente do CNIg, Paulo Sérgio de Almeida, convidou-a junto a Irmã Rosita Milesi ${ }^{224}$, ambas com histórico de atuação na causa de brasileiros no exterior.

Ainda em 2008, o MTE inaugurou a Casa do Trabalhador Brasileiro em Foz do Iguaçu, espaço de fornecimento de informações sobre trabalho e relações trabalhistas para os brasileiros que vivem na Argentina e Paraguai e para os imigrantes que vivem naquela região de fronteira. A Casa constituía uma parceria entre o MTE e a Prefeitura de Foz do Iguaçu, à qual se incorporou, em 2009, a Secretaria Especial de Políticas para as Mulheres a fim de fornecer atendimento especializado a mulheres migrantes vítimas de violência (MTE, 2009, p.59).

Ainda no final de 2007, o MTE havia realizado o Seminário "MERCOSUL e as Migrações”, ocasião que, de acordo com o então Ministro Carlos Lupi, "significou uma reflexão de várias áreas de Governo, de entidades ligadas ao mundo do trabalho e à sociedade civil, bem como de organizações internacionais sobre a realidade do movimento de pessoas entre os países que compõem o MERCOSUL" (LUPI, 2008, p.11). Em 03 de dezembro de 2008, o CNIg aprovou Resolução Recomendada n ${ }^{\circ}$ 10, aconselhando o Ministério das Relações Exteriores a promover a adesão do Brasil à Convenção Internacional para a Proteção dos Direitos dos Trabalhadores Migrantes suas Famílias no âmbito da Organização das Nações Unidas, com vistas a sua ratificação.

Foi também em 2008 que o MTE, junto ao CNIg, organizou o "Diálogo Tripartite sobre Políticas Públicas de Migração para o Trabalho", na cidade de

\footnotetext{
${ }^{223}$ Consultora legislativa do Senado, militante e estudiosa da temática imigrante.

${ }^{224}$ Diretora do Instituto Migrações e Direitos Humanos (IMDH), observadora do CNIg, militante da temática imigrante.
} 
Itapecerica da Serra (SP), reunindo representantes de diversos órgãos governamentais, sindicatos patronais e de trabalhadores, associações de apoio a migrantes e acadêmicos. O Diálogo foi realizado em parceria com a OIT, organização com a qual o MTE assinou, durante o evento, Declaração Conjunta Relativa à Cooperação na Área de Migrações Laborais.

Por meio desta declaração, ambas as instituições estabeleceram as bases de sua parceria no âmbito da promoção de políticas migratórias voltadas a trabalhadores, as quais consistiam em diretrizes estabelecidas em marcos normativos da OIT: Agenda Hemisférica do Trabalho Decente das Américas, Agenda Nacional do Trabalho Decente do Brasil e "Marco Multilateral da OIT para Migrações Laborais: Princípios e Diretrizes não vinculantes para um enfoque das migrações laborais baseado nos direitos" (OIT, 2009). A diretora do escritório da OIT no Brasil à época, Laís Abramo, explicou que:

De modo a implementar as diretrizes constantes nesses instrumentos internacionais, a Agenda Hemisférica também destacou a meta de que todos os países de origem e de destino de migrantes contem com uma estratégia e um plano de ação para uma gestão ordenada das migrações até 2010. Com o objetivo de contribuir à consecução dessa meta, as atividades empreendidas pelo MTE, o CNIg e a OIT no Brasil têm o objetivo de promover o diálogo tripartite entre governo, empregadores e trabalhadores para consolidar enunciados que figurarão num futuro plano de políticas públicas para a promoção do trabalho decente no âmbito das migrações (ABRAMO, 2009, p.viii - grifo nosso).

Nesse contexto, definiram-se ações a serem implementadas em conjunto, dentre as quais:

\footnotetext{
- Promoção de políticas que elevem ao máximo a contribuição da migração ao desenvolvimento nacional com a proteção necessária dos direitos do trabalhador migrante;

- Elaboração de políticas para uma migração ordenada e para o fortalecimento de instituições destinadas a apoiar os trabalhadores brasileiros emigrantes no exterior;

- Promoção de políticas de trabalho decente nas migrações como instrumento de desenvolvimento, em coordenação com os países receptores;

- Incorporação do tema migratório e de livre circulação de trabalhadores nos processos de integração regional, com especial ênfase ao MERCOSUL;

- Cooperação técnica na realização de estudos e pesquisas, além do desenvolvimento de instrumentos de informação destinados aos trabalhadores migrantes;

- Fortalecimento normativo e sua aplicação, com ênfase nos instrumentos multilaterais sobre o tema, como as Convenções no 97 e 143, que instam à cooperação entre Estados e à adoção de medidas sobre os fluxos migratórios e à proteção dos direitos dos trabalhadores migrantes (OIT, 2009, p. ix-x).
}

Desta forma, o documento resultante do Seminário, "Contribuições para a Construção de Políticas Públicas voltadas à Migração para o Trabalho" (OIT, 2009), elenca em seu preâmbulo os fundamentos normativos e referenciais conceituais da OIT. 
Tal documento, apontado por diversos entrevistados como um marco na política migratória brasileira (Marcia Sprandel, 03/03/2016; Paulo Sérgio de Almeida, 09/09/2016; Rinaldo Almeida, 09/03/2016; Paulo Illes, 05/09/2016), aprovou diretrizes norteadoras para as políticas públicas do país, dentre as quais: (i) desburocratização dos procedimentos e qualificação dos serviços prestados aos imigrantes; (ii) produção de estatísticas e estudos sobre a temática, recomendando-se a criação de Observatório de Migrações; (iii) promoção de políticas para brasileiros no exterior e retornados.

As sugestões se direcionaram, ainda, no sentido da inserção internacional da política migratória brasileira, mediante ratificação da Convenção Internacional sobre a Proteção dos Direitos de Todos os Trabalhadores Migrantes e Membros de Suas Famílias (1990) e da Convenção 143 da OIT sobre os trabalhadores migrantes (1975); edição pelo Conselho Nacional de Imigração (CNIg) de resolução sobre autorização de trabalho para nacionais dos países integrantes da União das Nações Sul-Americanas (UNASUL); ampla divulgação dos acordos do Mercosul nas áreas migratória e trabalhista (OIT, 2009).

Ressalte-se que o documento busca consolidar o enquadramento da temática migratória dentro da moldura do trabalho e dos direitos, afirmando que "É preciso considerar a centralidade da temática do trabalho no que concerne ao fenômeno migratório, bem como a importância do diálogo social no estabelecimento de políticas públicas voltadas às migrações" (OIT, 2009, p.15), e que "É necessário haver reflexão, esclarecimento e aplicação de linguagem adequada nas discussões sobre migração, evitando a utilização de termos com conotação de "criminalização" (OIT, 2009, p.16). No que concerne ao anteprojeto de lei que visava a substituir o Estatuto de Estrangeiro, recomendou que fosse adequado aos instrumentos internacionais de proteção aos trabalhadores migrantes e suas famílias; que fosse denominado "Lei de Migrações"; e que mantivesse a competência regulamentar do CNIg (OIT, 2009). Particularmente sobre este ponto, o documento apresenta as seguintes recomendações:

- Criação do Conselho Nacional de Migração, com atribuições relativas à imigração e emigração de brasileiras(os), sucedendo o atual CNIg, mantendose a atual representação quatripartite, que confere maior legitimidade às suas decisões.

- Recomendação da vinculação do Conselho Nacional de Migração ao Ministério do Trabalho e Emprego - MTE, tendo em vista a centralidade do trabalho na temática migratória, sua experiência na condução do diálogo tripartite e por ser o órgão responsável, junto à OIT, pela aplicação das convenções relativas à proteção dos trabalhadores migrantes (OIT, 2009, p.18). 
Tal recomendação não era aleatória: à época, jazia no gabinete do Ministério da Justiça anteprojeto de nova lei de migrações em que a alocação institucional do Conselho se encontrava indefinida, como se destrincha no item 4.5 deste capítulo.

Apresentando os resultados do Seminário em publicação da OIT de 2009, o Ministro do Trabalho e Emprego, Carlos Lupi, ratificou a necessidade de um novo marco regulamentar para as migrações no Brasil, em sentido de que se empenhava o MTE, via CNIg, inclusive buscando abarcar a temática dos brasileiros no exterior:

\begin{abstract}
Creio ser fundamental que as políticas migratórias sejam adotadas por meio do diálogo social entre o Governo e os principais interlocutores do mundo do trabalho e da sociedade civil, de forma a que sejam conhecidas e sustentáveis no mundo real e possam transformar-se em fatos concretos. Devo destacar que as migrações devem ser abordadas pela perspectiva dos direitos. É nosso dever velar para que os direitos fundamentais dos trabalhadores migrantes, qualquer que seja seu status migratório, não sejam violados e especial atenção seja conferida às mulheres e às crianças nos processos migratórios. Este contexto nos estimula a refletir sobre as atuais políticas migratórias brasileiras e a necessidade da adoção de novas diretrizes. O Conselho Nacional de Imigração, órgão que é vinculado ao Ministério do Trabalho e Emprego, tem atuado intensamente na construção de um novo marco regulamentar para as migrações no Brasil. Trabalhamos, inclusive, para que esse Conselho possa transformar-se em Conselho Nacional da Migração, incorporando a temática da emigração de brasileiros ao exterior, além de alargar a sua composição com a participação de outros órgãos de governo e da sociedade civil (LUPI, 2009, p.v-vi).
\end{abstract}

O objetivo de formação do Conselho Nacional de Migrações ganha força nos relatórios e atas do período, materializando-se na proposta de anteprojeto de substitutivo do Estatuto do Estrangeiro encaminhada pelo Executivo ao Congresso em 2009. Segundo afirmou Paulo Sérgio de Almeida,

Esse novo Conselho possibilitaria a construção de políticas equilibradas no relacionamento entre imigração e emigração, já que deve haver coerência entre o discurso destinado aos países receptores da emigração brasileira e as políticas existentes em relação aos imigrantes no Brasil (ALMEIDA, 2009, p.20).

Nesse sentido, o ano de 2009 testemunha a ampliação da atuação internacional do CNIg, que participa do III Encontro Europeu da Rede de Brasileiras e Brasileiros no Exterior, na cidade de Barcelona, e cria um "Grupo de Acompanhamento do Cenário Internacional e da Necessidade de Novas Políticas Migratórias”, voltado para a situação dos brasileiros no exterior e o fluxo de regresso ao Brasil. Das atividades do Grupo advieram propostas aprovadas pelo Ministro Carlos Lupi, dentre as quais: criação de estruturas de apoio no âmbito dos órgãos regionais do MTE destinadas aos trabalhadores brasileiros que regressaram ao País; possibilidade de saque das contas inativas do FGTS por quem se encontra no exterior e possua tal direito no Brasil; 
abertura de mais canais de comunicação entre o MTE e os brasileiros no exterior; criação de mecanismo de consultas bilaterais entre Brasil e Japão na área do trabalho.

Sublinhe-se que, em 2009, foram realizadas negociações visando a instalar a Casa do Trabalhador Brasileiro na cidade de Hamamatsu, no Japão, em razão de que o MTE assinou termo de cooperação com o $M^{225}$ e enviou representante junto à Missão Brasileira ao Japão para apresentar o projeto àquele país. Por solicitação do Ministério do Trabalho, o Congresso Nacional destinou-lhe crédito adicional no valor de $\mathrm{R} \$ 500.000,00$. A Casa de Hamamatsu foi inaugurada em 2010 tendo como plano de ação: informar os direitos e deveres trabalhistas do emigrante brasileiro no Japão e orientá-lo em caso de violação de direitos laborais; articular ações de qualificação profissional; em caso de retorno, prestar informações sobre o mercado de trabalho brasileiro e vagas disponíveis.

O ano de 2009 marcou, ademais, a ação do Ministério do Trabalho no âmbito do Mercosul: a CGIg passou a coordenar Grupo de Trabalho sobre Livre Circulação de Trabalhadores no bloco, criado no contexto do SGT-10 (Subgrupo de Trabalho 10 Relações Trabalhistas, Emprego e Seguridade Social) com o objetivo de editar uma cartilha de orientação sobre como trabalhar nos quatro países que compõem o Mercosul. No mesmo ano, o MTE participou do II Seminário sobre Livre Circulação de Pessoas em Montevidéu (MTE, 2009).

Internamente, a CGIg implementou, em 2009, duas ferramentas administrativas: o Cadastro Eletrônico de Entidades Requerentes de Autorização para Trabalho a Estrangeiros (CERTE), sistema no qual as empresas ou organizações podem se registrar e manter atualizadas as suas informações e documentação solicitadas para pedidos de autorização de trabalho; e o MigranteWeb, sistema que permite ao imigrante efetuar o pedido de autorização de trabalho através da internet. Ambas as ferramentas visaram ao aumento da celeridade na concessão de autorização de trabalho a imigrantes. A CGIg iniciou, também em 2009, a tradução da página eletrônica sobre "trabalho estrangeiro" no site oficial do MTE (MTE, 2009, p.58). Ressalte-se que, nos cinco anos

\footnotetext{
${ }^{225}$ De acordo com a Diretora do Departamento Consular e de Brasileiros no Exterior (MRE), Luiza Lopes, "o MTE financia a manutenção de atendentes e de eventos, e a gestão da casa é feita pelo MRE. A atividade realizada na casa está subordinada ao cônsul-geral, portanto o vínculo administrativo é com o MRE. Passamos relatório para o MTE, eles ajudam a capacitar. É um projeto de cooperação que funciona muito bem" (Entrevista, 13/09/2016). Ressalte-se que o programa passou por modificações desde sua criação e foi descontinuado no início de 2017.
} 
que seguem, o aprimoramento dos referidos mecanismos se mostra central nos relatórios de gestão do órgão, desembocando na implantação, em 2013, do sistema MigranteDigital, com digitalização dos processos e sua tramitação e análise de forma eletrônica $^{226}$. O tema aparece, ainda, com centralidade no depoimento do Coordenador Geral de Imigração:

(...) um avanço muito grande que nós tivemos, de 2013 para cá, os pedidos, hoje, são feitos todos por certificação digital, não tramita mais papel (...). Eu desafio qualquer país que tem uma situação similar fazer um processo com a mesma qualidade e rapidez do que o nosso. Eu desafio. Porque hoje, nós estamos bem assim, 15, 20 dias a gente já libera os processos que tiver vindo corretamente. Nós temos uma atitude, que já tomamos a tempo e hoje mantém, que um processo digital, ele não passa na frente do outro. Isso é muito interessante, porque você quebra qualquer ingerência (Aldo Cândido, Entrevista, 03/03/2016 - grifo nosso).

Ao fim e ao cabo, em 2010, o CNIg havia assumido o protagonismo em política migratória. É neste momento que, com fundamento nas propostas do Seminário de 2008, o Conselho aprova e torna pública a Política Nacional de Imigração e Proteção ao(a) Trabalhador(a) Migrante ${ }^{227}$. A política tinha o objetivo de estabelecer princípios, diretrizes e estratégias voltadas para a atuação dos órgãos governamentais relacionada aos fluxos migratórios, com vistas a "orientar as entidades e órgãos brasileiros na atuação vinculada ao fenômeno migratório, a contribuir para a promoção e proteção dos Direitos Humanos dos migrantes e a incrementar os vínculos das migrações com o Desenvolvimento" (BRASIL, 2010, p.1). Dentre as diretrizes, encontram-se:

2) A admissão de migrantes no território nacional é ato de soberania do Estado. Os procedimentos de admissão serão não discriminatórios, assegurados os direitos e garantias estabelecidos pela Constituição Federal, pelos Tratados e Acordos Internacionais e pelas Leis Brasileiras, em especial a proteção aos direitos humanos; (...)

5) A integração dos migrantes será promovida, para o melhor aproveitamento de suas capacidades pessoais e laborais, a fim de contribuir com o desenvolvimento do país; (...)

13) Aos trabalhadores migrantes em situação regular são assegurados os mesmos direitos e as mesmas garantias dos trabalhadores nacionais (BRASIL, 2010, p. 7 - grifo nosso).

${ }^{226}$ De acordo com relatório de gestão de 2013, "O Sistema busca: a)Agilizar os procedimentos para análise e decisão dos processos de autorizações de trabalho a estrangeiros; b)Aumentar o nível de satisfação do usuário; c) Otimizar recursos por meio da economia de material, principalmente papel; d) Permitir total transparência no acompanhamento dos processos; e) Recuperar e armazenar grandes volumes de informações reduzindo o espaço físico utilizado para o arquivo de processos" (MTE, 2013, p.75).

${ }_{227}$ Disponível em: http://www2.mte.gov.br/politicamigrante/imigracao_proposta.pdf. Acesso em: 14 dez. 2016. 
A Política foi encaminhada para Casa Civil, para sua publicação em decreto presidencial (MTE, 2010). De acordo com a consultora legislativa do Senado Marcia Sprandel (2012), a previsão era de que o Presidente Lula da Silva a promulgasse por decreto ao final de seu mandato, em dezembro de 2010. Entretanto, ainda segundo Sprandel, o Ministério da Justiça pediu para examinar o texto antes que ele fosse promulgado, o que nunca veio a ocorrer. Na avaliação de Paulo Sérgio de Almeida,

Então, eu acho que foram duas coisas, não é, a primeira é que quando ela foi
feita, nós ainda estávamos naquele momento onde uma parte do governo não
tinha certeza, de aprovar uma politica pró-direitos. Ali em 2009, 2010, ainda
havia alguma visão contrária... como há ainda hoje, algumas visões
contrárias a isso, mas eu diria que, hoje, minoritárias, bem minoritárias, eu
diria... A outra é uma questão de protagonismo, como foi uma política
proposta pelo Conselho, outros órgãos de governo, o próprio Ministério da
Justiça entendeu que deveria ter o protagonismo nisso, talvez, aperfeiçoar a
política de alguma maneira, enfim, colocar a marca do próprio Ministério da
Justiça, enfim, eu acho que isso também gerou dificuldades na aprovação da
política, essa, vamos dizer assim, disputa por protagonismo na formulação de
políticas públicas (Entrevista, 09/09/2016).

Em 2010, o MTE decidiu implementar um novo serviço: Núcleo de Informação e Atendimento a Trabalhadores Retornados do Exterior (NIATRE) na cidade de São Paulo, em resposta ao diagnóstico de existência de um fluxo de brasileiros em retorno ao Brasil, proveniente principalmente do Japão e dos Estados Unidos. A implantação se deu por meio de convênio com o ISEC (Instituto de Solidariedade Educacional e Cultural), que inaugurou o serviço em janeiro de $2011^{228}$. Ainda em São Paulo, o CNIg apoiou a realização de Seminário para debater a situação de imigrantes no estado.

Nota-se, no ano de 2010, o lançamento de diversas publicações por parte do MTE $^{229}$, dentre as quais a cartilha "Como Trabalhar nos Países do Mercosul”. Nesse sentido, o CNIg fortaleceu sua atuação regional, organizando o seminário "Obstáculos à Livre Circulação de Trabalhadores no âmbito do Mercosul" e participando da realização de mesa de debates sobre a livre circulação de trabalhadores na Cúpula Social do bloco.

Em 2011, sobressai a parceria do MTE com o Itamaraty para realização de Semanas do Trabalhador Brasileiro, compreendendo atividades de orientação aos migrantes brasileiros, tendo ocorrido: em Boston, ocasião em que o Ministro Carlos

\footnotetext{
${ }^{228}$ O repasse do convênio em 2011 equivaleu a $\mathrm{R} \$ 118.750,00$.

229 "Trabalhadores Migrantes e Trabalho Decente", livro editado em parceria com a OIT; "Autorização de trabalho a profissionais estrangeiros no Brasil - legislação base", apanhado da normativa brasileira sobre concessão de autorização de trabalho a estrangeiros; "Perfil Migratório do Brasil 2009", publicado em parceria com a OIM e a CNPD; a cartilha "Como trabalhar nos países do Mercosul"; e um balanço dos resultados da Política Laboral de Imigração e Emigração do MTE.
} 
Lupi assinou acordo com setor de Departamento de Trabalho dos EUA sobre fiscalização da área de segurança e saúde no trabalho; e na Guiana Francesa, semana em que o Ministro inaugurou a "Casa do Migrante" em Oiapoque, nos mesmos moldes daquela de Foz do Iguaçu.

No ano de 2012, o Ministério do Trabalho designa, dentro de sua rubrica orçamentária, um objetivo específico para política migratória, o qual passa a ter dotação orçamentária própria. Até então, não havia uma dotação orçamentária específica para a política migratória, de maneira que as despesas das referidas unidades eram pulverizadas em programas como "Gestão da Política de Trabalho, Emprego e Renda". Na vigência do Plano Plurianual 2012-2015, criou-se, vinculado ao MTE, o programa "Estabelecer e aprimorar as políticas vinculadas à migração internacional com vista ao ingresso e permanência de imigrantes e profissionais estrangeiros no Brasil, bem como de trabalhadores emigrantes no exterior" (0863). O quadro 4.2 mostra a evolução das alocações no período 2012-2015.

Quadro 4.2: Alocações orçamentárias para política migratória no MTE (2012-2015)

\begin{tabular}{|c|c|c|c|}
\hline Ano e programa & Objetivo & Dotação Inicial & Dotação Final \\
\hline $\begin{array}{l}2012 \\
2071 \text { - Trabalho, } \\
\text { Emprego e Renda }\end{array}$ & $\begin{array}{l}\text { 0863- Estabelecer e aprimorar as } \\
\text { políticas vinculadas à migração } \\
\text { internacional com vista ao ingresso e } \\
\text { permanência de imigrantes e } \\
\text { profissionais estrangeiros no Brasil, } \\
\text { bem como de trabalhadores emigrantes } \\
\text { no exterior. }\end{array}$ & $960.889,57$ & $960.889,57$ \\
\hline $\begin{array}{l}\mathbf{2 0 1 3} \\
2071 \text { - Trabalho, } \\
\text { Emprego e Renda }\end{array}$ & $\begin{array}{l}\text { 0869- } \\
\text { Assegurar ao trabalhador o direito ao } \\
\text { emprego e trabalho decente } \\
\text { Ação: Formulação, Articulação e } \\
\text { Execução da Política Laboral de } \\
\text { Imigração e Emigração }\end{array}$ & $2.464 .536,00$ & $2.464 .536,00$ \\
\hline $\begin{array}{l}\mathbf{2 0 1 4} \\
2071 \text { - Trabalho, } \\
\text { Emprego e Renda }\end{array}$ & $\begin{array}{l}\text { 0869- } \\
\text { Assegurar ao trabalhador o direito ao } \\
\text { emprego e trabalho decente } \\
\text { Ação: Formulação, Articulação e } \\
\text { Execução da Política Laboral de } \\
\text { Imigração e Emigração }\end{array}$ & 1.853 .640 & 1.853 .640 \\
\hline $\begin{array}{l}\mathbf{2 0 1 5} \\
2071 \text { - Trabalho, } \\
\text { Emprego e Renda }\end{array}$ & $\begin{array}{l}\text { 0869- } \\
\text { Assegurar ao trabalhador o direito ao } \\
\text { emprego e trabalho decente } \\
\text { Ação: Formulação, Articulação e } \\
\text { Execução da Política Laboral de } \\
\text { Imigração e Emigração }\end{array}$ & 1.853 .640 & 1.853 .640 \\
\hline
\end{tabular}

Fonte: Elaboração própria. 
Dentre as ações do ano de 2012, ressalta o diálogo com a OIT e a ampla participação em cursos e seminários no exterior. As metas do exercício, segundo o relatório de gestão (MTE, 2012), eram apoiar a ratificação e a implementação da Convenção das Nações Unidas para a Proteção dos Direitos dos Trabalhadores Migrantes e Membros de suas Famílias e da Convenção no 143 da OIT. Isso significava advocacy junto ao Legislativo e fortalecimento da posição governamental sobre o tema. Além disso, o convênio do NIATRE foi renovado até 2014, e foi assinado novo Termo de Cooperação com o MRE, com transferência de recursos ${ }^{230}$, voltado à reconfiguração da Casa do Trabalhador Brasileiro em Hamamatsu em "Espaço do Trabalhador Brasileiro".

Essa mesma orientação geral é observada em 2013, com ampla participação em foros internacionais ${ }^{231}$, destacando-se a promoção, em parceria com a OIM, de dois encontros de diálogo bilateral Brasil-Haiti ${ }^{232}$. A meta de promover mudanças no marco normativo das migrações continuava preponderante, mencionando o relatório de gestão de 2013 que

\begin{abstract}
Nesse sentido, a grande conclusão de 2013 é a necessidade de se reformular com urgência a legislação migratória materializando novo marco legal que garanta aos imigrantes os direitos previstos na Constituição Federal aos imigrantes, projetando procedimentos migratórios simples, ágeis, de baixo custo e que garanta, ainda, adequada governança dos fluxos migratórios (MTE, 2013, p.75 - grifo nosso).
\end{abstract}

Nos anos de 2014 e 2015, verifica-se uma nova estratégia de atuação do MTE, focada na produção de dados e conhecimento e na participação social. O Observatório das Migrações Internacionais (OBMigra) foi criado em 2014, fundamentado em acordo de cooperação técnica ${ }^{233}$ com a Fundação Universidade de Brasília, no intuito de aprofundar o conhecimento sobre o fenômeno migratório internacional brasileiro,

${ }^{230}$ O termo de cooperação foi pactuado em $\mathrm{R} \$ 487.654,27$, sem contrapartida financeira do MRE, correspondente ao período de 11/10/2012 a 11/01/2014.

231 Em 2013, o MTE enviou representantes para: IV Fórum Internacional sobre Migração e Desenvolvimento (realizado nos dias 20 e 21 de junho, na cidade de Nova Iorque - Estados Unidos da América); $1^{\circ}$ Seminário Ibero- Americano sobre Migrações e Desenvolvimento, (realizado nos dias 16 e 17 de julho, na cidade de Madri - Espanha); Seminário Regional sobre Circulação de Trabalhadores no MERCOSUL, (realizado no dia 10 de julho, na cidade de Montevidéu - Uruguai); Reunião Técnica Tripartite sobre Migração Laboral, (realizada no período de 04 a 08 de novembro, na cidade de Genebra Suíça); Encontro "Migração Brasil-UE no século 21: tendências, desafios e possibilidades de cooperação", (realizado no dia 20 de novembro, na cidade de Bruxelas - Bélgica)

${ }^{232}$ O primeiro ocorreu em Porto Príncipe, de 02 a 06 de setembro de 2013, com a participação de uma delegação do CNIg chefiada pelo embaixador do Brasil no Haiti José Machado e Costa; e o segundo ocorreu em Brasília, entre 08 e 11 de dezembro de 2013, com a presença de uma delegação do Haiti chefiada pelo Diretor de Assuntos Jurídicos do Ministério das Relações Exteriores, Jean-Claudy Pierre.

${ }^{233} \mathrm{O}$ termo de cooperação tem o valor global de $\mathrm{R} \$ 1.520 .200,00$, abarcando atividades no período de $11 / 12 / 2013$ a 11/12/2016. 
sublinhando-se seu objetivo de criar, manter e disponibilizar base de dados. Já em 2015, o MTE celebrou parceria com o Instituto Brasileiro de Geografia e Estatística (IBGE), também visando a criar bases de dados, e com a Fundação Getúlio Vargas (FGV) para realização de estudo voltado a propor sugestões de aprimoramento da estrutura do Estado brasileiro para lidar com a atração de imigrantes qualificados (FGV, 2015).

No que concerne à participação social, constata-se que a Resolução Administrativa do CNIg $\mathrm{n}^{\mathrm{o}}$ 10/2014 foi publicada no desígnio de consolidar o rol de membros observadores do órgão, que vinha paulatinamente sendo ampliado ${ }^{234}$. Ressalte-se que a medida levantou questionamentos entre conselheiros pois, a despeito de integrar novos membros governamentais (por exemplo, Polícia Federal) e internacional (OIT), não incluiu novos observadores da sociedade civil $^{235}$. Paradoxalmente, tal resolução foi aprovada junto à manifestação de apoio do Conselho ao Decreto $n^{\circ}$ 8.243/2014 - o qual institui a Política Nacional de Participação Social. A manifestação de apoio ao decreto tampouco foi consenso entre os membros, suscitando ressalvas nos representantes dos sindicatos patronais e do Itamaraty, Embaixador Rodrigo do Amaral Souza.

Em paralelo à participação social contingenciada no bojo da organização, o CNIg aprovou Resolução Administrativa $n^{\circ}$ 11/2015 236 , criando o Fórum de Participação Social como um mecanismo consultivo atrelado ao CNIg. De livre participação, o fórum se reuniria uma vez por ano e encaminharia contribuições ao Plenário do CNIg para apreciação e correspondentes encaminhamentos ${ }^{237}$.

Em 2014, dois novos arranjos políticos foram adotados pelo MTE em política migratória: assinatura de termo de cooperação técnica com a Organização Internacional

\footnotetext{
${ }^{234}$ A resolução qualifica como observadores, com direito a participar da reunião e sem direito a voto: I 1 (Um) representante de cada Órgão Federal abaixo indicado: a) Ministério da Previdência Social - MPS; b) Ministério do Desenvolvimento Social e Combate à Fome - MDS; c) Secretaria de Políticas para as Mulheres da Presidência da República - SPM-PR; d) Secretaria de Direitos Humanos da Presidência da República - SDH-PR; e) Secretaria de Políticas de Promoção da Igualdade Racial - SEPPIR-PR; f) Ministério Público do Trabalho - MPT; g) Ministério Público Federal - MPF; h) Defensoria Pública da União - DPU; i) Advocacia Geral da União - AGU; j) Departamento de Polícia Federal - DPF; k) Agência Brasileira de Inteligência - Abin; II - 1 (um) representante de cada Organismo Internacional abaixo indicado: a) Organização Internacional do Trabalho - OIT; b) Organização Internacional para as Migrações - OIM. III - 1 (um) representante de cada Organização da Sociedade Civil abaixo indicado: a) Comissão Nacional para População e Desenvolvimento - CNPD; b) Instituto Migrações e Direitos Humanos - IMDH.

${ }^{235}$ Questionaram esse fato os representantes da UGT, da CUT e do IMDH (CNIg, 11/11/2014).

${ }^{236}$ Disponível em: http://acesso.mte.gov.br/data/files/8A7C816A4BCC363F014BE5F917D67A4C/RA\%2011.pdf.

${ }^{237}$ A primeira reunião do Forum veio a ocorrer apenas em 05 de novembro de 2016.
} 
do Trabalho, junto à Agência Brasileira de Cooperação (MRE) ${ }^{238}$, voltado à implementação Projeto Cooperação Sul-Sul para proteção dos direitos dos trabalhadores migrantes $^{239}$; e o projeto "Migrações Transfronteiriças" financiado pela União Europeia, CNIg, SNJ e Escritório Federal para Migrações da Suíça, e implementado pelo International Centre for Migration Policy Development ${ }^{240}$ (ICMPD) com objetivo de fortalecer a capacidade do governo federal brasileiro no gerenciamento dos fluxos migratórios internacionais ${ }^{241}$. Ambos os projetos contavam com a participação de atores internacionais e se referiam, pois, à construção de capacidades estatais por meio do conhecimento. Neste mesmo sentido, o MTE continuou aplicando a estratégia de promoção de seminários, inclusive no âmbito regional.

Em junho de 2015, o MTE celebrou acordo em ação civil pública ajuizada pela Defensoria Pública da União (DPU) em conjunto com o Ministério Público Federal (MPF), comprometendo-se a garantir a diminuição do tempo de entrega e a descentralização do serviço de emissão da Carteira de Trabalho e Previdência Social (CTPS) para imigrantes - o que antes era ofertado apenas para brasileiros. A DPU e o MPF argumentaram que a espera da emissão da carteira para os estrangeiros era de cerca de dois meses, e pleitearam que ocorresse no prazo de três a 15 dias úteis, sob pena de multa diária por descumprimento. Em resposta, o MTE editou a Portaria ${ }^{\circ} 699$, em 28 de maio de 2015, que determinou a descentralização da emissão da CTPS para estrangeiros, garantindo o mesmo tratamento destinado aos brasileiros ${ }^{242}$.

O quadro 4.3 elenca as resoluções emitidas pelo CNIg segundo a temática no período em análise. Atente-se que a publicação de resoluções não engloba toda a atividade do órgão, mas corresponde a seu instrumental de formulação política.

\footnotetext{
${ }^{238}$ Transferência do MTE no valor de R \$ 500.000,00, com vigência entre 03/07/2014 e 03/01/2016.

239 "O projeto pretende contribuir com o conhecimento sobre a migração para fins laborais, através de estudos e análises de documentos oficiais e do intercâmbio de informações entre os países da região. Sua estratégia está vinculada à cooperação Sul-Sul e triangular já que, baseando-se fundamentalmente na experiência brasileira, o projeto deverá ser executado a partir do intercâmbio de experiências e de boas práticas com os países da América Central, da região Andina e do Caribe, considerando particularmente os processos de integração regional existentes nessas sub-regiões da América Latina e do Caribe" (OIT, 2016, disponível em: http://www.ilo.org/brasilia/programas-projetos/WCMS_430340/lang--pt/index.htm)

${ }^{240}$ Think tank europeu voltado para a temática migratória, com sede na Áustria. Site oficial: https://www.icmpd.org/. Acesso em: 21 mar 2017.

${ }^{241}$ De acordo análise do relatório do MTE de 2015 sobre o projeto, "No ano de 2015, foi realizada pesquisa sobre as principais necessidades e obstáculos para inserção laboral e a integração social dos imigrantes - estudo de caso em cidades do Rio Grande do Sul, Santa Catarina e Município de São Paulo, bem como acompanhamento do Curso sobre Migrações, Refúgio, Tráfico de Pessoas e Atendimento ao Migrante nos municípios de Belém/PA, Oiapoque/AP e Corumbá/MS".

$242 \mathrm{http} / / / \mathrm{www}$.dpu.def.br/noticias-sao-paulo/155-noticias-sp-slideshow/26744-ministerio-faz-acordo-emacp-sobre-carteira-de-trabalho-a-estrangeiros
} 
Quadro 4.3: Resoluções Normativas e Resoluções Recomendadas do CNIg (2003-2015)

\begin{tabular}{|c|c|c|c|c|}
\hline & \multicolumn{2}{|c|}{ 2003-2009 } & \multicolumn{2}{|c|}{$2010-2015$} \\
\hline & $\begin{array}{l}\text { Resoluções } \\
\text { Normativas }\end{array}$ & $\begin{array}{l}\text { Resoluções } \\
\text { Recomendadas }\end{array}$ & $\begin{array}{l}\text { Resoluções } \\
\text { Normativas }\end{array}$ & $\begin{array}{l}\text { Resoluções } \\
\text { Recomendadas }\end{array}$ \\
\hline $\begin{array}{l}\text { Trabalho/ Estudo/ Pesquisa/ } \\
\text { Investimento }\end{array}$ & $\begin{array}{l}\mathrm{RN} \mathrm{n} \mathrm{n}^{\circ} 61 / 2004 \\
\mathrm{RN} \mathrm{n} \mathrm{n}^{\circ} 62 / 2004 \\
\mathrm{RN} \mathrm{n} \mathrm{n}^{\circ} 63 / 2005 \\
\mathrm{RN} \mathrm{n} \mathrm{n}^{\circ} 68 / 2005 \\
\mathrm{RN} \mathrm{n} \mathrm{n}^{\circ} 69 / 2006 \\
\mathrm{RN} \mathrm{n} \mathrm{n}^{\circ} 70 / 2006 \\
\mathrm{RN} \mathrm{n} \mathrm{n}^{\circ} 71 / 2006 \\
\mathrm{RN} \mathrm{n} \mathrm{n}^{\circ} 72 / 2006 \\
\mathrm{RN} \mathrm{n} \mathrm{n}^{\circ} 76 / 2007 \\
\mathrm{RN} \mathrm{n} \mathrm{n}^{\circ} 78 / 2008 \\
\mathrm{RN} \mathrm{n} 79 / 2008 \\
\mathrm{RN} \mathrm{n} \mathrm{n}^{\circ} 81 / 2008\end{array}$ & $\mathrm{RR} \mathrm{n}^{\circ} 3 / 2003$ & $\begin{array}{l}\mathrm{RN} \mathrm{n} \mathrm{n}^{\circ} 86 / 2010 \\
\mathrm{RN} \mathrm{n} \mathrm{n}^{\circ} 87 / 2010 \\
\mathrm{RN} \mathrm{n} \mathrm{n}^{\circ} 88 / 2010 \\
\mathrm{RN} \mathrm{n} \mathrm{n}^{\circ} 93 / 2010 \\
\mathrm{RN} \mathrm{n} \mathrm{n}^{\circ} 94 / 2011 \\
\mathrm{RN} \mathrm{n} \mathrm{n}^{\circ} 98 / 2012 \\
\mathrm{RN} \mathrm{n} \mathrm{n}^{\circ} 99 / 2012 \\
\mathrm{RN} \mathrm{n} \mathrm{n}^{\circ} 100 / 2013 \\
\mathrm{RN} \mathrm{n} \mathrm{n}^{\circ} 101 / 2013 \\
\mathrm{RN} \mathrm{n} \mathrm{n}^{\circ} 103 / 2013 \\
\mathrm{RN} \mathrm{n} \mathrm{n}^{\circ} 104 / 2013 \\
\mathrm{RN} \mathrm{n} \mathrm{n}^{\circ} 107 / 2013 \\
\mathrm{RN} \mathrm{n} \mathrm{n}^{\circ} 109 / 2014 \\
\mathrm{RN} \mathrm{n} \mathrm{n}^{\circ} 114 / 2014 \\
\mathrm{RN} \mathrm{n} \mathrm{n}^{\circ} 116 / 2015 \\
\mathrm{RN} \mathrm{n} \mathrm{n}^{\circ} 118 / 2015 \\
\mathrm{RN} \mathrm{n}^{\circ} 119 / 2015\end{array}$ & \\
\hline Haiti & & & $\begin{array}{l}\mathrm{RN} \mathrm{n}^{\circ} 97 / 2012, \\
\text { alterada pelas } \\
\mathrm{RN}: \\
102 / 2013 \text {, } \\
106 / 2013 \text {, } \\
113 / 2014 \mathrm{e} \\
117 / 2015\end{array}$ & \\
\hline Reunião familiar & & $\begin{array}{l}\mathrm{RN} 77 / 2008 \\
\text { (revogada) }\end{array}$ & $\mathrm{RN} \mathrm{n}^{\circ} 108 / 2014$ & \\
\hline $\begin{array}{l}\text { Questões humanitárias } \\
\text { (permanência durante } \\
\text { cumprimento de pena; } \\
\text { trabalho escravo; refúgio } \\
\text { denegado) }\end{array}$ & & $\begin{array}{l}\mathrm{RR} \mathrm{n}^{\circ} 5 / 2003 \\
\mathrm{RR} \mathrm{n} \mathrm{n}^{\circ} 8 / 2006\end{array}$ & $\mathrm{RN} \mathrm{n}^{\circ} 110 / 2014$ & \\
\hline Regularização de estrangeiros & & & & $\mathrm{RR} \mathrm{n}^{\circ} 12 / 2010$ \\
\hline Legislação migratória & & $\begin{array}{l}\text { RR 7/2005 } \\
\text { RR n } 9 / 2008\end{array}$ & & \\
\hline $\begin{array}{l}\text { Instituições e acordos } \\
\text { Internacionais }\end{array}$ & & $\begin{array}{l}\mathrm{RR} \mathrm{n}^{\circ} 4 / 2003 \\
\mathrm{RR} \mathrm{n}^{\circ} 6 / 2005 \\
\mathrm{RR} n^{\circ} 9 / 2009\end{array}$ & & \\
\hline
\end{tabular}

Fonte: Elaboração própria.

Observa-se que as temáticas relacionadas a trabalho correspondem à grande maioria das resoluções do CNIg. Constituem sobretudo medidas tendentes a desburocratizar os trâmites previstos na legislação (e.g. RN 100/2013, permitindo que visto temporário de caráter técnico de três meses seja emitido diretamente pelos consulados, sem análise prévia do MTE); a flexibilizá-los (e.g. RN 103/2013, permissão de trabalho por até 90 dias para pós-graduandos que queiram trabalhar no Brasil durante férias letivas); ou, ainda, a adaptá-los a um setor ou evento específico (e.g. RN 98/2012, disciplinando a autorização de trabalho para estrangeiro que fosse trabalhar, exclusivamente, na preparação, organização, planejamento e execução da Copa das 
Confederações FIFA 2013, da Copa do Mundo FIFA 2014 e dos Jogos Olímpicos e Paralímpicos Rio 2016). Identifica-se neste grupo de resoluções do CNIg a mobilização da ideia de proteção do trabalhador nacional, como se verifica na RN 99/2012, que disciplina a concessão de autorização de trabalho para obtenção de visto temporário a estrangeiro com vínculo empregatício no Brasil:

Art. $1^{\circ} \mathrm{O}$ Ministério do Trabalho e Emprego poderá conceder autorização de trabalho para obtenção de visto temporário, previsto no art. 13 , inciso $\mathrm{V}$, da Lei $n^{\circ}$ 6.815, de 19 de agosto de 1980, ao estrangeiro que venha ao Brasil com vínculo empregatício, respeitado o interesse do trabalhador brasileiro.

(...)

Art. $6^{\circ} \S 2^{\circ}$. Na avaliação do pedido de transformação em permanente deverá ser considerado: I - a justificativa apresentada pelo estrangeiro sobre sua pretensão em fixar-se definitivamente no Brasil; II - a continuidade da necessidade do trabalho do estrangeiro no Brasil, respeitado o interesse do trabalhador brasileiro; e III - a evolução do quadro de empregados, brasileiros e estrangeiros, da empresa requerente.

Por outro lado, observa-se no quadro 4.3 que a emissão de resoluções sobre questões não relacionadas a trabalho se dá, no período de 2003-2009, recorrendo-se ao formato das resoluções recomendadas; ao passo que, nos anos de 2010 a 2015, a temática passa a ser tratada em caráter mandatório por resoluções normativas ${ }^{243}$. Duas explicações podem ser sugeridas para esta tendência: (i) um aumento da importância conferida às referidas temáticas, adotando-se a estratégia de revesti-las de caráter mandatório; (ii) maior protagonismo assumido pelo CNIg como instância formuladora de políticas.

Identifica-se nesses dois sentidos o posicionamento dos membros do CNIg vinculados ao MTE, disseminado em parte dos Conselheiros, sobre a atividade do Conselho: uma atividade sobretudo de formulação da política migratória que se fundamenta na questão do trabalho mas a extrapola de maneira a abarcar a proteção de direitos humanos. Observe-se, por exemplo, depoimentos do Presidente do CNIg e seu suplente, ambos do MTE:

O Conselho é voltado para as relações de trabalho, mas as ultrapassa. (...) Foi o CNIg que, de uma certa forma, ajudou a romper esse parâmetro, esse paradigma da segurança pública porque começou a trabalhar com o conceito de migrante como sujeito de direito. [...] Enfim, eu acho que o CNIg teve

\footnotetext{
${ }^{243}$ Dentre as resoluções normativas não relacionadas a trabalho, ressalta-se a RN 77/2008, que dispunha sobre critérios para a concessão de visto temporário ou permanente, ou de autorização de permanência, ao companheiro ou companheira, em união estável, sem distinção de sexo; a RN 93/2010, disciplina a concessão de visto permanente no Brasil a estrangeiro considerado vítima do tráfico de pessoas; a RN 97/2012, que cria o visto humanitário para imigrantes haitianos.
} 
esse papel de puxar o tema da proteção de direitos, no momento em que pouca gente do governo falava disso. Depois o CNIg, enfim, ajudou a engrossar as vozes que defendiam essa visão, não é... eu diria que ajudou a construir os principais processos de consolidação dessa visão, como por exemplo o anteprojeto de lei, a própria política que está aí mas nunca foi aprovada [Política Nacional de Imigração e Proteção ao Trabalhador Migrante, de 2010] (Paulo Sérgio de Almeida, 09/09/2016).

Mas se analisarmos o tema migratório, o aspecto laboral, via de regra, está envolvido. (...) Se a busca por trabalho com frequência é a motivação preponderante do migrante, a presença do Ministério do Trabalho torna-se fundamental por toda sua experiência e articulação com o mundo do trabalho. Observamos que, na maior parte dos países, mesmo naqueles com trajetória de defesa dos direitos humanos, a política migratória está centrada em um único órgão do governo federal, geralmente ligado à segurança interna. (...) Qual seria o melhor modelo para o Brasil, aquele observado na maioria dos países, ou o modelo atual do CNIg, onde nove Ministérios estão envolvidos, cinco representantes de empregadores, cinco de trabalhadores, além da sociedade civil, e com significativo protagonismo do Ministério do Trabalho? (...) Eu defendo que um modelo de gestão migratória da natureza do CNIg tende a preservar um olhar técnico sobre esta temática complexa, independente da mudança de Ministros ou mesmo de governos. Reforça também a possibilidade do Brasil construir uma perspectiva migratória com base em direitos de maneira menos conjuntural. Para finalizar, eu diria que o Ministério do Trabalho, com sua longa interlocução junto a OIT, possui uma forma particular de abordar conflitos através do tripartismo. (...) Essa cultura do diálogo social está no DNA do Ministério do Trabalho, na sua essência (Rinaldo Almeida ${ }^{244}$, Entrevista, 09/03/2016 - grifo nosso).

Por fim, ressalte-se na Coordenação Geral de Imigração (CGIg), unidade implementadora do MTE que concede as autorizações de trabalho, a lógica de ação organizacional relacionada ao trabalho se encontra ainda mais pronunciada. Nas palavras do seu coordenador,

Essas coisas são interessantes, por exemplo, nosso caso na Coordenação geral, posso falar assim, não é chocando, mas posso falar assim: aqui para nós, nós não analisamos questão humanitária. Aqui para nós, ou é ou não é: se o Conselho falou que você tem de ter 9 anos de escolaridade, se você tiver 5........) Isso é uma questão seguinte: aqui nós não somos só para analisar documento. Nós fazemos também um tipo de análise, se isso não está influenciando na mão-de-obra nacional, tem uma série de conjunturas.(...) Essa análise conjuntural, para mim, eu descreveria, assim, primeiro, não sei se o termo é esse, tem gente que fala diferente, é a preservação da mão-deobra nacional. Porque isso aí é no mundo, não é o Brasil, isso é no mundo (Aldo Cândido, Entrevista, 03/03/2016).

\section{b. Ministério da Justiça}

Antes de iniciar a análise da construção de capacidades estatais pelo Ministério da Justiça, é importante retomar que se fala, aqui, da Secretaria Nacional de Justiça ${ }^{245}$,

\footnotetext{
${ }^{244}$ Auditor fiscal do trabalho. Membro do CNIg desde 2006.

245 Nos termos do Decreto $n^{\circ} 8.668 / 2016$, a SNJ compreende, além do Departamento de Migrações, o Departamento de Recuperação de Ativos e Cooperação Jurídica Internacional e o Departamento de
} 
particularmente de seu Departamento de Estrangeiros, renomeado Departamento de Migrações em 2016. O Departamento de Polícia Federal, também vinculado ao Ministério da Justiça, tem um importante papel na implementação da política migratória, porém não será analisado aqui nesta tese.

Outra observação é que a análise da construção de capacidades estatais em política migratória pelo Ministério da Justiça está atrelada à sua atuação nas temáticas de refúgio e tráfico de pessoas. Assim, embora a hipótese aqui testada se refira à primeira, as últimas estão diretamente associadas ao seu desenrolar no período de 2003 a maio de 2016.

Neste quadro, o refúgio assume um maior destaque no Ministério da Justiça já em 2004, com a assinatura do Plano de Ação do México junto a países latinoamericanos e a condução, em parceria com o ACNUR, de um programa de reassentamento solidário voltado para refugiados colombianos que levou sua população de reassentados a passar de 25, em 2003, para 197, em 2006 (ACNUR; CONARE, 2007). Para além dos casos de reassentamento, o número total de pessoas protegidas pela Lei de Refúgio no Brasil cresceu consideravelmente no período em análise: em 2002, contavam-se 2.884 pessoas (ACNUR; CONARE, 2007); já em abril de 2016, eram 8.863 (CONARE, 2016). Para além da parceria com o ACNUR, a SNJ começou em 2004 a firmar convênios com o Instituto Migrações e Direitos Humanos (IMDH), em Brasília, e com a Cáritas Brasileira, notadamente dos estados de São Paulo e do Rio de Janeiro, de maneira a implementar uma política de garantia dos direitos dos refugiados. Nesse período, percebe-se o protagonismo de Luiz Paulo Barreto ${ }^{246}$, secretário-executivo do MJ de 2003 a 2010, quando assume como Ministro da Justiça, retornando à Secretaria Executiva entre 2011 e 2012.

Em 2005, o MJ conduziu a formulação de anteprojeto de nova legislação migratória, muito embora só o tenha remetido ao Congresso em 2009 (PL nº 5.655), processo que é detalhado no tópico 4.5 deste capítulo. Desenvolveu, ainda, proposta de "Projeto de Consolidação e Qualificação das Políticas de Migração e Acordos Internacionais", apresentada à Agência Brasileira de Cooperação do Ministério das Relações Exteriores (ABC/MRE), versando sobre cooperação técnica internacional

Políticas de Justiça (anteriormente designado Departamento de Justiça, Classificação, Títulos e Qualificação).

${ }^{246}$ Luiz Paulo Barreto fora diretor do DEEST desde 1994, tendo sido um dos redatores da Lei de Refúgio. 
junto ao Programa das Nações Unidas para o Desenvolvimento (PNUD), com vistas à “definição de um desenho institucional que permita consolidar as políticas de Estado sobre o tema migração e promover a modernização das estruturas funcionais do Departamento de Estrangeiros" (MJ, 2005, p.582).

Em 2006, observa-se a promulgação da Política Nacional de Enfrentamento ao Tráfico de Pessoas (Decreto $n^{\circ}$ 5.948), dois anos após a ratificação pelo Brasil do Protocolo de Palermo. Seguiu-lhe, em 2008, o Plano Nacional de Enfrentamento ao Tráfico de Pessoas, traçando diretrizes, objetivos e metas em torno de três eixos: prevenção ao tráfico; repressão e responsabilização dos seus autores e atenção às vítimas.

Nesse momento, percebe-se um direcionamento do foco do Ministério da Justiça para a mobilidade internacional que se encaixasse nessa moldura. Nesse sentido se pronunciaram alguns dos entrevistados ${ }^{247}$, pontuando que esta ênfase teria relegado a questão migratória a um segundo plano na agenda política, além de que teria levado a que o tratamento da temática fosse conduzido segundo princípios de criminalização e controle da imigração indocumentada. Essa opção, ainda segundo os entrevistados, foi fomentada pela existência de financiamentos internacionais para a temática, e correspondeu à gestão de Romeu Tuma Jr., delegado de polícia e ex-deputado estadual (PTC), na Secretaria Nacional de Justiça (2007-2010).

Um indício deste ajuste de foco se encontra no Programa Nacional de Direitos Humanos de 2009, o PNDH-III, o qual, ao contrário de seus dois predecessores, não coloca as migrações como objeto, nem menciona a alteração do Estatuto do Estrangeiro como meta. Em contrapartida, reserva um objetivo estratégico para o enfrentamento ao tráfico de pessoas (ETP):

OBJETIVO ESTRATÉGICO VI: Enfrentamento ao tráfico de pessoas. AÇÕES PROGRAMÁTICAS:

a) Desenvolver metodologia de monitoramento, disseminação e avaliação das metas do Plano Nacional de Enfrentamento ao Tráfico de Pessoas, bem como construir e implementar o II Plano Nacional de Enfrentamento ao Tráfico de Pessoas.

b) Estruturar, a partir de serviços existentes, sistema nacional de atendimento às vítimas do tráfico de pessoas, de reintegração e diminuição da vulnerabilidade, especialmente de crianças, adolescentes, mulheres, transexuais e travestis.

(...)

${ }^{247}$ Marcia Sprandel (03/03/2016), Paulo Illes (05/09/2016), João Guilherme Granja (09/09/2016). 
f) Fomentar a capacitação de técnicos da gestão pública, organizações não governamentais e representantes das cadeias produtivas para o enfrentamento ao tráfico de pessoas.

g) Desenvolver metodologia e material didático para capacitar agentes públicos no enfrentamento ao tráfico de pessoas.

h) Realizar estudos e pesquisas sobre o tráfico de pessoas, inclusive sobre exploração sexual de crianças e adolescentes (PNDH-III, 2009).

Esta orientação é corroborada na análise dos relatórios de gestão e no orçamento da Secretaria Nacional de Justiça do período: em 2008, nos termos do Plano Plurianual 2008-2011, o MJ reestrutura a estrutura programática de seu orçamento, eliminando o programa "Migrações e acordos internacionais" e criando o "Promoção de Direitos e Cidadania", com os objetivos de "democratizar e aperfeiçoar o acesso à justiça e à cidadania e promover a formulação, a implementação e o monitoramento de políticas públicas e serviços nacionais e internacionais de justiça e cidadania para a consolidação da democracia" (SNJ, 2008). O programa tinha como público alvo: vítimas e potenciais vítimas do tráfico de pessoas e seus familiares e agentes que atuam na prevenção, repressão e assistência às vítimas; estrangeiros no Brasil e comunidades brasileiras no exterior; crianças e adolescentes expectadores e usuários de diversões públicas em geral; entidades sociais; e autoridades requerentes e requeridas no âmbito da cooperação jurídica internacional (SNJ, 2008). A mudança não foi, apenas, de nomenclatura: a dotação reservada à temática passa de $\mathrm{R} \$ 810.000,00$ a $\mathrm{R} \$ 4.088 .000,00$, como se verifica no quadro 4.4 .

Sem embargo, a análise dos relatórios de gestão 2008 e 2009 apontam para a existência de apenas um projeto relacionado às migrações fora da perspectiva do ETP: a concepção do Centro de Memória da Imigração no Brasil, a ser instalado no Salão Negro do Ministério da Justiça, com o propósito de constituir "importante ferramenta de pesquisa sobre a imigração no Brasil e a integração dos estrangeiros na sociedade brasileira ao longo dos tempos, além de compor o rico roteiro do 'turismo cívico' característico de Brasília" (SNJ, 2008, p.8). O Centro não chegou a ter sua implementação levada a cabo. No mais, são elencadas duas atividades de informatização de divisões do Departamento de Estrangeiros. Por seu turno, o Enfrentamento ao Tráfico de Pessoas engloba trinta atividades, dentre a realização de diagnósticos e pesquisas; implementação de capacitações e divulgação de material informativo; realização de reuniões e eventos; monitoramento da implementação do Plano; avaliação dos serviços descentralizados; estruturação de banco de dados. 
Quadro 4.4: Alocações orçamentárias para política migratória no MJ (2003-2009)

\begin{tabular}{|c|c|c|c|}
\hline Ano e programa & Descrição do programa & Dotação Inicial & Dotação Final \\
\hline $\begin{array}{l}\mathbf{2 0 0 3} \\
\text { Programa 0696: } \\
\text { Atendimento e } \\
\text { Legalização de } \\
\text { Estrangeiros no País }\end{array}$ & & $490.000,00$ & $490.000,00$ \\
\hline $\begin{array}{l}\mathbf{2 0 0 4} \\
\text { Programa 0696: } \\
\text { Estrangeiros no Brasil }\end{array}$ & $\begin{array}{l}\text { - Prestar atendimento aos estrangeiros } \\
\text { residentes ou que se encontrem no país, } \\
\text { com vistas à regularização de sua } \\
\text { situação, controlar o fluxo imigratório } \\
\text { e promover as medidas compulsórias e } \\
\text { de transferências transnacionais de } \\
\text { presos. }\end{array}$ & $360.000,00$ & $360.000,00$ \\
\hline $\begin{array}{l}2005 \\
\text { Programa 0696: } \\
\text { Estrangeiros no Brasil }\end{array}$ & $\begin{array}{l}\text { - Prestar atendimento aos estrangeiros } \\
\text { residentes ou que se encontrem no país, } \\
\text { com vistas à regularização de sua } \\
\text { situação, controlar o fluxo imigratório } \\
\text { e promover as medidas compulsórias e } \\
\text { de transferências transnacionais de } \\
\text { presos. }\end{array}$ & $360.000,00$ & $360.000,00$ \\
\hline $\begin{array}{l}\mathbf{2 0 0 6} \\
\text { Programa 0696: } \\
\text { Migração e Acordos } \\
\text { Internacionais } \\
\end{array}$ & & $262.000,00$ & $262.000,00$ \\
\hline $\begin{array}{l}\mathbf{2 0 0 7} \\
\text { Programa 0696: } \\
\text { Migração e Acordos } \\
\text { Internacionais } \\
\end{array}$ & & $810.000,00$ & $810.000,00$ \\
\hline $\begin{array}{l}\mathbf{2 0 0 8} \\
\text { Programa 1413: } \\
\text { Promoção da Justiça e } \\
\text { da Cidadania }\end{array}$ & $\begin{array}{l}\text {-Democratizar e aperfeiçoar o acesso à } \\
\text { justiça e à cidadania; } \\
\text { - Promover a formulação, a } \\
\text { implementação e o monitoramento de } \\
\text { políticas públicas e serviços nacionais e } \\
\text { internacionais de justiça e cidadania } \\
\text { para a consolidação da democracia }\end{array}$ & $4.088 .000,00$ & $4.088 .000,00$ \\
\hline $\begin{array}{l}\mathbf{2 0 0 9} \\
\text { Programa 1413: } \\
\text { Promoção da Justiça e } \\
\text { da Cidadania }\end{array}$ & $\begin{array}{l}\text { - Democratizar e aperfeiçoar o acesso à } \\
\text { justiça e à cidadania; } \\
\text { - Promover a formulação, a } \\
\text { implementação e o monitoramento de } \\
\text { políticas públicas e serviços nacionais e } \\
\text { internacionais de justiça e cidadania } \\
\text { para a consolidação da democracia }\end{array}$ & $3.248 .395,00$ & $3.248 .395,00$ \\
\hline
\end{tabular}

Fonte: Elaboração própria.

Percebe-se, portanto, uma primeira mudança na SNJ: de um orçamento que cobria despesas com a oferta de serviços basicamente documentais para um orçamento apto a possibilitar projetos de políticas públicas, neste momento majoritariamente voltadas para o Enfrentamento ao Tráfico de Pessoas ${ }^{248}$.

Ainda no ano de 2009, a Lei ${ }^{\circ} 11.961$, de 02 de julho de 2009, regulamentada pelo Decreto $\mathrm{n}^{\mathrm{o}} 6.893$ da mesma data, determinou a anistia a todos os estrangeiros em

\footnotetext{
${ }^{248}$ Isto se dava em paralelo, ademais, ao Programa de Prevenção e Combate à Lavagem de Dinheiro, conduzido pela mesma SNJ, temática também priorizada no período.
} 
situação migratória irregular, levando à regularização de cerca de 43 mil imigrantes, dos quais 31.562 residentes na cidade de São Paulo (BARALDI, 2014). Partiu do Legislativo sua iniciativa: o projeto de lei 1.664/2007, que lhe deu origem, foi proposto pelo deputado William Woo (PSDB/SP). Em sua tramitação na Câmara dos Deputados, os debates foram em muito pautados por casos que vinham sendo publicizados de imigrantes sendo submetidos a condições de trabalho análogas à escravidão em oficinas têxteis, particularmente em São Paulo, como se depreende de parecer apresentado a Comissão de Relações Exteriores e de Defesa Nacional pelo Deputado George Hilton (PP/MG):

Dos estrangeiros indocumentados no Brasil, os bolivianos são os que se encontram em pior situação. Em 2004, reportagem publicada na revista Época denunciava que a maioria dos bolivianos em situação irregular trabalha em oficinas de costura improvisadas, submetidos a uma jornada de até 16 horas por dia, em regime que se assemelha à semi-escravidão. Muitos desses migrantes chegam ao Brasil sem o passaporte, outros têm o documento apreendido pelos empregadores, que utilizam do expediente para manter os trabalhadores em situação irregular.

É preciso por um ponto final nesse drama, que não se coaduna com a tradição de nosso País no que se refere ao acolhimento dos imigrantes estrangeiros, nem com os princípios constitucionais de respeito à dignidade da pessoa humana (art. $1^{\circ}$, inciso III, da CF) e de prevalência dos direitos humanos (art. $4^{\circ}$, inciso II, da CF) (Dep. George Hilton, Parecer da Comissão de Relações Exteriores e de Defesa Nacional, 03/10/2007).

Outro elemento levantado no processo de aprovação da lei foi suas consequências para a projeção internacional do Brasil, como se depreende do parecer da Comissão de Constituição e Justiça e de Cidadania da Câmara que teve como relator o Dep. Carlos Zarattini (PT/SP), e do discurso de sanção do Presidente da República Lula da Silva:

É muito importante destacar que esta nova proposta de anistia para estrangeiros em situação irregular vem num momento em que a grave recessão mundial ameaça subsumir o planeta numa onda de xenofobia de dimensões alarmantes. De fato, o desconforto social causado pelo desemprego crescente e pela diminuição dos rendimentos coloca em perigo os trabalhadores estrangeiros, especialmente nos países avançados, os mais atingidos pela crise. Portanto, tal projeto, se aprovado, colocaria o Brasil na contramão dessa nova onda xenófoba, elevando o nome do país no cenário internacional (Deputado Carlos Zarattini, parecer sobre o PL 1.6441-A/2007 na Comissão de Constituição e Justiça e de Cidadania da Câmara, 18/02/2009).

Primeiramente, gostaria de agradecer, em nome do povo brasileiro, a todos os imigrantes que ajudaram e continuam a ajudar a construir o nosso país. (...) Essas novas leis significam que o Brasil se coloca cada vez mais à altura da realidade migratória contemporânea, das condições globais do desenvolvimento econômico e social, e do respeito fundamental aos direitos humanos. (...)Não podemos esquecer que a própria Constituição brasileira, quando trata dos direitos e garantias fundamentais, estabelece que todos são iguais perante a lei, sejam brasileiros ou estrangeiros residentes. O Estado 
brasileiro, por meio de compromissos firmados em vários acordos internacionais, reconhece que os migrantes são titulares de direitos e deveres que devem ser respeitados. Defendemos que a migração irregular é uma questão humanitária e não pode ser confundida com a criminalidade. Adotamos sobre essa questão uma abordagem abrangente e equilibrada, levando em consideração os princípios da universalidade, interdependência e indivisibilidade dos direitos humanos (...) Consideramos injustas as políticas migratórias adotadas recentemente em alguns países ricos, que têm como um dos pontos a repatriação dos imigrantes. Para nós, a repressão, a discriminação e a intolerância não lidam corretamente com a raiz do problema. Já disse várias vezes e repito: ninguém deixa sua terra natal porque quer, mas sim porque precisa ou porque acha que pode construir uma vida digna e melhor para si e para seus filhos em outro lugar (Luiz Inácio Lula da Silva, 02/07/2009, p.33-34 - grifo nosso).

Nota-se, portanto, que em um momento no qual a política migratória no MJ era preterida em prol do enfrentamento ao tráfico de pessoas, emergia um debate político e um discurso presidencial sobre a temática baseado nos direitos humanos. Esse descompasso teve reflexos na implementação da lei de anistia ${ }^{249}$, marcada por indefinições e casuísmo, de maneira que apenas em 2011, já em outra gestão da SNJ, a na Lei $\mathrm{n}^{\circ} 11.961 / 2009$ foi regulamentada pela Portaria MJ $\mathrm{n}^{\circ} 1.700$, disciplinando a instrução dos pedidos de transformação da anistia e esclarecendo os documentos requeridos.

Em 2010, percebe-se uma mudança de perspectiva no DEEST, ao elencar como um de seus objetivos estratégicos para o período "Humanizar a imigração, tendo presente que esta é inerente ao homem, que deve ter assegurados os seus direitos fundamentais, independente de nacionalidade e de sua situação migratória no país de destino" (SNJ, 2010, p.32). Em que pese não serem identificadas no relatório políticas públicas finalísticas nesse desígnio, observam-se iniciativas de fortalecimento institucional em duas vias: i) participação em eventos e reuniões internacionais; e ii) reestruturação dos processos internos.

Quanto à primeira, o relatório da SNJ explica que "constitui oportunidade de divulgar e defender as políticas públicas brasileiras na área da migração, além de contribuir para difusão e fortalecimento da posição do Brasil em relação aos imigrantes, perante os mais diversos países"(2010, p.18). Além de fóruns, seminários e conferências, o relatório lista a participação do DEEST na negociação de acordo sobre Residência, Estudo e Trabalho para Nacionais Fronteiriços brasileiros e colombianos ${ }^{250}$.

\footnotetext{
${ }^{249}$ Sobre questões suscitadas na implementação da Lei de Anistia de 2009, ver CDHIC e ESF (2011).

${ }_{250}$ Disponível em: http://dai-mre.serpro.gov.br/atos-internacionais/bilaterais/2010/acordo-entre-ogoverno-da-republica-federativa-do-brasil-e-a-republica-da-colombia-sobre-permissao-de-residencia-
} 
No que concerne à reestruturação dos processos internos, o DEEST começa a pensar medidas de desburocratização da prestação de serviços, como na Portaria $\mathrm{n}^{\circ} 23$, de 22 de outubro de $2010^{251}$.

O maior foco de destinação do orçamento dentro da SNJ continuou, porém, o ETP, principalmente via convênios assinados com unidades da federação, dada a rede descentralizada de núcleos de enfrentamento, e termos de cooperação com a UNODC. Ressalte-se que, no ano de 2010, o orçamento destinado ao programa "Promoção da Justiça e da Cidadania" atingiu R\$ 24.125.000,00, dos quais um montante de R\$ 19.000.000,00 correspondeu a aporte para organização do $12^{\circ}$ Congresso de Prevenção do Crime e Justiça Criminal (quadro 4.5).

Nesse mesmo ano de 2010, o então Secretário Nacional de Justiça, Romeu Tuma Jr., foi exonerado após investigações da Polícia Federal amplamente divulgadas na imprensa apontarem sua ligação com a máfia chinesa, em esquema baseado na intermediação de vistos permanentes para nacionais chineses irregulares ${ }^{252}$.

O ano de 2011 pode ser considerado um turning point na atuação do MJ, no qual se divisa uma clara intenção de conduzir uma política migratória. De um lado, representantes do DEEST buscaram marcar presença em diversas reuniões e conferências internacionais - dentre elas, a Conferência de Ministros de Justiça dos Países Iberoamericanos; Reunião de Ministros de Justiça e de Interior do Mercosul e Estados Associados; Fórum Global sobre Migração e Desenvolvimento; e a Conferência Sul-americana sobre Migrações (SNJ, 2011). Ademais, o Brasil, tendo como ponto focal o DEEST, passou a integrar o Sistema Contínuo de Relatórios sobre Migração Internacional das Américas (Sicremi) ${ }^{253}$, iniciativa da Comissão Especial de Assuntos Migratórios da OEA voltada para a elaboração de relatórios anuais contendo informações sobre os fluxos migratórios e as políticas dos países membros. Nesse mesmo ano, o DEEST envia representantes a missão no Equador e Peru para tratar da entrada de haitianos no Brasil e negocia com a Argentina Acordo Operacional com o

estudo-e-trabalho-a-nacionais-fronteiricos-brasileiros-e-colombianos-entre-as-localidades-fronteiricasvinculadas/. Não há informações sobre sua incorporação ao ordenamento brasileiro.

251 Dispõe sobre vistas e extração de cópias de autos de processos administrativos no âmbito do Departamento de Estrangeiros.

${ }^{252}$ Estadão, "PF liga Tuma Júnior, secretário Nacional de Justiça, a chefe da máfia chinesa", 04/05/2010. Disponível em: http://politica.estadao.com.br/noticias/geral,pf-liga-tuma-junior-secretario-nacional-dejustica-a-chefe-da-mafia-chinesa,547000. O Globo, "Investigação da PF liga Tuma Júnior a chefe da máfia chinesa, diz jornal". 05/05/2010. Disponível em: http://oglobo.globo.com/politica/investigacao-dapf-liga-tuma-junior-chefe-da-mafia-chinesa-diz-jornal-3012904.

${ }^{253}$ Dados sobre a iniciativa disponíveis em: http://www.migracionoea.org/index.php/es/ 
objetivo de estabelecer modalidade de controle migratório integrado com base em registro compartilhado do movimento de pessoas.

Por outro lado, nota-se no relatório de gestão que o DEEST empreendeu uma iniciativas de fortalecimento institucional: além de ações de capacitação dos recursos humanos; procedeu à padronização e racionalização dos processos de trabalho e de gestão, destacando-se iniciativa de informatização e digitalização dos documentos e revisão dos documentos exigidos para a instrução e decisão dos processos ${ }^{254}$. Nesse contexto, determinadas revisões de fluxos levaram a melhorias na garantia de direitos: por exemplo, a Portaria SNJ n 13, de 09 de junho de 2011, disciplinou procedimentos para transformação da residência provisória em permanente concedida sob o amparo de caso omisso ou situação especial; e a Portaria MJ n n $^{\text {1.700, de }} 28$ de julho de 2011, disciplinou a instrução dos pedidos de transformação da anistia.

Esta mudança de curso está associada ao início da gestão de Paulo Abrão (20112014) na SNJ, após ocupar a função de Presidente da Comissão de Anistia do MJ. Trata-se de momento identificado por alguns dos entrevistados da tese como de busca do MJ por um maior protagonismo na política migratória brasileira ${ }^{255}$. De acordo com João Guilherme Granja ${ }^{256}$, chefe de gabinete da SNJ entre janeiro de 2011 e março de 2013 e Diretor do DEEST entre março de 2013 e setembro 2016, a estratégia inicial do Secretário Nacional de Justiça foi de empreender uma reestruturação interna do órgão:

\begin{abstract}
A nossa perspectiva era a de que o Departamento de Estrangeiros era o departamento que tinha uma lógica de operação mais distante da secretaria, da lógica que a gente queria imprimir à secretaria, do que os outros dois departamentos. Então era um departamento que a gente acompanhava com atenção pelas suas características justamente cartoriais, sua tendência a adotar uma retórica de controle, e a ter uma postura muito conservadora em relação à imigração. (...) Algo que se mantinha na base de um isolamento burocrático (João Guilherme Granja, Entrevista, 20/11/2014).
\end{abstract}

$\mathrm{Na}$ interseção entre atividades internacionais e de reestruturação interna, a SNJ assinou, ainda em 2011, Acordo de Cooperação Técnica com o PNUD, sob intermediação da Agência Brasileira de Cooperação do MRE. Intitulado "Promoção de Direitos no Contexto da Política Migratória Brasileira", o acordo tinha o objetivo de implementar mecanismos transparentes e participativos que assegurassem a exigibilidade de direitos pelos estrangeiros no Brasil, e vigência até 2014.

\footnotetext{
${ }^{254}$ Por exemplo, a Portaria $\mathrm{n}^{\mathrm{o}} 01$, de 02 de maio de 2011.

255 Paulo Sérgio de Almeida (09/09/2016); Duval Fernandes (10/05/2016); João Guilherme Granja (09/09/2016).

${ }^{256}$ Gestor Público do Ministério do Planejamento, Orçamento e Gestão.
} 
É no contexto deste acordo que o DEEST firmou, em 2012, parceria com a Organização Internacional de Migrações para desenvolver atividades de ampliação do diálogo social; e promoveu, em conjunto com o MRE e o MTE, o seminário "O Direito dos Migrantes no Brasil: o novo estatuto do estrangeiro como uma lei de migração". O evento contou, ainda, com a colaboração do ICMPD. Realizado no Rio de Janeiro, entre 16 e 18 de maio de 2012, o Seminário mobilizou representantes do governo, da sociedade civil e academia, "visando colher subsídios para uma proposta de nova regulamentação, como uma 'Lei de Migração Brasileira', com uma visão atual de integração entre os povos e garantia da cidadania global” (MJ, 2012, p.360). Em seu programa $^{257}$, o Seminário anunciava os seguintes objetivos:

1. Consolidar um espaço para discussão e troca de experiências entre organizações sociais e gestores de políticas públicas migratórias;

2. Promover debates para a coleta de contribuições para o $\mathbf{P L} \mathbf{n}^{0} \mathbf{5 . 6 5 5 / 2 0 0 9}$;

3. Promover o intercâmbio de experiências e modelos internacionais de políticas migratórias;

4. Propiciar uma ambiência para a apresentação de estudos e pesquisas do tema migratório pelas universidades brasileiras (MJ, 2012 - grifo nosso).

Marcia Sprandel (2012) aponta que o seminário teria sido histórico por reunir oficialmente os três Ministérios centrais para a formulação e implementação da política pública de imigração no Brasil; e por ter tido ampla participação dos demais setores. Nessa ocasião, ainda segundo depoimento de Sprandel (2012), um dos representantes governamentais à mesa afirmou ser aquele o espaço de formulação política, fazendo referência a notícias veículadas na mídia na qual o secretário executivo da Secretaria de Assuntos Estratégicos, Ricardo Paes de Barros, anunciava iniciativas de formulação de uma política migratória de atração de mão-de-obra especializada para o Brasil.

De acordo com João Guilherme Granja, o seminário constituiu uma espécie de "evento termômetro para a gente testar quais eram os limites do Estado, dos órgãos governamentais, da sociedade civil, e até mapear sobre quem nós estávamos falando enquanto Estado" (Entrevista, 09/09/2016). Observa-se que, nesse momento, o marco referencial para uma reforma migratória continuava o PL n ${ }^{\circ}$ 5.655/2009.

Ainda em 2012, apreende-se do relatório de gestão do MJ a atuação em política migratória no campo de campanhas informativas; na promoção de estudo sobre acesso à políticas públicas e serviços pelos migrantes e refugiados, por meio do projeto "Pensando o Direito"; e na cooperação internacional, intensificando as relações com

\footnotetext{
${ }^{257}$ Disponível em: http://www.ippdh.mercosur.int/wpcontent/uploads/2014/08/programa seminario_migrantes rio.pdf.
} 
organismos e blocos vistos como estratégicos, quais sejam, a ONU, OEA, OIM e o Mercosul (MJ, 2012, p.46).

Ressalte-se que o ano de 2012 foi marcado pela entrada de fluxos de haitianos pela fronteira do Acre, motivo pelo qual foi deslocada, no início de 2013, uma forçatarefa da SNJ para o local para atendimento e implementação de serviços públicos a imigrantes. Este tema será especificamente tratado no capítulo 5.

Sublinhe-se, por último, que o orçamento de 2012 destacou a política migratória como um objetivo específico do "Programa Cidadania e Justiça", alocando-lhe R\$ 2.100.000,00. No ano seguinte, retoma sua opção anterior de formular um objetivo conjunto para as áreas de migração, combate à lavagem de dinheiro e enfrentamento ao tráfico de pessoas, ao qual se reservaram $\mathrm{R} \$ 8.653 .020,00$.

Em 2013, a estratégica de atuação do MJ se dá sobretudo em duas frentes: i) a formação de Comissão de Especialistas (Portaria MJ no 2.162/2013) para apresentar proposta de anteprojeto de uma nova lei de migrações e promoção dos direitos dos migrante; ii) a ampliação de parcerias com a sociedade civil, via conveniamento, e da participação social, com criação do Comitê de Acompanhamento pela Sociedade Civil sobre Ações de Migrações e Refúgio - CASC Migrante, órgão de assessoramento do Ministério da Justiça composto por representantes de instituições e setores da sociedade civil (Portaria $\mathrm{n}^{\circ} 455$, de 19 de dezembro de 2013); e das conferências preparatórias e grupos de trabalho da COMIGRAR.

Tais estratégias se alinham ao discurso que passou a ser sustentado pelo MJ relativo à existência de três déficits na política migratória brasileira: um déficit de direitos, resultante de legislação promulgada durante a ditadura militar; um déficit de coordenação e governança, a ser enfrentado pelo estabelecimento de meios de coordenação entre diferentes níveis e áreas de governo; e um déficit de participação social. Tal discurso foi encontrado em entrevistas da tese, em pronunciamento público do Secretário Nacional de Justiça ${ }^{258}$, e em artigo escrito pelo Diretor do DEEST, João Guilherme Granja, publicado no periódico El País em 28 de outubro de $2013^{259}$. O texto afirma que:

\footnotetext{
${ }^{258}$ Paulo Abrão, discurso de abertura da I COMIGRAR, São Paulo, 30/05/2014. Disponível em: https://www.youtube.com/watch?v=ZRrelkcpJ2k\&feature=youtu.be. Acesso em: 22 fev. 2017.

259 João Guilherme Granja, "Brasil: algunas pistas para la política migratoria europea". El País, 28/10/2013, http://elpais.com/elpais/2013/10/28/3500_millones/1382940000 138294.html.
} 
El primer desafío comprende la actualización de las leyes nacionales sobre inmigración, la internalización de tratados y acuerdos internacionales y la armonización de los reglamentos administrativos. Se trata de elementos claves para establecer una cultura jurídica y política de no discriminación, protección efectiva de los derechos y prevención de sus violaciones. Representa la superación de un "déficit de derechos" generado por sucesivos regímenes autoritarios de Brasil que, durante el siglo XX, elegirán el inmigrante como enemigo de la seguridad nacional y antagonista de los mecanismos de protección económica y laboral. Un fenómeno cuyas consecuencias han sobrevivido a la redemocratización (GRANJA, 2013).

A I Conferência Nacional de Migrações e Refúgio (COMIGRAR) foi realizada entre os dias 30 de maio e $1^{\circ}$ de junho de 2014, na cidade de São Paulo, sob coordenação do DEEST, com objetivo de promover um diálogo social ampliado para subsidiar a construção de uma Política Nacional sobre Migrações e Refúgio na perspectiva dos direitos humanos. O evento teve parceria do MTE e MRE, mas, precisese, correspondeu a uma iniciativa do Ministério da Justiça, com condução técnica e política exercida pela pasta. Contou, ainda, com apoio de agências das Nações Unidas (UNODC, ACNUR e PNUD) e da OIM. De acordo com dados da SNJ, o processo participativo mobilizou um total de 5 mil pessoas, 788 delas na etapa nacional (SNJ, 2016). As resoluções dele advindas foram encaminhadas ao governo federal em Caderno Final de Propostas ${ }^{260}$.

Na cerimônia de abertura do evento, o Secretário Nacional de Justiça, Paulo Abrão, proferiu discurso no qual afirmava:

É a primeira vez que os migrantes de todo o Brasil e as pessoas que trabalham com migração e refúgio se reúnem em um mesmo momento para debater o futuro e planejar e construir projetos conjuntamente. É a primeira vez que as políticas públicas nacionais em matéria de migração e refúgio serão construídas com participação popular. Esse é um novo e importante passo, inserido em um ambiente de mudanças profundas que o Brasil vive. Nós voltamos a ser um país de imigração. (...) O Ministro da Justiça José Eduardo Cardozo colocou a temática de migração entre as suas prioridades de gestão no Ministério da Justiça, e nos autorizou a convocar e organizar essa conferência. Nesses três últimos anos, foram tomadas medidas pelo governo da presidenta Dilma Rousseff. Nós promovemos, sob a liderança do ministro Cardozo, uma ampla reforma do DEEST do MJ, que deixou de ser um mero espaço cartorial, de procedimentos burocráticos, e

260 O Caderno encontra-se disponível em: http://participa.br/comigrar/destaques/caderno-final-depropostas-da-comigrar\#.WKsBBtLyuM8. Acesso em: 20 fev. 2017. Dentre as recomendações, destacamse: i) revogação do Estatuto do Estrangeiro por necessidade de compatibilidade com a Constituição Federal e com os tratados internacionais de Direitos Humanos vigentes; ii) mudança de paradigma na política migratória, já que atualmente está subordinada à lógica da segurança nacional e controle documental; iii) utilização do termo "migrantes" de maneira a incluir na política os brasileiros que deixam o país; iv) criação de um órgão estatal centralizado para atendimento aos migrantes, em especial para regulamentação. 
passou a ser um órgão ativo de construção de políticas e direitos dos migrantes (...) ${ }^{261}$ (Paulo Abrão, São Paulo, 30/05/2014 - grifo nosso)”.

A COMIGRAR não estava desvencilhada da estratégia de mudança legislativa que começava a ser conduzida pelo MJ. De acordo com João Guilherme Granja,

\begin{abstract}
Isso é um pouco o caso da gente ter uma via de duas mãos, que era também legitimar o texto que estava sendo discutido e ter muita gente, ter um grupo de escuta muito grande, e tentando entender que ansiedades poderiam ou não estar sendo captadas naquele texto. A gente colocou a comissão de especialistas toda para circular na COMIGRAR e buscar fazer isso (João Guilherme Granja, Entrevista, 09/09/2016).
\end{abstract}

Ainda em 2014, o MJ atuou internacionalmente junto ao MRE na condução de negociações referentes à operacionalização do Acordo de Residência com Uruguai; e procedeu à articulação com estados e municípios com vistas a atender às demandas de atendimento de imigrantes e refugiados, notadamente acentuadas com o fluxo de haitianos ao Acre e São Paulo. Esta articulação federativa levou o MJ a receber aporte orçamentário suplementar de R 7.900.000,00, destinado a suprir necessidades de equipamentos de acolhimento em diversas regiões do país e de implementação de uma estratégia de deslocamento de imigrantes da fronteira para médios e grandes centros urbanos.

Ressalte-se que a questão dos haitianos modificou profundamente a atuação do MJ na política migratória brasileira: não apenas a instituição se viu com um papel de articulação, como também assumiu funções mais diretas relacionadas à implementação política na perspectiva da integração dos migrantes e começou a questionar a distinção entre política imigratória e para refugiados. Nesse quadro, o repasse anual que era feito para entidades da sociedade civil que trabalhavam com refúgio passou a englobar os haitianos.

Por fim, o DEEST procedeu, em 2014, à reestruturação de processos internos, com digitalização do trâmite de documentos por meio do sistema SEI; transformações nos mecanismos de atendimento ao público; e adaptações nos fluxos relacionados à desburocratização da prestação de serviços, particularmente dos pedidos de permanência e registro de estrangeiros, com a publicação da Portaria MJ nº 1.351/2014. Esta portaria, prorrogada com alterações pela Portaria $n^{\circ} 04 / 2015^{262}$, facilitou o pedido

\footnotetext{
${ }^{261}$ Disponível em: https://www.youtube.com/watch?v=ZRrelkcpJ2k\&feature=youtu.be. Acesso em: 3 dez. 2016.

${ }^{262}$ Disponível em: https://www.legisweb.com.br/legislacao/?id=279939
} 
da permanência ${ }^{263}$, o que diminuiu o prazo de entrega do documento de identidade ao estrangeiro. As mudanças por ela geradas foram, porém, mais profundas que uma maior celeridade administrativa: os procedimentos estabelecidos garantiram ao estrangeiro o direito à permanência, desde que cumpridas as condições exigidas, diminuindo a discricionariedade do órgão implementador. A portaria estabeleceu, ainda, a regra de não realização de diligências pela Polícia Federal, exceto nas hipóteses de indícios de fraudes, o que, além de simplificar o processo, eliminou um elemento investigatório e coercitivo antes presente. Tal providência se alinhou à estratégia do MJ de reduzir a atuação da PF em temática migratória, para a qual também concorreu o Decreto $\mathrm{n}^{\circ}$ 8.374, de 11 de dezembro de 2014, alterando as disposições do art. 66 do Decreto 86.715 que atribuíam à PF responsabilidades sobre prorrogação de vistos temporários e concentrando tais atividades, de maneira ampla, no Ministério da Justiça.

Entrevista com João Guilherme Granja remete as origens da Portaria 1.351 à necessidade de aumento da capacidade administrativa da instituição, em várias dimensões: havia um fluxo de atendimento com pouca transparência, que tramitava em um sistema paralelo (MJ-ESTRANGEIROS) e não no sistema unificado do próprio Ministério (MJ-DOC), e inexistia um mecanismo padronizado de acompanhamento. Por conseguinte, de acordo com Granja,

\begin{abstract}
O relato de servidores é o relato de que haviam processos de priorização que nem sempre estavam normatizados, e que era difícil inclusive determinar o que era uma fila de processos, um nível de tramitação de baixíssima qualidade, e que isso também de alguma forma era um mecanismo de controlar reclamações (...)[as quais] eram administradas pontualmente (João Guilherme Granja, Entrevista, 20/11/2014).
\end{abstract}

Esse contexto foi agravado com a diminuição de equipes, resultante da orientação governamental de restringir a terceirização de mão-de-obra a atividades de apoio. Desta forma, o tensionamento entre a baixa capacidade administrativa da unidade e o aumento da demanda por serviços levou ao acúmulo de quase 30 mil processos pendentes de decisão na Divisão de Permanência do DEEST. Nessa conjuntura, observou-se "um acréscimo das reclamações que eram levadas tanto aqui quanto à Polícia Federal, e um acréscimo também dos padrões de judicialização" (João Guilherme Granja, Entrevista, 20/11/2014).

\footnotetext{
${ }^{263}$ Nas modalidades de reunião familiar, prole, casamento e união estável, de prorrogação de visto temporário, de transformação do visto oficial ou diplomático em permanente, de transformação do visto oficial ou diplomático em temporário, de transformação do visto temporário em permanente, e de transformação da residência temporária em permanente.
} 
Desse processo tomou parte a Secretaria-Executiva do MJ, unidade responsável pelos projetos prioritários do órgão. O seu então Coordenador Geral de Planejamento Setorial, Flávio Prol, cujas atribuições gravitam em torno de controlar e otimizar a metodologia de implementação de processos, relata que havia uma preocupação do Secretário-Executivo sobre a dimensão da transparência dos processos de permanência, em razão do aumento de reclamações recebidas. Procederam, então, ao mapeamento dos fluxos, no que identificaram um excesso de burocratização e gargalos (Entrevista, $06 / 11 / 2014)$.

Em paralelo à consolidação do fluxo dos problemas, desenhava-se o fluxo das soluções a partir de proposta de simplificação dos procedimentos apresentada por representantes do Departamento de Polícia Federal, sobre a qual trabalharam burocratas do $\mathrm{MJ}^{264}$. Modificando amplamente as dinâmicas de trabalho da burocracia envolvida, a portaria encontrou resistência à sua aplicação dentro do próprio $\mathrm{MJ}$, como relatam o Diretor do DEEST e o chefe da Divisão de Permanência:

Há menos tempos, se notou também que o próprio departamento colocava
uma certa resistência à simplificação processual, como um mecanismo de
tentar se manter empoderado em relação a determinados processos. Então
isso é um traço cultural de um padrão de burocracia que se refletia no esforço
de manter sob sua tutela direta um processo de tomada de decisão, tentar
evitar que houvesse controles externos, ou que houvesse o registro das
práticas que eram feitas (João Guilherme, Entrevista, 20/11/2014).
O que eu tenho tentado na verdade é contextualizar um pouco a situação
jurídica e social do estrangeiro, para que as pessoas também compartilhem
esse desconforto entre a realidade e as limitações do arcabouço normativo.
Às vezes você não pode mudar um determinado procedimento, mas você
também não pode ficar confortável nessa impossibilidade de mudar. É
importante cultivar aquele desconforto. Tentar contribuir para revelar esse
desconforto, para haver a mudança. Fugir da perspectiva de conforto que a
burocracia oferece. (...) Agora, a desburocratização dentro de um sistema
legal ainda não alterado é um processo limitado. O desafio de renovação do
dispositivo de lei permanece (Muller Borges, Entrevista, 27/02/2015).

Esse período foi também marcante para a política para refugiados: só entre 2010 e 2015, as solicitações de refúgio cresceram 2.868\%, passando de 966 para 28.670 demandas anuais (CONARE, 2016). Em 2014, o Brasil sediou evento internacional de comemoração dos 30 anos da Declaração de Cartagena; e a temática ganhou visibilidade na mídia e opinião pública com a guerra na Síria e o afluxo de nacionais deste país para território brasileiro. De fato, a Síria ocupou aquele ano o primeiro lugar nas solicitações de refúgio ao CONARE - 1.047 demandas atendidas, totalizando 1.385 refugiados sírios no país (GODOY, 2014), o que foi influenciado pela publicação de Resolução

\footnotetext{
${ }^{264}$ João Guilherme Granja, Entrevista, 20/11/2014; Flávio Prol, Entrevista, 06/11/2014.
} 
Normativa $\mathrm{n}^{\mathrm{o}} 17$, de 24 de setembro de 2013, prevendo a facilitação da emissão de vistos, nas embaixadas e consulados brasileiros, àquelas pessoas diretamente afetadas pelo conflito na Síria ${ }^{265}$. O CONARE teve sua capacidade administrativa ampliada, aumentando a celeridade e a quantidade de apreciação dos pedidos ${ }^{266}$. Nesse contexto, o ACNUR exerceu um importante papel de parceria com o Comitê, contratando temporariamente consultores para processarem as demandas dirigidas ao CONARE.

Quanto à política de enfrentamento ao tráfico de pessoas, tivera em 2013 seu II Plano Nacional aprovado, bem como a criação, pelo MJ, do Comitê Nacional de Enfrentamento ao Tráfico de Pessoas - CONATRAP. Sua condução, porém, fora paulatinamente apartada da política migratória: com a consolidação, no bojo do MJ, da lógica de não-criminalização para a política migratória, evidenciou-se seu distanciamento da lógica securitária sobre a mobilidade humana presente no ETP.

Em 2015, a condução de articulação federativa em política migratória levou a SNJ a receber um crédito extraordinário de $\mathrm{R} \$ 15.000 .000,00$ (medida provisória $\mathrm{n}^{\circ}$ 697/2015), destinado em grande parte à assinatura de convênios com municípios e estados para implantação de Centros de Referência e Atendimento para Imigrantes (São Paulo, Porto Alegre e Florianópolis). Ainda em 2015, a SNJ negociou Acordo de Cooperação Técnica com o MTE, a Universidade de Brasília (UnB) e o Instituto Brasileiro de Geografia e Estatística (IBGE), a fim de levantar todas as bases de dados públicos sobre imigração, emigração e refúgio. Ademais, assinou novo acordo de cooperação técnica internacional com o PNUD intitulado "Fortalecimento da capacidade institucional e da participação social na política de justiça", com vigência até 2017. O Projeto busca desenvolver e implementar novos mecanismos de gestão nas políticas executadas pela SNJ, englobando política migratória, política nacional de

\footnotetext{
${ }^{265}$ A RN no 17 do CONARE criou uma espécie de visto de turismo especial, dispensando a apresentação de documentos, de maneira a possibilitar que o candidato a refúgio pudesse sair do território sírio e chegar ao Brasil. Como explica Juliana Benedetti, "Essa é uma questão que demandou bastante empenho e envolvimento do Itamaraty. Como você sabe, na atual lei do estrangeiro que está em vias de revogação, não existe um visto específico que permita a entrada de potenciais solicitantes de refúgio. Só que o refúgio é uma situação de fato, ele só existe quando o refugiado já está fora do seu país de origem. Antes disso ele não é um refugiado e nem é papel do agente consular lá fora verificar se aquela pessoa preenche ou não os requisitos internacionais pra ser considerado um refugiado. Então isso gerava um grande problema porque as pessoas não conseguiam chegar no Brasil pra solicitar o refúgio" (Entrevista, 07/03/2016). Entre 2013 e 2016, foram concedidos cerca de 9.000 vistos a pessoas afetadas pelo conflito na Síria (Entrevista, Paulo Iansen, 04/03/2016).

${ }^{266}$ Segundo dados divulgados pelo Secretário Nacional de Justiça Paulo Abrão (2014), em 2010, foram apreciados 360 pedidos ao ano, e em 2013, quase 6.000 .
} 
refúgio, enfrentamento ao tráfico de pessoas e enfrentamento à corrupção e lavagem de dinheiro (SNJ, 2015-2016).

Observa-se no quadro 4.5 que o protagonismo assumido pelo MJ na temática migrante refletiu-se no aumento do orçamento que lhe era destinado para tanto. A manutenção do programa conjunto, abarcando ações de migrantes e enfrentamento ao tráfico de pessoas, à exceção do ano de 2012, permitiu uma maior maleabilidade no direcionamento das ações para uma política ou outra. Houve ainda consideráveis aportes suplementares destinados à gestão da questão dos Haitianos.

Quadro 4.5: Alocações orçamentárias para política migratória no MJ (2010-2015)

\begin{tabular}{|c|c|c|c|}
\hline $\begin{array}{l}\text { 2010 } \\
\text { Programa 1413: } \\
\text { Promoção da } \\
\text { Justiça e da } \\
\text { Cidadania }\end{array}$ & $\begin{array}{l}\text { Democratizar e aperfeiçoar o acesso à } \\
\text { justiça e à cidadania - Promover a } \\
\text { formulação, a implementação e o } \\
\text { monitoramento de políticas públicas e } \\
\text { serviços nacionais e internacionais de } \\
\text { justiça e cidadania para a consolidação da } \\
\text { democracia }\end{array}$ & $\begin{array}{l}24.125 .000,00 \\
* 5.125 .000,00\end{array}$ & $\begin{array}{l}24.125 .000,00 \\
* 5.125 .000,00\end{array}$ \\
\hline $\begin{array}{l}\mathbf{2 0 1 1} \\
\text { Programa 1413: } \\
\text { Promoção da } \\
\text { Justiça e da } \\
\text { Cidadania }\end{array}$ & $\begin{array}{l}\text { Democratizar e aperfeiçoar o acesso à } \\
\text { justiça e à cidadania - Promover a } \\
\text { formulação, a implementação e o } \\
\text { monitoramento de políticas públicas e } \\
\text { serviços nacionais e internacionais de } \\
\text { justiça e cidadania para a consolidação da } \\
\text { democracia }\end{array}$ & $5.100 .000,00$ & $5.100 .000,00$ \\
\hline $\begin{array}{l}2012 \\
\text { Programa 2020: } \\
\text { Cidadania e Justiça }\end{array}$ & $\begin{array}{l}\text { Objetivo 0874: } \\
\text { Assegurar e expandir os direitos dos } \\
\text { migrantes por meio da consolidação de } \\
\text { mecanismos ágeis de acesso à informação, } \\
\text { construção de direitos e prestação de } \\
\text { serviços públicos gratuitos, } \\
\text { independentemente de sua situação } \\
\text { migratória. }\end{array}$ & $2.100 .000,00$ & $2.100 .000,00$ \\
\hline $\begin{array}{l}\mathbf{2 0 1 3} \\
\text { Programa 2020: } \\
\text { Cidadania e Justiça }\end{array}$ & $\begin{array}{l}\text { Objetivo 0880: } \\
\text { Estruturar e fortalecer a Política Nacional } \\
\text { de Justiça por meio da } \\
\text { defesa dos direitos dos migrantes, } \\
\text { intensificação da cooperação } \\
\text { jurídica internacional, e ênfase na } \\
\text { articulação e integração das ações } \\
\text { garantidoras de direitos no âmbito da } \\
\text { cidadania, realçando a } \\
\text { participação social e os diálogos } \\
\text { interfederativos. }\end{array}$ & $8.653 .020,00$ & $8.653 .020,00$ \\
\hline $\begin{array}{l}\mathbf{2 0 1 4} \\
\text { Programa 2020: } \\
\text { Cidadania e Justiça }\end{array}$ & $\begin{array}{l}\text { Objetivo 0880: } \\
\text { Estruturar e fortalecer a Política Nacional } \\
\text { de Justiça por meio da } \\
\text { defesa dos direitos dos migrantes, } \\
\text { intensificação da cooperação } \\
\text { jurídica internacional, e ênfase na } \\
\text { articulação e integração das ações } \\
\text { garantidoras de direitos no âmbito da } \\
\text { cidadania, realçando a } \\
\text { participação social e os diálogos }\end{array}$ & $9.153 .020,00$ & $17.053 .020,00$ \\
\hline
\end{tabular}




\begin{tabular}{|l|l|l|l|}
\hline & interfederativos. & & \\
\hline $\mathbf{2 0 1 5}$ & Objetivo 0880: & $9.753 .020,00$ & $26.483 .020,00$ \\
Programa 2020: & $\begin{array}{l}\text { Estruturar e fortalecer a Política Nacional } \\
\text { de Justiça por meio da } \\
\text { defesa dos direitos dos migrantes, }\end{array}$ & & \\
intensificação da cooperação & jurídica internacional, e ênfase na \\
& $\begin{array}{l}\text { articulação e integração das ações } \\
\text { garantidoras de direitos no âmbito da } \\
\text { cidadania, realçando a } \\
\text { participação social e os diálogos } \\
\text { interfederativos. }\end{array}$ & & \\
\hline
\end{tabular}

* Descontado o valor reservado ao $12^{\circ}$ Congresso de Prevenção do Crime e Justiça Criminal Fonte: Elaboração própria.

Em 11 de fevereiro de 2016, o Decreto $n^{\circ} 8.668$ alterou a estrutura do Ministério da Justiça, transformando o Departamento de Estrangeiros em Departamento de Migrações. A definição de suas competências, inalterada nos decretos anteriores sobre o mesmo objeto, foi amplamente reformulada, passando de atividades basicamente relacionadas à instrução de processos relacionados com o regime jurídico do estrangeiro $^{267}$, para atribuições mais amplas como "estruturar, implementar e monitorar a política nacional de migração e de refúgio" (art.11, I) ${ }^{268}$. O Departamento perde a competência sobre assuntos de extradição e transferência de pessoas condenadas ${ }^{269}$, o que, segundo João Guilherme Granja, se deu em função do objeto consistir em "uma cooperação jurídica, como qualquer outra, mas que, misturada com a migração, definia um viés criminal para a migração" (Entrevista, 09/09/2016). A reforma corrobora ainda

\footnotetext{
${ }^{267}$ Decreto $^{\circ}$ 6.061/2007, art. 9o Ao Departamento de Estrangeiros compete: I - processar, opinar e encaminhar os assuntos relacionados com a nacionalidade, a naturalização e o regime jurídico dos estrangeiros; II - processar, opinar e encaminhar os assuntos relacionados com as medidas compulsórias de expulsão, extradição e deportação; III - instruir os processos relativos à transferência de presos para cumprimento de pena no país de origem, a partir de acordos dos quais o Brasil seja parte; IV - instruir processos de reconhecimento da condição de refugiado e de asilo político; e V-fornecer apoio administrativo ao Comitê Nacional para os Refugiados - CONARE.

${ }^{268}$ Art. 11. Ao Departamento de Migrações compete: I - estruturar, implementar e monitorar a política nacional de migração e de refúgio; II - promover, em parceria com os demais órgãos da administração pública federal e com redes de atores da sociedade civil, a disseminação e a consolidação de garantias e direitos dos migrantes e refugiados, nas áreas de sua competência; III - atuar para a ampliação e a maior eficácia das políticas e dos serviços públicos destinados à prevenção da violação de garantias e à promoção dos direitos dos migrantes; IV - apoiar o desenvolvimento de planos, diagnósticos, políticas e ações voltadas à inclusão social de migrantes junto aos órgãos federais, estaduais, distritais e municipais e entidades da sociedade civil; $\mathrm{V}$ - negociar acordos e conduzir estudos e iniciativas para o aperfeiçoamento do regime jurídico dos migrantes; VI - promover a articulação dos órgãos dos Poderes Executivo e Judiciário e do Ministério Público no que se refere à migração; VII - instruir processos e deliberar sobre temas de nacionalidade e apatridia, naturalização, prorrogação do prazo de estada de migrante no País, transformação de vistos e residências e concessão de permanência; VIII-instruir processos de reconhecimento, cassação e perda da condição de refugiado e de asilado político, autorizar a saída e o reingresso no País e expedir o respectivo documento de viagem; IX - fornecer apoio administrativo ao Comitê Nacional para os Refugiados; e X - receber, processar e encaminhar assuntos relacionados ao tráfico de migrantes.

${ }^{269}$ A qual passa ao Departamento de Recuperação de Ativos e Cooperação Jurídica Internacional.
} 
o movimento de aproximação, que vinha sendo operado pelo $\mathrm{MJ}$, entre a política migratória e de refúgio, "pensando na não-segregação de equipamentos. (...) tem uma gama de serviços universais que não dá para ter uma portinha para refugiado, uma portinha para não refugiado" (João Guilherme Granja, Entrevista, 09/09/2016). Sobre a interface entre os temas, discorre funcionário do escritório do ACNUR no Brasil:

\begin{abstract}
As alternativas regulares são muito limitadas na Lei 6.815. Se você não é estudante, diplomata, turista, se seu visto de trabalho não foi tramitado pelo empregador, você vai migrar de forma irregular. Então, isso causa um impacto direto no procedimento de refúgio. Como você não tem vias migratórias regulares, muitas das migrações são irregulares e a regularização da migração se dá com o pedido de refúgio, para que a pessoa fique temporariamente regular. A gente tem um incremento enorme de pedidos de refúgio, que, pensamos nós, seriam menores se os canais migratórios fossem estabelecidos de maneira mais contemporânea, de acordo com a dinâmica do presente, de uma globalização econômica. Então, o nosso ingresso nessa área se dá dentro desse aspecto, de mostrar que a falta de uma legislação atualizada no campo da migração gera um impacto em uma legislação muito refinada e atualizada de proteção aos refugiados, e que, portanto, se a gente tivesse uma nova legislação migratória a gente poderia corrigir esse problema, que diminuiria a pressão sobre o sistema de refúgio brasileiro (Entrevista, 11/05/2016).
\end{abstract}

\title{
c. Itamaraty
}

A análise da construção de capacidades institucionais pelo Ministério das Relações Exteriores se distingue em razão de sua particularidade de, ao contrário das duas pastas anteriores, ter na arena externa seu locus principal de atuação. Desta forma, suas atribuições na política migratória concernem à sua dimensão internacional, à exceção de sua participação no CNIg e, no caso do refúgio, CONARE. Pontue-se ainda que não foi possível realizar exame orçamentário no caso do MRE visto que não há dados setoriais disponíveis: as despesas correspondentes à política migratória se inserem na ampla rubrica de manutenção da rede consular ${ }^{270}$.

Como já apontado, a emigração de brasileiros para o exterior se mostrou uma questão social já na década de 1990, com consequências políticas particularmente verificadas no MRE. Nesse contexto, Andrés Puntigliano (2008) avalia que, na virada do século, "one of the most important phenomena in Brazilian international relations was that of the increasing flow of Brazilians abroad" (2008, p. 48), o que, ainda segundo o autor, teria conduzido a uma aproximação entre as agendas diplomática e

${ }^{270}$ Entre 2012 a 2015, trata-se do objetivo: 0911 - Aprimorar e expandir os serviços consulares, o tratamento dos temas migratórios e as atividades de apoio às comunidades brasileiras no exterior, nos termos da política governamental estabelecida pelo Decreto $\mathrm{n}^{\circ}$ 7.214, de 15 de junho de 2010. No PPA 2008-2011 correspondia a Relações e Negociações do Brasil no Exterior e Atendimento Consular. 
consular. De acordo com o ex-Secretário-Geral das Relações Exteriores Sebastião do Rego Barros, a interseção entre a agenda diplomática e consular proporcionada pela emigração de brasileiros teria como fio condutor o conceito da imagem internacional do país:

$\mathrm{O}$ atento acompanhamento dos problemas enfrentados pelas comunidades brasileiras no estrangeiro e a pronta e eficiente assistência aos nacionais são importantes fatores da preservação da imagem positiva do País no exterior. E quando menciono a importância da imagem internacional do Brasil não estou me referindo apenas ao tema da credibilidade do Governo no exercício de suas relações exteriores, mas também e principalmente à maneira como são vistos, aceitos e recebidos os brasileiros nos demais países (BARROS, 1997, p. 95).

À relevância política da imagem internacional do país se une a da proteção de direitos de seus cidadãos para além das fronteiras, com fundamento no conceito de nacionalidade. Para o Ministro Luiz Felipe Lampreia, as comunidades de brasileiros no exterior influenciam a política externa "na medida em que contribuem para criar vínculos mais fortes, e de uma natureza diferente, com os países recipiendários" (LAMPREIA, 1996, p.116). A diplomata Maria Rita Faria (2015) acrescenta, ainda, a relevância econômica das remessas dos brasileiros imigrantes, bem como o potencial comercial da presença de um mercado brasileiro no exterior para produtos nacionais.

As medidas políticas adotadas no governo Fernando Henrique Cardoso, expostas no item 4.2 deste capítulo, foram debatidas e avaliadas pela sociedade civil em novos foros de discussão. Em 2002, o I Encontro Ibérico da Comunidade de Brasileiros no Exterior foi realizado em Lisboa, com promoção da Procuradoria Regional dos Direitos do Cidadão do Distrito Federal, patrocínio do Banco do Brasil e apoio organizacional da Casa do Brasil em Lisboa, Cáritas, IMDH e Pastoral dos Migrantes da CNBB (MILESI; FANTAZINI, 2008). O Documento de Lisboa ${ }^{271}$ resultante do evento reivindicava ao Estado brasileiro medidas de melhoria das condições de vida e de proteção aos direitos dos cidadãos brasileiros residentes no exterior.

Na opinião de Luiza Lopes da Silva, Ministra Diretora do Departamento Consular e de Brasileiros no Exterior, as iniciativas de criação dos primeiros Conselhos de Cidadãos Brasileiros no exterior empreendidas no governo Fernando Henrique Cardoso não surtiram os efeitos desejados porque não foram acompanhadas de mudanças institucionais no organograma do Itamaraty:

\footnotetext{
${ }^{271}$ Disponível em: http://www2.camara.leg.br/documentos-e-pesquisa/publicacoes/estnottec/arquivospdf/pdf/2004 3518 Anexo.pdf. Acesso em: 12 nov 2016.
} 


\begin{abstract}
À época, porém, ficou faltando prever que área, em Brasília, responderia às demandas que surgissem. As unidades da área consular e jurídica tinham a função de assistência, emissão de passaportes e vistos, repatriação e outros assuntos jurídicos. Não havia nenhum setor específico que versasse sobre outros temas que não os mencionados. Nesse contexto, os conselhos que se formaram extinguiram-se quase todos. (...) Até 2007, não tínhamos uma unidade na área Consular do MRE que tivesse atribuições específicas que fossem além do trabalho cartorial e assistencial (Entrevista, 13/09/2016).
\end{abstract}

No quadro das propostas da "Carta aos Brasileiros que vivem longe de casa" divulgada em sua campanha eleitoral, em julho de 2003 o Presidente Luiz Inácio Lula da Silva realizou a primeira visita de Estado de seu mandato a Portugal. Entre os instrumentos assinados na ocasião, encontra-se o Acordo sobre Contratação Recíproca de Nacionais, estabelecendo uma regulação da migração laboral mais simplificada e flexível que a Lei $n^{\circ}$ 6.815. Ainda em 2003, o Presidente reuniu-se com um grupo de brasileiros residentes em Boston, cidade onde ocorreria, em 2005, o I Brazilian Summit reunindo pesquisadores, parlamentares, diplomatas brasileiros e autoridades norteamericanas, e de cujas discussões resultou a Carta de Boston (MILESI; FANTAZINI, 2008), com pleitos dispondo sobre negociações bilaterais com os EUA e ampliação da capacidade estatal do Itamaraty.

Ressalte-se que o Legislativo se fez presente em ambos os eventos, denotando a relevância política que a questão assumia à época. Tanto o era que, em 2005, teve lugar a Comissão Parlamentar Mista de Inquérito sobre a Emigração, com a finalidade de apurar os crimes e outros delitos penais e civis praticados com a emigração ilegal de brasileiros para os Estados Unidos e outros países, e assegurar os direitos de cidadania aos brasileiros que vivem no exterior. As recomendações emitidas pela Comissão foram numerosas $^{272}$, englobando desde a promoção do censo dos brasileiros no exterior em cooperação; até ampliação e fortalecimento da rede consular com expansão de seu papel, de maneira que os consulados não fossem apenas órgãos emissores de documentos, mas atuassem como órgãos de apoio comunitário para responder às diversas necessidades dos cidadãos brasileiros residentes no exterior. Duas outras recomendações ressaltam do relatório da CPMI: a ratificação e encaminhamento para apreciação do Congresso Nacional da Convenção Internacional sobre a Proteção dos Direitos de todos Trabalhadores Migrantes e de seus Familiares (1990) e da Convenção

\footnotetext{
${ }^{272}$ Uma das recomendações da CPMI referiu-se aos direitos políticos dos imigrantes no Brasil: "No que diz respeito à participação política do estrangeiro domiciliado no Brasil, incitar o debate e a reflexão, em ambas as Casas legislativas, tendo em vista a evolução por que o tema tem passado nas democracias contemporâneas" (Relatório CPMI, 2005, p.524)
} 
$n^{0} 143$ da OIT relativa às Migrações em Condições Abusivas e à Promoção da Igualdade de Oportunidades e de Tratamento dos Trabalhadores Migrantes (1975).

Essa dinâmica de reivindicações sociais e compromissos políticos se refletiu na criação, pelo Decreto $\mathrm{n}^{\mathrm{o}}$ 5.979/2006, da Subsecretaria Geral das Comunidades Brasileiras no Exterior (SGEB) dentro da estrutura regimental do $\mathrm{MRE}^{273}$. A criação de uma unidade específica, reunindo as competências sobre os temas relativos aos brasileiros no exterior e aos estrangeiros que desejassem ingressar no Brasil, sinalizava, "de forma concreta, o reconhecimento de que a questão da emigração brasileira havia se tornado preocupação central da PEB" (FARIA, 2015, p.75) ${ }^{274}$.

Por sua vez, as demandas por participação da sociedade civil continuavam. Em 2007, o II Encontro de Brasileiras e Brasileiros na Europa foi organizado pela Comissão de Direitos Humanos da Câmara dos Deputados, Fundação Alexandre de Gusmão, IMDH e Pastoral de Brasileiros no Exterior da CNBB. Na situação, formaliza-se a criação da Rede Brasileira na Europa e aprova-se o Documento de Bruxelas que, dentre outras reivindicações, solicitava a criação do Conselho Nacional de Migração (MILESI; FANTAZINI, 2008).

Em 2008 e 2009, sob patrocínio da SGEB e da Funag, realizaram-se a I e a II Conferências Brasileiros no Mundo, reunindo representantes das comunidades brasileiras no exterior, atores governamentais e não-governamentais, organismos internacionais e acadêmicos. Em 2010, o Decreto $n^{\circ} 7.214^{275}$ institui formalmente a realização anual das conferências como uma responsabilidade do MRE, elencando-se a participação social como diretriz da política governamental quanto às comunidades de brasileiros no exterior e prevendo-se outros instrumentos para efetivá-la. Nesse contexto, conforme interpretação do próprio MRE,

Foi estabelecida assim nova forma de interlocução governamental com a sociedade civil brasileira no exterior, bem como atribuída ao Itamaraty função coordenadora adicional à que tradicionalmente exerce ao organizar e

\footnotetext{
${ }^{273} \mathrm{O}$ decreto $\mathrm{n}^{\circ} 5.979 / 2006$ foi revogado pelo Decreto $\mathrm{n}^{\mathrm{o}} 7.304 / 2010$ e, posteriormente, Decreto $\mathrm{n}^{\circ} 8.817$, de 21 de julho de 2016, que a renomeou Subsecretaria-Geral das Comunidades Brasileiras e de Assuntos Consulares e Jurídicos.

274 Observe-se que, nos termos do regimento anterior ao de 2006 (Decreto $n^{\circ}$ 5.032/2004), havia uma Subsecretaria-Geral de Cooperação e Comunidades Brasileiras no Exterior (SGEC) a qual continha a Agência Brasileira de Cooperação (ABC); o Departamento de Promoção Comercial (DPR); o Departamento Cultural (DC) e o Departamento das Comunidades Brasileiras no Exterior (DCB). Já nos termos do Decreto nº 4.759 de 2003, a temática era tratada por Direção-Geral de Assuntos Consulares, Jurídicos e de Assistência a Brasileiros no Exterior.

${ }^{275}$ Posteriormente alterado pelo Decreto 7.987, de 17/04/13.
} 
liderar a participação do Governo em foros internacionais e negociações bilaterais sobre temas consulares e migratórios (MRE, 2012, p.6).

Sublinhe-se que a política para brasileiros no exterior não foi implementada sem percalços diplomáticos. Afinal, consiste em objetivos que enfrentam, para sua materialização, a soberania de outros Estados e suas respectivas políticas migratórias, muitas vezes restritivas em detrimento dos nacionais brasileiros. Foi o caso da Operação “Amazon 2", organizada e executada pela Agência de Controle de Fronteiras Externas da União Européia (FRONTEX), em 2007, com o objetivo de impedir a entrada de cidadãos sul-americanos considerados potenciais imigrantes irregulares - e que denegou o ingresso de 412 cidadãos brasileiros a países comunitários. Além de prestar assistência consular, representantes do Itamaraty reuniram-se com as autoridades migratórias dos países da Operação, a fim de defender o direito de livre circulação dos nacionais brasileiros, e encaminharam nota à Comissão Europeia na qual o Estado brasileiro "reafirmou posição contrária a políticas migratórias dessa natureza e lembrou as tradicionais relações com a Europa, de cujo território o Brasil acolheu milhões de imigrantes no passado" (MRE, 2007, p.263-264).

Já no caso da denegação de entrada de brasileiros por autoridades imigratórias do Aeroporto de Madri, Espanha, em 2008, declaração de imprensa do MRE relata que o órgão "está examinando a adoção de medidas apropriadas em resposta ao ocorrido, tendo em conta, inclusive, o princípio da reciprocidade" (MRE, 2008, p. 172). Nesse mesmo ano, em cerimônia de abertura da I Conferência de Brasileiros no Exterior, o Ministro Celso Amorim afirmou que, "em função dessas últimas medidas da União Europeia - não só ela, mas em função sobretudo dessas últimas medidas - a questão da migração se tornou um problema de política externa" (AMORIM, 2008, p.51-52). Em abril de 2012, tendo em vista a não redução de casos de inadmissões de brasileiros, o governo passou a aplicar requisitos específicos para entrada de turistas espanhóis no Brasil, similares aos aplicados pelo Governo espanhol para brasileiros. Poucos meses depois, Reunião Técnica Brasil-Espanha sobre temas Consulares e Migratórios chegou a um entendimento sobre instrumentos de facilitação recíproca da regularização da entrada nos dois países.

Outras inovações empreendidas pela SGEB no período em análise foram: a partir de 2007, a Subsecretaria passou por amplas discussões sobre o Plano Diretor de Reforma Consular; lançou em 2008 e implementou nos anos seguintes o Sistema Consular Integrado (SIC), criando o Portal Consular e informatizando o processamento 
de passaportes, vistos, registros civis e atos notariais; criou a Ouvidoria Consular (2009); e lançou o Portal virtual das Comunidades Brasileiras no Exterior (2010). Procedeu, ainda, à internacionalização da Central de Atendimento à Mulher no Brasil (Ligue-180), em parceria com o MJ e a Secretaria de Políticas para Mulheres; à inauguração de TV Pública para Brasileiros no Exterior (2010); à realização de exames supletivos Exame Nacional para Certificação de Competências de Jovens e Adultos (ENCCEJA) no exterior; à realização de parceria com a Caixa Econômica Federal para possibilitar saque de FGTS no exterior (2010); a acordos previdenciários; e à promoção de concursos e outras iniciativas culturais com a finalidade de manter laços culturais com a diáspora.

Nesse sentido, o MRE amplia seu quadro de atuação de atividades consulares clássicas, isto é, serviços de proteção, apoio e documentação de brasileiros no exterior, para o que denomina atividades consulares de "segunda geração", ou seja, "de promoção da saúde, dos direitos trabalhistas, da previdência, da educação, da cultura, do bem-estar e do autodesenvolvimento desses nacionais" (MRE, 2012, p.5). A implementação dessas atividades corresponde a uma mudança do objeto da abordagem consular, passando do individual para a comunidade, com foco na identificação das demandas peculiares a cada uma delas. Essa perspectiva caracteriza-se pela visão das instâncias associativistas como instrumentos de capilarização dos serviços do Estado brasileiro no exterior e pela atuação no fornecimento de políticas públicas para além das fronteiras brasileiras, com fundamento no vínculo de nacionalidade e por meio de parcerias com órgãos governamentais. Na opinião da Ministra Luiza Lopes da Silva,

\footnotetext{
Questões relacionadas a brasileiros podem contribuir positiva ou negativamente para o relacionamento bilateral. Um problema consular sério pode prejudicar o relacionamento entre dois países. Quando a comunidade floresce e passa a contribuir positivamente para o país de acolhimento, ajuda a criar laços fortíssimos de diversas formas. Uma comunidade imigrante bem integrada fornece uma imagem positiva do país, e imagem, para nós, é soft power. Nossa comunidade é fundamental na relação bilateral em cada país onde está estabelecida. Quando há uma integração boa, gera simpatia, pontes e capilarização. Os Governos constroem as artérias, e as comunidades de brasileiros vão no nível capilar. Isso forma uma rede muito sólida. De outro lado, se temos uma comunidade envolvida com criminalidade, é péssimo para a imagem do país (Entrevista, 13/09/2016).
}

À SGEB, entretanto, cabem competências mais amplas que as comunidades de brasileiros no exterior: nos termos da estrutura regimental consolidada no Decreto 
$7.304 / 2010^{276}$, a Subsecretaria tem como finalidade assessorar o Secretário-Geral das Relações Exteriores no tratamento de temas relativos a brasileiros no exterior, à concessão de vistos a estrangeiros que desejem ingressar no Brasil, à cooperação judiciária internacional e à implementação do Sistema Consular Integrado. Dentre suas atribuições específicas, encontram-se coordenar negociações bilaterais e multilaterais sobre temas consulares, migratórios e de cooperação jurídica internacional, assim como promover contatos e entendimentos entre setores governamentais - no âmbito dos três Poderes e das três esferas de Governo - e não governamentais envolvidos nos assuntos em discussão. Sua estrutura organizacional nos termos do decreto $n^{\circ} 7.304 / 2010$ está desenhada na figura 4.6 .

Figura 4.6: Organograma da SGEB nos termos do Decreto nº 7.304/2010

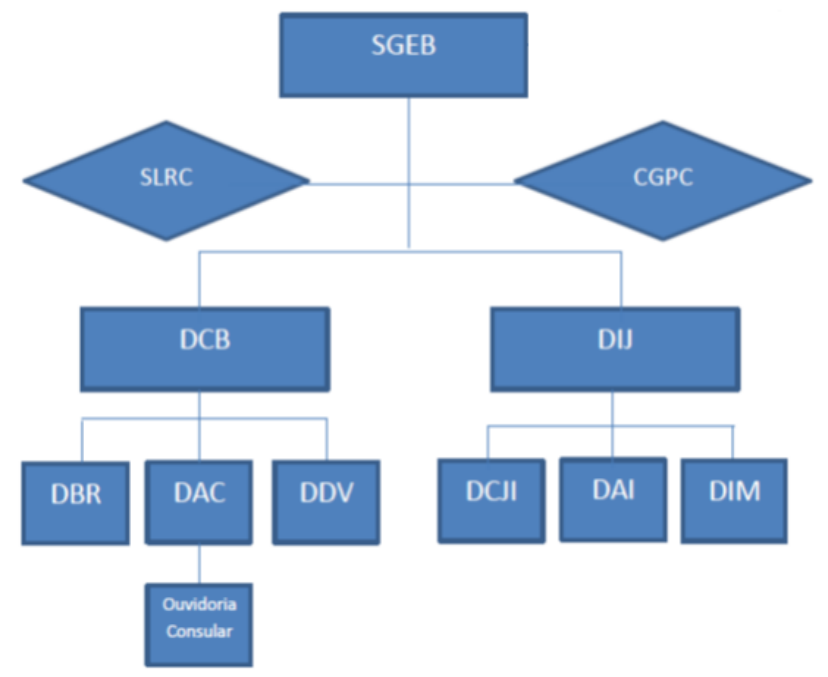

Fonte: SGEB, 2015, p.13

A Coordenação-Geral de Planejamento e Integração Consular (CGPC) e o Setor de Legalização de Documentos e Rede Consular Estrangeira (SLRC) são unidadesmeio: reúnem atribuições relativas, respectivamente, à implantação, manutenção e contínuo aprimoramento do Sistema Consular Integrado (SCI); e à legalização de documentos e gerenciamento da rede consular estrangeira no Brasil. Ao Departamento Consular e de Brasileiros no Exterior (DCB) subordinam-se: Divisão de Assistência Consular (DAC), Divisão das Comunidades Brasileiras no Exterior (DBR), Divisão de Documentos de Viagem (DDV) e Ouvidoria Consular (OUV). Engloba, portanto, atribuições consulares de primeira e segunda dimensão. Já o Departamento de

\footnotetext{
${ }^{276}$ O Decreto $n^{\circ} 7.304 / 2010$ é aqui tomado por referência por ter regido o Itamaraty a maior parte do período em análise neste estudo. Foi, entretanto, revogado pelo Decreto nº 8.817 , de 21 de julho de 2016.
} 
Imigração e Assuntos Jurídicos (DIJ) compõe-se da Divisão de Cooperação Jurídica Internacional (DCJI), Divisão de Atos Internacionais (DAI) e Divisão de Imigração (DIM). Quanto à última, cabe-lhe cuidar dos assuntos concernentes à política nacional de imigração, coordenando com os demais órgãos do Executivo envolvidos em sua formulação, ocupando assento no CNIg e conduzindo sua execução no âmbito do MRE.

Ressalte-se que, no plano multilateral, as negociações sobre imigrações são acompanhadas pela Divisão de Temas Sociais (DTS) do Departamento de Direitos Humanos e Temas Sociais. Por conseguinte, à SGEB, em geral, e à DIM, em particular, correspondem atribuições relacionadas, notadamente, à implementação da política e à representação do Itamaraty no xadrez político doméstico relativo às imigrações. Desta forma, dentre as metas arroladas anualmente pela SGEB para cumprimento do objetivo 0911, previsto no PPA 2012-2015 (“Aprimorar e expandir os serviços consulares, o tratamento dos temas migratórios e as atividades de apoio às comunidades brasileiras no exterior, nos termos da política governamental estabelecida pelo Decreto $\mathrm{n}^{\mathrm{o}} 7.214$, de 15 de junho de 2010"), encontra-se o acompanhamento e discussão das iniciativas em curso, tanto no Executivo como no Congresso Nacional, com vistas à reforma da legislação migratória brasileira. Na visão do ex-Chefe da DIM, Ministro Bernardo Velloso,

Nós temos no Brasil uma Lei de 1980, que data do regime militar, e que permanece vigente até que seja aprovada a nova lei de imigração. É possível que nós, em um prazo não muito distante, venhamos a ter uma lei nova, mais moderna, e baseada em princípios fundamentais de direitos humanos que caracterizam já a política migratória há muitos anos. O Estatuto é um diploma criado no regime militar, calcado na atração de mão de obra e segurança nacional. As práticas vinham sendo modificadas por decisões do CNIg, mas a legislação nos engessava muito (Bernardo Paranhos Velloso, Entrevista, 11/01/2017).

Quanto à implementação, ressalte-se que a SGEB se particulariza no contexto do MRE por sua atividade de prestar serviço de atendimento aos cidadãos. Isso engendra, inclusive, determinadas características organizacionais que a peculiarizam:

\footnotetext{
Alguns aspectos individualizam a unidade no âmbito do MRE, sendo o principal o fato de ser uma prestadora de serviços para o público brasileiro e estrangeiro. Por esse motivo, as unidades que compõem a estrutura da SGEB gozam de grau de autonomia, em geral, superior aos das demais unidades do MRE, principalmente na tomada de decisões que muitas vezes são urgentes (caso do atendimento a cidadãos brasileiros no exterior) e que, frequentemente, exigem pronta disponibilidade de recursos humanos e materiais e elevada capacidade de resposta a questões individuais e/ou específicas (SGEB, 2015, p.59).
} 
Nesse sentido, os burocratas da SGEB possuem uma determinada autonomia decisória, dentro de limitações orçamentárias, e exercem um papel importante na formulação e implementação das políticas, especialmente concretizado a partir de parcerias com outros órgãos federais e instituições privadas. Nesse processo, é conferida importância à participação social, como se depreende no depoimento de Aminthas Cardoso, assessor da Divisão de Comunidades Brasileiras no Exterior:

Respondendo sobre quem formula. Primeiro, resposta da comunidade. Segundo, a Ministra Luiza, que é Diretora do Departamento Consular e de Brasileiros no Exterior. Terceiro, nós diplomatas aqui do chão de fábrica, que temos ideias e fazemos (Entrevista, 15/05/2016).

Ainda no quadro da implementação política, observa-se que determinadas inovações administrativas concebidas para atender às demandas em prol das comunidades brasileiras no exterior proporcionaram avanços também no serviço prestado aos estrangeiros, dos quais se destaca o Sistema Consular Integrado (SCI). Tal ferramenta atraiu esforços contínuos do MRE para sua implantação e aperfeiçoamento, no intuito de padronização e aumento da eficiência dos procedimentos consulares e, desta forma, contribuir para elevação do Índice de Produtividade Consular Consolidado (IPCC), indicador qualitativo que sintetiza os resultados atingidos pela Subsecretaria e em relação ao qual se calcula o atendimento de suas metas (SGEB, 2015, p.51). Além de dar celeridade ao atendimento e fornecimento de visto aos estrangeiros, o SCI proporcionou melhorias na gestão de dados sobre concessão de vistos, de extrema importância para a formulação da política migratória.

Outro âmbito de efeitos mútuos para a política para brasileiros no exterior e a política de imigração são os acordos bilaterais - tanto aqueles relacionados a políticas setoriais, particularmente nas áreas laboral e de previdência social, quanto aqueles voltados especificamente para a circulação de pessoas. Assim, observa-se que, entre 2007 e 2015, foram criados e implementados grupos de trabalho e negociações bilaterais sobre temas consulares e migratórios com diversos países ${ }^{277}$. Com o México (2004), foi estabelecida cooperação operacional por meio dos Consulados-Gerais dos dois países em Nova York e Chicago, bem como participação em conferências sobre nacionais no exterior. Com o Reino Unido, assinou-se Memorando de Entendimento sobre cooperação em assuntos migratórios (2009), envolvendo sobretudo cooperação

277 De acordo com o MRE, os grupos de trabalho seguiam uma agenda básica que compreendia informações sobre as respectivas comunidades nacionais emigradas; circulação de pessoas em âmbito nacional, regional e internacional; utilização de novas tecnologias nas áreas consular e migratória; possibilidades de cooperação; e discussão de temas pontuais (MRE, 2012). 
técnica e sobre aspectos consulares de grandes eventos. Com a França, firmou-se Memorando de Entendimento para Criação de um Mecanismo Bilateral de Consulta sobre Questões Migratórias (2009), particularmente voltado para a imigração fronteiriça na Guiana Francesa. Também relacionado à imigração fronteiriça foi acordo assinado com o Suriname (2004). Com Portugal, celebrou-se Acordo sobre Facilitação de Circulação de Pessoas (2003) ${ }^{278}$.

Com a Bolívia, tendo em vista a não entrada em vigor do Acordo de Residência do Mercosul, foi negociado acordo para Permissão de Residência, Estudo e Trabalho a Nacionais Fronteiriços em $2004^{279}$. O instrumento tinha a finalidade de beneficiar o elevado contingente de bolivianos na cidade de São Paulo, mas acabou se aplicando também à comunidade de brasileiros na região de fronteira da Bolívia, afetados pela decisão do governo boliviano, em maio de 2006, de implementar dispositivo constitucional que proibia a presença de estrangeiros na faixa de cinquenta quilômetros das fronteiras do país (FARIA, 2012). Para solucionar a questão, o Itamaraty negociou com a OIM e o governo boliviano Instrumento Executivo Trilateral assinado em 2008, implementado internamente em parceria com o Ministério do Desenvolvimento Agrário e o INCRA. O acordo possibilitou o reassentamento voluntário de centenas de famílias brasileiras, na Bolívia e no Brasil.

Dois outros fluxos migratórios importantes foram também tratados bilateralmente pelo Itamaraty: a II Reunião Bilateral de Consulta sobre Assuntos Consulares e Migratórios Brasil-Angola (2012) debateu a cooperação sobre esses temas em países que contam, respectivamente, com consideráveis comunidades de nacionais dos contrapartes; e a III Reunião de Consultas Brasil-China sobre Temas Migratórios e Consulares (2013) insere a agenda migratória e consular no âmbito da Parceria Estratégica Brasil-China.

No que atine especificamente à concessão de vistos a cidadãos estrangeiros, percebem-se inovações de origem casuística, relacionadas a três eventos:

(i) em cumprimento às regulamentações da Copa do Mundo e dos Jogos Olímpicos, necessitou-se criar novo tipo de visto no âmbito do SIC, dadas

\footnotetext{
${ }^{278}$ Internalizado pelo Decreto $\mathrm{n}^{\circ} 6.427 / 2008$.

${ }^{279}$ Internalizado pelo Decreto n ${ }^{\circ} 6.737 / 2009$. Disponível: http://www.planalto.gov.br/ccivil_03/_ato20072010/2009/decreto/d6737.htm. Acesso em: 19 mar 2016.
} 
as especificidades do regime previsto para o caso, notadamente a gratuidade para o solicitante;

(ii) a implementação do Programa Mais Médicos ${ }^{280}$ requereu atuação do Itamaraty na formulação política, com a necessária criação de um novo visto, e em sua implementação, com adequação do SIC, remanejamento de pessoal para reforço de postos (em especial a Embaixada em Havana), e aumento da capacidade de entrega de documentos;

(iii) a concessão de vistos permanentes humanitários para cidadãos haitianos $^{281}$, no quadro da Resolução 97 do CNIg e suas sucessoras, exigiu novas soluções operacionais na Embaixada em Porto Príncipe, notadamente a assinatura de contrato com a OIM para implementação de centro de préprocessamento de vistos - o que aumentou a capacidade de entrega daquela Embaixada.

A exemplo do Centro de Pré-processamento de Vistos (Visa Centers) do Haiti, outros três entraram em funcionamento em Cantão, Pequim e Xangai, na China, para atender a demanda por vistos realizando serviços pré-consulares, como recebimento da documentação e agendamento (SGEB, 2015).

A DIM ainda representa o Brasil em instâncias regionais: no Foro Especializado Migratório do Mercosul; na Conferência Sul-Americana de Migrações; em Grupo de Trabalho da Unasul; e na CELAC. Articula, também, a relação do Brasil com a OIM. Por sua vez, a representação em instâncias multilaterais é atribuição da Divisão de Temas Sociais (DTS), a qual coordena as posições do Brasil nos debates em Genebra. A temática do refúgio, por seu turno, cabe à Divisão de Nações Unidas (DNU). De acordo com o depoimento dos entrevistados, a coordenação intraministerial é realizada, sobretudo, por relações informais entre os burocratas, não havendo uma instância formal de articulação sobre migrações. Veja-se o caso dos projetos de lei de migração, sobre os quais foram consultadas as diversas áreas sob liderança da DIM, conforme relata seu antigo Chefe de Divisão, Bernardo Paranhos Velloso:

A lei de imigração trata de outras questões que não são afetas a vistos. $O$ capítulo relativo a vistos tinha como ponto focal a Divisão de Imigração, e acima, o Departamento de Imigração e assuntos jurídicos. A divisão é unidade

\footnotetext{
${ }^{280}$ O Programa Mais Médicos e a cooperação intragovernamental que nele tem lugar são explorados no capítulo 5, item 5.3.

${ }^{281}$ A questão dos haitianos e a cooperação intragovernamental por ela desencadeada são exploradas no capítulo 5, item 5.2.
} 
básica de atuação, eu era subordinado ao Diretor do Departamento de Imigração e Assuntos Jurídicos, que além das questões migratórias trata das questões jurídicas. A Divisão de Cooperação Jurídica e Internacional, por exemplo, tem competência na área de extradição e nacionalidade. Essa divisão estava, então, envolvida. A lei também fala de brasileiros no exterior, então envolve tanto a Divisão Consular como a de Comunidades Brasileiras no Exterior. Fala de questões humanitárias, então são da alçada da Divisão das Nações Unidas, que acaba tendo uma incidência sobre a legislação, além do Departamento de Direitos Humanos e Temas Sociais. Acaba tendo uma coordenação intraministerial como fundamental, porque não vai se resumir a uma divisão ou unidade do Itamaraty (Entrevista, 11/01/2017).

Os relatos das entrevistas, no entanto, dão indícios de que o movimento de articulação intraministerial é recente. A conselheira Maria Rita Faria afirma que "a participação do Itamaraty se dava muito pela área de Migração e eu defendo na tese que esse tema de migração não pode ser tratado dessa maneira, compartimentalizado" (Entrevista, 04/03/2016). No mesmo sentido se posiciona Juliana Benedetti, segunda secretária da DNU:

Tem um contato também, mas esse contato só se intensificou nos últimos tempos porque os temas de imigração e refúgio vêm se misturando bastante. Eles vêm sendo tratados de forma mais coordenada, apesar de haver marcos normativos internacionais bastante diferentes em grau de completude e desenvolvimento bastante diferentes. (...) Agora, no âmbito das Nações Unidas esses temas vêm sendo tratado de forma muito próxima. Agora em setembro vai haver uma cúpula na Assembleia Geral da ONU sobre grandes movimentos de migrantes e refugiados, os dois temas juntos. Entendendo-se que há desafios comuns mas também reconhecendo que são dois tipos de deslocamentos com causas diferentes, motivações diferentes e às vezes até dinâmicas diferentes (Entrevista, 07/03/2016).

Nesse contexto, nota-se nas entrevistas realizadas com burocratas do Itamaraty a existência de uma visão convergente sobre a política migratória, a qual pode ser sintetizada nas falas do Conselheiro Paulo Iansen, Chefe da DIM, e Carlos Cuenca, Chefe da DTS:

É porque nos foros multilaterais que nós frequentamos, um ponto basilar da nossa posição é o respeito aos direitos humanos do migrante. Não se pode tratar de migração sem o pleno respeito do direito no migrante. Isso é premissa para que a gente possa conversar. Outro ponto é que a migração não pode ser tratada como um crime, ou como algo ilegal. Migração você pode ter regular e irregular, que não se adequou por questões documentais ao procedimento de determinado país. Mas o imigrante nunca pode ser criminalizado pela sua condição. Essas posições são muito claras no que a gente defende até por uma razão que se impõe ao Itamaraty por coerência. $O$ Brasil tem 3 milhões de brasileiros que vivem fora e nós temos uma luta diária para a defesa dos direitos desses cidadãos brasileiros no exterior, seria totalmente incoerente se nós tivéssemos uma opinião divergente em relação ao estrangeiro que quer vir para o Brasil (Paulo Iansen, Entrevista, 04/03/2016).

Nos foros multilaterais temos discussões de caráter mais geral. Afirmam-se e reafirmam-se certos princípios - a questão da importância do respeito aos direitos humanos de todos os imigrantes, independente da sua situação 
migratória, a ideia de não se criminalizar a migração irregular, a ideia de que o fenômeno migratório é muito relacionado com os diferenciais de desenvolvimento, etc. Há também a discussão sobre como tratar o tema internacionamente como por exemplo, a ideia de que é importante o reforço do tratamento multilateral do tema, com a criação de um fórum próprio ou o apoio a esse processo de convergência da OIM em relação a ONU (Carlos Cuenca, Entrevista, 09/09/2016).

Observa-se, por último, que tais declarações se alinham aos princípios orientadores da SGEB elencados em publicação oficial de 2012:

\begin{abstract}
A Subsecretaria-Geral das Comunidades Brasileiras no Exterior tem norteado suas ações e posições em negociações sobre assuntos consulares e migratórios em determinadas premissas e percepções. Em primeiro lugar, no entendimento de que a migração deve deixar de constituir a face esquecida de globalização. (...) Em segundo, na percepção de que o poder soberano dos Estados não está acima dos direitos inalienáveis do ser humano, de sua dignidade, de sua integridade, do seu direito a ser tratado com respeito e sem discriminações em qualquer circunstância. (...) Quinto, em atuação firme para evitar a indesejada associação que em muitas instâncias se procura fazer entre migração e criminalidade, o que ofusca os efeitos positivos da migração como instrumento de interação e intercâmbio entre os povos (a que toda diplomacia deve almejar) e dá pretexto a instituição de controles e tratamentos que não se justificam a não ser em situações de comprovada excepcionalidade. Sexto, na convicção de que com a mesma firmeza se deve evitar equiparação de tratamento a pessoas em situação migratória irregular e pessoas que cometeram crimes, sem diferenciar indocumentados de criminosos. (...) Oitavo, a diplomacia brasileira sustenta invariavelmente em quaisquer foros migratórios que é necessário estimular e não dificultar a regularização migratória, eliminando entraves burocráticos para isso, criando incentivos à migração regular, e não à irregular, e valorizando as comunidades estrangeiras radicadas em qualquer país. Nono, considera que a regularização migratória e a eliminação de entraves à circulação de pessoas, atendidas preocupações razoáveis com segurança e prevenção da criminalidade, é um dos principais instrumentos da integração regional e, portanto, deve ser prioridade no Mercosul e na Unasul. Décimo, entende haver uma dívida migratória - geradora de obrigação de compensação migratória - dos países desenvolvidos aos países latino-americanos que absorveram durante séculos grandes contingentes de estrangeiros, sobretudo da Europa, mas não apenas desse continente, como caso do Brasil, onde a comunidade nikkey, por exemplo, é a maior do mundo fora do Japão." (MRE, 2012, p.97-98 - grifo nosso).
\end{abstract}

\title{
4.4. Multilateralismo e integração regional: moldando e disputando o internacional
}

Analisa-se aqui o elemento internacional da política migratória brasileira em arenas multilaterais e de integração regional. No que atine ao multilateralismo, é importante observar o posicionamento mais geral do Brasil na seara. Cervo identifica quatro fases do multilateralismo brasileiro, segundo seus distintos objetivos: (i) contribuição à construção do sistema internacional do pós-guerra (1944-1949); (ii) esforço de reforma da ordem internacional, (1960-1980); (iii) inserção no sistema 
internacional (1990-2002); (iv) estabelecer a reciprocidade entre estruturas hegemônicas e países emergentes, de 2003 ao presente (2008, p.94).

Em todas as fases, observa-se o intuito mais amplo de conjugar $o$ multilateralismo à preservação da autonomia nacional (CERVO, 2008; LIMA, 2005; MELLO, 2012). Para alcançá-lo, a estratégia percebida após 2003 foi a de apresentar-se como mediador entre as grandes potências e os demais atores do sistema, demandando constantemente o reconhecimento de direitos e protagonismo de ambos os polos em pé de igualdade.

Esta orientação mais geral é claramente identificada na mobilização da política migratória nas arenas multilaterais. Com efeito, durante o governo Lula da Silva, as migrações são frequentemente levantadas como argumento de reivindicação de igualdade e reciprocidade no sistema internacional. Tal postura se acentua depois da aprovação, em 2008, da Diretiva de Retorno da União Europeia ${ }^{282}$, estabelecendo regras mais rígidas de tratamento a imigrantes indocumentados; e dos desentendimentos diplomáticos com a Espanha motivados pela denegação de entrada a brasileiros (20082012). Como exemplo, pode-se colacionar os discursos do Presidente em sessão do Conselho de Direitos Humanos da ONU, em 2009, e do chanceler Celso Amorim em sessão do Conselho de Administração da OIT, no mesmo ano:

Essa crise traz um efeito perverso, sobretudo quando os imigrantes sobretudo os pobres africanos, latino-americanos, asiáticos - que transitam pelo mundo à procura de oportunidade de trabalho, começam a ser enxergados como responsáveis por ocupar um lugar das pessoas filhas dos países. Como disse em meu documento, no Brasil nós acabamos de legalizar centenas de milhares de imigrantes que viviam ilegalmente no País, para dar uma resposta, para dar um sinal aos preconceituosos, àqueles que imediatamente querem encontrar os responsáveis pela sua própria desgraça, pelo seu desemprego. E não são os imigrantes os responsáveis pela crise, não são os pobres do mundo [os] responsáveis pela crise. Os responsáveis pela crise são os mesmos que durante séculos sabiam como ensinar a administrar os Estados. Sabiam ter ingerência nos Estados pobres da América Latina e da África. E esses mesmos senhores, que sabiam de tudo há algum tempo, hoje não sabem mais nada (SILVA, 2009, p.132 - grifo nosso).

O preconceito contra trabalhadores migrantes tornou-se também especialmente preocupante. Não raro, está incrustado em legislações nacionais e em políticas governamentais. A Alta Comissária para os Direitos Humanos tem condenado com veemência essas políticas, que, em suas próprias palavras, tratam o migrante como "lixo tóxico". Isso é o maior dos

\footnotetext{
${ }^{282}$ Em nota à imprensa sobre a diretiva, o MRE afirmou que: "O Brasil, país que deu acolhida a milhões de imigrantes e descendentes hoje harmoniosamente integrados na sociedade brasileira, lamenta uma decisão que contribui para criar percepção negativa da migração e vai no sentido contrário ao de uma desejada redução de entraves à livre circulação de pessoas e de um mais amplo e pleno convívio entre os povos”. (Resenha de Política Exterior do Brasil. Número 102, $1^{\circ}$ semestre de 2008 p.203)
} 


\begin{abstract}
absurdos que temos que enfrentar nos dias de hoje. Esses mesmos migrantes, que são chamados para perfazer as tarefas que as populações mais sofisticadas dos países ricos não querem perfazer, no momento da crise, são tratados como se fossem totalmente desprezíveis e como se devessem ser mandados de volta para seus países de origem. O Brasil, que é um país em desenvolvimento, aprovou recentemente uma legislação que permite a regularização e residência temporária em benefício de praticamente todos os imigrantes irregulares no País. Não é que o Brasil seja um país extraordinário, mas se um país em desenvolvimento pode fazer isso, por que países ricos não podem fazê-lo? (AMORIM, 2009, p.172 - grifo nosso).
\end{abstract}

Retrocedendo um pouco, pode-se apontar o ano de 2004 como um marco temporal no qual a imigração desponta como objeto levantado em arenas multilaterais pelo Brasil. O país deposita o Protocolo de Combate ao Tráfico de Migrantes nas Nações Unidas e participa da XIV Cúpula Ibero-Americana, da qual se origina Comunicado Especial sobre Direitos das Populações Migrantes. Também em 2004 o Ministro das Relações Exteriores Celso Amorim apresentou solicitação de ingresso do Brasil na Organização Internacional de Migrações. A adesão havia sido recomendada pelo CNIg em 2003.

Uma característica deste período inicial é a relevância assumida pelo problema das remessas: em 2004, dados divulgados pelo Banco Interamericano de Desenvolvimento revelaram que cerca de U\$5,6 bilhões havia entrado no Brasil naquele ano, provenientes de remessas de migrantes nos Estados Unidos, Japão e Europa. O Banco Central brasileiro constatou, porém, que apenas metade desse valor havia sido registrado formalmente, o que concluía dever-se principalmente à dificuldade de acesso ao sistema bancário e ao alto valor das taxas cobradas para o envio (OIM, 2009). Nesse contexto, em seu discurso na sessão de abertura da Reunião de Alto Nível da Assembléia Geral das ONU em 14 de setembro de 2005, o presidente Luiz Inácio Lula da Silva propôs a redução do custo das remessas internacionais, para que as mesmas pudessem atuar como vetores de desenvolvimento. Nesse contexto, é o conceito de desenvolvimento que fornece o enquadramento à abordagem brasileira das migrações no âmbito multilateral.

Em 2005, o Presidente Lula participou da XV Cúpula Ibero-Americana ${ }^{283}$, a qual se consolidava, desde a edição anterior, como instância de debate sobre política migratória - tanto que, em 2006, a XVI Cúpula teve por mote "Migrações e Desenvolvimento" e convocou a realização do Foro Iberoamericano sobre Migração e

\footnotetext{
${ }^{283}$ A Cúpula reúne chefes de Estado e de governo de países europeus e americanos de língua espanhola e portuguesa, e tem na Reunião de Ministros das Relações Exteriores a sua segunda instância mais importante.
} 
Desenvolvimento $^{284}$. A orientação da Cúpula pode ser verificada na declaração emitida por ocasião da reunião de 2005:

Declaração de Salamanca. O sucesso na gestão deste fenómeno complexo encontra-se vinculado à nossa capacidade de conceber um quadro iberoamericano de migrações, baseado na canalização ordenada e na regularização inteligente dos fluxos migratórios, na cooperação contra os tráficos e o tráfico de pessoas, e, além do mais, na responsabilidade de cada país em conceber políticas públicas a este respeito. Considerando o anterior comprometemo-nos a: a. coordenar políticas comuns para a canalização e o tratamento ordenado dos fluxos migratórios; b. desenvolver, com o apoio da sociedade civil, um programa de ações públicas que promovam o respeito pelos direitos humanos dos migrantes e das suas famílias, a sua integração, e o respeito pelos direitos nos países de destino; c. promover o valor da diversidade e o respeito pela dignidade humana, no âmbito do Estado de Direito, como elementos essenciais do tratamento dos emigrantes, e erradicar qualquer modalidade de discriminação em seu contra; d. promover experiências de desenvolvimento que vinculem os imigrantes e as suas famílias aos esforços, para potenciar o desenvolvimento nas suas áreas de origem; e. desenvolver políticas conjuntas entre países emissores, receptores e de trânsito que favoreçam e facilitem também processos temporários de migração laboral, com estímulos adequados de promoção, capacitação e poupança, para o seu retorno em melhores condições (Resenha de Pol. Ext. Brasil, a. 32, n. $97,2^{\circ}$ semestre 2005, p.106 - grifo nosso).

Por ocasião do Primeiro Diálogo de Alto Nível sobre Migrações Internacionais e

Desenvolvimento, em setembro de 2006, na Assembleia Geral da ONU, o então

Secretário Executivo do Ministério da Justiça, Luiz Paulo Barreto, proferiu o seguinte discurso pela delegação brasileira:

(...) O que se vê contemporaneamente, contudo, é um acentuado despreparo de governos, mídia e sociedade no tratamento do tema. Leis, políticas e estratégias de controle são adotadas com intensidade na busca do que se vem denominando "governabilidade dos fluxos migratórios". Tenta-se estabelecer controle sobre um fenômeno que na história mostrou-se natural do ser humano, que migra em busca de novas oportunidades. (...) Regras restritivas de imigração não têm sido eficazes para conter esses fluxos migratórios. (...). O resultado não se mostra satisfatório. Pelo contrário, aumenta a cada dia a ocorrência de violações de direitos humanos dos imigrantes, constrangimentos, discriminações, encarceramentos, punições e, ainda assim, as migrações seguem ocorrendo em ritmo ascendente. (...)

Nenhum país está livre de responder perante a comunidade internacional por essas violações. Há uma consolidada transnacionalidade dos Direitos Humanos. Não se pode admitir, ainda que sob o manto da soberania, a vinculação das migrações ao Direito Penal, as deportações em massa, o tratamento discriminatório, a desoneração na proteção internacional aos refugiados, o tratamento dos imigrantes como pessoas não dotadas de direitos.

O Brasil, que neste semestre exerce a presidência Pró-Tempore do Mercosul, chama atenção para o documento que está disponível às delegações interessadas que detalha o significativo progresso do bloco regional quanto à simplificação da circulação e regularização de pessoas, ao mesmo tempo em que promove ações comuns de prevenção e combate ao tráfico de pessoas e imigrantes (...) (BARRETO, 2007, p. 29-33).

\footnotetext{
${ }^{284}$ Realizado em 2008 (Equador) e 2010 (El Salvador).
} 
Ressalte-se que o discurso de Luiz Paulo Barreto se contrapõe à Declaração de Salamanca que, embora tangencie os direitos humanos, reforça seu objetivo de “canalização ordenada e na regularização inteligente dos fluxos migratórios". O Secretário Executivo do MJ afirmou a perspectiva de direitos humanos na arena multilateral de maneira que não se observara nos posicionamentos anteriores, mais voltados a considerações sobre desenvolvimento.

Sublinhe-se, que nas instâncias multilaterais, a participação de representantes de Ministérios distintos do Itamaraty se dá a convite do último ou das próprias organizações internacionais. A interação entre a Divisão de Temas Sociais e outras instituições federais ocorre com frequência, como explica Carlos Cuenca, então chefe da divisão:

Temos muito contato com outros Ministérios. Isso é importante, porque
falamos de um trabalho mais geral aqui da DTS, cuidamos de uma
quantidade grande de temas. TRATAMOS de saúde, trabalho, segurança
alimentar, nutricional, alguns dos chamados grupos vulneráveis
(mulheres, pessoas com deficiência, idosos, juventude), desenvolvimento
social, desenvolvimento urbano, população E desenvolvimento. Então, é
um conjunto bem amplo, que no fundo, todos tem em comum o fato de
que o Itamaraty não é o ministério-fim desses temas. Cada um desses
temas tem algum Ministério na Esplanada que é o responsável
nacionalmente pelas políticas públicas. Então, as nossas posições tem
que ser definidas em articulação com esses outros ministérios. NAO
PODEMOS NESSES TEMAS definir nossas posições sozinhos
(Entrevista, 09/09/2016).

A participação do então Secretário Nacional de Justiça no Diálogo de Alto Nível não ocorreu imune a disputas: observa-se na ata do CNIg de 20 de junho de 2006 que, ao ser mencionada a futura realização do Diálogo de Alto Nível das Nações Unidas, o Presidente do Conselho, Nilton Freitas, observou que os Ministérios operacionais da área de migrações (MTE, MJ e MRE) “deveriam se organizar de forma a possibilitar, antecipadamente a esses encontros internacionais, a oitiva do Conselho Nacional de Imigração sobre as questões migratórias" (CNIg, 20/06/2006, p.2). Questionado sobre se os Conselheiros poderiam compor a delegação brasileira, o representante do MRE, Conselheiro Ralph Peter Henderson sugeriu que o CNIg apresentasse formalmente ao MRE esse questionamento. O CNIg aprovou, então, o encaminhamento de consulta ao MRE, na qual demandou "seja informado com a antecedência devida, sobre foros e processos internacionais de debate sobre o tema "migrações", assim como em relação a todas as atividades promovidas pela OIM e outras organizações internacionais, quando o assunto estiver relacionado com migrações" (CNIg, 20/06/2006, p.3). Em resposta, a Ministra Ana Cabral, Diretora do Departamento de Direitos Humanos e Temas Sociais 
do MRE, compareceu à reunião seguinte do Conselho, esclarecendo que seus membros poderiam compor, se assim o desejassem, delegação brasileira para o evento (CNIg, 10/08/2006).

Anos depois, novamente um membro do MJ chefiou a delegação brasileira junto ao Segundo Diálogo de Alto Nível sobre Migrações Internacionais e Desenvolvimento, ocorrido nos dias 3 e 4 de outubro de 2013 durante a 68 ${ }^{a}$ Sessão da Assembleia Geral das Nações Unidas. Nessa ocasião, o Secretário Nacional de Justiça Paulo Abrão publicizou pela primeira vez o discurso dos três desafios que marcaria o posicionamento do MJ sobre a temática migratória no decorrer de sua gestão:

(...)4. We are witnessing today a period of reflection on the Brazilian State's attitude towards migration. As to generate development conditions, migration policies should be based on a concept of development grounded in the consideration of three concrete and current challenges.

5. The first challenge covers upgrading national immigration laws, the internalization of international treaties and agreements, harmonization of administrative provisions in order to establish a political and legal culture of nondiscrimination, protection of human rights and violations prevention.

6. The second challenge is linked to the establishment of means of coordination between migration institutions and between levels of Government in a country with continental proportions: federal, state and local. It also covers the definition of a field of institutional action, focused on the integration of migrants in all its dimensions: economic, social, cultural, productive. (...)

7. The third is the challenge of establishing a commitment engage in social listening, social participation and social supervision of the main aspects of processes in the policy cycle of programs and initiatives for migrant groups and populations living in Brazil. It is the natural extension of the Brazilian perspective of policy making based on transparency, openness and social collaboration. This also means reversing the paradigm of migration management as population control, and emphasizing citizen participation and the voice and autonomy of the person who migrates. (...)

10. In our view, the human rights of migrants and the fulfillment of conditions of effective integration are pivotal to the promotion of national policies, regional cooperation strategies and to the adherence to international mechanisms. The human rights of migrants are a condition of possibility for global development. In this sense, the Brazilian delegation reinforces the commitment to strive for the still pending internalization of the International Convention on the Protection of the Rights of All Migrant Workers and Members of their Families ${ }^{285}$.

A afirmação de Paulo Abrão na Assembleia Geral da ONU corroborava o posicionamento de outros setores do Estado brasileiro sobre a Convenção de Proteção dos Direitos de Todos Trabalhadores Migrantes e suas Famílias: ela também tivera sua assinatura recomendada por resolução do CNIg n $^{\circ} 10$, em 03 de dezembro de 2008, e pelo relatório final da CMPI da Emigração (2005). Ressalte-se que a adesão ao

\footnotetext{
${ }^{285}$ http://www.justica.gov.br/noticias/integra-do-discurso-do-secretario-nacional-de-justica-paulo-abraono-segundo-dialogo-de-alto-nivel-das-organizacoes-das-nacoes-unidas-onu-nesta-quinta-feira-03-10
} 
instrumento internacional era, além disso, levantada com frequência como recomendação em diversas arenas regionais das quais o Brasil participa (Conferência Sul-Americana de Migrações, Cúpula IberoAmericana).

O Brasil, embora tenha participado da sessão da Assembleia Geral da ONU que aprovou por consenso a Convenção (Resolução 45/158, de 18 de dezembro de 1990), todavia não a assinou. O Ministério das Relações Exteriores, cuja praxe usual é a de assinar os atos internacionais e, em seguida, remetê-los ao Poder Legislativo para aprovação, optou por encaminhar a Convenção ao Congresso Nacional previamente à sua assinatura, buscando desta maneira um aval legislativo para a adesão ao instrumento (CAMINO; FONTANIVE, 2014).

Nesses termos, a Mensagem $n^{\circ} 696$ do Poder Executivo foi apresentada ao Congresso Nacional em 15 de dezembro de 2010. A tramitação foi dificultada pelo fato da matéria ter sido distribuída a mais de três comissões de mérito na Câmara dos Deputados, o que, por força do Regimento Interno da Casa, exige a criação de Comissão Especial sobre o objeto. Desta forma, a matéria aguardou por instalação de Comissão Especial até junho de 2015, após o que não houve qualquer deliberação.

No que concerne à OIM, após Resolução Recomendada do CNIg nº 04/2003, solicitação de ingresso foi apresentada à organização pelo Ministro Celso Amorim em 2004, tendo sido acatada na sua $88^{\text {a }}$ Reunião por meio da Resolução no 1.105 , de 30 de novembro de 2004. Ao encaminhar tal Resolução para aprovação do Congresso Nacional, exposição de motivos interministerial (MRE/ MJ/ MTE/ MEC) argumentou que o ingresso do Brasil na OIM

(...) possibilita o apoio daquela organização no estudo do fenômeno migratório recorrente no Brasil, tanto em termos de crescente imigração regional aos nossos centros urbanos, além de melhor compreensão dos processos de livre circulação de pessoas no âmbito do Mercosul (Exposição de Motivos Interministerial $\mathrm{n}^{\circ}$ 00073/MRE/MJ/MEC/MTE, Mensagem do Executivo nº750, 02/10/2008 ${ }^{286}$ ).

Observe-se que a Resolução da OIM definia a contribuição do Brasil ao orçamento administrativo da organização como $1,702 \%$ do mesmo, o que equivale a aproximadamente US\$ 466.770,00 anuais. Após longas negociações, entendimentos havidos entre MRE, MJ e MTE atribuíram a este último o pagamento da quantia anual. Assim, a previsão orçamentária para as contribuições do Brasil à Organização está na

\footnotetext{
${ }^{286}$ Disponível em:

http://www.camara.gov.br/proposicoesWeb/prop_mostrarintegra?codteor $=601394 \&$ filename $=$ Tramitacao -MSC+750/2008
} 
Lei Orçamentária Anual de $2013^{287}$ como a Ação Orçamentária 00E8, do Ministério do Trabalho e Emprego, com a rubrica "Contribuição à Organização Internacional para as Migrações (OIM) - MTE", nos montante de R\$ 776.177,00²88. Esta regulamentação diferencia a OIM de organizações do sistema ONU, que costumam ter suas contribuições vinculadas ao MRE.

O ingresso do Brasil na OIM, assim como a Constituição da organização, foram aprovados pelo Decreto Legislativo no 302, de 24 de outubro de 2011, e promulgados pelo Decreto $n^{\circ} 8.101$ de 06 de setembro de 2013. Na mesma data da aprovação do Decreto, o Vice-presidente Michel Temer encaminhou para o Congresso Mensagem número 386/2013, solicitando aprovação do Acordo sobre Posição Legal, Privilégios e Imunidades da OIM no Brasil, condição para a organização estabelecer escritório no país. O Acordo fora firmado em 13 de abril de 2010 pelo Embaixador Oto Agripino Maia, então Subsecretário-Geral das Comunidades Brasileiras no Exterior, e pelo Representante da OIM no Cone Sul.

Em linhas gerais, o Acordo autoriza a OIM a abrir escritório no Brasil e ter os mesmos privilégios e imunidades concedidos às agências especializadas da ONU instaladas no país, dentre os quais a isenção tributária para ativos, rendas e outros bens da organização. Saliente-se que, mesmo antes da promulgação do Acordo, a OIM iniciou trabalho de colaboração com órgãos federais, mantendo inclusive equipe de consultores no Brasil nas instalações do DEEST/MJ no quadro do Projeto PNUD "Promoção de Direitos no Contexto da Política Migratória Brasileira".

O Acordo tramitou na Câmara dos Deputados como Projeto de Decreto Legislativo $n^{\circ} 1.295$ de 2013 e foi aprovado como Decreto Legislativo $n^{\circ} 82 / 2015$, promulgado pelo Decreto $\mathrm{n}^{\circ}$ 8.503/2015. Durante esse processo, manifestações em contrário chegaram a levar à sua retirada de pauta, como se pode verificar no depoimento do então líder do partido DEM, deputado Ronaldo Caiado:

Sr. Presidente, a posição do Democrata será contrária, até porque a solicitação que fizemos não foi esclarecedora, principalmente no art. $3^{\circ}$, item 4: "essa estrutura poderá transferir seus fundos, ouro ou moeda de um país para outro, ou, dentro do país-sede, para qualquer indivíduo ou entidade. $\mathrm{Ou}$ "no país-sede, possuir e usar fundos ou instrumentos negociáveis de qualquer tipo, e manter e operar contas em qualquer moeda, assim como converter qualquer moeda que possua". Sr. Presidente, a esses pontos aí, diante deste momento em que estamos vivendo, com todos esses precedentes que foram criados, principalmente com essa operação cubana, nós, realmente, vamos

\footnotetext{
${ }^{287}$ Programa de Operações Especiais (Volume II, Item XIV) da Lei no 12.798/2013.

${ }^{288}$ Esse montante se repete em 2014 e chega a R\$ 1.753.073 em 2015.
} 
nos colocar contrários e, caso a matéria seja pautada, entraremos em obstrução e solicitaremos a retirada da pauta (DCD, 14/02/2014, p.53).

Por seu turno, arenas de integração regional correspondem a uma versão do multilateralismo, na qual a cooperação entre os membros é aprofundada “(...) a fim de melhorar a capacidade de cada um deles para lidar com problemas que individualmente teriam maiores dificuldades de solucionar" (VIGEVANI; MARIANO, 1997, p.270). Os processos de integração sul-americanos, Mercosul e Unasul, constituíram-se inclusive como estratégias de inserção internacional de seus países-membros, correspondendo destarte a instâncias multilaterais restritas com aspirações relacionadas a instâncias multilaterais mais amplas.

A consolidação do propósito da integração regional trouxe maior complexidade à relação entre política externa brasileira e migração, dada a facilitação da livre circulação de pessoas como caminho para o aprofundamento do processo de integração regional. À migração corresponde um papel importante na integração comercial, com o movimento de capital, tecnologia e, evidentemente, força de trabalho que promove. Nesse sentido, Carlos Lupi, no exercício do cargo de Ministro do Trabalho brasileiro, afirmou:

\footnotetext{
Mais do que uma área de livre comércio, a ambição dos países que se lançam na busca da integração regional é a criação de um espaço onde o desenvolvimento econômico e social possa ocorrer para todos os sócios. Ou seja, a criação de uma comunidade de nações.

O MERCOSUL é muito mais do que a corrente de comércio que entrelaça seus constituintes. São as pessoas, no seu ir e vir, que tornam este projeto uma realidade. O Tratado de Assunção, em 1991, já traduzia este anseio ao estabelecer a idéia de uma futura área de livre circulação de pessoas (MTE, 2008, p.11)
}

Não obstante a livre circulação de pessoas ser meta desde o início do Mercosul (1991), o Acordo sobre Residência para Nacionais dos Estados Partes do Mercado Comum do Sul, aliados a Chile e Bolívia, só foi assinado em 2002, e sua entrada em vigor ocorreu apenas em 2009 - tendo sido posteriormente ratificado também por Peru, Equador e Colômbia. O Acordo confere a todos os migrantes nacionais de um EstadoParte residentes no território de outro Estado-Parte a igualdade de direitos e a simplificação e facilitação do pedido de residência, inclusive permitindo ao interessado requerê-la em seu país de origem ou de destino, independente de estar em situação irregular neste último.

Esta é uma das várias características que diferenciam a regulação da imigração mercosulina do regime geral brasileiro nos termos do Estatuto do Estrangeiro. De modo 
amplo, pode-se afirmar que o Acordo Mercosul garante o direito à residência aos nacionais mercosulinos no território do bloco, havendo apenas um controle documental da nacionalidade e de antecedentes judiciais e criminais. Em contrapartida, a regulamentação da Lei $n^{\circ}$ 6.815/1980 é a de concessão de residência contingenciada ao enquadramento do indivíduo a uma série de condições derivadas notadamente do objetivo de proteção do trabalhador nacional.

O Acordo, assinado em 2002 pelos chefes de Estado em Decisão do Conselho Mercado Comum $n^{\circ} 28$, foi negociado no âmbito da Reunião de Ministros do Interior (RMI) do bloco. As RMIs foram criadas após Decisão CMC n07/96, estabelecendo a necessidade de elaboração de mecanismos comuns para cooperação áreas de competência dos Ministérios do Interior ou equivalentes, tendo a primeira reunião se dado em 30 de maio de 1997. O exame das atas das RMI $^{289}$ permite observar que, já em 1998, a temática migratória foi inserida no escopo de sua atividade, nesse momento sob a ótica do controle (Ata RMI no 2/98). Verifica-se, ainda, que o Acordo de Residência começa a ser negociado concomitantemente ao Acordo Regional sobre Tráfico Ilícito de Imigrantes, cujo anteprojeto já se encontrava em estágio de discussão mais avançado.

Em reunião de março de 2002, a Argentina expõe plano de trabalho para concessão de tratamento mais favorável aos cidadãos do Mercosul em matéria de regularização migratória, que veio a ser discutido nas reuniões seguintes (abril, maio, e agosto), junto a debates sobre trânsito vicinal fronteiriço; intercâmbio de informações e estudos sobre fluxos migratórios. Já em reunião de outubro de 2002, a Argentina apresenta anteprojeto de Acordo sobre Residência Permanente para Nacionais do Mercosul e Estados Associados, aprovado com modificações na reunião seguinte, em novembro. Em dezembro de 2002, o Conselho Mercado Comum ratifica a decisão.

Nota-se a prontidão no encaminhamento da proposta e a liderança assumida pela Argentina que, à época, discutia sua própria legislação migratória - Lei n 25.871/2004 (FARIA, 2015). O processo de internalização do acordo, contudo, não foi tão célere. No caso brasileiro, a tramitação no Legislativo levou à aprovação do Acordo sobre Residência para Nacionais dos Estados Partes do Mercosul por meio do Decreto Legislativo $n^{\circ}$ 210/2004, e do Acordo sobre Residência para Nacionais dos Estados

\footnotetext{
${ }^{289}$ Disponíveis em:

http://www.migraciones.gov.ar/foro_migratorio/portugues/pdf/memoria_institucional_n.pdf
} 
Partes do Mercosul, Bolívia e Chile pelo Decreto Legislativo $n^{\circ}$ 925/2005 290 . Argentina havia incorporado a normativa em 2004, Chile e Bolívia o fizeram em 2005, e o Uruguai em 2006.

Já o Paraguai se mostrava reticente em realizar a internalização, em razão especialmente da questão dos imigrantes brasileiros, que detinham a maior parcela das grandes propriedades rurais em território paraguaio. De acordo com a diplomata Maria Rita Faria (2015), entre 2007 e 2008, o contexto de hostilidade em relação a colonos brasileiros levou a SGEB a realizar missões in loco e a iniciar negociações bilaterais que resultaram na criação de Grupos de Trabalho Bilaterais Migratório e Fundiário. Na opinião de Faria, "os trabalhos no âmbito dos GTs, conjugados à evolução das negociações sobre Itaipu, contribuíram para a decisão do Paraguai de ratificar o Acordo de Residência em 2009” (2015, p.101). Já Paulo Illes (05/09/2016), presidente do CDHIC, narra a importância da sociedade civil na desconstrução do argumento, que vinha sendo sustentado pelo Paraguai, de que a adesão ao acordo implicaria em riscos à sua soberania ${ }^{291}$, e no convencimento do presidente Fernando Lugo. De todo modo, após a ratificação do Paraguai, o acordo entra em vigor em 2009 para todos os Estados signatários $^{292}$.

O Acordo de residência não emergiu isoladamente como único instrumento voltado à livre circulação de pessoas no bloco. O quadro 4.7 enumera outras normas que o precederam, sucederam ou complementaram, indicando o órgão de formulação e decisão e dados sobre a incorporação de cada uma delas nos países membros.

\footnotetext{
${ }^{290}$ Disponível em: http://www2.camara.leg.br/legin/fed/decleg/2005/decretolegislativo-925-15-setembro2005-538501-acordo-34332-pl.html. Acesso em: 16 jun 2016.

${ }^{291}$ De acordo com Paulo Illes (Entrevista, 05/09/2016), argumentou-se que, dada a já existência de dispositivo no direito paraguaio que concede a permanência a partir da detenção de grandes propriedades de terra, o Acordo de Residência do Mercosul não respaldaria os grandes latifundiários, mas sim aqueles que não conseguem regularizar-se via propriedade.

292 Isso não garantiu, entretanto, a eficácia de sua implementação. Camila Baraldi (Entrevista, 18/06/2016) narra que, mais de seis meses após a entrada em vigência do Acordo sobre Residência para o Peru, cidadãos peruanos vinham tendo seus pedidos de residência rejeitados pela Polícia Federal, a qual alegava não haver recebido qualquer orientação nesse sentido por parte do Ministério da Justiça.
} 
Quadro 4.7: Normas do Mercosul afetas à temática migratória

\begin{tabular}{|c|c|c|c|}
\hline Decisão & $\begin{array}{l}\text { Órgão de } \\
\text { formulação }\end{array}$ & Órgão decisório & Incorporação \\
\hline $\begin{array}{l}\text { Entendimento sobre } \\
\text { Trânsito Vicinal } \\
\text { Fronteiriço entre os } \\
\text { Estados Partes do } \\
\text { MERCOSUL }\end{array}$ & $\begin{array}{l}\text { Acordo RMI } \\
\text { n}^{\circ} 17 / 99\end{array}$ & Decisão CMC nº 18/99 & Não necessita. \\
\hline $\begin{array}{l}\text { Entendimento sobre } \\
\text { Trânsito Vicinal } \\
\text { Fronteiriço entre os } \\
\text { Estados Partes do } \\
\text { MERCOSUL, Bolívia e } \\
\text { Chile }\end{array}$ & $\begin{array}{l}\text { Acordo RMI no } \\
18 / 99\end{array}$ & Decisão CMC nº 19/99 & Não necessita. \\
\hline $\begin{array}{l}\text { Acordo de Isenção de } \\
\text { Tradução de Documentos } \\
\text { Administrativos para } \\
\text { Efeitos de Imigração entre } \\
\text { os Estados Partes do } \\
\text { MERCOSUL }\end{array}$ & $\begin{array}{l}\text { Acordo RMI n } \\
21 / 00\end{array}$ & Decisão CMC N $44 / 00$ & $\begin{array}{l}\text { Decreto } \mathrm{n}^{\circ} 5.851, \mathrm{de} \\
18 / 07 / 2006\end{array}$ \\
\hline $\begin{array}{l}\text { Instalação de Canais } \\
\text { Privilegiados de Entrada } \\
\text { em Aeroportos para } \\
\text { Cidadãos do } \\
\text { MERCOSUL, da } \\
\text { República da Bolívia e da } \\
\text { República do Chile }\end{array}$ & Acordo RMI 24/00 & Decisão CMC N $47 / 00$ & Não necessita. \\
\hline $\begin{array}{l}\text { Acordo de Isenção de } \\
\text { Tradução de Documentos } \\
\text { Administrativos para } \\
\text { Efeitos de Imigração entre } \\
\text { os Estados Partes do } \\
\text { MERCOSUL, a } \\
\text { República da Bolívia e a } \\
\text { República do Chile }\end{array}$ & Acordo RMI 22/00 & Decisão CMC No $45 / 00$ & $\begin{array}{l}\text { Decreto } n^{\circ} 5.852, \text { de } \\
18 / 07 / 2006\end{array}$ \\
\hline $\begin{array}{l}\text { Acordo sobre Isenção de } \\
\text { Vistos entre os Estados } \\
\text { Partes do MERCOSUL }\end{array}$ & Acordo RMI 25/00 & $\begin{array}{l}\text { Decisão CMC No } 48 / 00 \\
\text { - Não vigente porque } \\
\text { pendente de ratificações }\end{array}$ & $\begin{array}{l}\text { Decreto Legislativo } \mathrm{n}^{\circ} \\
971,17 / 12 / 2003\end{array}$ \\
\hline $\begin{array}{l}\text { Acordo sobre Residência } \\
\text { para Nacionais dos } \\
\text { Estados Parte do } \\
\text { MERCOSUL }\end{array}$ & Acordo RMI 13/02 & $\begin{array}{l}\text { Decisão CMC No } 28 / 02 \\
\text { - Vigente desde } 28 \text { de } \\
\text { julho de 2009, após } \\
\text { ratificação do Paraguai }\end{array}$ & $\begin{array}{l}\text { Decreto }^{\circ} 6.964 / 2009 \\
\text { Decreto Legislativo } n^{\circ} \\
210 / 2004\end{array}$ \\
\hline $\begin{array}{l}\text { Acordo sobre Residência } \\
\text { para Nacionais dos } \\
\text { Estados Parte do } \\
\text { MERCOSUL, Bolívia e } \\
\text { Chile }\end{array}$ & Acordo RMI 14/02 & $\begin{array}{l}\text { Decisão CMC no 28/02 } \\
\text { Vigente desde } 28 \text { de } \\
\text { julho de 2009, após } \\
\text { ratificação do Paraguai. } \\
\text { Adesão do Peru: } \\
\text { Decisão CMC n } \\
\text { 04/2011 } \\
\text { Adesão do Equador: } \\
\text { Decisão CMC n } \\
\text { 21/2011 } \\
\text { Adesão da Colômbia: } \\
\text { Decisão CMC no } \\
\text { 20/2012 }\end{array}$ & $\begin{array}{l}{\text { Decreto } \mathrm{n}^{\circ} 6.975 / 2009} \\
\text { Decreto Legislativo } \mathrm{n}^{\circ} \\
925 / 2005\end{array}$ \\
\hline
\end{tabular}




\begin{tabular}{|c|c|c|c|}
\hline $\begin{array}{l}\text { Acordo de Regularização } \\
\text { Migratória Interna dos } \\
\text { Cidadãos do Mercosul, } \\
\text { Bolívia e Chile }\end{array}$ & $\mathrm{CMC}$ & $\begin{array}{l}\text { Decisão CMC n } \text { n }^{\circ} 28 / 02 \\
\text { - Não vigente, pendente } \\
\text { de incorporação da } \\
\text { Argentina }\end{array}$ & $\begin{array}{l}\text { Decretos Legislativos } \mathrm{n}^{\circ} \\
\text { 923/2005 e 928/2005 }\end{array}$ \\
\hline $\begin{array}{l}\text { Acordo para a Criação do } \\
\text { "Visto MERCOSUL" }\end{array}$ & $\mathrm{CMC}$ & Decisão CMC N $16 / 03$ & $\begin{array}{l}\text { Decreto Legislativo }{ }^{\circ} \\
346 / 2008\end{array}$ \\
\hline $\begin{array}{l}\text { Acordo para Facilitação } \\
\text { das Atividades } \\
\text { Empresariais no Mercosul }\end{array}$ & CMC & Decisão CMC nº 32/04 & Não necessita. \\
\hline $\begin{array}{l}\text { Projeto de Acordos contra } \\
\text { o Tráfico Ilícito de } \\
\text { Migrantes entre o } \\
\text { MERCOSUL, Bolívia e } \\
\text { Chile }\end{array}$ & $\begin{array}{l}\text { Acordo RMI n } \\
10 / 03\end{array}$ & $\mathrm{CMC} \mathrm{N}^{\circ} 37 / 04$ & Não necessita. \\
\hline $\begin{array}{l}\text { Plano de Ação do } \\
\text { MERCOSUL para a Luta } \\
\text { contra o Tráfico de } \\
\text { Pessoas entre os Estados } \\
\text { Parte do Mercosul e } \\
\text { Estados Associados }\end{array}$ & $\begin{array}{l}\text { Acordo RMI No } \\
01 / 06\end{array}$ & Não possui. & $\begin{array}{l}\text { Portaria } \mathrm{MJ} \mathrm{n}^{\circ} 2.167 \text {, de } 7 \\
\text { de dezembro de } 2006 \text {. }\end{array}$ \\
\hline $\begin{array}{l}\text { Plano de Ação do } \\
\text { Estatuto de Cidadania do } \\
\text { Mercosul }\end{array}$ & $\mathrm{CMC}$ & $\begin{array}{l}\text { Decisão CMC } \\
\text { n}^{\circ} 64 / 2010\end{array}$ & Não necessita. \\
\hline
\end{tabular}

Fonte: Elaboração própria, a partir de dados de dados do site do Mercosul http://www.mercosur.int/innovaportal/v/526/11/innova.front/decisiones, cumulados com os dados de incorporação do site do MRE paraguaio

http://www.mre.gov.py/v1/Adjuntos/mercosur/mercosurprincipal.htm.

Ressalte-se que, enquanto aguardava a entrada em vigência do Acordo de Residência, o Brasil firmou entendimentos bilaterais com outros Estados-partes no desígnio de permitir sua implementação: Portaria Interministerial de 28 de agosto de 2006 deu execução a acordo, por troca de notas, entre o Brasil e a Argentina ${ }^{293}$; e Acordo Operacional entre o DEEST do Brasil e o Departamento Nacional de Migração do Ministério do Interior da República Oriental do Uruguai foi assinado em 23 de junho de 2006. Ambos foram capitaneados pelo Ministério da Justiça. Já o Acordo de Regularização Migratória assinado em 15 de agosto de $2005^{294}$, entre os Governos da República da Bolívia e da República Federativa do Brasil, com vigência prorrogada em 2006 e 2007, o qual não operacionalizava o Acordo de Residência do Mercosul mas criava mecanismo de regularização de imigrantes dos nacionais dos respectivos países, foi conduzido pelo Ministério das Relações Exteriores, após Resolução Recomendada

\footnotetext{
${ }^{293}$ Há, ainda, acordo Brasil-Argentina para concessão de permanência a portadores de vistos temporários ou a turistas, promulgado pelo Decreto ${ }^{\circ} 6.736 / 2009$ e regulamentado pela Portaria SNJ no 17/2011.

${ }^{294}$ Disponível em: http://dai-mre.serpro.gov.br/atos-internacionais/bilaterais/2005/b_130/. Acesso em: 20 mar 2017.
} 
$\mathrm{n}^{\text {o }}$ 06, de 07 de junho de 2005, do CNIg ${ }^{295}$. À época, a proximidade entre os presidentes Luiz Inácio Lula da Silva e Evo Morales favoreceu a apropriação política do tema.

Dois espaços dentro da estrutura mercosulina atuam com maior intensidade na questão da mobilidade de pessoas: o Subgrupo de Trabalho ${ }^{\circ}{ }^{10}$, de Assuntos Laborais, Emprego e Previdência Social, coordenado pelos Ministérios do Trabalho; e a Reunião de Ministros de Interior, em cujo âmbito se criou o Foro Especializado Migratório (FEM).

A análise das atas das RMI demonstra que, para além do intercâmbio de informações em matéria de sua competência e da coordenação de posições comuns, trata-se de espaço importante de formulação da política migratória: além dos acordos que são submetidos à deliberação do $\mathrm{CMC}$, seus integrantes operacionalizam diretamente diversos aspectos dessa política, no esforço de harmonização de regulamentações e procedimentos nacionais. Por vezes, esse processo implica no comprometimento de membros em realizar a articulação doméstica com os fins concordados, especialmente os diálogos com as respectivas chancelarias ${ }^{296}$.

O Foro Especializado Migratório (FEM) é um espaço, dentro do âmbito das RMIs, destinado ao estudo do impacto dos fluxos migratórios, à análise e ao desenvolvimento de propostas relacionadas à política migratória nos países do bloco (FEM, 2017). Sua criação data de 21 de novembro de 2003 por ocasião da XIV RMI. Em 2004, o FEM publicou a Declaração de Santiago sobre Princípios Migratórios, delineando as diretrizes da política migratória do bloco. Dentre elas, encontram-se:

I. Reconocer el importante aporte de los migrantes en la formación de nuestros Estados;

II. Fortalecer las iniciativas en curso para facilitar y regularizar los flujos migratorios entre los Países de la región;

III. Asegurar a los migrantes el respeto a los derechos humanos y todos aquellos reconocidos por las Convenciones Internacionales vigentes en la materia; $(\ldots)$

V. Requerir a los Países extra-bloque otorgar un tratamiento justo y humanitario a los inmigrantes de nuestra región, en correspondencia con el trato brindado a sus nacionales en nuestros territorios; (...)

VII. Reconocer el derecho de los Estados de ejercer el adecuado control de sus fronteras, pero sin tratar la irregularidad migratoria como hecho punible de derecho penal (MERCOSUR, 17/05/2004).

\footnotetext{
${ }^{295}$ Disponível em: http://acesso.mte.gov.br/trab_estrang/resolucao-recomendada-n-06-de-07-062005.htm. Acesso em: 20 mar 2017.

${ }^{296}$ Atas RMI 27/01/1998; 16/02/1998; 04/04/2000; 22/1 1/2004; 16/03/2005; 05/10/2005; 15/04/2009.
} 
Ressalte-se que as reuniões do FEM são frequentadas não apenas por representantes do DEEST/SNJ do Ministério da Justiça, mas também da DIM/SGEB do Ministério das Relações Exteriores.

O SGT-10 "Assuntos Trabalhistas, Emprego e Seguridade Social" é órgão de apoio técnico ao Grupo Mercado Comum (GCM) a quem compete analisar os temas laborais e previdenciários, sendo integrado, em sua etapa decisória, por representantes governamentais, e nas etapas preparatórias, por convidados de setores de empregadores e trabalhadores. Suas origens podem ser traçadas ao SGT-11, "Emprego e Migrações Laborais", instituído em 1991 com o objetivo explícito de identificar as medidas necessárias para alcançar a livre circulação de trabalhadores. Seu plano de trabalho estimava para 31 de dezembro de 1994 uma proposta de medidas para implementar a livre circulação na região (VICHICH, 2005). A meta não foi alcançada, e já em 1996 o subgrupo de trabalho foi substituído pelo SGT-10, que não continha a livre circulação de pessoas como objetivo declarado. Nesse contexto, o tema da migração laboral perdeu relevância e não foi aprofundado na primeira década do bloco, à exceção do Acordo de Multilateral de Previdência Social, assinado em 1997 e em vigor desde 2005.

Após a aprovação do Acordo de Residência, o Programa de Trabalho do Mercosul 2004-2006 considerou prioritário avançar nas questões relacionadas à livre circulação de mão de obra e promoção de direitos de trabalhadores. Em seu contexto, a Decisão CMC n 32/04 aprovou acordo para facilitar as atividades empresariais, no qual previu-se que "os empresários de nacionalidade dos Estados partes poderão se estabelecer no território de qualquer outro Estado parte para o exercício de suas atividades, sem outras restrições que aquelas emanadas das disposições que rejam as atividades exercidas por empresarios do Estado receptor".

Este pode ser considerado um momento de retomada do papel do SGT-10 na temática migratória comunitária. Em junho de 2008, foi realizada em Buenos Aires a I Oficina sobre Livre Circulação de Trabalhadores e Integração Fronteiriça no Mercosul, da qual participaram representantes dos governos, OIT, setores empresariais e sindicatos. Dentre as propostas aprovadas na oficina, encontram-se:

- Debe darse mayor visibilidad de las normas que indican "como trabajar en el MERCOSUR";

- Avanzar en el Plan de Acción Regional;

- Homogenizar las normas de acceso al empleo;

- Examinar las categorías migratorias contempladas en el Acuerdo de Residencia a la luz de las necesidades laborales; 
- Mayor participación de los Ministerios de Trabajo en los temas vinculados con la circulación de los trabajadores en particular en el Foro Migratorio;

- Tomar conocimiento de todas las normas que hacen a la practica de la circulación de trabajadores en el MERCOSUR;

- Organizar un sistema de información (CNIg, 2008, p.173).

A Oficina teve forte liderança do MTE brasileiro em sua organização. Com efeito, em prefácio de publicação institucional de 2008, o Ministro do Trabalho brasileiro Carlos Lupi afirmara:

As migrações no MERCOSUL constituem, portanto, um fator de coesão, que verdadeiramente impulsiona a integração entre nossos povos.

Por esta razão é que tenho solicitado ao Conselho Nacional de Imigração que dê especial atenção a este tema, em conjunto com a Coordenação do MERCOSUL da nossa Assessoria Internacional (CNIg, 2008, p.11).

Conforme relatório da OIM (2012), em 2009 o Conselho de Mercado Comum e o Grupo Mercado Comum teriam instruído o SGT-10 e o FEM a buscarem uma maior coordenação e integração de suas atividades na temática da mobilidade regional. Ainda de acordo com o relatório, "cada estructura se maneja primodialmente en la órbita de sus ministerios de adscripción y muchas veces respondiendo a sus intereses corporativos" (OIM, 2012, p.101).

Em dezembro de 2010, o CMC aprovou Decisão no 64 contendo Plano de Ação para Conformação do Estatuto de Cidadania Mercosul. No intuito de concretizar direitos fundamentais e benefícios relacionados à livre circulação de pessoas, o Plano se estrutura em torno de três objetivos: (i) implementação de política de livre circulação de pessoas na região; (ii) igualdade de direitos e liberdades civis, sociais, culturais e econômicos para os nacionais dos Estados Partes do Mercosul; e (iii) igualdade de condições para acesso ao trabalho, saúde e educação. Já a Decisão CMC 12/2011 aprovou o Plano Estratégico de Ação Social do Mercosul (PEAS) elencando, dentre seus objetivos prioritários, "articular e implementar políticas públicas voltadas a promover o respeito aos direitos humanos e a plena integração dos migrantes e proteção aos refugiados".

O Mercosul se tornou não apenas uma instância de integração regional em que normas sobre a circulação de pessoas foram implementadas, mas também plataforma de ação conjunta dos países com propósito de pleitear internacionalmente sobre o tema. Em reunião da 35ª Cúpula de Chefes de Estado do Mercosul, em 01 de julho de 2008, os presidentes dos Estados-partes e associados emitiram declaração sobre a Diretiva de Retorno aprovada em junho de 2008 pelo Parlamento Europeu, na qual afirmam que: 
Lamentan que Naciones tradicionalmente generadoras de corrientes migratorias que -en la actualidad- son receptoras de migrantes no reconozcan, en base al principio de reciprocidad histórica, la responsabilidad compartida entre los países de origen, tránsito y destino de los flujos migratorios (MERCOSUL, 2008, p.1).

Essa postura se alinha ao posicionamento multilateral brasileiro sobre migrações no período, caracterizado pelo antagonismo em relação às nações desenvolvidas com vistas à reivindicação de reciprocidade. Progressivamente, combina-se a este discurso reivindicativo aquele dos direitos humanos, engendrando inclusive resultados paradoxais: no caso de Comunicado da XL Cúpula de Presidentes dos Estados Partes do Mercosul e Estados Associados, de 17 de dezembro de 2010, os participantes clamam pela adesão dos países desenvolvidos à Convenção Internacional dos Trabalhadores Migrantes, algo não efetivado pelo Brasil:

\begin{abstract}
Nesse sentido, ratificaram a necessidade de garantir o respeito e a promoção dos Direitos Humanos dos migrantes e de suas famílias, independentemente de sua nacionalidade, condição migratória, origem étnica, gênero, idade ou qualquer outra consideração discriminatória. Finalmente, reiteraram a importância de avançar gradualmente em direção à conformação de um espaço regional de livre circulação de pessoas seguro, respeitando a legislação interna do Estado receptor e em concordância com o pleno exercício dos direitos dos migrantes, como um dos pilares fundamentais do processo de integração. (...)Instaram os países desenvolvidos a subscrever e ratificar a Convenção Internacional sobre a Proteção dos Direitos de Todos os Trabalhadores Migrantes e seus Familiares, aprovada, em 1990, pela Assembléia Geral das Nações Unidas, instrumento fundamental de Direitos Internacional em matéria de proteção dos direitos dos trabalhadores migrantes e de suas famílias, sob o princípio fundamental da nãodiscriminação (XL Cúpula de Presidentes dos Estados Partes do Mercosul e Estados Associados, 17 de dezembro de 2010. Resenha de Política Exterior do Brasil. $\mathrm{N}^{\mathrm{o}} 107,2^{\circ}$ semestre de 2010 p.390-391).
\end{abstract}

A União das Nações Sul-Americanas (Unasul) se consolidou institucionalmente com forte apelo discursivo à identidade sul-americana (MEUNIER; MEDEIROS, 2013), consagrado no objetivo, elencado em seu Tratado Constitutivo (2008), de constituir uma cidadania sul-americana através do reconhecimento progressivo de direitos a nacionais de um Estado Membro residentes em qualquer outro Estado Membro (art. $3^{\circ}$, i). Para tanto, a organização busca a cooperação em matéria de migração, com enfoque integral e baseada no respeito irrestrito aos direitos humanos e trabalhistas para a regularização migratória e a harmonização de políticas (artigo $3^{\circ}$, k) ${ }^{297}$. Nesse desiderato, a Decisão no 8 em 30 de novembro de 2012, aprovada pelo

\footnotetext{
297 Já durante o processo de formação da Unasul, a temática migratória era objeto de especial atenção, como se verifica no Comunicado de Brasília (2000) e na Declaração de Ayacucho (2004), esta última tendo convocado Conferência Internacional Especial, em nível ministerial, de países em desenvolvimento com fluxos internacionais substanciais de migrantes (Lima, Peru, 2005).
} 
Conselho de Chefes de Estados da Unasul, decidiu iniciar a construção da cidadania sulamericana a partir da ampliação dos acordos regionais, sub-regionais e bilaterais em temática migratória; e criou o Grupo de Trabalho para a Conformação da Cidadania Sul-Americana, do qual participam representantes da DIM/SGEB. Segundo Maria Rita Faria, o Brasil seria um dos países mais assíduos no Grupo de Trabalho (2015, p.105).

No entanto, para além de comunicado conjunto sobre a Diretiva de Retorno europeia $^{298}$, a Unasul não conseguiu consolidar uma arena de cooperação própria sobre migrações. Ainda de acordo com Faria (2015), há sugestões de absorção ${ }^{299}$ pelo bloco comunitário de arena consultiva regional não-vinculante sobre política migratória: a Conferência Sul-Americana sobre Migrações (CSM), um espaço intergovernamental não-vinculante de debate sobre política migratória. A I Conferência foi realizada em Buenos Aires no ano 2000 e estabeleceu três eixos centrais de atuação: (i) as migrações como parte do processo de integração regional e extrarregional; (ii) a vinculação entre o desenvolvimento econômico e social dos países de origem e as migrações; (iii) a defesa dos direitos humanos dos migrantes.

Entre a primeira e a XVI Conferência, realizada em Assunção em 2016 ${ }^{300}$, a CSM se consolidou como um processo consultivo regional (PCR) com o propósito de promover o intercâmbio de informações e boas práticas na área migratória, bem como de desenvolver programas e coordenar políticas sobre a matéria. No entendimento de que a governança das migrações deve ser multilateral, incorporando vários espaços e atores na discussão, as Conferências contam com reuniões de representantes da sociedade civil previamente àquelas de delegados governamentais, com encaminhamento de recomendações dos primeiros aos segundos. Ademais, as reuniões foram gradativamente agregando delegações de outros países e altos-representantes da CAN e Mercosul, além de atores internacionais como ACNUR e OIT. À OIM, cabe realizar o secretariado técnico.

\footnotetext{
298 “ (...) los países miembro de UNASUR expresan su rechazo a la aprobación por parte de la Unión Europea (UE) de la llamada 'Directiva de Retorno', y cualquier intento de criminalización de los migrantes que pueda implicar la aplicación de esta normativa, y subraya que los derechos humanos de que son titulares estan garantizados por diversos instrumentos internacionales suscritos por los Estados de ambas regiones. En UNASUR estaos convencidos que la libre movilidad es un derecho inherente al ser humano, y en ese sentido el orden internacional debe contemplar la libre circulación de las personas (UNASUL, 2008)".

299 Consoante a autora, consta em ata da XI CSM (2011) a solicitação para que a Presidência Pró-Tempore formalize o interesse, junto à Unasul, de incorporação da CSM à estrutura institucional da primeira.

300 A lista do total de encontros e documentos deles originados pode ser encontrada no site da Conferência, disponível em: http://csm-osumi.org/. Acesso em: 11 dez 2016.
} 
Na X CSM, realizada em 2010 na cidade de Cochabamba, Bolívia, aprovaram-se a Declaração de Princípios Migratórios e Alinhamentos Gerais da CSM e o Plano SulAmericano de Desenvolvimento Humano das Migrações, os principais documentos programáticos da Conferência. Suas principais diretrizes podem ser identificadas no seguinte trecho do Plano:

\begin{abstract}
En primer lugar, porque se concibe a los movimientos migratorios no como espacio de negociación intergubernamental y eventual cooperación para el "control de los flujos", sino como una expresión del proceso de integración de la región, por lo tanto como un factor que debe lograr la libre movilidad dentro de ese espacio regional. En segundo lugar, la inclusión del desarrollo económico social, se hace explícita desde el primer encuentro, en el sentido de presentarlo como la principal causa de las migraciones, más allá de la voluntad de los migrantes, y vinculado con las asimetrías del desarrollo económico a nivel mundial. En tercer lugar, los derechos humanos de los migrantes y sus familias van a constituirse en la temática relevante y permanente de las sucesivas reuniones, asumiendo el compromiso de respetar y hacer cumplir esos derechos en el marco de todos las Convenciones y Acuerdos internacionales vigentes en la materia, e instando a todos los países de la región a ratificar estos instrumentos y a hacer efectiva su aplicación (CSM, 2010 - grifo nosso).
\end{abstract}

Ressalte-se que os delegados do Brasil na CSM correspondem, em todas suas reuniões, a representantes do MRE (DIM/SGEB), acompanhados por vezes de representantes do Ministério da Justiça e, com menor frequência, do Ministério do Trabalho.

A Comunidade dos Estados Latino-americanos e Caribenhos (Celac), por sua vez, aprovou em sua primeira Cúpula (2011) o Plano de Ação de Caracas ${ }^{301}$, contendo uma meta de desenvolvimento de estratégia regional para facilitar a integração dos migrantes às sociedades de acolhimento. No ano seguinte, ocorreu a I Reunião sobre Migrações da Celac, uma arena preparatória para primeira Cúpula sobre Migração com a União Europeia, com o objetivo de estabelecer uma estratégia regional para lidar com os processos migratórios interregionais (CELAC, 2012 ${ }^{302}$ ). Na ocasião, emitiu-se comunicado desaprovando a Diretiva de Retorno e acordou-se com a UE a realização periódica de um Diálogo Estruturado e Abrangente sobre Migrações (Declaração de Santiago, 2013).

Já a II Reunião sobre Migração da Celac (2013) voltou-se para a coordenação da posição regional tendo em vista o II Diálogo de Alto Nível das Nações Unidas sobre

\footnotetext{
${ }^{301}$ Disponível em: http://www.itamaraty.gov.br/pt-BR/notas-a-imprensa/2890-i-cupula-da-comunidadedos-estados-latinoamericanos-e-caribenhos-celac-caracas-2-e-3-de-dezembro-de-2011-documentosaprovados. Acesso em: 28 ago 2016.

${ }^{302}$ Disponível em: http://www.sela.org/celac/prensa/?nID=29953. Acesso em: 28 ago 2016.
} 
Migrações Internacionais e Desenvolvimento (2013). A Declaração de Havana (2014), emitida na II Cúpula da CELAC, avalia positivamente o II Diálogo de Alto Nível, dada a ênfase conferida aos direitos humanos, mas insiste "en la necesidad de un mayor involucramiento de las Naciones Unidas, sus agencias, fondos y programas en la materia" (Resenha de Política Exterior, 2014/1, p.137). As Reuniões sobre Migrações da CELAC continuaram ocorrendo anualmente, sendo integrada por membro da DIM/SGEB.

Percebe-se tanto na CSM quanto na CELAC uma clara orientação para concertar um posicionamento regional a ser sustentado no cenário internacional. As diretrizes das duas instâncias são em muito coincidentes: assumem como premissa básica a defesa dos direitos humanos dos migrantes independente do status migratório; posicionam a pessoa imigrante no centro da política migratória; apontam a necessidade de vincular-se o debate sobre migrações internacionais ao de desenvolvimento; repudiam a criminalização da migração irregular; defendem a inserção do tema migratório na ONU. O Mercosul e a Unasul, esta em menor escala, tomam o mesmo caminho, com a particularidade de constituírem arenas com o potencial, no caso do Mercosul concretizado, de emitirem decisões vinculantes aos Estados-membros - desta forma, influenciando diretamente a formulação das políticas migratórias.

Por último, uma outra arena de cooperação multilateral se destaca na temática das migrações: a Comunidade dos Países de Língua Portuguesa ${ }^{303}$ (CPLP). Segundo seu Estatuto, a CPLP constitui "o foro multilateral privilegiado para o aprofundamento da amizade mútua, da concertação político-diplomática e da cooperação entre os seus membros ${ }^{304}$, , fundamentando-se em similaridades culturais e ressaltando seu objetivo geral de promoção e difusão da língua portuguesa. Uma das estratégias propostas para consecução dos intuitos do bloco é a promoção de medidas que facilitem a circulação dos cidadãos dos Estados Membros no espaço da Comunidade. Desta forma, na V Conferência de Chefes de Estado e de Governo da CPLP (2002), levantou-se a proposta de elaboração de um Projeto de Convenção Quadro Relativa ao Estatuto do Cidadão da $\mathrm{CPLP}^{305}$, um regime comum de circulação de pessoas e cidadania. O Grupo de Trabalho

\footnotetext{
${ }^{303}$ Criada em novembro de 1986, reúne um conjunto de nove Estados que têm o idioma oficial português e é dotada de personalidade jurídica internacional.

${ }^{304} \mathrm{O}$ Estatuto foi incorporado ao ordenamento brasileiro pelo Decreto $\mathrm{n}^{\circ} 5.002 / 2004$. Disponível em: https://www.planalto.gov.br/ccivil_03/_Ato2004-2006/2004/Decreto/D5002.htm

${ }^{305} \mathrm{O}$ site da CPLP descreve que o Estatuto constituiria "um elemento facilitador da integração das comunidades migrantes e da circulação entre os Estados-membros, contribuindo para o sentimento de
} 
alargado sobre Cidadania e Circulação de Pessoas no Espaço da CPLP foi criado na VI Conferência (2006) com vistas a avançar no sentido de sua implementação.

Embora o Estatuto do Cidadão ainda seja um objetivo pouco palpável da CPLP, outras normas relacionadas à mobilidade de pessoas foram adotadas pelo bloco e se encontram incorporadas pelos seus membros, como se verifica no quadro 4.8 .

Quadro 4.8: Normas afetas à temática migratória na CPLP

\begin{tabular}{|c|c|c|}
\hline Acordo & Data e situação & Incorporação no Brasil \\
\hline $\begin{array}{l}\text { Acordo sobre Concessão de } \\
\text { Visto Temporário para } \\
\text { Tratamento Médico a } \\
\text { Cidadãos da Comunidade dos } \\
\text { Países de Língua Portuguesa }\end{array}$ & $\begin{array}{l}\text { Brasília, } 30 \text { de Julho de } 2002 \\
\text { Em vigor }\end{array}$ & Decreto $^{\circ} 6.471 / 2008$ \\
\hline $\begin{array}{l}\text { Acordo sobre a Concessão de } \\
\text { Vistos de Múltiplas Entradas } \\
\text { para Determinadas Categorias de } \\
\text { Pessoas }\end{array}$ & $\begin{array}{l}\text { Brasília, } 30 \text { de Julho de } 2002 \\
\text { Em vigor }\end{array}$ & Decreto $^{\circ} 6.475 / 2008$. \\
\hline $\begin{array}{l}\text { Acordo sobre o Estabelecimento } \\
\text { de Balcões Específicos nos } \\
\text { Postos de Entrada e Saída para o } \\
\text { Atendimento de Cidadãos da } \\
\text { CPLP }\end{array}$ & Brasília, 30 de Julho de 2002 & Não foi encontrado. \\
\hline $\begin{array}{l}\text { Acordo sobre o Estabelecimento } \\
\text { de Requisitos Comuns Máximos } \\
\text { para a Instrução de Processos de } \\
\text { Visto de Curta Duração }\end{array}$ & $\begin{array}{l}\text { Brasília, } 30 \text { de Julho de } 2002 \\
\text { Em vigor }\end{array}$ & Decreto $^{\circ} 6.529 / 2008$ \\
\hline $\begin{array}{l}\text { Acordo sobre a Isenção de Taxas } \\
\text { e Emolumentos devidos à } \\
\text { Emissão e Renovação de } \\
\text { Autorização de Residência para } \\
\text { os Cidadãos da } \\
\text { Comunidade dos Países de } \\
\text { Língua Portuguesa }\end{array}$ & $\begin{array}{l}\text { Brasília, } 30 \text { de Julho de } 2002 \\
\text { Em vigor }\end{array}$ & Decreto $^{\circ} 6.771 / 2009$ \\
\hline $\begin{array}{l}\text { Acordo sobre a Concessão de } \\
\text { Visto para Estudantes Nacionais } \\
\text { de Estados-membros da CPLP }\end{array}$ & $\begin{array}{l}\text { Lisboa, } 02 \text { de Novembro de } \\
2007 \\
\text { Em vigor }\end{array}$ & 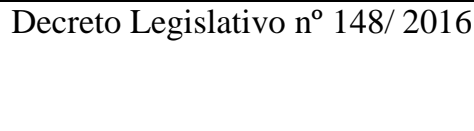 \\
\hline
\end{tabular}

Fonte: Elaboração própria.

As negociações no quadro da CPLP são conduzidas pelo MRE, pela Subsecretaria-Geral Política correspondente ao continente africano, e os objetivos de política externa a ela concernentes se materializaram na inclusão, no PNDH-3 (2009), da ação programática: “Construir e aprofundar agenda de cooperação multilateral em Direitos Humanos que contemple prioritariamente o Haiti, os países lusófonos do continente africano e o Timor-Leste".

pertença à Comunidade e para a concretização dos objetivos que estão na origem da sua fundação"disponível em: https://www.cplp.org/id-2767.aspx. Acesso em: 12 nov 2016. 


\subsection{Projetos de Lei}

O presente tópico avalia os processos de tentativa de substituição do Estatuto do Estrangeiro entre 2003 e abril de 2016. Opta-se por restringir o escopo do trabalho apenas às iniciativas de revogação da Lei $\mathrm{n}^{\circ}$ 6.815/1980, motivo pelo qual projetos de alterações pontuais na legislação não serão analisados ${ }^{306}$.

Em 2003, marco temporal deste process-tracing, foi retirado de tramitação o Projeto de Lei (PL) $n^{\circ} 1.813 / 1991$. O projeto fora criado por Comissão Interministerial integrada por representantes do MJ, MRE e MTE, tendo sido encaminhado para o Congresso Nacional em 21 de outubro de 1991. Na exposição de motivos ${ }^{307}$ dirigida ao então presidente Fernando Collor de Melo, o Ministro da Justiça Jarbas Passarinho explicava que "As profundas modificações introduzidas na ordem jurídica pela nova Constituição e a experiência adquirida no trato da legislação de estrangeiros, desde o ano de 1980, motivam o aperfeiçoamento do texto legal em comento" (DCD,13/09/1997, p.28091 ${ }^{308}$ ). Ainda de acordo com o Ministro,

O fim social, como objetivo maior da lei que se disponha a regular a situação jurídica dos estrangeiros no País, materializa-se na defesa do trabalhador nacional, na seleção de mão-de-obra técnica na transferência de tecnologia, na captação de recursos externos para os setores produtivos e no desenvolvimento sócio-econômico (DCD,13/09/1997, p.28102).

No quadro dessa diretriz, o projeto pouco se afastava da Lei $n^{\circ} 6.815 / 1980$. As inovações propostas eram sobretudo procedimentais e estruturais, como a criação da Secretaria administrativa do CNIg, a qual estaria situada no interior da estrutura do MJ mas seria subordinada ao Conselho. Enviado em 1991 à Comissão de Relações Exteriores, recebeu em 1993 parecer favorável do deputado relator Jorge Uequed enaltecendo o potencial da lei de contribuir para a imagem do país no exterior, além de 31 emendas. Remetido à Comissão de Constituição, Justiça e Cidadania, o PL recebeu parecer favorável do relator deputado Almino Affonso em 07 de maio de 1997, com 55

\footnotetext{
306 Projetos de alterações pontuais na Lei $\mathrm{n}^{\circ}$ 6.815: PL 3.637/2008, permite a concessão de visto estrangeiro portador de documento de vagem emitido por governo não-reconhecido pelo Brasil; PL 1499/2007, concede visto temporário para estrangeiros que vierem trabalhar em eventos esportivos de nível internacional. Leis: Lei $\mathrm{n}^{\circ} 12.968 / 2014$, com procedimento alternativo para o visto de turista; Lei 12.878/2003, nova disciplina para a prisão preventiva para fins de extradição. Ademais, propostas de emenda constitucional $n^{\circ}$ 14/2007, 88/2007, 25/2012 e 347/2013 relacionam-se a direitos políticos dos estrangeiros.

307 Exposição de motivos $\mathrm{n}^{\mathrm{o}}$ 0268-A, de 11 de junho de 1991. Disponível em: http://www.camara.gov.br/proposicoesWeb/fichadetramitacao?idProposicao=17245. Acesso em: 16 jun 2016.

${ }^{308}$ Note-se que esses documentos foram consultados no Diário Oficial da Câmara dos Deputados de 1997, porém são datados de 1991 .
} 
emendas, após o que foi levado a Plenário. Destaca-se do referido parecer o trecho seguinte:

\begin{abstract}
Elaborado por Comissão Inteministerial de alto nível, o projeto de lei levou em conta as profundas modificações introduzidas na ordem jurídica pela Constituição de 1988, notadamente no campo dos direitos e garantias fundamentais. Não mais se invoca, agora, os então denominados "interesses da Segurança Nacional", cujo atendimento ainda é reiteradamente ressalvado quanto a estrangeiros no vigente Decreto $n^{\circ} 86.715 / 81$, artigos $27, \S 3^{\circ}, 37,69$, parágrafo único, 101 e 104. Gerados no mais triste período obscurantista de nossa história, conceitos como esse foram abolidos no documento, exceto em um só deslize, reparado (art. 142 do projeto) (DCD,13/09/1997, p.28118).
\end{abstract}

Em 2001, o Ministro da Justiça José Gregori enviou mensagem ${ }^{309}$ ao Congresso solicitando a retirada de tramitação do projeto, classificando-o como defasado, inclusive por trazer em seu bojo uma seção que tratava dos refugiados, disciplinados pela Lei $\mathrm{n}^{\circ}$ 9.474 de 1997. Ademais, aponta sua falta de coesão, resultante do fato de ter sido objeto de numerosas emendas. Tal proposta foi votada e o projeto retirado de tramitação em 13 de novembro de 2003. Entretanto, a previsão do Ministro Gregori de que a retirada abriria lugar para que o Executivo apresentasse nova proposta de regulamentação, mais condizente à realidade dos fluxos migratórios de então, não chegou a ser concretizada no governo Fernando Henrique Cardoso.

Em 10 de agosto de 2004, Portaria do $\mathrm{MJ} \mathrm{n}^{\mathrm{o}} 2.209^{310}$ instituiu comissão interministerial encarregada de elaborar, no prazo de noventa dias, anteprojeto de lei de estrangeiros. Presidida por Luiz Paulo Barreto, então Secretário-Executivo do Ministério da Justiça, e coordenada por Izaura Miranda (DEEST/MJ), a Comissão contava com representantes dos órgãos diretamente envolvidos com temática migratória - dentre os quais Nilton Freitas (CNIg/MTE) e Ralph Peter Hendersen (DIM/MRE) além de diversos juristas especialistas em direito internacional.

Em audiência pública ${ }^{311}$ realizada na Câmara dos Deputados, em 04/05/2005, para discutir o PL 2.430/2003, que visava à dispensa de visto para entrada de turistas nacionais dos Estados Unidos, Luiz Paulo Barreto defendeu o anteprojeto do MJ nos seguintes termos ${ }^{312}$ :

\footnotetext{
${ }^{309}$ Disponível em:

http://imagem.camara.gov.br/MostraIntegraImagem.asp?strSiglaProp=PL\&intProp=1813\&intAnoProp=1 991\&intParteProp $=1 \# /$.

${ }_{310}$ Disponível em: http://portal.mj.gov.br/Estrangeiros/legislacao/Portaria\%20n\%C2\%BA\%202.209.pdf

${ }^{311}$ Audiência Pública n ${ }^{\circ}$ 0507/05, em 4/5/2005, sobre PL 2430/2003, proposto pelo Deputado Carlos Eduardo Cadoca.

${ }_{312}$ Disponível em:

http://www.camara.leg.br/internet/sitaqweb/textoHTML.asp?etapa=11\&nuSessao=0507/05\&nuQuarto=0
} 
O Ministério da Justiça, por meio de grupo formado no ano passado, com a participação do Ministério das Relações Exteriores, do Ministério do Turismo e de outros Ministérios, apresentou a proposta de uma nova lei de imigração.(...) Esse grupo elaborou um novo projeto de lei de imigração e naturalização, que está indo para consulta pública e deve vir para o Congresso Nacional nos próximos 2 meses. Esse novo projeto tem uma série de avanços. Ele reconhece a imigração como tema de direitos humanos; reconhece os direitos civis dos estrangeiros, outorgados pela nossa Constituição; dispõe de um sistema moderno de vistos; tenta trazer para o Brasil, com facilidade, o investidor, o pesquisador, o professor, o profissional de alta qualificação, o aposentado estrangeiro, que poderá gastar seu dinheiro no País. O projeto de lei tem uma série de novos dispositivos, que vão incentivar muito mais a imigração inteligente(...).

Em primeiro de setembro de 2005, o Ministério da Justiça brasileiro publicou o anteprojeto em Diário Oficial da União (DOU, 01/09/2005, seção 1, p.46 ${ }^{313}$ ) e disponibilizou-o, em sua página na internet, para consulta pública por 30 dias. A principiologia da norma denota um forte caráter de proteção do trabalhador nacional e explicita não ser o imigrante seu sujeito, mas sim o Estado em seu anseio de atração de pessoas:

Art. $2^{\circ}$ A aplicação desta lei deverá nortear-se pela política nacional de migração, garantia dos direitos humanos, interesses sócioeconômicos e culturais do Brasil, defesa do trabalhador nacional, preservação das instituições democráticas, segurança da sociedade e relações internacionais. Art. $3^{\circ}$ A imigração objetivará, primordialmente, a admissão de mão-deobra especializada aos vários setores da economia nacional, ao desenvolvimento econômico, social, cultural, científico e tecnológico do Brasil, a captação de recursos para setores específicos e geração de emprego e renda.

Dois pontos ressaltam do anteprojeto. Um deles é o fato de prever a possibilidade do Poder Executivo estabelecer, sob reciprocidade, tratamento migratório mais favorável em duas situações: para indivíduos provenientes de países do Mercosul e Estados Associados ou da Comunidade de Países de Língua Portuguesa - CPLP (art. 145, III).

O segundo ponto é o fato do texto não haver previsto a que órgão estaria vinculado o Conselho Nacional de Migração, submetendo uma curiosa redação à consulta pública:

Art. 142. Fica criado o Conselho Nacional de Migração, órgão autônomo de deliberação coletiva, vinculado ao [Ministério do Trabalho e Emprego/Justiça/Presidência da República], com a presidência

$\&$ nuOrador $=0 \&$ nuInsercao $=0 \&$ dtHorarioQuarto $=10: 00 \&$ sgFaseSessao $=\&$ Data $=4 / 5 / 2005 \&$ txApelido $=$ RE LA $\%$ C3\%87\%C3\%95ES\%20EXTERIORES\%20E\%20DE\%20DEFESA\%20NACIONAL\&txFaseSessao $=$ Audi $\%$ C3\%AAncia\%20P\%C3\%BAblica $\% 20$ Ordin $\%$ C3\%A1ria\&txTipoSessao=\&dtHoraQuarto=10:00 \&txEtapa $=$

${ }^{313}$ Disponível em: https://www.jusbrasil.com.br/diarios/725939/pg-46-secao-1-diario-oficial-da-uniaodou-de-01-09-2005 
alternada dentre órgãos governamentais que o compõe, com as atribuições constantes desta lei (DOU, 01/09/2005, seção 1, p.50- grifo nosso).

Na ocasião, de acordo com Marcia Sprandel (2012), foi criado um grupo de trabalho reunindo a Comissão de Direitos Humanos e Minorias da Câmara dos Deputados e mais 16 instituições de estudo e/ou apoio a migrantes a fim de analisar o anteprojeto e encaminhar sugestões, o que se deu em Audiência Pública realizada na Câmara dos Deputados ainda em 2005. Também no governo a proposta gerou debates: ata da reunião do CNIg de 13 de setembro de 2005 mostra as discussões que ocorreram naquele Conselho quando da análise do anteprojeto. Dentre os vários temas suscitados, destacam-se a pertinência de transformar o Conselho Nacional de Imigração em Conselho Nacional de Migração, e a vinculação institucional deste último. Trecho da referida ata descreve que:

O Dr. Paulo Sérgio [MTE, então Coordenador Geral de Imigração] informou que a Coordenação Geral de Imigração apresentaria à Comissão responsável por receber as sugestões e críticas advindas da consulta pública uma manifestação formal, a qual abordaria temas como: criação da residência temporária; extensão dos direitos fundamentais aos estrangeiros em situação irregular no país; estatuto de regulação das condições de saída do emigrante brasileiro; atribuições e competências do Conselho Nacional de Migração; participação de estrangeiro na administração ou representação de sindicato ou associação profissional; e rotatividade da presidência do Conselho entre todos os seus membros. O Dr. Nilton Freitas [MTE, então Presidente do CNIg], expressou sua opinião pessoal de que o Ministério do Trabalho e Emprego era o Ministério do diálogo social e do tripartismo e, portanto, o Conselho Nacional de Migração estaria muito bem colocado nesse Ministério (CNIg, 13/09/2005, p.2).

Após as manifestações, o CNIg aprovou a Resolução Recomendada $n^{\circ}$ 07, de $13 / 09 / 2005^{314}$, encaminhando suas observações ao MJ e à Comissão Interministerial. O impasse sobre a vinculação do Conselho Nacional de Migração não foi facilmente resolvido, e o anteprojeto não foi enviado ao Congresso nos anos seguintes.

Apenas em 2008 a negociação do texto do anteprojeto foi retomada, sob liderança do Secretário Nacional de Justiça Romeu Tuma Júnior (2007-2010). Nesse momento, previu-se que o Conselho Nacional de Migração seria atrelado ao Ministério do Trabalho e Emprego. Em 20 de julho de 2009, o Projeto de Lei 5.655/2009 começou

\footnotetext{
${ }^{314}$ Disponível em: http://acesso.mte.gov.br/trab_estrang/resolucao-recomendada-n-07-de-13-092005.htm. Acesso em: 04 mar 2017.
} 
sua tramitação no Congresso Nacional após encaminhamento de mensagem presidencial $n^{\circ}$ 507, acompanhada de Exposição de Motivos do Ministro da Justiça Tarso Genro ${ }^{315}$ :

Quando da promulgação da Lei $\mathrm{n}^{\circ} 6.815$, de 19 de agosto de 1980, atual Estatuto do Estrangeiro, alterada pela Lei $\mathrm{n}^{\circ}$ 6.964, de 9 de dezembro de 1981, o foco era precipuamente a segurança nacional. Essa realidade nos dias atuais encontra-se em descompasso com o fenômeno da globalização, que tem revolucionado os movimentos migratórios. Impõe-se, assim, que a migração seja tratada como um direito do homem, ao se considerar que a regularização migratória seja o caminho mais viável para a inserção do imigrante na sociedade. Essa é a orientação mundial. Instrumentos internacionais, como as Convenções de Viena e Genebra e a Carta das Nações Unidas, vêm destacando a importância de se acolher bem os imigrantes, até mesmo pela sua notada contribuição para o desenvolvimento do país. (MJ, EM nº70, 2008 - grifo nosso).

À parte da transformação do CNIg em Conselho de Migrações, abarcando o contingente de brasileiros no exterior, as alterações que o Ministro destaca em sua exposição de motivos ou constituem alterações procedimentais, ou correspondem a uma regulação mais restritiva do que a da Lei $n^{\circ}$ 6.815. É o caso da necessidade de prévia autorização dos órgãos competentes para atuação de estrangeiros em regiões estratégicas, como áreas indígenas ou ocupadas por quilombolas ou por comunidades tradicionais; e da ampliação de quatro para dez anos do prazo mínimo para naturalização ordinária.

O texto tem algumas sutilezas: em seu artigo $3^{\circ}$ dispõe que "A política nacional de migração contemplará a adoção de medidas para regular os fluxos migratórios de forma a proteger os direitos humanos dos migrantes, especialmente em razão de práticas abusivas advindas de situação migratória irregular", e no art. $5^{\circ}$ afirma estenderem-se aos imigrantes indocumentados (i) o acesso à educação e à saúde; (ii) os benefícios decorrentes do cumprimento das obrigações legais e contratuais concernentes à relação de trabalho, a cargo do empregador; e (iii) as medidas de proteção às vítimas e às testemunhas do tráfico de pessoas e do tráfico de migrantes. Nota-se, portanto, um reconhecimento da necessidade de proteção de direitos dos imigrantes mais vulneráveis.

Em contrapartida, o projeto prevê uma política imigratória de atração seletiva de mão-de-obra ( $\operatorname{art} .4^{\circ}$ ), na qual evidencia sua lógica de subordinar o imigrante aos interesses do Estado. Adicionalmente, elenca uma série de atividades proibidas aos imigrantes $\left(\operatorname{art.} 7^{\circ}\right)$ e mantém sem grandes alterações as regulamentações concernentes à

\footnotetext{
${ }^{315} \mathrm{EM} \mathrm{n}^{\circ} 70-\mathrm{MJ}$, de 10 de abril de 2008. Disponível em: http://www.camara.gov.br/proposicoesWeb/prop mostrarintegra?codteor $=674695 \&$ filename $=$ Tramitacao -PL+5655/2009.
} 
concessão de vistos e à naturalização. Nesse contexto, Marcia Sprandel (2012) narra que determinados pontos do projeto suscitaram reação da comunidade acadêmica e da sociedade civil, organizada no Fórum Social pela Integração e Direitos Humanos dos Migrantes no Brasil.

Em 6 de agosto de 2009, em regime de prioridade, o PL 5.655/2009 foi distribuído às Comissões de Relações Exteriores e de Defesa Nacional e de Constituição e Justiça e de Cidadania, em resposta ao que o Deputado Carlos Eduardo Cadoca (PSCPE) apresentou requerimento para oitiva da Comissão de Turismo e Desporto, alegando que o projeto abordava a questão dos vistos para turistas. $\mathrm{O}$ requerimento foi aprovado e Cadoca solicitou a relatoria da matéria, apresentando seu parecer mais de 2 anos depois, em março de 2012, na forma de um substitutivo que apresentava medidas destinadas a beneficiar a indústria do turismo e empresários estrangeiros.

Em 11 de julho de 2013, contudo, começou a tramitar no Senado Federal o Projeto de Lei do Senado (PLS) 288/2013, de autoria do Senador Aloysio Nunes (PSDB-SP). Exilado durante a ditadura militar, Nunes participara ativamente da tramitação e aprovação da Lei de Refúgio de 1997, e apresentara um projeto de emenda constitucional para direitos políticos dos estrangeiros (PEC 25/2012). Seu projeto se diferenciava das propostas anteriores já em sua denominação: "Lei de Migração". Tal opção se deveu, de acordo com justificativa do Senador Nunes, ao fato de que

\begin{abstract}
A denominação da lei em vigor [Lei $n^{o}$ 6.815] revela que o objetivo é a proteção diante do outro e não sua recepção. Essa observação pode parecer secundária, não refletisse ela concepções sectárias, em atraso à perspectiva constitucional, à evolução jurisprudencial, às necessidades práticas hodiernas e à visão mais humanista do relacionamento internacional (2013, p.24).
\end{abstract}

Ainda segundo o Senador, a proposta parte da consideração do tema como inserido no contexto da proteção internacional de direitos humanos, motivo pelo qual se inicia destacando "interdependência, universalidade e indivisibilidade dos direitos humanos dos imigrantes, decorrentes de tratados dos quais o Brasil seja parte" (2013, p.25). O repúdio à xenofobia e ao racismo, a não criminalização da imigração, a acolhida humanitária e a garantia à reunião familiar estão, portanto, previstos como princípios da política migratória brasileira (art. $2^{\circ}$ ); e uma série de direitos e garantias dos imigrantes é elencada, dentre os quais o amplo acesso à justiça e a promoção da integração do imigrante nas respectivas comunidades locais. 
Ressalta no PLS 288/2013 sua opção por não apresentar previsões relacionadas a competências dos órgãos do Executivo federal. O Senador Aloysio Nunes expressamente argumenta em sua justificativa que:

Por fim, importa destacar que esse projeto zela por não afetar as faculdades do Executivo e seu poder de iniciativa legislativa, já que não atribui funções, nem cria órgãos para a administração pública. Contudo, sobre esse aspecto cabe pontuar que importaria repensar os papéis do Ministério da Justiça, da polícia federal, do Ministério das Relações Exteriores, do Ministério do Trabalho e do Conselho Nacional de Imigração (CNIg). Diante do grande aumento do fluxo migratório ao Brasil, está no momento de pensarmos na oportunidade de criar uma Agência Nacional de Migração, fundada em lei federal de migração inspirada pelos direitos humanos, como se pretende com esse projeto, e não em decisões administrativas casuísticas, e com pessoal preparado para exercer essa função, sem utilizar a polícia federal para o que ela não é vocacionada $\left(2013\right.$, p. $\left.30^{316}\right)$.

Paralelamente, o PL 5.655/2009 ainda tramitava, embora a CREDN tenha retido a tramitação do projeto nos primeiros meses de 2013 no aguardo de posicionamento do Executivo sobre o tema (Marcia Sprandel, Entrevista, 03/03/2016). Em julho de 2013, relatora da CREDN, deputada Perpétua Almeida (PCdoB-AC), solicitou realização de audiências públicas com representantes governamentais. Por ocasião da segunda audiência, em 15 de outubro de 2013, o Embaixador Sérgio Danese ${ }^{317}$, Subsecretário das CEB, após pontuar que o projeto de lei em debate já se encontrava ultrapassado, explicitou ressalvas e posicionamentos do Itamaraty sobre a reforma da Lei $\mathrm{n}^{\mathrm{o}}$ 6.815/1980:

O MRE tem um papel em parte acessório no que diz respeito à implementação dos dispositivos de legislação migratória. Um papel acessório porque é agência do governo brasileiro que, no exterior, expede vistos; é também intermediário no papel de cooperação jurídica internacional, que são aspectos que são tratados em uma legislação dessa natureza (...). Temos obviamente interesse numa legislação desse tipo pelo impacto inegável que ela tem nas relações exteriores do Brasil, a mobilidade de pessoas é um assunto que ocupa lugar de destaque na agenda diplomática do Brasil, com seus mais variados parceiros e organizações internacionais, e portanto nós devemos também zelar para que os interesses mais amplos da diplomacia brasileira estejam contemplados quando se trata de alterar a legislação brasileira em política migratória. (...) Uma preocupação que nós devemos ter é o fato de que não necessariamente concessões unilaterais que o Estado brasileiro faça em matéria de direitos dos imigrantes serão reciprocadas, seria uma ilusão achar que apenas dando o bom exemplo o Brasil conseguirá melhorar a situação das comunidades brasileiras no exterior (...). Uma última observação é que o Itamaraty, nesse papel acessório de executor de parte da legislação, nós enfrentamos um problema sério de recursos limitados, tanto no exterior quanto no Brasil. Então provisões do tipo que o MRE deveria se ocupar da concessão de vistos na entrada em território brasileiro é uma discussão que apresenta para nós todo tipo de dificuldade,(...) nós não teríamos recursos para ter agentes do MRE em

\footnotetext{
${ }^{316}$ Disponível em: http://www25.senado.leg.br/web/atividade/materias/-/materia/113700

317 Áudio disponível em: http://imagem.camara.gov.br/internet/audio/Resultado.asp?txtCodigo=46088
} 
todos os pontos de entrada do território nacional para garantir o visto na entrada.(...)

Acho que a legislação não deve refletir apenas conjunturas.(...) Estamos vivendo uma conjuntura muito favorável, mas a lei deve ter o cuidado de não refletir apenas essa conjuntura, ela deve ter o cuidado de nos fornecer mecanismos para que nós possamos reagir da melhor maneira possível a mudanças conjunturais (...). [A lei imigratória deve] responder a interesses concretos do país em matéria de circulação de pessoas, de acolhida dessas pessoas, por exemplo, essa questão da mão-de-obra qualificada que foi mencionada aqui, a questão do monitoramento da capacidade de absorção que a economia brasileira, que a sociedade brasileira tem, em relação a esses contingentes de imigrantes que buscam o Brasil, o direito do Estado brasileiro de fazer, sim, algum tipo de seleção, por exemplo, tentando evitar a vinda de pessoas que seriam indesejáveis em função de um passado criminoso ou de um passado de atividade que pudessem representar algum tipo de perigo para a sociedade brasileira. (...) [Nós lutamos por]uma legislação que possa refletir, da melhor maneira possível, o rápido exercício ou da reciprocidade, ou da retorsão, quando se trata de lidar com a forma como Estados estrangeiros tratem nossos nacionais (DANESE, 2013 - grifo nosso).

Particularmente o Embaixador salientou dois anseios sustentados pelo Itamaraty a respeito da reforma da legislação migratória: (i) prever um sistema de vistos que contemple as diferentes situações em que alguém possa requerê-lo, inclusive com possibilidade de alteração de status migratório dentro do Brasil; e ii) permitir uma reciprocidade simplificada, para que o MRE possa, se for de seu interesse, reciprocar uma isenção de vistos sem a necessidade de firmar um acordo internacional. Verifica-se desta forma que a prerrogativa da reciprocidade foi o interesse precipuamente defendido pelo Itamaraty nos processos de reforma, algo confirmado nas entrevistas.

Para além do debate no Congresso Nacional, o Ministério da Justiça conduziu, ainda em 2013, iniciativa própria de mudança da legislação. Por meio da Portaria $n^{\circ}$ 2.162, de 31 de maio de 2013, criou Comissão de Especialistas com a finalidade de apresentar uma proposta de Anteprojeto de Lei de Migrações e Promoção dos Direitos dos Migrantes no Brasil. Além de sete professores universitários ${ }^{318}$, a Comissão contava com o Secretário Nacional de Justiça, Paulo Abrão; o Diretor do DEEST/MJ, João Guilherme Granja; o Procurador Federal dos Direitos do Cidadão Aurélio Veiga; e o consultor legislativo do Senado Federal Tarciso Dal Maso - o qual fora o consultor principal que atuara na redação do PLS 288/2011. Nota-se, destarte, que a Comissão não contou com representantes do MTE, CNIg ou MRE.

\footnotetext{
318 André de Carvalho Ramos (Universidade de São Paulo); Clèmerson Merlin Clève (Universidade Federal do Paraná); Deisy Ventura (Universidade de São Paulo); José Luis Bolzan de Morais (Universidade do Vale do Rio dos Sinos); Pedro de Abreu Dallari (Universidade de São Paulo); Rossana Rocha Reis (Universidade de São Paulo); Vanessa Berner (Universidade Federal do Rio de Janeiro).
} 
De acordo com uma de suas integrantes, Prof. Deisy Ventura, havia o entendimento de que conduzir um processo em apartado do Legislativo, com autonomia para propor modalidades diversas de instâncias participativas, "geraria massa crítica, abriria espaço pra falar sobre o assunto" (Entrevista, 13/06/2016). Desse modo, além de ter promovido duas audiências públicas, a Comissão tomou conhecimento das recomendações da I Conferência Nacional sobre Migrações e Refúgio - COMIGRAR, ocorrida entre 30 de maio e $1^{\circ}$ de junho de 2014. Durante sua atuação, a Comissão de Especialistas definiu cinco principais características de sua proposta: (i) compatibilização com a Constituição de 1988; (ii) promoção de uma mudança de paradigma da legislação migratória brasileira; (iii) enfrentamento da fragmentação e incoerência em matéria migratória; (iv) preparação do Brasil para enfrentar o momento histórico atual, com a inauguração de um novo ciclo de migrações internacionais; e (v) acolhimento de propostas oriundas da sociedade brasileira.

Com efeito, é em demandas da sociedade civil que o anteprojeto busca legitimidade para muitas de suas disposições, dentre as quais aquela que mais causou polêmicas no governo: a criação de Autoridade Nacional Migratória, autarquia especial sem subordinação hierárquica a nenhum Ministério, reunindo as atribuições de formulação e implementação da política migratória e de refugiados. O texto de apresentação do anteprojeto alega que:

\begin{abstract}
Por conseguinte, como elemento crucial da consolidação da democracia brasileira, este Anteprojeto acolhe demandas históricas de entidades sociais que atuam em defesa dos direitos dos migrantes. Entre elas, destacaríamos a criação de um órgão estatal especializado para atendimento dos migrantes, em especial para gestão dos processos de regularização migratória, com o necessário aprofundamento das capacidades do Estado para produção de dados e formulação de políticas públicas relacionadas a esta temática. Com efeito, atualmente, todo avanço da legislação sobre migrações internacionais se vê comprometido, no plano da efetividade, pela inadaptação dos serviços públicos à nova realidade da mobilidade humana. No cenário mundial, o Brasil desponta como um dos poucos países desprovido de um serviço de migrações, cabendo à Polícia Federal grande parte do processamento dos pedidos de residência e de refúgio, de caráter eminentemente administrativo. (MJ, 2014, p.8-9).
\end{abstract}

No que se propõe a promover "uma mudança de paradigma da legislação migratória brasileira", o anteprojeto consolida uma abordagem de direitos humanos, o que corresponderia a "uma dívida histórica do Brasil para com os migrantes que são parte imprescindível da cultura e do desenvolvimento econômico de nosso país" (MJ, 2014, p.4). Uma das providências tomadas nesse sentido foi a de adotar a tipologia "migrante" em detrimento daquela de "estrangeiro". Por último, observe-se que a 
Comissão de Especialistas afirma inspirar-se no direito internacional, notadamente na Convenção Internacional sobre a Proteção dos Direitos de Todos os Trabalhadores Migrantes e dos Membros das suas Famílias.

Nesse contexto, uma das medidas tomadas pelo Anteprojeto foi a de possibilitar a entrada regular de quem busca um emprego no Brasil, desvinculando a regularidade da estada do indivíduo da detenção de uma autorização para trabalho. No entendimento de Deisy Ventura,

(...) uma questão chave era - e acho que é um obstáculo maior em relação ao CNIg - permitir a permanência legal no país de quem procura emprego. É induzir a eliminação da chamada clandestinidade. Isso, para mim, é a grande revolução. Eu posso pedir um visto sem trabalho nenhum. Eu vou procurar emprego. Essa pessoa não pode estar aqui irregularmente só porque ela está procurando trabalho e porque o trabalho dela é precário. Isso é uma coisa que eu tinha do convívio com eles [migrantes], mas depois eu me dei conta que isso desmonta a máquina de autorização para trabalho (Entrevista, 13/06/2016).

Cabe aqui resgatar que o Secretário Nacional de Justiça, Paulo Abrão, em discurso na abertura da COMIGRAR em maio de 2014, apresentara sua percepção de existência de três déficits estruturais a serem superados na política migratória brasileira, já mencionado supra, com uma modificação pontual: associando o déficit administrativo à ausência de uma estrutura centralizada de gestão da política migratória. Segundo Abrão, a política migratória enfrentava:

Um déficit democrático, na necessária alteração do atual Estatuto dos Estrangeiros, forjado à luz da doutrina de segurança nacional, e pela ausência de participação efetiva dos migrantes na elaboração das políticas, e que essa conferência procura superar, bem como o Comitê de Acompanhamento Social; nós temos um déficit administrativo e institucional, com a ausência de uma estrutura central de gestão e de atendimento e apoio aos refugiados e migrantes no Brasil; nós temos ainda um déficit de integração na rede de serviços para que se promova adaptações culturais, serviços de apoio, orientação e abrigamento $^{319}$ (Paulo Abrão, São Paulo, 30/05/2014 - grifo nosso).

Em 29 de agosto de 2014, movimentos da sociedade civil organizada ${ }^{320}$ entregam ao Ministro José Eduardo Cardozo documento com posicionamento conjunto

\footnotetext{
${ }^{319}$ Disponível em: https://www.youtube.com/watch?v=ZRrelkcpJ2k\&feature=youtu.be

320 Assinam: Comité de Acompanhamento da sociedade Civil - CASC Migrante; Centro de Direitos Humanos e Cidadania do Imigrante - CDHIC; Associação Latino Americana de Arte e Cultura Andina ALAC; Faculdade Latino Americana de Ciências Sociais - FLACSO; Força Sindical; Comunidade Internacional de Estudantes Evangélicos; Conferencia das Mulheres do Brasil; Articulação SUL; Associação Latino Americana das Micro, medias e pequenas empresas- ALAMPYME; Associação Brasileira das Organizações não Governamentais - ABONG; Visão Mundial; União Geral dos Trabalhadores - UGT; Programa MERCOSUL Social e Solidário - PMSS; Movimento Social de Catadores - MNCR; Instituto Brasileiro de Análises Sociais e Económicas - IBASE; Instituto de desenvolvimento e Direitos Humanos -IDDH.; Fundação Friedrich Ebert do Brasil -FES; Federação
} 
em prol da reforma na legislação, expressando apoio ao Anteprojeto de Lei de Migrações e salientando os princípios que marcam seu posicionamento na temática: direito à migração, o que acaba com a ideia de "migrante irregular"; respeito aos direitos humanos das pessoas migrantes; criação de uma Instituição Nacional Migratória autônoma, permanente e especializada; ratificação da Convenção Internacional sobre a Proteção dos Direitos de todos os Trabalhadores Migrantes e dos Membros de suas Famílias.

Em reunião do CNIg de 21 de outubro de 2014, integrantes da Comissão de Especialistas do MJ apresentaram oficialmente ao Conselho seu anteprojeto. A ata da reunião relata discussões acaloradas nas quais se criticaram aspectos relacionados à centralização tanto de seu processo de formulação, quanto da institucionalidade proposta. Desta forma, parte dos Conselheiros julgou pouco inclusivo o processo de elaboração do texto e questionou a ausência de diretrizes relacionadas ao trabalho, bem como a convergência de atribuições na Autoridade Migratória. Na opinião de Deisy Ventura, a ocasião revelou que "o CNIG não nos reconhecia como uma comissão que fosse fazer o projeto, que fosse representar a vontade do governo" (Entrevista, 13/06/2016).

$\mathrm{Na}$ oportunidade, o CNIg circulou proposta própria de Anteprojeto de Lei de Migração. Paulo Sérgio de Almeida, presidente do Conselho, informou que ela fora construída a partir de contribuições dos Conselheiros, que teriam se fundamentado nos projetos já existentes - PLS 288/2013, PL 5.655/2009 e o próprio anteprojeto da Comissão de Especialistas. Segundo conselheiros entrevistados, o Itamaraty exerceu participação intensa nesta redação, formulando e destrinchando uma nova tipologia de vistos. O órgão amadureceu a proposta na reunião seguinte e, no início de 2015 , o Ministro do Trabalho e Emprego, Manoel Dias, levou-a a conhecimento dos demais Ministérios e do Legislativo.

Democrática Internacional de Mulheres - FDIM; Central Única dos Trabalhadores - CUT; Associação Brasileira de Antropologia (ABA); Centro de Estudos de Migrações Internacionais (CEMI), IFCH/UNICAMP; Grito de los Excluídos Continental; Central Geral dos Trabalhadores do Brasil CGTB; Presencia da América Latina - PAL; Comitê Estadual para Refugiados e Migrantes no Estado do Paraná - CERM; ONG Casa Latino Americana de Curitiba - CASLA; Comissão de Direitos dos Refugiados e Migrantes da Ordem dos Advogados do Brasil - Seção do Paraná; Projeto "SI YO PUEDO"; Coletivo Educar para o Mundo; Associação Antônio Vieira - Jesuíta Brasil; Rede Sul Americana Espaço Sem Fronteiras -ESF; Conectas Direitos Humanos; Escritório de Assistência à Cidadania Africana em PE - EACAPE 
Tendo em vista as dissidências interministeriais, porém, o governo não acolheu os anteprojetos paralelos dos Ministérios, e o debate sobre a reforma legal se concentrou no PLS 288/2013.

Em 16 de dezembro de 2014, o projeto de lei do Senador Aloysio Nunes foi objeto de parecer do Relator da Comissão de Relações Exteriores e Defesa Nacional, Senador Ricardo Ferraço (PSDB-ES). Nele, o Senador Ferraço apresentou substitutivo ao PLS 288/2013 em que encampava a grande maioria das disposições do anteprojeto da Comissão de Especialistas do MJ - embora isso não esteja expresso em sua justificativa. Um cotejamento entre os três textos mostra que os princípios são semelhantes em todos eles, mas nos demais temas, inclusive toda a disciplina de vistos e o título relacionado aos emigrantes brasileiros no exterior, o substitutivo proposto por Ferraço absorve, com mínimas modificações, o texto da Comissão de Especialistas. Entretanto, aparta-se desse último em dois pontos importantes: na regulação da extradição, que não está presente no anteprojeto do $\mathrm{MJ}$; e na eliminação do título referente à Autoridade Nacional Migratória. No que atine ao desenho de competências, o substitutivo do Senador Ferraço segue a orientação do projeto original do Senador Aloysio Nunes, omitindo-se a atribuí-las e realizando previsões genéricas "à autoridade competente".

Após apresentação de 24 emendas durante os três meses de tramitação na CREDN, a nova redação do substitutivo acolheu o regime de vistos que houvera sido proposto pelo MRE no anteprojeto do CNIg. Nessa versão, a reciprocidade é mais amplamente acolhida e mencionada em uma série de dispositivos. Em seu segundo parecer sobre o projeto, o Senador Ferraço opina que "É dívida histórica do Brasil a consolidação de uma lei mais humanitária, coerente com a busca por uma sociedade justa, livre e democrática, que respeite os direitos humanos e seja ciente quanto à contribuição cultural, social e econômica dos imigrantes para o país" (Entrevista, 20/05/2015, p. $4^{321}$ ). Finalmente, o substitutivo foi aprovado, em detrimento do projeto inicial, em 02 de julho de 2015.

Remetido para a Câmara como PL 2.516/2015, o projeto correu inicialmente em paralelo ao PL 5.655/2009, porém este último acabou lhe sendo apensado ${ }^{322}$ e,

\footnotetext{
${ }^{321}$ CREDN. Parecer do Senador Ricardo Ferraço sobre PLS 288/2013, de 20/05/2015. Disponível em: http://www25.senado.leg.br/web/atividade/materias/-/materia/113700. Acesso em:

322 Também lhes foram apensados o PL 3.354/2015, de autoria do Deputado Luiz Nishimori (PR), que dispõe sobre a concessão de visto permanente ao estrangeiro que invista e pretenda fixar-se no Brasil; O
} 
posteriormente, retirado de tramitação. Por ter sido distribuído a mais de três Comissões, foi-lhe designada Comissão Especial, tendo como relator o Deputado Orlando Silva (PCdoB-SP) e como presidenta a Deputada Bruna Furlan (PSDB-SP). Há relatos nas entrevistas de que teria havido interferência do Senado em tal composição, no intuito de provê-la de um caráter suprapartidário.

Em seus primeiros meses na Câmara, o PL 2.516/2015 destacou-se pelo elevado número de requerimentos dos deputados para realização de audiências públicas, convidando-se representantes do governo, Legislativo, Judiciário, organismos internacionais, organizações da sociedade civil e especialistas para o debate. A Comissão Especial promoveu um total de dez Audiências Públicas, além de três visitas técnicas, realizadas às cidades de Rio Branco, São Paulo e Porto Alegre ${ }^{323}$.

Nesse período, o projeto recebeu várias emendas, destacando-se numerosas propostas dos deputados Carlos Zarattini (PT/SP) e Leo de Brito (PT/AC). O substitutivo da Câmara, que viria a ser apresentado em 06 de julho de 2016, incorporou demandas da sociedade civil e organizações internacionais (particularmente a OIT) como a substituição do termo "imigrante" por "migrante" e a extensão dos direitos a todos os migrantes, independentemente de sua condição migratória. Acatou, outrossim, demandas do CNIg, notadamente adicionando ao substitutivo o artigo 117, o qual institucionaliza o Conselho Nacional de Migração, vinculado ao Ministério do Trabalho, com função de regular e coordenar as políticas públicas relacionadas ao trabalho do imigrante em território nacional.

Ressalte-se que, enquanto órgão colegiado que inclui representantes de organizações patronais e de trabalhadores, o CNIg encerra múltiplas e distintas vozes em sua defesa. Em evento correalizado pelo Conselho e a Confederação Nacional de Instituições Financeiras (CNF) em 20 de novembro de 2015 sobre a expatriação de trabalhadores, o vice-presidente executivo da CNF, José Ricardo Alves, abriu os trabalhos salientando a importância do CNIg:

PL n ${ }^{\circ}$ 206/2011, do Deputado Sandes Júnior, que “Dispõe sobre a obrigatoriedade de registro, perante o órgão competente do Poder Executivo, das pessoas que entrarem ou saírem do território nacional"; e o Projeto de Lei $\mathrm{n}^{\circ}$ 5.293, de 2016, do Deputado Jean Willys (PSOL), pretende revogar os artigos 62, 71, 107 e 110, os quais, em resumo, tratam da expulsão e proíbem os estrangeiros de exercer atividades de natureza política.

${ }^{323}$ De acordo com parecer do relator Deputado Orlando Silva (06/07/2016, disponível em http://www.camara.gov.br/proposicoesWeb/prop_mostrarintegra?codteor=1474314\&filename=Tramitaca $\underline{\mathrm{o}-\mathrm{PL}+2516 / 2015)}$ 
A CNF vê o Conselho como um órgão político nos dois sentidos da palavra. Isso ocorre porque é um órgão que formula as políticas e também acolhe, reflete e repercute as inquietações e demandas da sociedade. Nesse sentido, tem-se ventilado a possibilidade de o CNIg ser transformado eventualmente num departamento de Ministério e, com isso, não haveria a participação da sociedade como ocorre atualmente. (...) A participação da CNF no CNIg se dá pela defesa da legalidade e é por isso que a Confederação enxerga com preocupação os rumores, ainda não confirmados, mas que inquietam, da transformação do CNIg num órgão ministerial sem a participação da sociedade (CNF, p.10-11).

Sobre a questão, os entrevistados do MTE e membros não-governamentais do CNIg se manifestaram unanimemente sobre a manutenção do órgão, sustentando argumentos relacionados à sua natureza participativa, ao seu histórico de proteção de direitos e a necessidade de um arranjo institucional que contemple a possibilidade de atualização constante da legislação:

Agora, eu acrescento uma questão lá dele [PL 2.516/2015], que não está $100 \%$ definida: para mim, tem que ter o Conselho... Sem Conselho, pode dar problema (Aldo Cândido, Coordenador Geral de Imigração-MTE, 03/03/2016)

Eu acho que em uma política, em um sistema legal, você falar assim, "nossa lei foi votada, aprovada e foi publicada ontem". Ela pode ter saído atualíssima. Mas como o movimento migratório, ele é dinâmico. Quem poderia pensar que ia acontecer desse jeito? Então você tem de ter um órgão dinâmico, com uma competência residual em matéria normativa, que possa responder a esses desafios que nascem a partir do dia seguinte (Luiz Alberto Matos, Coordenador do CNIg-MTE, 03/03/2016).

Então, quando o Ministério da Justiça propõe a criação de uma agência para tratar do tema, onde o CNIg é substituído por uma comissão consultiva composta por um representante dos trabalhadores e por um representante dos empregadores, é óbvio que você perde a riqueza do diálogo social (...) Alguns dos projetos que tramitam no congresso não falam a respeito da figura do CNIg, e isso é uma questão que nos preocupa, porque claramente existe uma disputa de poder na Esplanada, de onde e como o tema migratório será administrado após a nova lei de migração (Rinaldo Almeida, representante do MTE no CNIg, 09/03/2016).

Nossa primeira luta é de tentar contribuir na mudança dessa lei, pra que o paradigma mude e vá para um paradigma de direitos humanos, e avance também na proteção do trabalhador migrante, até pra que ele possa ser filiado ao sindicato, porque de acordo com o atual estatuto isso não é possível. (...) E, esperamos que o CNIg também saia fortalecido, porque é uma certa incerteza se o CNIg seria mantido ou não. Mas, aparentemente sim. (Claire Ruppert, representante da CUT no CNIg, 08/03/2016).

O CNIg é muito diferente mesmo. Aquilo é uma cachaça. Todo mundo é compromissado com o CNIg. Nós fomos cutucar o Palácio do Planalto, cheguei lá de manhã e o Paulo Sérgio olhou pra mim e falou: "Marjo, nós não podemos perder essa briga". Peguei, coloquei os meninos embaixo do braço e falei: "Vamos embora lá pro Palácio do Planalto." É minha área, eu vou onde eu quiser, eu sei como chegar a todo mundo. Ontem, eu tava de manhã com a presidenta. Chegamos lá, e o pessoal falou: "Não, por decreto...". Por decreto, um caramba! (...) O que é que o Ministério de Trabalho fez? Escolheu um homem importante, (...) que foi no Ministério da Justiça e disse: "Não sai do Ministério do Trabalho!" Porque ficou um conselho tão importante, tão atuante, tão redondinho, que todo mundo queria o conselho. (...)[Mas tem que 
ficar no MTE] Porque é laboral. Aqui quem tem que falar é trabalhador e empresário. É uma questão de cidadania. Se o cara é criminoso, se está com o passaporte em dia, isso tudo é com vocês. Não é verdade? Aí, foi uma briga porque quando ele tava pronto, funcionando bem, todo mundo cresceu o olho. O Luiz Paulo já brigava. Ele um dia virou pra mim e falou 'Já cansei de querer trazer o CNIg pra cá.' (Marjolaine Canto, representante da Confederação Nacional do Comércio, 09/03/2016).

No MJ, a orientação do Secretário Nacional de Justiça, Beto Vasconcelos (20152016) foi a de acatar um acordo mínimo para que o projeto de lei tramitasse, baseado na separação entre questões relativas ao regime de direitos daquelas de desenho institucional: "Vamos ver o desenho institucional depois, vamos garantir os direitos antes" (João Guilherme Granja, Entrevista, 09/09/2016). No auge da crise dos haitianos, Beto Vasconcelos foi nomeado para a Secretaria Nacional de Justiça após ter sido secretário executivo e chefe de gabinete da Casa Civil, sendo apontado como pessoa de confiança da Presidenta Dilma Rousseff.

A acomodação de interesses atingida quando da tramitação na Câmara, na qual não se procede à partilha de competências, adotando-se a previsão genérica do termo “autoridade competente", porém se garante a perpetuação do CNIg, gerou um consenso mínimo entre os órgãos do Executivo no que se refere ao marco legal.

\begin{abstract}
A expectativa é que a nova Lei de Migrações, atualmente em discussão em Comissão Especial na Câmara dos Deputados, amplie o campo de atuação dos diversos atores sociais a partir da perspectiva de reconhecimento da imigração como fenômeno inerente à dignidade humana, e do imigrante como elemento constitutivo da história e da cultura do povo brasileiro, vetor essencial ao desenvolvimento social e econômico do país.

A SNJ procurou conduzir, ao lado da SAL/MJ, o processo de debate do Projeto de Lei $\mathrm{n}^{\mathrm{o}} 2.516 / 2015$ de forma articulada, e a proposta hoje representa um esforço suprapartidário para modernizar o regime de direitos relacionados às migrações no Brasil, dando os fundamentos normativos para políticas, programas e ações futuras (MJ, 2015-2016, p.37-38).
\end{abstract}

A própria sociedade civil acatou a estratégia de debater a institucionalidade em momento posterior a fim de garantir direitos, embora seja uma demanda histórica de organizações a dissociação da temática migrante da Polícia Federal - conforme se verifica em nota técnica divulgada por uma coalizão dessas organizações ${ }^{324}(2015$, p.5).

Nesse momento, a arena de disputa interministerial se desloca e passa para a regulamentação da legislação e de sua implementação. O Ministério da Justiça inicia a estruturação da Política Nacional de Migrações, Refúgio e Apatridia (PNMR). Em 23 de novembro de 2015, a SNJ encaminhou à Secretaria de Assuntos Legislativos (SAL),

\footnotetext{
${ }^{324}$ Conectas Direitos Humanos, Centro de Referência e Acolhida aos Imigrantes - CRAI São Paulo, Centro de Estudios Legales y Sociales - CELS, Missão Paz São Paulo, Instituto Terra, Trabalho e Cidadania - ITTC.
} 
do Ministério da Justiça, a Minuta de Decreto da PNMR, dividido em princípios, diretrizes e objetivos.

A PNMR contaria com duas instâncias de governança: a Coordenação Tripartite, formada por MJ, MTE e MRE, responsável pela coordenação e gestão estratégica; e o Comitê Nacional para Migrações, Refúgio e Apatridia, formado por integrantes de órgãos da União, de governos estaduais e municipais, representantes da sociedade civil e da comunidade acadêmica e científica. Esse Comitê teria competências de articulação governamental e federativa; de apresentação de subsídios para formulação de planos, políticas e programas; de promoção de capacitações, campanhas, estudos e pesquisas; e de estímulo à participação social. Ainda segundo a proposta de Decreto, caberia à SNJ/MJ prestar suporte técnico e administrativo para o funcionamento das instâncias de governança instituídas na PNMR, bem como para a compilação e sistematização de dados e informações e a guarda de sua memória institucional (SNJ, 2015-2016).

A proposta de modelo de governança, embora inclusiva, fornece à SNJ papel de liderança dadas as competências administrativas que lhes são atribuídas. Ademais, ao não incluir o CNIg, diminui seu papel na formulação política. A proposta, apresentada ao CNIg em reunião de 10 de maio de 2016, não avançou para promulgação.

No mesmo dia 10 de maio de 2016, dois dias antes de ser afastada da cadeira presidencial, Dilma Rousseff assinou o Decreto $n^{\circ} 8.757$, alterando o Decreto $n^{\circ}$ 86.715/1981. A norma teve um caráter conciliador entre visões do MJ e MTE, e foi elaborada com participação de burocratas do Programa Bem Mais Simples da Presidência da República ${ }^{325}$, o qual se voltava, em linhas gerais, para desburocratização do governo federal. Nesse contexto, promoveu algumas mudanças incrementais na política migratória, sob o mote de desburocratizar procedimentos ${ }^{326}$. Sua aprovação no apagar das luzes do governo Dilma Rousseff é um (melancólico) retrato da trajetória observada na política migratória entre 2003-2016, marcada pelo incrementalismo ante a incapacidade de reforma.

\footnotetext{
${ }^{325}$ Página oficial do programa: http://www.brasil.gov.br/economia-e-emprego/2015/04/programa-bemmais-simples-menos-burocracia-no-ambiente-de-negocios. Acesso em: 23 mar 2017.

${ }^{326}$ Dentre elas, possibilitou a concessão de visto temporário para estrangeiro na condição de beneficiário de bolsa vinculada a projeto de pesquisa, desenvolvimento e inovação; autorizou a concessão de visto temporário para familiares e dependentes legais do titular de visto temporário de trabalho independente de proposta de trabalho prévia em nome próprio; simplificou procedimentos para a prorrogação do visto temporário e para transformação de vistos temporários em permanentes; facilitou a concessão de visto, pelo CNIg, no caso de capacidades profissionais estratégicas para o país.
} 
Após o término do intervalo temporal desse process-tracing, o PL 2.516/2015 foi aprovado na Câmara de Deputados em 06 de dezembro de 2016, e a Lei $\mathrm{n}^{\circ} 13.445$ foi sancionada em 24 de maio de 2017.

\subsection{Análise integrada}

Como resultado da agregação de diferentes áreas políticas em um único arranjo, o qual foi historicamente desenvolvido a partir de reformas parciais que acresciam novas instituições a estruturas previamente estabelecidas, a política migratória brasileira se tornou uma arena na qual atores burocráticos e políticos buscaram ampliar as capacidades estatais e a autonomia organizacional de suas instituições. As estratégias empreendidas de maneira a atingir tais objetivos levaram a um duplo resultado: mudanças incrementais na política associadas a dificuldades para reformá-la.

A mudança de arranjos institucionais é uma empreitada especialmente complexa quando exige a mobilização de diversas arenas, compreendendo não apenas as organizações com competência para formular a política, mas também aquelas que a implementam, bem como o Legislativo, entidades de outros níveis federativos, organizações sociais e não-governamentais envolvidas na implementação e em advocacy. Nessas conjunturas, às quais Abers e Keck (2013) denominam embaraçamento (entanglement), mudanças institucionais levarão a alterações na maneira com que o poder será acumulado e partilhado entre os diversos atores, públicos e privados. Desta forma, os atores envolvidos nas tomadas de decisão e na formação de agendas tenderão a buscar influenciar o remodelamento das instituições - configurandose, ainda de acordo com Abers e Keck (2013), como ativistas institucionais.

O estudo de caso mostrou que a reforma da política migratória, com revogação da Lei $n^{\circ} 6.815 / 1980$, era a alternativa de preferência de todos os atores entrevistados. Todos possuíam uma política preferível ao status quo. Trata-se, ademais, de uma demanda da sociedade, amplamente publicizada e veiculada em instâncias participativas, e de uma agenda que já vinha sendo mobilizada no Executivo e no Legislativo desde a década de 1990. Havia um reconhecimento geral de que precisava haver uma reforma migratória. No entanto, a reforma não ocorria. O process-tracing traz evidências de que mecanismos engendrados pela fragmentação do desenho institucional, nos quais atores burocráticos e dirigentes políticos empreendem esforços 
para manutenção e ampliação da capacidade estatal e da autonomia das suas organizações, levaram a disputas interorganizacionais que constituíram fator determinante para perpetuação do arranjo institucional sub-ótimo.

Poder-se-ia afirmar que o Legislativo seria o ponto de veto, que haveria uma indisposição ideológica no Congresso quanto a reformular o tratamento dado às migrações ou um total descaso em relação ao tema. Entretanto, a análise da tramitação de projetos de lei sobre a temática migratória não corrobora esta conclusão. À exceção da MSG nº 696/2010, que submete a ratificação da Convenção Internacional de Proteção aos Trabalhadores Migrantes e suas Famílias, os demais projetos tramitaram sem grandes percalços. Em que pese se observarem manifestações contrárias nos debates das Casas Legislativas, elas não obstaram a aprovação dos Decretos Legislativos $n^{\circ}$ 210/2004 e $n^{\circ}$ 925/2005, aprovando os Acordos de Residência para Nacionais do Mercosul e para Mercosul e Associados; da Lei de Anistia (Lei ${ }^{\circ}{ }^{\circ}$ 11.961/2009); do Decreto Legislativo no 302/2011 aprovando a entrada do Brasil na OIM e o $\mathrm{n}^{\mathrm{o}} 82 / 2015$ aprovando seus privilégios e imunidades; diversas normativas bilaterais; bem como a própria aprovação do PLS 288/2013 no pleno do Senado (15/07/2015) e do PL 2516/2015 no pleno da Câmara (06/12/2016). Para além desses indícios, os numerosos projetos de lei e de emenda constitucional de iniciativa de deputados e senadores com propostas de reformulação do regime aplicado aos imigrantes, assim como a mobilização da questão dos imigrantes nos debates e relatório provenientes da CPMI da Emigração, denotam não se tratar de temática negligenciada pelo Legislativo.

A ordem dos atores elencada no ponto 4.3 não é sem propósito: visa a indicar a sucessão dos atores do Executivo que despertaram para a questão. Se mecanismos constituem, tal como proposto por Beach e Pedersen (no prelo), a sequência de eventos e processos que levam ao evento que se quer explicar causalmente, a ordem dos eventos importa. Nesse contexto, observa-se o Ministério do Trabalho reforçando seu papel em política migratória já em 2005, quando desperta para a temática dos brasileiros no exterior e o CNIg começa a concentrar-se em atividades normativas. No MJ a questão ganha alguma centralidade já neste período, porém secundando a primazia concedida à temática do refúgio e, posteriormente, ao tráfico de pessoas. Em 2011, por seu turno, nota-se um claro ímpeto do MJ em construir uma política migratória - e ser dela protagonista. O MRE é um caso a parte: assumiu protagonismo sobre a política de 
emigração em um momento no qual o CNIg pleiteava a temática, assimilou-a como um objetivo da política externa brasileira e gradativamente foi construindo seu posicionamento em relação às migrações internacionais a partir do ponto de vista de um país de origem e destino de imigrantes.

Neste processo, conforme se depreende do process-tracing, os burocratas de médio escalão tiveram papel central. No esforço de construção de capacidades estatais, foram confrontados com condições ou informações que levaram à adoção de determinadas estratégias. Em consequência, empreenderam, no seu âmbito de ação, mudanças incrementais na política migratória. Dentre as mudanças incrementais observadas entre 2003 e 2016, destacam-se:

-Mudanças procedimentais no âmbito dos três Ministérios, simplificando os fluxos e aumentando sua celeridade, o que fortalece a garantia de direitos;

- Regulamentação de lacunas legais pelo CNIg, especialmente no que atine a vistos temporários, facilitando a entrada;

- Acordo sobre Residência para Nacionais dos Estados Partes do Mercosul, aliados a Chile, Bolívia, Peru, Equador e Colômbia;

- Fortalecimento do instituto da reunião familiar a partir de resoluções do CNIg;

- Portaria MJ 1.351/2014, com as modificações da 4/2015, facilitando o pedido de permanência;

- Criação de instâncias de participação social para oitiva da população imigrante e de organizações que trabalham com o tema;

- Criação do Visto humanitário para haitianos;

- Criação do Visto Temporário de Aperfeiçoamento Médico (VICAM);

- Medidas políticas de integração da população imigrante;

- Decreto $n^{\circ}$ 8.757/2016: desburocratização e simplificação do sistema de vistos.

Dentro do quadro conceitual proposto por Mahoney e Thelen (2010), as inovações identificadas na política migratória brasileira correspondem aos mecanismos de disposição em camadas, ou seja, à introdução de novas regras acima ou ao lado de regras já existentes. Isso estaria associado, de acordo com os autores, a pontos de veto numerosos e pouca discricionariedade. Embora o primeiro elemento seja inegável, é de 
se observar que a discricionariedade observada na implementação na ponta, isto é, nos agentes das fronteiras, é alta. No entanto, nas demais instâncias da política migratória, a discricionariedade se mostrava contingenciada pela obsoleta legislação.

No modelo de múltiplos fluxos de John Kingdon (1995), a mudança na agenda de uma política pública ocorreria a partir da convergência de três fluxos. O fluxo da política (politics) compreende as negociações, barganhas e consensos sobre o tema, e tem nos atores políticos seus protagonistas; o fluxo dos problemas corresponde à atuação de "atores visíveis" como políticos, empresas, candidatos, partidos, organizações da sociedade civil, que investem recursos nas políticas e atuam para que um "estado de coisas" seja reconhecido como problema; e no fluxo das alternativas políticas, desenvolvem-se soluções para os problemas elencados dentro de uma comunidade política de "atores invisíveis", dentre os quais burocratas, comunidades epistêmicas e lobbies.

O estudo de caso sobre a política migratória brasileira indica que tais fluxos não são de tal modo apartados e, principalmente, que a atuação dos burocratas não é nem invisível, nem adstrita ao fluxo das alternativas. Os burocratas de médio escalão atuaram com intensidade também no fluxo dos problemas, fazendo-se valer, para tanto, da promoção de seminários, oficinas e eventos, bem como de instâncias de participação social. O fluxo político de negociações, barganhas e formação de consensos sobre o tema também contou com burocratas, os quais, junto a outros atores de dentro e fora do Estado, conseguiram construir uma janela de oportunidade para a reforma migratória.

Com efeito, em muitos aspectos da política migratória, atingiram-se consensos. O primeiro deles, sobre a necessidade de substituição da política migratória; seguido dos princípios gerais que deveriam reger a nova legislação: respeito aos direitos humanos de todos os migrantes, independente da situação migratória; nãocriminalização das migrações e relação entre migrações e desenvolvimento. Paralelamente, percebe-se a estruturação de uma comunidade política (KINGDON, 1995) em temática migratória, com o aumento da densidade de contatos interorganizacionais, das interações entre atores estatais e não-estatais e do fluxo de informações - para o que concorreram os mecanismos de construção de capacidades estatais político-relacionais.

Assim, a política migratória brasileira é formulada e implementada em contexto de interação entre atores burocráticos, dirigentes políticos, outros atores estatais, setores 
privados, sociedade civil e comunidade epistêmica; no qual se identifica um entendimento mínimo comum sobre qual o problema a política deve enfrentar e quais as alternativas institucionais adequadas. Não obstante, há particularidades nas preferências específicas de cada ator. Notadamente, percebe-se que burocratas de médio escalão, junto aos dirigentes políticos, defenderam modelos que julgavam fortalecer a autonomia de suas respectivas organizações.

Esta tese recorreu a dois mecanismos organizacionais de maneira a explicar, a partir do desenho institucional, a dinâmica entre mudanças incrementais e ausência de reforma. O primeiro deles é o fortalecimento setorial das capacidades estatais da organização, sejam elas técnico-administrativas ou político-relacionais. Nesse ponto, o estudo de caso mostrou uma forte atuação burocrática, por meio de estratégias plurais.

Quanto às capacidades técnico-administrativas, nota-se que nos três Ministérios analisados foram implementadas mudanças institucionais para solucionar problemas de gestão administrativa, as quais acabaram repercutindo em garantias de direitos para os imigrantes. Desta forma, ao modificar fluxos de maneira a torná-los mais eficientes, céleres e transparentes, ou ao aprimorarem seus sistemas de informações, os burocratas incitaram mudanças incrementais no conteúdo da política ou em seus resultados. É o caso, por exemplo, das Portarias MJ 1.351/2014 e 4/2015, da implementação dos sistemas Migranteweb e MigranteDigital no MTE e o Sistema Consular Integrado (SCI) do MTE. Percebe-se que os argumentos de gestão estão fortemente presentes nos discursos dos burocratas de médio escalão analisados, inclusive a gramática do "universalismo de procedimentos" em oposição à do "clientelismo", conforme apontado por Nunes (2010). Ressalta-se, no caso do MJ, o papel de liderança exercido pelos burocratas de médio escalão ante resistência a mudanças encontrada nas equipes subordinadas.

Em um contexto de recursos limitados, outra estratégia de fortalecimento das capacidades técnico-administrativas foi o recurso a organizações internacionais para obtenção de financiamento e, principalmente, de expertise. Constata-se que tanto o MTE quanto o MJ, no momento em que passam a buscar fortalecer seu papel no contexto da política migratória, procuram contactar, respectivamente, a OIT e a OIM para executar projetos de fortalecimento institucional em política migratória, além de ações junto ao think tank ICMPD. Observam-se três objetivos nessas iniciativas: (i) busca da expertise dessas organizações; (ii) consultores das organizações internacionais 
contornam as dificuldades das instituições governamentais com contratação de pessoal; (iii) maneira de conseguir financiamento, especialmente via PNUD. No caso do Itamaraty, esta estratégia se apresenta de maneira um pouco distinta, não se percebendo projetos de fornecimento de expertise para redesenhos e estruturações institucionais internas, mas se notando a assinatura com a OIM de instrumento operacional (2008) para reassentamento de indivíduos na Bolívia e de acordos para implementação dos visa centers - os quais ampliam administrativa e tecnicamente a capacidade de implementação política do órgão.

Ressalte-se que tal estratégia se dá em paralelo a dificuldades que os Ministérios possuem de ampliarem seus quadros de recursos humanos, decorrentes da rígida estrutura de cargos em comissão em paralelo à orientação de não-contratação de terceirizados para atividades-fim.

Por último, ressalte-se que informação e dados foram elementos constantemente observados nas entrevistas desse estudo, sendo levantados tanto como um objetivo estratégico, quanto como instrumento de convencimento nas narrativas de negociações dentro do governo. Observa-se que as mudanças procedimentais implantadas pelos Ministérios mencionadas acima em muito se dirigem à reunião de dados e informações. No mesmo intuito, o MTE cria o ObMigra em 2014, em parceria com a Universidade de Brasília, e posteriormente assina acordo com a FGV e com o IBGE. Em 2016, iniciamse discussões com a SNJ para triangularizar o acordo com o IBGE.

Já quanto às capacidades político-relacionais, destaca-se de antemão a criação de espaços de debate como seminários, conferências e grupos de trabalho para discutir como as migrações deveriam ser geridas. Trata-se de estratégia de propagar sua visão sobre o problema e fomentar o debate sobre soluções para resolvê-los junto à sociedade civil organizada, setores privados e outros atores governamentais. Tanto o MTE quando a SNJ possuem em seminários os marcos de mudanças de sua trajetória no sentido de buscarem maior protagonismo na temática migratória. O MRE o faz paralelamente na temática das comunidades de brasileiros no exterior. Nas palavras do Presidente do CNIg, os motivos para realização dos seminários seriam:

Bom, é ... dois motivos. O primeiro é estimular o debate. Estimular que determinados temas, a gente possa envolver governo, sociedade, debatê-los e aprofundar, vamos dizer assim, o consenso em relação a determinados temas. E o segundo, é claramente a gente ter protagonismo no debate, o CNIg ter, ser uma das maneiras de como o CNIg é visto, como órgão promotor de 
discussões, de debates, para além de outras funções que nós temos (Paulo Sérgio de Almeida, Entrevista, 09/09/2016).

Mecanismos de participação social também são setorialmente observados: o MJ promove a COMIGRAR em 2014, além de implantar o Comitê de Acompanhamento pela Sociedade Civil sobre Ações de Migrações e Refúgio - CASC Migrante, enquanto o MTE cria o Fórum de Participação Social no ano seguinte. Já o MRE implementou em paralelo iniciativas de participação no que atine à emigração.

Identificou-se ainda a articulação federativa como mecanismo de expansão da atuação dos Ministérios do Trabalho e da Justiça para políticas de integração do imigrante. Para tanto, fazem uso de convênios e fortalecem a interlocução via seminários. Nota-se ademais a persecução da estratégia de advocacy junto ao Legislativo durante a tramitação do PL 2.516.

A estratégia de ampliação da capacidade estatal político-relacional que foi adicionada ao esquema de Gomide e Pires (2014), qual seja, mecanismos e procedimentos de interface com instituições internacionais, é também observada no process-tracing. Percebe-se que a interação com organismos internacionais identificada nos Ministérios se dá não apenas no desígnio de obter recursos e expertise, mas também de revestir-se de legitimidade ao aderir a suas boas práticas. Nesse processo, os atores se inserem em uma comunidade política migratória mais ampla, internacional, e passam a participar de seminários, eventos e diálogos internacionais. Tomam parte, ainda, em arenas multilaterais, inclusive nelas disputando espaço, como se verifica no caso da atuação do MJ e MTE no Mercosul. Paralelamente, mobilizam o recurso ao regime internacional em sua política, apoiando a ratificação do Brasil à Convenção de 1990 Resolução Recomendada do CNIg 10/2008, mensagem n ${ }^{\circ} 696$ do Ministro das Relações Exteriores Celso Amorim, discurso de Paulo Abrão no Diálogo de Alto Nível sobre Migrações (2013), anteprojeto da Comissão de Especialistas (2014).

Ragin (2008) coloca que definir conceitos compreende idas e vindas entre a pesquisa empírica e a revisão teórica. Nesses termos, observa-se que o mecanismo proposto expõe as condições estatais que conduzem às mudanças incrementais, mas não explora os fatores intervenientes que tensionam os mecanismos de ampliação das capacidades estatais e, desta forma, estimulam as respostas de mudança. $\mathrm{O}$ estudo de caso realizado aponta para três fatores: i) alterações críticas no objeto, isto é, nos fluxos migratórios; ii) judicialização; e iii) pressão social. Tais fatores tensionaram as 
instituições em diversos momentos, incitando a que ampliassem sua capacidade estatal, estando nas bases de mudanças como a Portaria MJ 1.351/2014, o visto humanitário para haitianos e modificações no procedimento de entrega de carteira de trabalho. Esses achados corroboram a visão de capacidades estatais como resultados não apenas de uma estrutura interna estanque, mas de processos de interação com atores múltiplos e negociação dos resultados políticos.

Por outro lado, o estudo de caso mostrou que, ao lado da promoção setorial de mudanças incrementais, as iniciativas de reforma migratória enfrentaram uma série de disputas interorganizacionais para sua consecução. Tais disputas se fundamentaram no objetivo de manutenção ou ampliação do espaço de poder das organizações, e se materializaram em desacordos sobre desenhos institucionais que permearam o debate dos vários projetos de lei no período em análise. Basearam-se, ainda, nas diferentes lógicas de ação organizacional, com os burocratas sustentando que a lógica institucional a ser impressa na reforma migratória deveria ser aquelas das suas respectivas organizações. No caso do Itamaraty, há uma predominância do segundo elemento: embora a instituição não se veja ameaçada em perder suas competências e até rejeite propostas que as ampliem, atém-se firmemente à sua lógica de ação, particularmente no que atine ao princípio da reciprocidade e ao sistema de vistos.

Por fim, observa-se que não se podem associar diretamente mudanças no âmbito internacional em política migratória a mudanças domésticas sobre o mesmo objeto, até porque uma tal perspectiva negligenciaria o caráter processual destas mudanças e seus potenciais efeitos mútuos. No entanto, o process-tracing revela, de um lado, uma construção conjunta da posição externa do país na temática, e de outro, uma capilarização do internacional na política doméstica como estratégia de ampliação da capacidade estatal das burocracias.

Evidenciou-se no estudo de caso que a posição externa do Brasil sobre migrações é construída paulatinamente por diversos atores domésticos em instâncias de interação domésticas e internacionais. Isso porque tanto atores de outros Ministérios participam de instâncias multilaterais, a convite do Itamaraty ou por iniciativa própria, quanto a interação de burocratas do MRE na comunidade política doméstica, seja no CNIg ou nos seminários e eventos organizados, contribuiu para construção de uma visão mínima comum do governo sobre política migratória. Essa visão se reflete na evolução do posicionamento externo do MRE sobre a temática: se em 2008 os 
pronunciamentos internacionais do Brasil sobre migrações acompanhavam a tradição da política externa e se focavam em questões de desenvolvimento econômico e de autonomia do país no sistema internacional, em 2012 a declaração da SGEB sobre princípios que devem reger a política migratória a alinhava ao que vinha sendo discutido pelos outros órgãos do governo, inclusive em instâncias multilaterais, sobre o tema. Essa postura governamental se harmoniza, ademais, com as recomendações oriundas das instâncias regionais sobre migrações nas quais o Brasil toma parte, particularmente Mercosul, CSM e CELAC.

Nota-se, ainda, que a projeção internacional do Brasil em temática migratória reflete o fato do Brasil ser país de destino e de origem de migrantes. É no contexto de objetivos de política externa relacionados aos brasileiros no exterior que a temática começa a ser mobilizada externamente, acomodando-se ao intento de mostrar o Brasil como exemplo de boas práticas na área, dentro do quadro de reivindicações de igualdade e reciprocidade que marcavam a atuação multilateral do país à época. Os múltiplos aspectos da temática levaram a um curioso paradoxo: o Brasil não ratifica instrumentos centrais do regime migratório, mas exorta outros países a fazê-lo em instâncias multilaterais.

Ressalve-se ainda que é no quadro de um objetivo de política externa a iniciativa responsável pela mais ampla mudança da política migratória brasileira no período em comento: o acordo de residência do Mercosul. A livre circulação no Mercosul é um interessante exemplo de construção compartilhada da projeção internacional: o acordo de residência foi costurado pelos Ministérios da Justiça, sob liderança determinante da Argentina; demandou intervenção do MRE para sua entrada em vigor no bloco; teve problemas em sua implementação relacionados a falta de coordenação entre os órgãos governamentais; foi operacionalizado em reuniões de Ministros da Justiça; e começou a ser objeto de iniciativas dos Ministérios do Trabalho. 


\title{
Capítulo 5: O Executivo em interação: arranjos de coordenação na política migratória brasileira
}

\author{
"No phrase expresses as frequent a complaint \\ about the federal bureaucracy as does "lack of \\ coordination." No suggestion for reform is more \\ common than "what we need is more \\ coordination.” Pressman and Wildavsky (1984, \\ p.133)
}

\subsection{Introdução}

O capítulo 4 empreendeu análise de como um arranjo institucional estrutura processos organizacionais que moldam, por conseguinte, os resultados políticos em imigração. O presente capítulo foca na dinâmica interorganizacional observada nesse processo. De fato, a conclusão do capítulo 4 é que os resultados políticos em migração em muito refletem dinâmicas organizacionais de salvaguarda da autonomia institucional, o que corrobora a visão de Allison de que governos constituiriam “(...) $a$ conglomerate of semi-feudal, loosely allied organizations, each with a substantial life of its own” (ALLISON, 1969, p.698).

No entanto, isso não significa que as organizações não interajam, sendo que mesmo o conceito de insulamento entende-as como semipermeáveis ao ambiente externo (GEDDES, 1994). Ademais, a diversificação dos processos de políticas públicas, muitas vezes marcados pela pluralização dos atores, complexifica a agregação de preferências na formação do output político, podendo demandar mecanismos de coordenação intragovernamental e de interlocução sócio-estatal. Nesses arranjos, como atores organizacionais agregam suas preferências em uma política pública?

De acordo com Peters (1998), a coordenação em arranjos institucionais complexos se refere à concertação para que organizações públicas e privadas de diferentes níveis hierárquicos e federativos atuem na formulação e implementação de políticas públicas, de maneira a reforçar sua coerência e evitar sobreposições, contradições ou lacunas na entrega dos serviços à população. Por vezes, essa coordenação obedece a uma lógica intersetorial, implicando no ajuste entre as competências setoriais dos atores com foco em um território, público-alvo ou problema complexo (LOTTA et al., 2016). 
A tendência centrífuga observada em interações organizacionais foi explicada pela literatura à luz de vários fatores, dentre os quais se destacam a proteção de território (turf protection), na qual cada agência se esforça para manter seu domínio de atuação e excluir deste espaço os demais, e as percepções das organizações de que haveria contradições entre seus programas (PETERS, 1998) ou suas missões, orientações profissionais, estruturas e processos das organizações (JENNINGS JR.; KRANE, 1994). Pode ser remetida, ainda, nos termos do capítulo 4, ao esforço das organizações de manterem seu espaço de poder e lógica de ação organizacional.

Não obstante tais fatores, determinados arranjos institucionais exigem que a coordenação intragovernamental ocorra, situações em que há um tensionamento entre a tendência centrífuga das organizações e a necessidade de coordenação da política pública. Nesse contexto, e com fundamento nas ideias de Peters (1998), desenha-se a hipótese descritiva deste capítulo, segundo a qual se verifica, no arranjo institucional complexo na política migratória brasileira, elementos de coordenação de arranjos hierárquicos, de mercado e de redes, no qual burocratas operam por meio de relações e trocas não previstas no desenho institucional formal e interagem com atores nãogovernamentais.

\subsection{A política e os burocratas: o alarme da crise - Haitianos no Brasil}

Uma tentativa de aplicar modelos explicativos unicausais de fluxos migratórios internacionais para o deslocamento de haitianos para o Brasil enfrentaria sérias dificuldades de isolar uma única variável. A crise política que se estendeu por cerca de 20 anos, e em consequência da qual se instalou, em 2004, a Missão das Nações Unidas para a Estabilização do Haiti - MINUSTAH, desenhou uma conjuntura na qual 58\% da população haitiana não usufruía de água limpa, 40\% não tinha acesso à alimentação adequada e 38\% da população acima de 15 anos era completamente analfabeta em 2009 (GODOY, 2011). O terremoto que atingiu o país em janeiro de 2010 levou a mais de 200.000 mortes e destruiu cerca de $60 \%$ da infraestrutura governamental administrativa e econômica, tendo sido seguido de uma epidemia de cólera que matou mais de 8.000 pessoas. Nesse contexto, o Banco Mundial estimou a diáspora haitiana, no ano de 2011, em $10 \%$ da população do país (apud FERNANDES et al., 2012). 
Se esse conjunto de fatores constitui os push factors haitianos, cabe ainda identificar quais seriam os pull factors do território brasileiro. Esse não constituía um destino tradicional dos fluxos haitianos, que majoritariamente se deslocavam para a República Dominicana, Estados Unidos, Canadá, França, ilhas do Caribe e Guiana Francesa. Alguns fatores teriam potencialmente estimulado o seu direcionamento para o Brasil: (i) o comando brasileiro na MINUSTAH, com a presença de soldados em território haitiano, teria disseminado uma imagem atrativa do Brasil; (ii) o país constitui corredor de acesso a Guiana Francesa e, também, etapa para conseguir vistos para outros países como Estados Unidos ou França; (iii) a construção da rodovia Transoceânica, ligando a Amazônia brasileira ao Pacífico via Peru, favorecendo o trânsito terrestre de pessoas; (iv) conjuntura econômica de pleno emprego no país, em detrimento de outros locais, no início da década de 2010; (v) informação propalada por agenciadores de redes de tráfico de imigrantes, os coiotes, de que o migrante teria elevada remuneração e benefícios ao chegar ao país; (vi) política migratória de abertura aos haitianos a partir da definição do visto humanitário (GODOY, 2011; FERNANDES et al. 2012; FERNANDES; CASTRO, 2014; METZNER, 2014; OBMIGRA, 2016).

Especificamente sobre o fator apontado do comando brasileiro da MINUSTAH, assumindo a frente de cerca de mil e duzentos soldados em junho de 2004 a despeito de sua habitual resistência a participar de operações de paz, se deveria, na opinião de Maria Regina Soares de Lima (2005c), ao duplo objetivo do Brasil de consolidar sua liderança na América Latina e conquistar o assento permanente no Conselho de Segurança da ONU. A adesão à MINUSTAH foi, à época, justificada pelo chanceler Celso Amorim como fundamentada no conceito da não-indiferença, cunhado em contraponto ao de não-intervenção. Ainda de acordo com Lima, "o conceito é revelador das novas disposições internacionais do país e vincula esse tipo de prática ao compromisso expresso do Governo Lula com a inclusão social e sua política de eliminação do problema da fome endêmica e da pobreza absoluta" (2005c, p.19).

Alguns anos depois, em 2009, a inclusão de objetivo no Programa Nacional dos Direitos Humanos - 3, relativo à consolidação de agenda de cooperação multilateral em direitos humanos que contemplasse prioritariamente o Haiti, explicitava essa dimensão da política externa brasileira para o país latino-americano. Tinha como órgãos responsáveis pela execução a Secretaria de Direitos Humanos da Presidência, o Ministério do Desenvolvimento Social e Combate à Fome e o MRE. 
Pouco menos de um mês após o terremoto, a Unasul publicou, em 09 de fevereiro de 2010, a Decisão de Quito de Solidariedade da Unasul com o Haiti ${ }^{327}$, na qual, dentre várias medidas, exorta os Estados Membros que ainda não o tivessem feito a aplicar processos especiais de regularização migratória a favor de cidadãos haitianos. A solidariedade com a nação haitiana configurou, deste modo, um posicionamento externo regional, tendo nas migrações um de seus elementos. O Brasil, em que pese haver assinado a declaração, não havia estabelecido canais especiais de regularização migratória para haitianos, nem viria a fazê-lo ato contínuo.

Durante o ano de 2010, pequenos grupos de haitianos chegaram à fronteira brasileira por rotas terrestres, após atravessarem o território do Peru, principalmente, e da Bolívia, assomando nas cidades de Tabatinga (Amazonas), Brasileia (Acre), Epitaciolândia (Acre). As rotas, muitas vezes operadas por coiotes, foram influenciadas pelo fato de Peru e Equador não exigirem, à época, visto de entrada para haitianos; bem como das fronteiras brasileiras com o Peru e a Bolívia serem precariamente controladas.

A recepção e acolhida desse fluxo foi, em um primeiro momento, realizada pela sociedade civil. Fernandes e Castro (2014) salientam uma diferença entre as respostas dos governos estaduais envolvidos: enquanto no Acre notou-se a montagem de estrutura de atendimento governamental, o estado do Amazonas a princípio ignorou o problema e, posteriormente, forneceu pequenas contribuições para ações da sociedade civil. O fato é que, em cidades com tão poucos habitantes ${ }^{328}$, a chegada daquelas centenas de indivíduos tensionou a infraestrutura local. Com entradas diárias que chegaram a ultrapassar 40 pessoas (FERNANDES et al., 2014), os municípios fronteiriços passaram a não conseguir atender suas necessidades básicas.

Em fevereiro de 2011, após reunião instada pelo governador do Acre, Tião Viana e coordenada pelo Ministro da Casa Civil, Antônio Palocci, o governo federal decidiu intervir na questão, enviando forças-tarefas para as principais cidades de acolhida a fim de coordenar ações de registro daqueles migrantes, o que se deu a partir do encaminhamento de pedido de refúgio. Como a Lei $n^{\circ}$ 6.815/1980 não contempla a possibilidade de uma pessoa vir para o Brasil e aqui procurar emprego, a solicitação de refúgio acaba constituindo uma alternativa, visto que gera um protocolo que confere a

\footnotetext{
${ }^{327}$ Disponível em: http://www.itamaraty.gov.br/images/ed_integracao/docs_UNASUL/DEC.2010.SOLHAITI.pdf. Acesso em: 26 mar 2016.

${ }^{328}$ Dados do Censo 2010: Brasileia (AC), 21.398 habitantes, Epitaciolândia (AC), 15.100 habitantes, Tabatinga (AM), 52.272 habitantes (IBGE, 2010).
} 
seu titular o direito à carteira de trabalho, vigente enquanto o pedido pender de decisão. As forças-tarefas federais contemplavam, ainda, atendimento médico aos migrantes. Desta maneira, a primeira abordagem do governo federal consistiu em regularizar os haitianos já presentes em território brasileiro.

O Ministério Público Federal no Acre (MPF/AC) promoveu, em 4 e 5 de maio de 2011, uma audiência pública para discutir o encaminhamento jurídico e humanitário a ser dado aos haitianos ${ }^{329}$. No intuito de instar os órgãos competentes a assumirem suas respectivas responsabilidades no atendimento a esta população, o procurador regional dos direitos do cidadão, Ricardo Gralha Massia, convidou uma série de atores governamentais para debater o tema junto à sociedade civil $^{330}$.

Segundo Gabriel Godoy (2011), oficial de proteção do ACNUR presente na audiência, evidenciou-se na ocasião o desacordo entre agentes públicos sobre o status migratório que deveria ser aplicado à situação. Uma vez que não se encontrava guarida jurídica para a acolhida no Estatuto do Estrangeiro, levantou-se a possibilidade de enquadrá-los na condição de refugiado nos termos do inciso III, art $1^{\circ}$ da Lei 9.474/1997, isto é, devido a grave e generalizada violação de direitos humanos. Godoy (2011) explica a decisão tomada no CONARE sobre o assunto:

Sobre a definição mais ampla de refugiado, três aspectos foram considerados
relevantes para a aplicação do inciso III da Lei 9.474/1997: a incapacidade
total de ação do Estado de origem; a carência de paz duradoura; e o
reconhecimento da comunidade internacional sobre a grave e generalizada
violação de direitos humanos no território ou Estado em questão. Ademais, o
solicitante deveria demonstrar que existe ameaça contra sua vida, segurança
ou sua liberdade. Finalmente, outro ponto considerado foi que o conceito de
refugiado da Convenção de 1951 não inclui os casos de vítimas de desastres
naturais, a menos que estas também tenham fundado temor de perseguição
por um dos motivos referidos pela legislação sobre refúgio. Portanto, a
conclusão do CONARE é que a proteção de pessoas que não podem voltar a
seu país de origem devido a catástrofes naturais deveria ser pensada no marco
de outro cenário, para além da Convenção de 1951 e da Lei de refúgio
brasileira (GODOY, 2011, p.62).

A categoria dos "refugiados ambientais", embora reivindicada por determinados países na arena internacional, não é pacífica nem se encontra recepcionada pelo regime internacional. No entanto, o caráter humanitário das situações que envolve levou o Alto

\footnotetext{
${ }^{329}$ Notícia oficial disponível em: http://www.prpa.mpf.mp.br/news/2011/noticias/audiencia-publicadiscutira-situacao-juridica-de-haitianos-em-solo-brasileiro. Acesso em: 13 nov 2016.

${ }^{330}$ Foram convidados para a reunião representantes do Ministério Público do Trabalho, Ministério da Justiça, Polícia Federal, Exército, Itamaraty, Conselho Nacional de Refugiados (Conare), Conselho Nacional de Imigrantes (CNIg), o Alto Comissariado da ONU para refugiados (ACNUR), Secretaria de Estado de Justiça e Direitos Humanos do Acre (SEJUDH/AC), Secretaria de Estado de Saúde do Acre (Sesacre), Comitê de Solidariedade aos Haitianos e a organização Cáritas Brasileira.
} 
Comissário das Nações Unidas para Refugiados, António Guterres, e a Alta Comissária das Nações Unidas para os Direitos Humanos (ACNUDH), Navanehtme Pillay, a emitirem comunicado em junho de 2011 pedindo aos países que, em razão da situação ainda debilitada do Estado e sociedade haitiana, não procedessem a deportações de haitianos (GODOY, 2011).

Nesse contexto, o governo brasileiro buscou respaldar a acolhida, em um primeiro momento, mediante remessa dos pedidos de refúgio de haitianos pelo CONARE ao CNIg, à luz da $\mathrm{RN} \mathrm{n}^{\mathrm{o}}$ 27/1998 do CNIg, que o permite decidir em situações especiais e casos omissos, combinada com a RR n ${ }^{\circ}$ 08/2006 do mesmo órgão, posteriormente corroborada pela $\mathrm{RN} \mathrm{n}^{\mathrm{o}}$ 13/2007 do CONARE, prevendo que um pedido de refúgio que não atenda aos requisitos de elegibilidade pode ser encaminhado ao CNIg para concessão de permanência por razões humanitárias. Nesse quadro, em março de 2011, o CNIg concedeu residência permanente por razões humanitárias a 199 haitianos (FERNANDES et al., 2014).

No entanto, a solução encontrada se baseava em fluxo processual bastante ineficiente. Isso porque exigia que um primeiro órgão da administração fosse instado, o CONARE, para que ele reconhecesse não ser sua atribuição e remetesse a solicitação para um segundo órgão, o CNIg, o qual não possuía estrutura para realizar a relatoria de tamanho vulto de processos. Ademais, a ausência de meios para entrada regular no Brasil fomentava a atuação das redes de coiotes, impelindo os migrantes a rotas irregulares e inseguras.

Nesse contexto, a Casa Civil seguia convocando reuniões interministeriais de coordenação da resposta do Governo Federal ao influxo de migrantes haitianos. Nelas, optou-se pela estratégia de regularizar a entrada desses últimos no país. O CNIg então aprova, em 12 de janeiro de 2012, a Resolução Normativa $n^{\circ} 97^{331}$, determinando a concessão de visto permanente de caráter humanitário para os haitianos, com duração de 5 anos. A resolução estabelecia uma cota de 1.200 vistos humanitários por ano a serem concedidos pela Embaixada brasileira, exclusivamente, em Porto Príncipe - sem prejuízo das demais modalidades de vistos.

\footnotetext{
${ }^{331}$ Prorrogada pelas Resoluções n ${ }^{\circ}$ 106/2013, 113/2014, 117/2015 e 123/2016.
} 
Muito embora a $\mathrm{RN} \mathrm{n}^{\circ} 97$ tenha sido aprovada em reunião do CNIg, apreende-se de entrevistas com burocratas ${ }^{332}$ e da ata da reunião que seu locus decisório havia sido outro mais elevado. No relato de Paulo Sérgio de Almeida,

Mas, assim a decisão de criar o visto acabou sendo... Embora o CNIg tenha colocado essas opções para os muitos órgãos, acabou que a própria Casa Civil, na época, acionou o CNIg, entendendo que nós deveríamos... propondo que fosse criado o visto, e o CNIg entendeu que era razoável, de fato, a pressão, já tinha feito o debate e já havia consenso, inclusive, em plenário, para essa criação (Entrevista, 09/09/2016 - grifo nosso).

Já Fábio Balestro Floriano, à época assessor internacional da Secretaria de Direitos Humanos da Presidência, relata que o plano que vinha sendo discutido no CNIg era distinto dos termos insculpidos na Resolução: envolvia acordos com sindicatos de trabalhadores e patronais para assegurar qualificação e empregabilidade aos migrantes, inclusive com vistas a seu retorno ao Haiti para auxiliar na reconstrução do país. De fato, em ata da reunião de 23 de novembro de 2011, o Presidente do CNIg discorre sobre programa a ser implementado nos seguintes termos:

(...) canal esse [de regularização] que seria circular, ou seja: o imigrante permaneceria em território brasileiro tão somente com o objetivo de alcançar qualificação profissional e retornar ao seu país de origem, sendo que, durante esse período, teria acesso à possibilidade de exercício profissional a fim de prover seu próprio sustento (CNIg, 23/11/2011, p.6).

O debate apresentou algumas reações à proposta: Marjolaine Canto (representante da CNC) opinou que "enviar instrutores brasileiros ao Haiti através de programas de parceria para qualificação de mão de obra seria mais eficiente do que trazer esses imigrantes para serem treinados no Brasil", (CNIg, 23/11/2011, p.6), e Odilon Braga (representante da Central de Trabalhadores e Trabalhadoras do Brasil CTB) afirmou que "as centrais sindicais provavelmente aceitarão bem a proposta de estabelecimento de um canal migratório formal se restar claro que se trata de migração circular, ou seja: que o imigrante se comprometerá a deixar o Brasil e retornar ao Haiti tão logo se encerre o processo de qualificação"(CNIg, 23/11/2011, p.7). Ao final, os representantes foram orientados a consultar suas organizações e trazer a resposta na reunião posterior, em 14 de dezembro de 2011. Nessa ocasião, tampouco foi desenhada proposta de programa, repetindo-se o encaminhamento de consultar entidades a fim de subsidiar sua elaboração.

332 João Guilherme Granja, 09/09/2016; Flávio Balestro Floriano 01/06/2016; Paulo Sérgio Almeida, 09/09/2016. 
Na reunião seguinte, convocada extraordinariamente em 12 de janeiro de 2012, compareceu o então Secretário Executivo do Ministério da Justiça, Luiz Paulo Barreto, com o respaldo do Ministro do Trabalho Paulo Roberto, e apresentou a proposta da RN no 97, alegando já haver sido acertada com a Presidenta Dilma Rousseff. Afirmou o secretário:

\begin{abstract}
Quanto à questão do estabelecimento do canal formal de migração, a Presidência da República entendeu por bem remeter o assunto ao CNIg, por entender ser o Conselho dotado de competência para regular as situações especiais e os casos omissos, motivo pelo qual o Ministro de Estado do Trabalho e Emprego convocou a presente reunião, com o fito de se debater o tema e apreciar proposta de resolução relativa ao mesmo. A ideia inicial foi de se propor a concessão de um visto de trabalho (item V), mas observou-se o óbice imposto pela necessidade de vinculação o visto a um contrato de trabalho. Outro ponto é a preocupação em se limitar o número de vistos, de modo a evitar que a concessão dos mesmos venha a fomentar uma diáspora haitiana. A própria precariedade econômica foi pesada como fator de inibição da migração, tendo em vista que não são muitos os haitianos que atualmente possuem condições econômicas para arcar com as próprias despesas da viagem. Esses fatores conduziram a uma estimativa média de cem vistos mensais, ou seja, a um limite de 1.200 vistos por ano concedidos nessas bases (Luiz Paulo Barreto, Ata do CNIg, 12/01/2012, p.2).
\end{abstract}

A fixação do teto de vistos, sem dados ou estudos que a acompanhassem e, particularmente, sem levar em conta os fluxos migratórios em sua justificativa, foi alvo de questionamentos do representante da Secretaria de Direitos Humanos, Fábio Balestro, e da representante do IMDH, Ir. Rosita Milesi - ambos membros observadores e sem direito a voto. A isso replicou o Ministro do Trabalho, com novos argumentos:

O Min. Paulo Roberto informou que o número de vistos estabelecido como limite foi firmado tendo por base diversos aspectos, dentre os quais a capacidade operacional da Embaixada do Brasil no Haiti e a capacidade do mercado de trabalho brasileiro de absorver essa mão de obra sem prejuízo das vagas para trabalhadores nacionais e o fato de que a publicação da resolução não impede que trabalhadores haitianos ingressem no Brasil por meio dos outros canais formais já estabelecidos, os quais se encontram disponíveis equanimemente a todos os estrangeiros (CNIg, 12/01/2012, p.4).

A $\mathrm{RN} \mathrm{n}$ ( 97/2012 foi aprovada pelo Conselho nos termos propostos pelo Secretário Executivo do MJ, em que pese nunca haverem sido divulgados os fundamentos das cotas. Ato contínuo à aprovação, os ministros da Justiça, José Eduardo Cardozo, e das Relações Exteriores, Antônio Patriota, publicaram artigo na Folha de São Paulo intitulado "Brasil e Haiti: parceria para o desenvolvimento", no qual justificavam a medida:

Esse espírito nos leva a tratar da questão migratória com sensibilidade humanitária e solidária. Preocupa que cidadãos haitianos sejam vítimas de intermediários inescrupulosos, que sejam objeto de extorsão, de violência e 
de abusos. Tornou-se necessário, assim, implementar medidas de ordenação do fluxo migratório de haitianos para o Brasil, de modo a garantir o respeito à dignidade e aos direitos humanos dos migrantes. O Conselho Nacional de Imigração (CNIg) adotou uma resolução que permitirá a concessão de até 1.200 vistos de trabalho por ano, além dos concedidos normalmente. (...) Erra quem vê na nova medida uma restrição à entrada de haitianos no Brasil. Pelo contrário, trata-se de uma abertura, em caráter excepcional, que estabeleceu condições especiais de ingresso no Brasil, para além da liberdade de ingresso já permitida. Essa manifestação adicional de solidariedade é bem recebida por todos aqueles, inclusive as autoridades haitianas, que se insurgem contra o tráfico de imigrantes (Folha de São Paulo, 15 de janeiro de $2012^{333}$ ).

Dias depois, a Presidenta Dilma Rousseff realizou visita oficial ao Haiti, em $1^{\circ}$ de fevereiro de 2012, ocasião na qual discutiu com o Presidente Michel Martelly aspectos relativos ao processo de reconstrução e desenvolvimento econômico e social do Haiti e à migração de seus nacionais para o Brasil (Resenha de Política Exterior do Brasil. Número $110,1^{\circ}$ semestre de 2012).

Ressalte-se que, em paralelo à concessão de visto humanitário, as reuniões interministeriais na Casa Civil articularam ações de auxílio humanitário e integração laboral dos migrantes haitianos, as quais envolveram Ministério do Desenvolvimento Social e Combate à Fome (MDS), Ministério da Saúde (MS), a Secretaria Geral da Presidência, o Ministério da Defesa, Agência Brasileira de Inteligência (ABIN), o MJ e o MTE. Este último viabilizava a emissão de carteiras de trabalho na região, o que constituiu a tônica da intervenção governamental naquele momento. De acordo com Diogo de Sant'Ana, então Chefe da Assessoria Especial da Casa Civil:

Naquele momento houve uma grande mobilização no governo voltada para
procurar empresários para que empregassem essa população, particularmente
na construção civil, nos frigoríficos de Santa Catarina, uma área que
necessitava à época de mão de obra, e no turismo. O fato é que isso
conseguiu absorver uma parte dos haitianos que estavam chegando.
(Entrevista, 09/02/2017).

De fato, a população haitiana no Brasil, majoritariamente composta de homens em idade produtiva, empregou-se principalmente em atividades de construção civil, frigoríficos, restaurantes e limpeza nos estados de São Paulo, Paraná, Santa Catarina e Rio Grande do Sul (CAVALCANTI et al., 2016). As condições de aliciamento desta mão-de-obra por empresas que se dirigiam ao Acre, entretanto, foram denunciadas pela sociedade civil:

No começo, como se tinha uma demanda enorme, sobretudo no setor da construção civil, as empresas acabaram absorvendo essa mão-de-obra

\footnotetext{
${ }^{333}$ Disponível em: http://www1.folha.uol.com.br/fsp/opiniao/20185-brasil-e-haiti-parceria-para-odesenvolvimento.shtml. Acesso: 26 mar 2016.
} 


\begin{abstract}
diretamente de Brasiléia, o que se tornou, segundo muitos pesquisadores e organizações de direitos humanos, uma espécie de retorno ao período da escravidão. Quando chegavam os negros escolhia-se os mais forte e os levavam para trabalhar. Inclusive o MP [Ministério Público] de Rondônia tem um inquérito bem interessante nesse sentido, onde o procurador diz que olhava-se as canelas dos imigrantes para ver se eram fortes, olhavam até a genitália. Aconteceram cenas absurdas ali. Nós, como sociedade civil, sempre tivemos uma posição muito clara, que era preciso que o governo federal tivesse um plano e que não permitisse que os haitianos ficassem muito tempo lá no Acre (Paulo Illes, 05/09/2016).
\end{abstract}

No período, o MJ e o MRE atuaram junto ao Peru e Equador no intuito de convencê-los a demandar vistos para nacionais haitianos, o que foi feito pelo governo peruano no início de 2012. No entanto, a medida não foi suficiente para dissipar as rotas irregulares, com os coiotes atuando inclusive via novas rotas que compreendiam Venezuela, Bolívia e Argentina (FERNANDES; COSTA, 2014). Maria Rita Faria (2015) aponta que um aumento no fluxo teria sido desencadeado pelo anúncio de que o governo equatoriano imporia requisitos para o ingresso de haitianos, o que teria levado migrantes a aproveitarem as oportunidades de entrada naquele país enquanto ainda havia. Assim, voltava-se a desenhar uma situação de calamidade pública na fronteira, com a lotação do abrigo em Brasileia no início de 2013. Entre os meses de março e abril, cerca de mil pessoas chegaram ao abrigo, conjuntura que levou o governador do Acre, Tião Viana, a decretar situação de emergência humanitária. Na ocasião, Viana alertou que a rota Equador-Peru-Acre tornara-se uma das principais rotas de migração ilegal na região.

Em resposta ao ato do governador, uma força tarefa interministerial foi enviada aos municípios de Brasileia e Epitaciolândia, no Acre, em abril de 2013 a fim de promover regularização migratória e documental dos haitianos, realizar seu cadastramento em programas assistenciais federais, e articular com municípios e estado a expansão da infraestrutura local, particularmente no que diz respeito ao abrigamento. O Itamaraty cedeu funcionários e equipamentos do Consulado do Brasil em Cobija, Bolívia (FARIA, 2015). A força-tarefa foi acompanhada à distância pela Casa Civil.

Ademais, em 26 de abril de 2013, a RN no 97 foi alterada pela Resolução Normativa $\mathrm{n}^{\circ} 102$, a qual eliminou a limitação do número de vistos humanitários por ano e autorizou o Itamaraty a emiti-los também em outros postos consulares. As Embaixadas em Quito, Lima e São Domingos passaram a conceder vistos permanentes para haitianos - entretanto, em razão de problemas com fraude documental, a emissão 
em São Domingos foi rapidamente suspensa ${ }^{334}$. Tal medida visava a possibilitar que haitianos em trânsito para o Brasil regularizassem sua situação no decorrer da rota migratória, refreando desta forma as redes de coiotes.

Em 15 de maio de 2013, o Brasil promoveu a Reunião de Coordenação Regional sobre a Migração de Cidadãos Haitianos para a América do Sul, na qual estiveram presentes autoridades de Bolívia, Brasil, Colômbia, Equador, Haiti, Peru e República Dominicana. Os trabalhos, dirigidos pelo Subsecretário-Geral das Comunidades Brasileiras do Exterior, Embaixador Sérgio Danese, concentraram-se em iniciativas e projetos de cooperação regional para enfrentar o tráfico de migrantes, enfatizando o combate a atividades criminosas (Resenha de Política Exterior do Brasil. Número 112, $1^{\text {o }}$ semestre de 2013). Por conseguinte, as delegações acordaram em promover campanhas informativas no Haiti, Equador, Peru e República Dominicana sobre os riscos e perigos da migração irregular, bem como cooperação policial e de inteligência e reforço do controle fronteiriço com os países vizinhos para coibir a atuação da rede de coiotes (SGEB, 2013). Alguns meses depois, o Equador adotou a exigência de cartaconvite com o objetivo de restringir a imigração ilegal. Predominava, portanto, a visão de que a melhor alternativa política para o problema estaria em fortalecer o combate aos fluxos irregulares de migrantes.

Em que pese tais medidas, os fluxos continuaram se dirigindo ao Brasil. Paralelamente, as filas de solicitantes de vistos na embaixada de Porto Príncipe persistiam. As tensões crescentes no Acre levaram as organizações da sociedade civil Conectas e a Missão Paz a acionarem a Comissão Interamericana de Direitos Humanos, em outubro de 2013, para realização de audiência sobre a precária situação dos migrantes no abrigo de Brasileia. No ano seguinte, a Conectas levou a questão ao Conselho de Direitos Humanos da ONU, em Genebra (Suíça).

Dados do governo do Acre divulgados em agosto de 2013 relatavam que os migrantes, majoritariamente haitianos, compunham cerca de $10 \%$ da população de Brasileia (FARIA, 2015), e que desde 2010, mais de dez mil estrangeiros teriam passado pelo estado. Nesse momento, constata-se um afluxo também de senegaleses e, em menor vulto, dominicanos e nacionalidades variadas. Um grupo da Comissão de Relações Exteriores do Senado, criado pelo Senador Ricardo Ferraço (PMDB-ES) a requerimento do Senador Jorge Viana (PT-AC), se deslocou ao Acre para visitar os

\footnotetext{
${ }^{334}$ Informação obtida com o MRE via Lei de Acesso à Informação.
} 
abrigos e discutir com as autoridades locais. A situação foi deteriorando-se e, em 2014, o administrador do abrigo em Brasileia afirmou haver 2.000 migrantes em suas instalações, que comportavam 400 pessoas $^{335}$. Ante reações da população, crise ambiental provada pela cheia do Rio Madeira, ampla cobertura midiática e em ano eleitoral, a resposta encontrada pelo governador do Acre foi desativar o abrigo de Brasiléia, transferindo parte dos imigrantes para abrigo em Rio Branco e enviando outra parte para São Paulo, em abril de 2014.

Em consequência, cerca de 650 haitianos passaram no mês de abril pela Missão Paz, entidade confessional que realiza atendimento a migrantes e refugiados em São Paulo $^{336}$. Enquanto os governos do Acre e de São Paulo trocavam farpas publicamente $^{337}$, a sociedade civil reivindicava a implementação de uma política migratória nacional ${ }^{338}$. Nesse sentido, relata Paulo Illes, à época Coordenador de Políticas para Migrantes da Prefeitura de São Paulo:

Imagine um município como Brasiléia que tem 6 mil moradores e de repente recebe 8,9 mil imigrantes. Isso saturou tudo, virou um problema eleitoral pro Acre, a xenofobia estourou, foi uma situação bastante complicada. Acho que o maior problema aqui foi a inércia do governo federal até que o Acre colocou as pessoas em um ônibus e mandou para São Paulo(...) Nós da prefeitura de São Paulo, digo nós porque eu estava lá na época, tivemos um papel fundamental que foi justamente mostrar para o Governo Federal que quem era responsável por isso tudo era o Governo Federal (Paulo Illes, 05/09/2016).

De fato, o envio dos ônibus a São Paulo e as tensões políticas disso decorrentes evidenciaram um vácuo de responsabilidade sobre a questão migratória. Nesse contexto, o Procurador-Chefe do Ministério Público do Trabalho (MPT) em Rondônia e Acre, Marcos Gomes Cutrim, compareceu à reunião do CNIg de 13 de maio de 2014 para convidar os conselheiros para Reunião Técnica em Rio Branco, objetivando incitar os

\footnotetext{
${ }^{335}$ MIGRAMUNDO, "Borges diz que 50 migrantes chegam em média ao abrigo de Brasileia por dia, sendo que apenas 20 deles conseguem deixar a cidade". 28/03/2014. Disponível em: http://migramundo.com/imigrantes-no-acre-situacao-proxima-do-caos-entidades-no-limite-e-criticas-aatuacao-dos-governos/. Acesso em: $27 \mathrm{dez} .2016$. ${ }^{336}$ MIGRAMUNDO, "Em coletiva, Missão Paz faz apelo urgente por política migratória nacional". 22/05/2014. Disponível em: http://migramundo.com/em-coletiva-missao-paz-faz-apelo-urgente-porpolitica-migratoria-nacional/. Acesso em: 27 dez. 2016.

${ }^{337}$ G1. "Tião Viana rejeita reunião com Alckmin para tratar sobre haitianos".07/05/2014. Disponível em: http://g1.globo.com/ac/acre/noticia/2014/05/tiao-viana-rejeita-reuniao-com-alckmin-para-tratar-sobrehaitianos.html. Acesso em: $27 \mathrm{dez} 2016$.

G1. "Tião Viana acusa governo de SP de preconceito contra imigrantes". 24/04/2014.Disponível em: http://g1.globo.com/ac/acre/noticia/2014/04/tiao-viana-acusa-governo-de-sp-de-preconceito-contraimigrantes.html. Acesso em: 27 dez. 2016.

${ }^{338}$ Idem, ibidem.
} 
atores governamentais ao debate a fim de definir a política de acolhimento. De acordo com Cristiane Lopes, procuradora do MPT,

\begin{abstract}
Houve um problema de articulação pois não possuímos instâncias de articulação entre esferas do governo, é necessária a criação de fóruns ad hoc. Trata-se de um dos elementos que levou o MPT à criação de fórum ad hoc de debate, para que os governos não ficassem mais atribuindo responsabilidade uns aos outros (Entrevista, 27/10/2016).
\end{abstract}

O Ministério da Justiça passou a assumir maior protagonismo no manejo da articulação federativa, não sem relutância: Paulo Illes narra que, em reunião realizada em Brasília, "Chegamos lá com o pessoal do Acre e não conseguimos nenhum acordo. O Paulo Abrão disse para nós de São Paulo entrarmos em acordo com o Acre. Mas peraí, São Paulo e Acre não têm que entrar em acordo, quem tem que cuidar disso é o MJ" (Entrevista, 05/09/2016). O Ministério da Justiça então implementou uma ação que definiu como receptivo dos imigrantes, com postos de informação e documentação na cidade de São Paulo, e passou a financiar o transporte dos haitianos entre Acre e São Paulo $^{339}$. Em 30 de maio, o MJ aproveitou a abertura da COMIGRAR para firmar termo de cooperação para atendimento e integração dos imigrantes com a Prefeitura de São Paulo e os governos estaduais de São Paulo e Acre. No segundo semestre de 2014, foram inaugurados o Centro de Referência e Acolhida para Imigrantes, da Prefeitura de São Paulo, com financiamento compartilhado entre o governo federal (infraestrutura) e municipal (recursos humanos e manutenção).

Tais medidas de integração não solucionaram a questão, uma vez que as entradas pelo Acre continuavam numerosas. O MPT decidiu propor uma ação civil pública ${ }^{340}$, com fundamento na Convenção 97 da OIT e finalidade de cobrar protagonismo do Governo Federal no controle das migrações, na adoção de medidas efetivas para regularização da rota migratória, bem como na prestação de serviços aos migrantes, entre eles a atenção médica, transporte interestadual, intermediação de mão de obra, documentação e capacitação laboral (LOPES, 2016). Representantes do MJ, MRE, MDS, MTE, MS e CNIg foram chamados a negociar um fluxo geral para a execução de políticas públicas. Dentre os acordos atingidos, encontra-se previsão expressa de que a União deve dar aporte técnico e financeiro à oferta de serviços e políticas para

\footnotetext{
339 Só nos anos de 2014 e 2015, o Ministério da Justiça destinou mais de R\$ 6,65 milhões do seu orçamento a convênio com a Secretaria de Desenvolvimento Social do Estado do Acre, com a finalidade de mobilidade de haitianos daquele Estado para outras destinações do território nacional (SNJ, 20152016).

${ }^{340}$ Ação Civil Pública 0000384-81.2015.5.14.0402 ajuizada na 2a Vara do Trabalho de Rio Branco
} 
migrantes.

A persistência dos fluxos irregulares evidenciou que uma nova abordagem para a questão precisava ser encontrada. Logo, a Casa Civil convocou os Ministérios envolvidos para novas reuniões, em 12 e 21 de maio. Nelas, a temática da segurança das fronteiras passou a ser vocalizada com maior intensidade. De acordo com João Guilherme Granja, essa postura foi contra-argumentada a partir do levantamento de dados e estudos sobre o tema:

\footnotetext{
De fato, foi a primeira vez que a gente estava com muito material empírico, muito dado, muita informação de campo para mostrar que no começo de 2015 ainda era a aposta de investir em aumento da capacidade de visto, esquecer a ação da fronteira. A fronteira não é causal para nada, as causas dos fluxos migratórios não serão resolvidas na fronteira (Entrevista, 09/09/2016).
}

A Casa Civil apoiou uma tríplice estratégia: de um lado, descentralização das estruturas de acolhimento, expandindo-a para outros estados com grandes populações imigrantes, como Paraná e Rio Grande do Sul. De outro lado, controle migratório mais intensificado nas fronteiras terrestres aliado à gestão diplomática junto a Peru, Bolívia e, principalmente, Equador. Reunião técnica e ministerial em Brasília entre autoridades desses países, nos dias 13 e 14 de julho, presidida pelo Ministro da Justiça, José Eduardo Cardozo, e pelo Secretário-Geral das Relações Exteriores, Embaixador Sérgio Danese, discutiu iniciativas e projetos de cooperação regional para enfrentar a ação de redes criminosas organizadas. No caso do Equador, que não cobrava visto, o Brasil teve sucesso em convencê-lo a instaurar um sistema de pré-registro, a fim de que houvesse um mínimo controle do trânsito de indivíduos.

Por último, optou-se pelo fortalecimento da capacidade operacional do Itamaraty para aumentar o número de entregas de vistos e, desta forma, desincentivar a vinda por rotas ilegais. Entrevistados governamentais narram que particularmente esse processo de convencimento do Itamaraty demandou tempo e esforço, e teve finalmente sucesso quando a OIM aventou a possibilidade de fornecer serviços para o órgão.

A iniciativa da OIM veio somar-se a outras ações que já vinham sendo exercidas pela organização, assim como pela OIT, sobre o manejo dos fluxos haitianos dentro do território brasileiro.

Em 29 de setembro de 2015 entrou em funcionamento o serviço de vistos humanitários na embaixada de Porto Príncipe, Haiti, após assinatura de acordo entre OIM e Brasil. O Brazil Visa Application Centre (BVAC) volta-se especificamente a 
cidadãos haitianos demandando o visto humanitário de residência permanente, dedicando-se a serviços pré-consulares: assistência ao preenchimento de formulários, verificação da documentação e transporte da documentação ao posto consular. Em consequência, este último passa a focar-se na tomada de decisão. Nesses termos, o BVAC processou, entre setembro de 2015 e setembro de 2016, 23.462 demandas de visto - uma média de, aproximadamente, 2 mil por mês (OIM, 2016). Nos meses anteriores à implementação do acordo, o posto de Porto Príncipe vinha entregando uma média de 700 vistos ao mês. Na avaliação de Paulo Iansen, "Essa experiência também vem constituindo um laboratório de ensaio do governo brasileiro, para aumento de sua capacidade estatal" (Entrevista, 04/03/2016).

A atuação da OIM no local também envolve campanhas de sensibilização e guias de informação sobre a migração para o Brasil em colaboração com as ONGs Viva Rio e Centro ZANMI. De fato, em um país que ainda não conseguiu reerguer grande parte de sua infraestrutura, as redes de tráfico de migrantes encontram um ambiente propício para disseminar falsas informações e cometer fraudes. As campanhas de informação sobre os vistos especiais, veiculadas primordialmente pelo rádio, são instrumentos essenciais da política.

A implementação dessas medidas permitiu o direcionamento do fluxo migratório para uma rota segura, evitando a submissão dos imigrantes haitianos a violações de direitos humanos por organizações criminosas. A entrada desses imigrantes no Brasil por rotas aéreas cresce de 731 em janeiro para 2.149 em dezembro de 2015, diminuindo em $98 \%$ o número de imigrantes que escolhiam a via terrestre (SNJ, 2016). Na Figura 5.1 observam-se os dados relativos à entrada de haitianos por rotas aéreas e terrestres juntamente ao número de vistos concedidos pela embaixada brasileira Porto Príncipe durante o ano de $2015^{341}$. Estima-se uma correlação negativa altamente significativa entre o número de entradas terrestres e o número de vistos (coeficiente de Pearson $r$ = 0,88; $\mathrm{p}<0,001)$, o que, embora não tenha o condão de indicar relações de causa e efeito, acusa a covariância entre a ampliação da capacidade estatal da embaixada e a diminuição do uso de rotas ilegais.

\footnotetext{
$\overline{{ }^{341} \text { Dados disponíveis em SNJ (2016). }}$
} 
Figura 5.1: Entradas terrestres e aéreas de haitianos $v s$. emissão de vistos humanitários (2015)

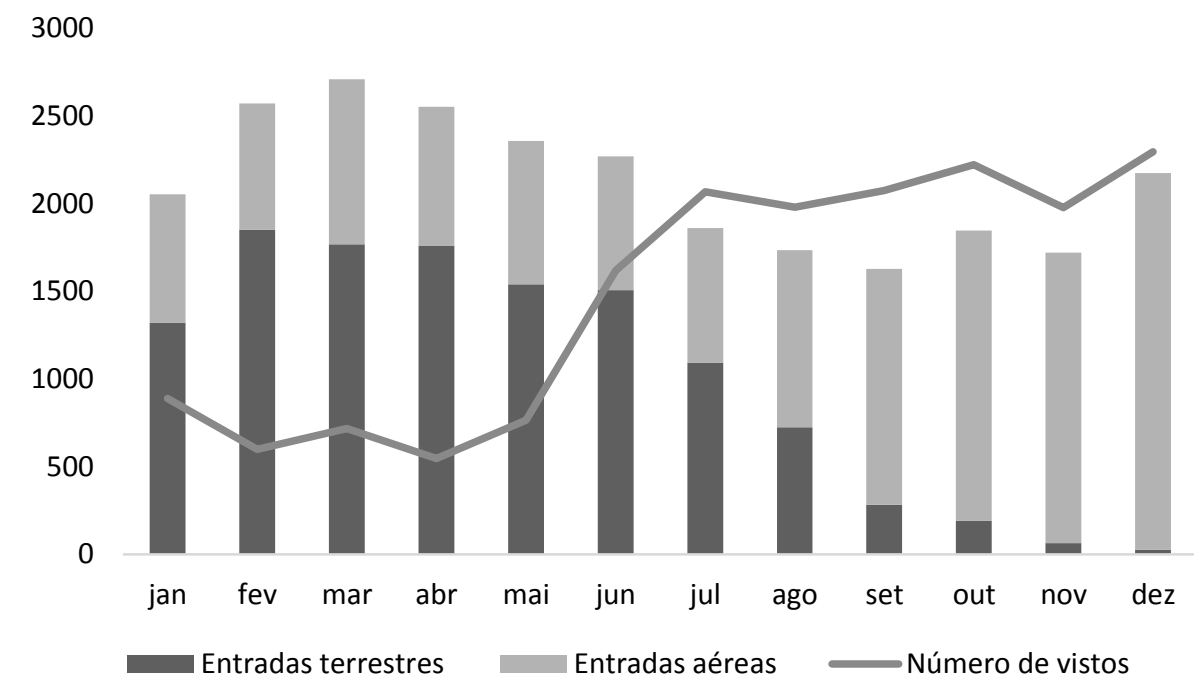

Fonte: Elaboração da autora, com base em dados da SNJ (2016).

Em paralelo às iniciativas de intervenção na rota migratória, os ministros do Trabalho e da Justiça, Miguel Rossetto e José Eduardo Cardozo, assinaram em 11 de novembro de 2015 ato conjunto de concessão de permanência a imigrantes de cidadania haitiana no Brasil. $\mathrm{O}$ ato favoreceu 43.781 imigrantes haitianos que haviam entrado no Brasil pela fronteira terrestre com o Acre a partir de 2010 e contavam apenas com documentos provisórios de solicitação de refúgio. Em respostas a decisão interministerial, o número de autorizações de residência concedidas pelo CNIg aos haitianos sofreu expressivo incremento em 2015 (Figura 5.2).

Figura 5.2: Número de autorizações concedidas a haitianos pelo Conselho Nacional de Imigração com fundamento na RN 27, entre 2011 e 2015.

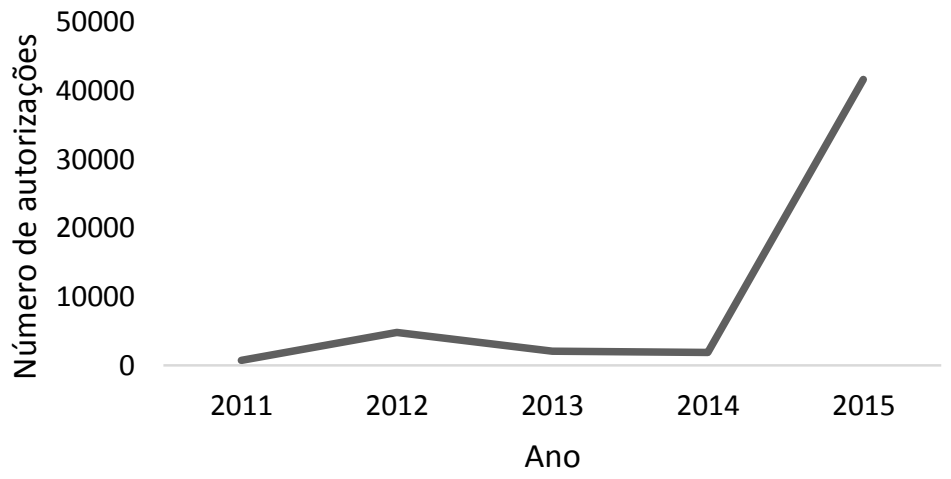

Fonte: Elaborado pela autora a partir dos dados do CNIg/ MTE (2015) apud Cavalcanti; Oliveira e Araújo (2016). 
Entre janeiro de 2012 e maio de 2016, foram emitidos 47.793 vistos permanentes pelo MRE nas Embaixadas de Porto Príncipe, Quito e Lima ${ }^{342}$, mais de $83 \%$ deles requeridos no Haiti. Foram concedidas, no mesmo período, 51.124 autorizações de residência (CNIg/MTE, 2016). O número de imigrantes haitianos empregados cresceu mais de 400\% entre 2011 e 2012, 256\% entre 2012 e 2013; e $107 \%$ entre 2013 e 2014: seu número absoluto passou de 815 pessoas em 2011 a 30.484 em 2014 (CNIg/MTE, 2016). Cavalcanti e Oliveira (2016) arrolam dados do Sistema de Tráfego Internacional (STI) consoante os quais 72.406 haitianos entraram pelos postos de fronteiras brasileiros entre os anos de 2010 e 2015. A estimativa da SNJ é de cerca de 80 mil imigrantes (SNJ, 2016, p.49).

A entrada inesperada de tamanho contingente populacional em cidades de reduzida infraestrutura após um trajeto em que, muitas vezes, estava-se sujeito a graves violações de direitos não constituía, evidentemente, um problema político de fácil solução. Crises humanitárias como a que se configurou em Brasileia envolvem diversas áreas políticas, instrumentos administrativos e serviços públicos, visto que se referem a indivíduos que, em situação de vulnerabilidade, possuem necessidades diversas para sua sobrevivência e dignidade. Ademais, como sugeriu em entrevista Diogo de Sant'Ana, ex- Chefe da Assessoria Especial da Casa Civil, a legislação administrativa não fornece ao governo instrumentos flexíveis adaptados para fornecer atendimento na ponta em situações de emergência (Entrevista, 09/02/2017).

Sem embargo, a análise da resposta governamental à migração haitiana revela não apenas dificuldades de coordenação interministerial e federativa, mas também um descompasso entre a política externamente apregoada e a internamente efetivada. $\mathrm{O}$ princípio da não-indiferença mostrou ter limites, bem como a política humanitária declarada por ocasião dos comunicados de reuniões multilaterais contrastava com as condições de crise humanitária encontradas no Brasil. As contradições no governo sobre o que significaria a política migratória humanitária se somaram à exaustão das capacidades estatais de órgãos diversos. Nesse contexto, destaca-se a relutância ou morosidade do Itamaraty em realizar mudanças na implementação da política em esfera consular.

Um ponto a ser destacado no caso dos Haitianos é o papel exercido pela Casa Civil, configurando um exemplo de centralização política, com deslocamento de

\footnotetext{
${ }^{342}$ Dados do MRE, obtidos via Lei de Acesso à Informação.
} 
funções para o órgão presidencial (MOE, 1989). Não apenas o locus decisório da RN 97/2012, a qual deitou as bases da política delineada, se deu na cúpula do Executivo: as reuniões na Casa Civil deram o norte da resposta governamental durante todo o período em análise, o que se afere das entrevistas realizadas e das atas do CNIg. Sobre a dinâmica de coordenação estabelecida, observa-se que se concentra nos aspectos políticos e de monitoramento, como mostram os depoimentos de um burocrata de médio escalão da Casa Civil e um do MJ:

Tinha um papel de coordenação da Casa Civil, além de convocação e monitoramento do que estava acontecendo. Teve reunião com o Mercadante, Tião Viana, o Secretário Geral do Itamaraty, e nos momentos mais tensos subiu para a máxima autoridade. Nessa crise toda, acho que só conseguimos ter o desempenho que tivermos por conta do comprometimento das áreas, especialmente do Ministério da Justiça, que era quem tinha contato com todas as áreas e com as entidades subnacionais. MJ no papel de coordenação com os entes federativos foi, talvez, uma das coisas mais importantes do período porque criou um fluxo, com os ônibus e os receptivos. O Beto Vasconcelos e o João Guilherme Granja tiveram um papel fundamental porque tinham a mão na massa. Sem eles, o trabalho que faríamos de coordenação seria um trabalho de cobrança. Do ponto de vista da articulação e coordenação, foi um trabalho bastante afinado (Diogo Sant'Ana, Entrevista, 09/02/2017).

Na Casa Civil você não discute questões operacionais, você pode até monitorar (...) É uma reunião daquelas que ninguém quer ter porque é claramente colocar na berlinda ou uma recalcitrância, que acho que não é o caso, ou uma incapacidade de mobilizar o maquinário para uma resposta básica para uma coisa que está devida, está em mora, sendo cobrada (João Guilherme Granja, Entrevista, 09/09/2016)

\subsection{A política e os burocratas: implementando uma plataforma de governo - Programa Mais Médicos}

Uma das plataformas de governo da gestão Dilma Rousseff, o Mais Médicos possui o caráter de ser um programa de atração de mão-de-obra do governo federal $^{343}$. Seu objetivo, porém, é mais amplo: consiste em resolver a questão emergencial do atendimento básico ao cidadão e criar condições para continuar a garantir um atendimento qualificado no Sistema Único de Saúde (SUS). Desta forma, o programa foi concebido em três eixos: provimento emergencial de profissionais, abarcando a

\footnotetext{
343 O programa gerou muitos debates e foi altamente politizado em várias esferas públicas, tendo sido alvo de ação direta de inconstitucionalidade ( $\mathrm{n}^{\circ}$ 5037), tema de audiências públicas ( 25 e 26 de novembro de 2013) e objeto de calorosos debates na opinião pública: pesquisa Datafolha de julho de 2013 apontou que $47 \%$ dos brasileiros seriam favoráveis e $48 \%$ contrários à vinda de médicos estrangeiros para trabalhar no Brasil (Folha de São Paulo, "País se divide sobre projeto de trazer médicos estrangeiros", 01/09/2013, http://www1.folha.uol.com.br/cotidiano/2013/07/1304128-pais-se-divide-sobre-projeto-detrazer-medicos-estrangeiros.shtml. Acesso em: 20 jan. 2017).
} 
vinda de médicos estrangeiros para atuar em regiões onde não há oferta suficiente; educação, com reestruturação da formação de médicos e ampliação de vagas nas faculdades de medicina; e infraestrutura (MINISTÉRIO DA SAÚDE, 2015).

Instituído pela medida provisória $\mathrm{n}^{\circ} 621$, de 08 de julho de 2013, posteriormente convertida na Lei 12.871/2013, o Mais Médicos tem um arranjo que mobiliza vários níveis federativos: sua primeira etapa de implementação é a abertura de um edital de municípios para sua adesão voluntária, assinando termo de compromisso com contrapartidas como garantia de condições específicas e funcionamento das Unidades Básicas de Saúde (UBS). Assinado o termo, o município solicita vagas de acordo com as regras definidas pelo Programa.

$\mathrm{Na}$ segunda etapa, abre-se para a inscrição dos médicos, respeitando-se a seguinte ordem: médicos com registro no Brasil, de qualquer nacionalidade; médicos brasileiros formados no exterior e sem diploma revalidado; médicos estrangeiros com habilitação para exercício da medicina no exterior, mas sem diploma revalidado. Ao chegarem ao Brasil, os médicos estrangeiros passam por treinamento intensivo oferecido pelas universidades brasileiras, que aborda linguagem clínica, os protocolos assistenciais nacionais e o SUS. Essas universidades garantem, ainda, a supervisão médica continuada para os participantes. Os médicos são submetidos periodicamente a avaliações teóricas. O contrato assinado pelos participantes tem a duração de três anos, renováveis por mais três.

O arranjo mobiliza, ademais, diversos órgãos federais: Ministério da Saúde (MS), Ministério da Educação (MEC), Ministério da Defesa (MD), MRE, Ministério da Previdência Social (MPS), Casa Civil, Ministério do Planejamento, Orçamento e Gestão (MP), Banco do Brasil, Polícia Federal, Receita Federal. O Ministério do Trabalho participou das primeiras discussões, mas se afastou quando se formatou o modelo de vinda do estrangeiro no quadro de formação profissional. O Ministério da Justiça não participou da formulação, mas tomou parte na implementação. A coordenação operativa é feita pelo Departamento de Planejamento e Regulação da Provisão de Profissionais da Saúde (DEPREPS), do MS. Na opinião de Gabriela Lotta e colaboradores, o programa "tem sucesso relativo, embora importante, na dimensão intersetorial, por construir uma agenda prioritária que depende de ampla articulação entre atores setoriais mas para a qual tem legitimidade" (2016, p.2770). De acordo com o Ministério da Saúde (2015), 
nos dois primeiros anos de execução do programa, toda a demanda das prefeituras que a ele aderiram foi atendida, beneficiando 63 milhões de pessoas.

Em janeiro de 2013, no Encontro Nacional de Prefeitos, os mandatários municipais encaminharam para a presidenta Dilma Rousseff a campanha "Cadê o Médico?”, em resposta ao que a Presidenta solicitou formalmente ao Ministro da Saúde, Alexandre Padilha, a formulação de proposta que atendesse à demanda.

Com a Atenção Básica à Saúde alçada à prioridade do governo em 2011, haviam sido identificados dois principais desafios ao seu desenvolvimento: a expansão de sua cobertura a importantes contingentes populacionais e o aumento da qualidade e efetividade da atenção à saúde. Esses desafios eram afetados por uma série de fatores, dentre os quais a escassez de profissionais médicos. Ainda em 2011 foi lançado o Programa de Valorização da Atenção Básica (PROVAB), no qual se ofereciam incentivos a médicos brasileiros para que se alocassem em regiões afastadas dos grandes centros urbanos, mas os candidatos não supriram a demanda. O déficit, em 2012, atingiu o índice de 53 mil médicos (MINISTÉRIO DA SAÚDE, 2015).

A oferta de médicos brasileiros não se mostrando capaz de respaldar a política pública, a burocracia do MS começou a amadurecer a ideia de trazer médicos do exterior para o Brasil. Segundo burocrata entrevistado, “o projeto já estava sendo pensado, gestado, mas quando vimos a deixa, mergulhamos" (Entrevista). As linhas gerais do projeto foram então apresentadas à Presidenta Dilma, que acatou a ideia.

Percebe-se na formação de agenda do Mais Médicos uma significativa interface com a arena internacional. A Organização Mundial de Saúde (OMS) tem devotado atenção ao tema, à luz de estimativas de que 50\% da população mundial reside em áreas rurais remotas, mas são servidas por menos de $25 \%$ da força de trabalho médico. De acordo com a OMS, as estratégias para enfrentar essa problemática seriam complexas e multidimensionais (MINISTÉRIO DA SAÚDE, 2015). Dentre elas, muitos países buscaram ampliar a cobertura da Atenção Básica em áreas vulneráveis e remotas atraindo profissionais de saúde estrangeiros para estas regiões. Dados divulgados pela OCDE em 2009 e pelo General Medical Council do Reino Unido em 2011 revelam as seguintes proporções de médicos estrangeiros por país: $37 \%$ no Reino Unido; $25,9 \%$ nos Estados Unidos; 22,8\% na Austrália e 17,9\% no Canadá (apud MINISTÉRIO DA SAÚDE, 2015, p.29). 
Por outro lado, a OMS possui um Código Global de Práticas para Recrutamento Internacional de Profissionais da Saúde (2010), orientando os Estados-Membros da ONU a se comprometerem a observar princípios e práticas éticas no que diz respeito ao recrutamento internacional de profissionais de saúde. Tal documento visa a obstar que a emigração provocada pelo recrutamento de profissionais de saúde gere problemas de saúde pública em países em desenvolvimento ${ }^{344}$. Nesse quadro, o Brasil se propôs a não recrutar médicos graduados em países que tivessem uma relação de médico por 1.000 habitantes menor do que a sua, correspondente a 1,8. Esse índice chegava a 3,9 na Argentina, 3,7 no Uruguai e 6,72 em Cuba (MINISTÉRIO DA SAÚDE, 2015), mas era menor que o brasileiro na Bolívia, Paraguai, Equador e a maioria dos Estados vizinhos sul-americanos e centro-americanos - motivo pelo qual não puderam se inscrever médicos que fossem formados ou que atuassem nesses países.

Conforme apontado por burocratas de médio escalão do MS, a formulação política foi iniciada a partir de diálogos bilaterais sobre boas práticas da Austrália, Reino Unido e Canadá, e se intensificou por meio dos contatos estabelecidos pelo Ministro Alexandre Padilha na Assembleia Mundial de Saúde em maio de 2013. Iniciaram-se, então, rodadas de negociação bilateral com Portugal e Espanha. Como decorrência dos diálogos com os dois países, cerca de 400 médicos vieram ao Brasil. Paralelamente, estabeleceram-se tratativas com Argentina e Uruguai, de onde provieram algumas dezenas de profissionais. Tais negociações bilaterais se deram majoritariamente entre os Ministérios da Saúde dos respectivos países, com mediação operacional das embaixadas e consulados nos países com que se negociava.

Em julho de 2013, começaram a pensar mais intensamente em Cuba, país que possuía, à época, uma proporção médico/habitante quatro vezes maior que a do Brasil, bem como experiência com cooperação internacional sobre o tema. A Organização PanAmericana da Saúde (Opas), organismo ligado à OMS, triangularizou os diálogos entre os governos brasileiro e cubano: o Brasil firmou cooperação com a OPAS em agosto de 2013 e esta última, por sua vez, estabeleceu cooperação com Cuba, que disponibilizou médicos com experiência e formação para atuação na Atenção Básica e que já haviam atuado em missões internacionais. De acordo com burocrata entrevistado, as negociações com a OPAS se davam diretamente com o Ministério da Saúde.

\footnotetext{
${ }^{344}$ Esse fenômeno é particularmente grave na África subsaariana: na Zâmbia, somente cinquenta dos seiscentos médicos treinados no país desde sua independência permaneceram (PANG et al., 2002).
} 
A Assessoria Internacional do MS participava dessas negociações com assessores que não pertenciam ao quadro do MRE - de acordo com os entrevistados, o Ministério tendia a priorizar pessoas com experiência e formação em política de saúde. O MRE veio a participar mais intensamente apenas em um segundo momento, de formulação da medida provisória.

Essa fase de formulação e operacionalização da medida provisória teve articulação intersetorial da Casa Civil, enquanto o debate político e a operacionalização ficaram a cargo do MS. Havia ainda três estruturas de gestão: a Comissão Gestora, formada pelos Ministros da Saúde, Educação, Casa Civil e Planejamento; o Comitê Gestor, formado pelos Secretários Executivos dos mesmos órgãos; e a Coordenação Nacional, composta por burocratas de médio escalão do MS e MEC.

Essa última constituía a arena de operacionalização, à qual acudiam atores dos demais Ministérios envolvidos. Nessa instância, as reuniões eram quase diárias, e se mostravam arenas de socialização dos burocratas sobre a matéria, como se depreende de depoimentos de burocratas entrevistados. Nas palavras de um deles,

Foram discussões em que os grupos estavam alinhados e construindo juntos. Tratava-se de um assunto da Presidência da República, então a Casa Civil coordenava, porque pode cobrar dos Ministérios: apresentava as demandas, organizava os processos, facilitava a integração entre as diferentes áreas. Mas todo mundo tinha contato com todo mundo, foi um dos programas mais interministeriais, em termos efetivos (Entrevista).

Uma das estratégias de manejo da intersetorialidade empreendida pelo MS foi apresentar periodicamente devolutivas para os atores sobre as ações executadas e seus resultados parciais. Observa-se, no caso, o papel do compartilhamento de informações na coordenação intersetorial.

$\mathrm{Na}$ formulação da Medida Provisória, o MRE exerceu uma importante participação, instado pela Casa Civil. De acordo com entrevistados, a convocação do MRE para participar da formulação já definia quais seriam os limites e as diretrizes de sua atuação: o órgão deveria oferecer uma solução que viabilizasse a vinda de estrangeiros com suas famílias, dentro de contornos que não corresponderiam a vínculo de trabalho, mas sim de formação com bolsa. Sua participação se estenderia, ainda, à implementação do programa, mediante a mobilização de suas embaixadas e postos consulares para recebimento e encaminhamento dos pedidos, incluindo a legalização de documentos, e para divulgação do programa no exterior. Sobre o desenvolvimento da 
alternativa política, o Ministro Bernardo Velloso, então Chefe da Divisão de Imigração, esclarece:

A legislação nos engessava muito em termos de como se enquadrar o Programa Mais Médicos, com suas características, dentro dos vistos que estavam no Estatuto do Estrangeiro. Essa discussão ocorreu, em junho e julho de 2013, no contexto da coordenação da Casa Civil, na definição da medida provisória inicial que estabeleceu o programa. Primeiro no contexto mais amplo interministerial e depois no grupo de trabalho que teve como participantes principais os órgãos mais afetos à política migratória, como MJ, MT, PF e MS. Nessas discussões, a primeira tentativa foi de enquadrar no regime geral a situação específica objeto de consulta. No entanto, foi ficando claro que seria necessário regulamentar na própria lei específica sobre o programa como se aplicaria o sistema de vistos, pois os vistos que eram previstos no Estatuto do Estrangeiro não se adequavam ao programa. Isso porque eles não seriam nem trabalhadores stricto sensu, nem estudantes ou pesquisadores stricto sensu. Havia elementos específicos do Mais Médicos, relacionados a bolsa de estudos, a atividades de formação. Então tivemos que inverter: em vez de mudar o programa para se adequar ao regime geral, tivemos que adequar o regime migratório ao programa. Isso era possível uma vez que o programa seria alvo de consulta ao Congresso Nacional. Assim, criou-se um visto específico para atender às necessidades de programa, o VICAM (Entrevista, 11/01/2017).

Nesse contexto, criou-se o Visto Temporário de Aperfeiçoamento Médico (VICAM), contornando as dificuldades impostas pelo rígido Estatuto do Estrangeiro. Anteriormente à concessão do visto pelo MRE, o participante deveria se inscrever e ser selecionado para o programa, decisão esta de competência do MS.

No que atine à implementação, o programa também exigiu do MRE inovações, como de resto o fez com os demais Ministérios. De acordo com Bernardo Velloso,

\begin{abstract}
A implementação do programa, no início, trouxe vários desafios, envolvendo várias áreas do Itamaraty e inclusive a minha. Paralelamente à coordenação mais ampla exercida pela Casa Civil, havia uma estreita coordenação com o MS diretamente para desdobrar o que era previsto na medida provisória. Nós desenvolvemos uma série de mecanismos para que os vistos pudessem ser aprovados, para que os documentos pudessem ser inseridos com maior agilidade no site, isso tudo foi feito a quatro mãos com o Ministério da Saúde e o Itamaraty. Na fase inicial, sobretudo, necessitou uma série de ajustes de operacionalização, inclusive no nosso sistema de emissão de vistos. Havia que fazer alterações no sistema, a área que cuidava disso precisou ser mobilizada, havia uma série de desdobramentos práticos que envolviam diversas áreas do ministério, particularmente várias divisões da Subsecretaria de Comunidades de Brasileiros no Exterior. (...)
\end{abstract}

Temos recursos limitados de pessoal e materiais, tivemos que aprender a buscar ganhos de eficiência, otimizar sistemas, para poder dar conta (Entrevista, 11/01/2017). 
Essas inovações, esclarece o burocrata, não teriam sido insculpidas em tabula rasa, mas teriam em muito aproveitado as modificações de fluxos de trabalho e de sistema: "Essas coisas acabam se retroalimentando, são desafios a que o agente governamental tem que responder de alguma forma. Então trazemos inovações, dentro dos limites da competência do órgão, e uma vez que se encontra uma solução para um caso podemos aplicá-la para outra" (Bernardo Velloso, Entrevista, 11/01/2017).

Ressalte-se que a interlocução das embaixadas e consulados com o governo brasileiro não se deu, no caso em análise, apenas via Itamaraty. Com a acentuada pulverização da implementação, visto que mais de 30 nacionalidades foram abrangidas pelo programa, e dada a exigência de celeridade processual, o Ministério da Saúde atuou, junto à DIM, na harmonização operacional entre os diferentes postos consulares.

Ao fim e ao cabo, concedeu-se no quadro do Programa Mais Médicos, entre 2013 e 2015, aproximadamente 15 mil Vistos Temporários de Aperfeiçoamento Médico (VICAM) aos profissionais estrangeiros selecionados, sendo a maior parte para médicos de nacionalidade cubana, que participam do programa por meio de cooperação do Brasil com a OPAS (SGEB, 2015).

Diante do exposto, nota-se que o Mais Médicos constituiu um exemplo importante de intersetorialidade envolvendo, dentre outros temas, a temática migratória. Nas palavras de um dos burocratas envolvidos, "nesse programa, não dá para afirmar: 'isso aqui é minha peça', não dá para desconsiderar o papel de cada um, e a integração entre todos" (Entrevista). Observa-se, ainda, uma acentuada interface internacional do programa, protagonizada pelos burocratas do Ministério da Saúde e mobilizada em quatro dimensões: (i) a apropriação do regime internacional, com obediência ao Código Global de Práticas para Recrutamento Internacional de Profissionais da Saúde da OMS; (ii) interlocução com outros Estados na busca de boas práticas; (iii) acordo de cooperação com organização internacional, a OPAS; (iv) diálogo com médicos estrangeiros via embaixadas e postos consulares. 


\subsection{Os burocratas e a política: arranjos de coordenação horizontal}

Para além dos casos em que a Casa Civil centralizou o processo político e conduziu a coordenação intragovernamental, a pulverização das competências exige que as organizações envolvidas com a política migratória coordenem horizontalmente as atividades. Este desígnio tem condicionantes institucionalmente delineadas, com a previsão do Conselho Nacional de Imigração e com atribuições de implementação compartilhadas.

O Conselho Nacional de Imigração, conforme exposto no capítulo 1, é um órgão colegiado formado por representantes do governo, entidades patronais e sindicais, e organizações da sociedade civil, entre membros titulares e observadores. Como se discorreu no capítulo 4, o CNIg foi paulatinamente concentrando seus esforços na formulação política, embora remaneça sua competência de decidir sobre a concessão de permanência em casos omissos e situações especiais. Nessas situações, cada membro faz a relatoria de um processo administrativo, levando-a à apreciação de seus pares durante a reunião.

A despeito do Decreto $n^{\circ}$ 840/1993 atribuir-lhe a competência de "coordenar e orientar as atividades de imigração" (art. 1º, II), não esclarece se está se referindo à coordenação dos fluxos migratórios ou da implementação política migratória. Ainda que verse sobre a segunda opção, a norma não destrincha como isso seria feito, nem confere ao Conselho instrumentos administrativos para fazê-lo. Tampouco seu regimento (Portaria $\left.\mathrm{n}^{\circ} 634 / 1996\right)$ tem previsões nesse sentido. Desta forma, e tendo em vista a análise das atas de suas reuniões, percebe-se que o CNIg não atua como uma instância decisória na coordenação das atividades de implementação da política migratória, conquanto funcione como um espaço de interação e troca de informações nesta seara.

Já no que atine à formulação da política migratória, o CNIg constitui, sim, uma instância decisória, com algumas características que lhes são peculiares. A deliberação das Resoluções Normativas, recomendadas e administrativas, nos termos do art. $9^{\circ}$ de seu regimento, se dá por consenso ou por maioria de seus membros. No entanto, a análise das atas das reuniões no período de 2004 a $2015^{345}$, havendo 9 ou 10 reuniões por ano $^{346}$, em cada uma das quais se decidem entre 20 a 50 processos administrativos e

\footnotetext{
${ }^{345}$ Um total de 110 atas.

${ }^{346} \mathrm{O}$ regimento interno do CNIg não estabelece a periodicidade das reuniões, motivo pelo qual ela varia no período em análise.
} 
nas quais, no total, foram aprovadas 64 Resoluções Normativas, 7 Resoluções Recomendadas e 4 Resoluções Administrativas, demonstrou uma totalidade de decisões por consenso no caso das resoluções. Quanto às decisões de processos individuais, observou-se 1 decisão por maioria e 3 pedidos de vistas ao processo, os quais indicam uma necessidade maior de convencimento ${ }^{347}$. Esses números foram corroborados pelas impressões de participantes do Conselho:

Eu nunca tive brigas nem discussões mais acaloradas dentro do CNIG, no máximo senti uma divergência de opinião, mas nunca chegava num ponto incisivo de conflito. Até porque ali é meio um clube de amigos, todo mundo está lá desde sempre. Os que mudam mais são os do governo, porque a representação tripartite é sempre a mesma (Fábio Balestro, Entrevista, 01/06/2016 - grifo nosso).

$\mathrm{Na}$ verdade, o Conselho não vota, é raríssimo isso. Nesses sete anos, não, nesses nove anos que estou lá, recordo, conto nos dedos os casos que tivemos de votar, e todos eles referentes a casos individuais, nunca na construção de uma Resolução. As Resoluções, todas elas, praticamente, que eu me lembre, foram construídas com consenso. E aí, quando você constrói Resoluções, a voz é dada a todos. E influencia a decisão. Irmã Rosita é uma pessoa que tem tido uma voz ativa em plenário, tem influenciado as decisões do Conselho, e graças a essa forma de você trabalhar, não é, acaba que o papel dos observadores e dos conselheiros, eles são muito próximos um dos outros (Paulo Sérgio de Almeida, Entrevista, 09/09/2016 - grifo nosso).

É curioso observar-se tal dinâmica decisória em órgão quadripartite com 20 membros titulares, dentre os quais os Ministérios da Justiça, do Trabalho e das Relações Exteriores, cujas particularidades das visões sobre a política migratória foram abordadas no capítulo 4. A coexistência de visões distintas no Conselho é reconhecida por seus próprios participantes: "muito embora você busque sempre a harmonização, mas há, sim, visões distintas" (Luiz Alberto Matos, Coordenador do CNIg, Entrevista, 03/03/2016). Sobre isso, opinam os seguintes membros observadores do órgão:

A atividade do Conselho é uma prova de que a democracia é possível, porque os membros chegam com muitas divergências mas se acaba atingido um consenso (Cristiane Lopes - MPT, Entrevista, 27/10/2016).

Sim, há nuances. É muito interessante. É lógico, o patronato tem interesse na migração qualificada, para aumentar a mão de obra. Os sindicalistas têm interesse em segurar a situação. (...) têm uma visão, em alguns momentos, da defesa do trabalhador brasileiro (Duval Fernandes - CNPD, Entrevista, 10/05/2016).

Nesse sentido, observem-se as diferenças entre as declarações da Conselheira Marjolaine Canto, representante da Confederação Nacional do Comércio, e do

\footnotetext{
${ }^{347}$ As aprovações por maioria se deram nas reuniões de 09/06/2010. Nas de 16/02/2004, 06/07/2005, 07/12/2005, 15/10/2008 foram pedidas vistas ao processo.
} 
Conselheiro Odilon Braga, representante da Central dos Trabalhadores e Trabalhadoras do Brasil:

\begin{abstract}
Olha, a SBPC [Sociedade Brasileira para o Progresso da Ciência, com assento no $\mathrm{CNIg}]$... tinha pavor desse negócio de cientista, nós tínhamos essa reserva de mercado que tava entranhada na agência, essa falta de democracia, esse medo da concorrência. Hoje não, a concorrência é a melhor coisa que existe para melhorar a qualidade de trabalho. As pessoas mais velhas que viveram o governo de exceção elas tinham dificuldade em fazer essa abertura. (Marjolaine Canto, Entrevista, 09/03/2016 - grifo nosso)

O Sr. Odilon Braga manifestou o entendimento de que o debate sobre a resolução normativa se estabelece em boa hora, dadas as circunstâncias que ora se apresentam. Lembrou que o debate não deve perder de vista a necessidade de que sejam preservados os interesses do trabalhador brasileiro e o impacto dessa necessidade nas medidas que porventura venham a ser adotadas (Ata do CNIg, 12/01/2012, p.3).
\end{abstract}

Essa divergência de perspectivas por vezes se nota em uma mesma discussão, como, por exemplo, no debate do CNIg sobre a proposta da Secretaria de Assuntos Estratégicos da Presidência de atração de mão-de-obra qualificada:

A Conselheira Regiane Ataíde informou que existe uma preocupação com a dificuldade que o setor da construção civil tem para encontrar profissionais especializados e agradeceu a criação da comissão porque é uma demanda cada vez mais crescente. O Conselheiro Odilon Braga noticiou que na Central não há registro de falta de mão de obra, que as resoluções até então tem atendido a demanda, inclusive na marinha mercante já há oficiais desempregados (Ata do CNIg, 19/02/2013, p.4).

Diante do exposto, pode-se concluir que, em termos de classificações de estruturas de coordenação, o CNIg se aproxima do conceito de grupo interorganizacional proposto por Alexander (1993): nível mais baixo de coordenação formal, formado por profissionais que mantêm suas afiliações originais, sem orçamento ou pessoal próprio, de maneira que os serviços demandados são executados por uma das organizações integrantes. O Conselho não se adapta totalmente à classificação "pura" de grupos interorganizacionais do autor devido a não se tratar de instância temporária de coordenação, no entanto, Alexander defende que "few interorganizational groups are so pure, most occupy intermediate points on a continuum of autonomy" (1993, p.335). O fato é que o CNIg se distancia do próximo nível da escala de coordenação, o coordenador ou a unidade coordenadora, na qual um indivíduo ou agência independente realiza a coordenação entre as diferentes organizações. No que se refere às possíveis consequências da coordenação em grupos interorganizacionais, Alexander (1993) sugere que "The unwanted result may be a weakening of the group's coordinative 
capacity and of the participating organizations' commitment to its decisions" (1993, p.336)

No que diz respeito à dinâmica do processo decisório coletivo, na escala de 1 a 9 proposta por Les Metcalfe $^{348}$, na qual o 9 corresponde à estratégia política governamental, o CNIg se situa entre o nível 4, esquiva de diferenças entre ministérios, e o 5, busca de acordo entre ministérios. Não chega, porém, ao nível 6, de arbitragem das diferenças políticas. Já nos termos propostos por Hermann e colaboradores (2001), constata-se que o CNIg se enquadra no modelo da concorrência, no qual há ênfase na supressão do desacordo de maneira a preservar o bem-estar da unidade decisória. Para Hermann et al. (2001), nos casos em que os grupos são formados por indivíduos provenientes de distintas organizações lidando com a mesma questão política, uma identidade grupal vincularia esses membros à coletividade, aditada a suas vinculações organizacionais originárias: com efeito, observa-se no depoimento dos entrevistados a percepção de uma solidariedade entre os membros do CNIg, e de um senso de responsabilidade atrelado à sua condição de membro do órgão (Marjolaine Canto, 09/03/2016; Rinaldo Almeida, 09/03/2016; Bela Feldman, 18/07/2016; Lídia Miranda, 13/05/2016).

Nesse contexto, aduzem os autores, os membros tenderiam a evitar desacordos a fim de preservar o bem-estar do grupo, arriscando desta forma a reduzir o exame crítico das ideias apresentadas. Por conseguinte, o grupo tenderá a adotar soluções dominantes, endossadas sem debates mais aprofundados. Ressalte-se que, além da concorrência, os dois outros modelos previstos por Hermann et al. (2001) são o da pluralidade, no qual se aceitam conflitos no grupo, e o da unanimidade, no qual há uma tendência a resolver o conflito no grupo. Em ambos, porém, o possível produto da solução integrativa, isto é, uma alternativa que se torna a preferida por todos os membros no decorrer das discussões, é matizado com soluções de subconjunto, aquela que é satisfatória para uma parcela do grupo. Essas últimas não são observadas empiricamente no caso do CNIg.

No que tange à implementação da política migratória brasileira, observa-se que sua estrutura fragmentada aciona órgãos diversos. Ademais, em decorrência da incompletude e obsolescência da legislação, as atribuições de cada órgão nas dimensões

\footnotetext{
${ }^{348}$ A escala é composta dos seguintes níveis: 1. Tomada de decisão independente pelos ministérios; 2. Comunicação a outros ministérios; 3. Consulta a outros ministérios; 4. Esquiva de diferenças entre ministérios; 5. Busca de acordo entre ministérios; 6. Arbitragem das diferenças políticas; 7. Estabelecimento de limites a ação ministerial; 8. Estabelecimento de prioridades centrais; 9. Estratégia governamental (METCALFE, 1994).
} 
específicas da implementação política não são claras, e acabam se fundamentando em uma miríade de normativas distintas. Tome-se como exemplo a concessão da permanência, instrumento basilar da política migratória posto que autoriza a entrada e estada de imigrantes no território do país em caráter permanente, e desta maneira amplia o rol de direitos a que têm acesso. Passados mais de trinta anos da promulgação da Lei 6.815/1980, o instituto da permanência contempla múltiplas modalidades, fundamentadas em diversas regulamentações e envolvendo diferentes arranjos decisórios, como se verifica no quadro 5.3.

Quadro 5.3: Órgãos competentes e fundamentos normativos da concessão dos diferentes tipos de permanência

\begin{tabular}{|c|c|c|}
\hline Tipo de permanência & Fundamento normativo & Órgão competente \\
\hline $\begin{array}{l}\text { Permanência definitiva } \mathrm{de} \\
\text { refugiado ou asilado }\end{array}$ & $-\mathrm{RN} \mathrm{n}^{\circ} 06 / 97$ e $\mathrm{RN} \mathrm{n}{ }^{\circ} 91 / 2010$ & MJ \\
\hline $\begin{array}{l}\text { Permanência definitiva de } \\
\text { cônjuge de brasileiro ou genitor } \\
\text { de prole brasileira }\end{array}$ & $\begin{array}{l}\text {-Art. } 75, \text { II, da Lei } \mathrm{n}^{\circ} 6.815 / 1980 \\
\text { (inexpulsabilidade); } \\
\text { - Regulamentada pela } \mathrm{RN} \mathrm{n}^{\mathrm{o}} \\
36 / 1999 \text {, posteriormente alterada } \\
\text { pela na } \mathrm{RN} \mathrm{n}^{\circ} 108 / 2014 \text {. } \\
\text { - Procedimento de concessão } \\
\text { regido pela Portaria } 04 / 2015 \text { do } \\
\text { MJ }\end{array}$ & MRE no exterior; MJ no Brasil. \\
\hline $\begin{array}{l}\text { Permanência definitiva com base } \\
\text { em reunião familiar } \\
\text { (Beneficia o dependente legal de } \\
\text { brasileiro ou de estrangeiro } \\
\text { permanente ou temporário } \\
\text { residente no País) }\end{array}$ & $\begin{array}{l}\text {-RN } \mathrm{n}^{\circ} 36 / 1999, \text { posteriormente } \\
\text { alterada pela na RN n }{ }^{\circ} 108 / 2014 ; \\
\text { - Procedimento de concessão } \\
\text { regido pela Portaria 04/2015 do } \\
\text { MJ }\end{array}$ & MRE no exterior; MJ no Brasil \\
\hline $\begin{array}{l}\text { Permanência definitiva com base } \\
\text { em união estável } \\
\text { (beneficia o companheiro de } \\
\text { brasileiro ou estrangeiro } \\
\text { permanente, sem distinção de } \\
\text { sexo) }\end{array}$ & $\begin{array}{l}\text { - } \mathrm{RN}^{\circ} 108 / 2014 ; \\
\text { - Procedimento de concessão } \\
\text { regido pela Portaria } 04 / 2015 \text { do } \\
\text { MJ; } \\
\text {-OBS: Era regulamentada pela } \\
\text { RN n } 77 / 2008 \text { do CNIg, nos } \\
\text { termos da qual o próprio CNIg } \\
\text { detinha a competência para } \\
\text { concedê-la. }\end{array}$ & MRE no exterior; MJ no Brasil \\
\hline $\begin{array}{l}\text { Permanência a ministro de } \\
\text { confissão religiosa ou membro } \\
\text { de instituto de vida consagrada e } \\
\text { de congregação ou ordem } \\
\text { religiosa (VITEM VII) }\end{array}$ & $\begin{array}{l}\text { - Arts. } 69 \text { e } 70 \text { do Decreto } 86.715 \text {; } \\
\text { - Permanência por conversão do } \\
\text { visto temporário VII (art. 13, Lei } \\
6.815 \text {; art. 22, Decreto } 86.715 \text { ) } \\
\text { - Procedimento de concessão } \\
\text { regido pela Portaria } 04 / 2015 \text { do } \\
\text { MJ. }\end{array}$ & $\begin{array}{l}\text { MJ concede a transformação, } \\
\text { comunicando-a ao MTE. }\end{array}$ \\
\hline $\begin{array}{l}\text { Permanência ao titular de visto } \\
\text { temporário na condição de } \\
\text { professor, técnico ou pesquisador } \\
\text { de alto nível ou cientista } \\
\text { estrangeiro que comprovar sua } \\
\text { nomeação para o serviço público } \\
\text { ou a contratação por prazo } \\
\text { superior a } 2 \text { anos, junto a } \\
\text { entidades, públicas ou privadas, } \\
\text { de ensino, ou de pesquisa }\end{array}$ & $\begin{array}{l}\text {-Arts. } 69 \text { e } 70 \text { do Decreto } 86.715 \\
\text { - RN no } 01 / 97 \text { do CNIg }\end{array}$ & $\begin{array}{l}\text { - MTE concede o visto } \\
\text { permanente, podendo ouvir o } \\
\text { Ministério da Ciência e } \\
\text { Tecnologia. } \\
\text { - A transformação do visto } \\
\text { temporário V (o qual é } \\
\text { concedido pelo MRE após } \\
\text { autorização do MTE) em } \\
\text { permanente é de competência do } \\
\text { MJ, com oitiva do MTE. }\end{array}$ \\
\hline
\end{tabular}




\begin{tabular}{|c|c|c|}
\hline científica e tecnológica & & \\
\hline $\begin{array}{l}\text { Permanência ao titular de } \\
\text { VITEM V - cientista, professor, } \\
\text { técnico ou profissional de outra } \\
\text { categoria, sob regime de contrato } \\
\text { ou a serviço do Governo } \\
\text { brasileiro, nos casos que não se } \\
\text { enquadrem no tópico anterior. }\end{array}$ & $\begin{array}{l}\text { - Art. } 69 \text { e } 70 \text { do Decreto } 86.715 \\
\text { (Transformação de temporário } \\
\text { para permanente). }\end{array}$ & $\begin{array}{l}\text { MJ concede, com oitiva do } \\
\text { MTE. }\end{array}$ \\
\hline $\begin{array}{l}\text { Permanência ao titular de visto } \\
\text { diplomático ou oficial }\end{array}$ & $\begin{array}{l}\text { - Art. 39, Lei } 6.815 \text {; art. } 69 \text { e } 70 \\
\text { do Decreto } 86.715\end{array}$ & $\begin{array}{l}\text { MJ concede, com oitiva do } \\
\text { MRE. }\end{array}$ \\
\hline $\begin{array}{l}\text { Permanência à vítima de tráfico } \\
\text { de pessoas }\end{array}$ & $\begin{array}{l}\text { - Art. } 18 \text { da Lei } \mathrm{n}^{\circ} 6.815 / 1980, \mathrm{c} / \mathrm{c} \\
\text { Lei }^{\circ} 13.344 / 2016 \\
\text { - RN n } \text { n }^{\circ} 93 / 2010 \text { do CNIg }\end{array}$ & $\begin{array}{l}\text { - Cabe ao MJ apreciar os } \\
\text { pedidos das autoridades policial, } \\
\text { judicial ou do MP que tenham a } \\
\text { seu cargo uma persecução } \\
\text { criminal em que o estrangeiro } \\
\text { seja vítima. Se o estrangeiro } \\
\text { estiver em situação regular no } \\
\text { país, o MJ poderá autorizar a } \\
\text { permanência de imediato (art. } 3^{\circ} \\
\text { da RN); porém caso se encontre } \\
\text { em situação migratória irregular, } \\
\text { o MJ diligenciará junto ao MRE } \\
\text { para a concessão do respectivo } \\
\text { visto no Brasil (art. } 3^{\circ} \text {, §único). } \\
\text { - No caso de órgãos públicos } \\
\text { envolvidos no atendimento às } \\
\text { vítimas de tráfico de pessoas } \\
\text { encaminharem parecer técnico } \\
\text { ao MJ recomendando a } \\
\text { concessão de visto permanente, } \\
\text { o pedido será decidido pelo } \\
\text { CNIg (arts. } 5^{\circ} \text { e } 6^{\circ} \text { da RN). }\end{array}$ \\
\hline $\begin{array}{l}\text { Permanência com amparo no } \\
\text { Acordo sobre Residência para } \\
\text { Nacionais dos Estados Partes do } \\
\text { Mercado Comum do Sul - } \\
\text { MERCOSUL, Bolívia e Chile, } \\
\text { promulgado pelo Decreto n }{ }^{\circ} \\
\text { 6.975/2009 }\end{array}$ & $\begin{array}{l}\text { - Decreto } \mathrm{n}^{\circ} 6.975 / 2009 \\
\text { - O procedimento é regido pela } \\
\text { Portaria MJ 04/2015. }\end{array}$ & MJ \\
\hline $\begin{array}{l}\text { Permanência por razões } \\
\text { humanitárias para nacionais do } \\
\text { Haiti }\end{array}$ & $\mathrm{RN} \mathrm{n}^{\circ} 97 / 2012$ & $\begin{array}{l}\text { - MRE concede, com duração } \\
\text { de } 5 \text { anos. } \\
\text {-Antes da expiração deste } \\
\text { prazo, o nacional haitiano deve } \\
\text { convalidar sua permanência } \\
\text { mediante comprovação de sua } \\
\text { situação laboral, porém a } \\
\text { resolução não discrimina que } \\
\text { órgão deverá fazê-lo }{ }^{349} \text {. } \\
\text { - No caso de imigrantes } \\
\text { haitianos em situação irregular } \\
\text { no Brasil, cabe ao CNIg } \\
\text { autorizar a permanência. }\end{array}$ \\
\hline
\end{tabular}

Fonte: Elaboração da autora.

${ }^{349}$ Até a data de finalização desta tese, não havia orientação governamental estabelecida sobre o tema, sendo que os primeiros vistos vencerão já em 2017. Embora a convalidação da permanência tenda a ser competência do MJ, condicioná-la à situação laboral sugere que haverá atuação do MTE na decisão. 
Ressalve-se que o Departamento de Polícia Federal é órgão de atendimento na ponta dos serviços prestados ao estrangeiro, particularmente nos atinentes ao registro, exercendo as funções de recepção de pedidos relativos à situação documental350. Nos termos do artigo 58 do Decreto 86.715, os estrangeiros admitidos no Brasil na condição de temporários, permanentes, asilados ou refugiados, são obrigados a se registrarem junto ao Departamento de Polícia Federal no Sistema Nacional de Cadastro e Registro de Estrangeiros (SINCRE), o que lhes possibilita receber a Carteira de Identidade de Estrangeiro (CIE). Por conseguinte, todos os órgãos em análise interagem, também, com a Polícia Federal na implementação da política migratória. Não obstante, à exceção da prorrogação de vistos de turista e em decorrência de mudanças incrementais identificadas no capítulo 4, a PF não reúne atribuições decisórias sobre a situação documental dos estrangeiros.

O exame do instituto da permanência permite concluir o quão intrincadas são as competências na implementação da política migratória, e o quanto compreendem múltiplas e diversas interações entre os órgãos: comunicação da decisão tomada a outra organização; oitiva de outra organização prévia à tomada de decisão; decisão complexa; decisão colegiada no CNIg. Observa-se a aproximação entre esses formatos de interação e os primeiros níveis da escala proposta por Les Metcalfe (1994) sobre coordenação intragovernamental: 1. Tomada de decisão independente pelos ministérios; 2. Comunicação a outros ministérios; 3. Consulta a outros ministérios ${ }^{351}$. No entanto, identifica-se a necessidade de adicionar um quarto nível à escala de Metcalfe: o das decisões complexas, aquelas que dependem da manifestação de vontade de órgãos diversos. As decisões complexas se diferencias dos dois níveis anteriores porque naqueles há a manifestação de vontade de apenas um órgão, levada à ratificação ou ciência de outro. Com base nessa escala, e visando a observar a interação entre as diversas organizações na implementação da política migratória brasileira, o quadro 5.4 apresenta uma matriz interorganizacional da implementação da política, na qual se sublinha em qual ponto da escala a interação se encaixa.

\footnotetext{
${ }^{350}$ Além de suas funções de controle na entrada e saída das fronteiras.

351 As próximas fases da escala de Metcalfe são afetas às características do processo decisório coletivo, não se aplicando à distribuição de competências neste momento em análise.
} 
Quadro 5.4: Matriz interorganizacional da implementação da política migratória relativa à situação documental

\begin{tabular}{|l|l|l|l|}
\hline & MTE & MRE & MJ \\
\hline MTE & $\begin{array}{l}\text { Não possui competências } \\
\text { relativas à situação } \\
\text { documental independentes } \\
\text { de outros órgãos. }\end{array}$ & $\begin{array}{l}\text { Escala 4. MTE concede } \\
\text { atorização de trabalho, MRE } \\
\text { concede o visto (VITEM V e } \\
\text { VII). }\end{array}$ & $\begin{array}{l}\text { Escala 3. MJ concede } \\
\text { transformação, ouvido o MTE. } \\
\text { Escala 2. MJ concede } \\
\text { prorrogação, comunicando ao } \\
\text { MTE. }\end{array}$ \\
\hline MRE & $\begin{array}{l}\text { Escala 4. MTE concede } \\
\text { autorização de trabalho, } \\
\text { MRE concede o visto } \\
\text { (VITEM V e VII). }\end{array}$ & $\begin{array}{l}\text { Escala 1. Conceder vistos } \\
\text { temporários e permanentes a } \\
\text { estrangeiros fora do país. }\end{array}$ & $\begin{array}{l}\text { Escala 3. MJ concede a } \\
\text { transformação de visto oficial ou } \\
\text { diplomático, ouvido o MRE. }\end{array}$ \\
\hline MJ & $\begin{array}{l}\text { Escala 3. MJ concede } \\
\text { transformação, ouvido o } \\
\text { MTE. }\end{array}$ & $\begin{array}{l}\text { Escala 3. MJ concede a } \\
\text { transformação de visto oficial } \\
\text { ou diplomático, ouvido o } \\
\text { MRE. } \\
\text { Escala 2. MJ concede } \\
\text { prorrogação, comunicando } \\
\text { ao MTE. }\end{array}$ & $\begin{array}{l}\text { Escala 1. Conceder prorrogação } \\
\text { de visto, transformação de } \\
\text { permanência e permanência. }\end{array}$ \\
\hline
\end{tabular}

Fonte: Elaboração da autora.

Os burocratas públicos entrevistados nesta tese narram que a intersetorialidade na implementação da política migratória é respaldada por contatos informais rotineiros, sendo que, no caso do MRE e MTE, afirmam que as trocas de informações são diárias (Paulo Iansen, 04/03/2016; Aldo Cândido, 03/03/2016). Observe-se que tanto os burocratas do MTE quanto os do MJ entrevistados nesta tese apontaram o MRE como seu maior parceiro, acrescentando que as interações se dão via a sede do órgão, não ocorrendo trocas de informações diretamente com as missões do Brasil no exterior.

O CNIg, por constituir arena de encontros mensais aos quais comparecem as organizações, representa um locus importante de troca de informações sobre a implementação, embora nele não ocorra a tomada de decisão sobre questões operacionais, provavelmente em virtude de possuir composição muito mais ampla que os órgãos implementadores. Outros espaços de trocas informais entre os órgãos são os seminários, oficinas e eventos por eles promovidos, como ressaltado no capítulo 4.

Ainda sobre a dinâmica de interações na implementação, percebe-se que a destinação de recursos ocorre de maneira setorial e que inexiste um sistema de informação unificado, a despeito de negociações entre os órgãos no intuito de harmonização (João Guilherme Granja, Entrevista, 09/09/2016). Para Luiz Alberto Santos, Coordenador do CNIg, 
Outro ponto que é um grande desafio, hoje, é de você fazer a harmonização dos sistemas de gestão desses órgãos, porque aqui tem um, Ministério das Relações Exteriores tem outro, Ministério da Justiça e o Departamento da Polícia Federal têm outro. E esses sistemas precisam conversar entre si. Para nós é importante saber se aquela autorização de trabalho redundou na efetiva entrada do estrangeiro. Porque, a partir do momento, se a gente não for avisado pelo MRE e pela Polícia Federal, fica para nós como uma autorização ativa, que não sei se se transformou efetivamente em entrada (Entrevista, 03/03/2016)

Como observado nos capítulos 1 e 4, competências de implementação não encerram as atribuições dos órgãos em política migratória, que acumulam também atividades de formulação, assim como competências relativas ao status migratório não contemplam todas as ações empreendidas pelos órgãos. Particularmente, atividades relacionadas à integração do migrante ficam de fora da análise. No entanto, é interessante observar que justamente essas atividades tendem a ser desempenhadas setorialmente, sendo que a ampliação do escopo das políticas nessa seara se relaciona à dinâmica de construção de capacidades estatais analisada no capítulo 4.

No que atine a políticas de integração, o padrão de relações das organizações se distingue daquelas afetas à situação documental, caracterizando-se por interações sócioestatais e com entidades subnacionais. As primeiras se referem tanto a termos de cooperação com entidades da sociedade civil para implementação das políticas, quanto ao diálogo com essas organizações no quadro do CNIg e de instâncias de participação formais (COMIGRAR, Comitê de Acompanhamento Social, Fórum de Participação Social) e informais (seminários, oficinas, eventos).

Uma significativa parcela dessas organizações da sociedade civil é confessional, com atuação histórica no Brasil na prestação de assistência a migrantes e refugiados. De acordo com Padre Paolo Parisi e Dirceu Cutti, as ações dessas entidades envolvem "desde o agente da pastoral, que numa sala pequena cuida da saúde do imigrante, até o representante que tem assento junto ao CNIg" (2008, p.223). Outra parte é composta por organizações de defesa dos direitos dos imigrantes e associações de migrantes. $\mathrm{O}$ conjunto dessas entidades presta serviços $\operatorname{como}^{352}$ : (i) acesso ao Estado, prestando informações, divulgação das publicações em Diário Oficial, auxílio direto em questões burocráticas, assessoria jurídica - p.ex. IMDH, CDHIC; (ii) acolhida, inclusive

\footnotetext{
${ }^{352}$ Para um mapeamento das associações de imigrantes, ver Parisi e Cutti (2008). Há também o mapeamento das associações atuantes na cidade de São Paulo pela Coordenação de Políticas para Migantes da Prefeitura de São Paulo:

http://www.prefeitura.sp.gov.br/cidade/secretarias/upload/direitos humanos/2016 mapeamento\%20grupo s.pdf.
} 
promovendo mutirões de prestação de serviços públicos em parceria com órgãos públicos - p.ex. Missão Paz; (iii) integração à sociedade: ensino de língua portuguesa, cursos profissionalizantes, inserção profissional, atividades de geração de renda, criação de espaços de convívio, celebração de festas e celebrações populares, apoio às associações de imigrantes - p.ex. Sí yo puedo, Presença da América Latina - PAL, Centro Scalabriano de Promoção do Migrante (CESPROM); (iv) advocacy e mobilização pelos direitos dos imigrantes, p.ex. Pastoral do Migrante, Conectas Direitos Humanos, Instituto Terra, Trabalho e Cidadania - ITTC, Centro de Apoio ao Migrante CAMI; (v) assento junto ao CNIg, ocupado pelo IMDH.

Quanto às relações com entidades subnacionais, nota-se que tanto o MJ quanto o MTE firmaram parcerias com municípios e estados no período em comento, sendo que o primeiro articulou um canal mais direto de diálogo a partir do manejo da questão dos haitianos, conforme testemunho da Coordenadora de Políticas para Migrantes do Município de São Paulo, Camila Baraldi (Entrevista, 19/05/2016).

Por último, ressalte-se que, enquanto o MJ e o MTE possuem uma área específica destinada à política migratória, o MRE trata da temática em distintas divisões. Assim, o MRE enfrenta não apenas a coordenação interorganizacional, mas também intraorganizacional no tema. A SGEB, em geral, e a DIM, em particular, interagem com o MJ e o MTE rotineira e informalmente na implementação da política, articulam-se com eles eventualmente para constituir delegações do Brasil em eventos no exterior, e coordenam seus esforços de maneira mais estruturada no caso das negociações de acordos internacionais e nas reuniões interministeriais conduzidas pela Casa Civil (Haitianos e Mais Médicos). Participam, ainda, do CNIg. Nesse contexto, nota-se uma acentuada interatividade informal de burocratas do Itamaraty detentores de postos de Chefia de Divisão e inferiores, uma interação mais restrita e formal envolvendo o Subsecretário-geral, e uma marcante formalidade nas articulações com o Secretário Geral - essas últimas intermediadas pela Casa Civil.

No entanto, como observado no capítulo 4, não é apenas na seara da DIM que a temática migratória é abordada no Itamaraty: o Departamento de Direitos Humanos e Temas Sociais (DTS) conduz a representação em instâncias multilaterais, a Divisão de Nações Unidas (DNU) cuida da temática do refúgio, as Divisões de Assuntos Consulares e das Comunidades de Brasileiros no Exterior abordam as migrações sob o prisma dos brasileiros no exterior. A coordenação entre essas unidades é feita 
informalmente pelos próprios burocratas, notadamente por meio de consultas e ciências, não havendo instâncias ou mecanismos estruturados de coordenação ${ }^{353}$. É marcante, porém, a setorialidade intraorganizacional do Itamaraty em temática migratória (Maria Rita Faria, 04/03/2016), com cada área decidindo dentro de sua esfera de competência e de acordo com sua lógica de ação. Aplicando a escala de Metcalfe (1994) à coordenação intraorganizacional, pode-se afirmar que o máximo nível encontrado é o 3, de consulta a outras áreas.

Uma explicação plausível para este fato está na importância que o princípio hierárquico assume na organização do MRE, de maneira que articulações internas são ou informais e operacionais, ou submetidas ao crivo de decisão hierarquicamente superior, e a projeção externa da visão do órgão passa pelo mesmo caminho. Segundo relato do Ministro Bernardo Velloso.

\begin{abstract}
Houve uma orientação da Secretaria Geral no sentido em que as posições que eram defendidas nas instâncias interministeriais, no momento em que se levava a posição do órgão para outros ministérios, essa posição tinha que ser aprovada pelo Secretário Geral. No limite, nós não agimos por conta própria, tem que haver uma coordenação intraministerial e interministerial (Entrevista, 11/01/2017).
\end{abstract}

\title{
5.5. Análise integrada
}

Como coloca Immergut (1998), políticas públicas não constituem um produto eficiente da agregação de preferências individuais. Ao contrário, consistem em processos políticos do qual participam atores diferenciados, cada um com sua especialização (BOUCKAERT et al, 2010) e com seu respectivo espaço de poder. Nesse quadro, a coordenação intragovernamental assume especial relevância.

Nesses termos, a política migratória brasileira confirma a previsão de Peters (1998) sobre a coordenação em Estados contemporâneos: em seu arranjo institucional complexo, convivem elementos de coordenação de arranjos hierárquicos, de mercado e de redes, mostrando-se ainda semi-permeável a atores não-governamentais na elaboração e implementação de políticas públicas. Os elementos hierárquicos são verificados dentro das organizações, particularmente do Itamaraty, com influência sobre seus padrões de interação e coordenação interministerial. São observados, ainda, nos

\footnotetext{
${ }^{353}$ De acordo com entrevistas de Paulo Iansen (04/03/2016), Luiz Felipe Vilela (04/03/2016), Maria Rita Faria (04/03/2016), Juliana Benedetti (07/03/2016).
} 
momentos de avocação do tratamento do tema pela Casa Civil, no caso dos Haitianos e Mais Médicos. Nesses casos, a coordenação é empreendida em uma perspectiva top down, na qual os custos de transação da cooperação são minimizados a partir do recurso à autoridade a fim de diminuir os graus de conflito e competição.

Arranjos em rede compreendem diversos meios de interação intragovernamentais e entre atores estatais e sociais voltados para uma determinada área política, em que se observam visões e objetivos compartilhados sobre o tema. Já os de mercado são desenvolvidos em ambientes de competitividade nos quais os agentes possuem total autonomia, não havendo um centro estratégico de concertação, e a dinâmica das interações é baseada na barganha. Com elementos de ambos os modelos se descreve o CNIg: nota-se nessa instância a emergência da política migratória como um campo com abordagem própria, distinta da lógica de ação das organizações de origem, mas por elas influenciada. Em seu processo decisório, evita-se o conflito e o enfrentamento às diferenças, embora tais diferenças se mostrem constantemente presentes. Tais características aproximam a organização do modelo da concorrência proposto por Hermann et al. (2001), caracterizado pela supressão do desacordo de maneira a preservar o bem-estar da unidade decisória, e daquele de grupo interorganizacional, proposto por Alexander (1993), instância de baixa capacidade de coordenação. Trata-se, contudo, de espaço importante de interações, consultas e trocas de informações que reforça, junto a seminários, eventos e oficinas, o desenvolvimento da comunidade política em migrações - da qual fazem parte não apenas atores governamentais, mas também de outros setores do Estado, da sociedade civil, de setores privados, acadêmicos e organizações internacionais.

Acrescente-se que os padrões de redes são também percebidos nas relações interorganizacionais operadas pelos burocratas na implementação da política. Tais interações se estabelecem informalmente com acentuada periodicidade, envolvem os três Ministérios e são estruturadas horizontalmente entre burocratas de médio escalão. Não possuem instância institucionalizada de concertação superior. Ressalte-se que os recursos são destinados setorialmente e que não há integração dos sistemas de informação das organizações (COSTA; BRONZO, 2015).

Em geral, não se observa, nesse arranjo, coordenação voltada à construção de uma agenda governamental comum em política migratória, com metas e objetivos que sejam intersetorialmente compartilhados. A única situação em que esse intuito é 
verificado é no caso dos Haitianos, com a intervenção da Casa Civil. No entanto, ainda nessa ocasião, a coordenação das ações foi marcada pela dificuldade em definir-se uma agenda governamental comum sobre o tema.

A análise da coordenação exercida pela Casa Civil no caso dos Haitianos e do Mais Médicos, este último correspondendo a um programa que tangenciou a política migratória, mas que corresponde a agenda da área de saúde, demonstra alguns similaridades e diferenças. Dentre as inúmeras divergências, encontra-se o motivo que levou à centralização da questão nas mãos da Casa Civil: no Mais Médicos, por se tratar de uma importante plataforma de governo, no caso dos Haitianos, por assumir dimensões de crise humanitária com reflexos para as relações federativas. Por conseguinte, o Mais Médicos passou por um período de gestação antes de sua implementação e desenhou um arranjo institucional de coordenação, enquanto o manejo da questão dos haitianos tendeu a responder ao ressoar de alarmes de crises.

A centralização por órgão da Presidência nesses dois casos corrobora a previsão de Rudalevige (2005) de aumento da centralização quando a questão requerer urgência, mostrando-se inviável aguardar resposta da burocracia, e quando a questão constitui um tema novo. No entanto, a ausência de outros casos de centralização pela Casa Civil na temática migratória desconfirma sua hipótese de que órgão da Presidência avocaria a formulação quando o projeto envolver vários setores do governo, algo também defendido por Moe (1989).

Tanto o caso dos Haitianos quanto o Programa Mais Médicos convergem, contudo, no ponto de que a Casa Civil formaliza a coordenação, com autoridade para cobrar e demandar dos Ministérios, mas é um Ministério-fim quem conduz a sua operacionalização e participa de sua implementação - o Ministério da Saúde, no caso do Mais Médicos, e o da Justiça na questão haitiana. Dessa maneira, o movimento de centralização pela Casa Civil não significa que as decisões dali emanadas não terão influência das organizações. Ao contrário, as reuniões interministeriais visam a coordenar as visões dos Ministérios, não preteri-las. Desta forma, não se tratou, como previsto em estudos do Executivo que enfatizam a lógica do governo, de uma centralização no intuito de escapar aos pontos de veto e implementar as políticas de sua preferência (MOE, 1985; TSEBELLIS, 1995). Tratou-se, sim, de agregar as preferências individuais das organizações em uma estratégia de governo comum. 
Ademais, notou-se nos casos analisados de coordenação intragovernamental pela Casa Civil que a implementação e seus resultados afetam diretamente as decisões que lhes sucedem, em um movimento retroalimentado entre formulação, implementação e monitoramento. Nesse contexto, os burocratas de médio escalão assumem um papel bastante relevante, atrelado a suas atividades de intermediação entre a implementação e os atores políticos e aos seus recursos técnicos, de conhecimento e informacionais, demandados mesmo em situações de centralização por órgão da Presidência.

Por último, acrescente-se que, no Itamaraty, discernem-se três modalidades de interação com os outros órgãos afetos à política migratória: interação ordinária, conjuntural e participativa ${ }^{354}$. A interação ordinária, informal e associada à implementação da política, é empreendida por burocratas detentores de postos de Chefia de Divisão e inferiores. Já a interação conjuntural foi observada no capítulo 4 nas negociações de acordos bilaterais ou multilaterais, casos em que podem tomar parte, além dos chefes de Divisão, o Diretor de Departamento ou Subsecretário-geral. Também se enquadram como interações conjunturais aquelas observadas nas reuniões interministeriais convocadas pela Casa Civil, situações em que envolvem o Secretário Geral do Itamaraty. Por último, a interação participativa se dá no CNIg e nos eventos, fóruns e seminários organizados sobre o tema, aos quais normalmente atendem os Chefes de Divisão e Diretores de Departamento. ${ }_{354}$ Essa nomenclatura é utilizada por Hoyler (2014) em sua análise das relações público-privado na
política de uso e ocupação do solo no município de São Paulo. 


\section{Conclusão e Considerações Finais}

As fronteiras transformam uma conclusão em início: no espaço que demarca o fim de um Estado e o início de outro, indivíduos migrantes começam novas etapas de suas vidas. Nesse reinício, experimentam a reformatação de seu vínculo com a comunidade política. É o Estado, por meio de suas instituições, quem delineia essa alteração de status político dos indivíduos e determina suas consequências. Nesse sentido, esta tese se alinha à visão de que pensar a imigração significa pensar o Estado, e entender a política migratória implica em situá-la no quadro da ação estatal.

O Estado, porém, não é uma entidade una e coesa, mas um conglomerado de agências em constante interação entre si, com atores não-estatais e mesmo internacionais. Tampouco corresponde a uma entidade estática: é dinâmico e plural, motivo pelo qual o entendimento das mudanças em política migratória passa pela análise de mudanças que ocorrem no próprio Estado.

Essa tese nasceu do seguinte questionamento: por que, a despeito de amplas reivindicações da sociedade civil e comunidade epistêmica, de percepções dos burocratas e de iniciativas legislativas, a Lei $n^{\circ} 6.815 / 1980$ continuou vigente por 37 anos? Nesse sentido, o objetivo do trabalho foi o de analisar os padrões de mudança e continuidade na política migratória brasileira, de maneira a observar o papel neles exercido pela dinâmica político-burocrática interorganizacional. Empreendeu, portanto, uma análise do funcionamento do Executivo segundo uma lógica de políticas públicas, centrando-se no processo político subjacente aos resultados em política migratória. A perspectiva institucionalista aqui adotada, focada em tomadores de decisão, não ignora a influência de fatores intervenientes extra-estatais sobre a política migratória, mas sugere que essa influência é balizada pelo processo decisório e pelas instituições que o fundamentam.

A política migratória tem a peculiaridade de versar sobre fenômeno de caráter inerentemente internacional. Desta forma, ao analisá-la em uma perspectiva estatal esta tese buscou observar não apenas o Estado em ação, examinando o processo da política pública, mas também o Estado em interação, o que se deu em duas perspectivas: (i) explorando como ele interage com outros Estados e atores internacionais; e (ii) detalhando como as diversas organizações que o compõem coordenam suas atividades. 
Assim, a tese se propôs a responder a três questões de pesquisa: (i) quais consequências a fragmentação de competências engendra para a política migratória no Brasil?; (ii) como as arenas internacional e doméstica se influenciam mutuamente no processo político migratório?; (iii) como ocorre a coordenação intragovernamental no contexto do arranjo institucional complexo da política migratória brasileira?

O arranjo institucional da política migratória brasileira é formado por várias agências com competências distintas, por vezes compartilhadas ou concorrentes, conferidas justamente de maneira a preservar lógicas setoriais na política. Essas lógicas setoriais estão associadas a objetivos governamentais que, em distintos momentos históricos, fundamentaram as políticas migratórias no país. Formado pelos Ministérios das Relações Exteriores, da Justiça e do Trabalho, o triunvirato da política migratória brasileira revezou o protagonismo na seara durante todo o século XX.

A análise das trajetórias institucionais da política migratória demonstrou a importância histórica da imigração como um fenômeno político, estruturante e estruturado pelo Estado brasileiro. Expôs que a política migratória brasileira passou por sucessivos redesenhos institucionais que se situam na interface entre os processos de state-building e nation-building do país, e que as reformas verificadas no decorrer do século XX, ao criarem novas instituições ou redistribuírem as competências entre organizações existentes, tenderam a não excluir os atores envolvidos do jogo político. Dessa forma, as reformas parciais levaram a uma pluralidade de organizações com responsabilidades sobrepostas.

A tese defendeu que esse arranjo institucional fragmentado e de competências sobrepostas é estruturante de processos organizacionais que conduzem a um duplo mecanismo: de um lado, o aumento das capacidades técnico-administrativas e políticorelacionais das organizações gera mudanças incrementais setoriais. De outro, estratégias voltadas para manter ou ampliar o espaço de poder e a lógica de ação organizacional levam as organizações a oporem obstáculos a reformas mais amplas. Esse duplo mecanismo corresponde a duas faces de um mesmo objetivo: a manutenção ou ampliação da autonomia da organização.

Entende-se que as organizações são formadas por dirigentes políticos e burocratas públicos, agentes que empreendem os mecanismos teorizados. Dentre esses burocratas, destacou-se o papel exercido por aqueles de médio escalão. O processtracing trouxe evidências de que, ao empreenderem esforços para manutenção e 
ampliação da autonomia das suas organizações, esses atores burocráticos e políticos protagonizaram disputas interorganizacionais que determinaram a perpetuação do arranjo institucional sub-ótimo.

O process-tracing observou que todos os atores entrevistados reconheciam a necessidade de haver uma reforma migratória, o que corresponde ademais a uma demanda da sociedade e a uma agenda que já vinha sendo mobilizada no Executivo e no Legislativo desde a década de 1990. No entanto, a reforma não ocorre. Com efeito, as inovações identificadas na política migratória brasileira correspondem a mecanismos de disposição em camadas, ou seja, à introdução de novas regras acima ou ao lado de regras já existentes (MAHONEY; THELEN, 2010). Mudanças na maneira com que o poder seria acumulado e partilhado entre os diversos atores foram, no entanto, repetidamente obstacularizadas - o que se concretizou em desacordos sobre desenhos institucionais que permearam o debate dos vários projetos de lei no período em análise.

Por seu turno, mudanças incrementais no âmbito de cada organização foram implementadas, destacando-se nos três Ministérios analisados inovações destinadas a solucionar problemas de gestão administrativa que acabaram repercutindo em garantias de direitos para os imigrantes. Notadamente conduzidas por burocratas de médio escalão, tais mudanças incrementais consagram objetivos de gestão relacionados a eficiência e transparência, vinculados à gramática do "universalismo de procedimentos" (NUNES, 2010) e aos princípios da gestão por resultados. Estão associadas, desta forma, a mudanças observadas no Estado brasileiro a partir do final da década de 1990.

A esta estratégia de fortalecimento das capacidades técnico-administrativas adiciona-se a internacionalização: em um contexto de recursos limitados, observou-se o recurso a organizações internacionais para obtenção de financiamento, recursos humanos e, principalmente, expertise. Destaca-se ainda a estratégia de obtenção e sistematização de dados e informações, o que se relaciona com a preocupação com a eficácia da política.

Já quanto às capacidades político-relacionais, destaca-se de antemão a criação de espaços de debate como seminários, conferências e grupos de trabalho para discutir como as migrações deveriam ser geridas. A isso se somaram mecanismos de participação social, de articulação federativa e de advocacy observada junto a atores políticos durante os processos de tramitação dos projetos de lei. A estratégia de ampliação da capacidade estatal político-relacional que foi adicionada ao esquema de 
Gomide e Pires (2014), qual seja, relações e mecanismos de interface com instituições internacionais, foi também observada no process-tracing. Constatou-se que a interação dos Ministérios com instituições internacionais se dá não apenas no desígnio de construir capacidades técnico-administrativas por meio de recursos e expertise, mas também de revestir-se de legitimidade ao aderir a suas boas práticas e recorrer ao regime internacional; inserir-se na comunidade política migratória internacional, participando de seminários, eventos e diálogos; e tomar parte em arenas multilaterais.

Desta forma, nota-se uma capilarização do internacional na política doméstica como estratégia de ampliação da capacidade estatal das burocracias - o que alinha esta tese à literatura segundo a qual, para atores domésticos, os atores e instituições internacionais são meios e recursos no processo político doméstico (MORAVCSIK, 2000). Paralelamente, observou-se a construção da posição externa do Brasil em política migratória de maneira compartilhada entre diferentes burocracias, embora dentro dos limites das diretrizes de projeção internacional do país à época, que aliavam reciprocidade e direitos humanos às tradicionais autonomia e desenvolvimento.

Em suma, observou-se no process-tracing da política migratória brasileira entre 2003 e 2016 a continuação da tendência historicamente verificada de ser domesticamente estruturada por características do modelo de Estado, e externamente vinculada às linhas gerais da projeção internacional do país.

Ao questionamento sobre se há um regime internacional de migração, esta tese defendeu que, de acordo com a definição de regimes como instituições, normas e procedimentos que regulamentam o comportamento dos atores de maneira a afetar a interdependência internacional, pode-se afirmar que há um regime internacional de migrações, muito embora formado por normas e instituições fragmentadas e pouco formalizadas. Ainda que inexista uma instância multilateral com mandato específico e abrangente sobre as migrações e que sejam poucas as normas vinculantes, a criação de fóruns e diálogos; a atuação setorial de agências ONU; os diagnósticos e recomendações do Relator Especial em Migrações e da Comissão Global sobre Migrações Internacionais; a atuação da OIM em 188 países, dentre outros elementos, contribuem para a criação e consolidação de conceitos e boas práticas aptos a serem mobilizados pelos Estados e a enquadrarem suas interações. A mobilização do regime internacional por diversos atores domésticos brasileiros leva a um curioso paradoxo: o Brasil não ratificou a Convenção Internacional de 1990 sobre a Proteção dos Direitos de Todos os 
Trabalhadores Migrantes e Membros de Suas Famílias, mas exorta outros países a fazêlo em instâncias multilaterais e utiliza-a como argumento interno de legitimidade nos debates políticos.

Os eventos estudados mostram, ademais, o caráter de processo da política pública, que não se compartimenta em fases incomunicáveis. Nesse processo, os burocratas de médio escalão exercem o importante papel de dutos de transmissão entre a formulação e a implementação, notadamente ao canalizarem informações e conhecimento entre os polos.

O destaque da agência burocrática observado na política migratória brasileira a tornaria uma política camuflada, tal como no conceito proposto por Virginie Guiraudon (2006)? De fato, a atuação dos burocratas ocorre paralelamente, no caso em análise, à ausência de formação de uma estratégia governamental sobre o tema. Entretanto, a criação de arenas de participação social, as parcerias com entidades da sociedade civil, a promoção de eventos, seminários e outros fóruns de debate, bem como a frequente interveniência de atores do Legislativo e Judiciário sugerem que a formulação política no seio do Executivo, ainda que com forte influência burocrática, não está imune à ação de freios e contrapesos e se deu em diálogo com a sociedade.

Desta forma, percebe-se que os burocratas de médio escalão não atuam insuladamente, mas costuram redes junto a atores políticos, sociais, privados e burocráticos de outros níveis e organizações. Nesse sentido, observou-se a existência de uma comunidade política migratória, na qual as migrações emergem como um campo político com abordagem própria, no qual coexistem, todavia, diferentes lógicas de ação organizações participantes.

Nesse quadro, emerge o difícil tradeoff entre especialização e coordenação. A tese observou como, no arranjo institucional complexo da política migratória brasileira, a coordenação envolve elementos de arranjos hierárquicos, de mercado e de redes, em que burocratas operam por meio de relações e trocas não previstas no desenho institucional formal e promovem interações com atores não-estatais. Nesse contexto ressalta a baixa capacidade de coordenação do CNIg, que se configura como um grupo interorganizacional, nos termos propostos por Alexander (1993). Em seu processo decisório, observa-se a esquiva do conflito e do enfrentamento às diferenças, o que aproxima o Conselho do modelo da concorrência proposto por Hermann et al. (2001). Trata-se, contudo, de espaço importante de interações, consultas e trocas de informações 
que reforça, junto a seminários, eventos e oficinas, a consolidação da comunidade política em migrações.

Verificaram-se padrões de redes nas relações interorganizacionais operadas pelos burocratas na implementação da política, por meio de intercâmbios de informações que ocorrem com significativa frequência, destacando-se a participação de burocratas de médio escalão, inclusive os do Itamaraty. Nesse ponto, concluiu-se que a interação do Itamaraty com os outros órgãos afetos à política migratória se dá em três modalidades: (i) interação ordinária, informal, empreendida por burocratas detentores de postos de Chefia de Divisão e inferiores; (ii) interação conjuntural, por ocasião de negociações de acordos bilaterais ou multilaterais, casos em que podem tomar parte, também, o Diretor de Departamento ou Subsecretário-geral, ou de reuniões interministeriais sob convocação da Casa Civil, quando envolvem o Secretário Geral; (iii) interação participativa, no CNIg e eventos, fóruns e seminários organizados sobre o tema, aos quais normalmente atendem os Chefes de Divisão e Diretores de Departamento.

A avocação da coordenação pela Casa Civil no caso dos Haitianos e no programa Mais Médicos, a despeito de inúmeras diferenças, mostra uma dinâmica comum na qual o órgão formaliza a coordenação, com autoridade para cobrar e demandar dos Ministérios, mas é um Ministério-fim quem conduz a sua operacionalização e participa de sua implementação - o Ministério da Saúde, no caso do Mais Médicos, e o da Justiça na questão haitiana. Ao coordenar a tomada de decisão em reuniões interministeriais, a Casa Civil buscou agregar as preferências individuais das organizações em uma estratégia de governo comum. Nesse contexto, os burocratas de médio escalão exercem um relevante papel, atrelado a seus recursos técnicos, de conhecimento e informacionais, inclusive referentes à implementação.

Nesses termos, se a análise da trajetória histórica das instituições relacionadas à política migratória no Brasil denota sua associação ao state-building brasileiro, há um indicativo de que $o$ atual momento desse Estado seja caracterizado pelo incrementalismo burocrático, pela participação social introjetada pelo próprio Executivo, que se mostra ator autônomo e proativo no diálogo democrático, e pela capilarização do internacional em diversas agências burocráticas. Entretanto, trata-se de Estado também marcado por deficiências de coordenação entre diferentes organizações, cada uma com seu espaço de poder e lógica de ação. 
Um dos fundamentos teóricos deste trabalho, qual seja, o de que a cada policy corresponde uma politics, bem como a metodologia qualitativa adotada, levaram a que as explicações aqui ofertadas tenham se baseado em determinadas peculiaridades da política migratória, particularmente seu desenho institucional com fragmentação de competências, seu caráter intersetorial, e sua regulamentação geral por uma normativa antiga e com problemas de adaptação à realidade fática. No entanto, dadas as categorias analíticas selecionadas para composição dos mecanismos e as relações causais encontradas, pode-se esperar comportamentos semelhantes, resguardada a homogeneidade causal, em uma população de casos caracterizada por intersetorialidade e/ou pulverização de competências. As hipóteses descritivas da internacionalização e da coordenação em arranjos institucionais complexos, ao visarem à descrição do caso específico, não pretendem estabelecer inferências sobre uma classe de eventos, muito embora tenham sido concebidas mediante uso de categorias analíticas mais gerais a fim de possibilitar seu teste em outros casos.

De fato, as dificuldades de generalização constituem um desafio enfrentado pelos estudos de caso. A despeito disso, avaliamos que a escolha metodológica permitiu explorar em detalhes o mecanismo teorizado, e desta maneira tornar patente a vinculação da política migratória a elementos institucionais que caracterizam o funcionamento do Executivo e o desenho do Estado brasileiro. Possibilitou, ademais, identificar sutilezas do processo político, particularmente relacionadas à internacionalização e coordenação intragovernamental.

Para além das respostas que oferece, a tese suscita uma variedade de perguntas aptas a embasar futuras agendas de pesquisa. As primeiras delas se relacionam a um de seus achados mais interessantes, mas que não pôde ser devidamente explorado por limitações do seu objetivo e metodologia: a interface entre a formação estatal e a formação nacional observada na política migratória brasileira. Nesse contexto, qual a contribuição do Itamaraty para formação da identidade nacional brasileira por intermédio de suas reflexões de nação em questões atinentes à política migratória? $\mathrm{O}$ que os debates parlamentares sobre os projetos de lei de reforma migratória revelam sobre características e contradições da nação brasileira?

No quadro dos estudos sobre agência burocrática, cabem análises sobre a atuação dos agentes de postos consulares como burocratas street-level, explorando o contraponto entre a discricionariedade por eles exercida e a hierarquia do Itamaraty. 
Além disso, impendem estudos sobre o papel dos burocratas na consolidação de políticas de direitos no Brasil, particularmente as de direitos humanos. Por último, outra agenda que deriva da presente tese é aquela relacionada a arranjos institucionais de políticas intersetoriais, mais voltada para estudos de gestão pública: quais os tradeoffs entre arranjos centralizados e fragmentados? 


\section{BIBLIOGRAFIA}

ABERS, Rebecca Neaera; KECK, Margaret E. Practical Authority: agency and institutional change in Brazilian Water Politics. Nova York: Oxford University Press, 2013.

ABRAMO, Laís. "Introdução". In: ALMEIDA, Paulo Sérgio; PENNA, Rodrigo (Orgs.). OIT - Contribuições para a Construção de Políticas Públicas Voltadas à Migração para o Trabalho. Brasília: Escritório Internacional do Trabalho, 2009.

ABRANCHES, Sérgio. Presidencialismo de coalizão: o dilema institucional brasileiro. Dados, Rio de Janeiro, v. 31, n. 1, p. 5-44, 1988.

ABRUCIO, Fernando Luiz; PEDROTI, Paula; PÓ, Marcos Vinícius. "A formação da burocracia brasileira: a trajetória e o significado das reformas administrativas". In: LOUREIRO, Maria Rita; ABRUCIO, Fernando Luiz; PACHECO, Regina Silva. Burocracia e política no Brasil: desafios para a ordem democrática no século XXI. Rio de Janeiro: Editora FGV, 2010. p.27-72.

ALEXANDER, Ernest. Interorganizational Coordination: Theory and Practice. Journal of Planning Literature, v. 7, n.4, p.328-343, 1993.

ALLISON, Graham. Conceptual Models and the Cuban Missile Crisis. The American Political Science Review, v.63, n.3, p.689-718, 1969.

ALMEIDA, Paulo Roberto de. "Introdução: Em busca da simplicidade e da clareza perdidas: Delgado de Carvalho e a historiografia diplomática brasileira". In: CARVALHO, Carlos Delgado de. História diplomática do Brasil. Introdução: Paulo Roberto de Almeida. Ed. Fac similar. Brasília: Senado Federal, 1998.

"Do alinhamento recalcitrante à colaboração relutante: o Itamaraty em tempos de AI-5". In: MUNTEAL FILHO, Oswaldo et al. (Orgs.), Tempo Negro, temperatura sufocante: Estado e Sociedade no Brasil do AI-5. Rio de Janeiro: Ed. PUC-Rio, Contraponto, p. 65-89, 2008.

; ARAÚJO, João Hermes Pereira de. "Oswaldo Aranha: na continuidade do estadismo de Rio Branco". In: PIMENTEL, José Vicente de Sá (Org.). Pensamento diplomático brasileiro : formuladores e agentes da política externa (1750-1950), v.3. Brasília : FUNAG, p.669-714, 2013.

ALMEIDA, Paulo Sérgio. Conselho Nacional de Imigração (CNIg): Políticas de Imigração e Proteção ao Trabalhador Migrante ou Refugiado. Cadernos de Debates Refúgio, Migrações e Cidadania, v.4, n. 4. Brasília : Instituto Migrações e Direitos Humanos, 2009.

AMORIM, Celso. "II Conferência das Comunidades Brasileiras no Exterior". In: MRE. Resenha de Política Exterior do Brasil, Número 103, $2^{\circ}$ semestre de 2008, p.51-52. Disponível em: http://www.itamaraty.gov.br/pt-BR/resenha-de-politica-exterior-dobrasil. Acesso em: 10 nov. 2016.

، "306a Sessão do Conselho de Administração da Organização Internacional do

Trabalho". In: MRE. Resenha de Política Exterior do Brasil, Número 105, $2^{\circ}$ semestre de 2009. Disponível em: http://www.itamaraty.gov.br/pt-BR/resenha-depolitica-exterior-do-brasil. Acesso em: 10 nov. 2016.

AMORIM NETO, Otávio. Presidencialismo e Governabilidade nas Américas. Rio de Janeiro: Ediora FGV, 2006. 
De Dutra a Lula: a condução e os determinantes da política externa brasileira. Rio de Janeiro: Elsevier, 2011.

ANDRADE, José Henrique Fischel de. A proteção internacional dos refugiados no limiar do século XXI. Travessia, maio/agosto, 1996.

ARANGO, Joaquín Las migraciones internacionales en un mundo globalizado. Vanguardia Dossier. Barcelona: La Vanguardia Ediciones, nº 22, p. 6-17, enero-marzo de 2007.

ARANTES, Rogério B. "Polícia Federal e construção institucional". In: AVRITZER, Leonardo; FILGUEIRAS, Fernando (Org.). Corrupção e sistema político no Brasil. Rio de Janeiro: Civilização Brasileira, p.99-132, 2011.

ARDITTIS, Solon; LACZKO, Frank. "Introduction". In: ARDITTIS, Solon; LACZKO, Frank (Org.). Assessing the Costs and Impacts of Migration Policy: An International Comparison. Genebra: IOM e Eurasylum, 2008.

ARRETCHE, Martha. "Uma contribuição para fazermos avaliações menos ingênuas". In: BARREIRA, Maria Cecília; BRANT Maria do Carmo de (Org.). Tendências e Perspectivas na Avaliação de Políticas e Programas Sociais. São Paulo: IEE/PUCSP, 2001.

BARALDI, Camila. Migrações internacionais, direitos humanos e cidadania sulamericana: o prisma do Brasil e da integração sul-americana. Tese (doutorado). Universidade de São Paulo, Instituto de Relações Internacionais, Programa de PósGraduação em Relações Internacionais. São Paulo, 2014.

BARDACH, Eugene .Turf barriers to interagency collaboration. In: KETTL, D.; MILWARD, H. The state of public management. Baltimore: John Hopkins University Press, p.168-192, 1996.

BARRETO, Luiz Paulo Teles. Discurso da delegação brasileira no Diálogo de Alto Nível das Nações Unidas sobre Migração e Desenvolvimento. Refúgio, Migrações e Cidadania - Caderno de Debates 2. Brasília: IMDH, 2007.

BARROS, Sebastião do Rego. A execução da política externa brasileira: um balanço dos últimos 4 anos. Revista Brasileira de Política Internacional, v.41, n.2, p.18-28, 1998.

"Assistência aos brasileiros no exterior". In: MRE. Resenha de Política Exterior do Brasil, a. 23, n. 78, $1^{\circ}$ semestre 1997. Disponível em: http://www.itamaraty.gov.br/pt-BR/resenha-de-politica-exterior-do-brasil. Acesso em: 10 nov. 2016.

BATISTA, Mariana. O Poder no Executivo: explicações no presidencialismo, parlamentarismo e presidencialismo de coalizão. Revista de Sociologia e Política, v.24, n.57, p.127-155, mar. 2016.

O mistério dos ministérios: a governança da coalizão no presidencialismo brasileiro. Tese (doutorado) - Universidade Federal de Pernambuco, CFCH. Programa de Pós-graduação em Ciência Política, 2014.

BAUMGARTNER, Frank; JONES, Bryan. Agendas and instability in American Politics. Chicago, Londres: The University of Chicago Press, 2009.

BEACH, Derek; PEDERSEN, Rasmus Brun. Causal Case Studies Methods: foundations and guidelines for comparing, matching and tracing (no prelo). Sob contrato na University of Michigan Press. Disponibilizado pelo autor. 
BENNETT, Andrew; ELMAN, Colin. Case study methods in the International Relations subfield. Comparative Political Studies, v.40, n.2, p. 170-195, 2007.

BEIGUELMAN, Paula. A crise do escravismo e a grande imigração. São Paulo: Brasiliense, 1987.

BELÉM LOPES, Dawisson. Política externa e democracia no Brasil. São Paulo: Editora Unesp, 2013.

BERSCH, Katherine; PRAÇA, Sergio; TAYLOR, Matthew. State Capacity and Bureaucratic Autonomy Within National States: Mapping the Archipelago of Excellence in Brazil. Paper apresentado na Conferência da Latin American Studies Association. Washington D.C. 29 maio -1 junho, 2013

BIAGGI, Marcus Vinícius Correia. Sobre diplomacia e território (1831-1834): edição de documentos do Arquivo Histórico do Itamaraty. Dissertação de mestrado. $224 \mathrm{fl}$. Universidade de São Paulo, Departamento de História, 2014.

BOMMES, Michael; GEDDES, Andrew. Immigration and Welfare: Challenging the Bordes of the Welfare State. New York: Taylor \& Francis, 2002.

BONIS, Daniel de; PACHECO, Regina. "Nem político nem burocrata: o debate sobre o dirigente público". In: LOUREIRO, Maria Rita; ABRUCIO, Fernando Luiz; PACHECO, Regina Silva. Burocracia e política no Brasil: desafios para a ordem democrática no século XXI. Rio de Janeiro: Editora FGV, 2010. p.329-362.

BORJAS, George. Economic Theory and International Migration.International Migration Review, v.23, p.457-485, 1989.

BOUCKAERT, Geert; PETERS, Guy; VERHOEST, Koen. The Coordination of Public Sector Organizations: Shifting Patterns of Public Management. Hampshire: Pallgrave Macmillan, 2010.

BRESSER-PEREIRA, Luiz Carlos. Ideologias econômicas e democracia no Brasil. Estudos Avançados, v.3, n.6, 1989.

Burocracia e Classes Dirigentes no Brasil. Revista Soiologia Política, v.28, p.9-30, jun. 2007.

BRETTELL, Caroline; HOLLIFIELD, James “Introduction". In: BRETTELL, Caroline; HOLLIFIELD, James (Eds.). Migration Theory: Talking Across Disciplines. New York: Taylor \& Francis, 2015.

BRUBAKER, Roger. Citizenship and Nationhood in France and Germany. Cambridge, London: Harvard University Press, 1992.

BUENO, Clodoaldo. A República e sua Política Exterior (1889-1902). São Paulo: Editora Umsp, 1995.

CALÓGERAS, João Pandiá. A Política Exterior do Império. Brasília: Senado Federal, 1998.

CÂMARA DOS DEPUTADOS. Câmara dos Deputados - site oficial. Disponível em: http://www2.camara.leg.br/. Acesso em: 02 jan. 2017.

CAMINO, Maria Ester; FONTANIVE, Vicente. Nota técnica sobre Mensagem 696, 2010, do Poder Executivo. Brasília: Câmara dos Deputados, 2014. Disponível em: http://www2.camara.leg.br/documentos-e-pesquisa/publicacoes/estnottec/areas-daconle/tema3/2014_11685.pdf. Acesso em: 28 fev 2017. 
CAMPOS, Marden Barbosa. Reversão do saldo migratório internacional negativo do Brasil? Evidências preliminares com base nos dados do Censo 2010. Revista Paranaense de Desenvolvimento, n.121, p.189-200, 2011.

CAPOCCIA, Giovanni; KELEMEN, R. Daniel. The Study of Critical Junctures: Theory, Narrative and Counterfactuals in Historical Institutionalism. World Politics, v.59, n.3, p.341-369, abril 2007.

CARNEIRO, Maria Luiza Tucci. A Imagem do Imigrante Indesejável. Revista Seminários - PROIN, Projeto Integrado do Arquivo Público do Estado e Universidade de São Paulo, $\mathrm{n}^{\circ} \quad 3, \quad 2003 . \quad$ Disponível em: http://www.usp.br/proin/publicacoes/revista.php.

CARVALHO, Carlos Delgado de. História diplomática do Brasil. Introdução: Paulo Roberto de Almeida. Ed. Fac similar. Brasília: Senado Federal, 1998.

s y redes de actores en España y Europa. Barcelona: Fundación CIDOB, 2008. p. 2343.

CARVALHO, José Alberto Magno; CAMPOS, Marden Barbosa. A variação do saldo migratório do Brasil. Estudos Avançados, v.20, n.57, p.55-58, 2006.

CARVALHO, José Murilo de. Political Elites and State Building: The case of Nineteenth-Century in Brazil. Comparative Studies in Society and History, v.24, n.3, p.378-399, jul. 1982.

CASADO, Rut Bermejo. "Los Controles a la inmigración en España y el Reino Unido: dinámicas y actores nacionales implicados". In: ZAPATA-BARRERO, Ricard; PINYOL, Gemma (Eds.). Los gestores del proceso de inmigración. BONFÁ, Rogério Luís Gianpietro. "Com ou sem Lei: a expulsão dos estrangeiros na Primeira República. Cadernos AEL, v.14, n.26, p.185-214, 2009.

CASON, Jeffrey W.; POWER, Timothy J. Presidentialization, Pluralization, and the Rollback of Itamaraty: Explaining Change in Brazilian Foreign Policy Making in the Cardoso-Lula Era. International Political Science Review, v.30, n.2, p.117-140, 2009.

CASTLES, Stephen; MILLER, Mark. The Age of Migration: international population movements in the modern world. Guilford Press: Basingstoke, 2003.

CAVALCANTE, Pedro Luís Costa; LOTTA, Gabriela Spanghero. "Introdução". In: CAVALCANTE, Pedro; LOTTA, Gabriela (Orgs.). Burocracia de médio escalão: perfil, trajetória e atuação. Brasília: ENAP, p.13-22, 2015.

ENAP, 2015.

Burocracia de médio escalão: perfil, trajetória e atuação. Brasília:

CAVALCANTI, Leonardo; OLIVEIRA, Tadeu. "A Caminho Da Conclusão: Meia Década De Novos Fluxos Imigratórios No Brasil”. In: CAVALCANTI, L; OLIVEIRA, T.; ARAUJO, D., A inserção dos imigrantes no mercado de trabalho brasileiro. Relatório Anual 2016. Observatório das Migrações Internacionais; Ministério do Trabalho/ Conselho Nacional de Imigração e Coordenação Geral de Imigração. Brasília, DF: OBMigra, p.142-146, 2016

CDHIC - Centro de Direitos Humanos e Cidadania do Imigrante; ESF - Espaço Sem Fronteiras. Brasil: Informe sobre a Legislação Migratória e a realidade dos imigrantes. São Paulo: CDHIC, 2011. 
CERVO, Amado Luiz. As relações históricas entre o Brasil e a Itália: o papel da diplomacia. Brasília: Editora Universidade de Brasília; São Paulo: Istituto Italiano di Cultura, 1992.

Política exterior do Brasil: o peso da História. Revista Plenarium, Brasília, ano $2, \mathrm{n}^{\circ} 2$, pp.10-26, 2005.

" "Introdução à política externa e às concepções diplomáticas do período imperial". In: PIMENTEL, José Vicente de Sá (Org.). Pensamento diplomático brasileiro : formuladores e agentes da política externa (1750-1950), v.1. Brasília : FUNAG, p.41-49, 2013.

CHEIBUB, Zairo Borges. Diplomacia e Construção Institucional: o Itamaraty em uma perspectiva histórica. Dados - Revista de Ciências Sociais, v.28, n.1, p.113-131, 1985.

A carreira diplomática no Brasil: o processo de burocratização do Itamarati.

Revista de Administração Pública, v.23, n.2, p.97-128, 1989.

CHRYSOSTOMO, Maria Isabel de Jesus; VIDAL, Laurent. Do depósito à hospedaria de imigrantes: gênese de um "território da espera" no caminho da emigração para o Brasil. História, ciências e saúde - Manguinhos, v.21, n.1, p.1-23, 2014.

CNV - Comissão Nacional da Verdade. Relatório da Comissão Nacional da Verdade, volume 1. Brasília: CNV, 2014.

COENTRO, Luciana. Políticas públicas e gestão das migrações internacionais no Brasil: uma reflexão sobre os migrantes qualificados. Dissertação (mestrado). São Paulo, Escola de Administração de Empresas de São Paulo, 2011.

COLLIER, David. Translating Quantitative Methods for Qualitative Researchers: The Case of Selection Bias. The American Political Science Review, v.89, n.2, p.461-466, jun 1995.

CONECTAS. "Política migratória brasileira: por uma política além de 'remendos"'. In: CONETAS. Relatório Anual Conectas Direitos Humanos. 2012. Disponível em: http://www.conectas.org/relatorio/2012/pt/desenvolvimento-dhs-1.as. Acesso em: 15 nov 2015.

CORNELIUS, Wayne; TSUDA, Takeyuki. "Controlling Immigration: The Limits of Government Intervention". CORNELIUS, Wayne et al. (Eds.). Controlling Immigration: A Global Perspective. Stanford: Stanford University Press, 2004. p.3-48.

COSTA, Bruno Lazzarotti; BRONZO, Carla. "Intersetorialidade no enfrentamento da pobreza: o papel da implementação e da gestão". In: FARIA, Carlos A. Pimenta de (Org.). Implementação de políticas públicas: teoria e prática. Belo Horizonte: Ed. PUC Minas, 2012.

DANESE, Sérgio. Diplomacia presidencial: história e crítica. Rio de Janeiro: Topbooks, 1999.

D’ARAUJO, Maria Celina. "Elites burocráticas, dirigentes públicos e política no poder Executivo". In: D’ARAUJO, Maria Celina (Org.). Redemocratização e mudança social no Brasil. Rio de Janeiro: Ed. FGV, 2014. p.205-229.

DIAS, Guilherme Mansur. Migração e crime : desconstrução das políticas de segurança e tráfico de pessoas. Tese (doutorado) - Universidade Estadual de Campinas, Instituto de Filosofia e Ciências Humanas. 2014.

DIMAGGIO, Paul J. "Constructing an Organizational Field as a Professional Project: U.S. Art Museums, 1920-1940". In: POWELL, Walter W.; DIMAGGIO, Paul 
J. (Orgs.). The New Institutionalism in Organizational Analysis. Chicago: University of Chicago Press, 1991. p.267-292.

; POWELL, Walter W. "Introduction". In: POWELL, Walter W.; DIMAGGIO, Paul J. (Orgs.). The New Institutionalism in Organizational Analysis. Chicago: University of Chicago Press, p.1-35, 1991a.

; POWELL, Walter W. "The Iron Cage Revisited: Institutional Isomorphism and Collective Rationality”. In: POWELL, Walter W.; DIMAGGIO, Paul J. (Orgs.). The New Institutionalism in Organizational Analysis. Chicago: University of Chicago Press, p.63-82, $1991 b$.

DINIZ, Simone; RIBEIRO, Cláudio Oliveira. The Role of Brazilian Congress in Foreign Policy: an empirical contribution to the debate. Brazilian Political Science Review, v.2, n.2, p.10-38, 2008.

DIZNER, Gabriel Felipe da Fonseca. Política Externa e Política Migratória no Brasil: convergências e distanciamentos (1995-2010). Dissertação de Mestrado. Universidade de Brasília: Programa de Pós-graduação do Instituto de Relações Internacionais. 2015.

DOMÍNGUEZ, Jorge. "Immigration as Foreign Policy in U.S. - Latin America Relations". In: TUCKER, Robert et al. (Eds.). Immigration and Foreign Policy. Boulder: Westview Press, p. 150-166, 1990.

DOWNS, Anthony. Uma Teoria Econômica da Democracia. São Paulo: Edusp, 1999.

DRAIBE, Sônia. Rumos e Metamorfoses: Estado e Industrialização no Brasil (1930-1960). Rio de Janeiro: Paz e Terra, 1985.

DREZNER, Daniel W. Ideas, Bureaucratic Politics, and the Crafting of Foreign Policy. American Journal of Political Science, v.44, n.4, p.733-749, 2000.

DULCI, Tereza Maria Spyer. As Conferências Pan-americanas: identidades, união aduaneira e arbitragem (1889 a 1928). Dissertação (Mestrado - Programa de PósGraduação em História Social). Departamento de História da Faculdade de Filosofia, Letras e Ciências Humanas da Universidade de São Paulo. São Paulo, 2008.

ELLERMAN, Antje. Street-level democracy: how immigration bureaucrats manage public opposition. West European Politics, v.29, n.2, p.293-309, 2006.

EVANS, Peter. O Estado como Problema e Solução. Lua Nova, n.28-29, abril 1993.

Embedded autonomy: states and industrial transformation. Princeton: Princeton University Press, 1995.

; RUESCHEMEYER, Dietrich; SKOCPOL, Theda (Eds.). Bringing State Back In. Cambridge: Cambridge University Press, 1985.

FARAH, Marta Ferreira Santos. Parcerias, novos arranjos institucionais e políticas públicas no nível local de governo. Revista de Administração Pública, v. 35, n.1, p.119-144, 2001.

FARIA, Carlos Aurélio Pimenta de. Ideias, conhecimento e políticas públicas: um inventário sucinto das principais correntes analíticas recentes. Revista Brasileira de Ciências Sociais, v.18, n.51, p.22-29, 2003.

Opinião Pública e Política Externa: insulamento, politização e reforma na produção da política exterior no Brasil. Revista Brasileira de Política Internacional, v.51, n.2, p.80-97, 2008. 
O Itamaraty e a Política Externa Brasileira: Do Insulamento à Busca de Coordenação dos Atores Governamentais e de Cooperação com os Agentes Societários. Contexto Internacional, v. 34, n.1, p.311-355, janeiro/julho 2012.

; NOGUEIRA, Joana Laura Marinho; LOPES, Dawisson Belém. Coordenação Intragovernamental para a Implementação da Política Externa Brasileira: o caso do Fórum IBAS. Dados - Revista de Ciências Sociais, v.55, n.1, p. 173-220, 2012.

FARIA, Maria Rita Fontes de. Migrações Internacionais no Plano Multilateral: Reflexões para a Política Externa Brasileira. Brasília: FUNAG, 2015.

FARIAS, Rogério de Souza. Processo decisório e política externa brasileira: o caso da busca do assento permanente na Organização Internacional do Comércio. Cena Internacional, v.8, $\mathrm{n}^{\circ} 2$, p.124-170, 2006.

FARIAS, Rogério de Souza; RAMANZINI JÚNIOR, Haroldo. A construção do horizonte e o futuro do estudo da política externa brasileira. Boletim Meridiano 47, v.14, n.137, p.03-12, 2012.

FELDMAN, Luiz. Soberania e Modernização no Brasil: Pensamento de Política Externa no Segundo Reinado e na Primeira República. Contexto Internacional, v.31, n.3, p.535-592, 2009.

FELDMAN, Luiz. Três atos da "consularização" da diplomacia brasileira. Política Externa, v.17, n.4, 2009a.

FERNANDES, Duval; MILESI, Rosita; FARIAS, Andressa. Do Haiti para o Brasil: um novo fluxo migratório. Caderno de Debates Refúgio, Migrações e Cidadania, v. 6, n.6, p. 73-97, 2012.

; CASTRO, Maria da Consolação; MILESI, Rosita. O fluxo de imigração recente para o Brasil e a política governamental: os sinais de ambiguidade. Caderno de Debates Refúgio, Migrações e Cidadania, v. 9, n.9, p. 93-103, 2012a.

. "A migração haitiana para o Brasil: resultado da pesquisa no destino". In: OIM - Organização Internacional para Migrações. La migración haitiana hacia Brasil: características, oportunidades y desafíos. Cuadernos migratórios $\mathrm{n}^{\circ} 6$. Buenos Aires: OIM, p.51-66, 2014.

FERRERO, Ruth. "La UE como actor em las políticas de inmigración de los Estados miembros? Una aproximación al escenario euromediterráneo. In: ZAPATABARRERO, Ricard; PINYOL, Gemma (Eds.). Los gestores del proceso de inmigración: actores y redes de actores en España y Europa. Barcelona: Fundación CIDOB, 2008.

FIANI, Ronaldo. "Arranjos Institucionais e Desenvolvimento: o papel da coordenação em estruturas híbridas". In: GOMIDE, Alexandre A.; PIRES, Roberto R. (Eds.). Capacidades Estatais e Democracia: Arranjos Institucionais de Políticas Públicas. IPEA: Brasília, 2014.

FIGUEIRA, Ariane Roder. Rupturas e continuidades no padrão organizacional e decisório do Ministério das Relações Exteriores. Revista Brasileira de Política Internacional, v. 53, n.2, p.5-22, 2010.

FIGUEIREDO, Argelina; LIMONGI, Fernando. Executivo e Legislativo na Nova Ordem Constitucional. Editora FGV: Rio de Janeiro, 2001.

Política Orçamentária no Presidencialismo de Coalizão. Rio de Janeiro, FGV Editora, 2008. 
FITTIPALDI, Ítalo. A "genética" dos modelos analíticos sobre burocracia: alcances e limites das opções ontológicas e epistemológicas dos estudos organizacionais. Revista de Sociologia e Política, v.23, n.54, p.137-153, jun. 2015.

FLYNN, Don. "New borders, new management: the dilemmas of modern immigration policies". Ethnic and Racial studies, v.28, n.3, p.463-490, 2005.

FOLHA DE SÃO PAULO. "Política migratória do brasil é 'de outra época', afirma Relator da OEA", In: Folha de São Paulo, 15 fev 2015. Disponível em: http://www1.folha.uol.com.br/mundo/2015/02/1590302-politica-migratoria-do-brasil-ede-outra-epoca-afirma-relator-da-oea.shtml. Acesso em: 15 mar 2017.

FRANÇA, Cassio Luiz de; BADIN, Michelle Ratton Sanchez. A inserção internacional do poder executivo federal brasileiro. Análises e propostas, $n^{\circ} 40$, agosto de 2010.

FRANCO, Álvaro da Costa (Org.). Documentos da Política Externa Independente. v.1. Rio de Janeiro: Centro de História e Documentação Diplomática; Brasília: Fundação Alexandre Gusmão, 2007.

FREEMAN, Gary. Modes of Immigration Politics in Liberal Democratic States. International Migration Review, v.19, p.881-902, 1995.

Toward a Theory of the Domestic Politics of International Migration in Western Nations. South Bend: Nanovic Institute, University of Notre Dame, 1998.

FREIRE, Alessandro; VIANA, Rafael; PALOTTI, Pedro Lucas. "Influência sobre o processo decisório: o que explica o protagonismo da burocracia federal de médio escalão?". In: CAVALCANTE, Pedro; LOTTA, Gabriela (Orgs.). Burocracia de médio escalão: perfil, trajetória e atuação. Brasília: ENAP, 2015. p.91-114.

FRIEDLAND, Roger; ALFORD, Robert R. "Bringing Society Back In: Symbols, Practices, and Institutional Contradictions. In: POWELL, Walter W.; DIMAGGIO, Paul J. (Orgs.). The New Institutionalism in Organizational Analysis. Chicago: University of Chicago Press, p.232-266, 1991.

GABLER, Louise. A Secretaria de Estado dos Negócios Estrangeiros e a consolidação das relações exteriores no Brasil. Cadernos MAPA n.7: Memória da Administração Pública Brasileira. Rio de Janeiro: Arquivo Nacional, 2013.

GALASKIEWICZ, Joseph. "Making corporate actors accountable: institution-building in Minneapolis - St. Paul". In: POWELL, Walter W.; DIMAGGIO, Paul J. (Orgs.). The New Institutionalism in Organizational Analysis. Chicago: University of Chicago Press, p.1-35, 1991.

GAMBINI, Roberto. O Duplo Jogo de Getúlio Vargas. São Paulo: Ed. Símbolo, 1977.

GEDDES, Barbara. Politician's Dilemma - Building state capacity in Latin America. Berkeley e Los Angeles: University of California Press, 1994.

GEDDES, Andrew. Immigration and European Integration: towards fortress Europe? Manchester: Manchester University Press, 2000.

GEORGE, Alexander L.; McKEOWN, Timothy. Case Studies and Theories of Organizational Decision Making. Advances in Information Processing in Organizations, v.2, p.21-58, 1985.

GEORGE, Alexander; BENNETT, Andrew. Case studies and theory development in the social sciences. Cambridge: MIT Press, 2005. 
GERALDO, Endrica. A "lei de cotas" de 1934: controle de estrangeiros no Brasil. Cadernos AEL, v.15, n.27, p.176-207, 2009a.

O combate contra os "quistos étnicos": identidade, assimilação e política imigratória no Estado Novo. Locus: revista de história, v.15, n.1, p.171-187, 2009.

GERRING, John. What is a case study and what is it good for? American Political Science Review, v.98, n.2, p.341-354, 2004.

GODOY, Gabriel. "O caso dos haitianos no Brasil e a via da proteção humanitária complementar". In: RAMOS, André de Carvalho et al. (Orgs.). 60 anos de ACNUR: perspectivas de futuro. São Paulo: Editora CL-A Cultural, p.45-68, 2011.

A crise humanitária na Síria e seu impacto no Brasil. Cadernos de Debates Refúgio, Migrações e Cidadania, v.9, n.9, p.83-93, 2014.

GOMES, Tiago de Melo. Problemas no paraíso: a democracia racial brasileira frente à imigração afro-americana (1921). Estudos afro-asiáticos, v.25, n.2, 2003.

GOMIDE, Alexandre A.; PIRES, Roberto R. "Capacidades estatais e democracia: a abordagem dos arranjos institucionais para análise de políticas públicas". In: GOMIDE, Alexandre A.; PIRES, Roberto R. (Eds.). Capacidades Estatais e Democracia: Arranjos Institucionais de Políticas Públicas. IPEA: Brasília, 2014.

GONÇALVES, Paulo Cesar. Mercadores de Braços: Riqueza e Acumulação na Organização da Emigração Europeia para o Novo Mundo. Tese de Doutorado. Universidade de São Paulo - Faculdade de Filosofia, Letras e Ciências Humanas, Departamento de História, Programa de Pós-Graduação em História Econômica. 2008.

GOUVÊA, Gilda Portugal. Burocracias e elites burocráticas no Brasil. São Paulo: Paulicéia, 1994.

GUIRAUDON, Virginie. Schengen: une crise en trope l'oeil. Politique Étrangère, n.4, p.773-784, 2011.

. "Different Nation, Same Nationhood: the Challenges of Immigrant Policy". In: CULPEPPER, Pepper; HALL, Peter; PALIER, Bruno (Eds.). Changing France: The Politics that Market Make. New York: Palgrave Macmillan, 2006. p.129-147.

European Integration and Migration Policy Vertical Policy-Making as Venue Shopping. Journal of Common Market Studies, v. 38, n.2, p.251-271, 2000.

HAGGARD, Stephen; SIMMONS, Beth. Theory of International Regimes. International Organization, v.41, n.3, p.491-517, 1987.

HALL, Peter A.; TAYLOR, Rosemary C. R. As três versões do neo-institucionalismo. Lua Nova, n.58, p.193-223, 2003.

"Historical institutionalism in rationalist and sociological perspective". In: MAHONEY, James; THELEN, Kathleen. Explaining Institutional Change: Ambiguity, Agency, and Power. New York: Cambridge, p.204-224, 2010.

HALPERIN, Morton H.; CLAPP, Priscilla A. Bureaucratic politics and Foreign Policy. Washington: The Brookings Institution, 2006.

HECLO, Hugh. "Issue networks and the Executive Establishment". In: KING, Anthony. The new American Political System, Washigton, D.C.: American Enterprise Institute. P.87-124, 1978.

HERMANN, Charles F. Changing course: when governments choose to redirect foreign policy. International Studies Quaterly, v.34, p.3-21, 1990. 
; et al. Resolve, Accept, or Avoid: Effects of Group Conflict on Foreign Policy

Decisions. International Studies Review, v.3, n.2, "Leaders, Groups and Coalitions: Understanding the People and Processes in Foreign Policymaking”, p. 133-169, 2001.

HERMANN, Margaret G. How Decisions Units Shape Foreign Policy: A Theoretical Framework. International Studies Review, v.3, n.2, "Leaders, Groups and Coalitions: Understanding the People and Processes in Foreign Policymaking”, p. 47-81, 2001.

HILL, Christopher. The changing politics of foreign policy. Hampshire, New York: Palgrave Macmillan, 2003.

HILL, Michael. The Public Policy Process. New York: Routledge, 2013.

HILTON, Stanley. "Afrânio de Melo Franco: a consolidação da estratégia de política externa”. In: PIMENTEL, José Vicente de Sá (Org.). Pensamento diplomático brasileiro : formuladores e agentes da política externa (1750-1950), v.2. Brasília : FUNAG, p.441-448, 2013.

HIRST, Mônica. Prefácio. In: PINHEIRO, Letícia; MILANI, Carlos R. S. (Orgs.). Política externa brasileira: as práticas da política e a política das práticas. Rio de Janeiro: Editora FGV, 2012.

HOLLIFIELD; James; WONG, Tom. "How can we bring the state in?". In: BRETTELL, Caroline; HOLliFIELD, James (Eds.). Migration Theory: Talking Across Disciplines. New York: Taylor \& Francis, 2015.

HOYLER, Telma. Incorporação imobiliária e intermediação de interesses em São Paulo. Dissertação (mestrado) - Universidade de São Paulo, Faculdade de Letras, Filosofia e Ciências Humanas, Departamento de Ciência Política, 2014.

HUDSON, Valerie M. Foreign Policy Analysis: Actor-Specific Theory and the Ground of International Relations. Foreign Policy Analysis, v.1, p.1-30, 2005.

HUJO, Katja; PIPER, Nicolas. South-south migration - implications for social policy and development. New York: Palgrave Macmillan, 2010.

IKENBERRY, John. Conclusion: an Institutional Approach to American Foreign Economic Policy. International organization, v. 42, n.1, p.219-243, 1988.

IMMERGUT, Ellen M. The Theoretical Core of the New Institutionalism. Politics \& Society, v.26, n.1, p.5-34, 1998.

INÁCIO, Magna. "Entre Presidir e Coordenar: presidência e gabinetes multipartidários no Brasil". Paper preparado para apresentação no $3^{\circ}$ Encontro Latinoamericano de Ciência Política. Campinas - Brasil, 2006.

IOTTI, Luiza Horn. O Olhar do Poder: a imigração italiana no Rio Grande do Sul, de 1875 a 1914, através dos relatórios consulares. Caxias do Sul: EDUCS, 2001.

A política imigratória brasileira e sua legislação 1822-1914. X Encontro Estadual de História da ANPUHRS. Santa Maria, 2010.

(Org.). Imigração e Colonização: Legislação 1747-1915. Porto Alegre: Assembleia Legislativa do Estado do RS. - Caxias do Sul: EDUCS, 2001a.

JENNINGS, Edward T. Jr.; KRANE, Dale. Coordination and welfare reform: the quest for the philosopher's stone. Public Administration Review, v.54, n.4, p.341348, jul/ago 1994. 
JORDAN, Bill; STRATH, Bo; TRIANDAFYLLIDOU, Anna. Contextualising immigration policy implementation in Europe. Journal of Ethnic and Migration Studies, v.29, n.2, p.195-224, 2003.

KEOHANE, Robert; NYE, Joseph. Power and Interdependence. New York: Longman, 2001.

KING, Gary; KEOHANE, Robert; VERBA, Sidney. Designing Social Inquiry: Scientific Inference in Qualitative Research. Princeton: Princeton University Press, 1994.

KINGDON, John. Agendas, alternatives and public policy. New York: Addison-Wesley Longman, 1995.

KLEEMANS, Marieke; KLUGMAN, Jeni. Understanding Attitudes Towards Migrants: A broader perspective. Human Development Research Papers, Unpd, v.53, 2009.

KODAMA, Kaori.Os debates pelo fim do tráfico no periódico O Philantropo (18491852) e a formação do povo: doenças, raça e escravidão. Rev. Bras. Hist. [online]. v.28, n.56, p. 407-430, 2008.

KOIFMAN, Fábio. "O Estado Novo e a admissão de estrangeiros no Brasil (19421945)". Trabalho apresentado no XXII Simpósio Nacional de História da ANPUH. João Pessoa, 2003. Disponível em: http://anais.anpuh.org/?p=17247. Acesso em: 11 set. 2016.

KRASNER, Stephen. International Regimes. Ithaca: Cornell University Press, 1983.

KYMLICKA, Will. Multicultural Citizenship. Oxford: Clarendon Press, 1995.

JEPPERSON, Ronald L. "Institutions, institutional effects, and institutionalism". In: POWELL, WALTER, W.; DIMAGGIO, Paul J. (Orgs.). The New Institutionalism in Organizational Analysis. Chicago: University of Chicago Press, p.143-163, 1991.

LABRA, Maria Eliana. Análise de Políticas, Modos de Policy-Making e intermediação de interesses: uma revisão. PHYSIS: Rev. Saúde Coletiva, Rio de Janeiro, v.9, n.2, p.131-166, 1999.

LAMEIRÃO, Camila. A Casa Civil como instituição do Executivo federal. Desigualdade \& Diversidade - Dossiê Especial, 2011.

LAMPREIA, Luiz Felipe. "A Política Externa Brasileira”. In: MRE. Resenha de Política Exterior do Brasil, a. 23, n. 79, $2^{\circ}$ semestre 1996, p.115-116.Disponível em: http://www.itamaraty.gov.br/pt-BR/resenha-de-politica-exterior-do-brasil. Acesso em: 10 nov. 2016.

. "A Política Externa Brasileira". In: MRE. Resenha de Política Exterior do

Brasil, a. 23, n. 78, $1^{\circ}$ semestre 1996, p.146-147. Disponível em: http://www.itamaraty.gov.br/pt-BR/resenha-de-politica-exterior-do-brasil. Acesso em: 10 nov. 2016.

LEÃO NETO, Valdemar Carneiro. A Crise da Imigração Japonesa no Brasil (19301934): Contornos Diplomáticos. Brasília: Fundação Alexandre Gusmão, 1989.

LESSER, Jeffrey. O Brasil e a Questão Judaica: imigração, diplomacia e preconceito. Rio de Janeiro: Imago, 1995.

LEVY, Maria Stella Ferreira. O papel da migração internacional na evolução da população brasileira (1872 a 1972). Revista de Saúde Pública, São Paulo, v.8 (supl.), p.49-90, 1974. 
LIMA, Maria Regina Soares. Eixos analíticos e conflitos de paradigma na Política Exterior Brasileira. Cadernos do IPRI, n¹1, "As Políticas Exteriores da Argentina e do Brasil frente a um mundo em transição: Diversidade, Convergência e Complementaridade", $1994 . \quad$ Disponível em: http://funag.gov.br/loja/download/cadernos-do-ipri-num-11.pdf. Acesso em: 30 out 2016.

Instituições Democráticas e Política Exterior. Contexto Internacional, v.22, n.2, p.265-303, 2000.

A política externa brasileira e os desafios da cooperação Sul-Sul. Revista Brasileira de Política Internacional, v. 48, n.1, p. 24-59, 2005a.

Aspiração internacional e política externa. Revista Brasileira de Comércio Exterior, n.82, ano XIX, janeiro/março 2005b.

Autonomia, não indiferença e pragmatismo: vetores conceituais da política exterior. Latin American Trade Network (LATN), Brief no 21. Buenos Aires: 2005c.

A politização da política externa e os interesses nacionais. Correio Braziliense, 11/06/2009, Opinião, p. 21. Disponível em: http://www2.senado.leg.br/bdsf/bitstream/handle/id/42063/noticia.htm?sequence=1.

Acesso em: 01 abr. 2017.

"Relações Internacionais e políticas públicas: a contribuição da análise de política externa". In: MARQUES, Eduardo; FARIA, Carlos Alberto Pimenta de (Orgs.). A Política Pública como Campo Multidisciplinar. São Paulo: Unesp; Rio de Janeiro: Editora Fiocruz, pp. 127-153, 2013,

LINDBLOM, Charles. The Science of "Muddling Through". Public Administration Review, v. 19, n. 2, p. 79-88, 1959.

Still Muddling, Not Yet Through. Public Administration Review, v. 39, n. 6, p. 517-526, 1979.

LOPES, Cristiane Maria. "A atuação do Ministério Público do Trabalho em Matéria de Imigração e Refúgio”. In: GEDIEL, José Antônio; GODOY, Gabriel (Orgs.). Refúgio e hospitalidade. Curitiba : Kairós Edições, p.119-138, 2016.

LOTTA, Gabriela S. "O papel das burocracias de nível da rua na implementação de políticas públicas: entre o controle e a discricionariedade". In: FARIA, Carlos A. Pimenta de (Org.). Implementação de políticas públicas: teoria e prática. Belo Horizonte: Ed. PUC Minas, p.20-49, 2012.

; CAVALCANTE, Pedro. "Conclusão - Perfis, trajetórias e relações: em busca de uma análise abrangente dos burocratas de médio escalão do Governo Federal". In: CAVALCANTE, Pedro; LOTTA, Gabriela. Burocracia de médio escalão: perfil, trajetória e atuação. Brasília: ENAP, p.293-208, 2015.

; GALVÃO, Maria Cristina; FAVARETO, Arilson. Análise do Programa Mais Médicos à luz dos arranjos institucionais: intersetorialidade, relações federativas, participação social e territorialidade. Ciência \& Saúde Coletiva, v.21, n.9, p.27612772, 2016.

LOUREIRO, Maria Rita; MACÁRIO, Vinícius; GUERRA, Pedro Henrique. "Democracia, Arenas Decisórias e Políticas Públicas: O Programa Minha Casa Minha 
Vida”. In: GOMIDE, Alexandre A.; PIRES, Roberto R. (Eds.). Capacidades Estatais e Democracia: Arranjos Institucionais de Políticas Públicas. IPEA: Brasília, 2014.

; ABRUCIO, Fernando Luiz; PACHECO, Regina Silva. "Introdução". In: LOUREIRO, Maria Rita; ABRUCIO, Fernando Luiz; PACHECO, Regina Silva. Burocracia e política no Brasil: desafios para a ordem democrática no século XXI. Rio de Janeiro: Editora FGV, p. 11-24, 2010.

Política e Burocracia no presidencialismo brasileiro: o papel do Ministério da Fazenda no Primeiro Governo Fernando Henrique Cardoso. Revista Brasileira de Ciências Sociais, v.14, n.41, p.69-89, 1999.

; OLIVIERI, Cecília; MARTES, Ana Cristina Braga. "Burocratas, partidos e grupos de interesse: o debate sobre política e burocracia no Brasil". In: LOUREIRO, Maria Rita; ABRUCIO, Fernando Luiz; PACHECO, Regina Silva. Burocracia e política no Brasil: desafios para a ordem democrática no século XXI. Rio de Janeiro: Editora FGV, p.73-108, 2010.

LOWI, Theodore. Four systems of policy, politics, and choice. Public Administration Review, v.32, n.4, p.298-310, 1972.

LUPI, Carlos. “Introdução”. In: CNIg. Mercosul e Migrações. Brasília: MTE, 2008.

“Introdução". In: ALMEIDA, Paulo Sérgio; PENNA, Rodrigo (Orgs.). OIT Contribuições para a Construção de Políticas Públicas Voltadas à Migração para o Trabalho. Brasília: Escritório Internacional do Trabalho, 2009.

LUSTICK, Ian. History, Historiography, and Political Science: Multiple Historical Records and the Problem of Selection Bias. American Political Science Review, v.90, n.3, 1996.

MAHONEY, James; THELEN, Kathleen. "A Theory of Gradual Institutional Change". In: MAHONEY, James; THELEN, Kathleen. Explaining Institutional Change: Ambiguity, Agency, and Power. New York: Cambridge, p. 1-37, 2010.

; GOERTZ, Gerry. A Tale of Two Cultures: Contrasting Quantitative and Qualitative Research in the Social Sciences. New Haven: Princeton University Press, 2012.

MANZUR, Tânia Maria Pechir Gomes. Opinião pública e política externa do Brasil do Império a João Goulart: um balanço historiográfico. Revista Brasileira de Política Internacional, v.42, n.1, p.30-61, 1999.

MANZUR, Tânia Maria. A Política Externa Independente (PEI): antecedentes, apogeu e declínio. Lua Nova, 93, p.169-199, 2014.

MARCH, James G.; OLSEN, Johan P. The New Institutionalism: Organizational Factors in Political Life. The American Political Science Review, v.78, n.3, p.734749, 1984.

MARIANO, Karina L. P.; MARIANO, Marcelo P. A formulação da Política Externa Brasileira e as novas lideranças políticas regionais. Perspectivas, v.33, p.99-135, 2008.

MARQUES, Eduardo. Government, Political Actors and Governance in Urban Policies in Brazil and São Paulo: Concepts for a Future Research Agenda. Brazilian Political Science Review, v.7, n.3, p.8-35, 2013.

MARTIN, Lanny; VANBERG, George. Policing the Bargain: Coalition Government and Parliamentary Scrutiny. American Journal of Political Science, v. 48, n. 1, 2004. 
MARTINS, Carlos Estevam. A evolução da política externa brasileira na década 64/74. Estudos Cebrap, n.12, p.55-98, 1974.

MARTINS, Luciano. Estado capitalista e burocracia no Brasil pós 64. São Paulo: Paz e Terra, 1985.

MASSEY, Douglas. International Migration at the Dawn of the Twenty-First Century: The Role of State. Population and Development Review, v. 25, n. 2, p.303-322, 1999a.

"Why does immigration occur? A theoretical synthesis". In: HIRSCHMAN, Charles; KASINITZ, Philip; DEWIND, Josh (Eds.). The Handbook of International Migration: The American Experience. New York: Russel Sage Foundation, p. 34-52, $1999 b$.

MCDONNALD, James. Letter of Resignation of James McDonnald - High Commissioner for Refugees (Jewish and Other) coming for Germany addressed to the Secretary General of the League of Nations. Londres: $27 \mathrm{dez}$, 1935. Disponível em: http://dl.wdl.org/11604/service/11604.pdf. Acesso em: 28 dez 2015.

MELLO, Flávia Campos. O Multilateralismo na Política Externa Brasileira. Carta Internacional, v. 7, n. 2, jul.- dez. 2012

MENDES, José Sacchetta Ramos. "O sistema de cotas nas Constituições de 1934 e 1937 e o ideal de integração étnica dos estrangeiros no Brasil”. In: ARRUDA, José Jobson de A. et al. De colonos a imigrantes: i(e)migração portuguesa para o Brasil. São Paulo: Alameda Casa Editorial, p. 457-464, 2013.

METCALFE, Les. International Policy Co-ordination and Public Management Reform. International Review of Administrative Sciences, v. 60, 271-290, 1994.

METZNER, Tobías. "La Migración Haitiana hacia Brasil: estudio en el país de origen". In: OIM - Organização Internacional para Migrações. La migración haitiana hacia Brasil: características, oportunidades y desafíos. Cuadernos migratórios $n^{\circ} 6$. Buenos Aires: OIM, p.15-30, 2014.

MEYER, John W.; ROWAN, Brian. "Institutionalized Organizations: Formal Structure as Myth and Ceremony". In: POWELL, Walter W.; DIMAGGIO, Paul J. (Orgs.). The New Institutionalism in Organizational Analysis. Chicago: University of Chicago Press, p.41-62, 1991.

MEYERS, Eytan. Theories of International Migration Policy - A Comparative Analysis. International Migration Review, v.34, p.1245-1282, 2000.

MILANI, Carlos Roberto Sanchez. A importância das relações Brasil - Estados Unidos na política externa brasileira. IPEA: Boletim de Economia e Política Internacional, n.6, 2011.

"Atores e Agendas no campo da política externa brasileira de direitos humanos". In: PINHEIRO, Letícia; MILANI, Carlos R. S. (Orgs.). Política externa brasileira: as práticas da política e a política das práticas. Rio de Janeiro: Editora FGV, p.33-70, 2012.

; PINHEIRO, Letícia. Política Externa Brasileira: Os Desafios de sua Caracterização como Política Pública. Contexto Internacional, v.35, n.1, p.11-41, 2013.

MILESI, Ir. Rosita; ANDRADE, William. "Atores e Ações por uma Lei de Refugiados no Brasil". In: Refúgio no Brasil: a proteção brasileira aos refugiados e seu impacto nas 
Américas / Luiz Paulo Teles Ferreira Barreto, organizador. - 1. ed. - Brasília: ACNUR, Ministério da Justiça,p. 22-47, 2010.

; FANTAZINI, Orlando. "Cidadãs e Cidadãos Brasileiros no Exterior - O Documento de Lisboa, a Carta de Boston e o Documento de Bruxelas." Texto apresentado na Conferência "Brasileiros no Mundo" Fundação Alexandre de Gusmão. 2008.

. Por uma nova Lei de Migração: a perspectiva dos Direitos Humanos. In. http://www.csem.org.br/pdfs/por_uma_nova_lei_de_migracao_no_brasil_\%20rosita_mi lesi.pdf. 2007.

MILNER, Helen. Interests, Institutions, and Information. Princeton: Princeton University Press, 1997.

; TINGLEY, Dustin. The Economic and Political Influences on Different Dimensions of United States Immigration Policy. Working Paper, outubro de 2011. Disponível em: http://papers.ssrn.com/sol3/papers.cfm?abstract_id=2182086. Acesso em: 12 out 2014.

MITCHELL, Christopher. International Migration, International Relations and Foreign Policy. International Migration Review, v.23, n.3, p. 681-708, 1989.

MOE, Terry. "The politicized presidency". In: CHUBB, John E.; PETERSON, Paul E. (Eds.). The New Direction in American Politics. Washignton: The Brookings Institution, p. 235-271, 1985.

"The Politics of Bureaucratic Structure". In: CHUBB, John E.; PETERSON, Paul E. (Eds.). Can the government govern? Washignton: The Brookings Institution, p. 267-329, 1989. 2005.

Power and Political Institutions. Perspective on Politics, v.3, n.2, p. 215-233,

MORAIS, Fernando. Corações sujos: a história da Shindo Renmei. São Paulo: Companhia das Letras, 2001.

MORAVCSIK, Andrew. The Origins of Human Rights Regimes: Democratic Delegation in Postwar Europe. International Organization, v. 54, n. 2, p. 217-252, 2000.

MOREIRA, Júlia Bertino. Redemocratização e direitos humanos: a política para refugiados no Brasil. Revista Brasileira de Política Internacional, v.53, n.1, p.111$129,2010$.

MORGEnthaU, Hans. A Política entre as Nações: A luta pelo poder e pela paz. Brasília: Ed. UnB, 2003 [1948].

MORRIS, Milton. Immigration - the beleaguered bureaucracy. Washington: The Brookings Institution, 1985.

MOURA, Cristina Patriota de. O inglês, o parentesco e o elitismo na Casa de Rio Branco. Cena Internacional, ano 8, nº 1, p. 20-34, 2006.

MOURA, Gerson. Relações Exteriores do Brasil 1939-1950: Mudança na natureza das relações Brasil- Estados Unidos durante e após a Segunda Guerra Mundial. Brasília: FUNAG, 2012.

NUNES, Edson de Oliveira. A gramática política do Brasil - clientelismo, corporativismo e insulamento burocrático. Rio de Janeiro: Garamond, 2010. 
OEA - Organização de Estados Americanos. Organización de los Estados Americanos: site oficial. Disponível em: http://www.oas.org/dil/esp/tratados_B32_Convencion_Americana_sobre_Derechos_Humanos_firmas.htm. Acesso em: 02 jan. 2017.

OLIVEIRA, Amâncio; ONUKI, Janina. Grupos de interesse e a política comercial brasileira: a atuação na arena legislativa. Papéis Legislativos, n.8, dez. 2007.

ONU - Organização das Nações Unidas. UN Treaty Collection. Disponível em: https://treaties.un.org/. Acesso em: 02 jan. 2017.

OSTROM, Elinor. Governing the Commons: the evolution of institutions for collective action. New York. Cambridge University Press, 2011.

O'TOOLE, Laurence Jr. Rational Choice and Policy Implementation: Implications for Interorganizational Network Management. American Review of Public Administration, v.25, n.1, p.43-57, mar. 1995.

PACHECO, Regina Silva. "A agenda da nova gestão pública". In: In: LOUREIRO, Maria Rita; ABRUCIO, Fernando Luiz; PACHECO, Regina Silva. Burocracia e política no Brasil: desafios para a ordem democrática no século XXI. Rio de Janeiro: Editora FGV, p.183-218, 2010.

PALERMO, Vicente. Como se Governa o Brasil? O Debate sobre Instituições Políticas e Gestão do Governo. Dados, v. 43, n.3, 2000.

PANG, Tikki; LANSANG, Mary Ann. Brain drain and health professionals. BMJ, v.324, $2002 . \quad$ Disponível em: http://www.bmj.com/content/324/7336/499?ijkey=dde81835424859ef366a438f69f6edc 8602317f6\&keytype2=tf_ipsecsha. Acesso em: 17 jan. 2017.http://www.bmj.com/content/324/7336/499?ijkey=dde81835424859ef366a438f69 f6edc8602317f6\&keytype2=tf_ipsecsha. Acesso em: 17 jan. 2017.

PAPADEMETRIOU, Demetrios G. "The shifting expectations of free trade and migration". In: AUDLEY, John et al. NAFTA's promise and reality: lessons from Mexico for the Hemisphere. Carnegie Endowment for International Peace, p.39-60, 2004.

PARISE, Paolo; CUTTI, Dirceu. "Sociedade Civil". ". In: CHIARELLO, Leonir Mario (Ed.). Las Políticas Públicas sobre migraciones y la sociedad civil en América Latina: los casos de Argentina, Brasil, Colombia y México. New York: Scalabrini International Network, 2011.

PARSONS, Craig. How to map arguments in political science. Oxford, New York: Oxford University Press, 2007.

PATARRA, Neide Lopes; BAENINGER, Rosana. Mobilidade espacial da população no Mercosul: metrópoles e fronteiras. Rev. bras. Ci. Soc., São Paulo, v. 21, n. 60, p. 83102, fev. 2006.

. "Introdução: Dimensões das políticas de migração internacional no mundo atual". In: CHIARELLO, Leonir Mario (Ed.). Las Políticas Públicas sobre migraciones y la sociedad civil en América Latina: los casos de Argentina, Brasil, Colombia y México. New York: Scalabrini International Network, 2011.

O Brasil: país de imigração?. E-metropolis, ano 3, n.9, p.6-18, 2012. 
PERES, Elena Pájaro. "Proverbial hospitalidade"? A Revista de Imigração e Colonização e o discurso oficial sobre o imigrante (1945-1955). Acervo, Rio de Janeiro, v.10, n², p.85-98, jul/dez 1997.

PETERS, Guy. Managing horizontal government: the politics of coordination. Canadian Centre for Management Development, research paper $n^{0} 21,1998$. Disponível em: http://publications.gc.ca/collections/Collection/SC94-61-21-1998E.pdf. Acesso em: $15 \mathrm{dez} 2016$.

PETRONE, Maria Theresa. O imigrante e a pequena propriedade. São Paulo: Brasiliense, 1982.

PIERSON, Paul. Increasing Returns, Path Dependence, and the Study of Politics. The American Political Science, v.94, n.2, p.251-267, 2000.

PINHEIRO, Letícia. Política Externa Brasileira (1889-2002). Rio de Janeiro: Zahar, 2004.

; BESHARA, Gregory. "Política externa e educação: confluências e perspectivas no marco da integração regional". In: PINHEIRO, Letícia; MILANI, Carlos R. S. (Orgs.). Política externa brasileira: as práticas da política e a política das práticas. Rio de Janeiro: Editora FGV, p.149-180, 2012.

; MILANI, Carlos R. S. (Orgs.). Política externa brasileira: as práticas da política e a política das práticas. Rio de Janeiro: Editora FGV, p.13-30; 331-345, 2012.

POWELL, Bingham. The chain of responsiveness. Journal of Democracy, v.15, n.4, p.91-105, 2004.

POWELL, Walter W. "Expanding the Scope of Institutional Analysis". In: POWELL, Walter W.; DIMAGGIO, Paul J. (Orgs.). The New Institutionalism in Organizational Analysis. Chicago: University of Chicago Press, p.183-203, 1991.

PRACA, Sérgio; FREITAS, Andréa; HOEPERS, Bruno. A rotatividade dos servidores de confiança no governo federal brasileiro, 2010-2011. Novos estudos - CEBRAP, São Paulo, n. 94, p. 91-107, Nov. 2012.

PRESSMAN, Jeffrey L.; WILDAVSKY, Aaron. Implementation. Berkeley: University of Carolina Press, 1984.

PRZEWORSKI, Adam; STOKES, Susan; MANIN, Bernard. "Introduction". In: PRZEWORSKI, A. et al. (Eds.). Democracy, Accountability, and Representation. Cambridge: Cambridge University Press, 1999. p. 1-26.

PUNTIGLIANO, Andrés Rivarola. 'Going Global': An Organizational Study of Brazilian Foreign Policy. Revista Brasileira de Política Internacional, v. 51, n.1, p.28-52, 2008.

RAMOS, Jair de Souza. O poder de domar do fraco: construção de autoridade pública e técnicas de poder tutelar nas políticas de imigração e colonização do serviço de Serviço de Povoamento do Solo Nacional, do Brasil. Horizontes Antropológicos, ano 9, n. 19, p.15-47, julho de 2003.

REGENS, James. Institutional coordination of program action: a conceptual analysis. International Journal of Public Administration, v.11, n.2, p.135-154, 1988.

REIS, Rossana Rocha. Soberania, direitos humanos e migrações internacionais. Revista brasileira de ciências sociais, v.19, n.55, p.149-161, 2004. 
Migrações: casos norte-americano e francês. Estudos Avançados, v.20, n.57, p.59-74, 2006.

A política do Brasil para as Migrações Internacionais. Contexto Internacional, v.33, n.1, p.47-69, 2011.

RICUPERO, Rubens. "A diplomacia do desenvolvimento". In: ARAÚJO, AZAMBUJA e RICUPERO. Três Ensaios sobre Diplomacia Brasileira. Brasília: MRE, 1989.

RICUPERO, Rubens. "A Política Externa da Primeira República (1889-1930)”. In: PIMENTEL, José Vicente de Sá (Org.). Pensamento diplomático brasileiro : formuladores e agentes da política externa (1750-1950), v.2. Brasília : FUNAG, p.333358, 2013.

ROSENAU, James N. Turbulence in World Politics: A Theory of Change and Continuity. Princeton: Princeton University Press, 1990.

RUDALEVIGE, Andrew; LEWIS, David. "Parsing the Politicized Presidency:

Centralization and Politicization as Presidential Strategies for Bureaucratic Control".

Paper apresentado no Encontro Anual 2005 da American Political Science Association.

Washington, DC - EUA, 1-4 dez., 2005.

SABATIER, Paul; MAZMANIAN, Daniel. The Implementation of Public Policy: a framework of analysis. Policy Studies Journal, v.8, n.4, p.538-560, 1980.

; JENKINS-SMITH, H. An Advocacy Coalition Model of Policy Change and the Role of Policy Orientated Learning Therein. Policy Sciences, v.21, p.129-168, 1988.

; WEIBLE, Christopher. "The Advocacy Coalition Framework: Innovations and Clarifications". In: SABATIER, Paul (Ed.). Theories of the Policy Process. Boulder: Westview Press, 2007, p. 189-220.

SAKURAI, Celia. Imigração tutelada : japoneses no Brasil. Tese (doutorado) Universidade Estadual de Campinas, Instituto de Filosofia e Ciências Humanas, Departamento de Antropologia, 2000.

SALES, Teresa; BAENINGER, Rosana. Migrações internas e internacionais no Brasil: panorama deste século. Travessia, p. 33-44, janeiro-abril 2000.

SALTER, Mark "The Border as State of Exception" In: BELL, Colleen; MANAGHAN, Tina (Eds.). Exceptional Measures for Exceptional Times: The State of Security Post 9/11. Toronto: Centre for International and Strategic Studies, York University, p. 9-21, 2006.

SANTOS, Wanderley Guilherme dos. Cidadania e Justiça: a política social na ordem brasileira. Rio de Janeiro: Campus, 1979.

SASAKI, Elisa. A imigração para o Japão. Estudos Avançados, vol.20 no.57 São Paulo May/Aug. 2006.

SAYAD, Abdelmalek. Imigração ou os paradoxos da alteridade.São Paulo: Edusp, 1998

SCHAIN, Martin. The Politics of Immigration in France, Britain, and the United States: a comparative study. New York: Palgrave Macmillan, 2008.

SCHILLER, Nina G.; BASCH, Linda; BLANC-SZANTON, Cristina. Transnationalism: A New Analytic Framework for Understanding Migration. Annals of the New York Academy of Sciences, v.645, p.1-24, 1992. 
SCHNEIDER, Ben Ross. Politics within the State: elite bureaucrats and industrial policy in authoritarian Brazil. Pittsburgh: University of Pittsburgh Press, 1991.

SCOTT, W. Richard. "Unpacking institutional arguments". In: POWELL, Walter W.; DIMAGGIO, Paul J. (Orgs.). The New Institutionalism in Organizational Analysis. Chicago: University of Chicago Press, p.164-182, 1991.

SCOTT, W. Richard; MEYER, John W. "The Organization of Societal Sectors: Propositions and Early Evidence". In: POWELL, Walter W.; DIMAGGIO, Paul J. (Orgs.). The New Institutionalism in Organizational Analysis. Chicago: University of Chicago Press, p.108-142, 1991.

SEYFERTH, Giralda. "Os imigrantes e a campanha de nacionalização do Estado Novo". In: PANDOLFI, Dulce (Org.). Repensando o Estado Novo. Rio de Janeiro: Ed. Fundação Getulio Vargas, p.199-228, 1999.

Assimilação dos Imigrantes no Brasil: inconstâncias de um conceito problemático. Travessia, p. 45-50, janeiro-abril 2000.

Imigrantes, estrangeiros: a trajetória de uma categoria incômoda no campo político. Paper apresentado na $\mathbf{2 6}^{\mathbf{a}}$ Reunião Brasileira de Antropologia. Porto Seguro, Brasil: 01 e 04 de junho de 2008.

SHUGHART, William et al. The political economy of immigration restrictions. Yale Journal on Regulation, v.4, n.1, p.79-97, 1986.

SKOCPOL, Theda. "Emerging Agendas and Recurrent Strategies". In: SKOCPOL, Theda (Ed.). Vision and Method in Historical Sociology. Cambridge: Cambridge University Press, 1984.

SIKKINK, Kathryn. Las Capacidades y la autonomía del Estado en Brasil y la Argentina. Un Enfoque Neoinstitucionalista. Desarollo Económico, v.32, n. 128, p.146, 1993.

SILVA, Luiz Inácio Lula. "Discurso do Presidente da República, Luiz Inácio Lula da Silva, durante cerimônia de sanção da lei que anistia estrangeiros em situação irregular no Brasil. Ministério da Justiça - Brasília-DF, 02 de julho de 2009”. In: MRE. Resenha de Política Exterior do Brasil, Número 105, $2^{\circ}$ semestre de 2009. Disponível em: http://www.itamaraty.gov.br/pt-BR/resenha-de-politica-exterior-do-brasil. Acesso em: 10 nov. 2016.

SILVA, Luiz Inácio Lula da. "Discurso do Presidente da República, Luiz Inácio Lula da Silva, durante Sessão do Conselho de Direitos Humanos da ONU. Genebra, Suíça, 15/06/2009". In: MRE. Resenha de Política Exterior do Brasil, Número 104, $1^{\circ}$ semestre de 2009. Disponível em: http://www.itamaraty.gov.br/pt-BR/resenha-depolitica-exterior-do-brasil. Acesso em: 10 nov. 2016.

SILVA, Tatiana Dias. Gestão da transversalidade em Políticas Públicas. XXXV Encontro Nacional da Associação Nacional de Pós-Graduação e Pesquisa em Administração (ANPAD). Rio de Janeiro, 4 a 7 de setembro de 2011. Disponível em: http://www.anpad.org.br/admin/pdf/APB2041.pdf. Acesso em: 28 jul. 2015.

SIMÕES, Mariangela Rebuá de Andrade. Novos Temas na Agenda Internacional e a posição brasileira: pobreza, pandemias e migrações. In: MOSCAARDO, Jeronimo; CARDIM, Carlos Henrique (Org.). I Conferência Nacional de Política Externa e Política Internacional (CNPEPI): o Brasil no Mundo que vem aí. Rio de Janeiro, 6 e 7 de julho de 2006. Brasília: Fundação Alexandre de Gusmão, p. 65, 2007, 
SJAASTAD, Larry. The costs and returns of human migration. Journal of political economy, v.70, p.80-93, 1962.

SOARES, Álvaro Teixeira. História Administrativa do Brasil: organização e administração do Ministério dos Estrangeiros. Brasília: Fundação Centro de Formação do Servidor Público, 1984.

SOUZA, Maria do Carmo C. Campello. Estado e Partidos Políticos no Brasil (1930 a 1964). São Paulo: Ed. Alfa-Ômega, 1983.

SOUZA, Ismara Izepe de. O Rigor da Intolerância: a seleção dos imigrantes espanhóis realizada pelo Ministério das Relações Exteriores e pelo Instituto Nacional de Imigração e Colonização (1950-1960). Revista UFG, ano XII, nº 9, dezembro 2010.

SOUZA, Celina. Capacidade Burocrática no Brasil e na Argentina: quando a política faz a diferença. Texto para Discussão IPEA. Brasília, Rio de Janeiro: IPEA, 2015

SOYSAL, Yasemin. Limits of citizenship: migrants and postnational membership in Europe. Chicago: The University of Chicago Press, 1999.

SPIRE, Alexis. O papel dos agentes administrativos na política de imigração. Antropolítica, n.5, p.75-96, 2008.

SPRANDEL, Marcia. Brasileiros na fronteira com o Paraguai. Estudos Avançados, vol.20 no.57 São Paulo May/Aug. 2006

. Políticas migratórias no Brasil no século XXI. Apresentação no "Seminário Internacional Deslocamentos, Desigualdades e Direitos Humanos". PUC São Paulo, 6 e 7 de julho de 2012. Disponível em: http://www.migracion-uealc.eu/documents/conf_y_eventos/2013/Pasantia\%20Brasil/Politicas\%20migratorias\%2 0no\%20Brasil\%20do\%20seculo\%20XXI.pdf. Acesso em: 17 jun 2016.

Migração e Crime: a Lei 6.815, de 1980. REMHU - Rev. Interdiscip. Mobil. Hum., ano 23, n. 45, p. 145-168, jul./dez. 2015

TAFT, Donald; ROBBINS, Richard. International Migrations: The Immigrant in the modern world. New York: The Ronald Press Company, 1955.

TAUNAY, Alfredo d'Escragnolle. Questões Politicas e Sociaes: Discursos proferidos na Primeira Sessão da $20^{a}$ Legislatura da Assembleia Geral Legislativa. Por Alfredo d'Escragnolle Taunay, Senador da Província de Santa Catarina. Rio de Janeiro: Typographia de G. Leuzinger e Filhos, 1886. Disponível em: http://www2.senado.leg.br/bdsf/handle/id/185597. Acesso emm: 01 ago 2016

TEITELBAUM, Michael. Immigration, Refugees, and Foreign Policy. International Organization, v. 38, n.3, p. 429-450, 1984.

THIOLLET, Helene. Migration as Diplomacy: Labor Migrants. Refugees, and Arab Regional Politics in the Oil-Rich Countries. International Labor and Working-Class History, n.79, p.103-121, 2011.

THOMSON, Ann Marie; PERRY, James. Collaboration Processes: Inside the Black Box. Public Administration Review, Special Issue: Articles on Collaborative Public Management, dez 2006.

TIMMER, Ashley; WILLIAMSON, Jeffrey. Immigration policy prior to the 1930s: Labor markets, policy interactions, and globalization blacklash. Population and development review, v.24, p.739-772, 1998. 
TSEBELIS, George. Processo decisório em sistemas políticos : veto players no presidencialismo, parlamentarismo, multicameralismo e pluripartidarismo. Revista Brasileira de Ciências Sociais, v. 12, n. 34, 1995.

TULLOCK, Gordon. The Politics of Bureaucracy. Washington, D.C.: Public Affairs Press, 1965.

VAINER, Carlos. Estado e Migrações no Brasil: anotações para uma história das políticas migratórias. Travessia, n. 36, 2000.

VENTURA, Raissa. O imigrante nas fronteiras da cidadania: uma análise dos limites normativos do ideal nacional. Dissertação (mestrado). Faculdade de Filosofia, Letras e Ciências Humanas da Universidade de São Paulo. Departamento de Ciência Política. São Paulo, 2013.

VENTURA, Deisy. Mobilidade Humana e Saúde Global. Revista USP, São Paulo, n.107, p.55-64, 2015.

; ILLES, Paulo. "Qual a política migratória do Brasil?" In: Le Monde Diplomatique, 07 mar 2012. Diponível em: http://diplomatique.org.br/qual-a-politicamigratoria-do-brasil/. Acesso em: 13 mar 2015.

VIANA FILHO, Luiz. Direito dos Estrangeiros no Brasil: Histórico e Situação Presente. Tese para Concurso de Professor Catedrático da Cadeira de Direito Privado Internacional. Bahia, 1938.

VIANNA, Hélio. História Administrativa e Econômica do Brasil. São Paulo: Companhia Editora Nacional, 1951.

VIGEVANI, Tullo; MARIANO, Karina. A Burocracia na Integração Regional (e no Mercosul): Influência no Processo Decisório. Contexto Internacional, v.19, $\mathrm{n}^{\circ} 2$, p.267-305, 1997.

; CEPALUNI, Gabriel. A política externa de Lula da Silva: a estratégia da autonomia pela diversificação. Contexto internacional, Rio de Janeiro , v. 29, n. 2, p. 273-335, Dec. 2007.

VISENTINI, Paulo Fagundes. A projeção internacional do Brasil: 1930-2012. Rio de Janeiro: Elsevier, 2013.

WEBER, Max. A política como vocação. P.116, 1971.

WEINER, Myron. On International Migration and International Relations. Population and Development Review, v.11, n.3, p.441-455, 1985.

WOOD, B. Dan. Principals, Bureaucrats, and Responsiveness in Clean Air Enforcements. The American Political Science Review, v. 82, n. 1, p. 213-234, 1988.

ZAPATA-BARRERO, Ricard; PINYOL, Gemma. "Los Gestores del Proceso de Inmigración: actores y redes de actores". In: ZAPATA-BARRERO, Ricard; PINYOL, Gemma (Eds.). Los gestores del proceso de inmigración: actores y redes de actores en España y Europa. Barcelona: Fundación CIDOB, 2008.

ZLOTNIK, Hania; KRITZ, Mary. "Global interactions: migration systems, processes, and policies". In: KRITZ, Mary et al. (Eds.). International migration systems: a global approach. New York: Oxford University Press, 1992.

ZOLBERG, Aristide. "International Migration in political perspective". In: KRITZ, Mary; KEELY, Charles; TOMASI, Silvano (Eds.). Global trends in migration: theory 
and research on international population movements. Staten Island: New York, Center for Migration Studies, p. 3-27, 1981.

"Matters of State: Theorizing Immigration Policy". In: HIRSCHMAN, Charles; KASINITZ, Philip; DEWIND, Josh (Eds.). The Handbook of International Migration: The American Experience. New York: Russel Sage Foundation, p. 71-93, 1999.

A Nation by Design: Immigration Policy in the Fashioning of America. New York: Russell Sage Foundation, 2006.

ZUCKER, Lynne. "The role of institutionalization in cultural persistence". In: POWELL, Walter W.; DIMAGGIO, Paul J. (Orgs.). The New Institutionalism in Organizational Analysis. Chicago: University of Chicago Press, p.83-107, 1991

\section{RELATÓRIOS E DOCUMENTOS INSTITUCIONAIS}

ALMEIDA, Paulo Sérgio; PENNA, Rodrigo (Orgs.). OIT - Contribuições para a Construção de Políticas Públicas Voltadas à Migração para o Trabalho. Brasília: Escritório Internacional do Trabalho, 2009.

ACNUR; CONARE. O reconhecimento dos refugiados pelo Brasil: comentários sobre decisões do CONARE. Org: Renato Zerbini Ribeiro Leão. Material de divulgação interna, 2007.

BRASIL. Secretaria de Estado dos Negócios do Império e Estrangeiros. O Conselho de Estado e a política externa do Império: Consultas da Seção dos Negócios Estrangeiros: 1858-1862. Rio de Janeiro: Centro de História e Documentação Diplomática; Brasília: FUNAG, 2005.

BRASIL. Ministério da Justiça e dos Negócios Interiores. Notícia Histórica dos Serviços, Instituições e estabelecimentos pertencentes a esta repartição, elaborada por ordem do respectivo Ministro, Dr. Amaro Cavalcanti. Rio de Janeiro: Imprensa Nacional, 1898.

BRASIL. Exposição de Motivos do Decreto n528, de 28 de junho de 1890. Disponível em: http://www2.camara.leg.br/legin/fed/decret/1824-1899/decreto-528-28-junho-1890506935-norma-pe.html. Acesso em: 02 set. 2015.

BRASIL. DCN - Diário do Congresso Nacional. No53, publicado em 27/05/1980, sessão de 26 de maio de 1980. Disponível: http://legis.senado.gov.br/diarios/BuscaDiario?datSessao=26/05/1980\&tipDiario=2.

Acesso em: 21 set 2016.

BRASIL. Lei orçamentária anual de 2003. Disponível em:https://www12.senado.leg.br/orcamento/documentos/loa/. Acesso em: 01 fev 2017.

BRASIL. Lei orçamentária anual de 2004. Disponível em:https://www12.senado.leg.br/orcamento/documentos/loa/. Acesso em: 01 fev 2017.

BRASIL. Lei orçamentária anual de 2005. Disponível em:https://www12.senado.leg.br/orcamento/documentos/loa/. Acesso em: 01 fev 2017.

BRASIL. Lei orçamentária anual de 2006. Disponível em:https://www12.senado.leg.br/orcamento/documentos/loa/. Acesso em: 01 fev 2017.

BRASIL. Lei orçamentária anual de 2007. Disponível em:https://www12.senado.leg.br/orcamento/documentos/loa/. Acesso em: 01 fev 2017. 
BRASIL. Lei orçamentária anual de 2008. Disponível em:https://www12.senado.leg.br/orcamento/documentos/loa/. Acesso em: 01 fev 2017.

BRASIL. Lei orçamentária anual de 2009. Disponível em:https://www12.senado.leg.br/orcamento/documentos/loa/. Acesso em: 01 fev 2017.

BRASIL. Lei orçamentária anual de 2010. Disponível em:https://www12.senado.leg.br/orcamento/documentos/loa/. Acesso em: 01 fev 2017.

BRASIL. Lei orçamentária anual de 2011. Disponível em:https://www12.senado.leg.br/orcamento/documentos/loa/. Acesso em: $01 \mathrm{fev} 2017$.

BRASIL. Lei orçamentária anual de 2012. Disponível em:https://www12.senado.leg.br/orcamento/documentos/loa/. Acesso em: 01 fev 2017.

BRASIL. Lei orçamentária anual de 2013. Disponível em:https://www12.senado.leg.br/orcamento/documentos/loa/. Acesso em: 01 fev 2017.

BRASIL. Lei orçamentária anual de 2014. Disponível em:https://www12.senado.leg.br/orcamento/documentos/loa/. Acesso em: $01 \mathrm{fev} 2017$.

BRASIL. Lei orçamentária anual de 2015. Disponível em:https://www12.senado.leg.br/orcamento/documentos/loa/. Acesso em: 01 fev 2017.

BRASIL. CONARE. Sistema de Refúgio Brasileiro - desafios e perspectivas. http://www.acnur.org/fileadmin/scripts/doc.php?file=fileadmin/Documentos/portugues/ Estatisticas/Sistema_de_Refugio_brasileiro_-_Refugio_em_numeros___05_05_2016.

BRASIL. MTE-CNIg. Política Nacional de Imigração e Proteção ao(a) Trabalhador(a) Migrante. http://www2.mte.gov.br/politicamigrante/imigracao_proposta.pdf. Acesso em: 1 fev. 2015.

CNF - Confederação Nacional das Instituições Financeiras. II Encontro CNF/CNIg: Expatriação de Trabalhadores. CNF, 2016.

CNIg. Ata da reunião do dia 13/09/2015. Disponível em: http://acesso.mte.gov.br/cni/atas.htm. Acesso em: 14 mar 2017.

CNIg. Ata da reunião do dia 11/11/2014. Disponível em: http://acesso.mte.gov.br/cni/atas.htm. Acesso em: 14 mar 2017.

CNIg. Ata da reunião do dia 21/10/2014. Disponível em: http://acesso.mte.gov.br/cni/atas.htm. Acesso em: 14 mar 2017.

CNIg. Ata da reunião do dia 19/02/2013. Disponível em: http://acesso.mte.gov.br/cni/atas.htm. Acesso em: 14 mar 2017.

CNIg. Ata da reunião do dia 12/01/2012. Disponível em: http://acesso.mte.gov.br/cni/atas.htm. Acesso em: 14 mar 2017.

CNIg. Ata da reunião do dia 23/11/2011. Disponível em: http://acesso.mte.gov.br/cni/atas.htm. Acesso em: 14 mar 2017.

CNIg. Ata da reunião do dia 10/08/2006. Disponível em: http://acesso.mte.gov.br/cni/atas.htm. Acesso em: 14 mar 2017.

CNIg. Ata da reunião do dia 20/06/2006. Disponível em: http://acesso.mte.gov.br/cni/atas.htm. Acesso em: 14 mar 2017.

CNIg - Conselho Nacional de Imigração. Ações do Conselho Nacional de Imigração (2015). Brasília: OBMigra, 2015. 
COMISSÃO EUROPEIA. Comunicado: Integrar as questões ligadas à migração nas relações da União Europeia com países terceiros. 03 dez. 2002. Disponível em: http://eur-lex.europa.eu/legal-content/PT/ALL/?uri=URISERV:133207. Acesso em: 24 jun 2016.

COMISSÃO MUNDIAL SOBRE AS MIGRAÇÕES INTERNACIONAIS. As migrações num mundo interligado: novas linhas de acção. Relatório da Comissão Mundial sobre as Migrações Internacionais. Fundação Calouste Gulbekian, 2005.

FGV - Fundação Getúlio Vargas. Análise e Avaliação do Desenvolvimento Institucional da política de Imigração no Brasil para o Século XXI: Caderno de Referência. Rio de Janeiro, 2015.

MERCOSUL. Declaración de Los Presidentes De Los Estados Parte Del Mercosur y Estados Asociados sobre la "Directiva De Retorno". Disponível em: http://www.observatoriomercosur.org.uy/UserFiles/File/Declaracion_presidentes_merco sur_directivaretorno.pdf Acesso em 18 out 2016.

MJ - Ministério da Justiça. Relatório de gestão 2012. Disponível em: https://contas.tcu.gov.br/. Acesso em: 01 fev 2017.

MJ - Ministério da Justiça. Relatório de gestão 2013. Disponível em: https://contas.tcu.gov.br/. Acesso em: 01 fev 2017.

MJ - Ministério da Justiça. Relatório de gestão 2014. Disponível em: https://contas.tcu.gov.br/. Acesso em: 01 fev 2017.

MRE - Ministério das Relações Exteriores. Resenha de Política Exterior do Brasil, $\mathrm{N}^{\circ}$ 107, $2^{\circ}$ semestre de 2010. Disponível em: http://www.itamaraty.gov.br/ptBR/resenha-de-politica-exterior-do-brasil. Acesso em: 10 nov. 2016.

MRE - Ministério das Relações Exteriores. Resenha de Política Exterior do Brasil, Número 102, $1^{\circ}$ semestre de 2008. Disponível em: http://www.itamaraty.gov.br/ptBR/resenha-de-politica-exterior-do-brasil. Acesso em: 10 nov. 2016.

MRE - Ministério das Relações Exteriores. Resenha de Política Exterior do Brasil, a.34, n.100, $1^{\mathrm{o}}$ semestre 2007. Disponível em: http://www.itamaraty.gov.br/ptBR/resenha-de-politica-exterior-do-brasil. Acesso em: 10 nov. 2016.

MRE - Ministério das Relações Exteriores. Resenha de Política Exterior do Brasil, a. 32, n. 97, $2^{\circ}$ semestre 2005. Disponível em: http://www.itamaraty.gov.br/ptBR/resenha-de-politica-exterior-do-brasil. Acesso em: 10 nov. 2016.

MTE - Ministério do Trabalho e Emprego. Relatório de gestão 2008. Disponível em: https://contas.tcu.gov.br/. Acesso em: $01 \mathrm{fev} 2017$.

MTE - Ministério do Trabalho e Emprego. Relatório de gestão 2009. Disponível em: https://contas.tcu.gov.br/. Acesso em: $01 \mathrm{fev} 2017$.

MTE - Ministério do Trabalho e Emprego. Relatório de gestão 2010. Disponível em: https://contas.tcu.gov.br/. Acesso em: $01 \mathrm{fev} 2017$.

MTE - Ministério do Trabalho e Emprego. Relatório de gestão 2011. Disponível em: https://contas.tcu.gov.br/. Acesso em: 01 fev 2017.

MTE - Ministério do Trabalho e Emprego. Relatório de gestão 2012. Disponível em: https://contas.tcu.gov.br/. Acesso em: $01 \mathrm{fev} 2017$.

MTE - Ministério do Trabalho e Emprego. Relatório de gestão 2013. Disponível em: https://contas.tcu.gov.br/. Acesso em: $01 \mathrm{fev} 2017$. 
MTE - Ministério do Trabalho e Emprego. Relatório de gestão 2014. Disponível em: https://contas.tcu.gov.br/. Acesso em: 01 fev 2017.

MTE - Ministério do Trabalho e Emprego. Relatório de gestão 2015. Disponível em: https://contas.tcu.gov.br/. Acesso em: 01 fev 2017.

OIM - Organização Internacional para Migrações. Essentials of Migration Management: A Guide for Policy Makers and Practitioners. Genebra: OIM, 2004.

OIM - Organização Internacional para migrações. Panorama Migratório da América do Sul 2012. Buenos Aires: OIM, 2012.

OIM - Organização Internacional para Migrações. Centre de Réception de Demandes de Visas pour le Brésil (BVAC) - site oficial. Disponível em: https://haiti.iom.int/bvac/fr/accueil . Acesso em: 14 dez. 2016.

OIT - Organização Internacional do Trabalho. Contribuições para a Construção de Políticas Públicas voltadas à Migração para o Trabalho. Brasília: Escritório Internacional do Trabalho, 2009. Disponível em: http://www.oit.org.br/sites/default/files/topic/tip/pub/contribuicao_para_construcao_374 .pdf.

ONU - United Nations, Department of Economic and Social Affairs, Population Division. International Migration Report 2015. ST/ESA/SER.A/384, 2016. Disponível em:

http://www.un.org/en/development/desa/population/migration/publications/migrationre port/docs/MigrationReport2015.pdf. Acesso em: 04 fev. 2017.

ONU - United Nations, Department of Economic and Social Affairs, Population Division. International Migration 2013: migrants by origin and destination, n.2013/3, rev 1 abr 2014. Disponível em: http://www.un.org/en/development/desa/population/publications/pdf/popfacts/popfacts 2013-3.pdf. Acesso em 04 fev 2017.

PNUD. Ultrapassar barreiras: mobilidade e desenvolvimento urbanos (2009). Disponível em: http://hdr.undp.org/sites/default/files/hdr2009-portuguese-summary.pdf. Acesso em: 17 jan. 2017. http://hdr.undp.org/sites/default/files/hdr2009-portuguesesummary.pdf. Acesso em: 17 jan. 2017.

PREFEITURA DE SÃO PAULO. Mapeamento dos grupos de migrantes ou ligados à temática migratória (2016). Disponível em: http://www.prefeitura.sp.gov.br/cidade/secretarias/upload/direitos_humanos/2016_mape amento\%20grupos.pdf. Acesso em: 02 jun 2017.

SGEB-Subsecretaria-geral de Comunidades Brasileiras no Exterior. Relatório de gestão 2008. Disponível em: https://contas.tcu.gov.br/. Acesso em: 01 fev 2017.

SGEB-Subsecretaria-geral de Comunidades Brasileiras no Exterior. Relatório de gestão 2009. Disponível em: https://contas.tcu.gov.br/. Acesso em: 01 fev 2017.

SGEB-Subsecretaria-geral de Comunidades Brasileiras no Exterior. Relatório de gestão 2010. Disponível em: https://contas.tcu.gov.br/. Acesso em: 01 fev 2017.

SGEB-Subsecretaria-geral de Comunidades Brasileiras no Exterior. Relatório de gestão 2011. Disponível em: https://contas.tcu.gov.br/. Acesso em: 01 fev 2017.

SGEB-Subsecretaria-geral de Comunidades Brasileiras no Exterior. Relatório de gestão 2012. Disponível em: https://contas.tcu.gov.br/. Acesso em: 01 fev 2017. 
SGEB-Subsecretaria-geral de Comunidades Brasileiras no Exterior. Relatório de gestão 2013. Disponível em: https://contas.tcu.gov.br/. Acesso em: 01 fev 2017.

SGEB-Subsecretaria-geral de Comunidades Brasileiras no Exterior. Relatório de gestão 2014. Disponível em: https://contas.tcu.gov.br/. Acesso em: 01 fev 2017.

SGEB-Subsecretaria-geral de Comunidades Brasileiras no Exterior. Relatório de gestão 2015. Disponível em: https://contas.tcu.gov.br/. Acesso em: 01 fev 2017.

SNJ - Secretaria Nacional de Justiça. Relatório de gestão 2008. Disponível em: https://contas.tcu.gov.br/. Acesso em: 01 fev 2017.

SNJ - Secretaria Nacional de Justiça. Relatório de gestão 2009. Disponível em: https://contas.tcu.gov.br/. Acesso em: 01 fev 2017.

SNJ - Secretaria Nacional de Justiça. Relatório de gestão 2010. Disponível em: https://contas.tcu.gov.br/. Acesso em: 01 fev 2017.

SNJ - Secretaria Nacional de Justiça. Relatório de gestão 2011. Disponível em: https://contas.tcu.gov.br/. Acesso em: 01 fev 2017.

SNJ - Secretaria Nacional de Justiça. Relatório de gestão 2015-2016. Disponível em: http://www.justica.gov.br/noticias/secretaria-nacional-de-justica-e-cidadania-divulgarelatorio-de-gestao-2015-2016/relatorio-de-gestao-snj-2015-

2016_versao_divulgacao.pdf .Acesso em: $01 \mathrm{fev} 2017$.

\section{RELATÓRIOS DO MINISTÉRIO DAS RELAÇÕES EXTERIORES}

BRASIL. MINISTÉRIO DAS RELAÇÕES EXTERIORES. Relatório apresentado ao Generalíssimo Chefe do Governo Provisório dos Estados Unidos do Brazil pelo Ministro e Secretário de Estado das Relações Exteriores Quintino Bocaiúva, em 1891. Rio de Janeiro: Imprensa Nacional, 1891.

BRASIL. MINISTÉRIO DAS RELAÇÕES EXTERIORES. Relatório apresentado ao Vice-Presidente da República dos Estados Unidos do Brazil por Innocencio Serzedello Corrêa, Ministro de Estado das Relações Exteriores, em junho de 1892. Rio de Janeiro: Imprensa Nacional, 1892.

BRASIL. MINISTÉRIO DAS RELAÇÕES EXTERIORES. Relatório apresentado ao Vice-Presidente da República dos Estados Unidos do Brazil pelo Ministro de Estado das Relações Exteriores, Felisbello Firmo de Oliveira Freire, em junho de 1893. Rio de Janeiro: Imprensa Nacional, 1893.

BRASIL. MINISTÉRIO DAS RELAÇÕES EXTERIORES. Relatório apresentado ao Vice-Presidente da República dos Estados Unidos do Brazil pelo Ministro de Estado das Relações Exteriores, Alexandre Cassiano do Nascimento, em maio de 1894. Rio de Janeiro: Imprensa Nacional, 1894.

BRASIL. MINISTÉRIO DAS RELAÇÕES EXTERIORES. Relatório apresentado ao Vice-Presidente da República dos Estados Unidos do Brazil pelo Ministro de Estado das Relações Exteriores, Carlos Augusto de Carvalho, em maio de 1895. Rio de Janeiro: Imprensa Nacional, 1895.

BRASIL. MINISTÉRIO DAS RELAÇÕES EXTERIORES. Relatório apresentado ao Presidente da República dos Estados Unidos do Brazil pelo Ministro de Estado das Relações Exteriores Carlos Augusto de Carvalho, em 30 de abril de 1896. Rio de Janeiro: Imprensa Nacional, 1896. 
BRASIL. MINISTÉRIO DAS RELAÇÕES EXTERIORES. Relatório apresentado ao Presidente da República dos Estados Unidos do Brazil pelo Ministro de Estado das Relações Exteriores General Dionísio de Castro Teixeira, em 14 de maio de 1897. Rio de Janeiro: Imprensa Nacional, 1897.

BRASIL. MINISTÉRIO DAS RELAÇÕES EXTERIORES. Relatório apresentado ao Presidente da República dos Estados Unidos do Brazil pelo Ministro de Estado das Relações Exteriores General Dionísio de Castro Teixeira, em 12 de julho de 1898. Rio de Janeiro: Imprensa Nacional, 1898.

BRASIL. MINISTÉRIO DAS RELAÇÕES EXTERIORES. Relatório apresentado ao Presidente da República dos Estados Unidos do Brazil pelo Ministro de Estado das Relações Exteriores Olyntho de Magalhães, em 23 de maio de 1899. Rio de Janeiro: Imprensa Nacional, 1899.

BRASIL. MINISTÉRIO DAS RELAÇÕES EXTERIORES. Relatório apresentado ao Presidente da República dos Estados Unidos do Brazil pelo Ministro de Estado das Relações Exteriores Olyntho de Magalhães, em 02 de agosto de 1900. Rio de Janeiro: Imprensa Nacional, 1899.

BRASIL. MINISTÉRIO DAS RELAÇÕES EXTERIORES. Relatório apresentado ao Presidente da República dos Estados Unidos do Brazil pelo Ministro de Estado das Relações Exteriores Lauro Müller. Rio de Janeiro: Imprensa Nacional, 1912.

BRASIL. MINISTÉRIO DAS RELAÇÕES EXTERIORES. Relatório apresentado ao Presidente da República dos Estados Unidos do Brazil pelo Ministro de Estado das Relações Exteriores Lauro Müller compreendendo o período de 1 de maio de 1912 a 17 de maio de 1913. Rio de Janeiro: Imprensa Nacional, 1913.

BRASIL. MINISTÉRIO DAS RELAÇÕES EXTERIORES. Relatório apresentado ao Presidente da República dos Estados Unidos do Brazil pelo Ministro de Estado das Relações Exteriores Lauro Müller compreendendo o período de 18 de maio de 1913 a 03 de maio de 1914. Rio de Janeiro: Imprensa Nacional, 1914.

BRASIL. MINISTÉRIO DAS RELAÇÕES EXTERIORES. Relatório apresentado ao Presidente da República dos Estados Unidos do Brazil pelo Ministro de Estado das Relações Exteriores Lauro Müller compreendendo o período de 03 de maio de 1914 a 30 de junho de 1915. Rio de Janeiro: Imprensa Nacional, 1915.

BRASIL. MINISTÉRIO DAS RELAÇÕES EXTERIORES. Relatório apresentado ao Presidente da República dos Estados Unidos do Brazil pelo Ministro de Estado das Relações Exteriores Nilo Peçanha, compreendendo o período de 01 de maio de 1917 a 03 de maio de 1918. Rio de Janeiro: Imprensa Nacional, 1920.

BRASIL. MINISTÉRIO DAS RELAÇÕES EXTERIORES. Relatório apresentado ao Presidente da República dos Estados Unidos do Brazil pelo Ministro de Estado das Relações Exteriores Nilo Peçanha, compreendendo o período de 01 de maio de 1918 a 03 de maio de 1919. Rio de Janeiro: Imprensa Nacional, 1921. 


\section{ANEXO 1 - Lista de entrevistados no trabalho de campo}

ATORES GOVERNO FEDERAL e CNIg

\begin{tabular}{|c|c|c|}
\hline NOME & CARGO A ÉPOCA DA ENTREVISTA & $\begin{array}{l}\text { LOCAL E } \\
\text { DATA }\end{array}$ \\
\hline $\begin{array}{l}\text { Paulo Gustavo Iansen de } \\
\text { Sant'Ana } \\
\end{array}$ & $\begin{array}{l}\text { Conselheiro Chefe da Divisão de Imigração - } \\
\text { MRE }\end{array}$ & $\begin{array}{c}\text { Brasília, } \\
04 / 03 / 2016\end{array}$ \\
\hline Luiz Felipe Vilela Pereira & $\begin{array}{l}\text { Primeiro Secretário da Divisão de Imigração - } \\
\text { MRE }\end{array}$ & $\begin{array}{c}\text { Brasília, } \\
04 / 03 / 2016\end{array}$ \\
\hline Juliana Cardoso Benedetti & $\begin{array}{c}\text { Segunda Secretária Divisão das Nações Unidas - } \\
\text { MRE }\end{array}$ & $\begin{array}{l}\text { Brasília, } \\
07 / 03 / 2016\end{array}$ \\
\hline Paulo Tarrisse & $\begin{array}{c}\text { Embaixador Diretor do Departamento de } \\
\text { Organismos Internacionais - MRE }\end{array}$ & $\begin{array}{c}\text { Brasília, } \\
07 / 03 / 2016\end{array}$ \\
\hline Maria Rita Silva Fontes Faria & $\begin{array}{l}\text { Conselheira Chefe da Divisão do Mar, da } \\
\text { Antártica e do Espaço/ Ex-Segunda Secretária da } \\
\text { Missão do Brasil em Genebra - MRE }\end{array}$ & $\begin{array}{l}\text { Brasília, } \\
04 / 03 / 2016\end{array}$ \\
\hline Luiza Ribeiro Lopes da Silva & $\begin{array}{c}\text { Diretora do Departamento de Consular e de } \\
\text { Brasileiros no Exterior - MRE }\end{array}$ & $\begin{array}{c}\text { Telefone, } \\
13 / 09 / 2016\end{array}$ \\
\hline Aminthas Cardoso Silva & $\begin{array}{c}\text { Assessor da Divisão de Comunidades Brasileiras } \\
\text { no Exterior - MRE }\end{array}$ & $\begin{array}{l}\text { Brasília, } \\
12 / 05 / 2016 \\
\end{array}$ \\
\hline Cláudia Angélica Vasques Silva & $\begin{array}{c}\text { Subchefe da Divisão de Comunidades Brasileiras } \\
\text { no Exterior - MRE }\end{array}$ & $\begin{array}{c}\text { Brasília, } \\
12 / 05 / 2016\end{array}$ \\
\hline Ana Maria Garrida & $\begin{array}{l}\text { Secretária da Divisão de Comunidades } \\
\text { Brasileiras no Exterior - MRE }\end{array}$ & $\begin{array}{l}\text { Brasília, } \\
12 / 05 / 2016\end{array}$ \\
\hline $\begin{array}{l}\text { Milton de Figueiredo Coutinho } \\
\text { Filho }\end{array}$ & $\begin{array}{c}\text { Conselheiro Chefe da Divisão de Assistência } \\
\text { Consular - MRE }\end{array}$ & $\begin{array}{l}\text { Brasília, } \\
12 / 05 / 2016\end{array}$ \\
\hline Carlos Cuenca & $\begin{array}{c}\text { Chefe da Divisão de Temas Sociais (DTS) - } \\
\text { MRE }\end{array}$ & $\begin{array}{c}\text { Brasília, } \\
09 / 09 / 2016\end{array}$ \\
\hline Bernardo Paranhos Velloso & $\begin{array}{l}\text { Ministro da Missão Permanente do Brasil na } \\
\text { OEA/ Ex Chefe da Divisão de Imigração - MRE }\end{array}$ & $\begin{array}{c}\text { Skype, } \\
11 / 01 / 2017 \\
\end{array}$ \\
\hline João Guilherme Granja & $\begin{array}{c}\text { Diretor do Departamento de Imigração da SNJ - } \\
\text { MJ }\end{array}$ & $\begin{array}{c}\text { Brasília, } \\
\text { 20/11/2014 } \\
\text { Brasília, } \\
\text { 09/09/2016 }\end{array}$ \\
\hline Flávio Marques Prol & $\begin{array}{l}\text { Coordenador Geral de Planejamento Setorial da } \\
\text { Secretaria Executiva - MJ }\end{array}$ & $\begin{array}{l}\text { Brasília, } \\
\text { 06/11/2014 }\end{array}$ \\
\hline Muller Borges & $\begin{array}{l}\text { Chefe da Divisão de Permanência do DEEST - } \\
\text { MJ }\end{array}$ & $\begin{array}{l}\text { Brasília, } \\
27 / 02 / 2015\end{array}$ \\
\hline Paulo Sérgio de Almeida & Presidente do CNIg - MTE & $\begin{array}{l}\text { Brasília, } \\
\text { 09/09/2016 }\end{array}$ \\
\hline Aldo Cândido Costa Filho & Coordenador Geral de Imigração - MTE & $\begin{array}{l}\text { Brasília, } \\
03 / 03 / 2016\end{array}$ \\
\hline Luiz Alberto Matos dos Santos & $\begin{array}{c}\text { Coordenador do Conselho Nacional de } \\
\text { Imigração - MTE }\end{array}$ & $\begin{array}{l}\text { Brasília, } \\
03 / 03 / 2016\end{array}$ \\
\hline Rinaldo Gonçalves de Almeida & $\begin{array}{c}\text { Conselheiro do CNIg (suplente) - Representante } \\
\text { do MTE }\end{array}$ & $\begin{array}{c}\text { Brasília, } \\
09 / 03 / 2016\end{array}$ \\
\hline Clair Ruppert & $\begin{array}{c}\text { Conselheira do CNIg - Representante da Central } \\
\text { Única dos Trabalhadores (CUT) }\end{array}$ & $\begin{array}{l}\text { Brasília, } \\
08 / 03 / 2016\end{array}$ \\
\hline Marjolaine Julliard do Canto & $\begin{array}{c}\text { Conselheira do CNIg - Representante da } \\
\text { Confederação Nacional do Comércio de Bens, } \\
\text { Serviços e Turismo }\end{array}$ & $\begin{array}{c}\text { Brasília, } \\
\text { 09/03/2016 }\end{array}$ \\
\hline Lídia Miranda & $\begin{array}{l}\text { Conselheira do CNIg - Representante do } \\
\text { Ministério da Ciência e Tecnologia (MCTI) }\end{array}$ & $\begin{array}{c}\text { Brasília, } \\
13 / 05 / 2016\end{array}$ \\
\hline Bela Feldman-Bianco & $\begin{array}{c}\text { Conselheira do CNIg - Representante da } \\
\text { Sociedade Brasileira para Progresso da Ciência } \\
\text { (SBPC) }\end{array}$ & $\begin{array}{l}\text { São Paulo, } \\
18 / 07 / 2016\end{array}$ \\
\hline Fábio Balestro Floriano & $\begin{array}{l}\text { Ex-Assessor Internacional da Secretaria de } \\
\text { Direitos Humanos da Presidência (SDH) }\end{array}$ & $\begin{array}{l}\text { São Paulo, } \\
01 / 06 / 2016\end{array}$ \\
\hline
\end{tabular}




\begin{tabular}{|c|c|c|}
\hline Ricardo Paes de Barros & $\begin{array}{c}\text { Professor e economista-chefe do Instituto Ayrton } \\
\text { Senna/ Ex-Secretário de Assuntos Estratégicos } \\
\text { (SAE) }\end{array}$ & $\begin{array}{c}\text { São Paulo, } \\
10 / 10 / 2016\end{array}$ \\
\hline Júlia França & (SAE) & $\begin{array}{c}\text { Telefone, } \\
18 / 11 / 2016\end{array}$ \\
\hline Felipe Proenço de Oliveira & Ex-Diretor do DEPRESP (MS) & Skype, \\
& Ex- Diretor Adjunto do DEPRESP (MS) & Skype, \\
& & $14 / 07 / 2016$ \\
\hline Jerzey Timóteo Ribeiro Santos & Ex-Assessora de Relações Internacionais (MS) & Skype, \\
& & $24 / 08 / 2016$ \\
\hline Juliana Vallini & Chefe da Assessoria Especial da Casa Civil & Telefone, \\
& & $09 / 02 / 2017$ \\
\hline
\end{tabular}

ATORES DE ORGANIZAÇÕES INTERNACIONAIS E DA SOCIEDADE CIVIL

\begin{tabular}{|c|c|c|}
\hline NOME & CARGO À ÉPOCA DA ENTREVISTA & $\begin{array}{c}\text { LOCAL e } \\
\text { DATA }\end{array}$ \\
\hline Anônimo & Funcionário do escritório do ACNUR no Brasil & $\begin{array}{c}\text { Brasília, } \\
11 / 05 / 2016\end{array}$ \\
\hline Pétalla Timo & Representante da organização Conectas Direitos & $\begin{array}{c}\text { Skype, } \\
24 / 05 / 2016\end{array}$ \\
\hline Paulo Amâncio & Humanos em Brasília & $\begin{array}{c}\text { São Paulo, } \\
27 / 06 / 2016\end{array}$ \\
\hline Paulo Illes & Diretor do Centro de Acolhida ao Imigrante em & São Paulo/ Membro da SEFRAS \\
& Diretor do CDHIC/ Ex- Coordenador de & São Paulo, \\
& Políticas para Migrantes da Cidade de São Paulo & \\
\hline
\end{tabular}

\section{OUTROS ATORES}

\begin{tabular}{|c|c|c|}
\hline NOME & CARGO Å ÉPOCA DA ENTREVISTA & $\begin{array}{l}\text { LOCAL e } \\
\text { DATA }\end{array}$ \\
\hline Marcia Sprandel & Consultora legislativa do Senado Federal & $\begin{array}{c}\text { Brasília, } \\
03 / 03 / 2016\end{array}$ \\
\hline Tarciso Dal Maso Jardim & Consultor legislativo do Senado Federal & $\begin{array}{l}\text { Brasília, } \\
10 / 05 / 2016\end{array}$ \\
\hline Camila Baraldi & $\begin{array}{c}\text { Coordenadora de Políticas para Migrantes do } \\
\text { Município de São Paulo }\end{array}$ & $\begin{array}{l}\text { São Paulo, } \\
19 / 05 / 2016\end{array}$ \\
\hline Leonardo Cavalcanti & $\begin{array}{l}\text { Professor da Universidade de Brasília/ } \\
\text { Coordenador científico do Observatório das } \\
\text { Migrações Internacionais (ObMigra) }\end{array}$ & $\begin{array}{c}\text { Brasília, } \\
13 / 05 / 2016\end{array}$ \\
\hline Tânia Tonhati & Pesquisadora do ObMigra & $\begin{array}{c}\text { Brasília, } \\
13 / 05 / 2016\end{array}$ \\
\hline Antônio Tadeu Oliveira & Pesquisador do ObMigra/ Pesquisador do IBGE & $\begin{array}{l}\text { Brasília, } \\
\text { 10/03/2016 }\end{array}$ \\
\hline Duval Fernandes & $\begin{array}{l}\text { Membro observador do CNIg (suplente) - } \\
\text { Comissão Nacional de População e } \\
\text { Desenvolvimento/ Professor PUC Minas }\end{array}$ & $\begin{array}{c}\text { Brasília, } \\
10 / 05 / 2016\end{array}$ \\
\hline Deisy Ventura & $\begin{array}{l}\text { Professora da Universidade de São Paulo/ } \\
\text { Membro da Comissão de Notáveis organizada } \\
\text { pelo Ministério da Justiça }\end{array}$ & $\begin{array}{l}\text { São Paulo, } \\
13 / 06 / 2016\end{array}$ \\
\hline Cristiane Lopes & $\begin{array}{l}\text { Procuradora do Ministério do Trabalho do } \\
\text { Paraná/ Membro observadora do CNIg }\end{array}$ & $\begin{array}{l}\text { Telefone, } \\
27 / 10 / 2016\end{array}$ \\
\hline
\end{tabular}

